${ }^{2}$ 6.

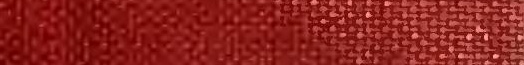

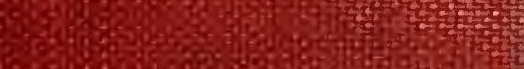

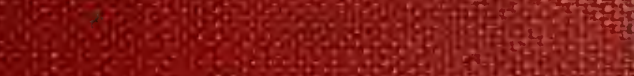

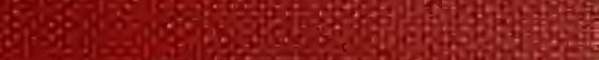

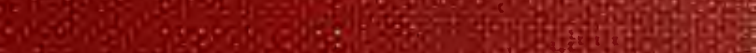

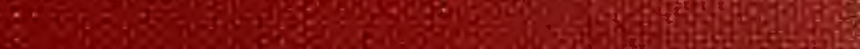

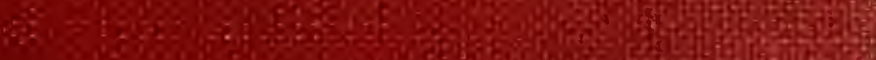

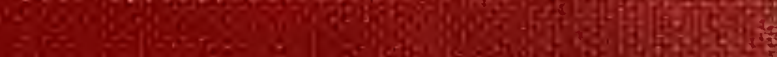

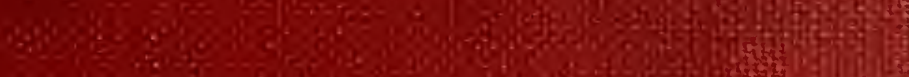

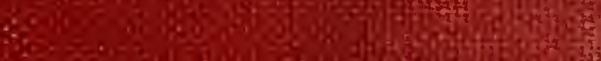

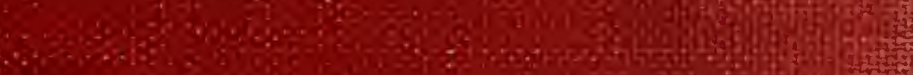

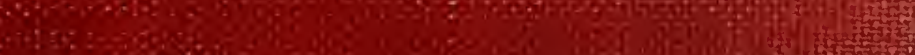

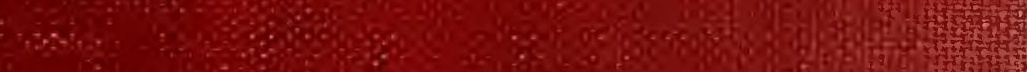

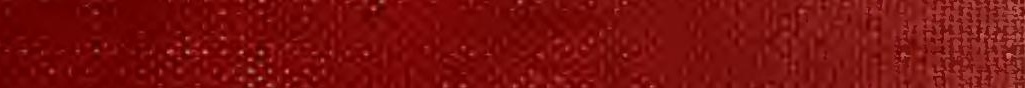

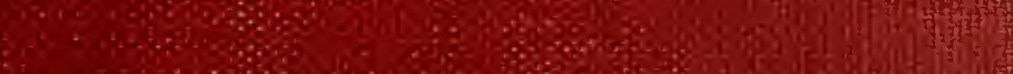

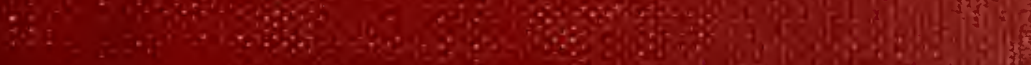

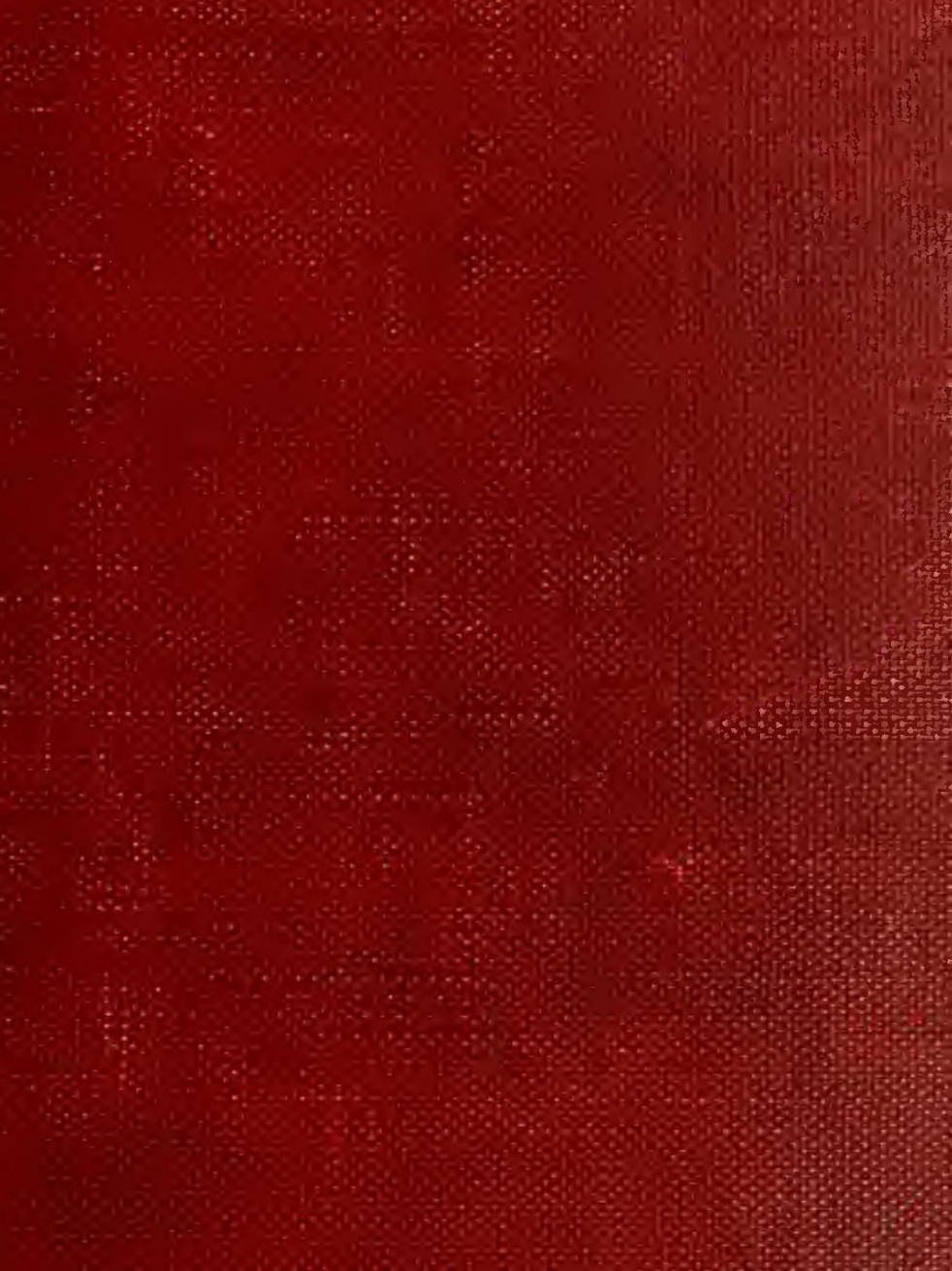




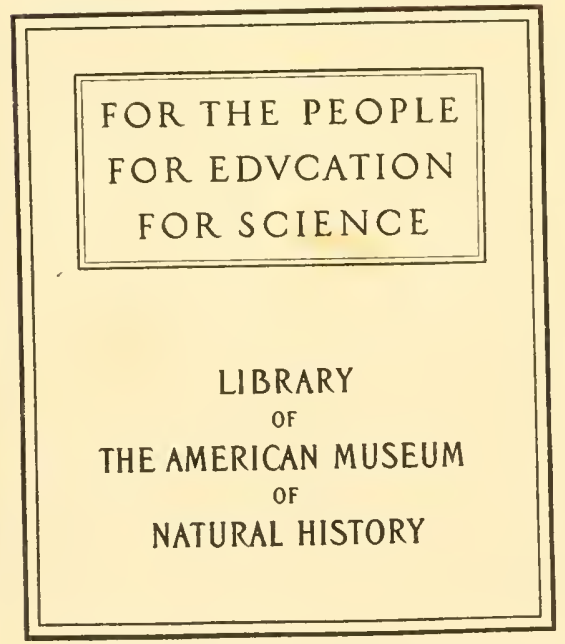




THE HORSE 




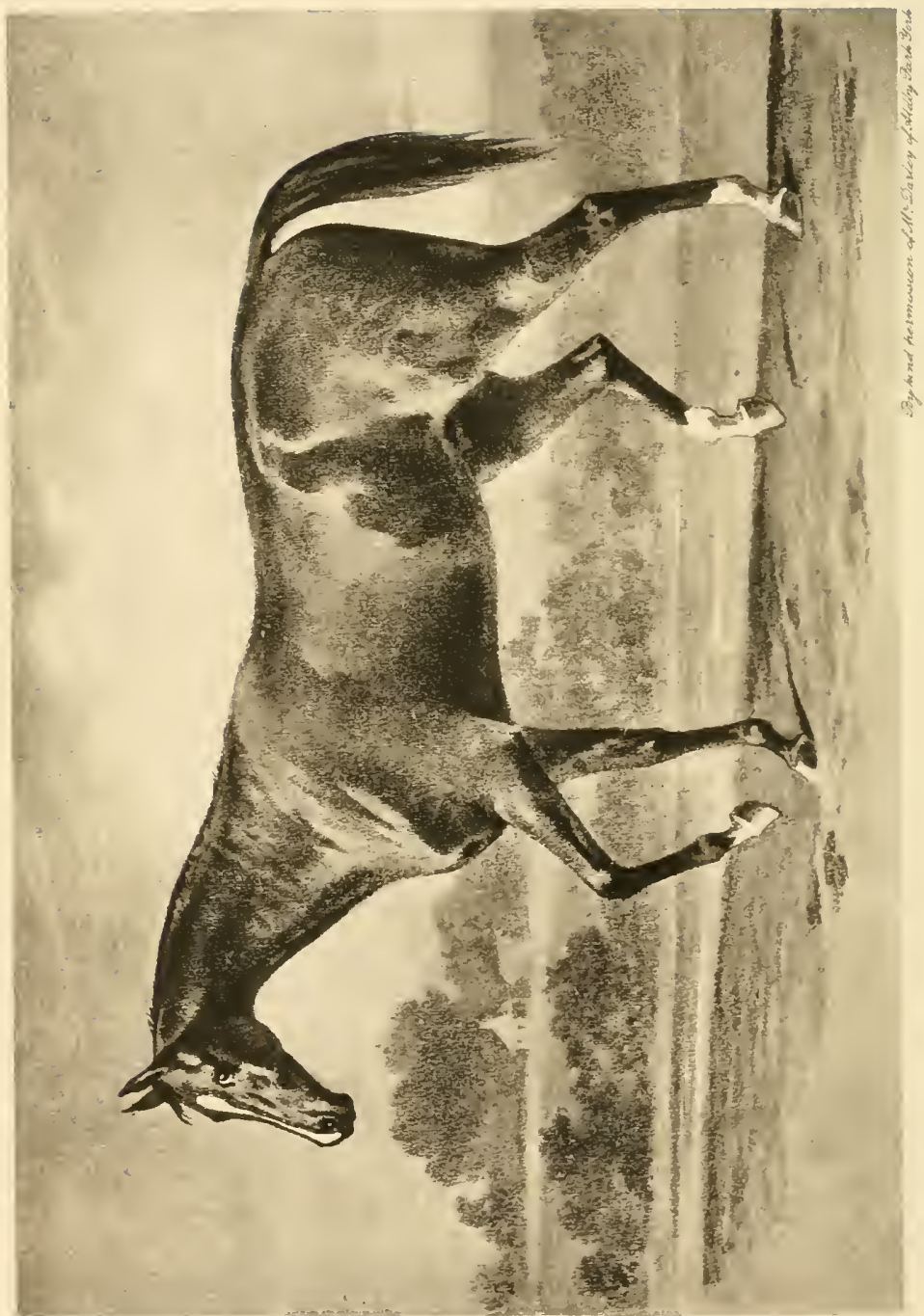

है 


\section{THE HORSE}

ITS ORIGIN AND DEVELOPMENT COMBINED WITH STABLE PRACTICE

$$
4.9,725
$$

BY

COLONEL R. F. MEYSEY-THOMPSON

AUTHOR OF "A hUNTING CATEChISM," "REMINISCENCES OF CAMP, COURSE AND CHASE," ETC.

ILLUSTRATED

LONDON

EDWARD ARNOLD

1911

[All rights reserved] 


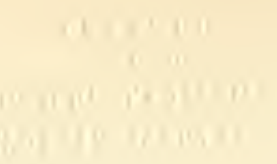

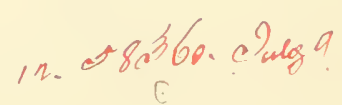




\section{PREFACE}

THE scheme of this work is to trace the history of 1 the horse from the earliest Ages; to continue its evolution to modern times, when the various breeds in Great Britain have been brought to a high state of perfection by the careful supervision and skill of enthusiastic breeders; and also to give in detail the methods of stable practice and training in vogue at present, as practised in my own stable.

There are many races of horses, admirable in their way, that have therefore not been touched upon, since they have had no part in the development of British horses. How hardy and useful some of these native breeds are may be gathered from a letter, October 23, 1910, from Mr. J. Tagg, F.R.C.V.S., who had a very prolonged experience in managing an immense Stud in the Tirhoot district of Bengal.

Referring to the Khirgiz, and the Manchurian ponies, and others of that breed, which are common from the Volga to China, he remarks: "What ripping ponies the Khirgisen are! When I was at Simbirsh, on the Volga-the town is between Kasan and Samara-I used to drive a Troïka. The middle pony, about $13 \cdot 3$, was a dun Khirgis stallion, and the two outspanners were geldings, with a dash of Arab in them. The outspanners, or 'outriggers,' used to gallop as hard as they could pelt on the frozen snow, but the Kirgis would never break. The hardiness of the little brutes was marvellous! On one occasion night overtook me, and I stayed in a village called Astradam, on the Kama River, and I gave my Ivooschick an extra rouble. 
My man, a Kalmuck Tartar, and a blackguard personified but faithful to me, went and got drunk promptly. In the night I went out into the yard-there were then about 50 degrees Fahrenheit of frost-and there stood my three ponies, one icicle from the tips of their ears to their heel sockets, comfortably eating rough hay from a crib of sorts."

Stories of hardiness that may even vie with the above have been often told from time to time of Indian ponies, Argentine, Norwegian, Basuto, and those of many other countries, showing the innate toughness of various national breeds, and that England has no monopoly of hard-working ponies. They take no part, however, in the composition of British horses or their descendants, and reference to them is unnecessary for the present purpose.

My best thanks are gratefully offered to the kind friends who have given me much valuable assistance in compiling this work, and bringing it to a successful conclusion : to $\mathrm{Mr}$. James E. Platt, the former eminent breeder of thoroughbred yearlings, and owner of the great Kendal in his days at the English Stud, who has given me most welcome help in preparing the chapters on Thoroughbreds, and on American Trotters; to Mr. Walter Winans, famous in many different spheres, but especially in the art of breeding and successfully showing horses, who has kindly revised the mention of American Trotters; to Lady Anne Blunt, who has unstintedly given me the great advantage of her unique knowledge of the Arabian horse, in preparing the description of her favourite breed; to Miss Daphne Darley for obtaining the most valuable letter concerning the purchase of the Darley Arabian; to Mr. Alfred Withers, the world-famous manager of the great establishments in Oxford Street and Edgware Road, for his hints with regard to carriage-horses; to Kaid Sir Harry Maclean, whose prolonged period of captivity by Raisuli thrilled the whole of Europe, and whose long service in the Councils of the late Sultan of Morocco, dating from 1876 till 1908, was the theme of wonder and admiration in all the Foreign Offices of Europe, who has now kindly 
revised the chapter on Barbs; to Mr. Hermon Biddell, whose intimate knowledge of the Suffolk Punch enabled him to write that most interesting account of them in the first volume of their Stud Book, and whose aid has been invaluable to me in writing about the merits of the breed ; and to Mr. Robert Thornton, so well known in connection with Lord Middleton's Stud Farm at Birdsall, who has supervised the remarks on Breeding. To all these kind friends, and also to those who have granted permission to embellish the work with the likenesses of their favourites, some even personally unknown to me, and to every one who has assisted in bringing this book to a happy conclusion, I now tend my hearty and grateful thanks.

November, 1911.

li. F. MEYSEY-THOMPSON. 



\section{CON'TEN'TS}

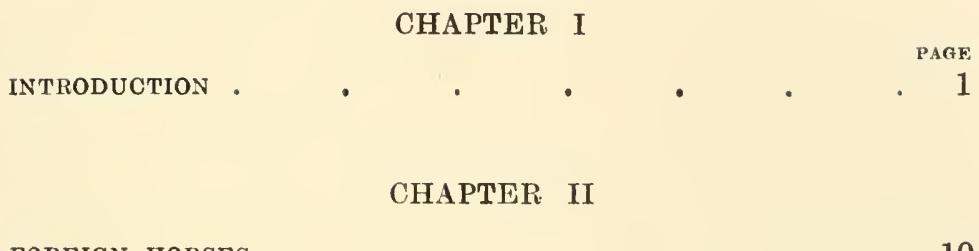

FOREIGN HORSES

CHAPTER III

THOROUGHBRED HORSES

33

CHAPTER IV

CARRIAGE-HORSES

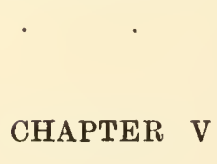

CART-HORSES

CHAPTER VI

ORIGIN OF AMERICAN TROTTING HORSES .

CHAPTER VII

CONFORMATION

CHAPTER VIII

BREEDING 


\section{CHAPTER IX}

\section{CHAPTER X}

STABLE MANAGEMENT

CHAPTER XI

SIMPLE AILNENTS

\section{CHAPTER XII}

DISINFECTANTS

\section{CHAPTER XIII}

ALCOHOL

\section{CHAPTER XIV}

EXAMIINING A HORSE FOR SOUNDNESS

\section{CHAPTER XV}

TRAINING FOR RACING, POINT TO POINT, ETC.

\section{CHAPTER XVI}

Driving, RIDING, HUNTING, RACE-RIDING .

\section{CHAPTER XVII}

HORSE SHOWS AND REMOUNTS 


\section{LIST OF ILLUSTRATIONS}

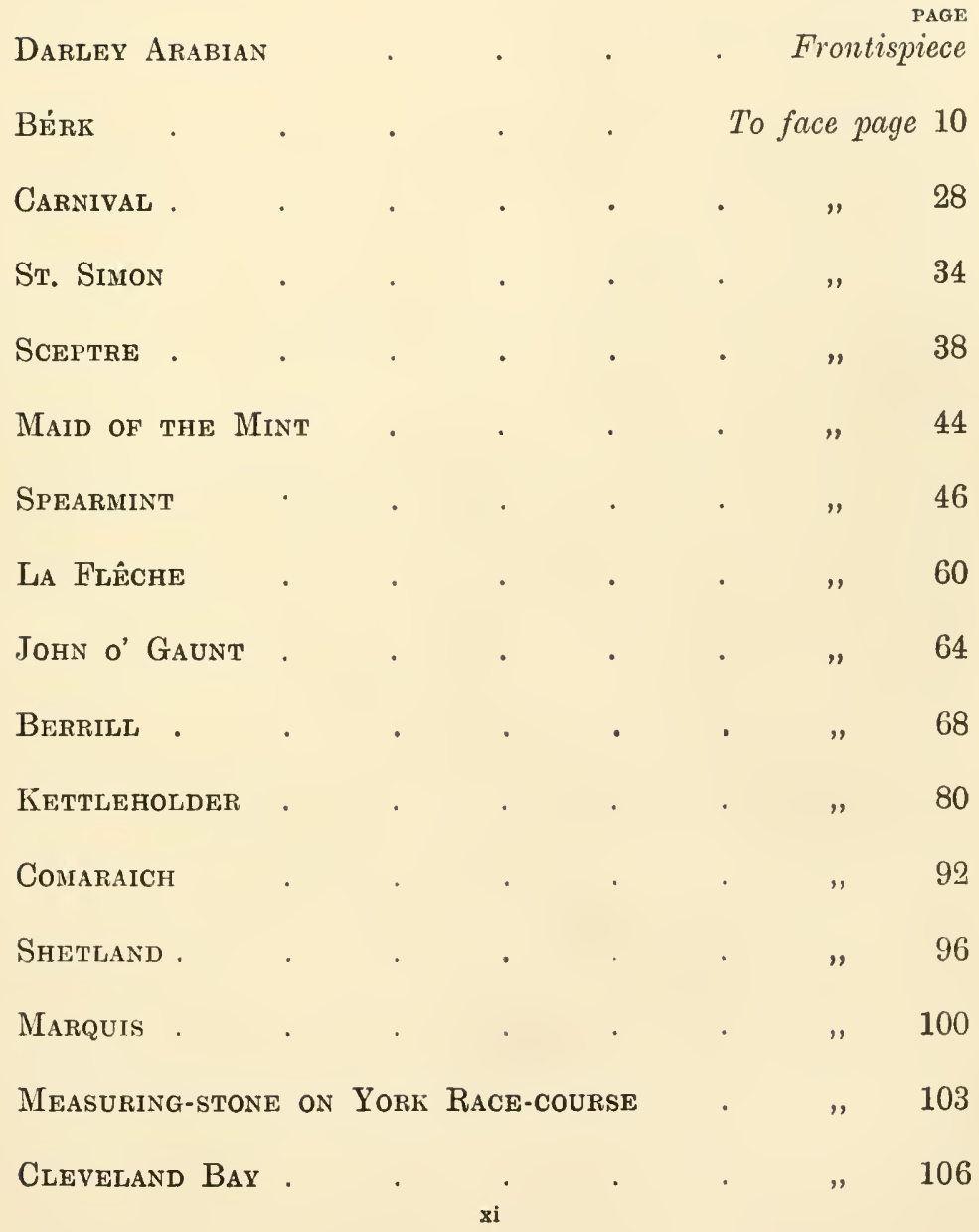


Two Hackneys . . . . . . To face page 110

Hackey Trotting . . . . . . . 112

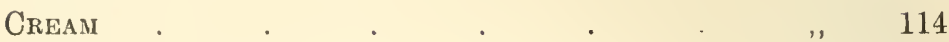

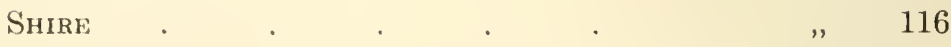

Clydesdale . . . . . . . . . . . . 118

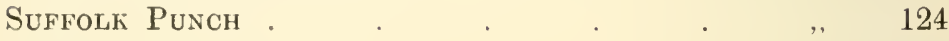

AMERICAN Trotter . . . . . . . . $\quad 132$

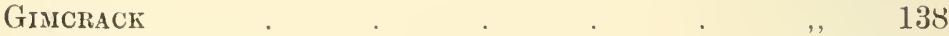

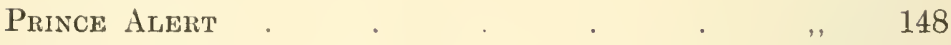

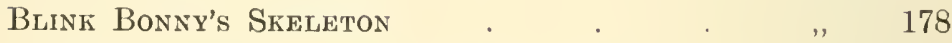

Arabian from Lady Anne Blunt's Stud . " " 188

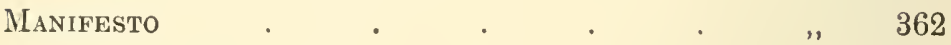

Carnival Jumping $\quad$ - $\quad$. $\quad$. $\quad$. $\quad 390$

Carival Cantering . . . . . . $\quad$. 390 


\section{THE HORSE}

\section{CHAPTER I}

\section{INTRODUCTION}

WING to the careful researches that have continuously ledge of the early history of the horse has been enormously increased. We now possess a comprehensive view of its evolution from prehistoric ancestors, the earliest date of which goes back to a period whose remoteness was little suspected a few years ago. Our knowledge has been gained through the finding of bones and teeth in the various deposits termed the Tertiaries; for the skeletons of mammals, like those of birds, reptiles, and osseous fishes, being composed of calcareous earth pervading an organic base, have withstood the passage of incalculable Ages, provided they were kept out of the reach of the solvent action of water, in almost a similar manner to the soil itself. Our knowledge thus gained has been further immensely increased by the discovery of marvellous drawings left by the Cave-dwellers (usually known as the Reindeer Men), which were carved in a most artistic, as well as realistic, manner on the tusks of the mammoth, and on various other bones, and depict both the pursuits of the human beings of that epoch, and the animals with whom they were acquainted. Though we do not know when the Tertiaries commenced to form, they have taken millions of years to do so; and as they consist of well-defined series of clay and sand, superimposed above each other, the finding of the 
remains of animals in the respective strata affords a reliable guide to the sequence of their evolution, and shows the different stages they have passed through to attain their modern form; while their total absence in the early geologic formations is conclusive proof that they must have evolved from the primitive forms, which then alone peopled the earth.

To commence at the beginning, there was first the Pre-Cambrian Age, that of the Torridonian Sandstone and various igneous rocks. No undoubted fossils in this formation have yet been found, but life most probably existed, as we find all the chief genera of invertebrates in the succeeding Cambrian period. Following in sequence came the Primary, or Palæozoic epoch, commencing with the Cambrian formation, when Trilobites were in existence. Later was included the formation of the Silurian, when there were plant-like animals, and small fish; the Devonian, when Ganoid fishes and true sharks first appeared; the Carboniferous, when (as the coal measures show) there were great forests, and plant-life was on a profuse scale; and lastly, the Permian-a formation of the limestone, slate, and sandstone, when reptiles first began to crawl.

Following this epoch came the Secondary, or Mesozoic Age. This included the Triassic; the Jurassic, (the flourishing period of Ammonites and reptiles, such as the Icthyosaurus, Deinosaurus, and Plesiosaurus, and when the first bird made its appearance); and lastly, the Cretaceous, or Chalk Age, when the remains have been found in America of birds possessing teeth! Whether mammals evolved from such birds or from reptiles yet remains to be proved. The evolution of fish into landanimals may possibly be traced through the curions catfish of Africa, and the climbing perch of India, both of which can live out of water for a considerable time. In the former this power is due to vascular structures above the gills, enabling them to breathe atmospheric air. One form is almost amphibious, and when the marshes are dried up can spend the dry season in burrows, which it 
leaves at night to seek for food. The transformation, too, of tadpoles into air-breathing frogs and toads, is an example familiar to everybody who frequents the country ditches in the summer-time, and is too common an occurrence to excite remark; whilst the breathing of atmospheric air by inhabitants of the ocean, which never leave it, is another case in point, exhibited by the whales and porpoises.

At the bottom of the chalk sea were deposited myriads of fossils, shells, and fish, which are marked features of the formation at the present day; but there are no traces of mammals. The few that have been discovered during the Secondary Period appear to have been of a small marsupial mimal, and also a small insectivorous one.

Although the actual genesis of the horse is thus veiled in obscurity, like that of other mammals, warmblooded animals which suckle their young, its evolution is clearly traced in the Old World from the Hyracotherium, a horse-like animal not larger than a fox. It was only about eleven inches high, existing in the Lower Eocene Period, the first, and lowest, of the Tertiary deposits, and possessing four toes on each fore-foot, with rudiments of another, and three on each hind-foot. In the New World the earliest direct ancestor was the Eo-hippus, which had the same characteristics as the Hyracotherium. Another small animal existed about the same period which possessed five toes on each foot, had the same characteristics as the Hyracotherium, and there is little doubt was a still more remote ancestor of the horse. It is termed the Phrenacodus, the first specimen being found by Professor Cope, who dug it up from the Eocene marl on Bear River, in Wyoming. All mammals, even elephants, are descended from similar five-toed ancestors (no larger than a fox), and there are no fossil remains (excepting those of which mention has been made above) of any of them earlier than the sands and clays forming the Tertiary deposits. These are divided into Lower, Middle, and Upper, as far as this country is 
concerned; or Eocene (the first and lowest), Oligocene, and Pliocene; while on the Continent there is a fourth, the Miocene, intermediate between the Oligocene and Pliocene. Then comes the Pleistocene or Quaternary epoch, divided into three periods: No. 1, the Upper, or Post-Glacial Pleistocene, the Age of the Reindeer, and the extremely artistic race known as the Reindeer Men; No. 2, the Middle Pleistocene, or Last Glacial Age, when another race existed known as the Neander Men; and lastly, No. 3, the Lower Pleistocene, when man must have lived, as flint implements have been found in the gravels of England and France, though no human remains have yet been discovered.

It was not until the Quaternary Period, millions of years after the epoch of the early Hyracotherium, that amongst its gravel and cave-deposits the weapons, implements, and carvings were found of the Cave-dwelling Men who flourished from 50,000 to 100,000 years ago. They had for company the lion, bear, mammoth, rhinoceros, and horse, whom they slew for food in vast numbers, with the assistance only of such poor tools as flint knives and bone javelins, at a time when the British Islands were still a solid part of the Continent.

Gradually the habits of the early horse changed; speed became of prime importance in the struggle for existence, both to escape from enemies and also to flee from arid districts to places where water could be found; and as the stature increased so also did the toes become shorter from disuse. In the Middle Tertiary the four toes (Fig. 1) had become only three (Fig. 2), still of equal dimensions, and the size of the animal had increased to that of a fair-sized donkey.

The form beginning to resemble that of the modern wild Mongolian horse, the Hipparion as it is thence called, continued to develop. Eventually the central digit became unduly elongated, the toe became rounded into hoof-like form (Fig. 3), and the lateral digits resolved themselves into well-developed pettitoes, such as we are familiar with in the domestic pig, and of 
which the splint-bones of the modern horse are an interesting survival.

From the carvings left by the Cave-dwellers, the Hipparion had already assumed a horse-like form; but even then there appears to have been a cleavage into two types, the one resembling the modern wild horse of the Gobi Desert, coarse in its head, inelegant in its neck, with a low-carried tail; while the other was of a more slender make, with a narrower, more tapering head, which undoubtedly signified "quality," as understood by horsemen at the present time. It is more than probable that this was the "old original " of the Arabian horse and the Barb, which conclusion is strengthened by the hollow depression in the skull, in front of the orbit, being common to both Hipparion and Arabian horses, and

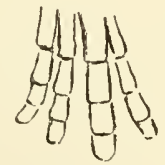

Fig. 1.

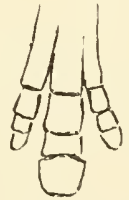

FIG. 2.

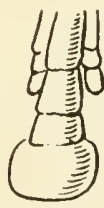

FIG. 3.

their descendants, even when crossed with other breeds. Moreover, it is entirely wanting in the skulls of the wild Mongolian horse, as well as in those of the horses of Northern Europe, such as the Iceland and Norwegian ponies, and the coarse-bred horse of the common type (the Shire horse alone excepted), more especially in those breeds where a dun colour prevails. This cavity is presumed to have contained a gland, such as is possessed by antelopes and deer, which secretes a fluid that is supposed to give out a special odour, by which individuals of a tribe may track each other if they happen to be separated and scattered. Such cavities in front of the eye can be traced in our thoroughbred horses, due to the introduction of the blood of Eastern horses into our indigenous racing stock. Professor Cosser Ewart has stated his opinion that in the Early Eocene Period 
horses may have been of a uniform colour, "a foxy-red" in hue; while the Miocene horses were either striped or spotted. No doubt at that period horses were dwelling in vastly different areas, some inhabiting bush and some open plains, and their colouring would assimilate to their surroundings. Stripes appeared first on the legs, as are sometimes still seen in dun horses, and then a dorsal band and shoulder stripes followed, though the markings were faint and ill-defined, until, as time ran its course, the zebras developed their characteristic coat.

Caves containing vast quantities of fossil remains of early quadrupeds have been discovered and investigated in many parts of the world; and it is likely that our own limestone ranges, whose vast fissures and caverns underground give no external indication of their existence, may reward future investigators with rich discoveries which will throw more light on prehistoric ages.

In England, “Kent's Cavern" at Torquay, the Creswell Cave and the "Kirkdale Cave," in Yorkshire, have been prolific of fossil treasures. North America has provided remains of the "Protohippus" in the Later Eocene, in which the splint-bones are fully developed, terminating inferiorly in small though perfect toes, a contemporary of the Hipparion; the Miocene "Anchitherium," the crowns of whose teeth are quite short and free from cement; and the "Pliohippus" in the Upper Pliocene, with shorter cheek teeth; while South America has the "Onohippidium Munizi," found in the superficial deposits of Argentina, and characterised by the great length of the nasal slit, which extends as far as the eye-socket. In the light of these fossil remains, it is curious that when America was discovered no living horses existed on that continent. It is the great caverns in the Pyrenees, and the Landes, and the celebrated cavern of La Madeleine in the Dordogne, which have yielded the great wealth of carvings and other evidences of the Cave-men. It has been stated that in one locality in France alone-Solutré, near Macon-the 
bones of 100,000 horses have been collected, which had been cooked and eaten; while an immense amount of carvings, some in line-engraving and some in relief, have been recovered and placed in the great Museum of St. Germain, near Paris, and also figure in private collections, largely through the indefatigable exertions of the late Vicomte de Lastic and the recently deceased M. Piette.

In common with other mammals the evolution of the horse may therefore be summed up in the following table (see p. 8), millions of years being consumed in the process of ascending from the lowest epoch to the date of the most recent winner of the Epsom Derby, or the First Prize Shire Horse at the Royal Agriculture Show; though undoubtedly all are links in one progressive chain of development from a lower to a higher form. The table should be studied from the bottom, working up from the Pre-Cambrian Age, the period of the Torridonian Sandstone, to the Palæolithic or Upper Glacial epoch, the links of which are superimposed upon each other, like the different layers of a sandwich.

The use of the horse by the Cave-dwellers was assuredly for food. It was probably a long time before they made any endeavour to utilise its services, but that they eventually did so is clearly indicated on some of the carvings discovered by M. Piette. Twisted thongs were placed round the head and muzzle in the fashion of a bridle, or halter, but whether any sort of bit was used is uncertain. In all probability the horse was primarily controlled by pressure with the nose-band, which latter may have been supplemented by a hard material such as bone, or wood, similar to the metal cavessons frequently employed instead of bits, in the Peninsula, at the present day. When man takes any species of animal in hand he invariably contrives to modify some of its characteristics to suit his wants, and it is likely the Cave-dwellers asserted their influence, and the horse as used by them changed somewhat in type from what Nature, free and unfettered, would have continued to produce; but it has been left to very modern times to originate and 
Age

Age. Period.

E. Palæolithic (Upper, or Post-Glacial Age of the Reindeer, and the

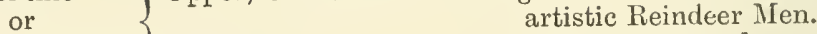

Post-Tertiary (Pleistocene ... ... ... Hipparion assumed complete or

Quaternary or Pleistocene

$\{$ Middle, or Last Glacial $\{$ Pleistocene ... ... ... Lower Pleistocene ... ...
Age of the Neander Men.

Mild climate. Age of the Hippopotamus in England, and other European rivers.

D.

\begin{tabular}{|c|c|c|c|c|}
\hline & Pliocene & $\left\{\begin{array}{l}\text { Upper } \\
\text { Lower }\end{array}\right.$ & $\begin{array}{l}\cdots \\
\ldots\end{array}$ & $\begin{array}{c}\cdots \\
\ldots\end{array}$ \\
\hline (Tertiaries. & Miocene & $\cdots$ & $\cdots$ & $\cdots$ \\
\hline$\{$ Advent of & Oligocene & ... $\quad \ldots$ & $\ldots$ & ... \\
\hline Mammals & Eocene & $\ldots \quad \ldots$ & ... & ... \\
\hline
\end{tabular}

Plio-hippus, extra digits entirely rudimentary.

Hipparion three-toed. About the size of a Shetland pony. American "Anchitherium."

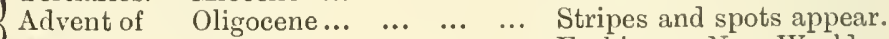

Eo-hippus, New World.

Hyracotherium, Old World, four-toed, probably foxyred in hue, and about eleven inches high.

Phrenacodus, the five-toed, earliest hoofed mammal yet discovered.

C.

$\begin{array}{ccccc}\text { Chalk Age } & \ldots & \ldots & \ldots & \text { Fossil shells, and birds found } \\ \text { in America possessing }\end{array}$
teeth.

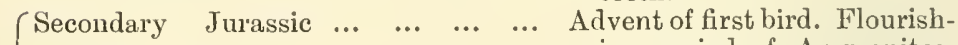
ing period of Ammonites, and Reptiles, such as the Icthyosaurus, Deinosaurus, Pleisiosaurus.

Triassic

B.

Permian ... $\quad \ldots \quad \ldots \quad \ldots \quad$... Formation of Limestone, Slate and Sandstone. Reptiles began to crawl.

Primary Carboniferous (Coal Mea- Great Forests, and profuse

Age of Fishes and Mollusks sures) $\ldots \quad \ldots \quad \ldots \quad \ldots \quad$ plant-life.

Devonian ... $\quad \ldots \quad \ldots \quad \ldots$ True sharks, and Ganoid fishes.

Silurian $\quad \ldots \quad \ldots \quad \ldots \quad \ldots \quad$ Plant-like animals, and small fishes.

Cambrian ... $\quad \ldots \quad \ldots \quad \ldots \quad$ Age of trilobites.

A. Pre-Cambrian Torridonian Sandstone No undoubted fossils yet and various igneous found, but probably existed, rocks $\quad \ldots \quad \ldots \quad \ldots \quad \ldots \quad$ as the chief genera of invertebrates are found in the Cambrian.

develop the numerous groups that now exist, specialised for the particular duties for which they are required. In this the breeders in the British Islands have taken a fore- 
most place, and the success they have achieved has been recognised by almost every civilised country, nearly all of which have repeatedly sought our best breeding stock, to raise the character of their own home produce. Moreover, up to now, other countries do not seem able to maintain the same high standard through their own efforts, and owing to some peculiarity in the climate of these Isles it is found necessary to return again for fresh supplies from British breeders, after every few generations, to prevent deterioration setting in.

Whether the first use of the horse was for riding or driving is hardly likely to be ever known for certain, though to get upon a horse's back necessarily requires less preparation than to provide means for draught, even of the simplest construction. On the other hand, although the Cave-dweller may have surmounted the initial difficulty when he had got on the animal's back, he had to manage to remain there, which is not such a very simple matter if the steed disapproves of such liberties being taken, and resents them accordingly! It is not to be supposed that these early men would be troubled with very refined feelings, and their methods of reducing a rebellious steed to subjection would be likely to be efficacious, if somewhat unpleasantly drastic; but then comes in also the question of whether they were troubled with nerves! Probably at that remote date they did not know what fear was, though by the time the Romans appeared on the scene Horace tells in a familiar passage how "atra cura" sits "post equitem," which the schoolboy felicitously translated, "He was in a blue funk." As the size of the animal was so diminutive it seems probable that it would be used for traction rather than riding, at the earliest period of its subjugation by man. 


\section{CHAP'TER II}

\section{FOREIGN HORSES}

\section{Arabians.}

TN building up our horses to the magnificent standard I to which they have attained, it may well be asked where we should be now withont the assistance of Eastern sires, and more especially of the Arabian. Our indigenous stock appears to have been a wiry, small horse-the type, no doubt, of our present mountain ponies-and on that foundation has been superimposed the blood of Arabians and Barbs, and frequently also that of the Spanish genet. Eastern blood has certainly been imported continually since the arrival of the Romans, who are credited with holding race-meetings in Yorkshire. Baron von Cettingen states in "Horse Breeding in Theory and Practice," p. 11: "Horse-racing as a popular amusement was indulged in even in the times of the Romans, and during the four years which King Severus passed at York (206-210 A.D.) the Roman soldiers arranged races with Arabians at Wetherby, near York." Such a race-course would be conveniently situated within reach of their great stations at York, Aldborough, and Tadcaster, though it is not to be supposed they would make any fine distinction between Barbs and Arabians, but would probably include all Eastern horses under one designation. No doubt the steeds remained, and died, in Britain, and never returned to Rome; and since they would almost certainly eventually be used for breeding, they must have exerted a considerable influence on the common stock of the 


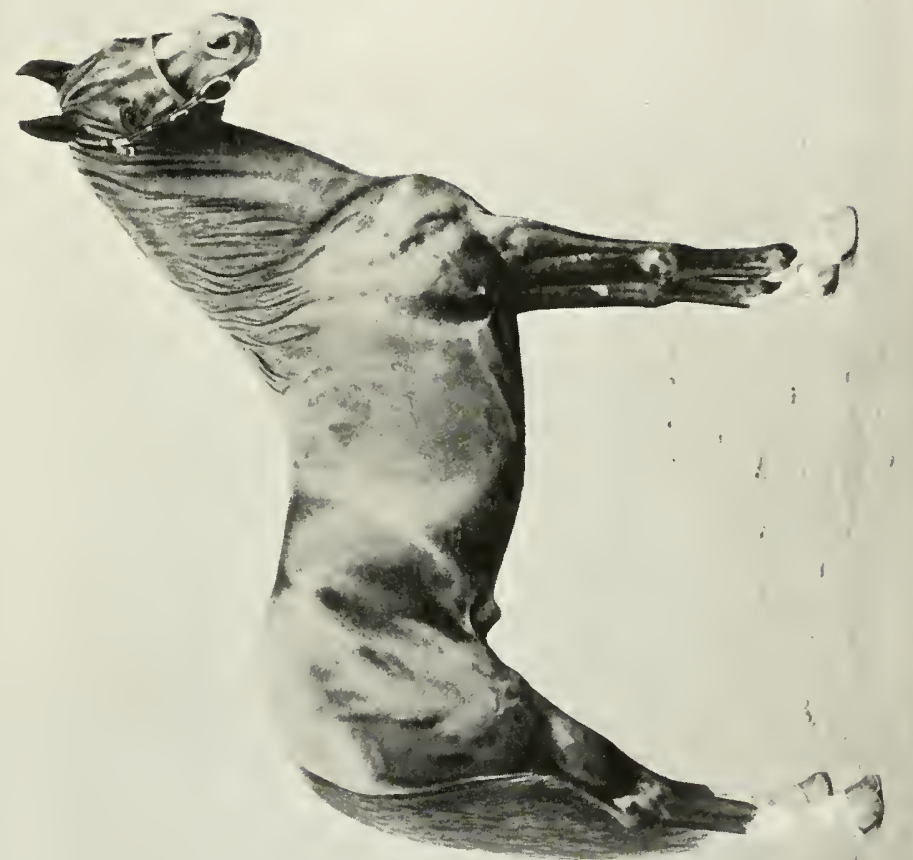



district around them.* TVe know, again, that numerous horses were brought back from Palestine in the train of the Crusaders, which would of a surety be Arabian in character; so the improvenent of our horses through the admixture of Eastern blood must have commenced at a very early period in our national story. Whether the Arabian horse of that epoch was identical with the animal of to-day, it is impossible to know for certain; but in all probability it was similar in all important respects, for the Eastern world changes very slowly, and the habits of the desert are now akin to the customs described in the Old Testament. The well-known description of a war-horse in the 39th chapter of the Book of Job is that of a spirited, courageous charger, befitting the present denizen of the desert.

The characteristic qualities of the high-caste Arabian, his endurance, hardihood, generous temper, and soundness, enable him to impart lasting benefit to any breed with which he is crossed. Like a foxhound he is a model of symmetry and power, and though his stature may be small the strength in that compact form is simply marvellous. As a war-horse his strong constitution, enabling him to withstand heat and cold, hunger and thirst, and the fatigues of the long, and often forced, marches day after day, renders him invaluable; for he

* Lady Anne Blunt in a letter dated 25th of September, 1910, pertinently remarks: "As to the Crusader's importations, what are the records? Query-May not Eastern horses, other than Arabian, have been the majority of these, for the fighting was against Turks, and the like, who had probably Turcoman and other Asiatic horses; and not against Beduin Nomads of Central Arabia, unless in very limited numbers. At that date the actual Nomads must have ceased pouring out of Arabia in a torrent, as they did at the beginning, being no longer driven out in haste by the hard conditions of life. The surplus, for whom there was not enough pasture, must have already cleared off for the time being. In the true Nomad tribes of Arabia the horse held the same position as now-witness the pre-Islamic poetry, in which are many descriptions of it in hunting and in war. The supply was always limited, as now. It is historical that in the early raids extra plunder was allotted to owners of pure-bred mares and stallions. So I wonder whether the Crusaders met with any considerable numbers of Arabian horses?" 
can live on rations on which an ordinary horse would starve, and fling himself into camp with undaunted courage after such toil that most other horses would have succumbed by the way. His pluck is such that he will face cheerfully any danger when he understands what is required, to which generations of pigstickers will willingly bear witness, as well as the participators in many a gallant fight. One thing is essential, however. He must be left entire, as Nature made him, for when subjected to a humiliating operation, as our War Office have sometimes been ill-advised enough to order, his spirit departs, and he is no longer the same gallant animal he was. His is a chivalrous nature. Treat him like a friend, be kind but firm, and never treat him harshly or ill-temperedly, and he will respond to the utmost, and give up his life to save yours if you have to ask him for his last effort, in your dire need.

English judges are frequently at a loss when they first meet with Arabians, as they expect to find the high wither they are accustomed to associate with "shoulders"; and when they see the broad, rounded wither usual in Arabians they at once exclaim, "What wretched shoulders!" It is really nothing of the kind! The shoulder-blade may be, and commonly is, well sloped with the utmost freedom of action, although the withers are rounded, and comparatively low; and this latter formation, with corresponding muscular development, is actually a sign of weight-carrying capacity. The Englishman, too, is taught by the ordinary artist to expect to see delicate, gazelle-like legs, and does not always appreciate at their true worth the great backsinews-the ropes which move the leg-bones-which the Arabians as a race are remarkable for possessing. The artist, also, is apt to sketch the head in repose terminating in a square muzzle, and reduced to the elegant proportion necessary "to drink out of a pint-pot," which tradition holds an Arabian should be able to do; and therefore, when the long tapering muzzle of a stallion is seen, with nostrils resembling those of a camel, and 
which are not so "becoming" as a square and narrow muzzle would be, the Englishman is apt to feel disappointed, and to show it by stigmatising the Arab's head as coarse. This idea is also helped by the enlargement of the skull on each side of the nasal bone, giving the appearance that a swelling has been caused by a severe blow, when the head is viewed from the front; so until the observer's eye has been educated, and his judgment matured, he is quite at a loss when dealing with Arabian stallions, and does not do sufficient justice to them. The head of a mare, however, more nearly approaches the popular ideal in its elegant proportions.

Much romance has gathered around the Arab and his steed, and not without good reason. There is a glamour wrapped round the life of both and their sharing of the same tent and food, which has more than a spark of truth in it, though it may not be their everyday portion. But the wild roving habits of the tribes, compelling such close intercourse with the animals in their possession, and the natural sympathy of the Arab for so responsive a nature, combine to bring out the best qualities of each, and make them the closest friends.

Having been bred for countless generations with one fixed ideal in view, that of carrying his master on raids and expeditions in an arid climate, exposed to extremes of heat and cold-for snow and frost are not unknown in the desert in winter-the qualities most required for such a task have naturally been kept steadily in view, until they have become ingrained in the nature of the animal. The constant close companionship with man in which he lives has also had its usual effect, and developed the intelligence to a very high degree, and the Arabian horse is the very reverse of being dull-witted.

$\mathrm{He}$ shows his lineage in his aspect, and, as with a gamecock, the first glance tells you he is a gentleman of high descent. The fine head, the broad forehead, and large intelligent eyes, all speak of high breeding, and 
no one would accuse him of being tainted with base-born blood. With his head and tail carried well up he gazes fearlessly on the world, giving evidence of his noble nature in his gallant bearing, and he it is who has given us our thoroughbred horse, the envy and admiration of the world. It is curious that on the majority of Arabians of high-caste, somewhere or other, often on the neck or quarters, there is a little indentation in the flesh known as "the mark of the Prophet's thumb," which is frequently present in our own thoroughbreds.

In that most interesting work by Lady Anne Blunt, " A Pilgrimage to Nejd," describing her journey thither with her husband, and their visit to the Emir's stables, the proper points of a horse's head are given, as esteemed by the Arabs, and I venture to quote them here.

"First of all, the head should be large, not smail. A little head the Arabs particularly dislike, but the size should be all in the upper regions of the skull. There should be a great distance from the ears to the eyes, and a great distance from one eye to the other, though not from ear to ear. The forehead, moreover, and the whole region between and just below the eyes should be convex, the eyes themselves standing rather a fleur de tête. But there should be nothing fleshy about their prominence, and each bone should be sharply edged. A flat forehead is disliked. The space round the eyes should be free of all hair in summer, so as to show the black skin underneath, and this just round the eyes should be especially black and lustrous. The cheekbone should be deep and lean, and the jaw-bone clearly marked. Then the face should narrow suddenly and run down almost to a point, not, however, to such a point as one sees in the English race-horse, whose profile seems to terminate with the nostril, but to the tip of the lip. The nostril when in repose should lie flat with the face, appearing in it little more than a slit, and pinched and puckered up, as also should the mouth, which should have the under-lip longer than the upper, "like the camel's,' the Beduins say. The ears, especially in the 
mare, should be long, but fine and delicately cnt, like the ears of a gazelle.

"It must be remarked that the head and tail are the two points especially regarded by Arabs in judging of a horse, as in them they think they can discover the surest signs of his breeding. The tails of the Nejd horses are as peculiar as their heads, and are as essential to their beanty. However other points might differ, every horse at Hail had its tail set on in the same fashion, in repose something like the tail of a rocking-horse, and not as has been described 'thrown out in a perfect arch.' In motion the tail was held high in the air, and looked as if it could not under any circumstances be carried low....

"With regard to colour, of the hundred animals in the Haïl stables there were about forty greys or rather whites, thirty bays, twenty chestnuts, and the rest brown. We did not see a real black, and of course there are no roans or piebalds, or duns, for these are not Arab colours. The Emir one day asked us what colours we preferred in England, and when we told him bay or chestnut he quite agreed with us. Nearly all Arabs prefer bay with black points, though pure white with a very black skin and hoofs is also liked. In a bay or chestnut, three white feet, the off fore-foot being dark, are not objected to. But, as a rule, colour is not much regarded at Haill, for there, as elsewhere in Arabia, a fashionable strain is all in all."

In the desert no written pedigrees are liept, and the foal takes rank according to the family of his dam; but then the greatest care is taken that she visits only a stallion of the highest caste. In a way this accords with the teaching of Bruce Lowe, to follow the lineage of the dam, in reckoning the descent of a horse. The "mark of the Prophet's thumb," above alluded to, refers to the ancient legend that Mahomet put his seal upon five favourite mares by imprinting his thumb upon them, and their families are frequently said to form the select " upper classes " of the desert under the distinguished title of "El Khamsa." 
It must, however, be pointed out that though Oasisdwellers in Nejd, and tribes that have migrated north to the edge of Ottoman territory, accept the ordinary Moslem traditions, it is not so with the Nomad tribes, to whom there is no Khamsa. On this point Lady Anne Blunt emphatically remarks: "What I have heard said is 'Ah! those are things the Northern folk (Ahl es Shemal), believe.' As to any of the equine race being descended from one of the Prophet's mares (a favourite dealer's phrase), the view expressed by my Muteyrè informant is that 'Any one who talks thus is fit to be shut up as a lunatic!' Moreover, of those Arabs, Northern or Oasis, who have adopted the Khamsa, hardly any two (as far as I know), quote the same list of five. My chief authority is never tired of impressing upon me that everything pure-bred (mazbute), goes back to Kehîlan Ajuz, therefore I now in the printed list" (i.e., of Lady Anne Blunt's Crabbet Park and Egyptian, Arabian studs), "place that first, as the original generic term for pure-bred." The talk of "ontside breeds" as reported in "Beduins of the Euphrates," on Sliene's authority, is a mistake; it is either all or nothing, as to breeding, although from certain strains having made themselves famous, they have acquired and liept a reputation of superiority.

"A strain, if it can be so called, with only one name means, that one parent, or ancestor, was not noble, and in Beduin eyes such a stain endures for ever. Strains mentioned as 'outside,' such as Dahman Shahwan, Dahman Nejíb, Shueyman Sbah, Wadnan Hursan, are especially Nejd strains, and very hard to find.

"The general view I take of the Arabian horse's present position is that although the Northern tribes, i.e., the Anezeh group and some Shammar, originally possessed strains identical with the present Nejd ones, the fact of their intercourse with the 'Dowla,' or Ottoman Government, has tended to corrupt their horses. 'Those late migrations were in search of pasture, and I think about two hundred or three hundred years ago. Even so late as thirty-two years ago, when we went, they were still very independent of the Dowla; but the policy of Abd el Hamid was 
successful in getting them very much in its grip, and now no Nejdean believes in the purity of blood amongst them, except in such families as Ibn Sbeyni, Ibn ed Derri, the Debbe, Ibn Rodan, and some others, who keep aloof both from wars and from the Turks. As to getting anything direct from Nejd, it is very difficult, even if one can hold direct communication. It is the getting across which is so risky, first from the central plateau to somewhere near the Persian Gulf, and then coming up by the Euphrates and westward. Hundreds of camels come, but they are afraid to bring valuable horses for the daugers of the way.

"I cannot discover any ground for the statement, also Skene's theory, of strains having certain particular characteristics; there is no distinction drawn between them, as he imagined, and no Beduin would dream of keeping them separately. As an example, the Abeyans being supposed to be small, Queen of Sheba was just the reverse. Nor is it true the Séglawi Jedrán are not generally handsome-they vary like every other strain."

This testimony of Lady Anne Blunt is invaluable, for her knowledge of the desert and its inhabitants, and especially of the families of Arabian horses, is everywhere recognised as the highest out of Arabia. Her acquaintance with them is, moreover, at first hand, for not only has she sought them in their own home, and has brought them from thence to Crabbet Park and there raised a breeding stud renowned hroughout the world, but at the death of Ali Pasha Sherif she also practically purchased the whole remnant of the magnificent stud, forned at vast expense by Abbas Pacha I., Viceroy of Egypt, 1848-1854, and has established them near Cairo, where she has a further breeding establishment at the Sheykh Obeyd stud.

Subject to the above criticism, to which the greatest weight must be attached, the five families held to constitute the Khamsa are usually arranged as follows:--

\section{EL Kinamsa}

1. Kehílan. 2. Séglawi. 3. Abeyan. 4. Hamdani. 5. Hadban. these being divided into many substrains. 
The real test, however, in a Beduin's eyes, is whether a strain has only one name, for if so it can never be accepted as pure-bred, and stallions are only used as sires from those strains which possess double names.

The reputation of the Kehîlan and the Séglawi Jedrán for speed received singular confirmation in 1884, when Hadramaut, the property of the writer, but bred by Mr. Wilfrid Blunt at Crabbet Park, won the Oriental Stakes, at Sandown Park, beating the winner of a similar race at Newmarket a fortnight previously, while Halfa, an own sister to Hadramaut, ran third. These two were by Kars, a Séglawi Jedrán of Ibn Sbeni, who was purchased by Mr. Blunt at Aleppo, from Mahmud Aga, a Kurdish Chief of Irregulars, who obtained him as a two-year-old from the Fedaan Ánezeh, and when he was three years old rode him to the war in Armenia, when nearly every other horse perished. The dam of the pair was Hagar, a Kehîlet Ajuz, and so the best strains of the desert were commingled, with satisfactory results. Moreover, the horse which divided the brother and sister, and was second, bore such plain indications of having English blood in his veins that when in the paddock at Newmarket, the late Major G. B. Luxford and the late Colonel G. Hutton, two friends of the writer, as well as himself, all having had experience in training and riding Arabians, and the Arabian-English cross, at once exclaimed, when Asil made his appearance, "That's not a pure-bred Arabian, but half-English." Nobody used to the two kinds can easily make a mistake, for there are very essential differences; and in this case it is not difficult to trace the probable source whence the English blood was derived. Captain Tryon purchased the mare, Belkis, at Aleppo in 1881, in foal with Asil to an Abeyan Sherik horse; but he probably was quite unaware that about twenty years previously the late Mr. John Johnstone, of Heath Hall, Annandale, had carried out a series of experiments at Aleppo crossing Arabian mares with English thoroughbred sires, and also English thoroughbred mares with Arabian stallions, the results of which he published in the Sporting Magazine 
in 1864. Many of the produce were parted with at Aleppo, so a cross of English thoroughbred blood is easily accounted for.

In the account published by Mr. William Palgrave of his visit to Nejd, disguised as an Oriental, he remarks :-

"Nejd horses are especially esteemed for great speed and endurance of fatigue; indeed in this latter quality none come up to them. To pass twenty-four hours on the road without drink and without flagging is certainly something, but to keep up the same abstinence and labour conjoined, under the burning Arabian sky for forty-eight hours at a stretch, is, I believe, peculiar to the animals of the breed!"

It is this spirit and endurance that give Arabians their chief value, which is appreciated far more by almost every foreign nation than by our own, for we perhaps set undue store by actual size. We forget the old saw, that it is "symmetry and action that carry weight"; to which must be added courage and resolution to bear fatigue and go through with the allotted task. We are afraid of losing bulk by reintroducing Arabian blood, though this seldom extends beyond the first cross; and on one occasion the winner of the first prize in the four-year-old class for weight-carrying hunters, at the Dublin Horse Show, was the son of a little Arabian sire, said to be barely 14 hands.

In testimony of the worth of Arabian horses for campaigning purposes, reference may be made to a memorandum drawn up by the late Colonel Barrow, of the 19th Hussars, who was so well known as one of the chief organisers of mounted infantry. The memorandum referred to the Arabians, on whom the 19th Hussars were monnted during the campaign on the Nile for the relief of Khartoum. They were stallions of 14 hands, between eight and nine years old, and were bought in Syria and Lower Egypt at about $£ 18$ per head. Colonel Barrow calls attention to the fact, as being very remarkable, that out of 350 horses during nine months in a hard 
campaign, only twelve died from disease, and this he attributes, firstly, to the climate of the Soudan being most suitable for horses; and, secondly, to the Arabian horse having a wonderful constitution, and being admirably suited for warfare in an Eastern climate. The distance marched, irrespective of reconnaissances, \&c., was over 1,500 miles, and the weight carried averaged over 14 stone. The weather during the last four months was very trying, food was often very limited, and during the desert march water was very scarce. When General Stewart's column made its final advance on Metammeh the 155 horses the 19th had with them marched to the Nile without having received a drop of water for fifty-five hours and having had only $1 \mathrm{lb}$. of grain, while some fifteen or twenty had no water for seventy hours. At the end of the campaign, and after a week's rest, the animals were handed over to the 20th Hussars at Assouan in as good order as when they left Wady Haifa nine months previously.

Such a record compares very favourably with the experience of the mounted troops during the South African War!

Professor H. F. Osborn, of the American Museum of Natural History, has formulated the distinctive features of the Arabian horse as having a relatively short skull, very wide between the eye-sockets, which are high and prominent, giving the eyes a wide range of vision; while the profile of the face is concave, due to a relatively large brain.

There is a slight depression in front of the eye-socket. The lower jaw is slender in front, and deep and wide-set behind. The chest is rounded; the back and loins well ribbed up, due to the fact that there are only five, instead of the normal six, lumbar or ribless vertebræ. The pelvis has a nearly horizontal position-a characteristic connected with great speed. The croup, or tail region, is comparatively high, while the tail has only sixteen instead of eighteen vertebrae.

In the limbs the shaft of the ulna, or small bone of 
the fore-legs, is complete, the same feature being also observed in a skeleton of Grévy's zebra. The cannon bones are elongated and slender, and the pasterns are long and sloping, while the bones are denser than in ordinary horses.

It was not until the seventeenth century, especially after the Restoration, that Eastern horses were imported in such numbers as greatly to influence our home stock. From some one or more of such sires all our best racehorses of those and modern times have been descended; and all the winners of the great three-year-old races may be invariably traced to one of the three celebrated sires of the eighteenth century, the Darley Arabian, the Godolphin Arabian, and the Byerley Turk, as chronicled in Weatherby's Stud-book.

The leading position must be assigned to the first named, and by the kindness of Miss Darley I am enabled to give the exact account of the purchase of this horse, the most famous in the world, from a letter forwarded by Mr. Darley from Aleppo to his brother at Aldby Park. This letter Miss Darley discovered when looking through old family documents, and has most kindly furnished an exact copy.

Aleppo,

Dear Brother,

$$
\text { Ye } 21^{\text {st }} \text { December, } 1703 .
$$

Your obliging favour of the $7 \mathrm{Aprill}$ came to my hands the $16^{\text {th }}$ October, by our convoy, and by whom I assygne these, $w^{\text {th }}$ hope will have better success in arriving safe than the many letters wrote you, besydes I have never been favoured with any letters from you but that $\mathrm{I}$ immediately answered $\mathrm{y}^{\mathrm{e}}$ first conveyance that succeeded after receipt thereof, being very desirous of maintaining a punctuall correspondence, for nothing is more gratefull to me than to hear the welfare of my Relations \& friends, and more particularly your good Self. I take notice what discourse you have had with my Father \& its very true he has ordered my returning, $w^{\text {ch }}$ I should gladly obey would my affaires permit, therefore hope he will be pleased to excuse my delay untill a more propper season, for I assure I am not in Love with this place to stay an hour longer than is absolutely necessary. Since my Father expects $I s^{1 \mathrm{~d}}$ send him a stallion I esteem myself happy in a colt I bought about a year and a half agoe, with a desygne indeed to send him $\mathrm{y}^{\mathrm{e}}$ first good opportunity. $\mathrm{He}$ comes four the latter end of March or the beginning of Aprill next; 
his colour is Bay \& his near foot before with both his hind feet have white upon them, he has a blaze downe his face something of the largest. He is about 15 hands high, of the most esteemed race amongst the Arabs both by Syre \& Dam, and the name of the said race is called Mannicka. The only fear I have at present about him is that I shall not be able to get him aboard this war time, though I have the promise of a very good \& intimate friend the Hon ${ }^{\text {ble } \&}$ Rev ${ }^{\text {nd }}$ Henry Bridges, son to $\mathrm{L}^{\mathrm{d}}$ Chandoes, who embarks on the Ipswich, Captain William Waklin, who presume will not refuse taling in a horse for him since his brother is one of $y^{e}$ Lords of $y^{e}$ Admiralty ; besides I desygne to go to Scand ${ }^{n}$ to assist in getting him off. W W $^{\text {eh }}$ if I can accomplish \& he arrives in safety, I believe he will not be dis. liked, for he is esteemed here where could have sold him at a considerable price if I had not designed him for England. I have desired Bridges to deliver him to my brother John or Cozen Charles who he can find first \& they are to follow my Father's orders in sending him into $y^{\mathrm{e}}$ country. For $y^{\mathrm{e}}$ ffreight \& all charges to his landing I will order payment of, tho' am not certain $w^{t}$ it may amount to. Ain told by a friend who sent home a horse last year, it cost him incre $100 \mathfrak{L}$ Stg. When you see Coz Peirson pray tender him my humble salutes, \& since his Daughter is ready I shall endeavour with all speed to prepare inyself. With Mr. Brailsford I am acquainted $\&$ were he not of too ficle a humour it $w^{\text {l }}$ be happyer for him ; yet I wish him success in his voyage to Portugl. I am sorry for the death of Lawrence, as of all ffriends. I have given my friend Mr. Bridges 2 chequuens to drink with you (in case you are in towne) $\&$ Brother John, \& Coz Charles, $w^{\text {h }}$ I w $w^{d}$ call to mind is a present worth $\mathrm{y}^{\mathrm{r}}$ notice.

I heartily wish you health and prosperity ( $\&$ as the season invites) amerry Xmas with many succeeding.

I respectfully remain dear brother, Your most affece Brother

Thomas Darley.

The statements that have from time to time been made, that the Darley Arabian belonged to the Kehîlan Ras el Fedawi family, are therefore now shown to be incorrect, and also that he was foaled in 1700, and not in 1702, as has also been published.

With war risks added to the usual ones inseparable from so long a voyage, especially before the days of steam transport, the anxiety must have been great until the colt was safely arrived at his future Yorkshire home; but if it had only been known at the time that the horse was the most valuable one ever known, how intensified would 
have been the anxious moments regarding him! Racehorses of the highest class, hunters, coach-horses, hackneys, trotters, and ponies, all claim descent in every civilised nation from that bay colt with " a blaze downe his face, something of the largest." If any mishap had happened to him on the voyage, or if Mr. Thomas Darley, tempted by "a considerable price," had resold him at Aleppo, England would have known no Flying Childers, no Eclipse, and might never have assumed that commanding position in manufaeturing the race of thoroughbreds, which has since been hers. It is true that the other two great Eastern horses already mentioned would have effected much, and the services of the three were necessary to achieve the magnificent result we can now boast of; but undoubtedly the greatest of the three was the Darley Arabian, and his blood now predominates over the other two combined. A full-length portrait in oils still hangs on the walls at Aldby Park, and is evidently an excellent likeness of the horse, with the precise markings mentioned by the consul at Aleppo.

Of the other two famous progenitors of our present thoroughbreds little is known of the Byerley Turk, beyond that he was ridden by his owner, Captain Byerley, as a charger during King William's campaign in Ireland (1689); and had been obtained by him as a prize of warfare, when its then rider, an Emir, had been slain in a battle with the Turks.

The Godolphin Arabian was imported in 1726, stood 14.2, and was a Jilfan Stam el Bulad. His story is a romance of the Turf. The legend runs that the horse was sent as a present by the Emperor of Morocco to Louis XIV.; and the black groom in charge of him was given orders never to lose sight of him, so long as the horse lived. Such were the spirits of the animal that he proved too great a handful for the royal grooms, and in order to tame him he was handed over to the chief of the kitchen, to be employed daily in fetching the requirements of the king's household. Even the hard work he then went through could not subdue his spirit, and so it befell 
he was sold to a water-carrier, and descended to the meanest servitude. Through all his misfortunes, however, he was attended by the faithful Moor, who scrupulously carried out the orders he had received. One fine morning it befell that the wife of a well-to-do Quaker living in Paris presented her husband with a little son. In gratitude the happy father registered a resolve to do some kind action that day, and taking his hat sallied forth into the streets. There had been a sharp frost, and the roads were slippery, and presently Mr. Coke was witness to a horse falling with a water-cart to which he was harnessed. The man in charge commenced to beat the horse without mercy, whereupon Mr. Coke, mindful of the purpose for which he had come out, remonstrated with the driver for his cruelty, and eventually purchased the animal for $t 3$. Mr. Coke then found himself in a dilemma as to the disposal of his newly-acquired property; but the Moor, who was as usual watching his charge, came up to him, and unfolding the whole history of the horse offered his services in looking after the animal, which Mr. Coke was only too glad to accept; and thus he learned the undoubted value of the animal he had so strangely acquired.

The hor'se was imported to England, was resold to Earl Godolphin, the heir to the Dukedom of Leeds, and was then sent to Gog and Magog, an estate of the Duke's about four miles from Cambridge, where the Duke maintained a breeding stud; and there the horse remained for three years in the humble and unsatisfying position of "teasing " the lord of the harem, Hobgoblin, into carrying out his duties. Each year a mare, Roxana by name, had been brought into the presence of the two, but in 1731 the Godolphin's passions overcame him; he broke loose from the groom, and fought Hobgoblin with such fury he killed him before they could be separated. Fortunately for the Godolphin, and still more fortunately for the Turf, it was decided to promote him to be sultan in the place of the vanquished Hobgoblin, no doubt on the principle that " the brave deserve the fair." Directly his first produce made their appearance on the race-course they justified the 
honour which had befallen to their sire by sweeping everything before them, and a host of his sons and daughters took rank amongst the great stud celebrities of their day. It is rather remarkable, however, that his descendent in tail-male, the famous and undefeated Barcaldine, and also his sire Solon, should be possessed of that fury which carried their great ancestor victorously through the duel with Hobgoblin, for they were two of the vilest-tempered horses of their own or any other day. Yet honour should be paid where honour is due, and the Godolphin established a great line, which has been adorned by the mighty deeds of some of our most famous horses. Although sent as a present by the Emperor of Morocco, and Syria is a long way from Morocco, Lady Anne Blunt gives in a letter these cogent reasons for giving credit to the statement that the horse was an Arabian, and not a Barb:-

"Then, as to the Emperor of Morocco, if he wished to make a present to the King of France, he would certainly have preferred to give a stallion brought from Arabia, rather than a local one. To this day it is, and has been for centuries, customary in North Africa to send to Arabia for anything wanted to be specially good. At least, I have heard instances of this and been informed that it is so.

"His personal stable name being 'Sham'-the Arabic word for Syria-implies importation via Syria. I say via Syria, as I should imagine he must have been from a desert tribe, since his portrait is not a bit like any of the many Barbs I saw in Algeria; nor is it like the Syrian country-breds, so-called Arabs (with much Arab blood in them, but nothing pure remaining) which one sees brought from Syria (and sometimes entered in the G.S.B., some that one knows cannot be real). In $1881 \mathrm{I}$ saw a beautiful bay four-year-old mare in Ali Pasha Sherif's stud in Cairo, with a crest the image of the Godolphin Arabian's, and otherwise resembling him."

Before taking leave of this subject, honourable mention must be made of the magnificent stud of Arabians at the Crabbet Park stud. There, gathered together by the un- 
remitting trouble and vast expense of Lady Anne Blunt and Mr. Wilfrid Blunt, may be seen magnificent specimens of the bluest blood of the desert; and the judicious care and rearing of these Eastern treasures has built up a reputation renowned throughout the world. From all quarters of the globe eager purchasers make long journeys to acquire some of the invaluable blood, to enrich that of their own home-bred stock, while the only nation apathetic in this respect, it must be allowed, is our own. England, it must be confessed, has not learned to appreciate the Arabian as he deserves. With the rapid growth of mechanical transport, and the consequent serious diminution in horse-breeding by the nation, it seems scarcely probable she will ever wake up to the opportunity she now possesses, that will only too surely slip away from her grasp altogether.

\section{BARBS.}

We are accustomed to look upon the Barb horse as the first cousin of the Arabian, though some persons claim that he is the elder brother. The Libyan horses were famous from very early times, and King Solomon showed his appreciation of them by sending into Egypt to buy horses, for which he paid an hundred and fifty shekels of silver ( 1 Kings $x$.), though the value is somewhat discounted when we are told in verse 21 that silver "was nothing accounted for in the days of King Solomon." He could only have sent so far to purchase horses for either, or both, of two reasons: that he could not buy sulficient horses at home, or that Libyan horses were the best that could be procured.

The Barb and the Arabian differ so much in appearance that the cleavage between them must have taken place many ages ago, presuming both are descended from the slender Hipparion, the one with the hollow depression in front of the orbit.

In evolving the thoroughbred horse the Barb has taken as large a share as the Arabian, and certainly resembles it more in general appearance. Many Barbs are perfect 
likenesses of small thoroughbreds, especially in the manner of carrying the tail, which is not held in the pronounced arch so characteristic of the Arabian. In the point of endurance the Barb is little inferior to the other, if, indeed, it is not the equal; but in point of racing ability as a rule there is a considerable difference, the ordinary allowance the Barb receives being 14 lbs. But in one important respect it certainly is superior, being a capital hack, rarely stumbling, an advantage which, unfortunately, cannot be claimed for its rival. This no doubt is the result of the different conditions prevailing in the respective countries, for Morocco is a rough, mountainous one, where the paces chiefly required are the trot and the walk. The Arabian, on the contrary, is not called upon to trot, only to wall; canter, and gallop, and long centuries have developed the special paces which are most desired.

The purest Barbs are found in the western portion of Morocco; for the invasion of Sidi-Okba into Africa, and still later the invasions of the fifth and sixth centuries after the Hegira, must have caused much mingling of blood in the eastern part of the country, through the Arabian horses the invaders brought with them. The Western Barbs have little or no trace of Arabian blood in their appearance or general characteristics.*

In the neighbourhood of Algiers the Barbs are much intermingled with Arabian blood, introduced by the French; and the dwellers in the desert also possess some good Arabian strains. Throughout Morocco, however, a vitiating influence has long been at work, and has made great inroads into the purity of the breed in recent years-the pernicious practice of almost universal mule-breeding.

* "A prevailing drawback to the improvement of the breed is mentioned by Kaid Sir Harry Maclean as follows: "There is an old custorn all over Morocco, except in Tafelet, that Governors can seize all exceptional good horses for the Sultan, and this is greatly the reason that the breed has deteriorated so much. Only Moors who have Foreign protection are able to breed good horses, and most of them have a good deal of English and French blood. In Tafelet the Governors have not the same power, and the tribes there would not submit to this." " (Drimnin House, Tangier, October 8, 1911.) 
However much scientists may teach the doctrine that the subsequent offspring are not affected by any influence resulting from a former alliance, practical horsemen will not endorse their teaching. The Moors themselves universally admit, and deplore, the custom, but-the prices for a good mule are so tempting they cannot refrain from breeding as many as they can. In only very few instances are animals to be now found free from the taint of the donkey amongst their female ancestors. Too often it can be detected by the shape of the foot, and there is also often a faint list on the back, sometimes stripes inside the forelegs, and very occasionally a faint marking at the withers, in the subsequent foals of a mare which has bred a mule.

Barbs must have been imported into England in very early days; and it is on record that Alexander I. of Scotland imported two in the reign of Henry I. of England, presenting one to that king and the other to the Church of St. Andrew's.

Of the Barbs there are three chief breeds, Mogador being the nearest port to their natural home.

\section{Abda.}

These are fine-bred, rather narrow-girthed, light-fleshed horses, showing great quality, and in general appearance like an English race-horse--in fact, it is impossible to discern at the first glance that they are not thoroughbreds. In height they are about 1.5 hands, though they are frequently taller, and occasionally reach 15.3 . They are bred near the coast of Mogador.

\section{Shawya.}

A strong, powerful, deep-bodied race, with great girth, and short-legged. The general type is that of the English Galloway, but with niore appearance of breeding. In height, about 15 hands to 15-1 $\frac{1}{2}$. These are excellent horses for work, strong constitutioned, with big bone. They are fast, and stay well, and are bred in the interior, behind Mogador. At Welbeck the Duke of Portland has a breed of Lippasano 


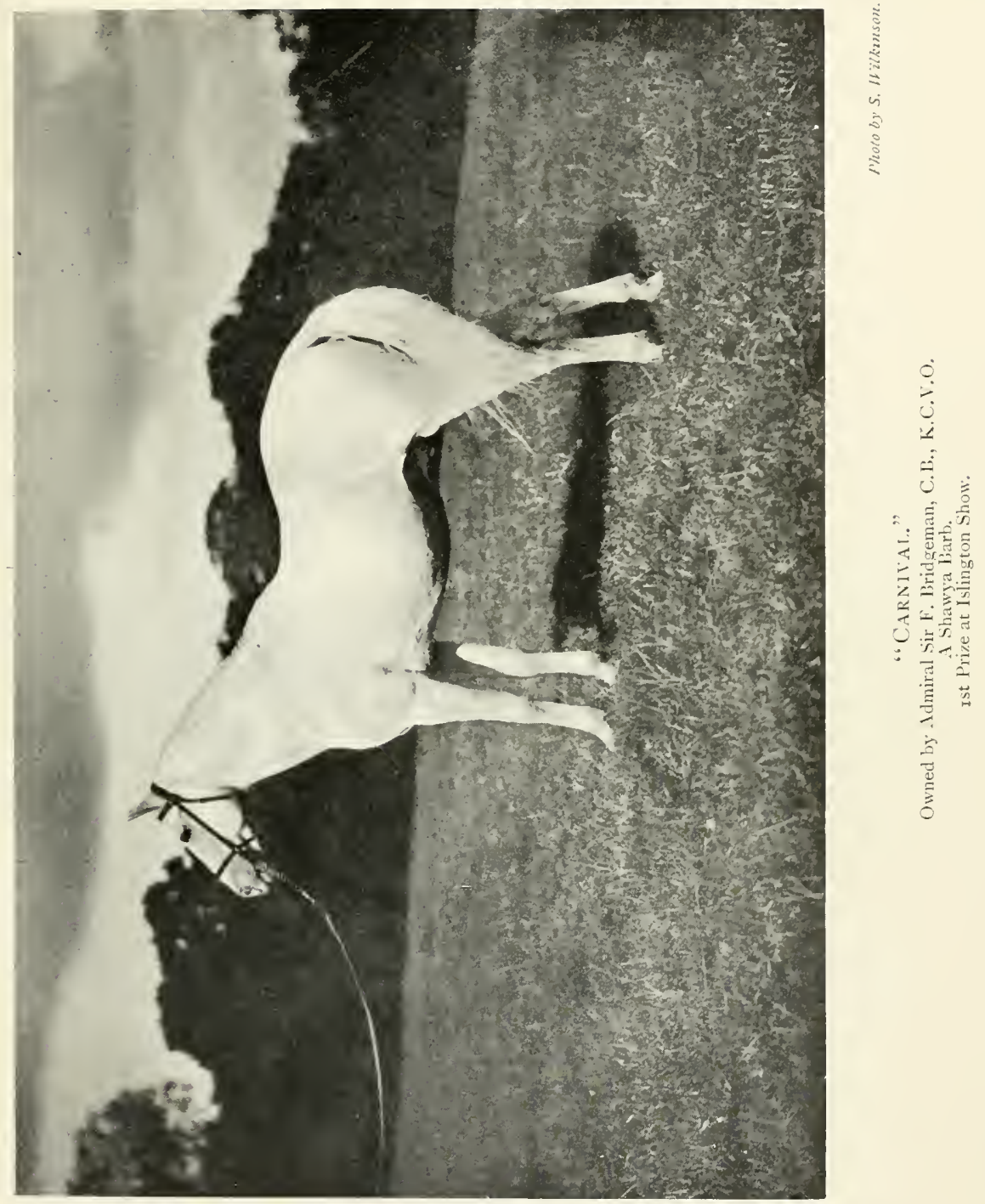



horses, which are so like the Shawya Barbs it seems probable they derive from this source. At Copgrove Hall, in Yorkshire, Admiral Sir Francis Bridgeman has a Barb stallion, Carnival, a winner at Islington, who has sired some excellent stock, and is an undoubted Shawya from his appearance. His colour, too, is typical of the breed, white being a prevailing colour anongst animals of this strain.

\section{Ducalla.}

An intermediate type between the other two, combining the characteristics of both. It is bred near the coast.

Besides these distinct breeds is the ordinary hack, termed "Kedar," with high knee action, and carrying the head well up; very suitable for its purpose, and a docile riding horse.

Nearly forty years ago Captain Parker Gillmore wrote his experiences of three years' sojourn in the East, and gave as his opinion that the chief cause which tends to produce dissimilarity in the action between Arabians and Barb horses is the different character of the districts in which each is reared. Where the high-caste Arabian is brought up the country is undulating, sandy, and sparsely covered with vegetation, and there the mare and colt can gallop without danger. But in Barbary it is rough, rocky, and mountainous, intersected with ravines, and in many portions thickly covered with shrubs. On such ground no horse can gallop with safety, and at any great pace would be sure to come to grief. He therefore trots, keeping his legs well under him, and is thus able to turn on one side or the other with great facility. The nature of the ground also causes him to raise his feet high at each step. And thus is produced a signal example of the survival of the fittest.

\section{Spanish Horses, The "Genet."}

When considering the foreign elements in our present horses, the share the Spanısh genet has had in the making of them must not be lost sight of. They are a hardy, 
docile, good-constitutioned race ; but, like Eastern horses in general, nature must not be interfered with, for geldings are only too prone to lose their natural characteristics. When subjected to a surgeon's knife they become timid creatures, apt to shy whether there is reason or no. Amongst many good qualities they have splendid bone, with excellent hocks and knees; and when I first lived in Spain nothing struck me more than the splendid limbs almost every animal had. They are capital hacks, bend the knees, and flex the hocks well, and seldom make a false step; they walk and trot well, but galloping is not one of their paces, unless they are crossed with Eastern or English blood. They are low in stature, especially in Andalusia, but still they are lengthy, and are "horses," not "ponies," and the want of size is chiefly attributable to the arid nature of their country during the long summer, when no rain falls for months, and food is therefore difficult to obtain. Their sure-footedness is remarkable, over ground worse even than the most rugged parts of Dartmoor, as any one hunting with the Calpe Hunt, either in the cork-woods or amongst the "craigs," will cordially endorse. When stabled their food is barley and chopped straw, and on this they thrive and do well. It used to be an interesting sight to watch an Andalusian farmer winnowing his grain. Some hard ground having been selected, droves of mares, many in foal', were tied in a long line by their necks, as many as thirty sometimes being in one string, and then they were driven round and round, hour after hour, over piles of barley straw laid on the ground. Often the mares had sharp shoes on their fore-feet to assist in breaking up the straw into little bits and treading out the grain, and this was the only use the mares were generally ever put to. At other times they ran in large droves, and in the spring of the year stallions were turned out amongst them.

As soon as the straw was adjudged to have been broken up sufficiently, and all the grain had been detached, the mares were withdrawn; and the next process was to cast the dusty mass high into the air with shovels when a brisk breeze was blowing, which quickly blew away the dust 
in clouds, while the straw was carried a short distance away, collecting together in a huge mass, and the heavier grain fell in a large heap close by. It was a primitive way of threshing, but it was cheap and effected its purpose, and no doubt had been carried on in the same way for countless ages. The grain was then collected and the straw put in the barn, and this was the everyday provender throughout the country.

The Spanish horse has need of first-rate legs and feet, for he is subjected to tests which would nake an English jobmaster quickly protest. There was nothing an ambitious young caballero loved more than when, got up in his very best, and mounted on his favourite steed, he galloped for about fifty or a hundred yards as hard as ever he could go, on the ill-paved street, and then with one jerk of his cruelly powerful bit stopped the animal dead in one stride, before an admiring crowd. Then he would turn round and gallop back in the same way, and repeat the performance several times. With an English horse one would expect to find a curb sprung or very swollen legs and joints the next morning, but I never knew a Spanish horse any the worse for such a performance. When trotting the exceeding suppleness of the limbs is remarkable, especially the knees and fetlocks which are most elastic, but the action is not always true, for dishing, such an eyesore to an Englishman, is rather admired in Spain if the horse lifts his knees well up. As a rule they are not handsome horses, but have big back-ribs; and owing to their vicinity to Morocco, and the long period of rule of the Moors in the South of Spain-they held Andalusia eight hundred yearsthere is a great deal of Barb blood even in the commonest horses. They are wonderful pack animals, carrying enormous loads for hours over very rough mountainous paths, and probably very much resemble the old pack-horse of England. There is no cart-horse blood in them, and therefore they respond at once when crossed with Eastern or thoroughbred blood, so that in a couple of generations they look almost like thoroughbreds. It was the palmy days of Spanish racing when I was there, and 
breeders were vieing with one another to produce animals to win races, many of which were valuable, for countrybred horses. What was found to be the best system was to cross the country mare with an Arabian, and then follow on with the thoroughbred horse. The Arabian at once knocked out the ungainly points, the very low croup and long back, and put a fashion into the progeny which remained for generations, and this was seldom effected by using an English sire in the first instance. No doubt good horses were occasionally bred by so doing, but then in all probability the mare was an exceptionally shapely animal, and most likely had some Barb breeding in the background which was not known. I have also seen good horses bred by using the English horse first, and then an Arabian. For the general run of mares, however, experience seemed to teach that it was preferable to use an Arabian sire first, and then to continue with English thoroughbred ones for subsequent generations.

It should be added that roaring and whistling are quite unknown amongst them, possibly due to the very dry climate. I even remember an English thoroughbred mare being taken out there "that made a noise," which in the course of twelve months became so perfectly clear in her respiratory organs she would have passed any veterinary examination, and have received a certificate of being "sound in wind." 


\section{THOROUGHBRED HORSES}

T VOLVED from the original sources of Eastern blood, and our own native racing stock, are our present thoroughbred horses, which have so often been the theme of brilliant writers that it seems difficult to approach the subject from a fresh standpoint. "Good wine needs no bush," however, while long familiarity has not in my case induced the contempt it is usually supposed to instil; for, on the contrary, my admiration for the intelligence, the usefulness, the courage, and the enduring capacity of the breed remains just as great as time goes on. Excepting possibly where ponderous weight is the chief attribute, there is no race which is not improved by a dash of thoroughbred blood, and without it there is apt to be lacking the metal and fire which are so necessary for the completion of arduous tasks. Ask a horse without breeding to gallop through two or three deep fields, and long before the end is reached the animal is reduced to a walk, and has no energy to surmount a stiff fence without a rest; yet a well-bred animal, apparently not equal to carrying half the weight, will gallantly gallop on, carrying quite as heavy a weight as the other, and take the fence without a pause. Though many an active under-bred horse is gifted with a surprising burst of speed for a short distance, it cannot sustain the effort, and is soon done up, and it is in the power of maintaining pace and strength when blown that the thoroughbred horse excels all others. Moreover, a good-tempered, docile bloodhorse can scarcely be put to any description of work in which he will not beat the low-bred animal, in proportion to the powers of the individual. Even in moving heary 
weights it is astounding what a light-looking thoroughbred horse can achieve, as may often be seen in cabs, omnibuses, and tram-cars - though mechanical traction is so rapidly usurping the place hitherto held by horses, that such spectacles must inevitably become much scarcer in the future. There is on record a match which took place at Dycer's Repository in Stephen's Green, Dublin, about sixty years ago (often related to me by my old friend, the late Mr. Joseph Studholme, of Ballyeighan, King's County, who was well cognisant of all the details, his neighbour, the late Mr. J. Bennet, of Grange, having been chosen the umpire). The question which was to be solved was whether a thoroughbred could stand up under as great a weight as a low-bred horse. Unfortunately I cannot give the actual details, through having mislaid my notes of the occurrence, but substantially what happened was this. Only two-year-olds could be obtained at such short notice to champion each race, and weight was piled up until the cart-bred animal lay down. The thoroughbred not only stood up under the same burthen, but also actually walked out of the yard with the weight on its back, which amounted to nearly 24 stone. The purebred horse is not, however, intended by nature for contests of this description, nor is his active temperament adapted to a long-sustained dead pull, for though his high courage may induce him to do his best, the more phlegmatic nature of the Shire, or Clydesdale, or Suffolk Punch, is better suited to jobs of this description.

The métier of the thoroughbred horse is speed, activity, and a high state of nervous energy, and this especially adapts him for the race-course, which is the most effective test that could possibly be conceived; while the animals which pass this ordeal with credit are invaluable as progenitors of the various light breeds of horses, whether hunters, hacks, cavalry remounts, or light harness horses. The training for a race searches out any weak spot in limb or constitution, while the actual contest exposes the working of the mechanism, and tests the courage to the last degree. It is in this respect that the showyard system is weak, for a great winner of prizes may never have done a day's work in 


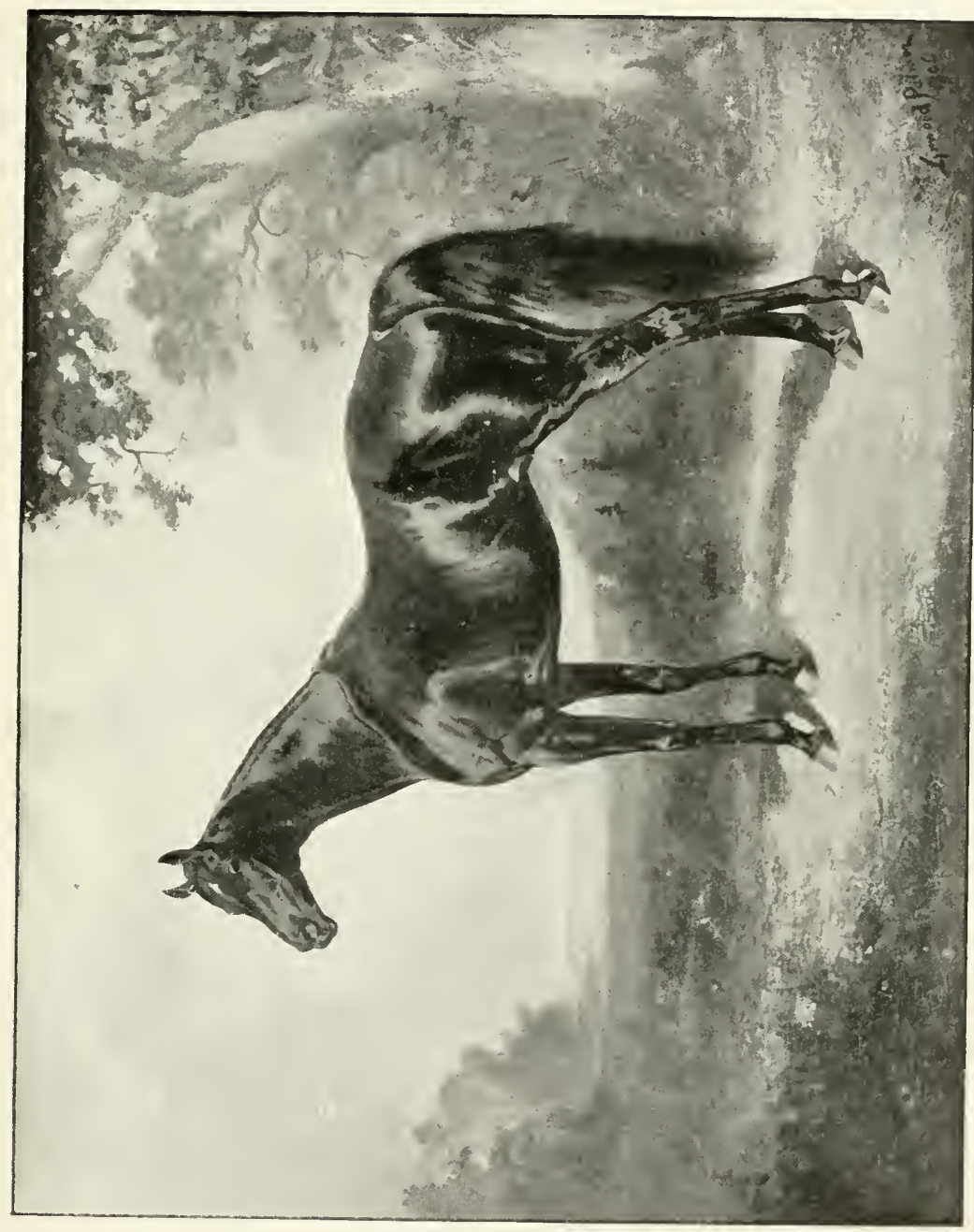

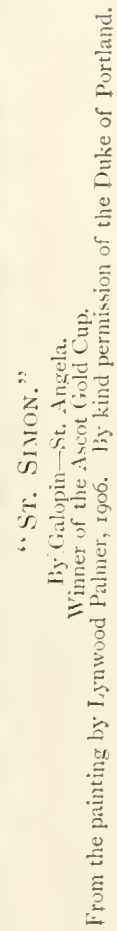



his life, and possess a soft spot which is sure to be transmitted to its half-bred progeny. Moreover, qualities allowed to lie dormant are very apt to wither from inanition and disappear in the course of time, and the progeny of the indolent and luxurious are inclined to become even more so than the parents.

The world-famous Oberlandstallmeister, H.E. Count Lehndorff, who for a great number of years has been entrusted by the German Government to apply, at his discretion, the annual sum of money voted by the Government for the purchase of stallions and brood-mares for their different studs, has placed on record in his " Horse-breeding Recollections" his views about the English thoroughbred horse, and they are so applicable to the present subject, that I venture to quote them here:-

"The principal requisite in a good race-horse is soundness, again soundness and nothing but soundness; and the object of the thoroughbred is to imbue the limbs, the constitution, and the nerves of the half-bred horse with that essential quality, and thereby enhance its capabilities.

"The thoroughbred can, however, fulfil its mission only provided the yearly produce be continually subjected to severe trials in public. The only appropriate test, proved by the experience of two centuries, is the race-course. The last struggle for victory, in which culminates the exertion of the racer, results from the co-operation of the intellectual, the physical, and the mechanical qualities of the horse, the development of which combined power is higher and more reliable than any that can be obtained in the same animal by other means. The combination of those three qualities forms the value of the horse destined for fast work: the mechanical, in respect to the outward shape and construction; the physical, as regards the soundness and normal development of the digestive organs and motive power; the intellectual, or the will and the energy to put the other two into motion and persevere to the utmost. The attained speed is not the aim but only the gauge of the performance.

"The grand ideal principle which places this test so 
incomparably higher than any other, based on the individual opinion of one or more judges, is the absolute and blind justice, personified in the inflexible winning-post, which alone decides on the race-course; and the irrefutable certainty that neither fashion nor fancy, neither favour nor hatred, neither personal prejudice nor time-servingfrequently observable in the awards at horse-showshave biased the decision of hotly contested struggles as recorded in the Racing Calendar for the space of 170 years. This it is that gives the English thoroughbred horse a value for breeding purposes unequalled and looked for in vain in any other species of animal creation.

"In the production of our half-breds it has become an absolute necessity to use thoroughbred stallions not only with performances of a high order, but also that our cavalry horses may answer certain conditions and forms about make and shape laid down in order to prevent their deterioration."

Fanatics who would put an end to racing, looking only from the one-sided view that an opportunity for gambling is thereby supplied, and quite ignoring the fact, only too notorious, that in these days the chief wagering which takes place amongst the middle and lower classes is upon football matches, and even cricket matches, would inflict such a crushing blow on all the different breeds of light horses as they can be little aware of, and which, if long continued, would reduce horses again to almost " prairie "value.

If further witness is required as to the great value of thoroughbred blood in improving other breeds, the very thoughtful chapter should be studied on the "Value of the Thoroughbred for other Breeds," by Baron Burchard von Oettingen, in his invaluable work, "Horse Breeding in Theory and Practice," the fruit of his many years of observation whilst holding the post of Landstallıneister and Director of the Royal Stud at Trakehnen. On p. 50 he remarks: "All half-bred horses of the old and new world, even the Trotters, have by mingling with the Thoroughbred, produced the required steel in their breeds, which otherwise could not have been produced as well and as quickly. Even 
the breeds of the Steppes of Russia, America, and Australia, have, with the aid of the Thoroughbred stallions (often unfortunately of very low character quality), influenced the capabilities of their horses. When the celebrated Cossack officer, Hetman Platoff (the celebrated stallion, Hetman Platoff, born 1836, was called after him), about a hundred years ago, during the fight for liberty against Napoleon in the West of Europe, learned to know and to esteem the Thoroughbred and other fine breeds derived from the same, he caused to be imported many Thoroughbred stallions of good and of the best class, into the Cossack breeding stables near the Don, and the neighbouring Steppe breedingplaces. The consequence was that Russian cavalry soon after, in fact up to the middle of the last century, were mounted on the best horses an army ever possessed."

A study of the earliest tap-roots of the various families which constitute the thoroughbred of to-day, about fifty in number, discloses the fact that a number of them were Barb mares, and some of them so-called Royal mares; but in no case, as far as is known, were any of them pure Arabian mares; and since the Arabian is fleeter, and in many respects superior, to the Barb, the tap-roots might have commenced from superior sources than was the case. The Royal mares may, indeed, have included a pure Arabian among their number, for what their breeding was can now never be known. Charles II. received as part of the dowry of his Portuguese wife, Catherine of Braganza, Tangiers in Morocco, and subsequently dispatched his Master of the Horse in quest of horses for the royal stables, and the mares brought over by him have since been called Royal mares; but it must not be forgotten that long before that date there was racing in England, and Gervase Markham, writing in the reign of King James I., bears testimony to the excellence of the English race-horse of that period. $\mathrm{He}$ writes :-

"Again, for swiftness, what nation hath brought forth that horse which hath exceeded the English-when the best Barbaries that ever were in their prime, I saw 
them overrunne by a black hobbie at Salisbury; yet that hobbie was more overrumne by a horse called Valentine, which Valentine neither in hunting nor running was ever equalled, yet was a plain-bred English horse both by syre and dam? Again for infinite labour and long endurance, which is to be desired in our hunting matches, I have not seen a horse to compare with the English. He is of tolerable shape, strong, valiant, and durable."

One hundred and fifty years later the opinion of Gervase Markham as to the superiority of English horses on the race-course, was not shared by another very close observer which possibly may be accounted for by the frequent importations that had been made of high-class Arabians during the intervening years, as well as the natural result of stock being bred from imported Barbs and reared in the favourable climate and rich pastures of England. In " A Dissertation on Horses," published in 1756, William Osmer makes the assertion, "Now as nothing is more certain than that no Horses but those of blood can race in our days ... I do here lay it down as a certain truth, that no Horses but such as come from foreign countries, or which are of extraction totally foreign, can race. In this opinion every man will readily join me, and this opinion will be confirmed by every man's experience and observation. . . Such horses who have the finest texture, elegance of shape, and most proportion, are the best racers, let their blood be of what kind it will, always supposing it to be totally foreign."

It is by working on the lines thus indicated that the present magnificent specimens of thoroughbred horses of the highest class have been evolved, but in breeding for speed alone, necessitated chiefly by the prevalence of very short-distance races, and especially the excess of two-year-old contests, many most serviceable qualities are overlooked, to the detriment of the breed in general. Before the development of railways, with their easy transit of competitors from their training grounds to the scene of contest, the mere fact of having to travel long distances by road necessitated the employment of hardy, good-constitutioned animals, 


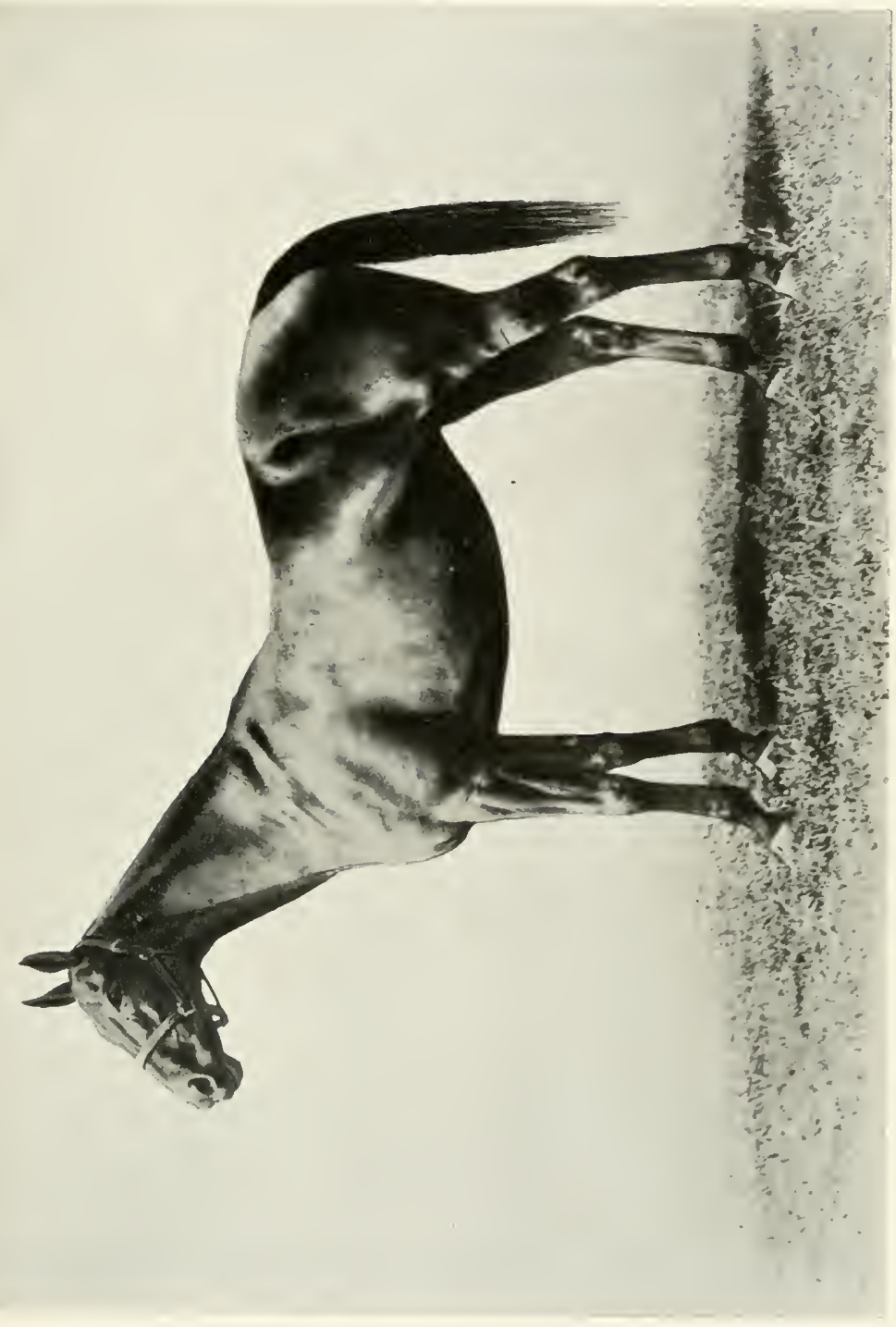

בิ

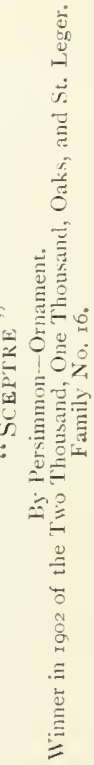



not easily upset by the constant change of stables or by the various incidents met with en route, which could be depended upon to feed with a hearty appetite at the end of each day's journey, a washy, bad feeder standing little chance of success in the race itself. Moreover, it required a capital constitution and the soundest of limbs to run a succession of long-distance heats, which then were the fashionable races of the time. The type of animal required was, therefore, a short-legged, round-barrelled animal, eminently adapted to improve the half-bred horses in the district in which he might be located, whenever his services were required in another sphere. It is no longer a necessity to employ such true-shaped animals to gain success in modern racing; and no matter how leggy or malformed a horse may be, provided he only possesses the gift of speed he is eagerly sought, and also used as a sire, the glamour of success causing breeders to overlook his imperfections. Any one whose mission it is to select a stallion for breeding hunters knows only too well the extreme difficulty there is in finding a true-shaped stallion, and may visit many training stables and look over scores of animals before his wants can be satisfied, even though he may be prepared to pay a considerable price. He will, moreover, see large numbers of horses who do not come up to his ideal, who have won races in their heyday, and would willingly be sold at a much less figure than he is ready to give for the sort required.

Baron Burchard von Oettingen has some trenchant observations on the present deterioration of the thoroughbred which afford much food for reflection, and which he traces to the prevalence of running horses at two years old, and, moreover, gives very carefully worked-out figures in support of his contention. Admitting that two-year-olds and three-year-olds have improved in comparison with older horses, he points out that while the weight-for-age scale has remained the same, as between thern, for over one hundred years, thus showing that each of the two ages has corresponded with the other, either 
advancing or otherwise, yet the scale of weight has continually been lowered between three-year-olds and older horses, showing they have not participated in the improvement claimed for the younger animals. He mentions further :-

"From these weight differences it can be seen that the abilities of four, five, and six-year-olds changed very little up to 1850. An improvement of horses, on the other hand, after six years old gradually ceases altogether. . . Therefrom it follows that the present four and five-year-old race-horses are each $3 \frac{1}{2} \mathrm{lbs}$. worse than those in the middle of the last century. . . . In breeding, where only two-year-olds improve, one can hardly speak of a general progress. .. . Taken altogether, these observations justify us in assuming that, considered from the standpoint of the altered weight differences, the improvement of race-horses took place up to about the middle of the nineteenth century, and also specially that a favourable development of four-year-old and older horses up to the sixth year existed. Furthermore, that simultaneously with the frequent occurrence of races for two-year-olds partly in the beginning of the year, and with the existence of the many short handicaps, a retrogression of the development of race-horses after their third year began soon after the second half of the nineteenth century. The time in which the number of two-year-old race-horses began to exceed the number of three-year-olds denotes the turning-point."

This statement is quite in accord with the apt remark, so frequently made, that modern race-horses are nearly always at the summit of their powers in the autumn of their threeyear-old season.

But the Baron has other serious statements to make on the evil influence of early racing, to which he ascribes the increasing lack of fertility among thoroughbred mares, which he proves by taking the statistics from 1851 to the year 1908 :-

"On the basis of physiological observations and practical experience, we must assume that the present over-exertion, 
especially of the younger thoroughbred stock, for many consecutive generations, has an unfavourable influence on the constitution. These unfavourable effects, which are an especial consequence of the many early races of two-yearolds, are distinctly recognisable, also outside the course, by many retrogressive signs. The most conspicuous of these consists in the fairly regular decrease of the percentage of pregnant mares, from about 80 per cent. in the year 1851 to 70 per cent. in recent years.

"It may further be pointed out that the length of life of stallions is slowly decreasing, which is all the more remarkable, as the progress of hygiene, improved stabling, and other conditions, as well as the more reasonable training of horses, would lead one to expect longer lives. ... The number of stallions which have attained twenty-five years and more has been in no decade greater than in that of 1850 to 1859 , namely, thirty. Already in the following two decades a distinct decrease is recognisable: 1860 to 1869 , twenty-four stallions; and 1870 to 1879 , twenty stallions."

Other practical men testify also to the alteration in the physique of the modern race-horse. John Osborne, the celebrated jockey, who rode his first race in 1816, and is still engaged in training horses, states in "Ashgill and Radcliffe," p. 428: "Horses are very much lighter now; they have neither the bone nor the substance that thoroughbreds had fifty years ago. Of course in the old times they were sweated a good deal. Heavy cloths were put on them, and they were galloped three and four miles in them. That plan has been discontinued for many years. I don't know that sweating is weakening to a horse. Old John Scott was a great believer in bleeding and sweating. I am certain that the constitution of horses of the present day would not stand such work; the modern breed is neither so robust nor so strong. Formerly it was quite a common thing for horses to run three- and four-mile heats. If they were subjected to that now they wouldn't be able to come out of the stable for a month after. . . I I am fully convinced the constitution of horses of the present day is not as strong as it was forty or fifty years ago." 
There is no doubt the successful animal of to-day is a slimmer, more elongated animal than in the old roadtravelling, heat-racing days, and this is well shown in comparing the admirable series of photographs of the two typical horses of their day, Eclipse and Persimmon, published by the Field journal. The skeleton of the former shows a round-barrelled animal, with remarkably wellsprung ribs, who must have had a back like a ram, possessing a first-rate constitution. The front and side views of his skull also corroborate this, while the width between the eyes gives evidence of a large brain within. Except that his withers are so low, the inference is that he would be likely to be a more useful sire for getting hardy stock than the other, who does not appear in so favourable a light in these respects. All my early acquaintances held the same opinion of the alteration in conformation of the thoroughbred horse during the nineteenth century, and were unanimous that the race-horses of their youth were shorterlegged and more hunter-like; and while they were probably not so speedy, they were undoubtedly much hardier and stouter than those we have now. Johnny Doyle, the crack jockey of Ireland in his day, who commenced his career at a race meeting held in Sharavogue Park in 1803, was emphatic on this point, especially stating to me in 1873 that the horses of his early days were much deeper-bodied than now. The owner of Sharavogue Park, Colonel Hon. $J$. Westenra, held the same opinion, and he was the breeder of Whim, by Drone, the dam of Chanticleer; her portrait, which hung in his dining-room, fully bore out his statements. He also bred the great Freney, by Roller, the celebrated four-miler of his day. Lastly, the famous old racing judge, Mr. Richard Johnston, who could remember seeing Blacklock win at York in 1819, and who lived almost to the end of the century, therefore being especially qualified to form an opinion, once stated to me that the racehorses of his early days "were much stouter and hardier, though undoubtedly not so speedy. Sixteen-hand horses were quite common then, and I do not see much difference in actual height. The shape and appearance, though, has 
changed very much, and the older horses were, as a rule, much deeper-bodied and shorter-legged and more hunter-like than they are now."

While no one disputes that the best horses of to-day are in advance of their ancestors, such animals are not available to sire the ordinary utility horse, whose fathers must be sought in a much lower class. It is these which are held to be less truly shaped and of a less hardy nature than a century ago ; and while heat-racing and travelling by road have been swept away for ever, it may be well to consider whether any causes exist for the present state of things, and whether it could be altered for the better. To begin with, the improvement of the breed is scarcely likely to be furthered by the racing of immature two-year-olds, generation after generation; nor is the vast prevalence of races under a mile likely to be of much assistance. It is true the sharp, quick horse is better adapted for crossing a country, and is a decidedly more useful animal as a sire, than the slow, plodding animal which may be a stayer, but has no pace or activity; but there is "reason in roasting eggs," and the horse which dies away after five furlongs is scarcely likely to produce stout stock. A mile is a fair criterion of combined speed and stoutness, and races under that distance should not be given much encouragement. Another probable reason for want of stamina is the very close inbreeding which is the fashion of the day, and many persons seem to imagine that so long as an animal can trace several lines of descent from a recent famous ancestor, nothing better can be desired. They overlook the probability of undesirable points being inherited, as well as good ones, and, indeed, in practice it is found that such is usually the case, while often the good ones seem to be swamped by the bad ones. Though in all animals a very near affinity between the parents seems almost necessary as a starting-point to fix a breed, it cannot be continued with advantage, and if persevered in the offspring may be comely to gaze upon, but will surely lack hardiness of constitution, while the mental faculties will either be feeble, almost to idiocy, or else the temperament will be nervous and excitable and hottempered in the extreme. 
Another regrettable cause for the lack of big bony sires, suitable for country stallions, is the prevalent practice of putting aside such animals for cross-country work if they have not sufficient pace for racing on the flat, and previous to teaching them to jump rendering them incapable of propagating their species. There is an idea now that stallions are more cunning and less to be depended on than geldings, and also are more difficult to train, requiring a greater amount of work through the extra development of crest, and being generally more lusty in habit. This used not to be a bugbear in the days when sweating in clothing was the general practice, and an extra hood or two soon had the desired effect of reducing too large a crest. Any one visiting our steeplechase courses may note numbers of fine, powerful, weight-carrying thoroughbreds, which would have been invaluable as sires in country districts, had they not been ruthlessly denied the pleasures of paternity.

In breeding race-horses it is imperative to choose mares of "running" blood, but it is not absolutely necessary they should have been great winners themselves, although this is very desirable if they have not been subjected too long to the ordeal of severe training, especially as two-year-olds. The late Lord Falmouth frequently expressed the opinion that mares should be sent to the stud after their three-yearold season on the Turf, and his wonderful success entitles his opinion to be considered of the greatest weight. The famous Sir Charles Knightley held as an article of faith that two-year-old racing was most pernicious, stating his conviction that at a time when the young animal ought to be making its frame-it is most striking how a two-yearold suddenly seems to change into a "horse" in the middle of the summer-and especially developing its internal organs with future hopes of maternity, it is unreasonable to expect it to be able to do so to advantage when every effort is being made in its training to denude it of fat, and to increase its muscles to the greatest extent. The system cannot be trusted to stand a dual strain, and the development of one quality must be at the expense of another. It is therefore not a matter for wonder that in 


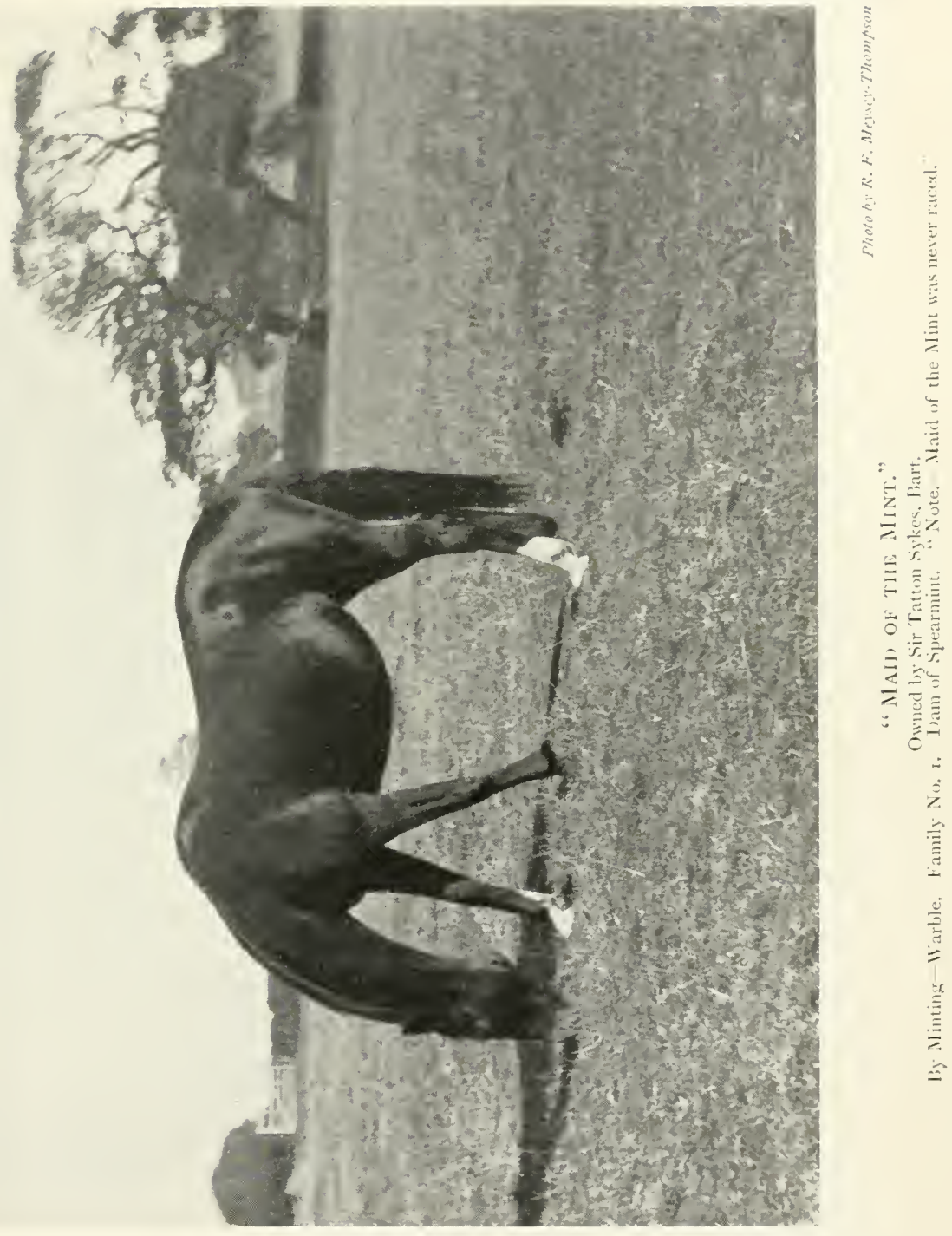



visiting stud farms nares should be pointed out as most successful dams, which for some reason have either never been trained-as instances taken at random may be mentioned Auchnafree, the dam of Robbie Burns, who could not be trained owing to a club-foot, and Suicide, the dam of Amphion, who had a crippled hind-leg-or who have been early sent to the stud, such as Mint Sauce, the dam of the great Minting. Though these instances could be multiplied to a large extent, it is still preferable that the dam should have been in training, for by this means alone can be tested the qualities of docility and gameness, both attributes of a race-horse of the highest value, which the dam may be expected to transmit to her offspring.

\section{The Bruce Lowe Figure System.}

Before quitting this part of the subject it may be as well to revert to the theory of the Figure System, as devised by the late Mr. Bruce Lowe and extended by his friend, Mr. William Allison, M.A., which is so freely commented on and often derided. We Britishers are a stubborn race, slow to assimilate new ideas, and the great value of Mr. Bruce Lowe's researches were much more quickly grasped by foreign breeders than by our own. "What nonsense," said the latter, "to imagine a mare, who lived perhaps one hundred and fifty years ago, can now influence her descendants! Of course we all know the importance of breeding back to a good mare of recent date, but the idea of setting any value upon a mare who lived all that time ago! Well, I am not going to believe it at any rate!" Pace, Mr. Breeder! Facts, as the Highlander remarked, " are chiels that winna ding." There have been great mares, of what our "high priest" terms "outside families," in plenty, but they have left no descendants of any renown, though they have been mated again and again with famous sires. It is a complete verification of the survival of the fittest, and it never was sought to force any family to the front, at the expense of others, except through the test of accomplished 
facts. What Mr. Bruce Lowe did was this: taking certain of the highest class three-year-old races as his standingpoint, he worked out the number of the descendants of each of the original mares who had won these races, and the family which had won the most he placed No. 1 ; and the other families in due order according to their number of wins. Any thinking man, wishing to breed the winner of a great race, would surely choose for his matron a mare which belonged to a family that had been frequently successful, and not select one from a family which had never won one at all! Both mares might be equally goodlooking and truly shaped, and there might be nothing to choose between them as far as the eye could judge, and yet it would be a not very intelligent act to proceed to breed from the mare of the unsuccessful family, in preference to the one that came from the winning strain! Moreover, if any other important weight-for-age races are taken, and in any of the chief foreign racing countries, the same winning families come invariably to the front, though abroad their order sometimes changes a little, generally owing to the prevalence, or otherwise, of mares of any particular family in that particular country.

In order to show how Mr. Bruce Lowe's system works out, some tables of the different families are here appended for sixty years-1850-1909-which have won any of the classic races he took as a test. Although in this limited period the placing of the families does not quite accord with that of the fuller tale of years, up to the time of his death, it is strikingly shown how prolific of winners his leading families have been, and what a falling off there is towards the end of the list, which is a very strong proof of the truth of his contention. Though other of the original mares bring the number up to fifty, none of their descendants have won a classic race during this period:-- 


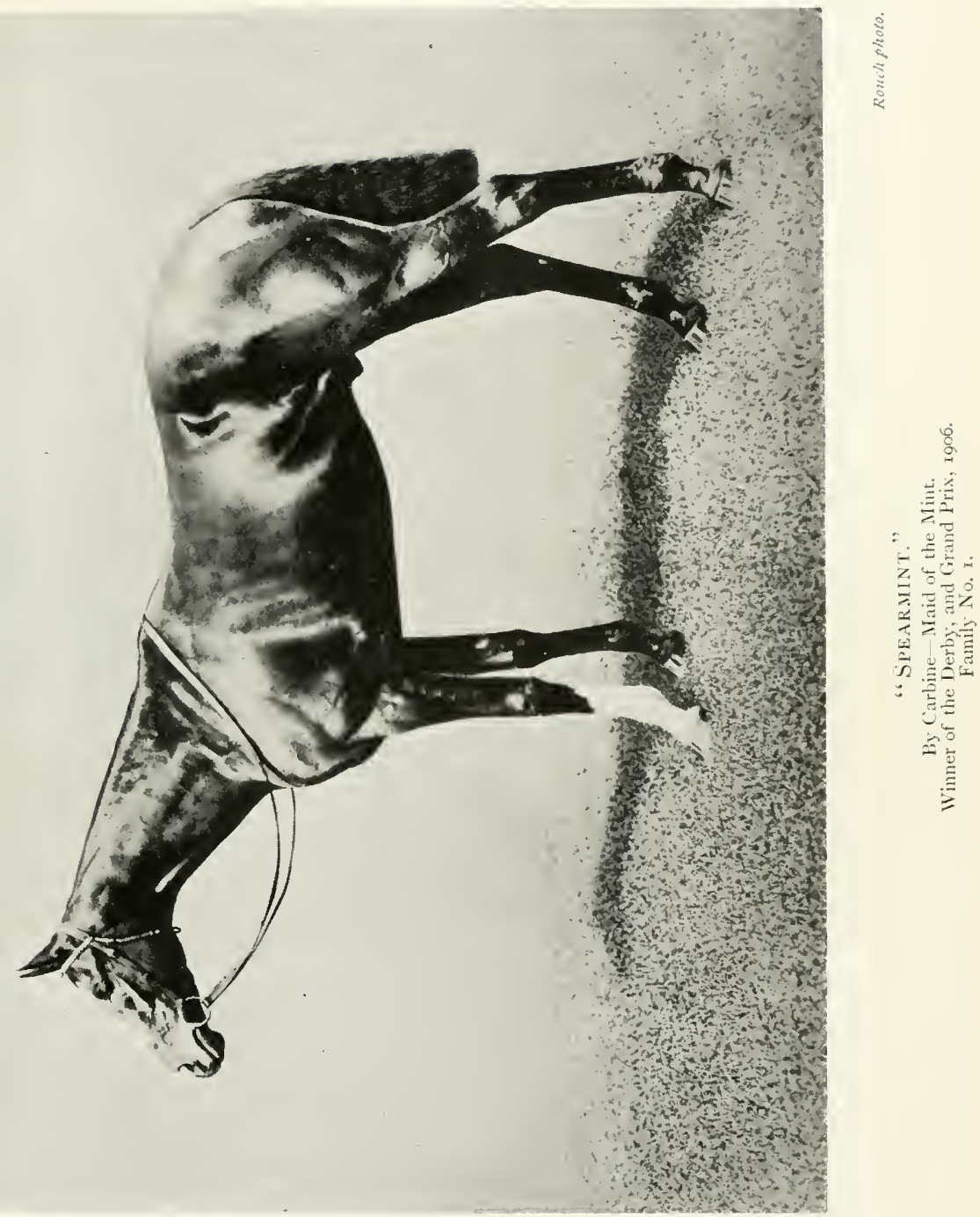





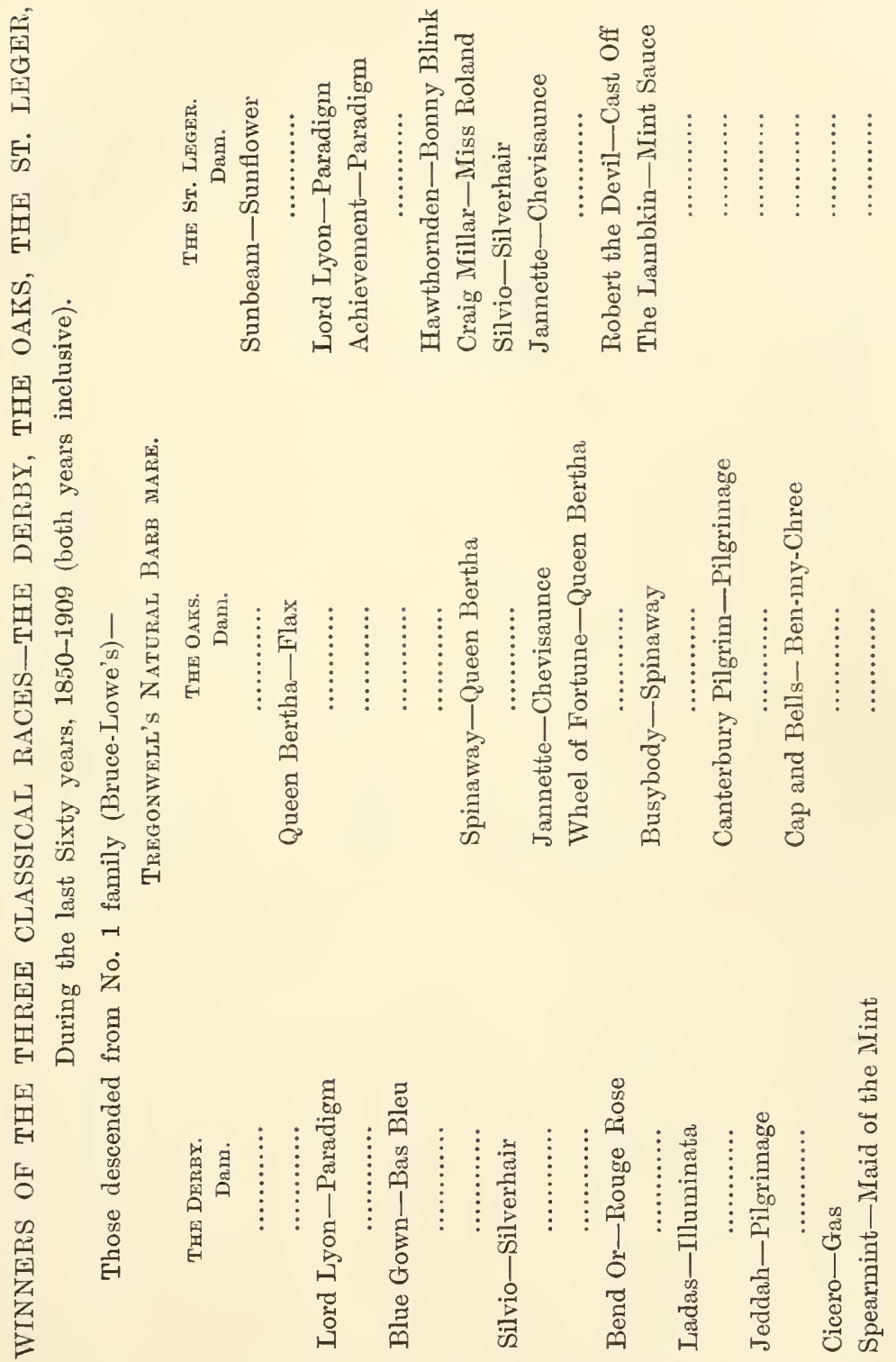

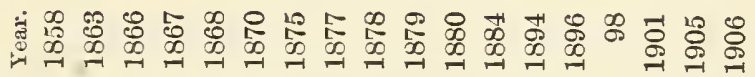




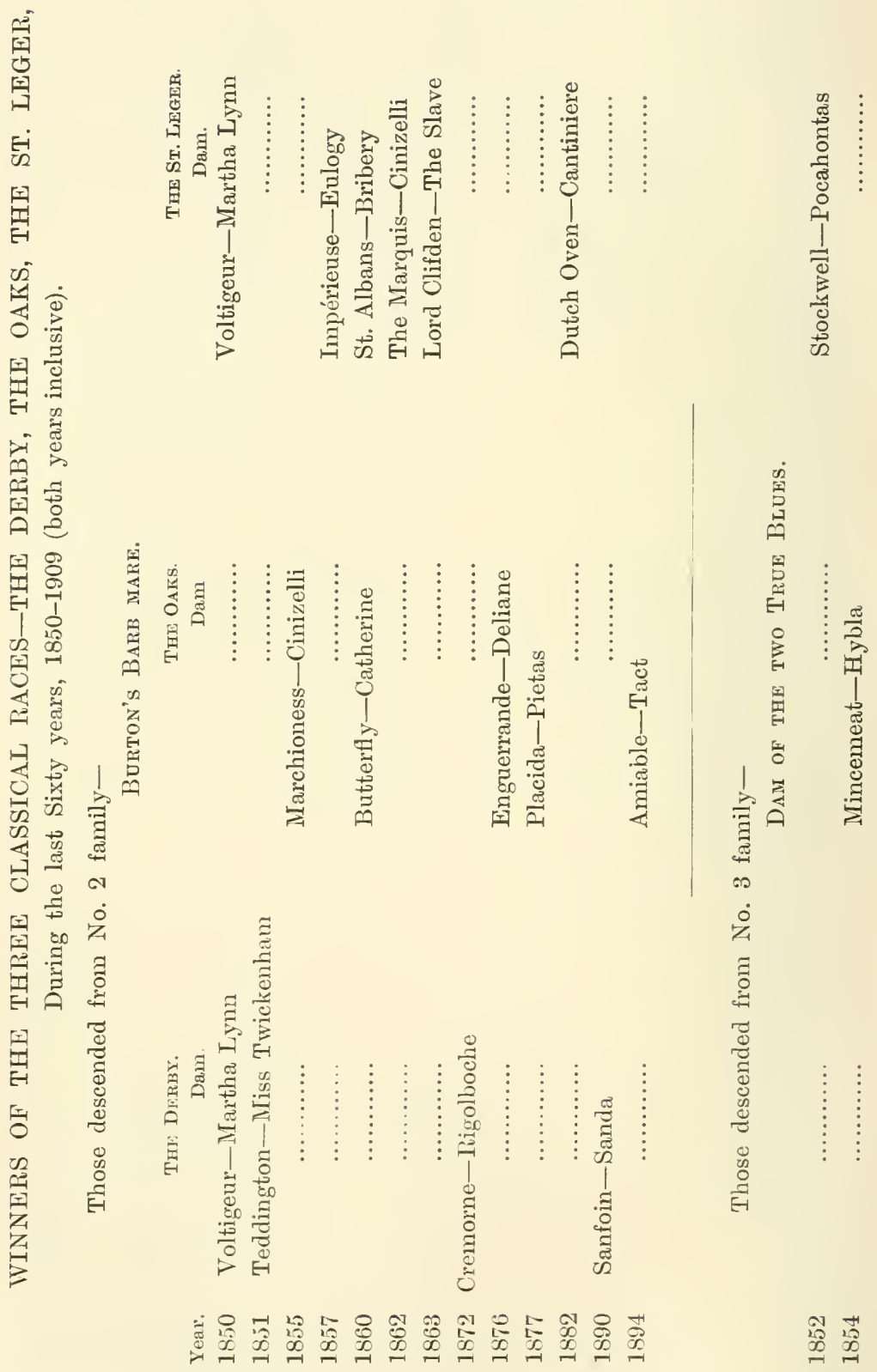



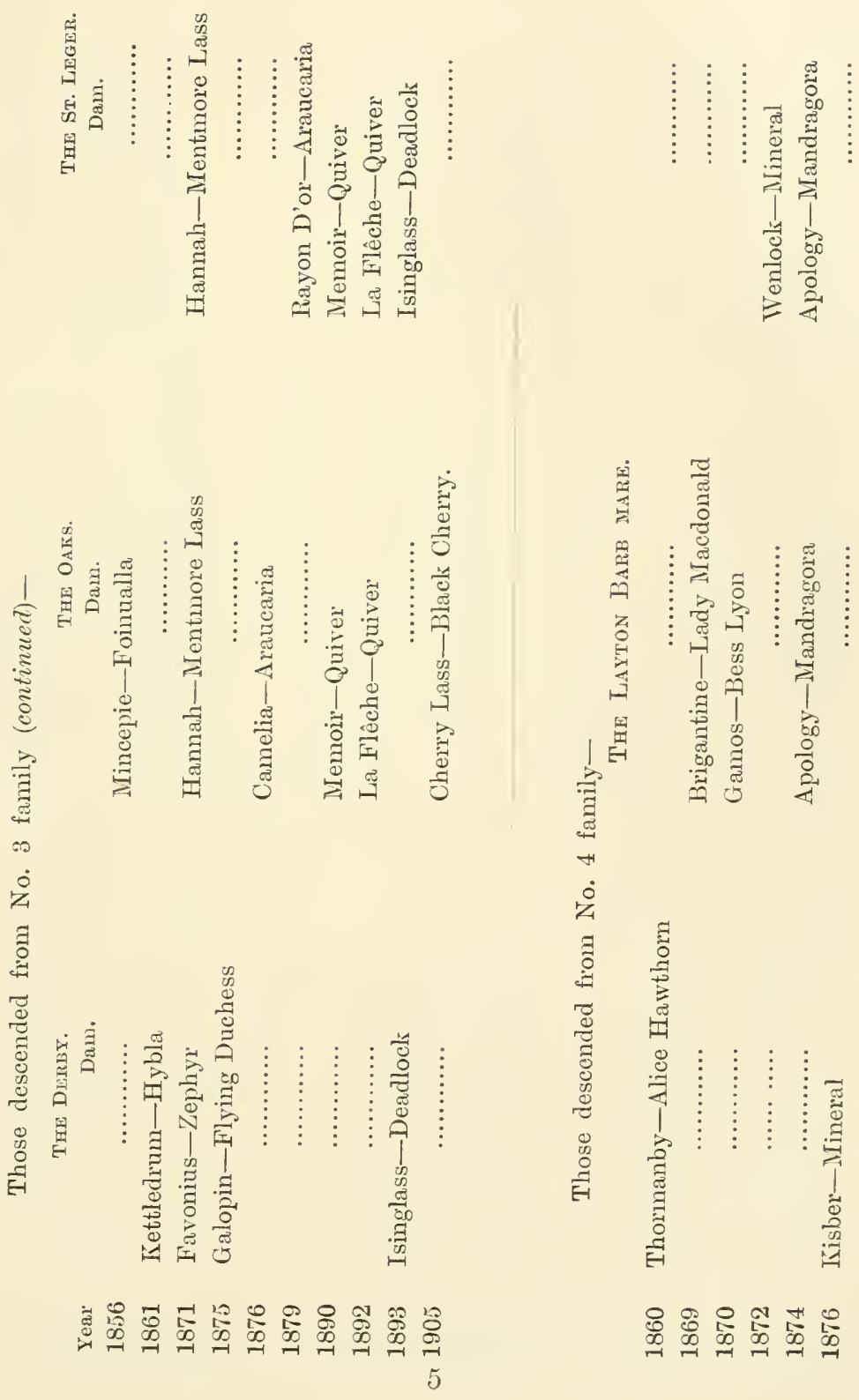


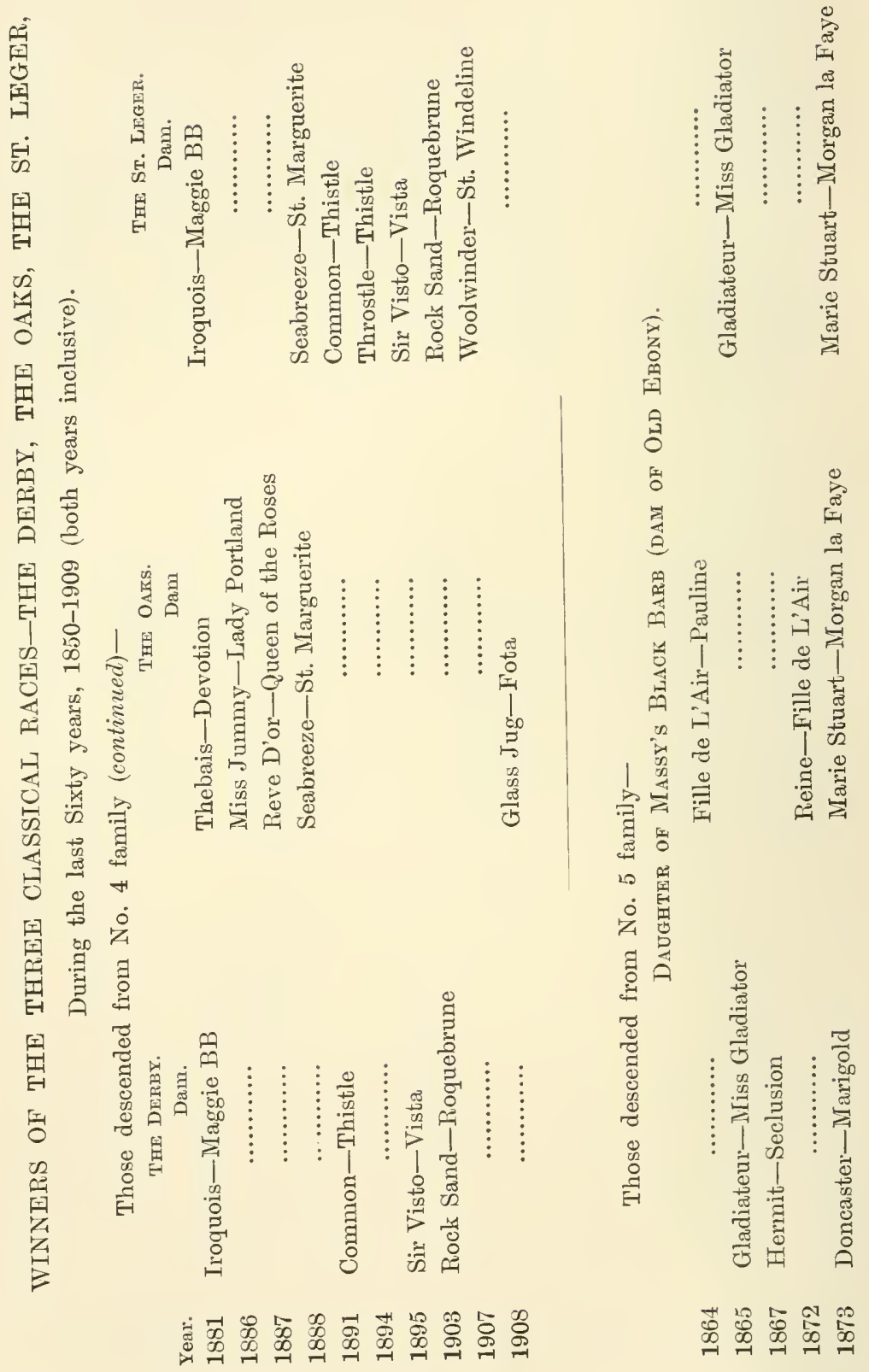



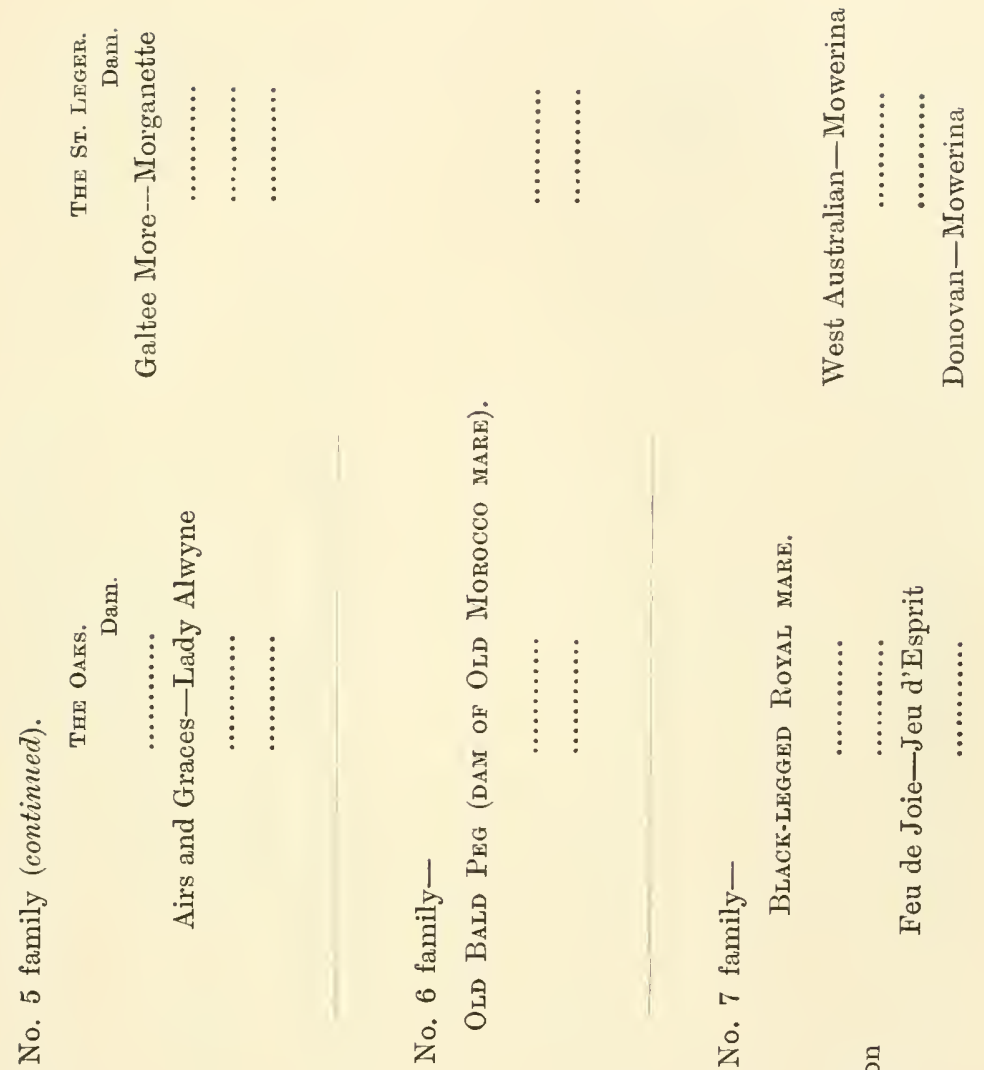

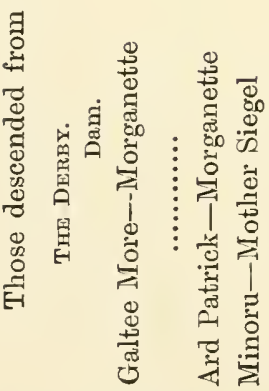

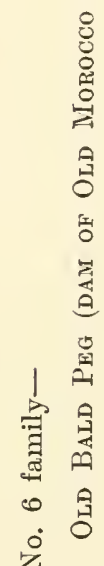

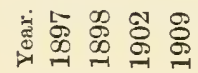
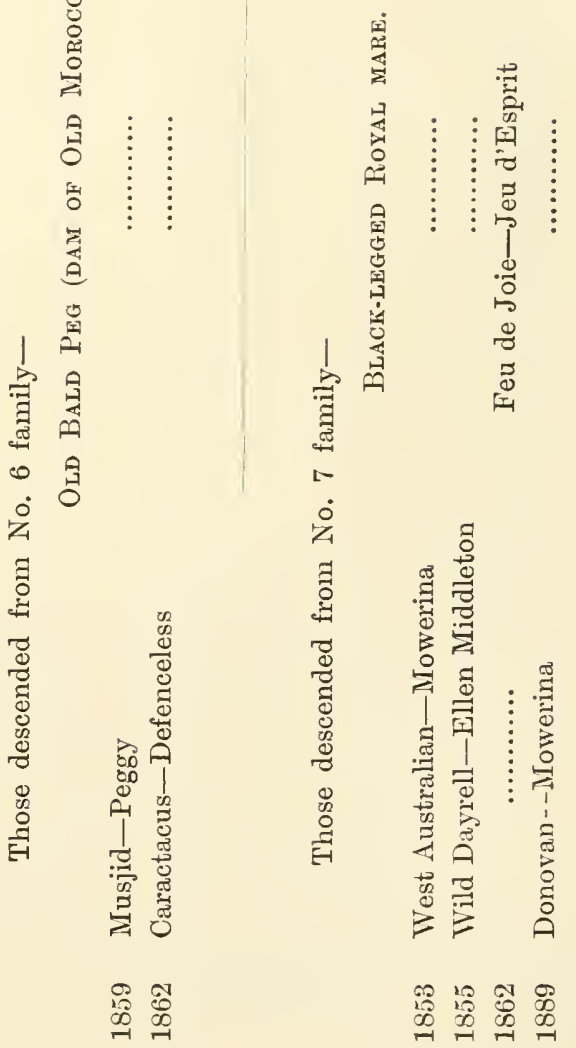

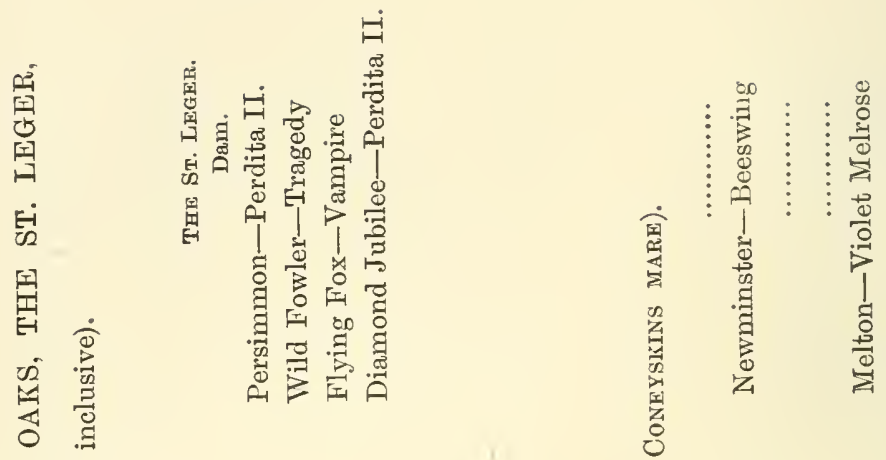

स्ञ

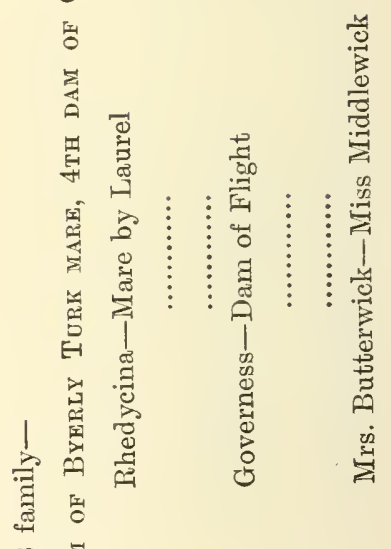

त्ञ

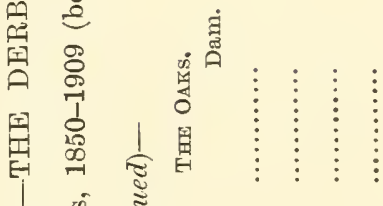

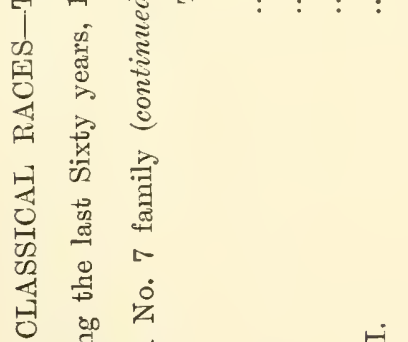

0 品

鼠菅苛

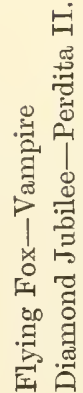

$\infty$

요

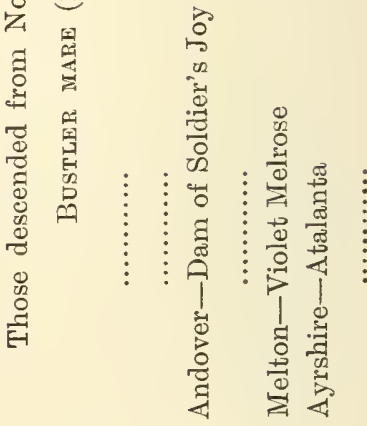

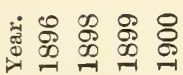

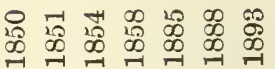



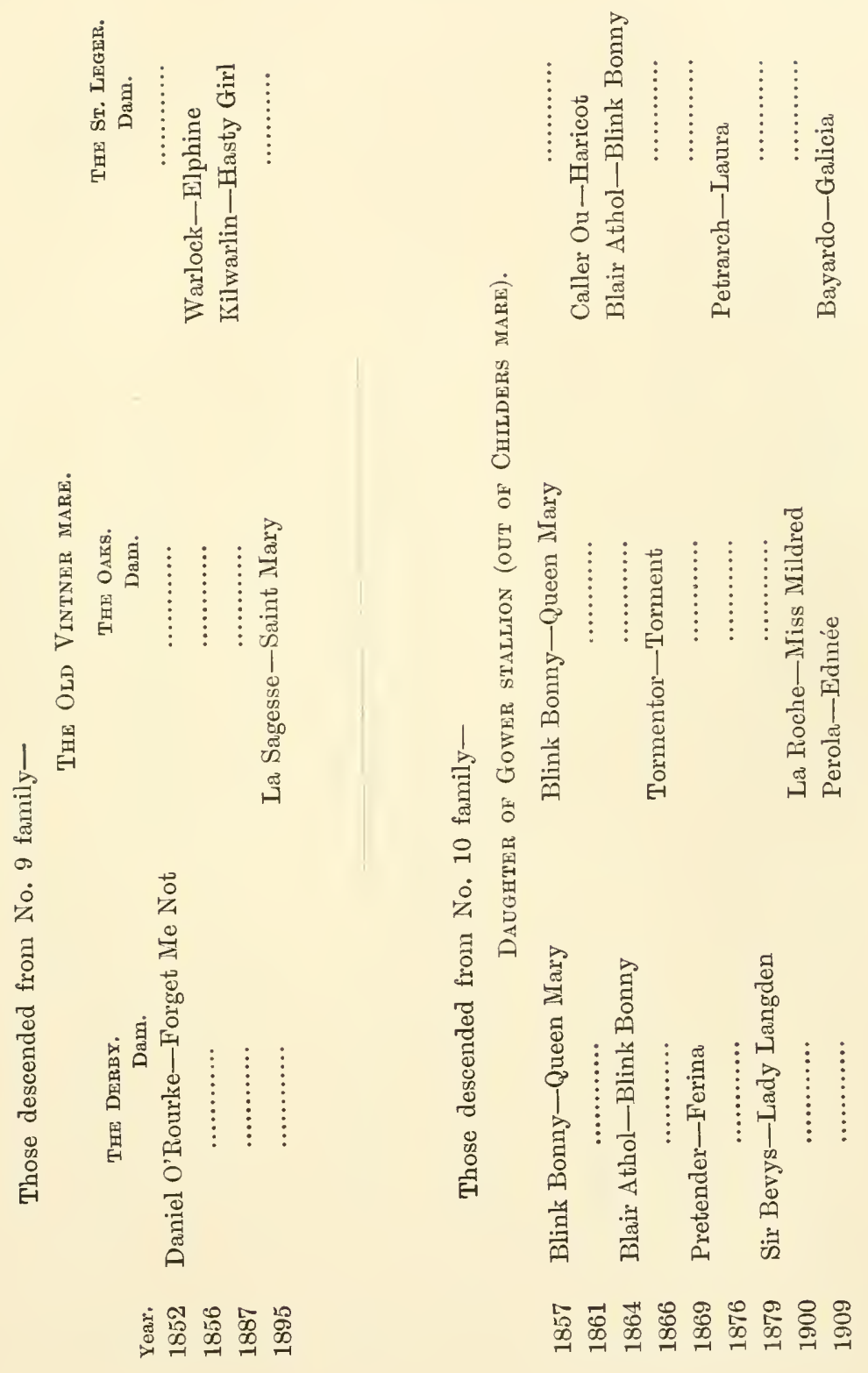
窇

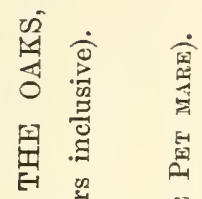

穴焉 田

舅莒告

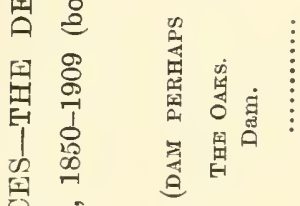

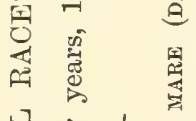

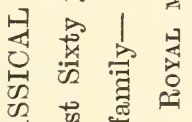

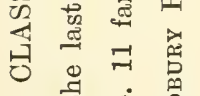

됟요

画言思

国

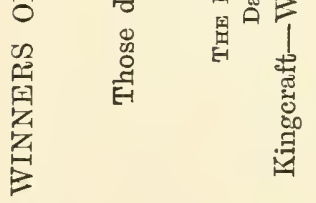

密: 욨

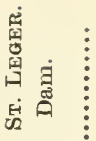

思
赵

㝵

흐 :

政

突

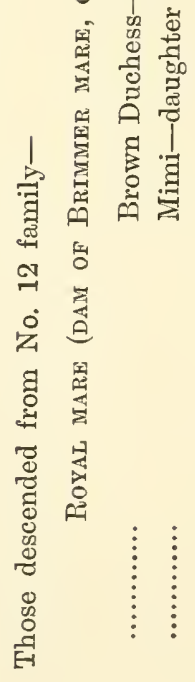

悉

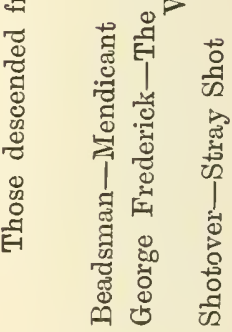

总离

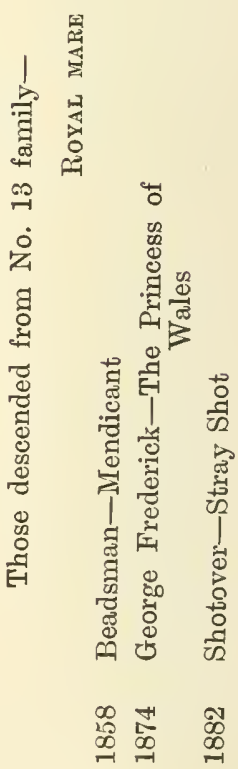




$$
\text { THOROUGHBRED HORSES }
$$

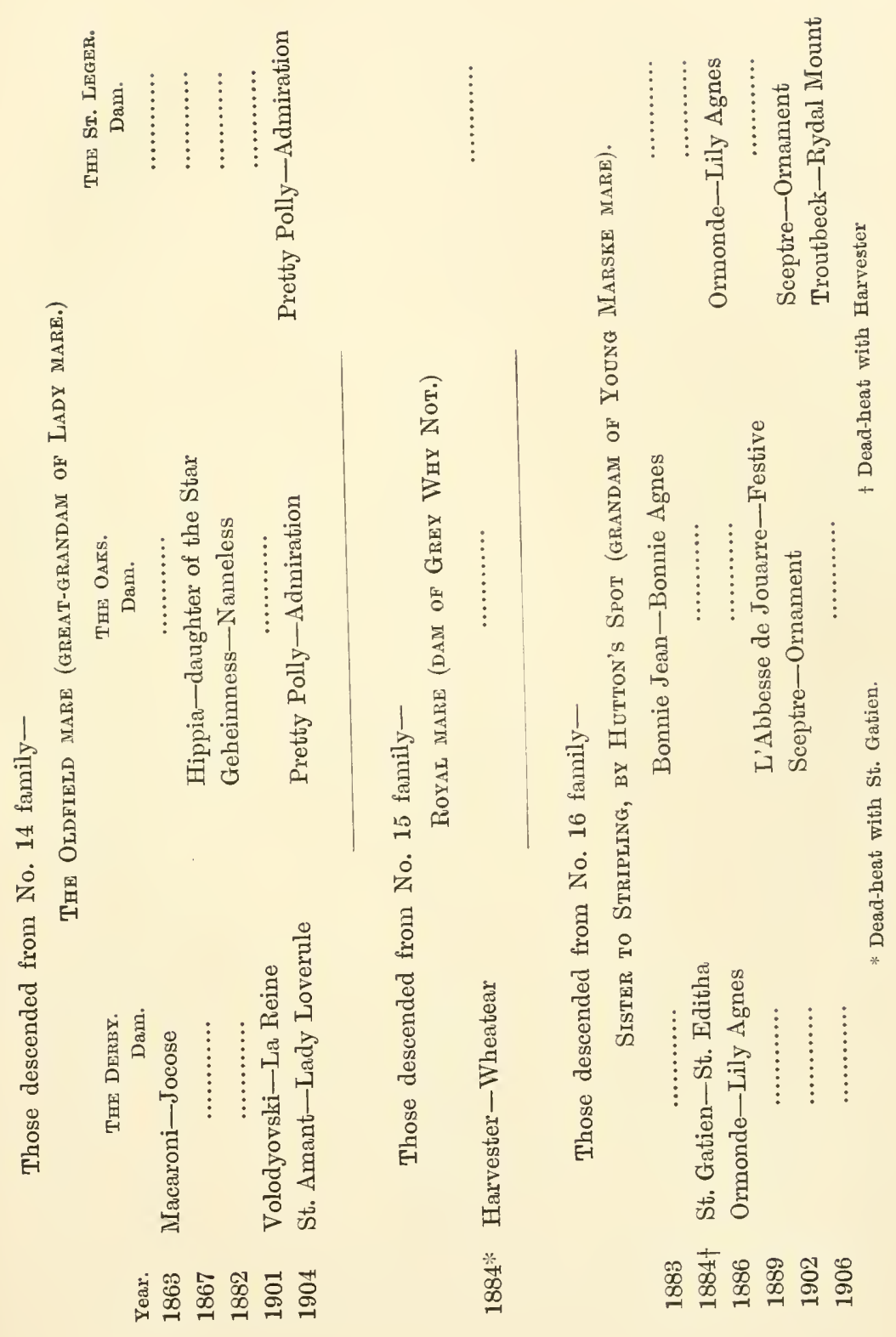


留

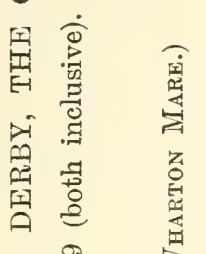

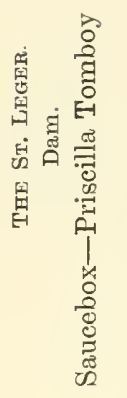

焉

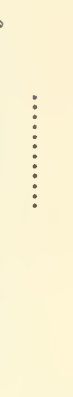

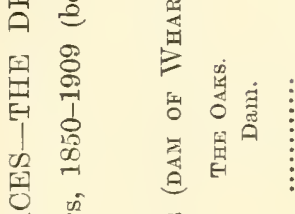

出

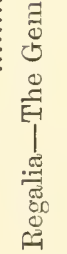

至䨔

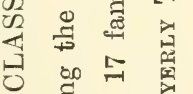

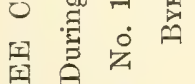

国

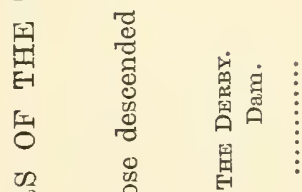

饮 娄

舀

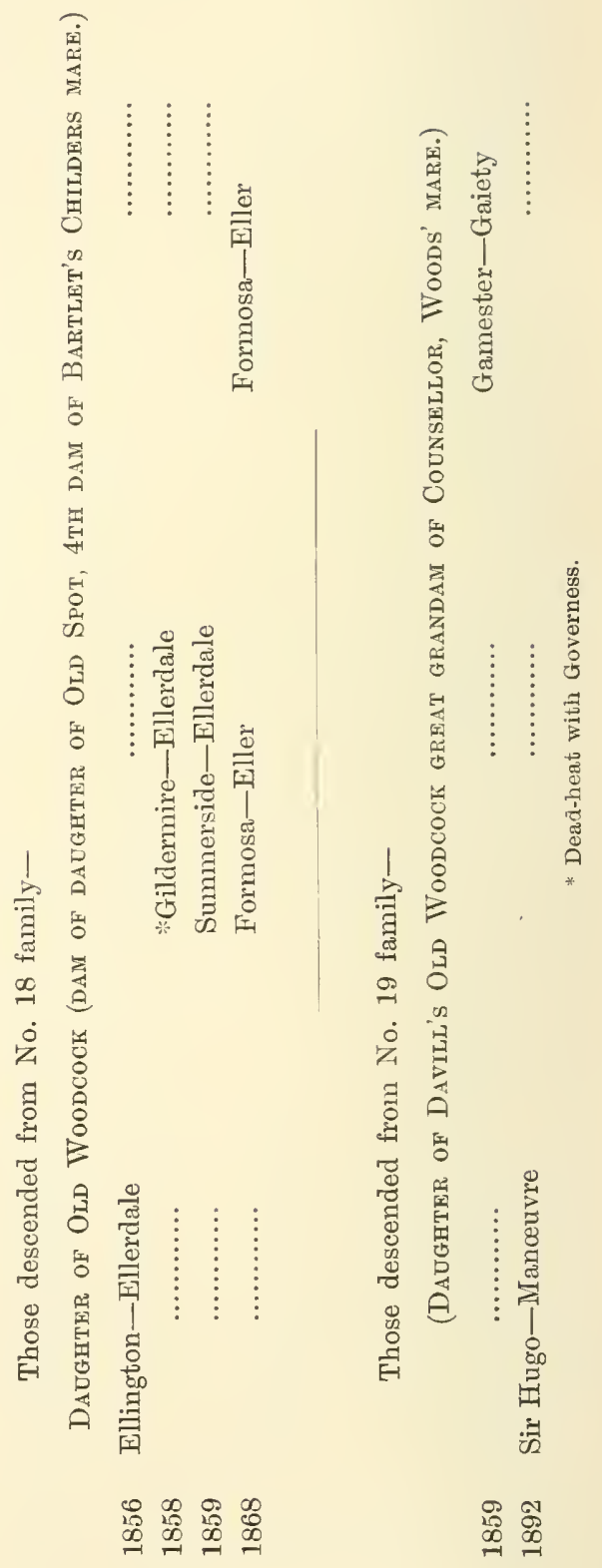




$$
\text { THOROUGHBRED HORSES }
$$

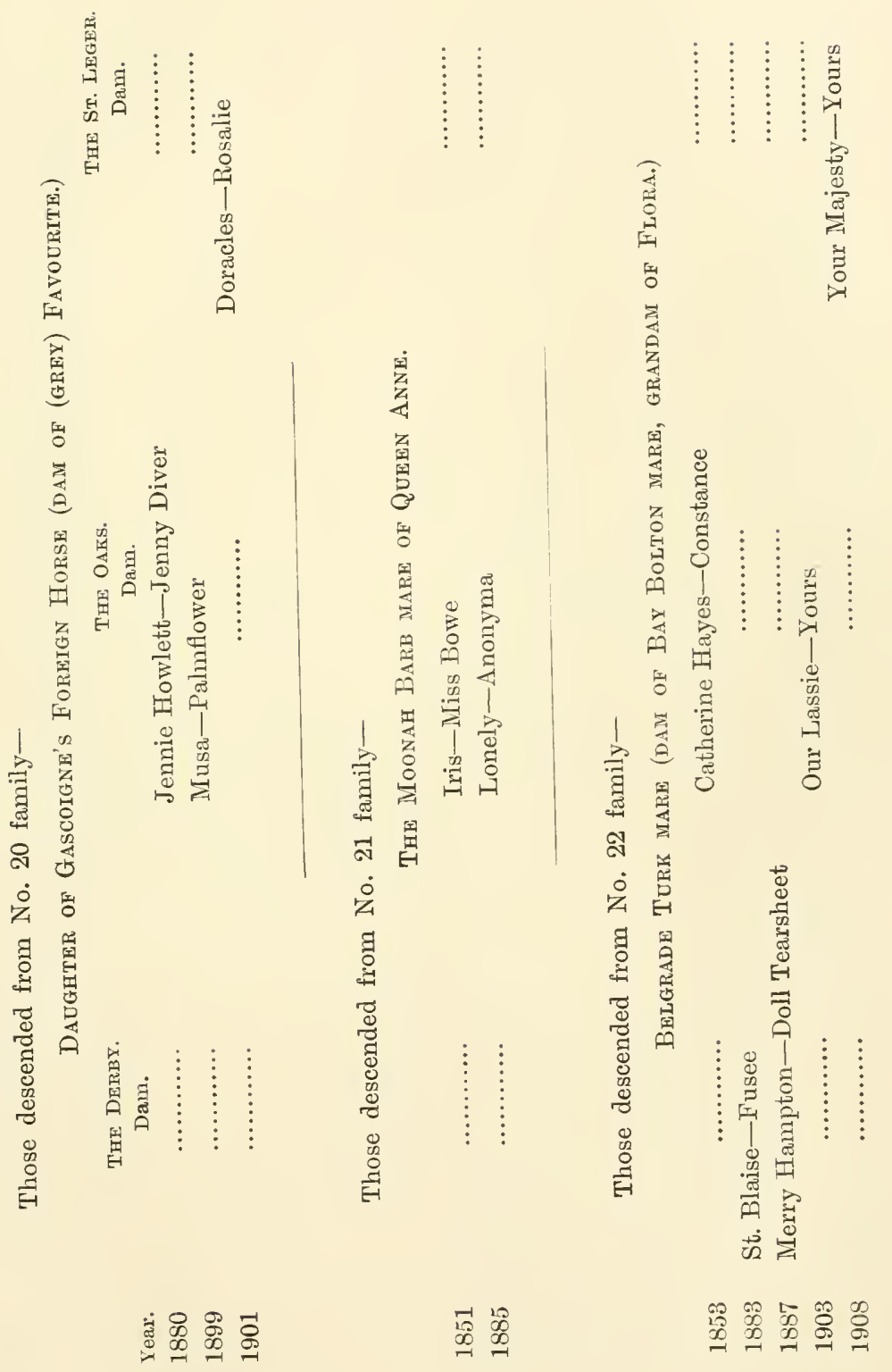


空

붕

兒

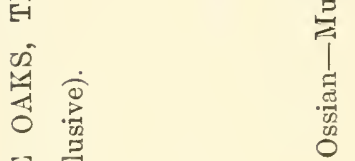

国

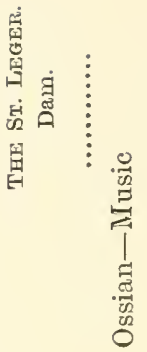

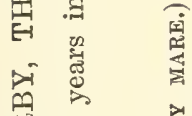

舅葍 总

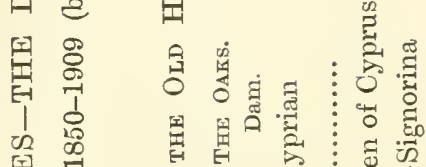

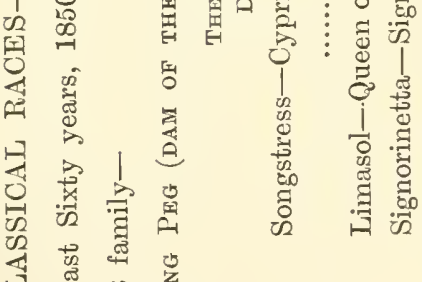

Ө ฐ

望吉完

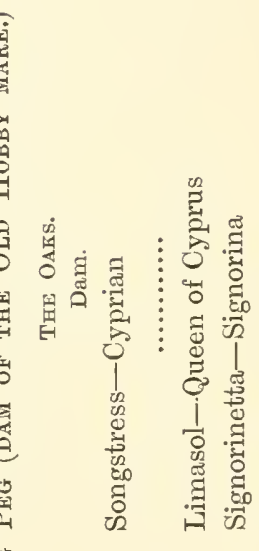

它蓄

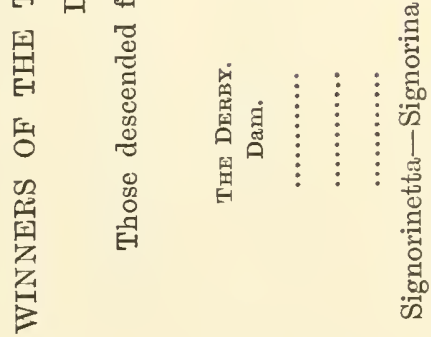

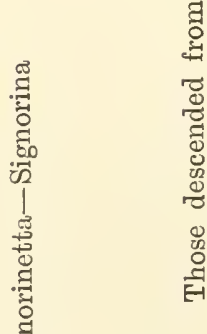

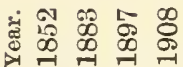

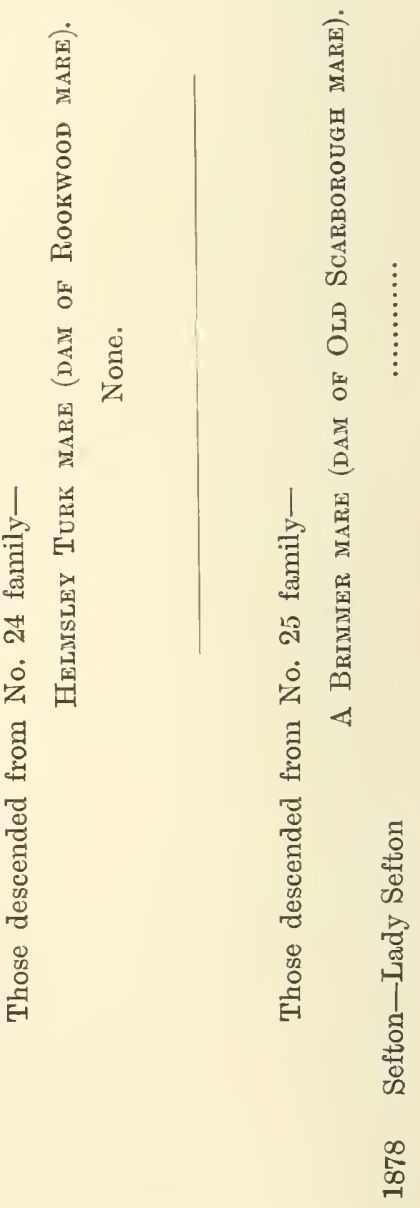




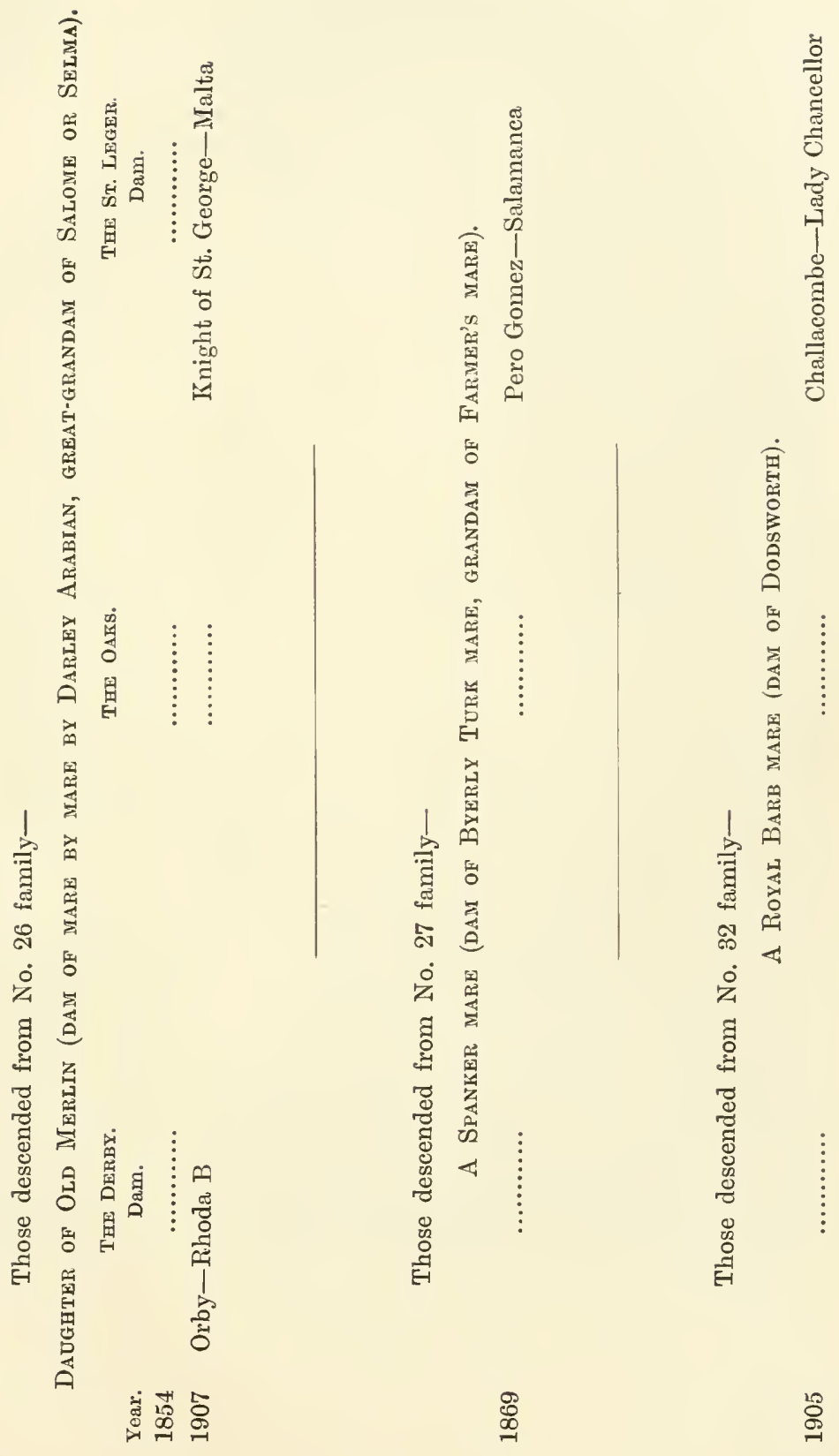


It is a noteworthy fact that the great lines of blood are very generally carried on by the winners of the Derby and St. Leger, who take, as a rule, the highest places amongst the successful stallions of their generation, though occasionally their immediate runners-up also make Turf history; but handicap winners, however meritorious their performances may have been, seldom figure conspicuously in the pedigrees of famous horses, and in a few years their names are totally forgotten. There could be no more convincing proof of the value of these great three-year-old races in providing such a test for the selection of the best animals of their year.

A general summary of the above list gives the amount of wins gained by each family as follows, though it must not be overlooked that in some instances the same animal has gained two, and occasionally three, of the races, so that though the family is credited with the full number of wins, it does not follow it possesses an equal tale of individual winners. In the case of the dead-heat for the Derby, between Harvester and St. Gatien, each of their respective families is credited with a win, and therefore there appear to be sixty-one winners of the Derby during the period of sixty years; and the same with the dead-heat for the Oaks between Governess and Gildermire, which, therefore, also shows 61 winners.

$\begin{array}{rcccccc}\text { Family. } & \text { Derby. } & \text { Oaks. } & \text { St. Leger. } & & & \text { Total. } \\ \text { No. } 1 & 8 & 7 & 9 & \ldots & \ldots & 24 \\ 2 & 4 & 5 & 6 & \ldots & \ldots & 15 \\ 3 & 4 & 7 & 6 & \ldots & \ldots & 17 \\ 4 & 6 & 8 & 9 & \ldots & \ldots & 23 \\ 5 & 6 & 4 & 3 & \ldots & \ldots & 13 \\ 6 & 2 & 0 & 0 & \ldots & \ldots & 2 \\ 7 & 6 & 1 & 6 & \ldots & \ldots & 13 \\ 8 & 3 & 3 & 2 & \ldots & \ldots & 8 \\ 9 & 1 & 1 & 2 & \ldots & \ldots & 4 \\ 10 & 4 & 4 & 4 & \ldots & \ldots & 12 \\ 11 & 1 & 0 & 0 & \ldots & \ldots & 1 \\ 12 & 0 & 2 & 0 & \ldots & \ldots & 2 \\ 13 & 3 & 0 & 0 & \ldots & \ldots & 3 \\ 14 & 3 & 3 & 1 & \ldots & \ldots & 7 \\ 15 & 1 & 0 & 0 & \ldots & \ldots & 1 \\ 16 & 2 & 3 & 3 & \ldots & \ldots & 8 \\ 17 & 0 & 1 & 1 & \ldots & \ldots & 2\end{array}$




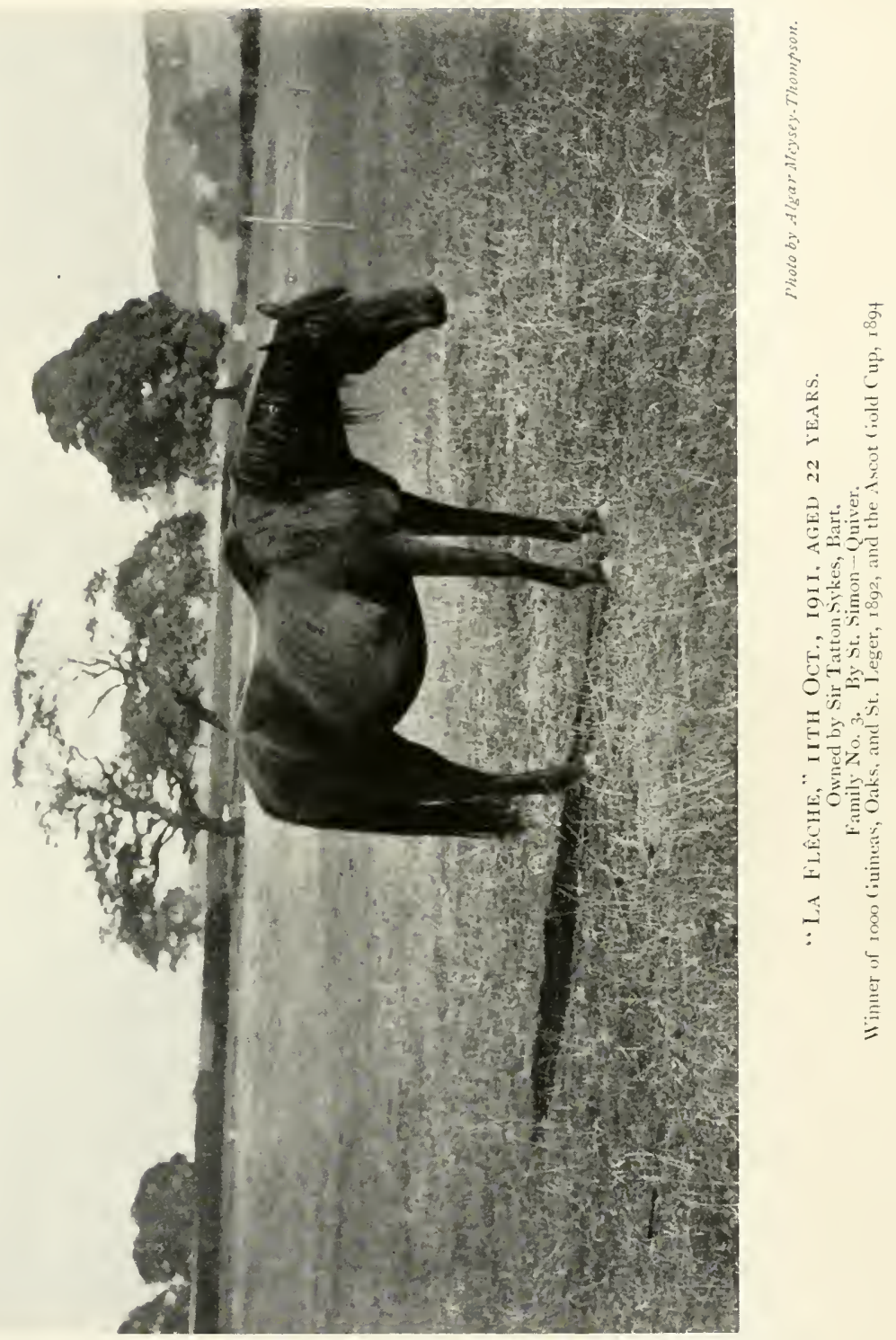





$\begin{array}{ccccccc}\text { Family. } & \text { Derby. } & \text { Oaks. } & \text { St. Leger. } & & & \text { Total. } \\ \text { No. } 18 & 1 & 3 & 1 & \ldots & \ldots & 5 \\ 19 & 1 & 0 & 1 & \ldots & \ldots & 2 \\ 20 & 0 & 2 & 1 & \ldots & \ldots & 3 \\ 21 & 0 & 2 & 0 & \ldots & \ldots & 2 \\ 22 & 2 & 2 & 1 & \ldots & \ldots & 5 \\ 23 & 1 & 3 & 1 & \ldots & \ldots & 5 \\ 25 & 1 & - & - & \ldots & \ldots & 1 \\ 26 & 1 & 0 & 1 & \ldots & \ldots & 2 \\ 27 & 0 & 0 & 1 & \ldots & \ldots & 1 \\ 32 & 0 & 0 & 1 & \ldots & \ldots & 1 \\ & -61 & -61 & 60 & & & -182\end{array}$

The remaining families have never won any of these three classic races.

To arrive at the true value of this table it is necessary to take into consideration the number of individual horses from different mares which have been instrumental in crediting their families with the respective wins.

The strength of a family in general is more apparent by the winning of animals not closely related, than by the same number of wins gained by brothers and sisters, who only represent one unit through their dam.

Mr. Bruce Lowe further selected from the leading families certain ones which had the most success in winning races, which he termed "Running Families"; and others which were conspicuous chiefly for the merit transmissible by the stallions, which he designated "Sire Families"; and it is noteworthy that the only one which combined both gifts was the one placed No. 3. He laid down the rule that unless the Running Families were strongly imbued with the blood of the Sire Families they did not transmit their great merit; nor has there been any great horse of recent years, of any family, without at least some of the Running and Sire blood amongst his immediate ancestors in the three nearest lines of his pedigree.

The classification was as follows :---

Running Families $\ldots \quad \ldots \quad \ldots \quad \ldots \quad$ Nos. 1, 2, 3, 4, 5 .

Sire Families $\quad \ldots \quad \ldots \quad \ldots \quad \ldots \quad$ Nos. 3, 8, 11, 12, 14 .

It is instructive to note how such has worked out during last Season's Racing, 1910.

The winner of the Derby, Lemberg, belongs to No. 10 
family, his sire Cyllene being No 9, his paternal grandsire Bona Vista No. 4, and his great-grandsires Bend Or, No. 1, and Isonomy, No. 19. On the maternal side the sire of Galicia was Galopin, No. 3, who was the son of Vedette, No. 19, while Isonomy, No. 19, was also the sire of his maternal grandam, Isoletta. This No. 19 was a strong sire line, though not in itself very successful in producing winners of the classical races, and it is noteworthy how much inbred Lemberg was to this family.

The requirements of Bruce Lowe's doctrine were, however, amply fulfilled, there being plenty of Running and Sire blood within the last three generations of Lemberg's ancestors. Success in transmitting his own excellence will, however, probably depend upon the careful selection of his mates. While he is likely to sire winners from good mares of the first five families, he may prove a failure with equally good mares low down in the list of family figures. His half-brother, Bayardo, being by a No. 3 horse, Bay Ronald, in theory should prove a more successful stallion than the Derby winner; but then comes in the all-powerful " personal equation," and no one can predicate that this or that horse will be a success until he is actually tried and proves his worth. Moreover, though an inbred mare may breed excellent foals, an inbred sire is seldom a stud-success, and requires mates without any of the closely related strains of his blood.

\begin{tabular}{|c|c|c|c|c|c|c|c|}
\hline Bend $\mathrm{Or}_{1}$ & $\underset{4}{\text { Vista }}$ & $\begin{array}{c}\text { Isonowy } \\
19\end{array}$ & $\begin{array}{c}\text { Distant } \\
\text { Shore } \\
9\end{array}$ & $\begin{array}{c}\text { Vedette } \\
19\end{array}$ & $\begin{array}{l}\text { Flying } \\
\text { Duchess } \\
3\end{array}$ & $\begin{array}{c}\text { Isonouly } \\
19\end{array}$ & $\begin{array}{c}\text { Lady } \\
\text { Muncaster } \\
10\end{array}$ \\
\hline \multicolumn{2}{|c|}{ Bona Vista 4} & \multicolumn{2}{|c|}{ Arcadia 9} & \multicolumn{2}{|c|}{ Galopin 3} & \multicolumn{2}{|c|}{ Isoletta 10} \\
\hline
\end{tabular}

Cyllene 9

Gallicia 10

Lemberg 10

Coming now to the Oaks, the winner, Rosedrop, is of the No. 2 family, but her sire, St. Frusquin, is only No. 22. Clearly he required a mate of the best Rumning blood to expect a signal success. The sire of St. Frusquin, however, was St. Simon, No. 11, his paternal grandsire, Galopin, 
No. 3, and his maternal grandsire, Plebian, No. 11, so here again there is plenty of the right sort in evidence. And this is further strengthened by the great-grandsires of Rosedrop, Bend Or, who brought No. 1 blood into the pedigree, and the famous Musket, No. 3, although that is somewhat discounted by the grandsire, Trenton, being a scion of the No. 18 family.

\begin{tabular}{c|c|c|c|c|c|c|c}
\hline $\begin{array}{c}\text { Galopin } \\
3\end{array}$ & $\begin{array}{c}\text { St. Angela } \\
11\end{array}$ & $\begin{array}{c}\text { Plebeian } \\
11\end{array}$ & $\begin{array}{c}\text { Parma } \\
22\end{array}$ & $\begin{array}{c}\text { Musket } \\
3\end{array}$ & $\begin{array}{c}\text { Frailty } \\
18\end{array}$ & $\begin{array}{c}\text { Bend Or } \\
1\end{array}$ & $\begin{array}{c}\text { Rosa May } \\
2\end{array}$ \\
\cline { 1 - 5 } St. Simon 11 & Isabel 22 & Trenton 18 & & Rosalys 2 \\
\hline
\end{tabular}

Rosedrop 2

Swynford won the last of the classic races, the St. Leger, and he belonged to No. 1. His sire, John o' Gaunt, is No. 3, and his sire again, Isinglass, belonged to the same No. 3 family. The dam of John o' Gaunt, by the way, the great La Flêche, was by St. Simon, No. 11, and granddaughter of Galopin 3, and Toxophilite, No. 3, so there is small wonder John o' Gaunt should sire a classic winner in his first season at the stud, and he should get winners from mares of every family.

The dam of Swynford, Canterbury Pilgrim, was a scion of the No. 1 family, while her sire, Tristan, belonged to No. 10, being a descendant of the wonderful family of Queen Mary, which chiefly contributed to the success of their number in the figure grouping. Canterbury Pilgrim could also point to two Nos. 5 in her immediate ancestry, for both her grandsires, Hermit and 'The Palmer, belonged to this, so that Swynford lacked nothing on the score of breeding as a classic winner, according to the theory of Bruce Lowe.

\begin{tabular}{|c|c|c|c|c|c|c|c|}
\hline $\begin{array}{c}\text { Isonomy } \\
19\end{array}$ & $\begin{array}{c}\text { Deadlock } \\
3\end{array}$ & St. Simon & $\underset{3}{\text { Quiver }}$ & $\underset{5}{\text { Hermit }}$ & $\begin{array}{c}\text { Thrift } \\
10\end{array}$ & $\begin{array}{c}\text { The Earl, or } \\
\text { The Palmer } \\
\quad 5\end{array}$ & Lady Audley \\
\hline \multicolumn{2}{|c|}{ Isinglass 3} & \multicolumn{2}{|c|}{ La Flêche 3} & \multicolumn{2}{|c|}{ Tristan 10} & \multicolumn{2}{|c|}{ Pilgrimage 1} \\
\hline \multicolumn{4}{|c|}{ John o' Gaunt 3} & \multicolumn{4}{|c|}{ Canterbury Pilgrim 1} \\
\hline
\end{tabular}


Successful Families, 1910.

If the figures of these horses, which won over $£ 6,000$ during 1910, are examined, the figure system is again triumphant. They are as follows:-

\begin{tabular}{llllrllllll} 
& & \multicolumn{4}{c}{ Family. } & \multicolumn{4}{c}{ Won. } & \\
Lemberg & $\ldots$ & $\ldots$ & $\ldots$ & 10 & $\ldots$ & $\ldots$ & $£ 23,839$ & \\
Winkipop & $\ldots$ & $\ldots$ & $\ldots$ & 1 & $\ldots$ & $\ldots$ & 11,439 & 15 & 0 \\
Neil Gow & $\ldots$ & $\ldots$ & $\ldots$ & 1 & $\ldots$ & $\ldots$ & 11,080 & \\
Swynford & $\ldots$ & $\ldots$ & $\ldots$ & 1 & $\ldots$ & $\ldots$ & 10,694 & \\
Bayardo & $\ldots$ & $\ldots$ & $\ldots$ & 10 & $\ldots$ & $\ldots$ & 6,698 & 10 & 0 \\
Rosedrop & $\ldots$ & $\ldots$ & $\ldots$ & 2 & $\ldots$ & $\ldots$ & 6,363 &
\end{tabular}

The Running families again came well to the front, while the half-brothers, Bayardo and Lemberg, had much of the blood in the three immediate preceding generations, as has already been shown above.

If the sires of these same horses are taken into consideration the weight of the scales is again in favour of Bruce Lowe's theory.

\begin{tabular}{|c|c|c|c|c|c|c|}
\hline & & & Sire. & & & Family \\
\hline Lemberg & $\cdots$ & $\ldots$ & Cyllene $\quad \ldots$ & $\ldots$ & .. & $\begin{array}{l}\ldots \\
\ldots\end{array}$ \\
\hline Winkipop & $\ldots$ & $\ldots$ & IVilliam III. & $\ldots$ & .. & $\ldots$ \\
\hline Neil Gow & $\ldots$ & $\ldots$ & Marco $\quad \ldots$ & $\ldots$ & .. & $\ldots$ \\
\hline Swynford & $\ldots$ & $\ldots$ & John o' Gaunt & $\ldots$ & .. & $\ldots$ \\
\hline Bayardo & ... & ... & Bay Ronald ... & $\ldots$ & .. & $\ldots$ \\
\hline Rosedrop & $\ldots$ & $\ldots$ & St. Frusquin & $\ldots$ & .. & 22 \\
\hline
\end{tabular}

The especial value of the No. 3 family as sires is here emphatically shown.

A very important point in favour of our breeders is that foreign countries do not seem able to maintain the vigour of the breed without frequently revivifying it by fresh importations from the British Islands, and thus a constant market is maintained for our surplus stock, even if they do help themselves rather plentifully to our choicest specimens. As an example may be quoted the list of winning stallions in the United States, during the past year, 1910. Of the first twenty, nine were imported from Britain ; and one was of English blood, though imported from France. The dams of six more had been brought from England; and one of these stallions was by an imported English sire. The 


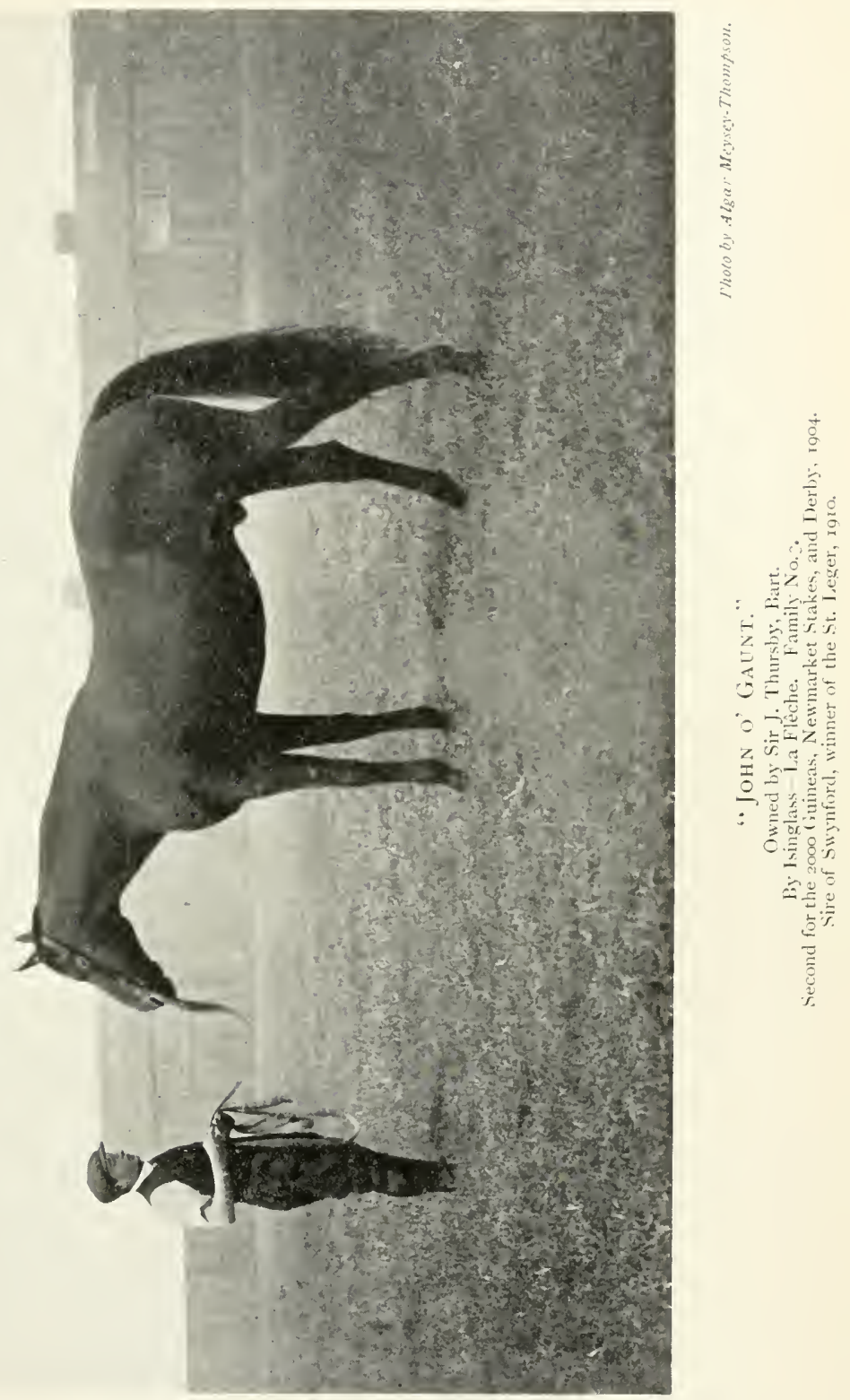



remainder had English blood within the three immediate preceding generations. From the length of time America has been breeding thoroughbred horses, it might have been expected she could now depend upon her own resources, without having further recourse to the parent stock.

It must not, however, be overlooked that sometimes England herself reaps the benefit by the readmission of lines of blood which have become scarce, or even extinct in this country; and which afford an excellent outcross to our own blood, that is sadly in need of such in far too many cases. The continued inbreeding which has been pursued has resulted in a delicacy of constitution, and a waywardness and irritability of temperament, that is now a constant source of trouble to both owners and trainers, and mars the racing career of many an animal which was full of promise at the commencement.

\section{Hunters.}

If ever an illustration was required for the old adage, "what is one man's meat is another man's poison," no better could be found than the different type of hunter which each individual considers the perfect one. On this he is prepared to stake-not his reputation as a judge, for that, in his own mind, he considers absolutely assured, but his opinion, about which he believes there can be no mistake. If other people do not agree with him, so much the worse for them, it only shows what bad judges they are. It is when he comes to test that opinion in public, at an auction sale such as Tattersalis, or a great Show such as the Dublin one, that he may find the public will not put down money for his very perfect piece of horseflesh. The reason is simple. People hunt with very different motives, and in very different countries, and consequently can get along with a type of animal in the one country which would be unsuitable in the other. When, however, a real judge speaks of "a high-class hunter," he has but one animal in his mind-a lengthy, well-built, and well-bred horse, which, if possessed of manners and docility, generous in dis- 
position and gifted with intelligence, is equally at home over the broad pastures and flying fences of Leicestershire, the cramped fences of Devonshire, or the intricate banks of Wexford, Kildare, or Westmeath. In countries where the enclosures are of considerable size, and scent lies well, it is of the utmost importance that a hunter should possess great pace, if his rider intends to be carried right up to the hounds; and if the horse can both gallop and jump, other faults, if not too pronounced, may be overlooked by a firstclass rider, who means "to be there." But in cramped, awkward countries, where it is often necessary to pull up and take a look at a fence before jumping, and then perhaps to crawl leisurely down, pace is not of such primary importance as docility and cleverness. Such a country, in fact, as one in which a youthful sportsman one day, when perched on the top of a high bank bordering the lane along which the huntsman was passing below with the pack, called out in tones of agonised entreaty, "Matthews! Matthews! Will I slither, or lep?" The rider who has hunted all his life in this latter country, does not therefore understand the value placed upon pace in the flying countries, where rivalry is keenest, as WhyteMelville so inimitably portrayed in the character of Mr. Sawyer when he visited Market Harborough; and he cannot comprehend why his own clever, stiff-built little nag, which has carried him without a mistake over the creepycrawly fences in his own country, should fetch sixty to eighty guineas at Tattersalls, whilst his neighbour's galloping hunter, which in his heart of hearts he considers quite inferior to his own, is eagerly competed for, far into three figures.

It is not, also, always the case that a hunter fetches a long figure on account of his performances, for looks play a great part, and hundreds of riders go out hunting who have no intention whatever of going straight, at any rate in England. In Ireland it is quite different, for the paucity of gates, and the almost certainty that if there is one to be seen it will be fastened to a stone gatepost with a strong chain and a stout padluck, makes it a sine quâ 
non for any one going out with the hounds that they must jump what comes in their way. The well-to-do, portly equestrian, with a good balance at his bank, a good cook, and a well-stocked cellar, is not so familiar a figure in an Irish hunting-field as in an English one. Such a rider usually comes out for the sake of his digestion, and to hear the last gossip or amusing tale, and has no intention whatever of taking unnecessary risks; but he likes his steed to be of good appearance and of as stout proportions as himself, with perfect manners, and he is willing to pay a really high price for one on which he will look noble at the Meet. Nor is he unwilling that the price he has paid for his steed should be on the tip of every one's tongue. Still, whatever the notions of the rider may be and whatever the character of the country he hunts in, there are some points his steed must possess or he cannot act his due part in the play. Good sound wearing legs and feet are among the first essentials, and cannot be overlooked; wellsloping shoulders he must possess, or he will be unable to extend himself, and be liable to fall. There must be strength, too, in the muscles of the shoulders, for a horse which is thin in this region and weak in that important point, cannot carry weight, and will soon tire in deep ground. Very essential are the muscles of the neck, for they have to sustain the whole weight of the head, situated as it is at the end of a long lever. Badly put on it may be, and without beauty, but if the muscles are strong the horse may yet be able to perform its task, which with a weak neck it is incapable of doing. The back must be powerful, and if so a little extra length, though far from being desirable, does not at once put the animal out of court. He may still be able to gallop and jump, though not equal to carrying as much weight as he otherwise would. And now we come to one of the chief essentials, the development of the thighs, and those great glutei muscles, which are, together with the triceps and biceps, known under the generic term of quarters. A hunter cannot have too great development in this region. When viewed from behind a horse must show "a good pair of breeches," the thighs meeting each 
other, and the whole presenting a good broad aspect. From a spectacular point of view, too, this is desirable, for it gives a bad impression to ride behind a rider whose rotundity of form is not equalled by that of his steed! In addition to being broad the thighs must be long, for on the length of a muscle rather than its breadth depends its retractability and its power. It is extremely important that the thighs should continue almost imperceptibly into the second thighs when viewed sideways, nearly forming the shape of a " $V$ " with the hock. If the thigh should appear to terminate suddenly, and then the second thigh be all of one breadth, forming an additional piece, as it were, have nothing to do with that animal and do not let it find a place in your stable, however taking in other respects, for no really good hunter was ever built in that way. The action must be free and elastic, the hind-foot at the walk covering the print made by the fore-foot by at least 6 or 7 inches. It is the freedom thus indicated which saves many a fall, when accompanied by a strong back, more so even than the shoulders, and many a time has the writer been thankful, when a mistake had been made, and a fall seemed inevitable, to see a hind-foot come sweeping past his leg, and with a brave heave of the back the good steed has saved the situation-and a cropper.

Amongst other necessary requirements are large welldeveloped joints, especially hocks and knees; while the arms must be long, with plenty of muscle, the tendinous termination of which should be markedly shown immediately above the knee itself. This part should appear broad from whatever side it is regarded, and on this very much depends the power of the leg, for any weakness here will result in the animal speedily tiring.

A most essential point in a hunter is that the bone should be very strong immediately below the hock-joint, which should run into it gradually and not give the appearance of a little bit having been scooped out in front, as is so often the case. When this is seen it is odds on the horse springing a curb in deep ground, and a lack of power in the limb generally is thus indicated. A hunter should 

possess a big barrel-a good "spur place" it is often termed-for this denotes a strong constitution, and the horse is likely to be a good feeder after hard work; but while the ribs should be well-hooped, and the larger they are the better, the actual length is not so important as that they should spring from the spine with a good arch. Many a comparatively short-ribbed horse is hardier and a better feeder when his ribs spring well from the back, than another with a much longer length of rib which has a drooping, rather than an arched curve, at the commencement. Moreover, the hinder rib must not approach the prominent part of the hip too closely, but leave sufficient room, so that when the hand is placed in the hollow between the last rib and the hip, and the fist is closed except the thumb and little finger, these last can just touch, when fully extended, the respective bones on each side. Without such room the horse can neither gallop nor jump, as he has not liberty to bring forward his hind-legs with sufficient swing. People with a little knowledge are apt to imagine a horse must be tightly ribbed up-with almost no hollow between the rib and the hip-to be a good feeder, but such is not the least necessary; though horses so fashioned have necessarily good constitutions, since they must possess both large and well-hooped ribs, or they could not cover up the hollow. There are plenty of horses to be found with wellshaped ribs which do not suffer from the defect of being tightly ribbed-up and yet are always ready for their food.

Hunters should bend their knees when trotting, and lift their feet well, but without any of the extravagant style of the hackney, which is quite unsuitable for a riding-horse, required to travel fast and far. Preferable indeed to showy action is the daisy-cutting, straight-kneed mode, at one time so prevalent amongst thoroughbred horses when Touchstone was a power in the land, for it was very characteristic of his progeny. Yet at any rate his stock possessed the merit of going fast, which no hackney ever yet succeeded in accomplishing at a gallop. When the fore-foot is extended, close attention must be given to see that the foot is placed level on the ground, neither 
digging the toe in nor putting too much stress upon the heel, and, moreover, the foot must come to the ground at the full stretch of the stride, and not be drawn back an inch or two, as is not unfrequently the case. Horses thus tightshouldered cannot gallop in proper form, or extend themselves for just those few extra inches, when a ditch is suddenly found to be unsuspectedly wide. Some riders never appear to grasp this, and one acquaintance seemed always to buy horses with this defect. Dealers used to lay themselves out for him, and bring him good-looking horses which they could not get a good price for on account of this fault, and he cheerfully bought them, priding himself on his acumen. During many seasons he never owned a horse that could go, though in the stable they looked superb. It never seemed to cross his mind that his own judgment might be in error!

A fault that may sometimes be excused in a first-rate performer is when the trotting action is not absolutely true and the horse dishes more or less. Many a good horse does this-an eyesore no doubt, but still it does not interfere with his going well, though the undue strain thrown on certain parts may provoke a splint to form. The famous hunter sire in Ireland, Haymaker, whose stock was eagerly sought and purchased, seldom sired an animal that was quite true in its action, but he scarcely ever got one that was not' a superior performer. A horse which brushes must be an unusually good hunter to retain its place in the stable, for though various kinds of boots may minimise the trouble, brushing gives rise to much extra care and attention, though it may not incapacitate the animal from work. Careful shoeing may often prevent it, and young animals may grow out of the habit as they get older; it is generally caused by the foot, and fetlock, being turned from the true line of the cannon bone. A pigeon-toed horse-one with its toes turned in-seldom hits itself, though the contrary might be expected, but whilst this is an indication of want of speed, turning out the toes is just the reverse.

When trotting a hunter should flex the hocks well, and sharply, and bring the hind-legs under its body with energy, 
thus showing promise of power in propelling itself forward, either in the gallop or when leaping. A slovenly mover, which drags its hind-legs with little bending of the hock, should be passed over at once.

\section{Character and Appearance.}

Much of the character of a horse may be learned by studying its countenance, and watching the motion of its ears. Sinall ears invariably denote temper of some sort, and should be studied for a few moments. If restless the horse will probably be hot-tempered and fidgety, never keeping still, wearying itself and its rider, and far from being a comfort to ride. If the small ears are seen to be constantly pricked forward, look out for shying; or if laid back, especially if the eye is small and sullen, be very sure that the animal has a sulky temper, is ungenerous in its work, and not to be depended on. The ear to be desired is a large and full one, and kept frequently in motion, without any tendency to restlessness. This is a sign of intelligence, and a quick brain, while a horse which seldom moves its ears is too apt to be lazy, and given to making blunders. A large lop ear, often in motion, is an invariable indication of a docile, sweet-tempered horse, ready to put forth its utmost powers at the call of its rider. While on the subject of the ear, let it be clearly laid down that on no account should the groom be allowed to cut out the thick covering of hair Nature places at the entrance, for mischief may ensue if this is done. It is placed there to keep out dust, rain-drops, and insects, and if either of the latter gain access to the interior the horse may get almost out of control for the time, shaking its head and trying to rid itself of the intruder.

The head should be long, and on this depends the length of the animal, for in a well-proportioned one, $2 \frac{1}{2}$ heads equal the length from the point of the chest to the remotest part of the haunch. A long head, with plenty of width in the forehead, is sure to belong to an intelligent horse, while a small, pretty head, too often indicates what children term "a silly." Especially is this the case with a gelding. The character of the head should befit the sex, the male having a 
larger, more bony head, not so pretty as that of a mare. Either sex, with a head which by rights ought to grace the other, is apt to be of abnormal temperament. The nostrils when at rest should be long, and resemble a widish slit, and when dilated expand into a large circular orifice. Especially is this the attribute of high-born Eastern horses, and their descendants our race of thoroughbreds; but it may be looked for in vain amongst cart-horses, and their progeny for several generations after the introduction of thoroughbred blood. There is no more sure sign or hallmark of caste.

The neck should be light when viewed sideways, but thick through when observed from the saddle, especially in the muscles just behind the setting on of the head, for on the development of this region largely depends the power of staying. The neck should be strong, too, where it is set into the shoulders, and this will probably correspond with the general muscular development of the body. Though the neck should be light and curved gracefully, when seen from the side, it should not be too small in circumference just behind the head, for unless there is plenty of room for the windpipe the misfortune of roaring may be experienced. There is one form of neck which must especially be avoided, known as " a roarer's neck," since a horse thus built almost invariably contracts that malady sooner or later. In this instance the neck is held on high, and is in most respects a porverful neck, but in the middle the throat is enlarged, and there is a noticeable outward curve, somewhat resembling the shape of a stag's throat. Why this should result in roaring seems to be that the nerve of the larynx is kept constantly stretched, and in time the strain becomes too much for it, causing it to become partially paralysed, when roaring follows. A friend used to admire these necks, and nearly every horse in his well-filled stables was so framed, but probably no man ever had so many horses which became roarers. He gave long prices for them, and constantly bewailed his bad fortune, but to the day of his death he would not learn the lesson that his judgment was in fault rather than his luck. 
That a hunter should bridle well and give freely to his bit goes without saying, for it adds immensely to the comfort of the rider as well as to the appearance of the horse; but unless there is sufficient width in the angle of the jaws, the animal may not be able to bend the neck sufficiently to do so with ease. Many a good hunter pokes his nose out, and is yet a safe conveyance. The width is desirable also in another way, for a jaw may be too close together to give sufficient room for the windpipe, and all first-rate stayers are wide in this region. There should be space enough for the outstretched forefinger to be inserted between the jaws, from the knuckle-joint to the tip of the finger, and less than this should cause the steed to be rejected.

The shoulders should be long and well sloped, and the withers sufficiently high and defined to make the saddle fit its proper place; but there must be plenty of muscle as well, or the horse cannot save itself in a bad scramble with a weight upon its back. Though a round wither makes it difficult to keep the saddle in its place, if there is plenty of liberty in the shoulder it is preferable to a high, thin, knifey wither, for this means weakness, while the other means strength. Whether the saddle keeps in its place depends much upon the depth of the heart-ribs underneath, for if these are not well developed and a straight line can be drawn parallel to the ground, under the chest, the girths will ever have a tendency to work forward. When this is the case they are apt to create a sore behind the elbow, which often happens with an undeveloped four-year-old. An excellent remedy for this is to tie an old bootlace tightly round the girth, bending back the front edge, so that it no longer comes in contact with the abrasion. While the chest itself should be of such width that the fore-legs are well apart, it should terminate in an arch when viewed from the front, for if it appears square there will be a falling off in speed. If the space between the legs is too narrow, there will be a tendency to hit the opposite limb when tired, in deep ground. 


\section{Docking AND Hogging.}

Mercifully the silly practice of docking hunters seems going out of fashion; it was a dealer's dodge to make the quarters appear broader than they naturally are, and unthinking sportsmen tumbled into the trap, and were led to believe it looked smart. When it is urged that "it does no harm," the answer is, "Look at horses who have been docked, after a sharp gallop, and compare their appearance with those untouched with the docking knife." If only an inch or two are taken off the bone of the tail no injury may be done, but all horses with short docks will show by the excessive shaking of the stumps that the nerves of the part have been seriously affected. Now that the tails are left long another absurd practice has come into vogue amongst grooms, who must be ever meddling with Nature, which is far more clever than they are, and they pull out all the upper hairs till they make the tail look little more than a rope. A full tail has a beauty of its own, and swings with a charming swagger to the stride of a well-bred horse, but the thing that is now the cherished object of the groom has neither meaning nor beauty. Still the poor horse may be thankful that for the nonce he is not deprived of his tail, and that he has some switch left to defend himself with from the attacks of the flies, when he is allowed the luxury of a run at grass. It is a pitiful sight to watch a horse deprived of his tail tormented with flies in the heat of summer, and obliged to stamp incessantly to obtain the briefest respite from the worrying pests. There is no rest for him, and the constant concussion has a bad effect upon his legs, which is attributed by the groom to the being at grass, and not traced to the real cause, that he has been deprived of his natural weapon and means of defence. When a mare comes to fulfil the first law of nature, and goes to the stud, how much unnecessary misery is she not caused, if she has been docked short in the days of her youth. Besides its office as a defence against flies, the tail is intended to protect very delicate parts from the vicissitudes of weather, and it may easily be observed that 
horses invariably turn their backs to the storm, relying on the shelter afforded by a flowing tail, down which the rain-drops harmlessly drip. How is the short-docked horse able to help himself under the same adverse circumstances? Moreover, the tail is again a protection when the animal is lying on damp ground, and acts as a para-pluie, or a parasoleil, according to circumstances. The animal provided as Nature intended, with a bushy tail, should be much envied by the one subjected to amputation, for when flies bother a whisk or two soon settles them, and when storms threaten it has plenty of thatch to protect itself also against them. From an artistic point of view the removal of the tail betrays a sad lack of culture, since the symmetry of the animal is at once destroyed. Nature is a consummate artist, and every detail is carefully thought out. The trunk of an animal may be regarded as a table, balanced on four supports, and then when a prolongation is added to one end, to obviate a top-heavy appearance something must be designed to add to the other end to balance the whole. Thus, when the head and neck are appended, the tail is also required for symmetry's sake; and a docked horse resembles nothing so much as a teapot, with the spout intact but with the handle broken off short! The opponents of vivisection are numerous, when most invaluable knowledge for the benefit of the human race can only be thus gained, but here are animals vivisected by the thousand for no earthly reason except a silly fashion, bringing discomfort and often misery to the victim for the remainder of its life.*

* In July, 1911, before Mr. Cecil Chapman, at Tower Bridge Police Court, a person was summoned for causing two horses to be ill-treated, by docking them; and his horsekeeper was also summoned for ill-treating them by performing the operation. He stated it was done to smarten their appearance, and to strengthen their backs. Mr. Chapman said the docking of horses was founded upon ignorance, and having become a custom it prevailed long after the ignorance had been exposed. A horse that was docked might fetch more money at a sale, but to enhance its value by inflicting pain was not justifiable. In order to mark the importance of the case, the owner would be fined $£ 3$, and $£ 33$ s. costs, while the horsekeeper would have to pay $2 \mathrm{~s}$. costs. 
Though the fashion of docking appears to be waning, another thoughtlesss one is still in vogue, though fortunately the animal suffers no pain, nor any permanent injury, through having its mane removed, or "hogged." While an artist, and Nature, delight in flowing lines, it is a curious trait in so-called civilised peoples that the mass of them seem to lose all artistic instinct, so prominent amongst savages in general, and rejoice in crude colours and rigid straight lines. This accords with their notions of smartness, and to this everything must be subservient, whether suitable or not. Cutting all the hair off the mane, and leaving a bare straight line instead of a picturesque flowing one, just accords with their ideas, and they never stop to think whether Nature had any especial reason for decorating the upper part of the neck with long hair. It does not occur to them that this covering was intended as a thatch, to ward off the powerful rays of the sun from the vertebræ of the neck, and to keep the rain from lodging there, and much discomfort is caused to hog-maned horses from the wet soaking down to the roots of the clipped hair, instead of running harmlessly off as it would otherwise do. If moorland ponies were treated in such barbarous ways, they would soon succumb to the vicissitudes of weather they are constantly exposed to, which they now defy, owing to their shaggy manes and tails.

If the broad lines Nature has laid down are intelligently followed it would be a gain in comfort to the animals and also to the artistic eye. Tails and manes may be trimmed, without doing away with them altogether. The old rule used to be that a hunter's tail should just reach the bottom of the thigh, in a state of rest. It is then short enough to be well out of the mud, while it is long enough to look handsome, if only the upper hairs are left intact; but a thin rope-like tail is a positive eyesore. A mane may be thinned judiciously, and curtailed in length, but plenty should be left; and it has its uses too in helping the rider to mount, while many a fall is saved by him, in bad scrambles, when enough mane has been left to catch hold of in an emergency. 
One of the not-always-acknowledged reasons for removing the mane is to give a fictitious appearance of breeding, and so help the sale of an under-bred animal, really incapable of carrying itself to hounds, let alone the rider as well. Therein lies the crux, perhaps, of the whole matter, the vendor hoping to persuade the purchaser that the animal is better bred than is the case, by the help of a fictitious air of "quality" through the medium of a hogged mane, for, as is frequently remarked by dealers, "hogging a horse gives it another cross of blood." This does not avail it, however, when the "Run of many Seasons" is taking place, and the rider finds his steed dropping away hopelessly into the rear. Of all, soul-vexing trials there is perhaps nothing more heart-breaking than to get a good start in a rideable country, with the hounds racing on a breast-high scent, and yet to find your steed getting further and further behind; you are overtaken and passed by one horse after another, till you are reduced to following some red coat in front, who is perhaps only following some one else who is as far before him again, and yet is not really with the hounds. As Whyte-Melville so truly sings in "Drink, Puppy, Drink," it is the "Pace that puts life into the Chase"; but what is the good of pace to you, when you are mounted on an animal that cannot gallop "as fast as you can kick your hat"! When a would-be authority on hunter-breeding advocates as a quite sufficient cross for a hunter to be by a thoroughbred horse out of a cart-mare-or even with two or three such crosses-it is conclusive evidence that either he was never a first-flight man to hounds; or else that he has hunted all his days in a very slow-going country. Certainly a really fast hunter may have but one known cross of thoroughbred blood, and his dam may have worked in a cart, but there must have been several good crosses of blood amongst her maternal dams, although unknown to the owner of the steed. Many a well-bred animal finds its way occasionally into a cart. Unless the animal has proved itself capable of going to the front in a good thing, it is not wise to purchase a horse about whose ancestry there is any doubt. Although pure-bred horses, 
suitably made and of docile and generous disposition, make the finest hunters in any country, there is a strange antipathy to them on the part of many riders, and I have been told by large dealers that they dare not admit to the generality of their customers that a horse they are admiring is in the Stud Book. "Almost thoroughbred, my lord-in fact as good as if he was so," sells many a horse, when if the truth were admitted it would cause the customer to turn away at once. Such is the power of prejudice! And yet, looking back over half a century of hunting, the great gallops which remain in memory were all on horses of blue blood, or so nearly thoroughbred that they were capable of winning races on the flat or between the flags.

\section{Some Good Gallops.}

First-hand evidence is ever held in the highest estimation in our Law Courts, and therefore proofs of the value of high descent will be shown by the narration of the following runs in totally different kinds of countries, not one of which would have been seen if mounted on an animal with but one or two crosses of blood. One great gallop was seen on Redbourne, then coming five years old, who had run as a three-year-old in the Derby won by Hermit twenty months previously, and who was half-brother to Wolsey who ran a dead-heat for the Cambridgeshire with Lozenge; while yet another brother was third for the Derby, in Lord Falmouth's colours, running as The Repentance colt. Getting rather a bad start from Goldsborough Moor, and with hounds racing at their topmost speed, Redbourne soon made up the lost ground, and in a short time we were absolutely alone with the pack. Just before the fox saved his brush for the moment, in a drain under a gateway in the road close to Scriven, I saw him in the last field not fifty yards before the leading hounds, who caught sight of their quarry before he reached the hedge, and raced him down the road till he was glad to squeeze into any refuge; and when Sir Charles Slingsby came up, it was a great satisfaction to be able to 
point out the spot where the fox had been seen to slip in. That was one of the fastest runs I ever saw, and all through deep-ploughed fields. There were plenty of well-bred horses out which got better away with the hounds, but could not live with them at that racing pace, and it needed a Derby horse to reach the pack, and live with them to the end. What would be my recollections now, if I had been mounted on the vaunted animal with ONE cross of blood! I fear the memory of that run would not have remained so vivid for forty-one years.

Four years later the scene was changed to Galway, in the heyday of that prince of huntsmen, the late Burton Persse of Moyode. The Meet of the far-famed Blazers was that day at Clonfert, the seat of Archdeacon Butson, and a large field was assembled there, for in addition to the usual members of the Galway Hunt there were many strangers from the Westmeath, King's County, and Ormonde Hunts, who gladly seized the opportunity of a hunt with the Blazers, when for once they met within reach. We quickly found, and it was immediately evident that there was a tearing scent, as the hounds flew over some large grass fields, girt with stone walls. I was riding Kettleholder, then seven years old, who as a three-year-old was heavily backed both for the Cambridgeshire and the Royal Hunt Cup at Ascot. He was half-brother to Elland, who won the Ascot Vase, and his sire was Kettledrum, winner of the Derby. His dam was the famous Ellermire, one of that wonderful family bred by Admiral Harcourt from Ellerdale of whom Ellington won the Derby, Summerside won the Oaks, while Gildermire ran a dead-heat for the Oaks; and a few years later, in 1868, the daughter of her own sister Eller, the beautiful Formosa ran a dead-heat with Moslem for the Two Thousand Guineas and further won the One Thousand, The Oaks, and also the St. Leger. Ellermire herself was a notable winner, and her most memorable race was thus described, many years after the event took place at York :-

"A couple of seasons later the County Plate supplied one of the most stirring contests of its kind that I can remember. The stake was of 15 sovs. each, 5 sovs. forfeit, and the added 
money but 100 sovs. The subscribers were forty-three, and the quality of eight out of the nine runners remarkable. One of them was Virago, then at the height of the reputation that was fully warranted by her remarkable performances during the earlier part of that season of 1854 . Up to the time of her appearance on Knavesmire she had, within a few months, carried off the City and Suburban and Great Metropolitan Stakes (on the same day); the Great Northern Handicap and the Flying Dutchman's Handicap at York; the One Thousand Guineas; The Goodwood Cup and the Nassau Stakes; and the Yorkshire Oaks. Amongst her opponents for the County Plate were older horses of remarkable speed. One was Ephesus, a winner of the Earl Spencer's Plate, under 9 st. $7 \mathrm{lb}$; another, Orestes, the property of Baron Rothschild; a third, Vindex, who had done smart things under the white, scarlet, and black of Sir Charles Monck; and another, King of Trumps, a good horse, but, on the whole, not a lucky one. Another competitor was the light-hearted Kingston, whose death caused the founder of the Middle Park Plate so much sorrow; a very fast Hetman Platoff three-year-old called Hospodar, the property of Lord Zetland; and Ellermire, by Chanticleer out of Ellerdale, a brown two-year-old filly, owned by Admiral Harcourt, and ridden by Aldcroft at 6 st. $9 \mathrm{lb}$.

"Although Virago had been trained for long-distance races, she was believed to be such a wonder that few doubted her ability to win over the T.Y.C. even when opposed by ' fliers.' Odds of 2 to 1 were betted on her, next in demand being Orestes at 6 to 1 . Of Virago it may be stated that she was to all intents and purposes never in the race, and after Orestes, King of Trumps, and Ephesus had looked dangerous, the two-year-old won a most stirring race from King of Trumps by a head, Ephesus being beaten half a length from the second, and finishing a head in advance of Hospodar, who only had a slight advantage over Orestes !"

Kettleholder was 16.1 in height, and a splendid fencer, and used to jump the walls in his stride as if he was steeplechasing. Though we did not get away with the very first, it did not take long before we were up with 


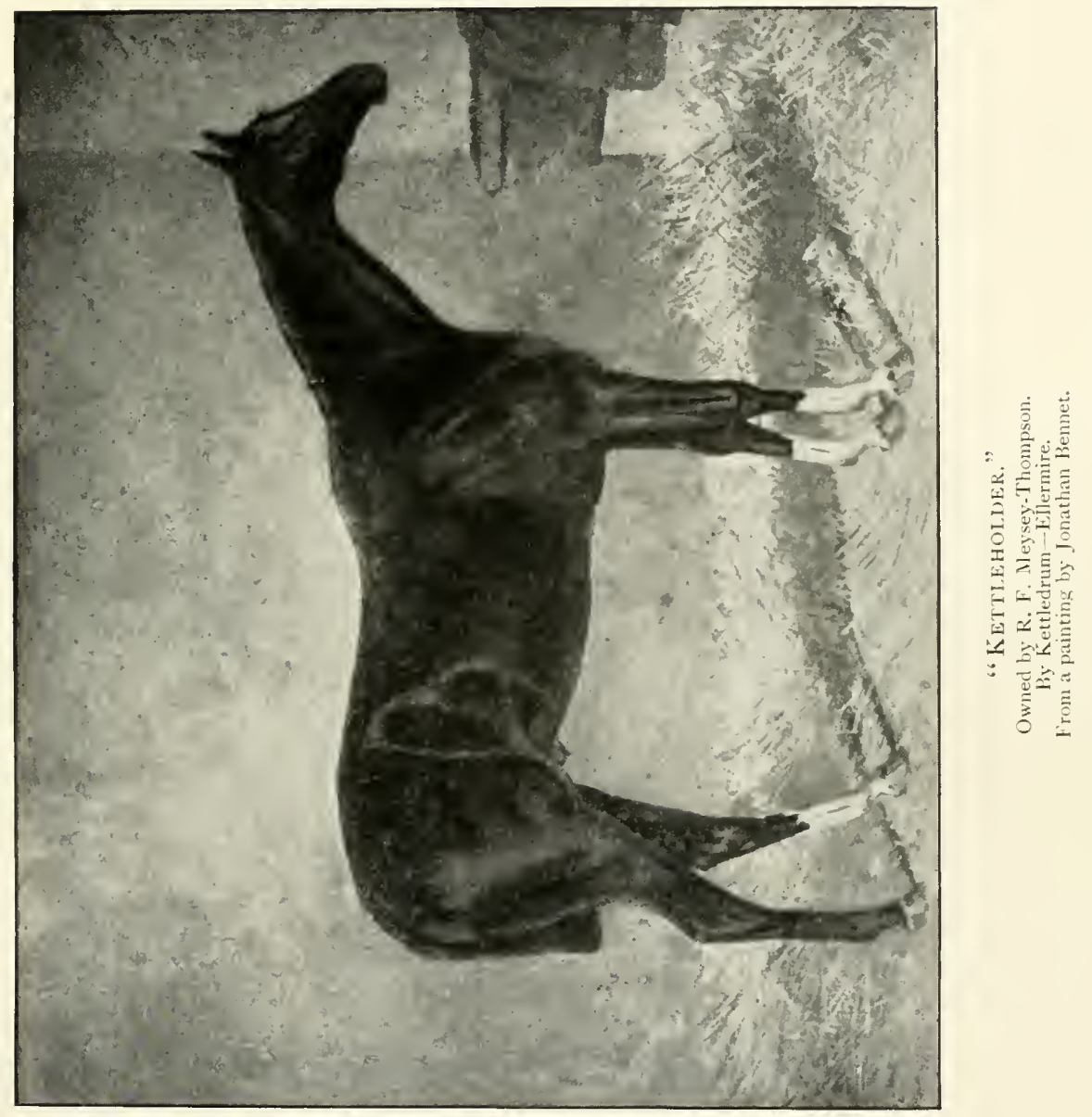



the leaders, which were reduced to two, for the hounds were running at a glorious pace, Burton Persse being on the right, and a local farmer on the left. An extremely high wall bounding a large grass field was taken by the three of us almost abreast, but while Burton Persse got over with difficulty, and the farmer, taking a lot of stones off, had a great scramble, Kettleholder took it in his stride, and raced on after the pack without hesitation. Though from that moment I lost sight of my companions I half thought I saw Burton Persse pulling off to the right, but there was no time to notice what he was doing, for the hounds were flying as fast as ever in front, and another huge wall was looming before me. If anything it was bigger than the previous one, standing well up above the horse's ears as he galloped at it, but he treated it in the same way as the other, and never touched a stone as he flew into the next field. I was new to Ireland, and to Galway, but this was the sort of thing I had expected to find, and it seemed to fit in with one's highest expectations. At the end of that field another immense wall had to be jumped, probably a continuation of the same we had just crossed, and I verily believe it was the highest of the three, but after jumping it the hounds did not carry on much further before they threw up, not far from a farmhouse. It was only then, whilst the pack was making its cast, that I had time to look round, and found I was alone, nor did any one else turn up for such a long time that I began to wonder what I should do. Then a clattering was heard, and several of the field, with Burton Persse at the head, came galloping down a lane leading to the house. Burton Persse proceeded to try to hit off the line, but the others galloped back to the last wall without drawing rein, and a sentence just reached me from their midst, "Did he jump that wall?" After satisfying themselves they returned, but the run was over, for though the line was eventually touched upon too much time had elapsed, and the fox had to be given up. I never realised that no one had been able to follow Kettleholder, and when at the meet of the King's County Harriers the next day, at Kilmaine, the Master, the late Mr. Joseph Studholme, rode up and said, 
"So I hear you cut down all the Blazers yesterday!" I at once replied, "Oh no, I didn't." "Oh yes, but you did though," he answered, as he turned his horse away; and then one of my brother-officers came up, the Hon. Algernon Grosvenor, and exclaimed, "I would gladly give a thousand pounds to do what you did yesterday with the Blazers." But even yet I was not convinced, and thought they intended kindly, but were mistaken in what they had heard about the run. It was not indeed till I stayed with my old friend, Mr. Studholme, in 1903, just thirty-one years afterwards, whom I had not seen for twenty-two years, that $I$ at last grasped the full significance of their remarks. When chatting over the old times, all of a sudden he remarked, "Do you remember the day when you cut down the Blazers on Kettleholder? What a horse he must have been!" And then I learned that his feat was still remembered, and had long been a local tradition. A further tribute to the memory of that gallant horse was paid only two years ago from a most unexpected quarter. Correspondence in connection with the letting of a grouse moor renewed a friendship begun on that very day, the outcome of that exhilarating run. The late Johnny Eyre, of Eyrecourt Castle, as popular and daring a comrade as ever lived, was one of the field, and when the hounds moved on to draw the Eyrecourt coverts, he invited me to ride up to the Castle to snatch a hasty lunch, and introduced me to his sister, Miss Alice Eyre, the acknowledged belle of Galway, a favourite partner at balls of our late lamented King, then Prince of Wales. Our paths in life had lain in very different directions since those days, but the grouse moor led to a happy renewal of our old friendship, and in one of the first letters was this sentence: "Do you remember that famous run, when you were quartered at Birr? Poor Johnny used to rave about it, and was never tired of talking about it." Kettleholder, it may be remarked, remained an inmate of my stable for seven years, and performed many a gallant deed, well worthy of his high lineage.

It has been shown what a high-class thoroughbred horse 
can do in a deep plough country, and what he can do in one of the most famous Irish countries; and now let me give an instance of what one can do in a rough moorland run. On this occasion the pack hunted by Captain, Hon. Francis Johnstone, near Scarborough, met at Ayton, and found a fox almost immediately, at the very beginning of Forge Valley. From the commencement the hounds settled down to run with a breast-high scent, crossed the River Derwent, and went up the hill and over the farm of the late Mr. Thomas Darrell. I was on a young mare, Chariberta, by Charibert out of Tita, who had won twenty-two races on the flat for the late Mr. Harry Hall. At first the hounds had the best of it, for we had to follow as best we could through the wood on the side of a steep hill, then ford a rocky stream, and afterwards clamber up a steep ascent; but when I got to the top I just saw the tail hounds jump a fence about two fields off, and therefore knew in which direction to gallop, instead of losing time in finding out where they had gone. From time to time I saw a hound here, and another there, and when after a little time we swung past the end of a plantation the whole pack was in sight, racing at top speed over the open moor. Gradually Chariberta gained upon them, and at length got up to them, the fox keeping either to a sheep track, or sometimes a cart-way, as they almost always do in a prolonged moorland run. Thus we skirted the head of the Crosscliff Valley, leaving it to our right, and held on for Saltersgate, but before reaching the descent the fox found his strength failing, and, coming round to the right, endeavoured to get back to the shelter of the Crosscliff woods. I now got a view of him, and soon afterwards the hounds did also, finally running into him on the moor, about a quarter of a mile above the Crosscliff shooting lodge. The distance the hounds had traversed was measured on the map to be about twelve miles, and there had scarcely been a check the whole way, though hounds do not travel so fast over heather, as they do when running over level grass fields. This was far the best moorland run I have ever seen in any country, but it needed a good thoroughbred horse to carry 
its rider in touch with the pack, and it is needless to speculate on the part the half-bred animal could take in such a gallop.

One more example of endurance, and this subject will be finished. This time I will select an animal not in the Stud Book, for though her dam, Kitty, an Irish-bred mare, was a winner of steeplechases, her pedigree was unknown. Kittiwake herself was by Speculum, and was sired by him the second year he was at the stud; and besides running second in 1879 she won the Light-weight Grand Military at Punchestown the following year by several lengths, ridden by that excellent jockey, the late Captain W. B. Morris, of the 7th Hussars. She also ran third for a two-mile hunters' race at the Curragh, in a large field, ridden by myself when carrying the prohibitive weight of 13 st. $4 \mathrm{lbs}$. I possessed but two horses at that time, both of which I rode as my chargers, and Kittiwake being the stouter of the twain was usually selected for riding with the Ward Union Staghounds, then at the summit of their renown, under the guidance of the late Leonard Morrogh. It was the period when the late Empress of Austria hunted in Meath, who was ever close to the pack, being splendidly mounted, and one of the best riders that ever graced a hunting-field. At that time a famous deer tenanted the paddocks at the Ashbourne kennels, of whom it used to be said she never was taken under fifteen miles; and on two occasions she far exceeded this distance, when I happened to have the luck to be out, and riding Kittiwake. It was in 1879, and on the first occasion we met at the "Black Bull," eleven and a half English miles from Dublin. The Enfield Doe led us very straight, and after crossing the well-known Bush Farm with its formidable fences she left Dunshaughlin about a mile to the left, went past Gerrardstown, and was taken near Boyne View, about a mile from Navan, a distance of nineteen miles in a straight line on the map, and, of course, much further as the hounds ran.

On the other occasion, on March 5th, the Enfield Doe was turned out at Norman's Grove, ten English miles from 
Dublin. After crossing the Fairyhouse race-course, the gallant deer left Ratoath some two miles to the right, and then, swinging round by Tobergregan House, she passed over Garristown Hill, and leaving Bellewstown race-course to the right, was taken within two miles of Duleek. This run was slightly over fourteen miles in a straight line on the map, but was a twisting run, so that a good many more miles were traversed. In neither run was there any check to speak of, we were galloping all the way, and I assisted to take the deer on both occasions. WVe had twenty miles to ride home, but Kittiwake showed no symptoms of being tired, and it was only a month afterwards that she ran second at Punchestown. The next year, when she won, she had been out with the Ward Hounds sixteen times that season. The insistence, therefore, of the absolute necessity of a hunter being highly bred, if you are to be carried up to hounds on those occasions which we are always talking about, and looking out for, when the run is both fast and far, has surely received ample justification. In many countries, however, such runs are never even dreamed of, and the necessity for blood-horses is not therefore such a vital requirement, and yet occasions must arise when little of the run will be seen, owing to being thrown out, unless a horse can rapidly make up the ground that has been lost; while few persons used to riding well-bred horses feel really at home when mounted on a low-bred animal. Although the value of blood is thus strongly urged, it must not be forgotten, when breeding hunters, that certain lines are pre-eminent for producing clever cross-country performers, while others are just the reverse, and their stock are seldom natural jumpers. Moreover, much depends upon the individual sire, apart from the family to which he belongs. To a few stallions is vouchsafed an especial faculty for begetting natural jumpers, as is speedily noted in their own neighbourhood, and to a certain extent is proclaimed to the world when they gain honour also between the flags. Some stallions, however, are famous hunter sires, when, for some reason or other, their stock do not contrive to show prominently amongst the winners 
of steeplechases, either from want of stamina, or of speed, or perhaps both. A stallion which has won over comparatively short distances is usually a sharp, quick horse, and is more likely to sire good hunters than a slow, plodding race-horse, which has never come to the front except over long distances. A horse that has shown winning form at both short and long distances is the animal required, but is not always to be found; and if a choice had to be made between two animals, I would personally select the animal that had shown speed and dash rather than one which had been slow, though a stayer. Speedy horses are often big powerful animals, with excellent shoulders and free action; but their very weight causes them to tire in a race more rapidly than a light, wiry horse. If the latter has been unable to show speed, it may be taken for granted that the machinery does not work with the due mechanical smoothness which probably will be inherited by its more plebeian offspring.

\section{Some Celebrated Sires.}

It has been mentioned above how certain individual sires have been a conspicuous success in siring hunters, and if within reach of such it is well worth a breeder's while to pay an extra fee for the services of such an animal, whose reputation stands on a well-established footing. 'To mention but a few whose names have been "household words," there were Old President, and Bay President, MacOrville, and Perion, in Yorkshire, in years now long past, and Gainsborough, Lifeboat, and Gunboat, in Devonshire. In Ireland, Sir Hercules was a mighty name, and afterwards his son, Birdcatcher, and his many descendants. The Stockwells could all jump, and so could the Melbournes, while the Beadsmans, the Flying Dutchmen, and the sons of Artillery were all constantly distinguishing themselves between the flags, and were eagerly sought for by trainers of steeplechasers. Of later years the Cedrics were renowned in Yorkshire, and then the Gordons, and Red Eagles, while Ireland boasted of her Arthurs, and Victors, and then, greatest of all, the incomparable Ascetic. It is 
very possible that a great part of the success of Ascetic was more due to the elements of Melbourne in his composition than to his descent from Hermit, for in their day the Touchstones and the Newminsters were by no means remarkable as natural jumpers, while the Melbournes were especially apt pupils. In the same way Gordon, who was a successful hunter sire, was very closely related to Ascetic, the one being by Hermit out of a mare by Young Melbourne, and the other by Hermit out of Lady Alicia, by Melbourne. The Voltigeurs were not noted as cross-country experts until Speculum took up the line, but he had a near strain of Birdcatcher, and such is invaluable for animals intended for crossing a country. The great tap-root, Sir Hercules, is a fine example of hereditary aptitude. If anything had occurred to prevent his arriving at maturity, and procreating his kind, the loss to Ireland alone would be quite incalculable, as. well as to the world in general, for his flat-racing descendants have been as distinguished as his jumpers. There are few families which have not been strengthened by an admixture of his blood, though in direct descent the innate gift of jumping has been more strongly developed in some of his sons and their offspring than in others, notably Birdcatcher, Lifeboat, and Gunboat. The badge of the family, "the Sir Hercules crest" as it used to be known, the grey hairs at the root of the tail and scattered over the body, has latterly become more associated with Birdcatcher in the minds of the public, though it was formerly properly attributed to his sire, in whose progeny it was a very characteristic distinction. These "birthmarks" are very curious as well as interesting. The black patches in the chestnut coats of the Pantaloon tribe, and the "hammer marks" on the quarters of the bay "Newminsters," continually show themselves, generation after generation; while the " marks of the Prophet's thumb" are generally to be found somewhere in thoroughbred horses, relics of their descent from Arabian ancestors.

It is often remarked that hunters are chance-bred animals; but is not this the result of many persons leaving the mating of their animals, and the selection of the dam, to chance, 
and taking very little trouble about it? Most individuals-certainly in England-breed from a mare because she has carried them to hounds for a certain period, to their own satisfaction, and they therefore think they would like to have a foal out of her as a matter of sentiment, and generally put off the attempt to realise their desire until the mare is well stricken in years. They probably know nothing whatever about her breeding, or whether she comes of a family which has been hunted for generations, and they have no intention of founding a line and carrying on the breed from mother to daughter. That the colt or filly which is thus bred should be a disappointment, and throw back to some former undesirable ancestor, is only in accord with experience and the teaching of present-day science; but having bred two or three foals, the owner quite believes he knows all about the question, poses as an authority, and impresses upon such as will believe him, "It is all a matter of chance, my dear fellow; why I HAVE TRIED IT MYSELF!" In his own mind this disposes of the matter! And, moreover, even if he does succeed in breeding a useful animal, it is more than likely he is far too indifferent a horseman to undertake the training of a high-spirited young horse himself ; while there is no groom in the stable fitted to act the rôle of a breaker, so that the young one either ends in gaining its own way, if it is masterful, or gets spoiled, and never takes its place in the hunting stable. This is not so much the case, however, in Ireland, which is one reason for the vast superiority, in general, of the Irish hunter. The dam has very frequently been well ridden to hounds, and shown her aptitude for crossing a country; and also is no chance-bred animal, her ancestors having belonged to the same family, or been in the neighbourhood, for many generations, and the capabilities of each scion having been well known to everybody. Since like begets like if the foal throws back to a female ancestor the type is a good one; and though it is impossible to breed what you like whenever you wish to do so, still a start is made with the elements in your favour. A certain amount of disappointment must be 
looked for, accidents will occur, and own brothers and sisters differ as much from each other in temperament and sagacity as they do in the human race. But a man must have more than his fair share of bad luck if he does not breed some good hunters, if he starts with a well-bred mare of a good, well-established strain of hunters, and is carcful to select a sire whose progeny are famed for good looks and performances in the hunting-field. It is for this end that that most useful body was established, the Hunter's Improvement Society, and breeders who are unsuccessful have only to thank themselves if they have not availed themselves of the opportunities placed in their way of obtaining mares of authenticated pedigree. Blood must tell, whether in man or in the animal kingdom. A striking example of what can be accomplished in establishing families of hunters is shown at Birdsall, where Lord Middleton, and his father before him, has for a long series of years bred almost all the horses required for his vast hunting establishment, and it may safely be said that no Hunt servants anywhere else are mounted on such superb hunters as those at Birdsall. Many of them are thoroughbred, and all the others have so many crosses of blood that virtually they are thoroughbred also, the pedigrees in many cases going back for seventy years. All are of the same stamp of shortlegged, short-backed, but lengthy horses, with plenty of bone, very much the type of the race-horse of former days when heat-racing was still in vogue. Perhaps the hardiest family of all, the one that is especially bred and kept for the whippers-in to ride during the severe and exhausting days on the Wolds, possessed as its foundation a well-bred Welsh pony, about the middle of the last century. This breed is almost tireless, and is especially valued and treasured, and with seven or eight crosses of pure blood added to the original pony cross they are now very well bred indeed. The Wold country somewhat resembles the Downs of the Southern counties, only it is almost all plough, and the fields, though large, sometimes extending to two hundred acres, are divided by very strong growing whitethorn fences, with a large amount of "timber" of various 
patterns and strengths. As the hounds fairly race up the steep hills and down the sharp declivities, whenever there is a scent, and the Meets are often very distant from the kennels, as well as the termination of the day's proceedings, necessitating long weary rides each way, no low-bred horse can be expected to carry its rider with credit or even safety. The very first hill will settle its pretensions, and the rider will be wise if he cautiously avoids the first strong fence he meets, timber or otherwise, when he has been galloping a few minutes up a steep incline. The Wolds, like all hill countries, are best suited by a compactly built horse, and a leggy or long-backed animal is not so handy there, though it may be accounted a good performer in a flatter district. This should be borne in mind by the Royal Commission when awarding premiums to stallions at the Spring Show, for an animal is often sent to a locality for which his conformation is not suitable, when he is not likely to beget the sort the district requires.

\section{The Points of a Hunter.}

To sum up the points of a hunter generally, suitable for almost every country, he should be $15.3 \frac{1}{2}$ or 16 hands in height, a long, deep-barrelled horse, with short legs, good shoulders, a well-developed wither, and a good blood head and neck, properly put on so as to bend nicely to the bit. His quarters must be strong and well let down, with a good back. His elbows must be at liberty, and not touch his ribs; his hocks must be large; and he should move with true hunting action, with full control of his hind-legs, and carry himself well balanced. When you are on his back his knees should show well in front. $\mathrm{He}$ should be free from all rush, easy to ride, and easy to guide, with plenty of sense: one that will steady himself when you require him, while you take a look at a fence, and then make a big jump at short notice, but who will gallop on and take the fence in his stride without any dwelling, if you ask him to do so. Of course pace comes first, but he must bend his knees, and get up at timber, and also creep 
through an awkward place when it is necessary to do so. The dictum of the late Mr. George Lane-Fox, Master of the Bramham Moor Hounds, that no horse is a hunter till he will walk through a gap, has very much truth in it, and common sense.

As a last word on the subject of hunters, mention may be made of the vast amount of money put in circulation through the chase alone, and I venture to refer to the statistics given by Mr. Orde in the first edition of his "Vade Mecum." In this carefully compiled work he estimates that 9,000 couples of foxhounds are in kennel during the hunting season, which at a low estimate require $£ 550,000$ per annum for their keep, and, in addition, 3,500 couples of harriers and beagles cost $£ 100,000$ more.

Two hundred thousand hunters are kept for the purpose of hunting with these hounds, which will have cost their purchasers $£ 12,000,000$, and whose keep will amount to $£ 8,000,000$ per annum-figures which have been worked out by experts and checked by them. As the average life of a hunter is reckoned at "probably less than four seasons," a view which I thoroughly endorse, it follows that the large sum of $£ 12,000,000$ has to be expended every four years in renewing the stud; though it is to be feared that the blighting incidence of the Budget will largely reduce these figures in the near future, through the inability of an everincreasing number of persons to meet its demands, and to continue to follow field sports of any description. Wages for grooms and labourers are calculated as being required for 60,000 to 70,000 men, but these also will have to be largely discounted, for the same financial reasons as those given above. When the families of these men are further taken into consideration, together with the saddlers and shoeing-smiths, and the various small shopkeepers, the butchers, the bakers, the shoemakers, the grocers, and the drapers, who supply their wants, and again the many more persons who act as purveyors to these latter, it will be seen at once what an army of people are dependent on the welfare of the hunting; what widespread destitution would be caused if anything interfered with its 
prosperity, and what an increase there would be to the ranks of the unemployed. The writer was living in Ireland during the disastrous days of the Land League, when it was so ill-advised as to order the stoppage of the various Hunts, and he has good cause to remember the distress and ruin caused by the edict in the county of Kildare, and how the evil blighted with its withering touch such different sections of the community whose intimate dependence on hunting had never before been suspected. History has a way of repeating itself, and when there is no market for hay, straw, oats, or bran, the farmer will also realise how valuable an asset hunting is to him, which is likely to become even greater since so few horses are being reared owing to the advent of mechanical traction.

\section{Ponies.}

In addition to thoroughbreds and hunters, our saddlehorses comprise invaluable native breeds of ponies, so surefooted, hardy, and sagacious, which afford an invaluable starting-point for crossing with other breeds. The one drawback to the dash of pony blood, when a considerable increase of height has been obtained in the course of generations, is the difficulty of obtaining length at the same time, for the short, compact form of the pony does not accord well in appearance with the stature of a 16-hands' horse. Though the Eastern horses are ponies in height, they are true horses in that when crossed with large animals the length is there, and the progeny show no trace of the pony in this respect. In every other way ponies cannot be too much praised, and when crossed with thoroughbred blood, if the height is not unduly increased, they make the best riding-horses in the world.

In general type the ponies of the North of England and Scotland are of a much more powerful build than the Welsh, Dartmoor, or Exmoor mountain ponies, or those bred in the New Forest, while the Irish ponies are rather intermediate between the others. But all seem to possess the same soundness of constitution, and do their work with 


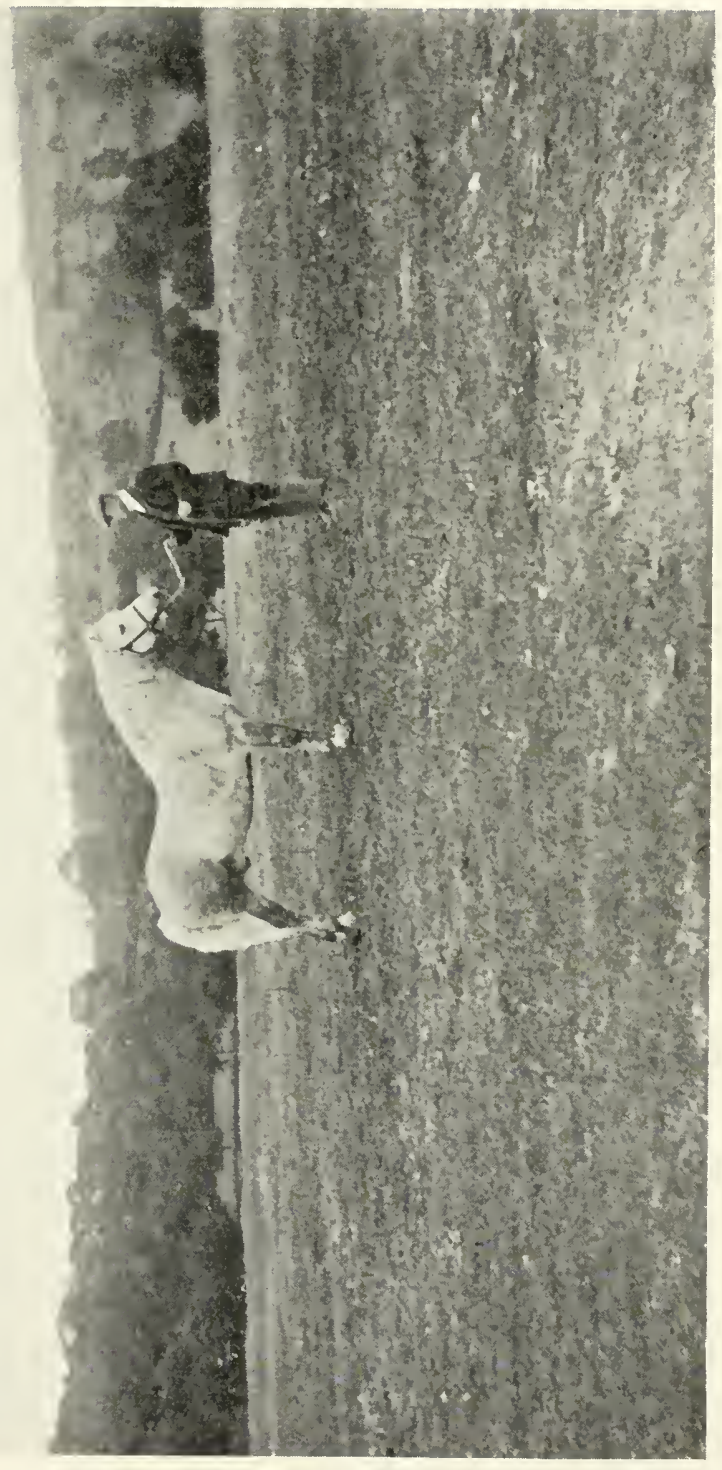



courage and generous temper. Unless crossed with the thoroughbred the Northern ponies are not adepts at galloping, their paces being the walk and the trot, but they are very sure-footed, can carry great weight, and are docile in the extreme. It is very rare to see a galloway from the dale country either kick, rear, or shy, while they can live on the roughest fare, and withstand the rigours of a very wet and very cold climate. In the neighbourhood of the oldestablished training stables at Middleham, Richmond, and Penrith, the fell galloways have often some good blood in them, which is seen at once in their improved quality, and many of these can gallop in good form. It is on these limestone hills, where the native pony averages about 14.1 or 14.2 , and very seldom reaches 15 hands, that the weight-carrying polo pony should be bred from this foundation stock, and kept and reared till he is three or four years old. The stock was sadly diminished during the Boer War, for from these mountains I purchased for the War Office, and sent to Africa, many hundreds of the best of the ponies; the stock has never recovered the drain upon it, and the great increase of cycling and motoring has so restricted the demand for this class, that now comparatively few are being bred. The great annual fair for these ponies is at Brough Hill, in Westmorland, in the autumn, and they are also sold in considerable numbers at Kirby Stephen, in the near vicinity, which fair precedes the other by a few days.

The Welsh ponies are of two distinct types. Those bred in the low country do not show the quality of the mountain ponies, but are much more powerful, rather cobby in character, resembling to a great extent the North Country galloway. It is the mountain pony that Wales is more especially famous for, small in stature so that it is difficult to find one of pure blood 13 hands in height, but full of fire, with pace, action, and good constitution. The feeding on their own ranges is not sufficiently good to encourage growth, but taken down to good pasturage they increase rapidly in height in succeeding generations. The Conway Show in the northern division, and the Welsh National Show, 
do good work in encouraging the breeds; whilst the Welsh Cob and Pony Stud Book is laying a foundation which should prove of very great value in the near future.

The Dartmoor ponies are wonderfully improved since I first knew them nearly fifty years ago. Then they were coarse, big-headed, and cow-hocked, larger than the Exmoors, but not held of nearly so much account. Now they are quite altered in character, and I purchased numbers for South Africa, during the war, of as beautiful ponies as could be desired; too good, indeed, for the work for which they were required. Their tors are very rugged, and covered with granite boulders, but the ponies are very sure-footed, and can carry great weights over long distances. The chief Show for them is the Brenton and Lydford Show, and the great fair for them and the Exmoors is Bampton Fair at the end of October.

The Exmoor ponies are little aristocrats-though they have not improved as fast as the Dartmoors-for they were taken in hand enthusiastically by Sir Thomas Acland and Mr. Frederick Knight long years previous to any attention being paid to the improvement of the Dartmoors. Katerfelto, the equine hero of Whyte-Melville's thrilling romance, was a famous pony stallion in his day. "The Druid" tells us in his fascinating work, "Scott and Sebright," how Katerfelto's dam was stolen by gipsies, and recovered in foal with him to an Arab. He relates, too, how Mr. Robert Smith, of Emmett's Grange, took a great hand in improving the breed of ponies, using Old Portthat famous sire of Devonshire hunters-for his pony mares, which he afterwards supplemented with other good blood. Old Port was the firstborn of the great Beeswing, through her alliance with Sir Hercules, and she, it will be remembered, was subsequently the dam of Newminster. Later the renowned Bobby was lord of the harem, "who could trace his descent through two degrees on his dam's side to Borack, who beat all the best horses, under high weights, at Madras"; and then an Arab succeeded Bobby, so there is little wonder Mr. Smith's ponies were full of quality, but they had not to rough it through the winter on 
the moor like those of the original stock. Bobby was bred by Mr. Ramsay, of Barnton, his sire being Robin, a son of Dr. Syntax, and a mare by Cotton, whose dam was by Borack. The method of rearing the young animals, according to "The Druid," was as follows: "'Three parts of the year these mares live on the mountain land, while the farm is making beef and mutton below. . . . Their foals are carefully wintered in paddocks with the yearlings, and if the weather is very severc the two-year-olds have hay as well. The paddocks are principally four acres in extent; little open sheds, neatly thatched, nestle in cunning nooks, to shelter the young stock, and when its whole array is marshalled on to the lowlands the stud is about 120 strong."

In these days of breeding extensively for polo it is well to know methods which have been proved to be successful.

Sir Thomas Acland maintained his original breed uncrossed, but Mr. Frederick Knight went in for improved blood, and commenced with two sires and three mares, concerning the importation of which from Dongala (the kingdom of King Solomon's visitor, the Queen of Sheba) "The Druid" relates a most interesting anecdote. The Dongala stallions were followed by Pandarus, a 15-hand son of Whalebone, and he in turn was succeeded by Canopus, a grandson of Velocipede, but again it was found the betterbred animals could not stand the rough climate in winter. "While the experiment was in progress the colts were wintered on limed land, which enabled them to bear up pretty well against the climate. When, however, the farms were let by the present Mr. Knight, they had to go back en masse to the naked moor, and then it was found that even if the mares with the first cross could put up with the fare and climate, they grew far too thin to give any milk, while those of the old stock stood it well with their foals."

While 12.2 hands is about the outside height at which the Dartmoor and Exmoor ponies can live all the year round on their own hills, they soon increase in height on lower ground with more generous treatment in winter; and yet, small as they are, it is perfectly marvellous what weight they can carry for extreme distances, and many hours at a stretch. 
They are better saddle-ponies, as a rule, than those bred in the New Forest, which are more sought after with a view to harness than the saddle, though good riding-ponies can be and are raised every year in the Forest and neighbourhood.

The New Forest pony is of a larger size than the Dartmoor and Exmoor, and those up to 13 hands can live and do well in the open. The Burley Association is doing excellent work in untiring efforts to improve the breed, but since stallions and mares run at large there is great difficulty in controlling the choice of sires, since three hundred persons enjoy the right of pasturage, and can turn out the animal which pleases their fancy. Each bunch of mares, with its reigning stallion, has its favourite haunts, and may be found there morning and evening. The New Forest pony has many crosses of outside blood, Arab, Welsh, Highland, Exmoor, and the North Country galloway all being represented in its lineage, and with its admirable distinguishing character for courage, docility, hardihood, and fine temper, it makes an excellent harness animal, and is in much request for this purpose. At the Burley Show there is a capital opportunity for any one who is desirous of seeing them at their best to note the standard these ponies are capable of attaining. All through the heaths of Dorsetshire this same type of pony is bred; and especially in the Isle of Purbeck, beyond Wareham, some excellent ponies may be seen, earning their living where even sheep cannot thrive.

The Burley and District New Forest Pony and Cattle Society was formed in 1906, and is affiliated to the Polo and Riding Pony Society. It not only holds an annual Show at Burley on August Bank Holiday, but has also recently started a New Forest Stud Book, of which the first volume has just been published, and contains the entries of 118 stallions and 356 mares. This should prove to be a valuable scheme for improving the local breed of ponies, and should have far-reaching consequences in the near future.

There is one little fellow that mention must be made ofthe tiny Sheltie so beloved by children, hardly larger than a big dog. In the Shetland Isles the soil and climate make it 


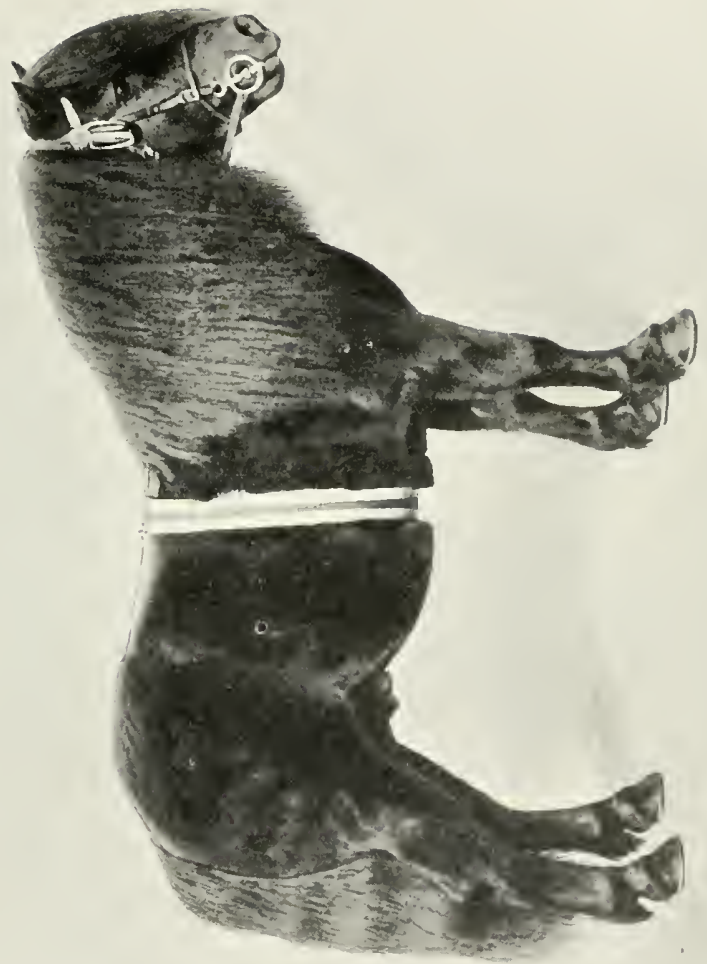

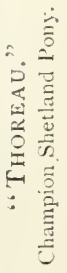



impossible to rear any animal of a large size, whether sheep, cow, or pony, but when one under 12 hands is required nothing is more suitable than a Shetland pony, with the exception it is too broad in the back to be safe for a little boy to bestride. At one time an Arab cross was tried with a few mares, and the produce was sufficiently narrow to carry a little boy, but they could not stand the rough weather, and had to be wintered elsewhere, so the experiment was soon abandoned. If well kept they may reach 11 hands, but the average is from $9 \frac{1}{2}$ to $10 \frac{1}{2}$ hands, and their chief use is for work in the mines underground.

As riding-ponies those from the sister island are, or perhaps used to be, quite super-excellent, for a mistaken zeal on the part of the Congested Districts Board induced that body to introduce hackney sires into Connemara and the wild district of mountainous Mayo, the very home of well-bred ponies. There are numerous animals of pony height in Ireland, very good in their way, but which are only undersized horses, and the true pony must be sought in the mountain regions, very possibly descendants of the early hobbies, which Strongbow and other English leaders found so difficult to cope with; and which, in the West, were undoubtedly afterwards much improved by the Barb sires which escaped from the ships of the Spanish Armada that were wrecked on that coast. Before the advent of the above Board a Connemara pony was a name to conjure with, a well-bred, active, fast galloper, and a rival of the Arab in the way of carrying weight. Indeed, Arab blood had largely found its way into the district, and had the Board been well advised it would have worked on the lines already proved successful. Hackneys were entirely out of place, but Eastern sires, either Arabians or Barbs, would have raised up a breed of ponies which there would surely have been a great demand for. The Andalusian wonld also have been a useful cross, for it is very hardy, with excellent legs, the bone of the cannons, and the hocks and knees, being extremely well developed. There is already a considerable amount of breeding in them, for their native land being so contiguous to Morocco, and having been so long under the 
dominion of the Moors, no doubt Barb blood has continually flowed into it. The ordinary animal of the country, the common "jaca" (pronounced "haca," and evidently the ancestor of our word "hack"), is a capital riding animal, never stumbling or making a mistake. The first cross with an Arab at once puts fashion into the produce, which continues for many generations, and if this cross is followed by mating with an English thoroughbred horse the result is a very elegant and excellent riding-horse. Many very fair race-horses have been bred by following these lines. The haca has good knee action, but it also has the length which is wanting in the backney, and therefore its descendants possess a frame suitable for riding, in contradistinction to the other.

\section{Polo Ponies.}

With the advent of polo, and the consequent great demand for galloping ponies up to weight, the merits of the various breeds of ponies are eagerly discussed, and their suitability considered for becoming the foundation for building up a type so much desired. It must be kept in mind that the different players in a team do not necessarily require exactly the same sort of animal to do brilliant work, and that it is easier to mount some of the posts than the others. No. 1 is the hardest to find ponies for, since so many good qualities must be combined. The strokes at goal come oftenest to him, and therefore the pony must be easy to ride, or he may miss them. It must be fast or the rider cannot keep his place, and withal be handy or the opposing back will slip him, but so long as it is up to its rider's weight it does not need the bulk so essential in a pony for No. 3.

A very intelligent pony is needed for No. 2, one that will follow the ball and alter its course without losing its stride, changing its legs, or propping. The ball seldom continues quite straight, especially as it loses its momentum, and as it twists to one side or the other the pony must follow smoothly in its track. Moreover, a fast-galloping pony is needed, and one from whose back a stroke can be made 
on either side as the circumstances of the moment require.

The pony for No. 3 will get most of the bumps, especially in a hustling game, and as, too, it will probably be ridden by the heaviest rider, it must be well up to weight and have plenty of substance. And yet it needs pace and a lengthy stride if it is to hold its own, though at the same time it must be very steady and clever. Probably no better No. 3 pony ever existed than the one-time celebrated Fritz, a portrait of whom and his then owner, the late Mr. John Watson, appeared in Baily's Magazine. Fritz was originally bought out of a Connemara drove by the writer, and beyond the fact that he was said to be by Kinsman, dam by Tom Steele, nothing further was known about him. $\mathrm{He}$ was a most powerfully built pony, and really was a weightcarrying hunter on very short legs, and being blessed with a placid and generous temper he became a celebrated polo pony under the tuition of Mr. Watson. He had one peculiarity-he stood much higher at the croup than at the withers, and whereas he only just passed the standard in front he could not nearly have done so behind, and yet he was not an uncomfortable pony to ride, having great length. His pace was such that he won two flat races at Baldoyle the same afternoon, ridden by the writer.

No. 4 needs to be a compactly built pony, for he must be able to jump off quickly to save a goal. He needs pace, too, for he linust be able to race after the ball while the other players ride off their opponents. An active, quick pony is needed here, one that can turn sharply as well as gallop.

One thing is essential to all polo ponies: they must not pull or they are useless, and they must be docile and generous in their work. When the right pony has been found, and the skill to train it is not wanting, its value represents almost a small fortune. This very season Swallow has been sold for $650 \mathrm{gs}$; and so also have those splendid ponies of Mr. Buckmaster, Play Actor, Jack, and Lottery. Whilst the average of $\$ 557$ 15s. made by Mr. Buckmaster's stud, and of $£ 4432$ s. 6d. made by the 
ponies of Mr. Freake, are convincing proofs indeed that there is money to be made at the game, by skilled players who are good judges of a pony. The problem to be solved is how to breed the animal desired. So many of the qualities required in polo ponies are inherent in Eastern sires, Arabians and Barbs, that a first cross of such blood seems a wise commencement, though the Barb is a taller animal in its own country than the Arab, and specimens occur up to 15.3. The docility of both breeds is of the highest order, and it must be borne in mind that the Arabian has been bred for centuries with one object-to carry his master in raids against his enemy, and make good his escape if his plans "gang agley." The latter supposition involves speed and activity in dodging the pursuing lance-qualities much required in playing polo. Since the Arab warrior, excepting in battle, invariably rides with only one rein, his steed must be both well trained and intelligent, to turn right or left at a critical moment, and to understand and obey its rider's wishes conveyed only by a halter and rope.

The Eastern cross should be followed up with a thoroughbred one, a sire being chosen from one of the many families that always run small; while if the produce are reared for three parts of the year on limestone hills there will be little danger of the polo limit, the bugbear to the breeder, 14.2 in height, being exceeded.

The efforts of the Polo and Riding Society to fix a type must, in the course of time, exert considerable influence in assisting breeders to produce the required pony, and it already can point to the fact that two ponies bred on the lines it advocates were chosen to play for England in International matches, Tubby being out of Silvertail (No 121), and Marquis out of Lady Polo (973). Moreover, the breeding of Marquis gives point to the hope that the polo pony of the future may to a large extent be produced by the mating of animals registered in their Stud Book, without recourse to assistance from the outside; and thus a true-bred breed may be formed of thorough polo type, in a similar manner that other British breeds have been established. Just as the race-course is the all-essential 


$$
F
$$



test of the merit of the race-horse, so may the polo-ground be looked upon as the test of the polo pony, and if polobred stallions can continue to beget animals of the standard of Marquis, assuredly nothing better can be desired. It may be long ere the services of thoroughbred stallions can be dispensed with, for there can, in all probability, be no great number of polo sires, since many animals are prevented from continuing their species through the early application of the surgeon's knife. Sufticient has already been accomplished, however, to prove that polo-bred stallions can be depended upon to reproduce their like, but it should be looked upon as an axiom that the sires must be themselves tested on the polo ground, as race-horses are on the racecourse, or softness, and other undesirable qualities, are eventually bound to creep in.

Marquis is by Sir John Barker's celebrated sire Sandiway, and his dam, Lady Polo, by Sir Walter Gilbey's famous Rosewater, who was by Sir Joseph Hawley's great racehorse, Rosicrucian. As Sandiway was also by Rosewater, the inbreeding of Marquis was very close, and if care is not taken to guard against continued alliances of this description, the eventual result will assuredly be a delicate, irritable race, such as our thoroughbred horses have so largely become. The dam of Sandiway was Cuddington, whose dam was a Welsh pony, while Lady Polo (dam of Marquis) had Exmoor blood in her veins, so these outside strains may have had some effect in preventing any deterioration in Marquis himself.

Amongst other polo-bred stallions should be mentioned the winner of the polo-bred class at Islington, 1910, Thite Wings by White Mask, by Whitehall, by Hermit, whose dam was First Flight, a winner of hurdle-races, while his grandam, Oh $\mathrm{My}$, won over $£ 2,000$ in jumping prizes. White Wings is the property of the Keynsham Stud, and should beget polo ponies of the right stamp, if as good as his breeding warrants.

In conclusion, it may be suggested that foundation mares for breeding fast-galloping ponies of lighter description may be found amongst the Exmoor, Dartmoor, Welsh, and 
New Forest breeds; but that for weight-carrying ponies, especially suitable for No. 3, the mares should rather be sought in the North Yorkshire and Westmorland mountains, in the vicinity of the training stables; or else in the West of Ireland, where in Connemara, and Mayo, some of the original famous ponies may yet be found.

A few words as to measuring polo ponies may perhaps be considered not out of season, since the writer has had much to do with this, having at one time officially measured the ponies for the All Ireland Polo Race Meetings; and, in the capacity of Purchasing Officer, during the South African War, measured nearly thirteen thousand horses. To be perfectly accurate in measuring an animal when standing still, the measuring-stick should have a spiritlevel in the extended arm; and there should be also a little extension of the arm to the back of the stick, from which a little plumb-line should depend, thus showing when the stick is absolutely perpendicular. The animal must stand upon a hard, smooth, level surface, and to obtain the true height the stick must be placed at the rear of the elbow, so that its arm rests exactly on the top of the withers. The horse's head should be pulled down a little till the ears are on a level with the withers, which gives a sharp definition to them; but the head must be kept in a straight line, neither inclined to the right or to the left, which would otherwise tend to reduce the height. The animal should be measured immediately it comes to a standstill, for if allowed to remain standing for some moments it will begin to sink on its pasterns, and some horses will drop more than an inch in a very brief space of time. If this should be noticed the animal should be backed a step or two, and then brought up again, when a quick operator should be able to measure the exact height. To induce a horse to sink down many plans are resorted to, such as galloping it for some time; keeping it standing many hours in a stall; or keeping it standing with a very heavy weight on its back; the object of all such manœuvres being to thoroughly tire it, and so induce it to sink down the moment it is brought to a standstill, though such designs should not meet with success if the 



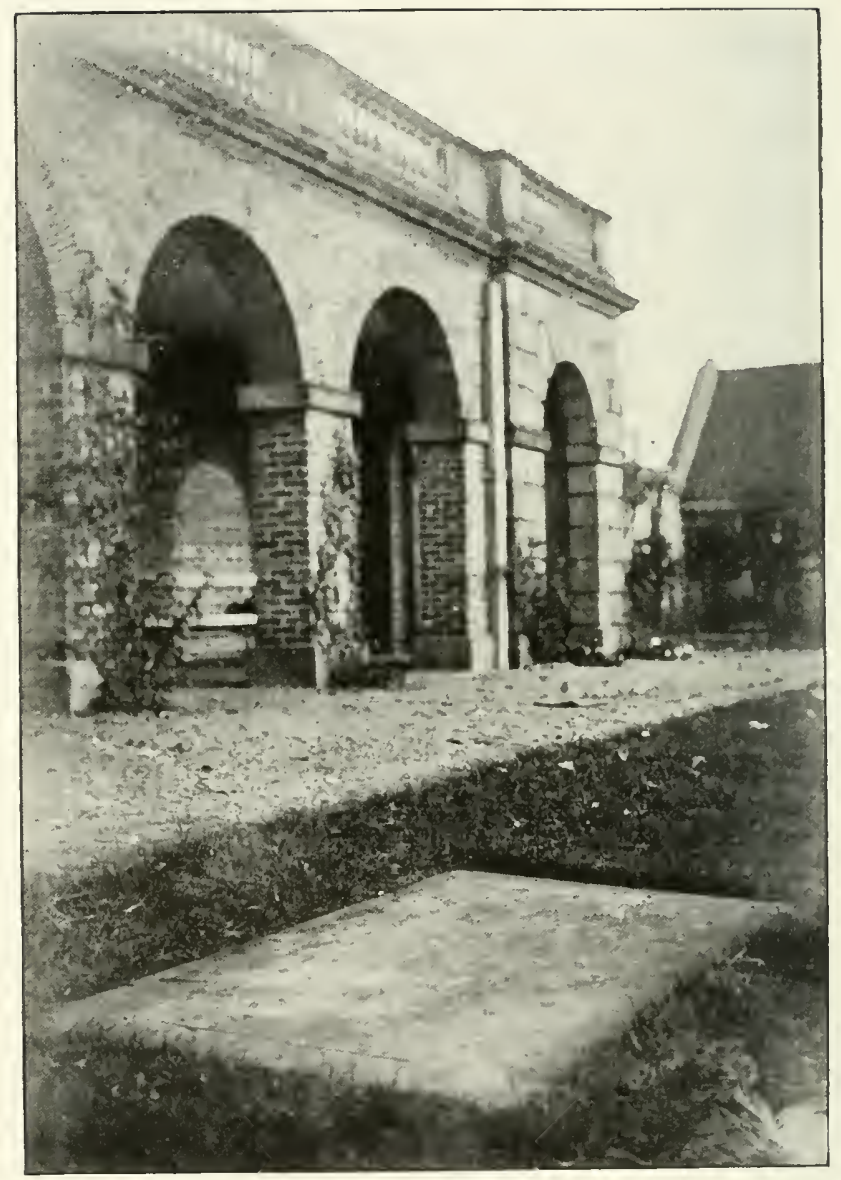

Proto by Algar Meysey. Thompson.

The Ancient Measuring Stone on York Race-course. 
measurer knows his business. To shave the withers so as to remove all possible hair, and to pare the heels down closely cannot be objected to, though if this last process is carried too far the soles may get bruised, and the horse become lame, so self-interest may be relied upon to prevent this being carried to extremes.

But another mode of getting round the measurer is also attempted-that of teaching the horse to stretch itself out with its legs far apart, in the style beloved of hackney grooms, when showing off their charges. This also troubled our ancestors, in the old days of Give and Take Plates; and the old stone on which the competitors were measured on York race-course is even now in existence, in the paddock of York race-stand, and may be seen at any time by any one interested in memorials of the past. It is believed to be the only one now remaining, and provides a valuable objectlesson of the ingenuity of our forefathers in defeating the wily trainers of their time. It was in use till the early part of the last century.

The stone itself is $6 \mathrm{ft} .4 \mathrm{in}$. long by $3 \mathrm{ft} .3 \mathrm{in}$. broad, and has two lines cut on it, 2 feet in length, and 5 feet distant from each other. The stone itself is perfectly flat.

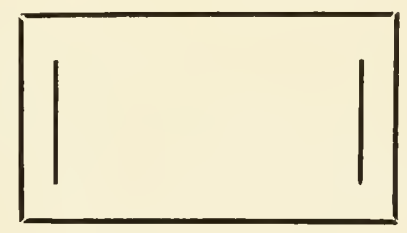

The length from one line to the other is the extreme distance the animal was allowed to extend its forefeet from its hind ones; and the length of the short lines ( 2 feet) was the distance allowed between the two fore-feet and hind-feet.

In Give and Take Plates horses carried weight for age, and weight for inches.

The usual scale was: 13 hands carried 7 stone, with 
an addition of $14 \mathrm{oz}$. for each extra eighth of an inch, which works out-

so that-

\begin{tabular}{|c|c|c|c|}
\hline Each & additional & $\frac{1}{8}$ inch & ........... \\
\hline " & " & inch & ......... \\
\hline & , & hand & ........... \\
\hline
\end{tabular}

13 hands carried 7 stone

$14, \quad, \quad 9$ stone

$15 \quad " \quad, 11$ stone

These were the weights for aged horses, with an allowance of -

4 lbs. for $6 \cdot$ year-olds.

$12 \mathrm{lbs}$. for 5 -year-olds. 


\section{CHAPTER IV}

\section{CARRIAGE-HORSES}

\section{Cleveland Bays.}

A CARRIAGE-HORSE must look well in harness, and an important point is the position in which he stands, his fore-legs and hind-legs being well apart. Many a good hunter has slightly bent knees, or has his hind-legs bent too much under him; but this will not do for a carriagehorse, and is fatal to making a handsome show when drawn up for parade. The neck must be long and carried well up, and be able to bend in a graceful curve; the mane should be plentiful and fall well; and the tail should be full and well carried. Such are the general characteristics of a handsome carriage-horse in a full-sized carriage, which requires length in the animals which draw it to match itself, for there is a want of symmetry when a pair of short horses are seen attached to a long carriage.

In colour they should be bays with black legs, browns with tan muzzles, dark chestnuts, or greys. The action must be smart, knees well bent, the hocks sharply flexed, and the feet lifted high off the ground; and the lighter the carriage the more active should be the horses, with a corresponding degree of pace.

When shorter and lighter vehicles are used the fashion of the day tends towards the employment of the hackney, with its showy action, hogged mane, and short-docked tail, but in a long carriage such seem wanting in the requisite length for harmony in appearance. All harness-horses must have strong loins, quarters, and hocks, that they may be able to turn sharply, hold back a carriage downhill, or stop it quickly when required. 
For the big, lengthy carriage-horse the Cleveland Bay and the Yorkshire Coach-horse fulfil all requirements-the former when a massive animal is required for a heavy load, more especially for artillery and transport service, and the latter when more pace is desired in a somewhat lighter vehicle. The Cleveland Bay originated in the Cleveland district of Yorkshire-celebrated for its ironstone mines, which caused the rapid growth of the town of Middlesbrough, with its smelting furnaces and other works. The Cleveland Bays were the horses of the district, available alike for the saddle or the carriage, and doing the ordinary daily work of the farm. They crossed well with thoroughbred horses, and in that way many superior weight-carrying hunters were bred, while they often made an excellent foundation on which to raise generations of luunters, by the continued use of well-bred sires. They were a hardy breed, full of courage and endurance, and very docile. The "Yorkshire Coach-horse Stud Book," vol. i. p. 9, states: "It is claimed these Cleveland horses are a pure breed, clear of both blood and black."

To be eligible for the Cleveland Bay Stud Book, the standard required is 16 hands to 16.2 , and bay colour without white. The address of the Secretary is Field House, Marton, S.O., Yorkshire.

\section{YORKSHIRE COACH-HORSE.}

'There were many persons, however, who came to the conclusion that the Cleveland Bay was too heavily built, and, with the old coach-horses in their mind, desired to form a society for breeding a higher-bred type, the outcome being the formation of the Yorkshire Coach-horse Society. It was then ordained that the first rolume of their Stud Book should " contain the pedigree of stallions foaled previously to the 1st of January, 1883, such pedigrees being satisfactory to the Council," while Rule 33 ordained: "No horse shall be registered in the Stud Book unless bred in the United Kingdonı"; and Rule 34: "The expression 'horse' includes stallion and mare." 


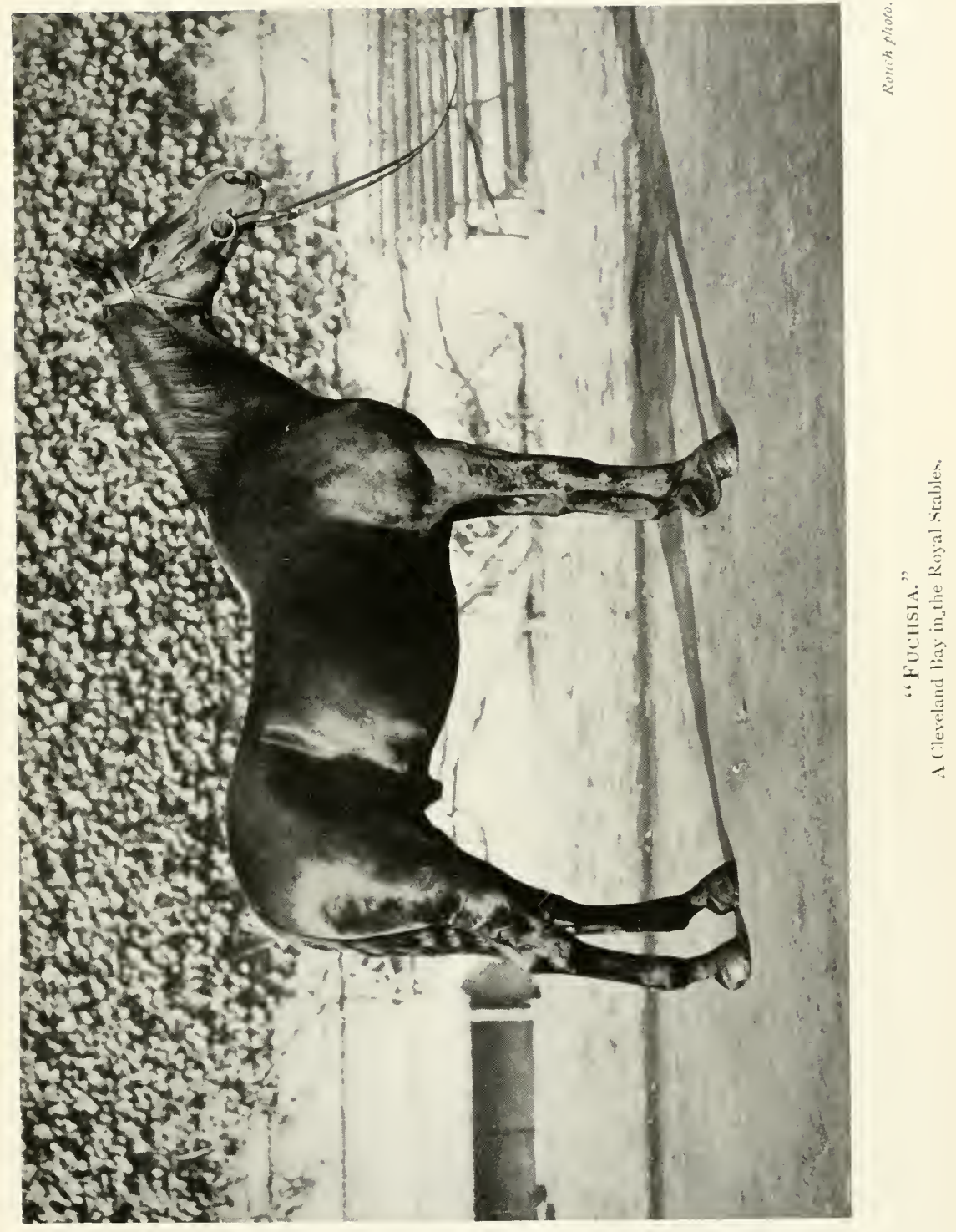



Resolutions passed by the Council at a meeting held in York, on April 17, 1888, laid down: "It is hereby agreed to admit as eligible for the Stud Book, any horse or mare showing three crosses of Coaching, or two crosses of Coaching and one of Blood, such horse or mare to be light or dark bay. No horse with direct Hackney or Carting Blood allowed to enter."

The result has been the establishment of a fine type of powerful large-boned horse, with a considerable amount of breeding, since a cross of thoroughbred blood is allowable every third generation. Though the level croup, a very characteristic point, is apt to give riding-horses rather a peacocky appearance, it is admirable for carriage work, involving a good carriage of the tail. A cross of coachhorse blood has frequently proved invaluable for light mares, reintroducing size and bone, when a resort to a thoroughbred horse might have produced a weed, useless for general purposes. Whenever a mare throws small, light foals, it is wise to try the effect of an alliance with a Yorkshire Coach-horse before turning her out of the stud altogether. In the writer's experience several good hunters have been thus bred.

The first volume of the Yorkshire Coach-horse Stud Book was published in 1887, and in the Preface the remarks of various writers are stated, showing that the animal the Society had in view was more blood-like than the old Cleveland Bay, and capable of travelling at a faster pace. Thus an extract is quoted from an article by Willoughby Wood in 1854 with evident approval :-

“'As to the antique 'coach-horse,' that gaunt animal with his red legs is now scarcely to be met with in his pristine purity. His legs have been shortened and turned from bay to black, his crest lowered, his head has been lessened in more directions than one; while evident crosses of blood, which he shows, have imparted to him a decidedly more modern and aristocratic appearance. His frame is deeper, his body shorter, he can get his hind-legs under him, and as to his pace, twelve miles an hour are easier to him than eight would have been to his venerable maternal 
ancestors. Such are the beneficial effects of blood, that is of a superior race judiciously engrafted on an inferior."

"It cannot then be claimed for the Yorkshire Coachhorse that he is a pure-bred animal, but that on the contrary, by the judicious crossing of large-sized good-coloured mares with stallions altogether, or nearly thoroughbred, a ciass of horses has been produced suited to the wants and circumstances of the times.

"Certain characteristics have been carefully cultivated -by universal consent the colours should be bay or brown with black legs, mane and tail abundant but not curly, in height from 16 hands to 16 hands 2 inches, with fine head, sloping shoulders, strong loins, and lengthy quarters, high-stepping action, good sound fect. flat legs, and abundance of bone and muscle for any effort that may be required of them."

Several celebrated coach-horses are mentioned in vol, i. that were sold for very high prices.

"Rainbow, afterwards called King George IV., sold to Robert Thomas, of Eryholme, Darlington, when seventeen

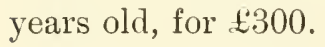

“Landmark (belonging to Mr. G. Holmes), foaled 1870, whose dam was by a thoroughbred sire, this horse was sold to the King of Bavaria for 400 guineas.

“Mr. Thompson's Necromancer was the progenitor of some high-priced animals. He was the sire of Sir Edmund, sold for $\& 600$ to go abroad; of Don Quixote, and another sold to Mr. Alders for $₫ 500$; also of Burton’s Eibor, which was sold for 500 guineas.

"Of the speed, power, and endurance of these horses we have recorded that Dreadnought, by Old Clothier, won a trotting match for $£ 100$, carrying 16 stone 16 miles, within the hour; Wonderful, a horse that obtained a high premium at Ripon Show in 1819, had a brother, Peirson's Plato, that trotted 18 miles within the hour, carrying 18 stone; and Bevas Pullen's King William trotted a mile in 3 minutes at Selby, carrying 14 stone.

"In conclusion, we can confidently recommend the Yorkshire Coach-horse as an animal that has been a source 
of great profit to the Yorkshire breeder, an animal that needs only to be seen to be admired, to be used to be appreciated."

\section{Hackners.}

Hackneys, the third great source from which the supply of carriage-horses is drawn, seem to be an endless bone of contention in the horsey world, dividing it into two camps, the one almost worshipping the animal, whilst the other will not have it at any price; the chief reason probably being that while the best of the breed are fine animals, there is a terrible tailing off amongst the inferior sort, which, as most breeders know to their sorrow, are much easier produced than the prize-winners. There is also a flashiness about the hackney, which is in fact the very essence of its being, and appeals more to the foreigner than to the average Englishman, for there is no doubt that as a race we do not like to attract notice to ourselves, and prefer to slip quietly along, attending to our own business, if possible unnoticed by the passer-by. But the hackney will not permit of our so doing. He, at any rate, means to be looked at and admired! And so it comes to pass that the hackney is valued by the admirationloving foreigner and many Englishmen, while others sneer at it and give it a wide berth. The hackney has been evolved out of the old roadster, and appears to have had his origin in Lincolnshire, and spread from there to Norfolk and Yorkshire; but in the last county they have been much localised, seldom spreading far from the neighbourhood of Market Weighton, in the East Riding. The best of them have a good deal of thoroughbred blood in their veins, and the great progenitor of all, the famous Old Shales, was got by Blaze, a pure-bred son of Flying Childers, out of a strong common-bred mare in Lincolnshire. There is a belief in the Yorkshire IVolds that the hackneys owe their high-stepping action entirely to the cross of cart-horse blood in their pedigree, and probably the compact form, wide chest, and round buttocks were derived from the same source. Crossing with pony blood produced that shortness which is one of their great characteristics, and which is so 
difticult to get rid of in any breed where it is introduced, for cross as you may it is sure to assert itself generation after generation.

Within the last three decades two of the most famous stallions have been Danegelt and his son Ganymede, and their stock and descendants have enriched their owners with immense sums of money. It may be of interest to trace back their pedigree, showing what famous names in the trotting world are blazoned on it, and how it is crowned at the beginning with the famous Darley Arabian, the most potent ancestor of the best race-horses, all the world over.

$\begin{array}{lllllll}\text { Darley Arabian } & \ldots & \ldots & \ldots & \ldots & \ldots & 1702 \\ \text { Flying Childers } & \ldots & \ldots & \ldots & \ldots & \ldots & 1715 \\ \text { Blaze } \ldots & \ldots & \ldots & \ldots & \ldots & \ldots & 1733 \\ \text { Old Shales } & \ldots & \ldots & \ldots & \ldots & \ldots & 1755 \\ \text { Driver } \ldots & \ldots & \ldots & \ldots & \ldots & \ldots & 1765 \\ \text { Fireaway (Jenkinson }{ }^{\text {s) }} & \ldots & \ldots & \ldots & \ldots & 1780 \\ \text { Fireaway (West's) } & \ldots & \ldots & \ldots & \ldots & 1800 \\ \text { Fireaway (Burgess's) } & \ldots & \ldots & \ldots & \ldots & 1815 \\ \text { IVildfire ... } & \ldots & \ldots & \ldots & \ldots & \ldots & 1827 \\ \text { Phenomenon } & \ldots & \ldots & \ldots & \ldots & \ldots & 1835 \\ \text { Performer } & \ldots & \ldots & \ldots & \ldots & \ldots & 1840 \\ \text { Sir Charles } & \ldots & \ldots & \ldots & \ldots & \ldots & 1848 \\ \text { Denmark ... } & \ldots & \ldots & \ldots & \ldots & \ldots & 1862 \\ \text { Danegelt } \ldots & \ldots & \ldots & \ldots & \ldots & \ldots & 1879 \\ \text { Granymede } & \ldots & \ldots & \ldots & \ldots & \ldots & 1887\end{array}$

Phenomenon was brought into Yorkshire by Mr. Robert Ramsdale, of Market Weighton, and it may be said that it was through him the great improvement in the Yorkshire hackneys took place; while the mares who were his consorts, having a good deal of thoroughbred blood in them, produced progeny with more quality than the Norfolk trotters, which were apt to be rather coarse about the head. A great merit in the race is its soundness of legs and feet, and for showy action it cannot be surpassed. The best type should not exceed 15.2, and should be well balanced and well coupled.

The Hackney Stud Book Society dates from a public meeting held at Norwich June 30, 1883, and the good work it has done since that day is amply proved every year by the animals shown at its annual Show each spring at Islington. 


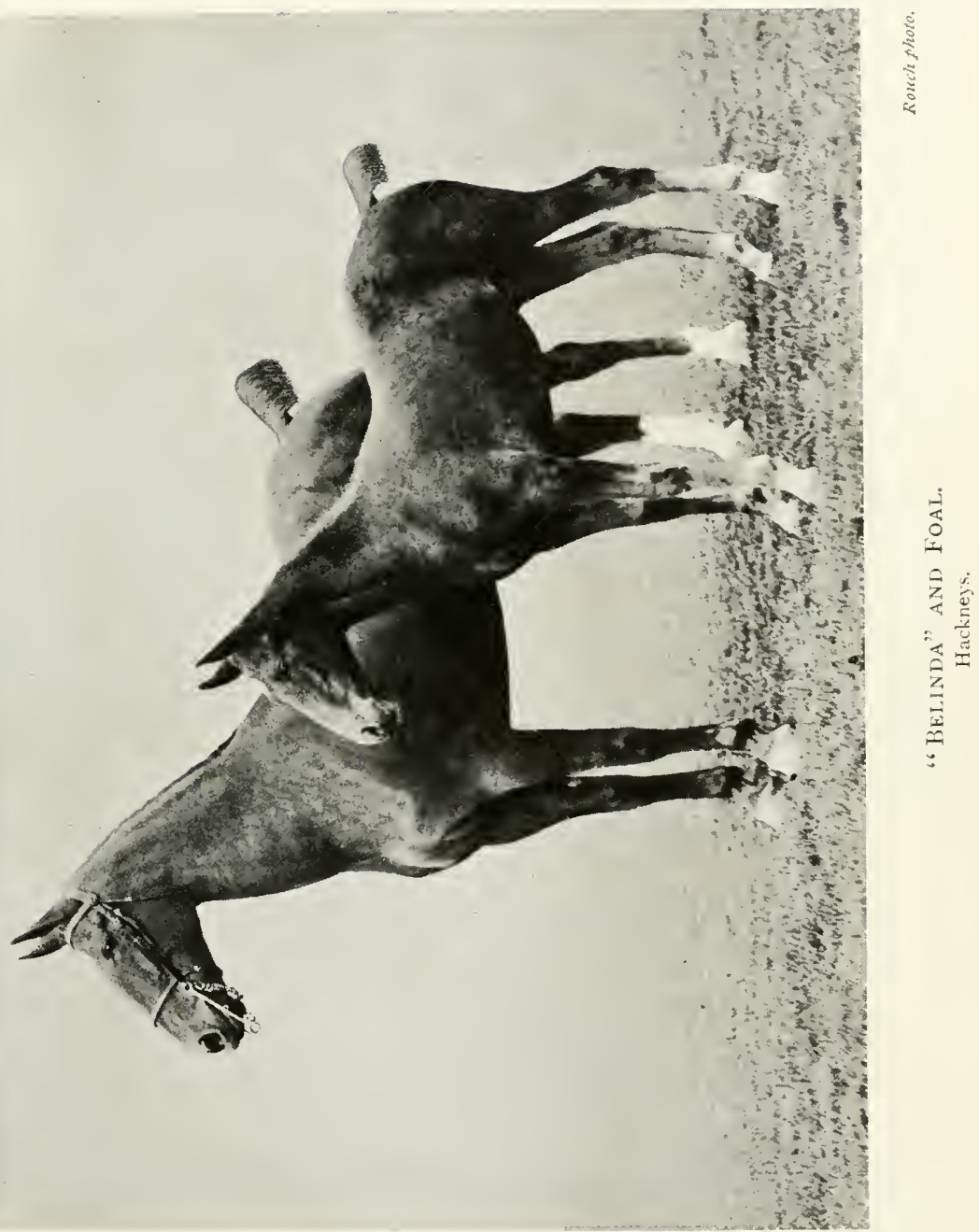



What the future has in store for the hackney is difficult to forecast in these days of mechanical traction, which is ever becoming more and more popular. The foreigners have always been the best purchasers of the breed, and may continue their custom. France especially, it is said, utilises them for breeding artillery horses, while the Argentine has consistently been a good buyer; but a considerable trade, which used to be done with rich young business men in provincial towns, has almost entirely fallen off, for, instead of driving a smart turnout from their homes to their places of business, they now prefer a motor-car. Still, as those persons who yet continue to drive in London mostly require quality, refinement, and style, and there is no other pure breed which can compare with the hackney in its showy action, it is probable that it may yet be in demand when the Cleveland Bay and the Yorkshire Coach-horse remain but a memory, "improved" out of existence by the motor-car, or possibly the flying machine.

The difference in the action of hackneys, the wrong way and the right, may be well exemplified by the following anecdote concerning two well-known stallions of their day, whose names crop up now in many a pedigree. On June 19, 1906, Mr. James Melrose, the veteran chairman of the York Race Committee, related these interesting personal reminiscences:-

"I remember the hackney stallion, Prickwillow, very well; he had high pumping action, but never got on, putting his feet down where he took them up from. I think it would be about 1832 that his owner, C. Hart, who thought a deal of him, brought him to York, and a match was made for him to trot against a local horse on Knavesmire. A crowd came to see it, and Hart rode in his shirt-sleeves, rolling them over his arms. The local horse, however, had different action, and went clean away from the start, leaving the other far behind. It was no race at all. Market Weighton was always a famous place for hackneys, and it was there I saw Fireaway trot. He had splendid action, and shot his legs out with tremendous force. He belonged to Mr. Ramsden. Flying Childers is said to have been put 
to a pony mare, and that Fireaway came from that alliance." (This is not quite correct, for it was Blaze, the son of Flying Childers, who was mated with a pony, the progeny being Old Shales.)

The origin of the fashion of hog-maning horses so universal with hackneys, no doubt may be traced to a desire to copy the horses figuring in antique friezes. These, however, may have owed their short manes to nature, and not to the hand of man, for Dr. Conrad Keller, professor of zoology at the Zurich Polytechnicum, has just published an account of a breed he has discovered in the Island of Majorca. These are naturally hog-maned, and closely resemble in appearance the horses depicted on ancient Greek vases.

\section{AMERICAN Horses.}

Besides these three pure breeds already mentioned, which have arrived at the dignity of possessing a Stud Book to conserve their interests, there are horses of various nationalities employed in harness work in England, of which before the days of mechanical traction there were very large numbers indeed. Though they cannot be classed amongst "foreigners," great numbers of powerful Irish hunter-bred horses were, and are still, bought for this purpose, especially by the great London dealers and jobmasters, and when Mackintosh was filling the vicinity of Limerick with beautiful black-browns, Messrs. East bought vast numbers of them, many of which seemed much too good to pass their lives in harness.

American horses, too, have been greatly valued, for the great attention which has been paid to the perfecting of the trotter has had an immense influence on the general horsestock of the country, besides the direct infusion of our own race-horses, originally imported from England. 'The old black harness horse of Canada, too, whatever his real origin, was an animal of transcendant merit, honest, hard-working, hardy, and a fast trotter, and the American trotters and pacers owe much to the blood of the famous old Canadian black horse, Pilot. The blood of which he was the most 


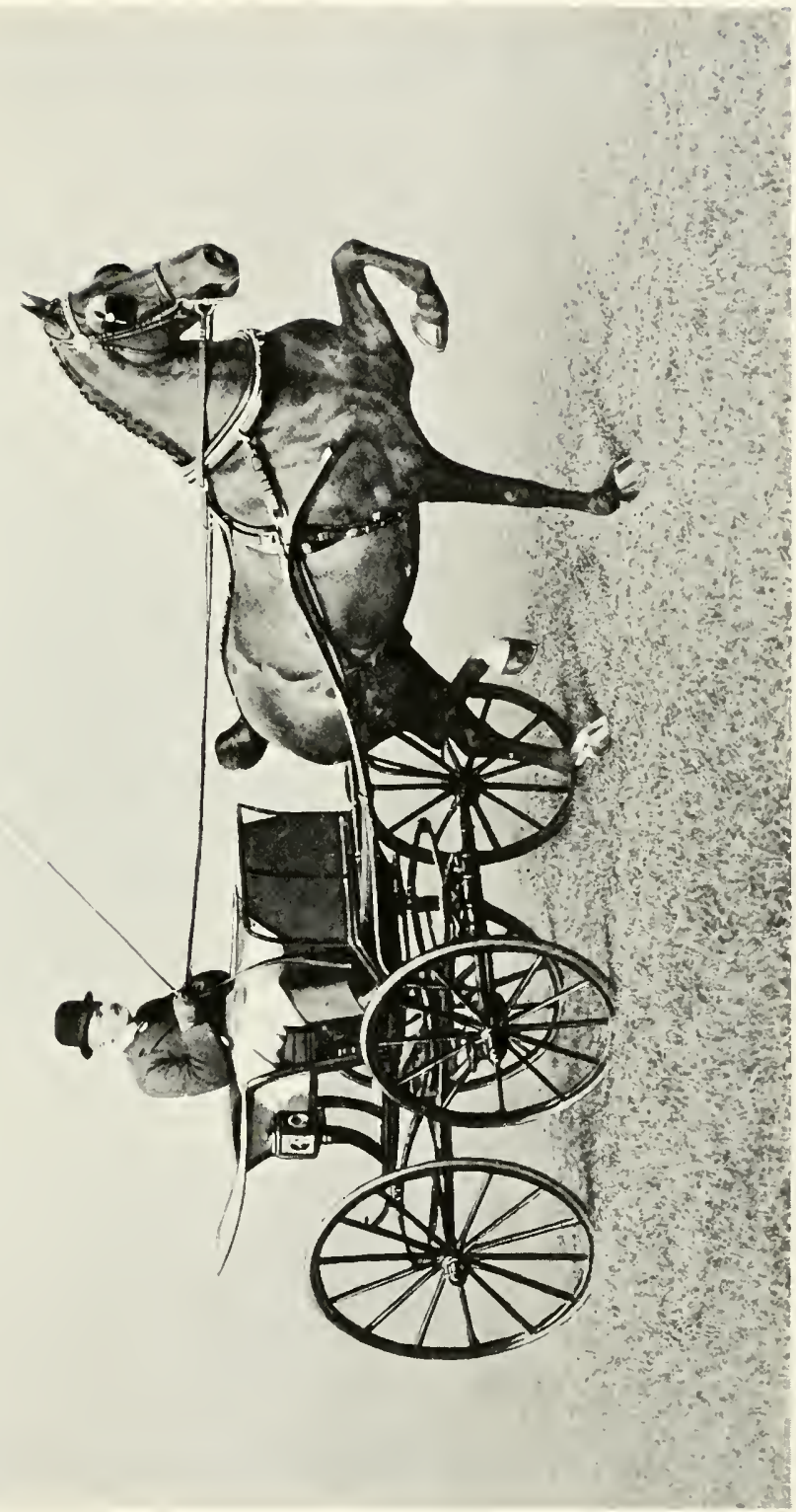



famous representative contained elements of the greatest value for work-horses of every description. In a letter, which must carry great weight, Mr. Alfred Withers, the head of the world-renowned establishments in Oxford Street and Edgware Road, has most kindly summed up the results of his long experience of the working qualities of the different classes of harness-horses, of which tens of thousands have passed through his hands:-

"There are two breeds of horses which, to my mind, absolutely eclipse the Cleveland, Yorkshire Coach-horses and hackneys, for carriage purposes. These are, firstly, the Irish horses of the 14 to 15 stone hunter type, with too much knee action in the trot to gallop fast enough for hunting; and, secondly, the American carriage-horses.

"Of the first class, for years and years, up to the time they gave up business, Messrs. East bought, and at the present time Messrs. Wimbush buy, three-year-old horses of this class in Ireland in large numbers; and we ourselves take every opportunity of buying such horses at any age we can get them, over four years old. The great charm of them, to my thinking, is that the natural courage of the breed enables them to keep up their knee action, and general stylish appearance when moving, so long after the time of life when the other breeds mentioned have lost those qualities. I believe their wearing qualities to be infinitely superior to either of them.

"With regard to the American carriage-horses, we have been very large importers of this class, having had two buyers in the States some years ago for a considerable period, besides which we have taken every opportunity of buying good American horses brought over to this country. I unhesitatingly say, from my experience, they are the best type of carriage-horse I have ever known, and I attribute this result very much to their having been bred for generations for road work, to draw weight, and for speed. The best American carriage-horses have a large dash of the best trotting blood in their veins, and this it is that gives them the courage and speed that is wanting in the Cleveland and hackney, and makes them so valuable for harness. 
"My opinion of this class of horse has been borne out in many ways. I distinctly remember talking to Mons. Arthur Marx, who died about ten years ago (and who was the leading dealer in Paris for about twenty-five to thirty years, dealing exclusively in the highest class of carriage-horses), and he confirmed my opinion, and told me at that time the best carriage-horses in Paris were American horses; moreover, he stated that the best pair of carriage-horses he had ever known were a pair of American horses in the English Ambassador's stables in Paris.

"Another great reason for the superiority of the American horses is the fact that until recent years Clydesdale and Cart blood was hardly known in the States, or Canada, and farmers did all their farm work with horses of the carriagehorse type. I remember buying in Canada twenty-five years ago a pair of splendid carriage-horses, black-brown, 16 hands, full of courage, good action, five and six years old, own brothers. I bought them from a farmer who bred them, and had worked them regularly on his farm ever since they were old enough to pull a load.

"Of course a great deal of rubbish has been imported to this country, but I have had such a number of good American horses in my business, and compared them with English, French, German, Russian, Dutch, and Hungarian horses for this particular purpose that I can speak with confidence in their favour.

"The one drawback to Irish carriage-horses is that they are occasionally inclined to canter in harness. The American horses, on the other hand, have been bred for generations to trot, and to trot only with a load, and they very seldom fail in this respect."

It is "money" which invariably "speaks," and the conclusions of a veteran professional at any game are worth all the ideas of enthusiastic amateurs put together. Mr. Withers draws his conclusions from actual experience of what answers, and has no fad to bias him in favour of one breed over another, except for what pays him the best. His testimony, therefore, in praise of Irish and American horses for high-class carriage work cannot be over- 


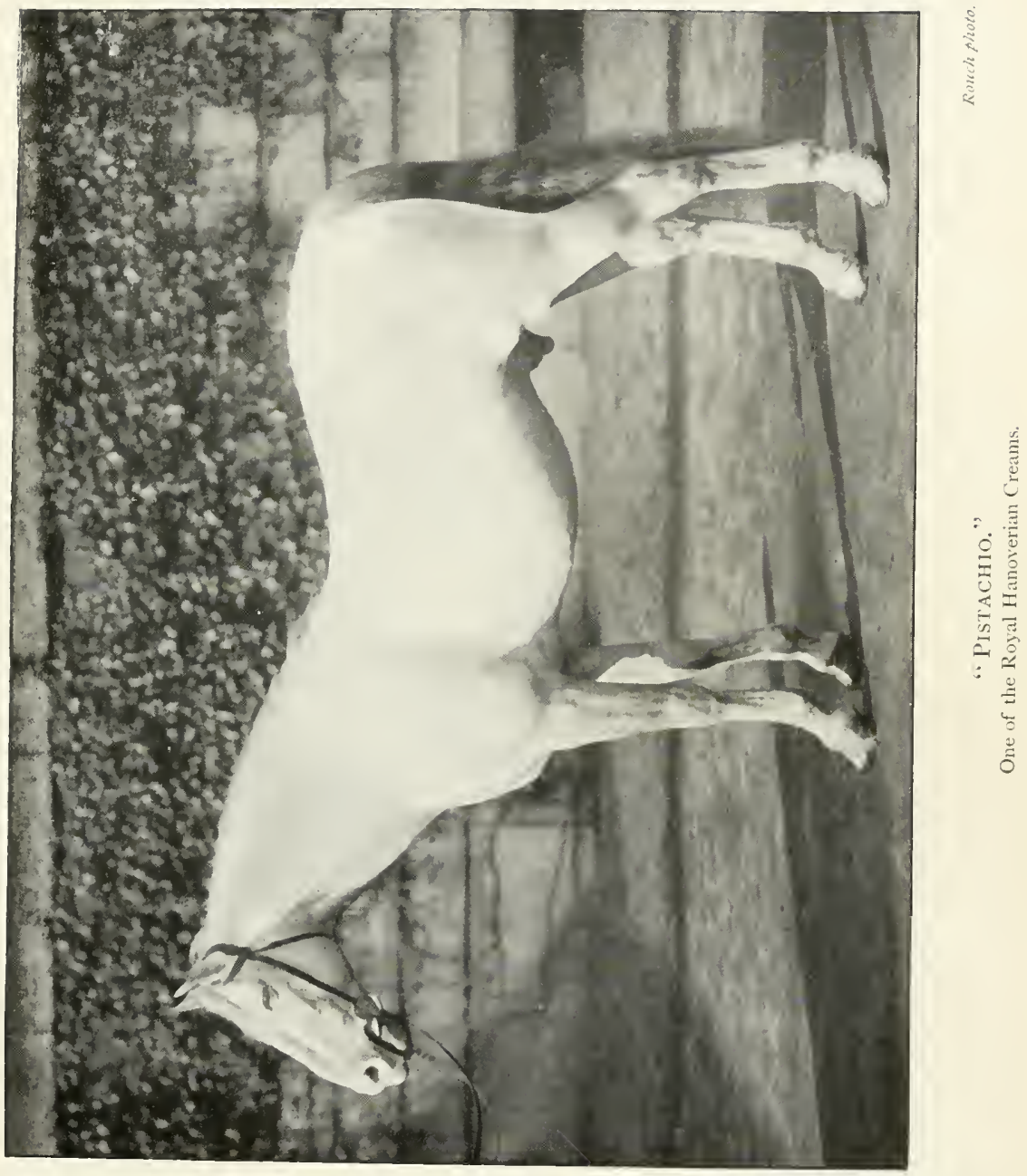



estimated; whilst he points out a way for recruiting our harness horses when our home stock fails, which at present there seems every chance of it speedily doing. The smallholder, so much in favour in certain quarters at the present time, will be of no assistance in rearing high-class stock of any description. 


\section{CHAPTER V}

\section{A R T - H O R S E S}

THE sheet-anchor of a farmer in breeding horses is Clydesdale, or Suffolk Punch. In our cities and towns mechanical traction may entirely supersede the horse, but on a farm it can never altogether do so, for there must ever be various jobs in the country which can only be performed by the help of an animal-and at least it is not likely that our farmers will revert to using oxen for draught. The ponderous dray-horse will probably disappear, since heavy vans and brewer's drays are now depending chiefly upon inotor traction; though there may still be a small demand for huge animals, as they are almost indispensable for shunter's' work at large railway stations, which they so efficiently perform; but apart from that there seems little opening for their services. The cart-horse of the future seems likely to be a quick, active animal, that ean walk at a good pace, and a pair of which can plough an acre of strong land in a day.

Though the cart-horse and the blood-horse have undoubtedly evolved from the same little animal of the Lower Eocene Period, the Hyracotherium, who possessed four toes on each fore-foot, and three on each hind-foot, the cleavage of their ways must have taken place ages ago, and certain characteristic differences have long existed between them. An essential one is the hollow depression in front of the orbit, invariably present in Eastern horses and their descendants for many generations, but ever absent from the coarse breeds of Northern Europe with but one exception to be presently mentioned. Large, too, as the bone of the 


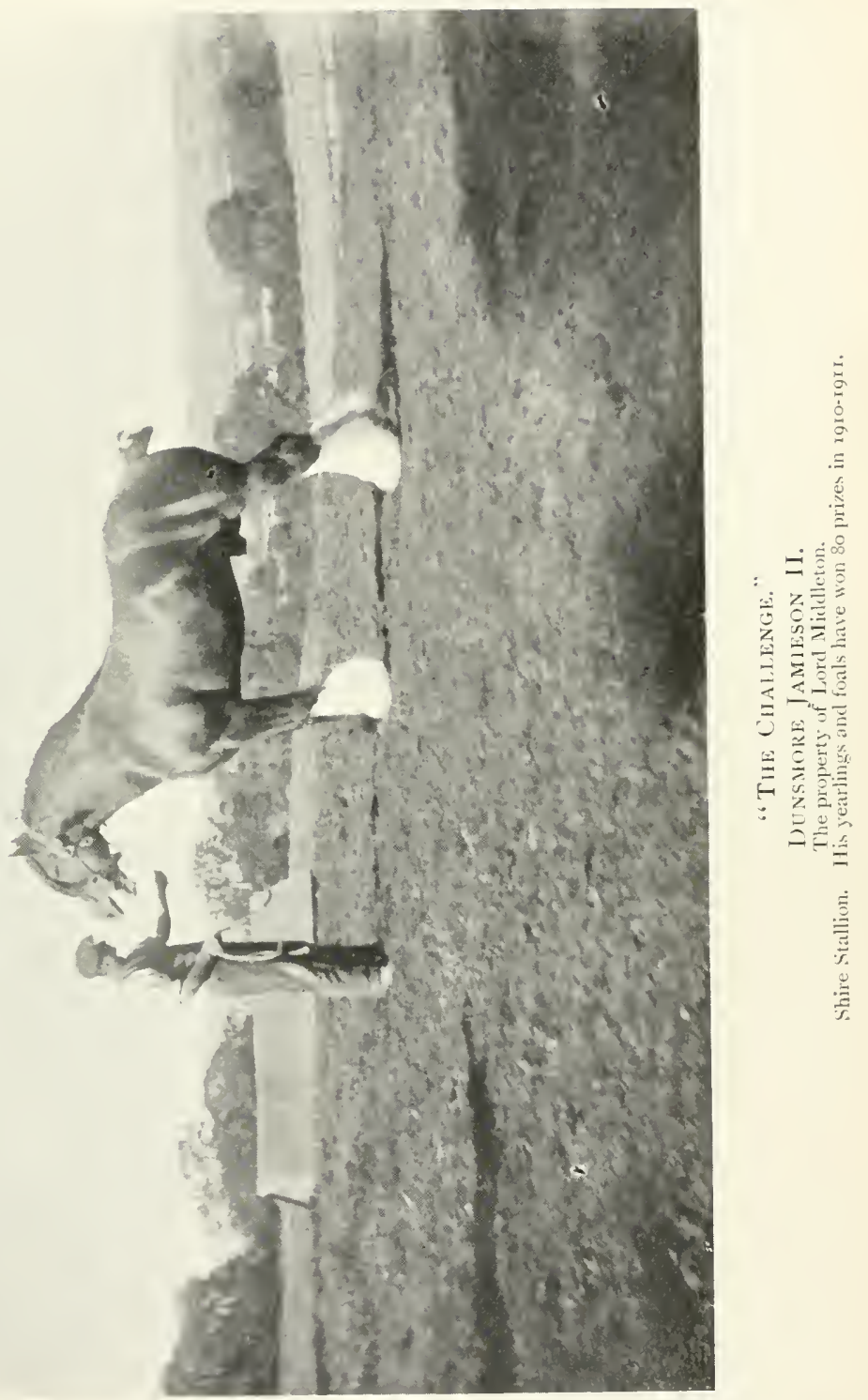



cart-horse appears to be in comparison with that of the thoroughbred, it is not entirely in favour of the former, for not only is the grain far more porous, but the cavity inside for containing the marrow is also disproportionately large, and therefore the actual bone it not so massive as at first sight it appears to be.

To a great extent the power of a cart-horse depends upon his weight, especially in a dead pull; and he requires considerable courage to continue to pull again and again at an inert mass until it moves, and then to draw it, perhaps for miles. Horses used in country work for drawing brewers' drays and such-like heavy vehicles, travel from twenty-five to thirty miles a day, the weight in a four-wheel van being from 6 to $6 \frac{1}{2}$ tons, which is a full load for three or sometimes four horses. Cart-horses require docile tempers, and a placid, though generous disposition; and must also possess the best of constitutions to withstand the changes of our variable climate. In breeding them a saving point in their favour is the early age at which they can begin to do something towards earning their lieep; while the dam also can work through almost the whole period of gestation, and again very shortly after the foal is born, so that the total cost is small compared with breeding well-bred horses. A young cart-horse can do light jobs when it is two years old without detriment to its growth or general well-being, whilst the well-bred hunting colt is of little use until it is at least four years old.

\section{The Lincolnshire Black Cart-horse.}

There was a famous breed of black cart-horses in Lincolnshire which existed as a class till the middle of the last century, which are traced to the times when the Dutch came over and drained the Eastern fens during the reign of William III., bringing their horses over with them. They spread into Yorkshire, where occasional specimens still crop up, throwing back to their Dutch ancestors. They are set much store by, being invariably active hard workers, and in their lean, game-looking heads they show evidence of superior blood in their ancestral pedigree. 
The bane of the cart-horse a few years ago was its tendency to put out ring-bones and side-bones, and also spavins; but there has been an extraordinary change for the better since the establishment of the great Shows and the enrolling of dams and sires in the respective Stud Books. The rigid rules, and careful administration of them, have gone far towards eliminating these serious ailments, and have certainly succeeded in establishing a much sounder race of horses in every breed; and the aims of the Shire Horse Society in 1877 "to improve the old English breed of cart-horses" have certainly been fulfilled with regard to their especial protégés.

\section{'THe Shire Horse.}

A Shire horse must be massive, with strength in the back and thighs, and deep in the ribs, with plenty of long, straight, silky hair on the legs, well covering the fetlocks, while a rosette of hair at the knee is much prized. The feet themselves should be big and solid, with sloping pasterns, and good razor-shaped bone. The body should be squarely built, with muscular arms and thighs; and there should be force as well as fire in the movements. A sluggish goer hanging back from his bridle is one to be avoided for work or for showing. Above all he must walk well, with plenty of liberty, and quite straight in his action, not rolling in his gait or turning out his hocks. In height he should be about 17 hands; and in colour dark grey, brown, bay, black, and chestnut-black. The Shire Horse is no doubt the descendant of the old English Great Horse used by the knights when heavy armour was worn; and so heavy was the knight and his accoutrements that the warrior seems only to have mounted his war-horse when actually required for the tournament or the battle-field. At other times the knight was mounted on a palfrey, whilst a squire led the Great Horse carrying the armour; and the necessity for this is easily understood when it is considered that the knight and his armour together weighed about 32 stone! 


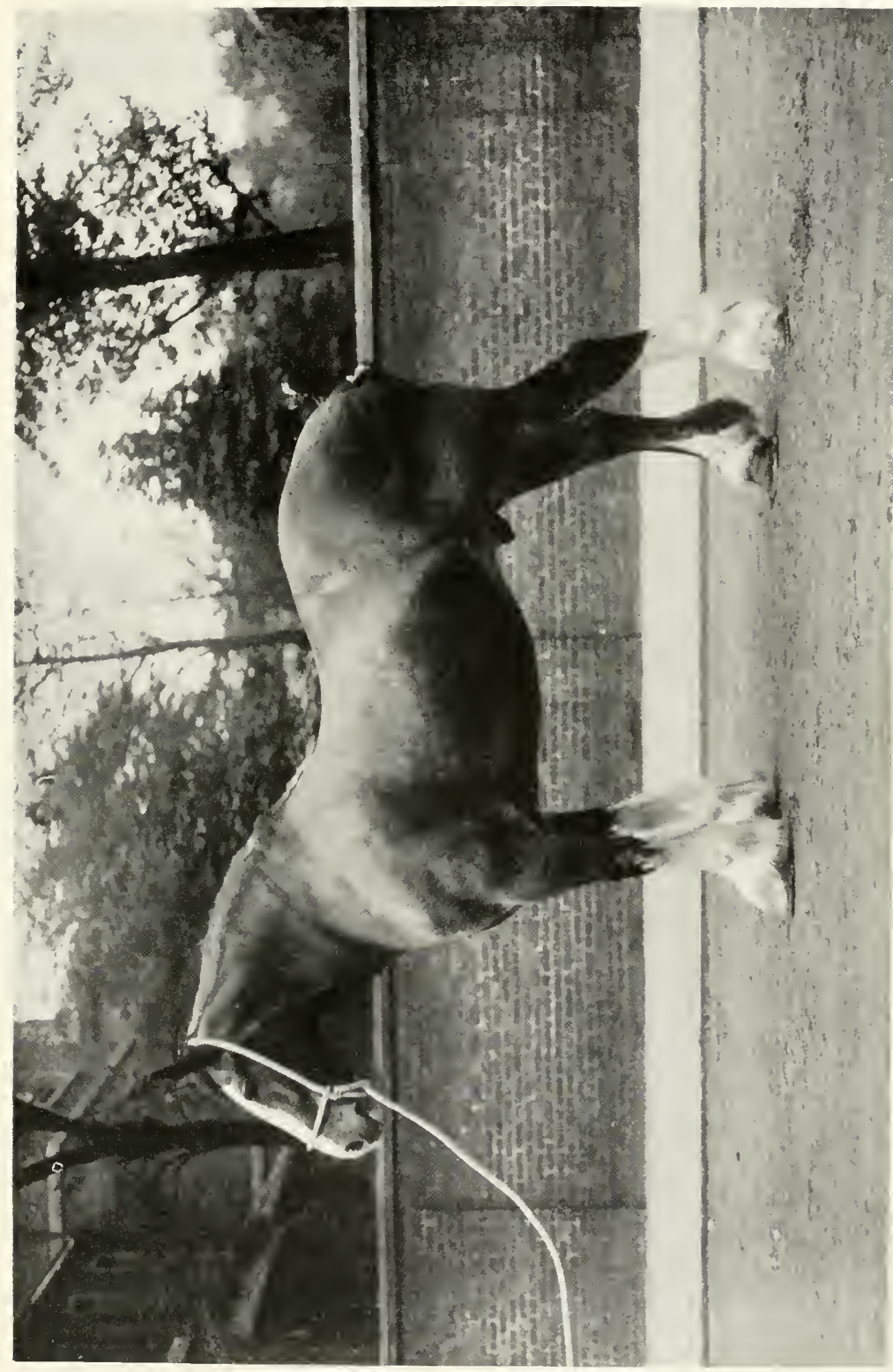



It is curious to reflect that there is an affinity between the massive Shire and the elegant Eastern horse in that the distinct depression in front of the eye-sockets, for the facegland, appears in each. It is, however, accounted for by remembering that the Great Horse at one time was crossed with Neapolitan and Flanders horses, who had Barb blood in their veins, and to this no doubt the Shires owe this unique distinction amongst coarse-bred horses.

The Shire Horse Society has this year (1911) issued from its office, 12, Hanover Square, London, the thirty-second volume of its Stud Book, which shows 4,676 new entries, comprising 1,090 stallions and 3,586 mares-surely conclusive evidence of its vitality and practical use. And a good sign is that many of the entries are made by tenant farmers; though future prospects under recent legislation may well give rise to anxiety, with the break-up of so many great estates, and the consequent withdrawal of the help and assistance of the hereditary landlords, which have been so invaluable in the times that have passed. The total number of registered stallions is now 28,954, and of mares 65,530, a most gratifying record, testifying to the wisdom of the original founders of the Society, and the ability of those who have looked after its interests since its formation.

\section{Clytesdales.}

Clydesdales, which emanate from the valley of the Clyde in Lanarkshire in Scotland, represent a lighter type of carthorse than the massive Shire, and should be altogether more active in appearance, being able to trot when occasion requires. It is partly from a cross between blood-horses and mares of the stamp of Clydesdales that the animal is produced which is in request for drawing that form of torture to the nerves of the town-dweller, the tradesman's spring-lorry, which, when empty and drawn at a trot, seems to shake loose every tooth in the head of the unfortunate passer-by. The Clydesdale, however, is not answerable for this, only the driver, who forgets that oil and cart grease are cheap, that leather washers are easily obtained, and that 
the rattle he makes and seems to enjoy is very trying to other folk.

The origin of the Clydesdales is ascribed to the action of the Duke of Hamilton in crossing six Dutch stallions imported by him on the draught mares of the country, more especially those belonging to John Paterson, of Lochy Lock, whose stock, however, died out about thirtyfive years ago. These mares were either black or brown, and had a distinguishing patch of white hair on the belly. The foundation appears very similar to that of the famous black horses of Lincolnshire, and there must have been great merit in these Dutch cart-horses to have produced two such excellent types. There is, however, another possible source from which they inherit good breeding, similarly to the ponies of the Isle of Rum, and those of Connemara, and Mayo, in Ireland; in that many of the ships of the Spanish Armada were wrecked within reach of the valley of the Clyde.

The Spaniards had intended not only to conquer but to colonise the British Isles, and therefore bronght with them their families, and also large quantities of farming stock, including stallions. All along the West Coasts of Scotland and Ireland, the unfortunate vessels were wrecked, but many of those on board were saved besides their live stock, and colonies of Spaniards were thus formed. They remained where they were, and traces of them may be seen in the native population at the present day; and in a similar way the influence of their well-bred stallions still remains amongst the horses and ponies of the districts where they settled.

The Clydesdale stallions have been much sought after by farmers' clubs in England, even as far as Cornwall ; while the Messrs. Morris, with their wonderful team of six bay Clydesdales, at the Olympia Show of 1909, caused general admiration, and proved to what a pitch of perfection it was possible to bring the breed.

It is not only in the British Isles that the merits of the Clydesdales are duly appreciated, for in all our great corngrowing colonies they are much valued, and in Canada, 
Australia, and New Zealand they are largely engaged in agricultural operations. They have been exported to South Africa and largely into the Argentine. Everywhere they prove themselves the farmer's friend, and their world-wide reputation has been honestly earned.

The Clydesdale Horse Society was founded in 1877. The best height is fixed at 16.2 to 17 hands. In colour they should be dark brown with dappling, or black. Mares may be grey, but not stallions. White on the legs is admissible, with plenty of silky feather from the very hocks, and knees, while "Ratch" on the face is held to be a sign of purity of blood.

\section{Suffolik Punch.}

A breed with an extraordinary reputation in its own district, always admired whenever seen, is the Suffolk Punch, with its beautiful, shining chestnut coat. It is an excellent walker, with a smart, quick step, and can trot in a railway van, moving well up to seven or eight miles an hour. It is one of our oldest established breeds, and that great authority on the agriculture of his day, Arthur Young, speaks of it as " an old breed," and he himself was born in 1741. Since that time they have been continually improved in general form, ungainly or weak points have been bred out, and soundness of wind and limb have been established; but their chief attribute, and most valuable distinction, gameness in the collar, was as fully developed then as it is now, even if it still exists in its former pre-eminence. The test of the sand-bag was peculiar to Suffolk and was a great test of merit in the old breed, whatever might be thought now of the hardship inflicted on the willing teams.

Sir Thomas Gery Cullum, in a note to the second edition of his brother's work, "The History and Antiquities of Flamstead and Hardwick, in the County of Suffolk," by the Rev. Sir John Cullum, Bart., F.R.S., F.S.A., explains the conditions of the test:-

"The trial is made with a waggon loaded with sand, the 
wheels sunk a little in the ground with blocks of wood laid before them to increase the difficulty. The first efforts are made with the reins fastened as usual to the collars, but the animals cannot, when so confined, put out their full strength; the reins are therefore afterwards thrown loose on their necks, when they can exert their utmost powers, which they usually do by falling on their knees and drawing in that attitude. That they may not break their knees by this operation, the area on which they draw is strewn with soft sand."

The Suffolk Mercury, June 22, 1724, thus advertises the first match that took place:-

"On Thursday, July 9, 1724, there will be a drawing at Ixworth Pickarel, for a piece of plate of $45 \mathrm{~s}$. value; and they that will bring five horses or mares may put in for it: and they that draw twenty the best and fairest pulls with their reins up, and then, they that can carry the greatest weight over the block with fewest lifts, and fewest pulls, shall have the said plate; by such judges as the masters of the teams shall choose. Yon are to meet at twelve o'clock, and put in your names (or else be debarred from drawing for it), and subscribe half a crown apiece to be paid to the second best team."

Such contests, fortunately for humanity's sake, have long died ont, but that they ever should have been common as trials of strength is a convincing proof of the gameness of the breed. The first volume of the Suffolk Stud Book, p. 41, quotes an advertisement of a drawing-match in 1766 , thirty-eight years after the one mentioned at Ixworth Pickarel, and many are known to have taken place between these dates.

"Harleston, Norfolk. This is to give notice, that on the 18th of this instant March, there will be a drawing for stallions at the house of John Hamblem, called the Magpie, for a silver cup value five guineas: no more than seven to enter, and not less than five. Each horse to draw single, to raise the most weight. The best of twenty pulls, and for every blank, to have a bushel of sand laid on the waggon." 
Youatt adds his testimony to the docile temper of the Suffolks:-

" Many a good draught horse knows well what he can effect; and after he has attempted it and failed, no torture of the whip can induce him to strain his powers beyond their natural extent. The Suffolk, however, would tug at a dead pull till he dropped. It was beautiful to see a team of true Suffolks, at a signal from the driver, and without whip, down on their knees in a moment and drag everything before them. Brutal wagers were frequently laid as to their power in this respect, and many a good team was injured and ruined. The immense power of the Suffolk is accounted for by the low position of the shoulder, which enables him to throw so much of his weight into the collar."

The original type, as given in the first volume of the Stud Book, p. 42, was "rather small, barely 16 hands; low in the forehand; upright on the shoulder; 'sorrel' or chestnut, with the occasional flaxen mane and tail; shortlegged; not over-handsome, but with the deep ribs, hardy constitution, and the aptitude to 'draw' well, which was the pride of the Suffolk farmer at that time." While Suckling, in his work on the "History and Antiquities of the County of Suffolk," describes them as "active in their paces, and on the lighter lands of the county will draw a plough at the rate of three miles an hour."

The first volume of the Stud Book, quoting from the Live Stock Journal Almanac for 1878 with much approval, states :--

"The deep back ribs, short legs, and close joints are rarely absent in an animal of the Suffolk breed good enough to go to London. The evenly turned quarters, the round barrel, and good chest mark the county of his birth; " and this description holds as good to-day as at the period when it was written. The Stud Book then proceeds to give the points of the breed, which are so clearly stated, that I cannot do better than repeat what is there laid down.

"So far as a leading feature in his character, colour stands first. . . The recognised colour is chestnut. Bays 
were very prevalent some years ago, but the presence of that colour can, in nearly every case, be traced to the introduction of extraneons blood. Of the chestnut there are seven shades... the dark, at times approaching a brown-black, mahogany, or liver colour; the dull dark chestnut; the light mealy chestnut; the red; the golden; the lemon; and the bright chestnut. The most popular, the most common, and the most standing colour is the last named. The bright chestnut is a lively shade, with a little gradation of lighter colour at the flanks and at the extremities-but not much. It is in most cases attended with a star on the forehead, or thin 'reach,' 'blaze,' or 'shim' down the face. The flaxen mane and tail prevalent 100 years ago, and occasionally found at the present day, are usually seen on the bright chestnut. This shade is also not unfrequently shot with white or silver hairs, hereditarily distinctive of certain strains.

"The golden is a beantiful colour, not many removes from the bright chestnut, but is not unfrequently faced up with a white heel behind. The lemon is a very light golden shade, known sometimes as the 'yellow' chestnut.

"The red chestnut is a very popular colour; and a red chestnut is almost sure to be a whole-coloured horse. There is no variation of shade in it, not even at the flanks, quarters, or extremities. It is said to come of a taint of bay origin, especially the lighter variety-the cherry red.

"The light mealy chestnut is condemned by all; it is indicative of a weak constitution, soft legs, and a slow phlegmatic temperament. Commencing with a dull chestnut body, the flanks and under-line are a mottled ash colour, gradually shading off to a dirty white at the extremities, which are usually covered with soft hair of the same hue.

"The dark chestnut is a favourite with some breeders, but is mostly a changing colour, varying with the season of the year, from almost a black to a dark cherry red. . . . It is said to be a hardy colour, but there can be no doubt that a first-class mare is considerably depreciated in value, if a dark instead of a bright or golden chestnut. The dull- 


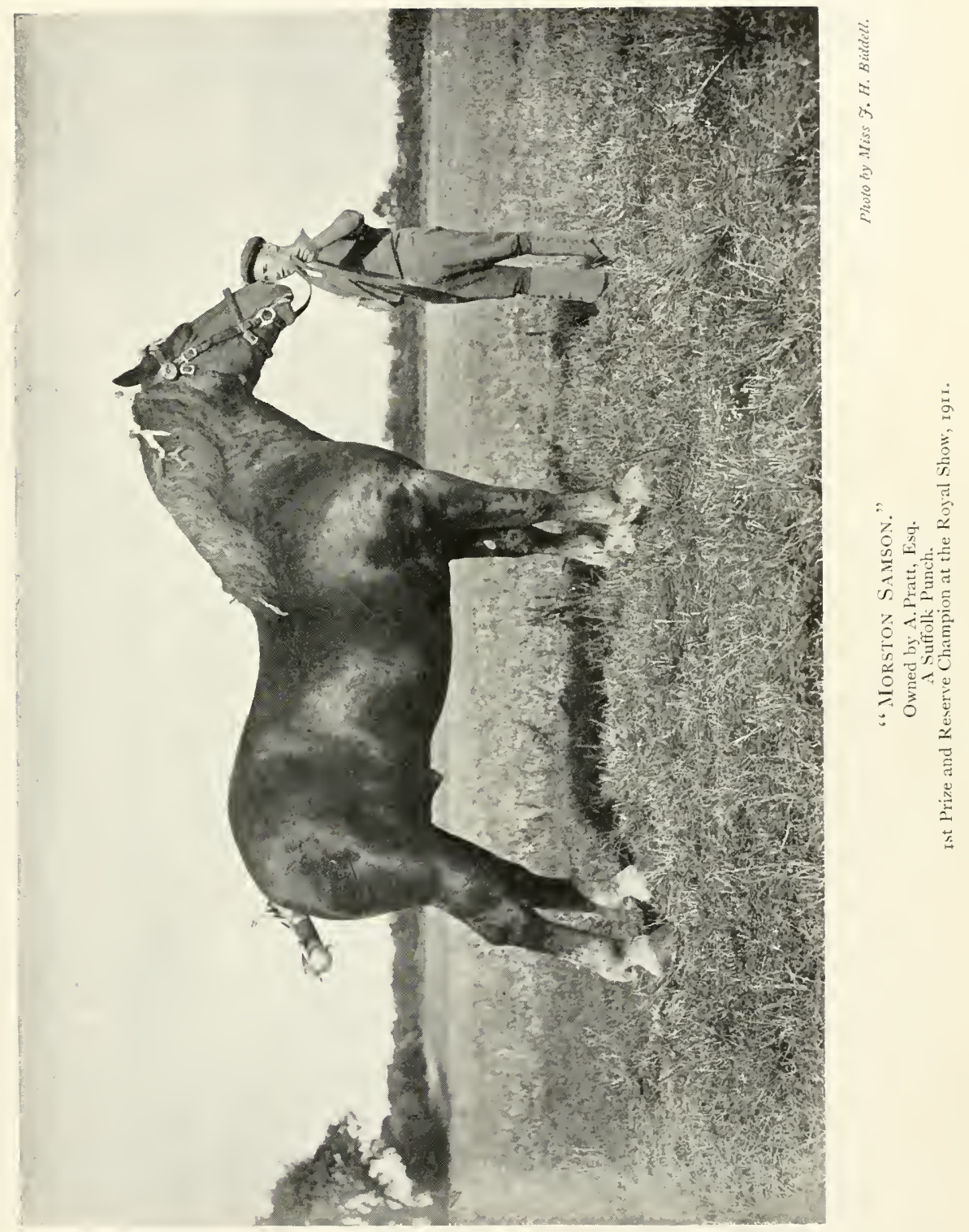



dark chestnut is only one remove above the light mealy chestnut, and is held in little better repute. . . . Sorrel was the name by which the chestnut was known many years ago. Black, white, grey, or dun is never mentioned in connection with the colour of a Suffolk horse.

"Next to colour comes that indescribable, but equally unmistakable, element in his composition, which is known by the term of 'quality.' . . . It is not necessary that a horse of a great deal of quality should be totally free from hair on his legs; it has no connection with a light bonesome of the heaviest-boned Suffolks show the most quality; ... it would perhaps be best described as a thin skin, with soft hair, and tightly fitted, and especially over the bones and joints of the legs. . . As regards the head of a Suffoll horse, no doubt many of the most valuable specimens of the breed have had the head described by Mr. Garrett ('Head rather large, thick through the gullet-not coarse. Eyes small, not prominent; ears small and pointing towards each other at the tips'), and Mr. Wilton ('Not too handsome, broad forehead, with a little thickness in the throatband; ear not large, but should look small on a masculine head; eyes fairly prominent; nostril rather thick, but open; chaps deep and a little heavy in appearance '); and as such, these small ears and non-prominent eyes and thick throat-band have been associated with the breed, not only in years gone by, but in more recent times. Manchester Boxer 298, French's Captain 541, some more of the sons of Catlin's Duke 296, and still more of the progeny of Crisp's Cupbearer 416, had more or less of these distinguishing points. ... The big bold head, long and thin - perhaps the best of all, and as indicative of pure blood as any yet noticed-may be traced in the descendants of Edward's Briton 490. Liverpool Captain 42:2, Crisp's old high-necked horse 408, and Cottingham's Captain 376 had such heads, and the mares left by them were much in the same character.

"An arched crest, with a fine silky mane, no doubt belongs to the Suffolk horse. Some prefer a more muscular neck, while others are inclined to a finer crest, all agreeing that 
it should be deep in the collar, tapering gracefully towards the setting on of the head. The straight ewe neck is rarely seen in a Suffolk horse, and is always rejected as a serious detriment. The enormously heavy neck and crest runs in certain families ... and is mostly accompanied by a hollow back.

"The sons of Catlin's Duke 296 were all short in the neck-a formation which is mostly accompanied by a hardy constitution. It was so in this case. The Newcastle Captains 89 were very thin in the crest, had beautiful hair, but were a little deficient in muscle.

"Whatever the shoulders of the Suffolk horse might have been in years gone by, there can be little doubt that a muscular shoulder, well thrown back at the top, prevails in the present race, and much of the comely appearance of the best Suffolks now in existence is the result of such a formation. The sinart step came in with the oblique shoulder, but the power of lifting, the facility for going from end to end on the plough in a stiff clay twenty-acre field was not increased by the 'improved' fore-end.

"The well-rounded rib, deep all the way from shoulder to flank, is a decided point in the build of a Suffolk horse. The inordinately deep mid-rib and light girth behind the shoulder, which in years past disfigured the breed, has been gradually worked out, and a better, rounder middle substituted. The deep carcase is, or should be, a sine quâ non with a Suffolk horse. The long hours without food, which seems a rooted practice all over the county, render a roomy carcase a positive necessity. A Clydesdale or Shire-bred with a light middle and short rib may do in London, where the nose-bag is always at hand, but the long day and the short rations, from 6.30 to 3 o'clock on the plough, in Suffolk, would soon reduce a horse of this form to a skeleton. The graceful outline of the back, loin, and hindquarter is rarely absent in a Suffolk horse. . . .

"The bone of the Suffolk horse is not large; it is more of the texture of the blood-horse, and does not require to be heavy to the eye. A girth of $10 \frac{1}{2}$ inches below the knee is ample for any Suffolk horse, nor is his value increased by 
a larger bone. The height of a Suffolk horse varies from $15 \frac{3}{4}$ to 17 hands, but $16 \frac{1}{2}$ is all that a good one ought to be. . . .

"The girth of a Suffolk horse behind the shoulders should be about 8 feet. Two inches short of this would not be looked upon as a light fore-rib, but anything further that way would begin to attract notice. ... In temper they are docile in the extreme. . . For the first three-andtwenty years of the Royal Society existence the prize was offered for 'the best horse for agricultural purposes,' and the various breeds took their chances among specimens representing every variety (1839-1861). Of these twentythree first prizes fourteen went to Suffolk horses, and the remaining nine represented the united success of all the other breeds which competed. . . In addition to these, more than half the second prizes awarded during the same period went to Suffolk horses."

It should be added this breed weighs well for its height, ranging from $1,900 \mathrm{lbs}$. to $2,240 \mathrm{lbs}$. (1 ton).

Since that time the Society has thought it wiser to separate the breeds, and prizes have been given for the best Shire, Clydesdale, \&c., most certainly a preferable plan. But in all that constitutes a farmer's horse, a hardy, strong-constitutioned, docile, staunch, active animal, a Suffolk horse is very bad to beat, be the others what they may. As a Suffolk breeder the reputation of Sir Cuthbert Quilter is now world-wide, and Mr. Smith of Woodbridge, Mr. Clark of Sudbourne, and Mr. Arthur Pratt of Morston Hall, Trimley, stand forth as champions of the breed at the present day; amongst their staunch friends of the past the late Duke of Hamilton, the late Earl of Stradroke, and the late Sir Edward Kerrison did a great deal for the Suffolks, but without the arduous labour of Mr. Hermon Biddell in compiling the Stud Book of the Society, which brought him such renown, the history of the Suffolk horse might still be incomplete, and to his researches inuch of the present fame and success of the breed is due. 


\section{CHAPTER VI}

\section{ORIGIN OF AMERICAN TROTTING HORSES}

ITHE hold that trotting horses have over the inhabitants 1 of America is difficult for Europeans to understand. Although the great founders of this race came from the Old World, the populace there has rarely been enthusiastic about the trotter, and his especial excellence is due to the genius of the Americans themselves. It is, moreover, within the last forty years or so that the great improvement in the breed has taken place, for in the year 1872 only 96 horses made a public record of a mile in 2.30 or better, though five years afterwards, in 1877,284 horses attained the same distinction, and now many thousands of trotters and pacers have reached the recognised standard of merit.

In his interesting work, "Anerican Roadsters and 'T'otting Horses," Mr. H. T. Helm lays down as an axiom in breeding trotting horses: "The sire should have the trotting qualities desired in high degree, and they should be derived from both inheritance and instruction. The dam, if possessed of endurance and pluck, and enough of what we call blood, may be lacking in the inherited trotting quality, yet be capable of producing a trotter of the highest excellence." He then proceeds to illustrate his argument by citing the example of Lady Thorn, who was by Mambrino Chief, a natural trotter, but who never raced in public, while her dam was by Cano, a thoroughbred race-horse, and her grandam by Sir IVilliam, also a thoroughbred race-horse. Lady Thorn was bred in 1856. Her greatness as a trotter was shown by the illustrious competitors she beat, anongst others being the famous Dexter (2.17主), Mountain Boy, Goldsmith Maid (2.14), 


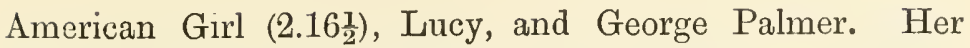
career ended through falling when being boxed at a railway station, when she got a hip down through striking an iron rail with it, the accident happening in 1870, and she then retired to the stud with a record of $2.18 \frac{1}{4}$.

Undoubtedly it was an event of the greatest national importance when the grey thoroughbred horse Messenger first trod American soil, for most of the fastest trotters of to-day inherit his blood. He was bred at Newmarket in England by John Pratt, Esq., in 1780, and stood 15.3 high.

Mr. Helm devotes some pages of his book to endeavouring to prove a supposition that Sampson, the great grand-sire of Messenger, was not by Blaze, as stated in the English Stud Book, but by a coarse-bred horse, and that it was due to this parentage that Messenger owed his phenomenal powers of transmitting trotting qualities. The chief arguments of Mr. Helm are that Sampson was black in colour, very coarse in appearance, with great strength, and he further states: "All persons acquainted with the character of the English race-horses descended from the pure Arab know that they possessed no such instincts (i.e., trotting). What they did not possess they could not transmit." Now in this reasoning he is certainly in error, for many thoroughbred horses are extremely fast trotters when put to that gait; frequently also the same may be said of Arabians at the present day, and Barb horses, some of which breed appear in the pedigree of Mambrino, the sire of Messenger. Again, though black is a rare colour amongst pure-bred Arabians, this does not apply to Barb horses, wherefore Sampson may have inherited his colour from his African ancestors. Some strains of Barbs, too, show great strength, especially the Shawya tribe, which are built after the fashion of the Fell galloways of the North of England, though at the same time they are possessed of great speed. Many Barb horses reach 15.3 in height and are frequently fast trotters, though the Moors themselves prefer the pacing gait, and take much pains to develop this by careful training. Mr. Walter Winans has pointed out an interesting fact in con- 
nection with this: "If you look at the Egyptian wall sculpture sand paintings you will notice that the Egyptian chariot horses are represented either galloping or pacing, never trotting."

An extremely fast trotter was Hadramaut, a pure Arabian, bred by Mr. Wilfrid Scawen Blunt at Crabbet Park in 1880, and it was claimed for him he could trot sixteen miles within the hour in an ordinary dog-cart when the property of Mr. H. Stephens, of Cholderton, near Salisbury. Moreover he won the Oriental Stakes on the flat, at Sandown Park in 1884, for his then owner Major R. F. MeyseyThompson, carrying the top-weight $10 \mathrm{st}$. $4 \mathrm{lbs}$, and though only a four-year-old he gave weight away to aged horses. He was ridden by Tom Cannon, and was by Kars, a Séglawi Jedran, out of Hagar, a Kehîlet Ajuz, a celebrated mare in the desert of Arabia, very powerful, and 15 hands in height. Mail Train, who came from Smyrna, was another fast trotter, also the property of the writer. Amongst many very fast trotting thoroughbreds may be mentioned Camaltha, by Camballo out of Violet by Janus, out of Kick-up-the-Dust, winner of eight races on the flat, yet who never broke from her trot when used as a hack. In the course of one winter the writer often had occasion to visit a relative who had met with an accident and lived fourteen miles away. Although there were some streets to traverse, when perforce the mare was obliged somewhat to restrain her ardour, also three, or sometimes four, gates to open, besides being compelled to walk for a short distance once or twice during the journey for the sake of resting, the longest time ever taken between the two houses was one hour and ten minutes. The mare used never to break from her trot, and such was her courage that it was impossible to make her go slower than her top speed. After she had walked about a hundred yards she would start off again at her best pace, though the rider would have preferred to take things easier. Almost if not quite as fast a trotter was Chariberta, by Charibert out of Tita, the latter the winner of twenty-two races on the flat. Again, another very fast trotter was Lady Bo-Peep, by Hagioscope out of 
the sister to Syrian, Baroness, by Mentmore. Numbers of other examples could easily be given, but enough has been said to show that Mr. Helm was mistaken in thinking English race-horses and pure-bred Arabians never possess the gift of trotting, for on the contrary many are very fast trotters indeed, and consequently are quite likely to transmit their gifts to their descendants.

When, therefore, Mr. Helm mentions "that Lord Grosvenor, the owner of the horse, offered to match Mambrino to trot fourteen miles in an hour for one thousand guineas," and attributes his trotting powers to his being "one degree closer to the coach-horse," he is scarcely treading on sure ground.

Other points that Mr. Helm relies on for proving coarse blood in Sampson are that he was 15.2 at a period when the thoroughbred horse rarely reached 15 hands, and also that his withers were round and flat; but this last characteristic is by no means uncommon amongst pure-bred Arabians, and both Hadramaut and Mail Train, mentioned above, were remarkably round in their withers, though they had great liberty of action and won many races. Lackland also, bred at Middle Park by Mr. T. Blenkiron, by King John out of Gaiety by Touchstone, the dam of Gamester, winner of the St. Leger, a winner of fourteen races on the flat, was as round in his withers as any mountain galloway, so this certainly cannot be relied upon as a certain proof of coarse breeding. As for the unusual height, Hagar, already mentioned, a desert-born Arabian mare, was 15 hands, and of her progeny, bred at Crabbet Park, Hadramant grew to 15.1 in the first generation reared in England. As Sampson's ancestors had been brought up in this country for some generations, the good keep may easily have sufficed to grow a horse of Sampson's size. He was, moreover, a racehorse of great excellence, having won all his races of four miles and under, except his last race, when he won his first heat. Surely therefore the convenient Scotch verdict of " not proven" may be applied to Mr. Helm's arguments as to the parentage of Sampson's sire. 


\section{The Points of a Trotter.}

Mr. Helm's work is so full of information, especially in regard to the characteristics of the early trotting stock, that when a seeming error is noticed it is well to draw attention to it, lest silence should be deemed to give consent. His description of the conformation of the trotter as being diametrically opposed to that of the race-horse may perhaps be accepted in America, but is certainly not so in England. He states: "Any one who has closely studied the crossing of the trotter with the blood of Diomed, Sir Archy, and other pure-bred horses in this country, has seen that the effect is a gradual shortening of the line from hip to hock, and also a lengthening of the distance of the hock from the ground ... longer hind cannons. This is the galloping leverage; the reverse is the trotting leverage." Whatever may be the case in America, the same conformation Mr. Helm mentions as being necessary for the ideal trotter is in England also sought for as essential to the highclass race-horse.

In other respects, indeed in this very instance just mentioned, his description of the requirements of a trotter is very sound. "A trotter should go level and steady before and behind, and he should not be a sprawler," is true of other breeds besides trotters, for unless the machinery works perfectly smooth there must be undue excess of motion and consequent loss of power. "A colt must not trot too high nor too low in front, and he must not do all his trotting with his fore-legs" is most excellent advice. It is the hind action which is the chief propelling force, and an animal which goes too close to the ground in front usually does so from a want of development of the flexor muscles of the leg. This the ordinary horseman, without any pretensions to veterinary lore, can easily see for himself by noticing whether the leg just above the knee looks broad, when viewed sideways, and the muscles prominent, with an appearance of strength. Any weakness here is a sure sign that the animal will quickly tire when called upon for a severe effort. 


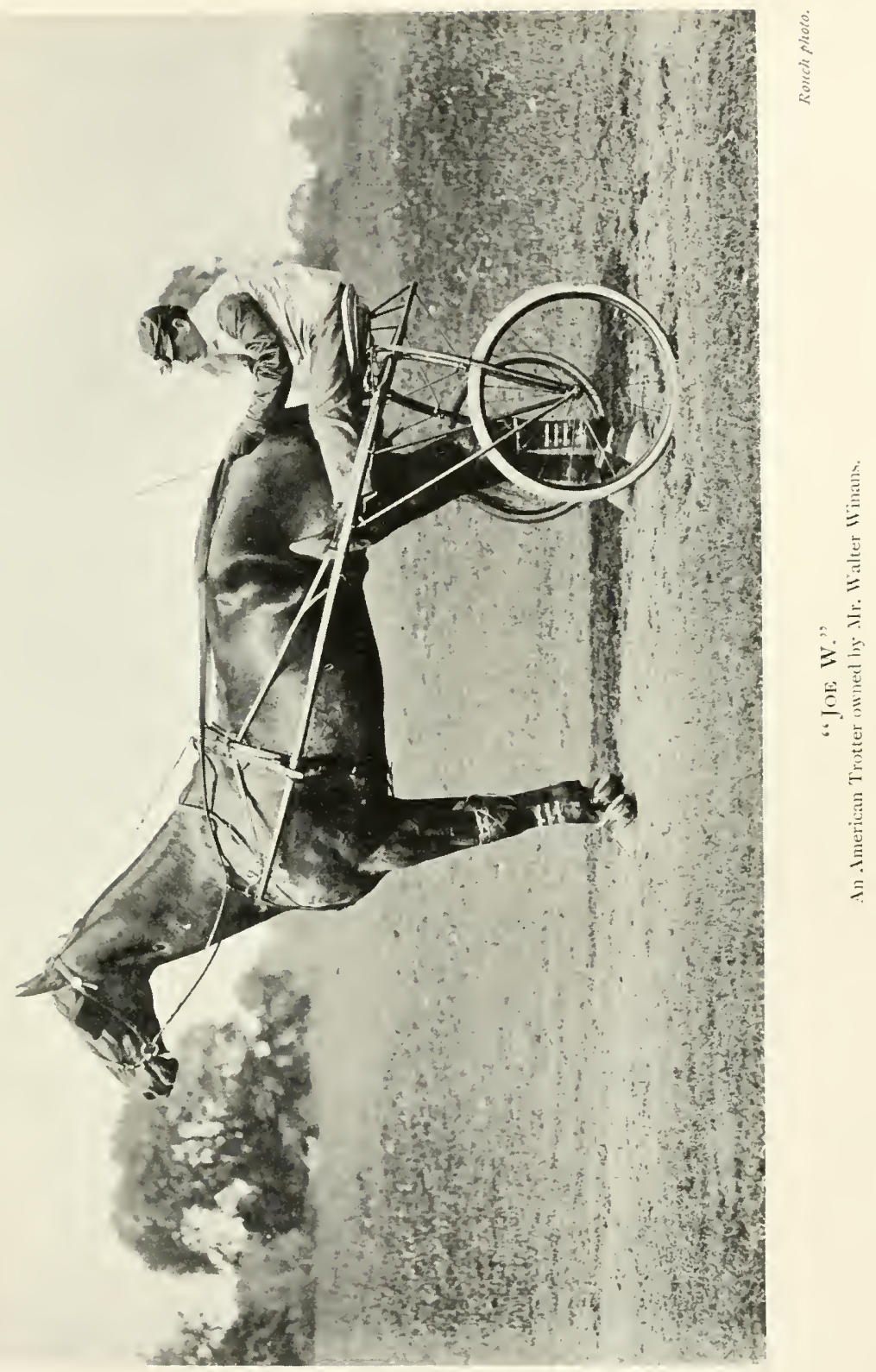



For fast trotting a far-reaching even gait is required, and this necessitates a long forearm with a short cannon-bone below the knee. A horse possessing the contrary shape is almost sure to lift his knee too high and bang his feet on the ground unduly hard, with the result that he is unable to continue the effort over a long distance or for any length of time, though from being endowed with great energy he may even show superior speed for short distances. For trotting purposes there may be too little bending of the knee, but a far more likely evil, and one more frequently met with, is that there is too much.

Mr. Helm gives some interesting measurements of various horses which should be valuable as indicating what the breeder should aim at. The forearm of Volunteer measured

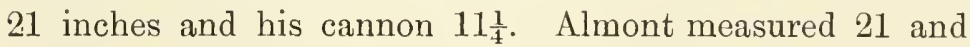
11, "and the common objection against his stock was that they lacked in knee action, while Thorndale, with his $11_{2}^{1}$ and $20 \frac{1}{2}$, has far-reaching yet rounding action of his front legs, lifting his knees and slightly bending them-about as pleasing in that respect as the most fastidious eye could demand."

Again he observes: "In those descended from St. Lawrence, measuring about $11 \frac{1}{4}$ and 21 , I have found, with unvarying uniformity, a far-reaching, gently curving, but never hard-pounding action of the front feet, that can hardly be surpassed."

Of course no absolute rule can be laid down as to exact measurements required, but it would appear that approximately a cannon of $11 \frac{1}{4}$ inches and a forearm of 21 is very near perfection.

Special families have had their own peculiarities of action. For instance, the Messengers were noted for little kneeaction, a consequence of their long forearms and short cannon-bones; while the Morgans, on the contrary, were remarkable for high action. Smuggler too, had very high knee action, and his front cannon-bone measured 12 inches, while his forearm was $20 \frac{1}{2}$. Mr. Helm states: "He lifts his knees, apparently, higher than his elbow . . . and the violence with which he brings them to the ground is shown in 
his hammering off two shoes in one race . . . and such shoes as he wears! They began with thirty-two ounce shoes in front and eight-ounce shoes behind. Does any one ask why they put such an enormous weight on his forefeet? It is because such weight is requisite to keep him level and perfectly balanced, otherwise he would break, would not hold to the trot, would gallop or trot unsteadily." The result of this conformation of the fore-legs and the mechanical means adopted to modify a faulty construction was only what might be expected. Thongh the winner of a notable race at the Cleveland Meeting in 1876, and able to trot below 2.16 when everything went right, it was more often that things went wrong, and he was distanced in consequence. Nor was he able to stand the constant training requisite to keep him in balance, and he therefore was early withdrawn to the stud from the trotting-track.

To measure the length of the forearm it is usual to take a line from the top of the elbow to the notch in the middle of the knee, though this really includes the upper series of carpal bones also. It is, however, a convenient point to measure to. From this latter to the centre of the anklejoint will give the length of the cannon-bone.

In considering the framework of the trotter, the hind-legs are necessarily one of the first points to be considered, for they are the chief propelling power, and on their leverage and length must depend the distance of each stride and the rapidity of its repetition. A low hock and a short hind cannon are as important as a long forearm and a short fore cannon, for thereby the length from hip to hock is increased, enabling the horse to cover more ground at each stroke than if the hock was situated higher, with consequently a shorter line from the hip. It is necessary also that the thigh should be lengthy from the stifle to the hock; and fully as important is the muscular development of this region. Muscles owe their chief force to length, and without long bones there cannot be long muscles. The chief ones concerned in the retraction of the leg are the glutæi, situated in the region of the hip; while those that straighten the leg and propel the horse forward are the triceps and 
the biceps, the latter forming the posterior border of the haunch. If the quarters are long, broad, and well developed generally, the owner of the animal may feel well satisfied that the power needed is sufficiently supplied by nature; though it is to a great extent due to the extra development in individuals of the especial muscles mentioned, that superiority in speed is shown over their rivals. In this respect attention should also be directed to the projecting bone at the back of the hock, the os calcis or "point of the hock," which acts as a lever to straighten the leg, and is moved by the tendon Achilles and other tendons arising from the muscles which clothe the upper part of the limb. An increase in the length of the lever adds considerably to the force of the spring.

According to Mr. Helm, the Messengers "had a thigh, and a length from hip to hock, that was exceedingly uniform in its ratio-being a thigh of about 23 inches, and a measure of 39 inches from hip to hock, in a horse of 15.2 or 15.3 ; but when the cross of the Clay and Bellfounder horse-known as Sayer's Harry Clay-came in, the length of thigh was slightly increased, while the other line was extended to 40 and even 42 inches, with wonderful uniformity."

Hambletonian was 24 and 41; Lady Thorn, with a thigh only 23 inches, was 42 inches from hip to hock. Smuggler was 40 inches, and so also was Volunteer. "It will be found, in a study of the trotters of the various families, that those members of each family respectively generally excelled which showed the greatest length in this line. . . . I like a thigh of fair, but not excessive length-23 to 24 inches, but no longer-and if a long one, then I want the hock well let down-a long line from hip to hock, 24 and 40 , or even 41 -but the long reach in this direction may also amount to a dwelling action. Until it approaches that, I want to see a horse's hock low down and far out behind when extended. I don't like one that lifts his hock and strikes the cross-bar of a sulky. Such fellows will display an excess of motion, and trotters that show excessive motion in any respect have a conformation that is unnecessarily exposed to wear 
and tear. The smooth easy-going fellows, that go much faster than they appear to go, are the ones for a long race. Such will be found to possess the middle ground of conformation, front and rear." These remarks practically sum up what is to be learned in this direction.

To obtain the accurate length, measure from the centre of the hip-joint to the outer point of the hock; and from the knuckle of the stifle-joint to the same place for the length of the thigh. In conclusion Mr. Helm may be again quoted: "The tape-line is no direct measure of speed, but it is an indicator of the adaptation of part to part-the speed and capacity for endurance at that way of going."

Other necessary attributes are good sound open feet, to stand the wear and tear of training and racing; large knees and hocks, with consequent well-developed carpal and tarsal bones, designed to minimise the shock of concussion, and long well-sloped shoulders that have the same end in view. There must also be ample room for the play of lungs and heart, wherefore the chest must be deep and the ribs well sprung; while to afford space for the windpipe, and give ease in breathing when at full speed, the angle of the jaws must be set wide apart, and the neck must not be so thick as to restrict the throat by the mass of muscular surroundings.

When the form of the horse is such that he is physically adapted to cover a length of ground at each stride, whilst his poise is so perfect he does not need artificial appliances to maintain his balance, with a free-and-easy passage of air to meet the demands of an increasing circulation, whilst his temperanient is so generous that he is ever desirous to obey the wishes of his master, yet of such high courage that he is ready to summon forth his utmost power when called upon to do so, then every element is there which is requisite for the highest class of trotter, and to enable him to obtain a niche amongst the noted champions of the track.

\section{The Breeding of Trotters.}

A careful study of the pedigrees of early famous trotting horses shows that while they had much thoroughbred blood 
in their veins, some of them having two or three crosses, it nearly always came through sires; and the produce of a thoroughbred mare by a trotting stallion seldom trained on after two or three years old, although it might display great speed at first. Blue blood, however, was a necessity in the family tree-for that alone has the capacity for imparting a high state of nervous vigour and action to the produce of a low-born animal. Many of the dams of the old-time champions were great road mares, capable of doing very fast performances in the course of their ordinary work, and when these came to be mated with a thoroughbred horse, which had the gift of getting animals which took naturally to trotting, the produce frequently became a star in the trotting world. As breeding progressed, however, thoroughbred mares came to play a great part as dams and grandams of famous horses.

When there was a sufficiency of blood in an animal to enable him to continue to travel at a very high rate of speed, he was well-bred enough to mate with mares that also possessed some "blood." This was very early shown by the success of the famous Bellfounder, who had a great deal of the best racing blood in his composition. His sire, Old Bellfounder, was a descendant of the Fireaways, who descended in tail male from Flying Childers. His dam Velocity was by Haphazard, a grandson of Eclipse, and must have had other good strains, since it is recorded of her that she trotted sixteen miles in one hour on the Norwich road in 1806, and won her match-which she had done her best to lose, since she broke into a gallop fifteen times, and had as often to be turned round in consequence. When the daughter of Bellfounder was mated with Abdallah, who was so closely inbred to Messenger, the produce was the mighty sire Hambletonian, whose descendants enrolled in the coveted 2.30 register may now be said to be legions. As Mr. Hamilton Busbey remarks in "The Trotting and the Pacing Horse in America": "It was not so much the speed of his sons and daughters as their ability to transmit speed which placed Hambletonian on the summit of the mountain." 
The pedigree of Messenger betrays many ancestors through whom the trotting instinct may have descended, for both Turks and Barbs are much more frequently ridden at a trotting gait than are Arabians, whose masters do not appreciate this gait.

Messenger's pedigree is as follows:-

\section{Breeding of Days.}

First dam, by Turf, by Matchem, by Cade, by Godolphin Arabian.

Second dam, by Regulus, by Godolphin Arabian.

Third dam, by Bolton Starling.

Fourth dam, by Fox.

Fifth dam, Gipsey, by Bay Bolton.

Sixth dam, by Newcastle Turk.

Seventh dam, by Byerly Turk.

Eighth dam, by Taffolet Barb.

Ninth dam, by Place's White Turk, out of a natural Barb mare.

\section{Breeding of Sires,}

First sire, Mambrino.

Second sire, Engineer, dam by Young Greyhound-mare by Curwen's bay Barb.

Third sire, Sampson, dam by Hip, son of Curwen's bay Barb.

Fourth sire, Blaze.

Fifth sire, Flying Childers.

Sixth sire, Darley Arabian.

Thus out of the ancestors of nine dams mentioned, three are Turks and two Barbs, while the Godolphin Arabian figures twice. Moreover, it is well known that the Byerly Turk was ridden as a charger by his owner, when trotting would be a gait constantly required from him, probably more so than galloping. Amongst the forefathers of Mambrino may be noted Curwen's bay Barb, who appears twice, thus bringing in still more strains of horses accustomed to the trotting gait. No surprise need then be felt that Messenger was able to leave a line of great trotters when crossed with mares accustomed to the road.

The portrait of Mambrino at Eaton Hall, by George Stubbs, shows him to have been a compactly built, powerful horse, with a great deal of Arab character about him, but at 


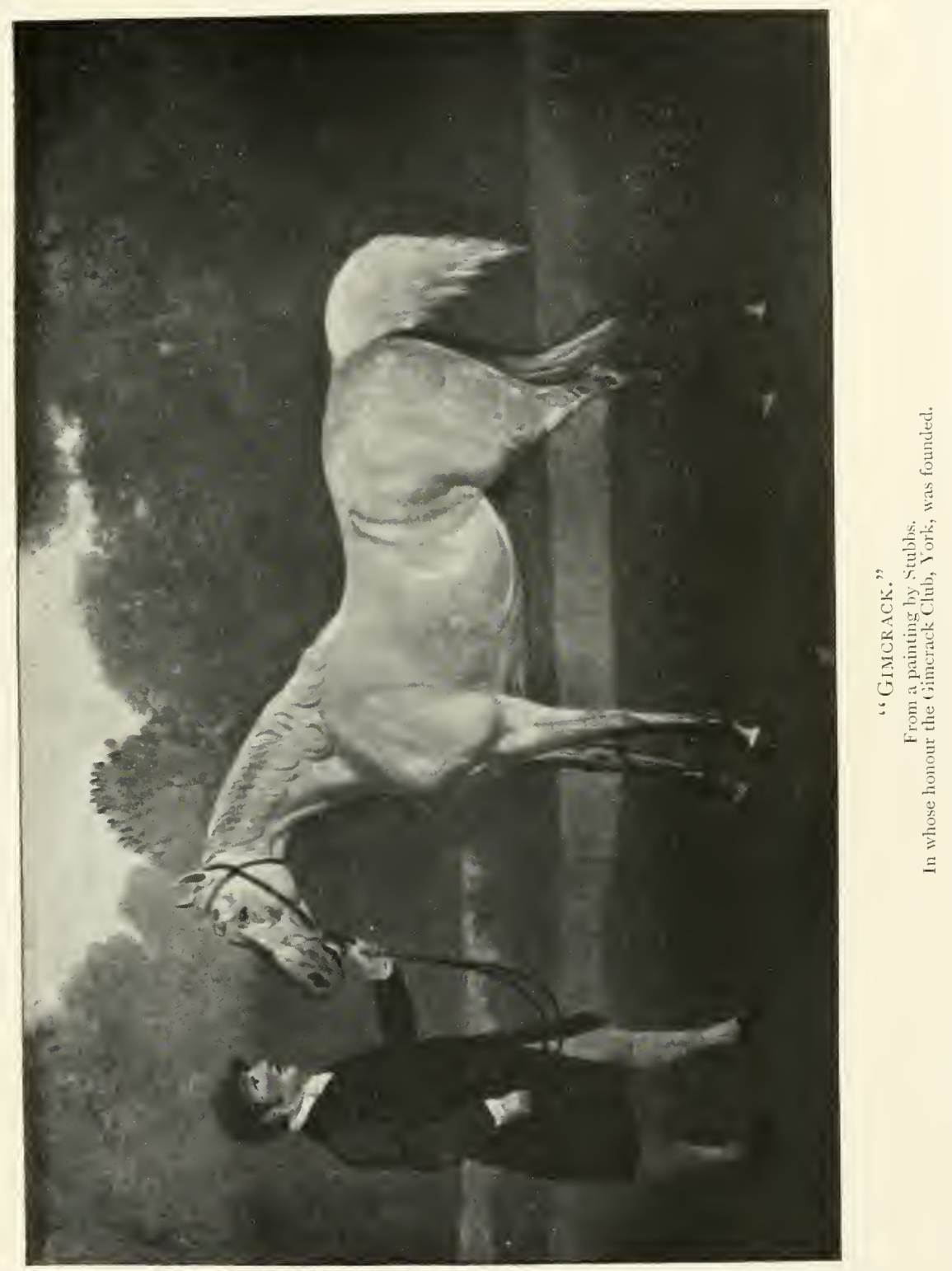



the same time taking more after the type of the Barb in his forehand, carrying his head well up, with a well arched neck and a considerable crest. He appears an active, well poised horse, likely to have been an excellent saddle-horse, but from his short forearms and long cannons he would apparently bend his knee too much for great pace, although as a matter of fact he was credited with trotting very fast indeed.

An important element in the American trotter is the blood of Duroc, who was a large and powerful chestnut horse, by imported Diomed, the first winner of the Epsom Derby. Duroc was foaled in 1806 in Virginia, and the breeding of his dam, Amanda, is especially interesting to Englishmen in general and to Yorkshiremen in particular, for she was by Grey Diomed (no relation to imported Diomed), son of imported Medley, who was by the renowned Gimcrack, in whose honour the celebrated Gimcrack Club at York give an annual dinner (the last was the one hundred and forty-second in direct succession), when a large number of the most prominent turfites in England are their guests. It is at this banquet that any great innovations in the Rules of Racing, or other important coming events, are foreshadowed in the speech of the principal guest of the evening, a member of the Jockey Club, and usually one of the three Stewards.

The chief features of the Duroc family were a large and powerful frame, long powerful thighs and gaskins, with good bone. The American Star and Mambrino Chief families all inherit the blood of Duroc, and with it the characteristic long thigh, 24 inches in horses of 15.2. In England the blood of Gimcrack has almost if not quite died out, but it shows much vitality in America, chiefly by aid of the great trotting strains. It was, however, also inherited by Ogden's Messenger, a thoroughbred horse, by Messenger out of Katy Fisher, by imported Highflyer, who was by Highflyer out of a mare by Gimcrack. Ogden's Messenger was the reputed sire of Tipoo, who through his son Black Warrior founded the family of Royal Georges. A further thoroughbred line from the celebrated little grey horse can 
be traced through Romp, by imported Messenger out of the imported Pot-8-os mare, who was out of a mare by Gimcrack.

A notable line of trotters was founded by the Barb horse Grand Bashaw, who was moreover jet-black, and was imported from Tripoli in 1820. Through his famous grandson, Andrew Jackson, he became the founder of the Clays, though some of these had an unenviable reputation for want of courage in a closely contested race. This unfortunate trait is generally admitted to have been introduced by the dam of Henry Clay, a Canadian mare named Surry, who was herself a trotting mare. Andrew Jackson, however, was also sire of Long Island Black-Hawk, who, distinguished both as a trotter and a sire, left a long line of descendants sans peur et sans reproche.

Beside Messenger and Bellfounder must be placed Justin Morgan as a most illustrious ancestor of trotting horses, and here again the value of thoroughbred blood is shown, for there is little doubt his sire, True Briton, or, as he is sometimes called, Beautiful Bay, was thoroughbred, while his dam was said to be of the Wildair breed, and undoubtedly possessed a large share of good blood. Justin Morgan was foaled in Springfield, Massachusetts, in 1793, and was bought when two years old by the gentleman, Mr. Justin Morgan, after whom he was named. Though the horse himself and his immediate descendants in the first generation had no great speed, they had many admirable qualities which they have transmitted to their progeny, and their blood has been valuable for crossing with the other strains. It is through three sons of the old horse-Woodbury Morgan, foaled in 1816, Bulrush Morgan, and Sherman-that lineal descent can now be chiefly traced.

A renowned animal, with undoubted good blood in his veins, that appeared later upon the scene was old Black Pilot, the Canadian pacer, who introduced a hardy and invaluable strain and was a most impressive sire. He could pace a mile in 2.26 carrying 11 st. $11 \mathrm{lbs}$. on his back, although he was under 15 hands in height, and thus proved himself an admirable weight-carrier. He was purchased from a 
pedlar at New Orleans, about 1832, but was soon afterwards sold to Mr. Heinshon, of Louisville, Kentucky, where many of the best-bred saddle-horses of America were to be found, and in such he infused his own vigour and hardiness, a fortunate boon for the country in general. He not only produced fast performers himself, but was able to transmit the same power to his sons, who have been noted sires, such as Pilot Junior, Tom Crowder, Ole Bull, and numerous others.

A great-great-grandson of Messenger, destined to become one of the most famous of the foundation sires, was Mambrino Chief, bred by Mr. Richard Eldridge, of New York, in 1844. Although he but sired six sons and daughters able to trot in 2.30 , or under, his descendants able to do so are almost countless, while the famous Lady Thorn alone, who trotted 106 heats inside the standard, was sufficient to make the reputation of any stallion.

The earliest trotting races were usually under the saddle, for, roads being primitive, riding was more general than driving, while the race-tracks were far from being in the state of perfection they are to-day. The wagons in use, too, were very different to the pneumatic-tyred, ball-bearing sulkies now in use, and it was difficult then to find an animal capable of trotting in harness a mile in three minutes, the first authentic record of such a performance being that of the black gelding Boston Blue, at Jamaica, New York, in 1818. By degrees, as the tracks and wagons improved, so also did the time records, though but slowly, and it was not till 1845 that the modern standard time was reached, when Lady Suffolk trotted the mile in $2.29 \frac{1}{2}$ on the Beacon Course, at Hoboken, New Jersey. Four years afterwards, on July 2, 1849, she reached 2.28, at Centreville, Long Island, a performance that had already been attained by a bay gelding, Pelham. Flora Temple first got inside 2.20, her record being 2.193, in 1859, at Kalamazoo, Michigan, and then Jay-eye-see reached 2.10 in 1884. Finally Lou Dillon, with the help of a pace-maker with a dirt-shield in front of her, trotted in 1.58 $\frac{1}{2}$, at Memphis, October 24, 1903. The bicycle sulky came into use in 1882, and Maud S. still 
holds the record for a high wheel on an oval track, when she trotted in $2.08 \frac{3}{4}$, at Cleveland, in 1885 . On a kite track the bay mare Sunol beat the record of Maud S. by half a second, trotting at Stockton in $2.08 \frac{1}{4}$, in 1891 , but the one long turn of such a configuration had a great advantage in point of speed over the ordinary track with two turns. Kite tracks were not popular with the spectators and soon went out of use.

It is estimated that a bicycle sulky is five seconds faster for a mile than the old high wheel. When comparing the respective merits of present horses with those of an earlier date these conditions, and also the constant improvement of the tracks, must be borne in mind, as they are all to the disadvantage of the older horses. The art of balancing horses by shoeing has been also brought to greater perfection. Smuggler used to trot at first with shoes weighing $32 \mathrm{oz}$. on each fore-foot, which were afterwards reduced to $25 \mathrm{oz}$, and when trotting a great race against Goldsmith Maid, at Cleveland, July 27, 1876, he had the misfortune to cast one of his shoes more than a quarter mile from home, which must have caused him much loss of balance. Even then he was only beaten by a length, Goldsmith Maid winning the race in $2.15 \frac{1}{2}$. It is a remarkable fact in connection with this celebrated mare, who was the first to reach 2.17 , that she was seventeen years of age when she made her best record, 2.14, at Mystic Park, Boston, on September 2, 1874. Such shoes as were deemed necessary for Smuggler are, however, very exceptional burthens, and when Lou Dillon made the record for wagon 2.0 at Readville, Massachusetts, in 1903 , she wore $4 \frac{1}{2} \mathrm{oz}$. shoes on her fore-feet and only $2 \frac{3}{4} \mathrm{oz}$. shoes behind.

Lou Dillon was foaled in 1898 , and so was five years old when she made her great record, 1.58 $\frac{1}{2}$, at Memphis, October 24, 1903, driven by Millard Sanders. Her great rival, Major Delmar, a gelding, also made his record the same year, trotting at Memphis in 1.59 under the guidance of E. E. Smathers, but he had the help of a pace-maker in front with a dirt-shield. The record for stallions is held by Cresceus, who, driven by his owner and 
breeder, Mr. G. H. Ketcham, of Toledo, trotted as a seven-

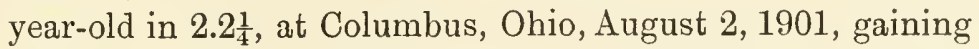
thereby the then record of the world, and placing his owner on the highest pinnacle of fame as combining in his own person the owner, breeder, and driver of the champion.

It is noteworthy that these three record-holders all trace back in tail male to Hambletonian, and so from Messenger, and, with many other famous names in their pedigrees, afford convincing proof of the rewards to be gained by careful selection in breeding, and the truth of the old proverb that "like begets like."

There is need, however, to guard against too close inbreeding to any animal, however illustrious, though such method is frequently unavoidable at the beginning, when there are few distinguished sires at the disposal of breeders; but, while it fixes a type and also often produces exceptionally brilliant individuals, it is yet apt to sacrifice sterling qualities, and result in the decadence of a race, by occasioning weak constitutions and nervous, excitable temperaments. Such has to a large extent been frequently the portion of breeders of British race-horses, carried away by the glamour of a great name. In a critical examination of the pedigree of Lou Dillon it will be seen how frequently the lines run back to Hambletonian, though in her case there has been safety in the extreme out-crosses of her two grandams, Venus and Fly. Others who seek to follow on the same lines may, perhaps, be less careful, and be disappointed in their expectations, through breeding in too closely to one famous animal. It is a principle that requires the utmost care to bring to a successful issue, so as to carry on the excellence through successive generations. 


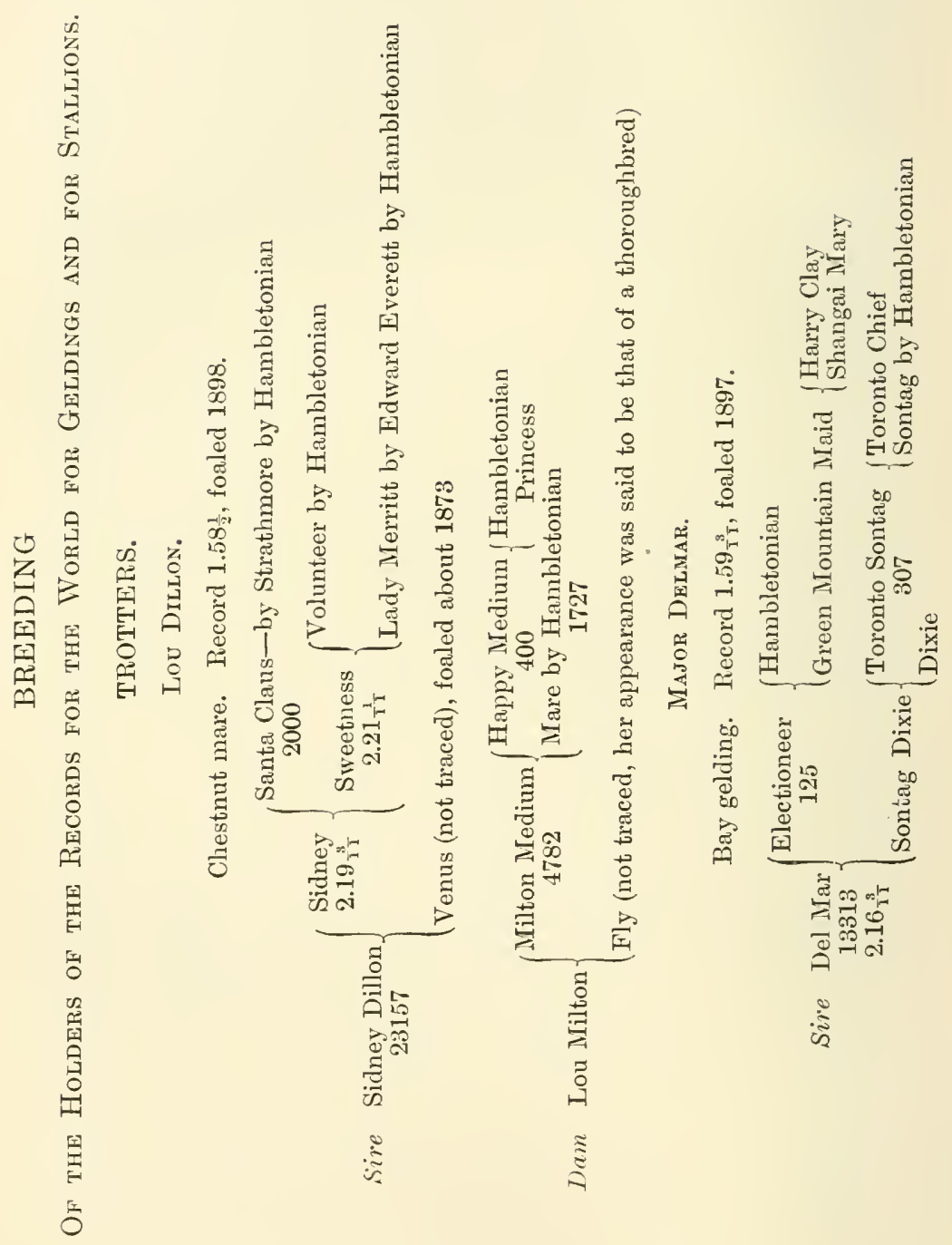




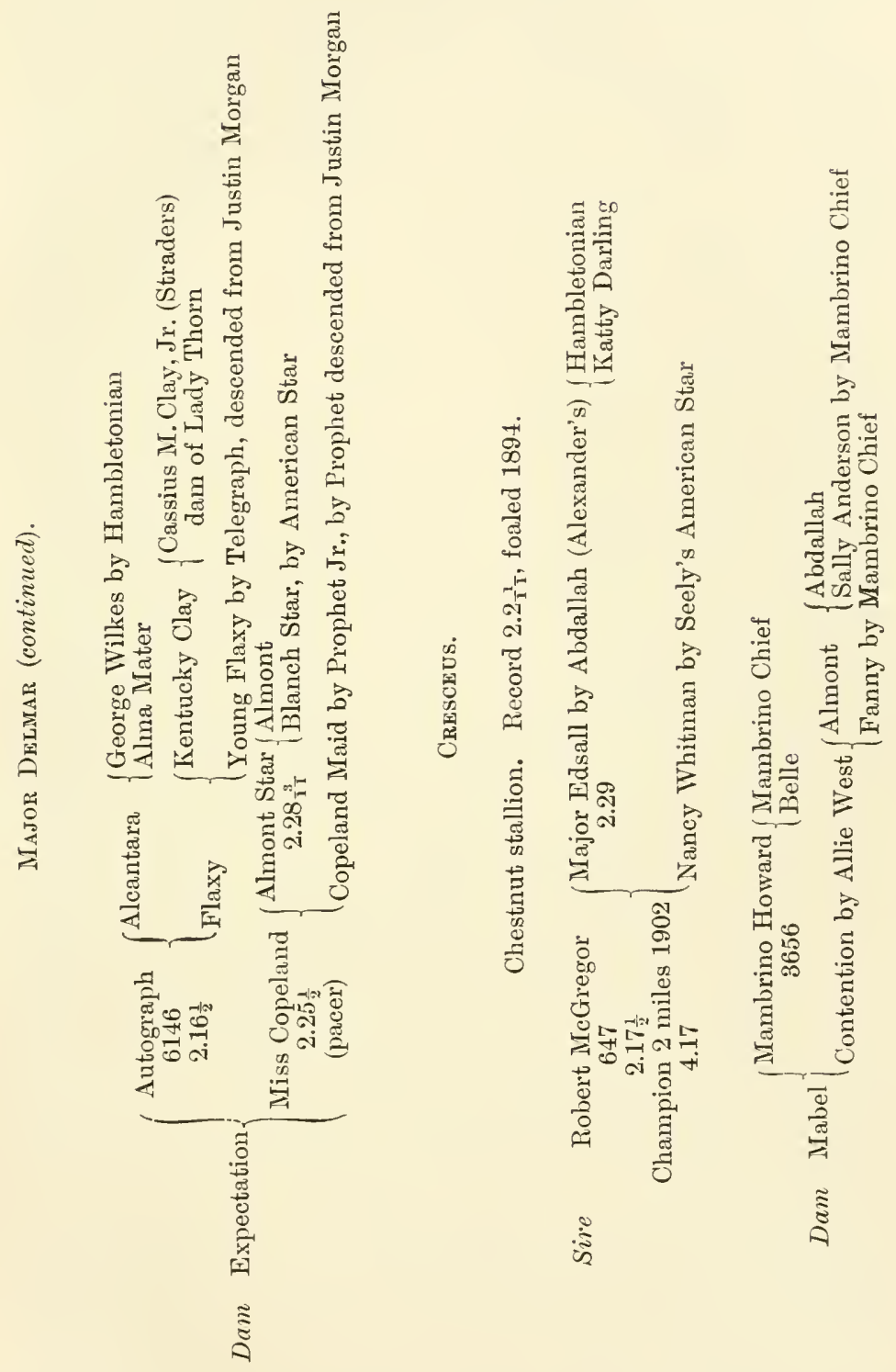


When compiling the American Trotting Register, Mr. J. H. Wallace wrote these interesting remarks, vol. i., 1871:-

"Is there a particular breed that trots?-Elaborate opinions have been given to the world from time to time, holding substantially that the English race-horse was as good a trotter as could be produced if trained to that gait.... However much may have been written, and however finely spun the theories that the true way is to go indiscriminately into thoroughbred families, no sane man will attach a particle of value to them till it has shown that such breeding has produced trotters. While the trotting gait is partly the result of education and training, there is no fact in the experience of at least a generation more clearly and fully established than that there must be a natural tendency to trot, or all efforts to make a trotter by training will signally fail. I do not wish to be understood as opening a crusade against the thoroughbred horse for the experience of two hundred years has shown him on the course, in the chase, on the march, and in the battle-charge to be vastly superior to all others, and when we get to the best trotting horse the world will produce, he must have the courage, the will, the speed and the endurance of the four-mile thoroughbred; which qualities he can only obtain by partaking largely of his blood.

"But notwithstanding the fallacy of the indiscriminate use of the thoroughbred to produce trotters, we are indebted to the thoroughbred after all for the trotter; but this debt is substantially limited to a single family of thoroughbreds or the descendants of one single horse 'Sampson' bred by Mr. Preston 1745, and trained by Robinson of Malton, from whom Mambrino was descended. Rysdyk's Hambletonian and Mambrino Chief were a fourth remove from the English Mambrino. It is true Rysdyk's Hambletonian is in a manner inbred to Messenger, and can thus trace to Mambrino through some different lines; but Mambrino Chief has but a single line."

Since these remarks were penned the value of thoroughbred blood in the trotting horse has been constantly emphasised, and so imbued is Mr. Walter Winans-whose 
successes at the International Horse Shows have been so great-with this fact that he has gone to the very highest source, and bred from a winner of the Derby, in confident hope of still further improving the type of trotter. The result of the alliance of the standard-bred Chiquito (by Almonarch 3234 out of Corona), with Common (by Isonomy out of Thistle), has been Gosudar, whose good looks are worthy of his distinguished parentage, and who should have a great future before him. With regard to Mr. Wallace's remarks it should be kept in mind that discrimination must be used in selecting thoroughbred horses to cross on trotting mares, for many families of race-horses have neither the aptitude nor the inclination for this gait, and it is only courting failure to resort to these. When wisely selected the magnificent qualities referred to by Mr. Wallace are of inestimable value to any breed for whatever purpose it may be required.*

The first volume of Wallace's Trotting Register was issued in 1871, and The National Association of Trotting Horse Breeders was formed in 1876. A rival Stud Book arose in 1881, under the editorship of J. H. Sanders, The Breeders Trotting Stud Book. The American Trotting Register Association eventually bought up the older interests of Mr. Wallace, The National Association of Trotting Horse Breeders passed away, and The Breeders Trotting Stud Book was also amalganiated in a more comprehensive scheme.

In 1870 began the nucleus of the National Trotting Association, and in 1887 the American Trotting Association sprang up, which two bodies now control the sport and race under the same rules, while the American Trotting

* This principle was well kept in mind by Mr. Winans when choosing a mate for Chiquito, for he mentions in a letter, July 12, 1909: "The reason I bred Chiquito to Common was because the late Sir Blundell Maple kindly let me send the mare to Common, as he said, "Common is a very fast trotter, and inclined to continue trotting when urged to go faster, instead of at once breaking into a canter like most thorough. breds." With such a foundation to build upon, the fruit of that union may prove to have a very far-reaching effect in the trotting world in years to come. 
R $\lrcorner$ gister Association watches over all other matters, closely in touch with the two other organisations. Its Rules for the Trotting Standard are now as follows :-

\section{The Trotting Standard.}

When an animal meets these requirements, and is duly registered it shall be accepted as a standard-bred trotter.

1. The progeny of a registered standard trotting horse and a registered standard trotting mare.

2. A stallion sired by a registered standard trotting horse, provided his dam and grandam were sired by registered standard trotting horses, and he himself has a trotting record of 2.30, and is the sire of three trotters with records of 2.30 from different mares.

3. A mare whose sire is a registered standard trotting horse, and whose dam and grandam were sired by registered standard trotting horses, provided she herself has a trotting record of 2.30 , or is the dam of one trotter with a record of 2.30 .

4. A mare sired by a registered standard trotting horse, provided she is the dam of two trotters with records of 2.30 .

5. A mare sired by a registered standard trotting horse, provided her first, second, and third dams are each sired by a registered standard trotting horse.

\section{American Pacing Horses.}

The origin of American pacing horses is wrapped in obscurity, though, as mentioned earlier in this work, it is a common gait amongst the Barb horses of Morocco, through whose influence it is occasionally seen amongst Spanish horses. It is by no means uncommon in England, though it is not prized there, and no pains are ever taken to develop it. The famous family of pacers in Rhode Island, the Narragansetts, are supposed to have originated from stock brought from Andalusia, and it is very probable such may have been the case, and that they inherited the gait from their Barbary ancestors. At first the pacing horse was generally used under the saddle, but as roads improved they began to be sought for harness; for many 


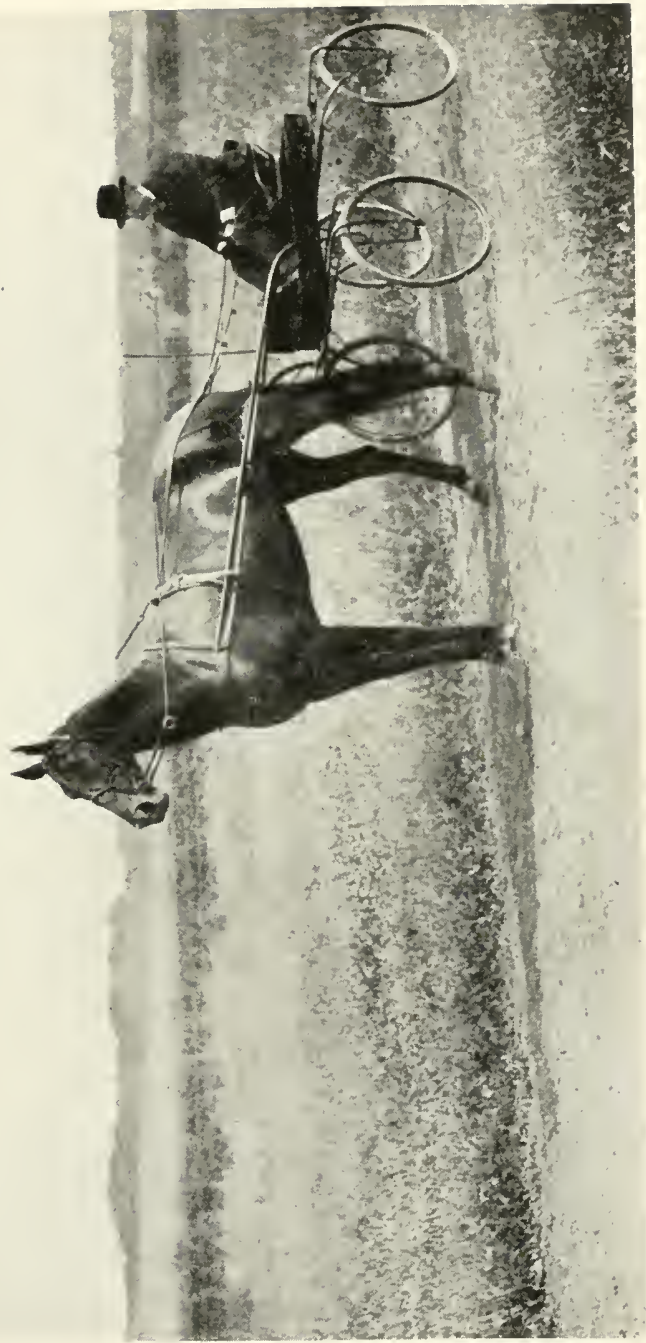

1. 

years, however, owners and trainers did not care to race them at their natural gait, and sought instead, by the use of toe-weights, hobbles, and other appliances, to convert them into trotters, a conspicuous example of which was Smuggler. Even when the chestnut mare, Pocahontas, had paced a mile in $2.17 \frac{1}{2}$ at Long Island in 1855, at a time when the trotting record was but 2.27, achieved by Highland Maid, trainers were not converted, and made little attempt to train their animals to a gait which was unfashionable. Many of the greatest sires, however, have produced both pacers as well as trotters, and with more valuable prizes offered for competition the list of fast pacers has grown. The present record-holders are Dan Patch, 1.55 $\frac{1}{4}$, who holds the record for stallions, Prince Alert that for geld-

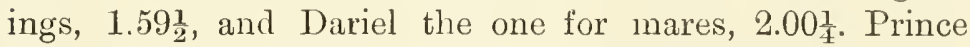
Alert is now in England, and in a letter, June 25, 1909, Mr. Walter Winans mentions: "My brother, Louis Winans owns Prince Alert, and drives him at Brighton every day."

Sentiment has been the main factor in the marvellous evolution of the American trotting and pacing horse, and the enthusiasm thus engendered has encouraged the straining of every nerve to possess an animal capable not only of defeating great rivals on the track, but also of acomplishing the still harder task of beating the common enemy, Time itself. As each record has been broken a thrill has permeated thousands of eager watchers in a fashion unknown to dwellers in more matter-of-fact Europe, and thus the magic names of Flora Temple and Dexter, Goldsmith Maid, George Wilkes, Jay-Eye-See, Maud S, Sunol, Nancy Hanks, and others have, in turn, swayed the passions of the nation, and been household words, as they flitted their hour upon the stage, in a way that the mere winning even large money prizes would have failed to effect. Whether any further development of actual speed is practicable it is impossible to forecast, but America may well be proud of having established such a remarkable breed of horses, which must have a far-reaching influence upon all their harnesshorses in general use, and is therefore of the greatest national importance. 


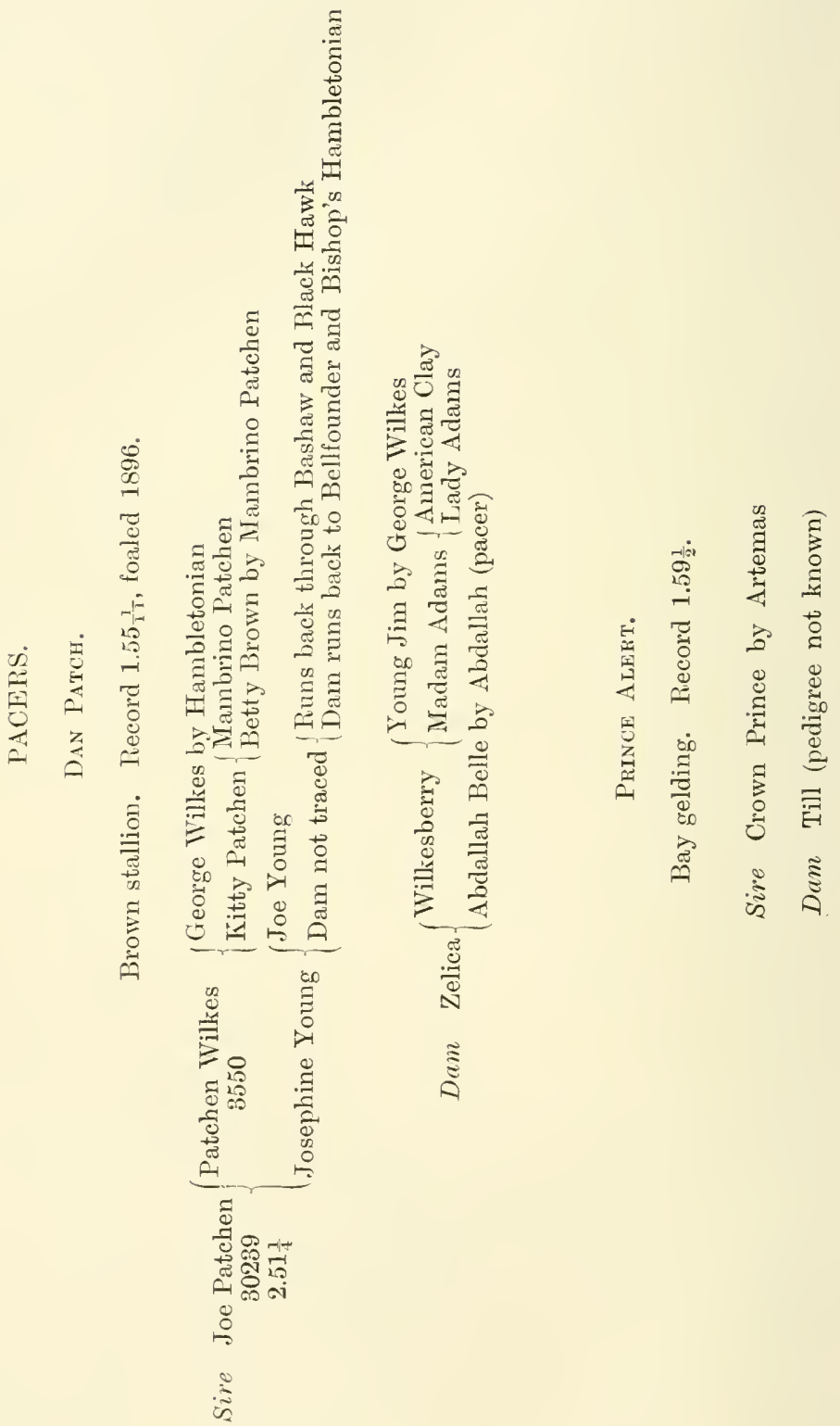


ORIGIN OF AMERICAN TROTTING HORSES 151

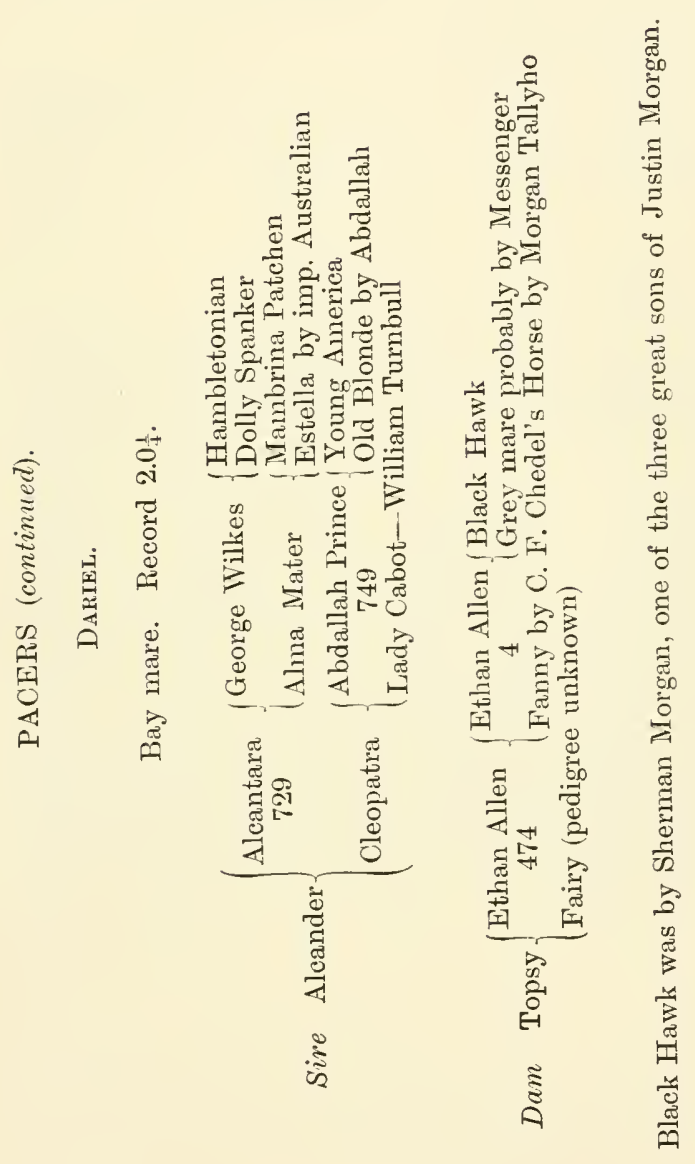


Subjoined are the Rules for the registration of pacers :-

\section{The Pacing Standard.}

When an animal meets these requirements and is duly registered, it shall be accepted as a standard-bred pacer.

1. The progeny of a registered standard pacing horse and a registered standard pacing mare.

2. A stallion sired by a registered pacing horse, provided his dam and grandam were sired by registered standard pacing horses, and he himself has a pacing record of 2.25, and is the sire of three pacers with records of 2.25 from different mares.

3. A mare whose sire is a registered standard pacing horse, and whose dam and grandam were sired by registered standard pacing horses, provided she herself has a pacing record of 2.25 , or is the dam of one pacer with a record of 2.25 .

4. A mare sired by a registered standard pacing horse, provided she is the dam of two pacers with a record of 2.25 .

5. A mare sired by a registered standard pacing horse, provided her first, second, and third dams are each sired by a registered standard pacing horse.

6. The progeny of a registered standard trotting horse out of a registered standard pacing mare, or of a registered standard pacing horse out of a registered standard trotting mare. 
T $\mathrm{N}$ considering the conformation of the horse, before dealing 1 with the external characteristics-the muscles and general appearance-attention inust be paid to the skeleton, the framework to which the muscles are attached, and on which the body is built up. Bone consists of phosphate and carbonate of lime in the proportion of 56 of the former, to 13 of the latter, the remainder being a kind of gelatine. These proportions differ somewhat in old and young animals, the latter having a larger proportion of gelatine, about one-half, whilst in older animals it does not amount to more than one-third. The series of bones composing the skeleton may be divided into two groups, the one comprehending those of the trunk, and the other those of the limbs.

In the first group are the-

Head, or Cranium.

Neck, or Cervical vertebræ.

Back, or Dorsal vertebræ (these are the only ones bearing the Ribs. ribs).

Loins, or Lumbar vertebre (between those bearing the ribs and the haunch-bones).

The Croup, or Sacral vertebræ (also termed the pelvic arch).

The Dock or Tail, or Caudal vertebræ.

Breastbone, or Sternum.

Haunch, or Pelvis. 
In the second group are:-

PLATE II.

Bones of the Fore-leg.

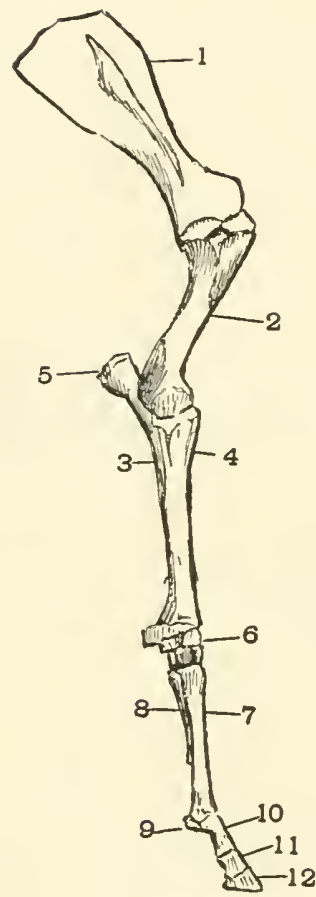

FIG. 1.

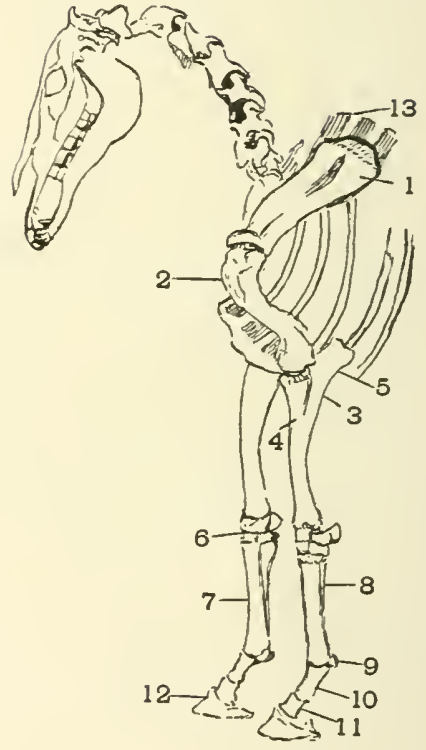

FIG. 2.

1 Shoulder-blade, or Scapula.

2 Lower bone of the shoulder, or Humerus.

3, 4 Arm, or Ulna and Radius.

5 Elbow, or Point of Ulna.

6 Kinee, or Carpus.

7, 8 Cannon-bones and Splint-bones, or Metacarpals.

9 Sesamoids (behind the fetlock).

10, 11 Upper and Lower Pasterns.

12 Coffin-bone.

Navicular-bone (not shown).

13 Withers. 
The bones of the Hind-leg are as follows:-

PLATE III.

Bones of the Hind-leg.

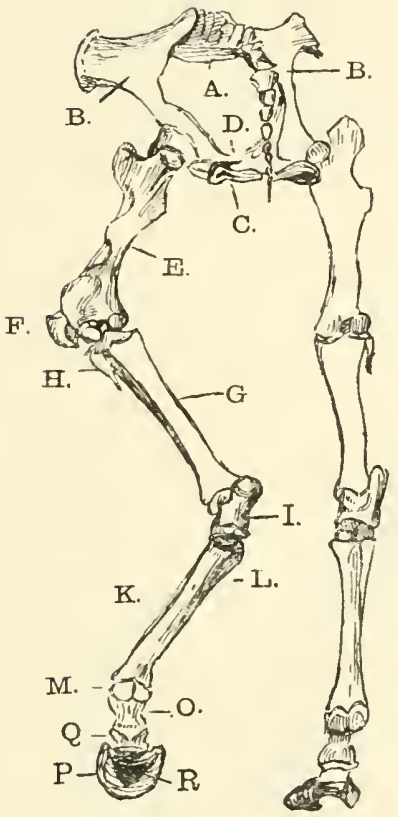

FIG. 1.

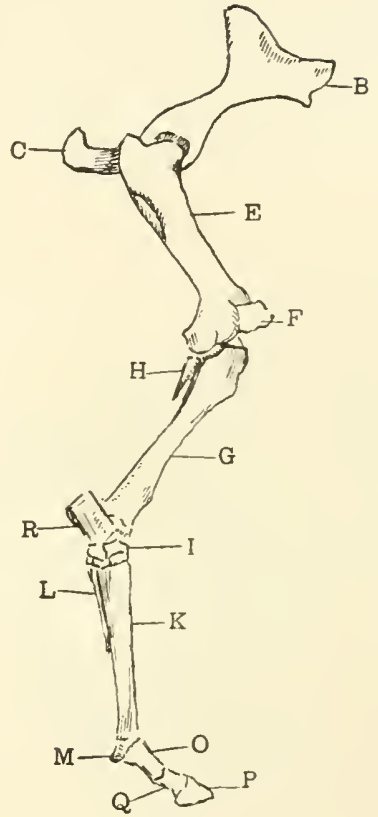

FIG. 2.

E True thigh, or Femur (This bone is so hidden under the mass of muscle, the ordinary horseman scarcely knows of its existence).

F Stifle joint, or Junction of the Femur and Tibia, in front of which is placed the knee-cap, or patella $(\mathrm{F})$.

G Thigh, or Tibia.

II Fibula.

I Hock, or Tarsus.

K Shank, or Metatarsus.

L. Splint.

M Sesamoids.

$\left.\begin{array}{l}\text { Q }\end{array}\right\}$ Upper and Lower Pasterns.

$\mathrm{P}$ Coffin bone.

$R$ Navicular bone. 
The bones of the skeleton may now be considered in detail, commencing with those of the head and neck.

At $(m)$ (Plate IV.) is an indentation where the artery passes over the lower jaw, and the pulse can be felt, and a tourniquet applied in an urgent case. At $(n)$ another small artery branches, and there also a tourniquet is often useful when a severe bleeding at the nose occurs.

They may be divided into two groups, those of the cranium and of the face. The cranial include all those

PI.ATE IV.

Head.

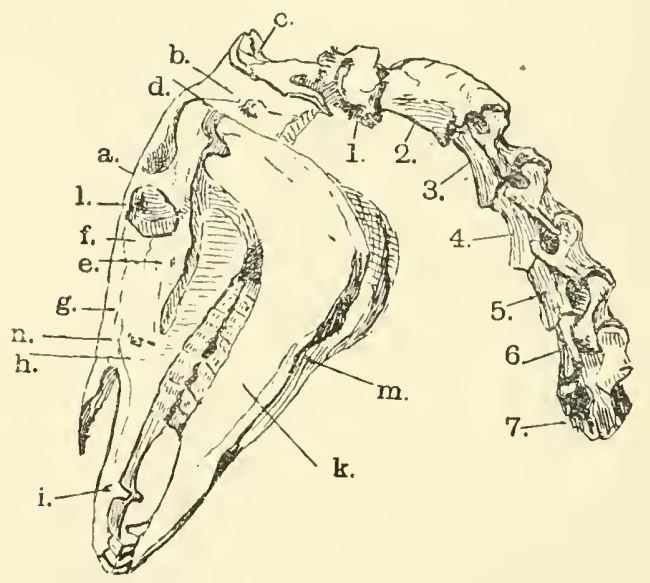

a Frontal.

$b$ Parietal.

c Occipital.

d Temporal.

$e$ Malar.

$f$ Lachrymal.

$g$ Nasal.

$h$ Superiormaxillary.

$i$ Pre-maxillary.

$k$ Inferior maxillaries, or lower jaw.

$l$ Orbit.

which enclose the brain, and though they are for the most part arranged in pairs, one on each side of the mesial line, it is more convenient to speak of them as single bones.

The frontal bone $(a)$ is the bone of the forehead, forming the broad flat surface between the eyes and extending towards the top of the head. This bone differs considerably in width, and is generally developed in the highest degree in the Arabian horse, being a mark of high breeding and superior intelligence.

The parietal $(b)$ extends backward from the frontal to the 
poll. It is mainly concerned in the protection of the brain, and has a ridge of great strength along the upper surface, from which the bone slopes down like a roof on each side.

Covering the entire back of the head, and immediately behind the parietal, comes the occipital (c), whose position exposes it to great strain, since it has to support the whole weight of the head, the back of which it covers. It is articulated to the first vertebra of the neck, the atlas, by two rounded protuberances, termed condyles, which lie at the base of the bone. It is either at the junction of this bone with the atlas, or at the junction of the atlas with the second vertebra, the dentata, that the Spanish bull-fighters give the death-stroke to the wretched maimed horses in the bull-ring; and the matador frequently despatches the bull. It is the usual method of killing employed by the butchers in Spain, and a merciful one, for death is instantaneous. The head must be drawn downwards, and the neck somewhat bent, thus separating the vertebræ to the utmost, when a sharp thrust transfixes the spinal cord, and the animal often dies without a struggle. On the outer sides of the occipital are two pointed projections for the attachment of some of the muscles of the neck which assist in supporting the head. They are termed styliform processes.

The temporal bone $(d)$ contains the internal parts of the ear, has a depression or hollow underneath for the articulation of the lower jaw, and forms the greater part of the orbit by joining with the extremity of the frontal bone, and also with the malar, or cheek-bone, thus forming the "zygomatic arch." The orbit is completed by the lachrymal $(f)$, a small facial bone at the inner corner of the eye. Above the temporal bone unites with the parietal, and behind with the occipital.

Immediately below the frontal is the nasal bone $(g)$, covering the delicate membranes of the nose, and one of the principal bones of the face. The superior maxillary $(h)$ is a large bone occupying the side of the face, and carrying the molar teeth, or grinders, and the tusk of the upper jaw. The nippers, or incisor teeth, are inserted in the pre- 
maxillary (i), which, uniting with the nasal bone and the pre-maxillary, completes the framework of the nose. The lower jaw consists of only two bones, the inferior maxillaries, which are rounded at the hinder extremity of the jaw, and terminate in two processes directed upwards. One, the condyloid process, articulating with the temporal bone, forms the hinge on which the whole lower jaw moves. The other, the coronoid, passes under the zygomatic arch, and receives the lower end of the large temporal muscle, which arises from the parietal bone and is principally concerned in moving the jaw when masticating food.

There are two small bones not visible externally, the sphenoid and ethmoid, under the parietal in the lower part of the cranium, which serve to connect the principal kones of the skull.

\section{The Vertebra.}

The vertebræ of the neck are seven in number, and comprise (Plate IV.)-
1. Atlas
2. Dentata
3. Third
4. Fourth
Cervical vertebræ.
5. Fifth
6. Sixth
7. Seventh

The atlas is a ring-shaped bone, articulating with the skull. It moves freely on the dentata, and on the peculiar articulation of these two vertebræ largely depends the power of turning the head. The remaining five bones, resembling one another, call for no comment. They have various processes to which the muscles and ligaments of the neck are attached.

The dorsal vertebræ, those of the back, are eighteen in number, and support the ribs; whilst those of the loins, the lumbar, which are situated between the ribs and the haunchbones, are six, the whole amounting to twenty-four, which are invariable. The normal number of ribs is eighteen, though sometimes nineteen occur, and occasionally even 
twenty, but in no case is there any increase in the number of vertebræ, so that if there is any excess of ribs the vertebræ supporting them are taken from the lumbar group and added to the dorsal series. 'Thin discs of cartilage are placed between each to serve as buffers, and the spinal cord traverses the whole through a canal in each segment. When an unfortunate accident occurs and a poor horse's back is broken, it is often the case that a vertebra is only cracked across, interfering with the spinal cord. This frequently happens when the animal is taking-off at a jump, the muscles, for some reason, making an extra effort to that which had been foreseen and telegraphed from the brain along the nerves; and the system therefore being unprepared for the unexpected exertion, the unlooked-for force of the muscles snaps the vertebra. It may be only a small place which causes the mishap. A tiny ditch will do it if its presence has been concealed, and the horse is galloping at a great pace. To a certain extent it resembles the jar when missing a step on going downstairs in the dark, and we have most of us experienced that unpleasant feeling. In this case we are going, literally, at a foot's pace, and there is no great momentum to add to the mishap, otherwise much greater injury would result than usually ensues.

The sacral vertebræ, which form the croup, are anchylosed, that is, are united together in one mass, and form a kind of wedge to the arch, formed by the approximation of the haunch-bones. They are five in number. The pelvic arch, as the united bones of the arch are termed, needs to be very strong and solid, for it is the pivot on which the hind limbs turn, and throw forward the whole weight of the animal.

The caudal vertebræ are usually fifteen in number, but often vary to the extent of two or three above or below the normal; and horsemen are well acquainted with the fact that there are short and long docks in Nature, without recourse to the veterinary surgeon's amputating knife. In these the spinal cord ends as a thread, and there is not much danger in docking a horse, though tetanus (lockjaw) occasionally follows. Still it is always impolitic to interfere with 
Nature's arrangements, if it can be helped, especially with regard to such delicate parts of the machinery as the spinal cord and the nervous system ; and to amputate the tail very short is certainly nearly approaching a possible peril.

The chief feature in each dorsal vertebra is the spinous process, or projection, along its upper surface, especially in the region of the shoulders, where is produced the elevation known as the withers. These are of considerable importance, as they afford a large surface for the attachment of the great ligament which supports the head and neck. There is no advantage, however, in their being excessively developed, for then the withers are apt to be thin and "knifey," and so become an indication of weakness, which is undesirable.

To recapitulate the number of each series of vertebræ there are-

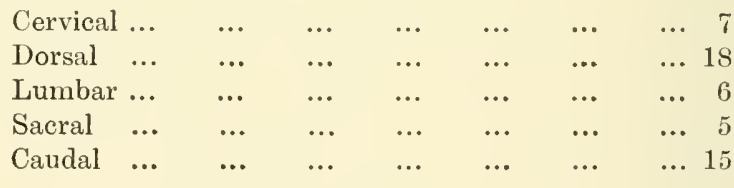

$$
\begin{aligned}
& \begin{array}{lllll}
\text { Total } & \ldots & \ldots & \ldots & 51
\end{array}
\end{aligned}
$$

The ribs are eighteen in number, and are distinguished as the true and the false ribs, the former being attached to the breast-bone at their extremities, and the latter having no immediate connection with it. The true ribs are either seven or eight, for the number sometimes varies, and to provide for the necessary elasticity the attachment to the breast-bone is composed of cartilage. All the ribs are jointed above to the transverse processes of the vertebræ. Though the individual false ribs have no direct connection with the breast-bone, they are united together by cartilages, and this cartilaginous union eventually terminates in the sternum, so that the whole of the ribs are able to act in unison when expanding and contracting. The sternum itself consists of six bones in the young horse, which gradually become united into a single piece. 
The Pelvis, or haunch, is in reality made up of six bones, three on each side, the whole united firmly into one. These are (Plate III.) -

B The Ilium.

C The Ischium.

D The Pubis.

The Ilium is strongly secured to the sacral vertebræ, which form the keystone of the pelvic arch, and has a very large, and often very conspicuous, prominence on each side, just above and in front of the hind-quarters, which stablemen recognise as the hips. When these are abnormally developed the horse is said to be "ragged hipped," and when the head of a prominence is broken off, as not infrequently happens through striking a sidepost when entering a stable, the animal is said to have a "hip down." As a portion of an important muscle, the glutœus medius, is attached to this prominence, an injury to the bone means a considerable reduction in the power of the muscle, and therefore in the capabilities of the horse.

The Ischium is the true hip-bone, and is a backward continuation of the ilium. It terminates in two prominences, which project on each side a little below the tail, and, though well covered with flesh, are easily recognised.

The Pubis is connected with the above, and forms the completion of the pelvic arch.

We now turn to the bones of the second group, and, commencing with the fore-limbs, note that the shoulderblade, or scapula (Fig. 1, Plate II.), consists of a single bone, of a long triangular form, and is divided into two portions by a ridge running nearly the length of the blade. This ridge of bone gives additional firmness to the shoulder-blade, and affords a surface for the attachment of some very important muscles. The object of the shoulder-blade is to connect the fore-leg with the trunk, just as the haunch-bone performs a similar office for the hind-leg; but there is this difference between the two; the shoulder-blade has only a muscular attachment to the trunk, while the haunch-bones are firmly united 
to the sacral portion of the backbone. A little consideration will show an important reason for this difference. The weight of the horse has to be sustained by the shoulder, and, especially when landing over a fence, a jar would be given to the spine, and possibly injury might be inflicted on the contents of the chest and the viscera if the shoulder was affixed to the spine by an unyielding attachment. The hind-legs, however, require, on the contrary, a very firm point, to use for their powerful leverage, and so by a skilful arrangement each is provided with what it needs.

At the lower extremity of the shoulder-blade is a cupshaped hollow, the glenoid cavity, with which the rounded head of the humerus, the lower bone of the shoulder, articulates. This humerus is so hidden by muscle as not to be visible externally as a distinct bone. It is short and strong, at almost right angles with the shoulder-blade, and its direction is backwards, and terminates in two heads, between which the upper end of the radius, or arm-bone, is received. The insertion of the humerus between the shoulder-blade and the forearm in such a manner that two angles are formed, makes splendid provision for minimising a shock, by the free bending of both joints. On the backward sloping of the shoulderblade greatly depends the freedom of the motion of the fore limb, and the consequent length of stride and ability to recover from the effect of a stumble, either in ordinary paces or when leaping; and it is the correct adjustment of the upper and lower shoulder-bones which ensures true action in walking and trotting, the elbow neither being turned out too much nor pinned in. When seated on the animal the working of the upper part of the shoulder-blade should not be visible under the skin if the bone is correctly laid, and such being the case affords an excellent indication of a good shoulder. With this the height of the withers has nothing to do, for that depends, as shown above, entirely on the development of the upper processes of the anterior portion of the dorsal vertebræ. Beginners are too apt to have a confused notion that a 
high wither (Fig. 13, Plate III., Fig. 2) must mean a good shoulder.

The upper portion of the fore-leg, the radius, commonly called the arm, which joins the lower bone of the shoulder, is composed of two bones, a long one in front termed the radius, which reaches to the knee, and a short one behind called the ulna. In old horses these two bones become firmly united into one. The ulna has a long projection above and behind the upper joint, and forms the point of

\section{PLATE V.}

The Bones of the Knee.

a Padius.

$b$ Trapezium, or pisiforme.

c Cuneiforme.

$d$ Lunare.

$e$ Scaphoides.

$f$ Trapezoides.

$g$ Magnum.

$h$ Unciforme.

$k$ Cannon-bone.

$j, l$ Splint-bones.

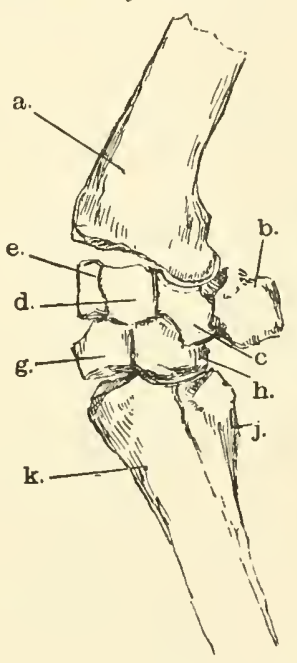

FIG. 2.

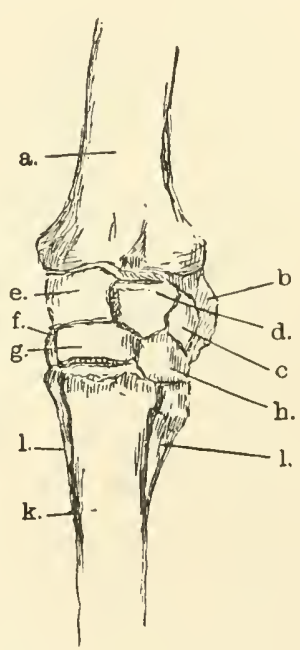

FIG. 1.

the elbow, to which some powerful muscles are attached for extending the forearm. The ulna rapidly diminishes size, and terminates in a point before reaching the knee, behind the middle of the radius.

The knee, the carpus, is composed of six small bones, and is therefore a very complicated joint, and exposed to many shocks and jars, but it is arranged so that these shall be distributed over a number of bones, each protected by a covering of cartilage, resting on a kind of semi-fluid cushion, and all united together by ligaments. 
These are interposed between the lower end of the radius $(a)$ and the upper part of the cannon-bone $(k)$ and the splint-bones $(j, l)$, six being placed in front, and the seventh, the trapezium, behind. It will be seen on examining Fig. 2, Plate V., that when the knee is bent there would be a very large opening between the radius and the cannon-bone were it not for the interpolation of the six small bones, which reduces the wide opening to three narrow ones; these are, moreover, well protected with a capsular ligament, extending from the radius to the shankbone, and therefore danger to the joint is very largely minimised by this ingenious arrangement.

The Cannon, or shank-bone $(k)$, and the Splint bones $(j, l)$, which have just been mentioned, form the leg-bone, and are termed the metacarpals, and all three articulate with the lower row of the bones of the knee. The two splintbones are situated behind, and a little on one side of the cannon-bone, and are probably the relics of the early period in the history of the horse when it possessed three toes. An interesting example of reversion to the primitive type was that of a mare which was racing in 1822-23, and ran in nine races, two of which she won. She was first named Pincushion, which was afterwards changed to Creeping Jenny. She suddenly commenced to throw out a new set of limbs, which began half-way below the hocks, on the hind legs, and from just above the fetlock on the near fore-leg. The cannon-bone is very subject to throwing out nodules of bone, especially in young horses, though old horses are also subject to this annoyance, and the writer has had cases when animals of fourteen and sixteen years have thrown them out, who had never previously suffered from them. These are termed splints, and frequently become absorbed, and disappear as age creeps on. During their formation they are very painful, and make the animal lame, which is chiefly due to their stretching the periosteum, a membrane that covers the bones very closely, and is inelastic, and also to the inflammation inseparable from the growth of the exostosis. The splint-bones, which have nothing to do with the 
above-mentioned splints, do not extend the whole length of the cannon-bone, but diminish to a point before reaching the fetlock. The cannon-bone articulates at its lower extremity with the upper pastern (Plate VI., o), and together they form the fetlock-joint $(n)$; and at the back of it are situated two small supplementary bones, termed sessamoids $(m)$, which serve to protect the joint, and also some important ligaments which pass over it.

PLATE VI.

Bones connected with the Foot.

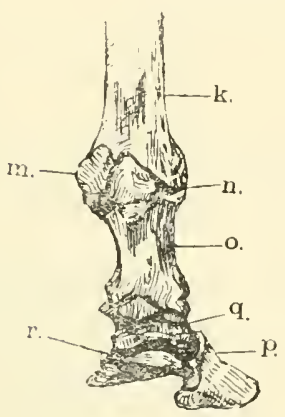

FIG. 1.

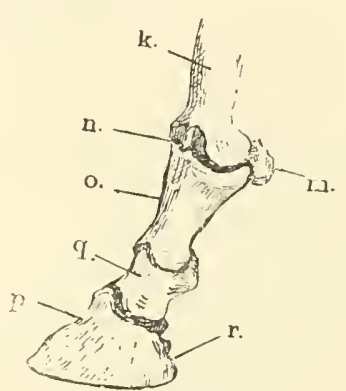

FIG. 2.

$k$ Cannon, or Shank.

$m$ Sesamoids.

$n$ Fetlock-joint.

o Upper pastern.

$p$ Coffin-bone.

$q$ Lower pastern.

$r$ Navicular-bone.

The toe is formed by the coffin-bone $(p)$, which is so surrounded by the horny covering of the hoof that it is never visible externally. Another little bone entirely hidden in a like manner is the navicular-bone $(r)$, which lies behind and partly within the junction of the lower pastern and coffin-bone. A very important tendon passes over it, previous to being attached to the coffin-bone, and an injury to the tendon not infrequently affects the navicular-bone also from the accompanying inflammation. Immediately below the navicular-bone is situated the sensible portion of the frog, which again is protected by the horny frog. 
The bones composing the haunch, or hind-quarters, have already been mentioned, and together with those of the hind-leg may be recapitulated (Plate III.) :-

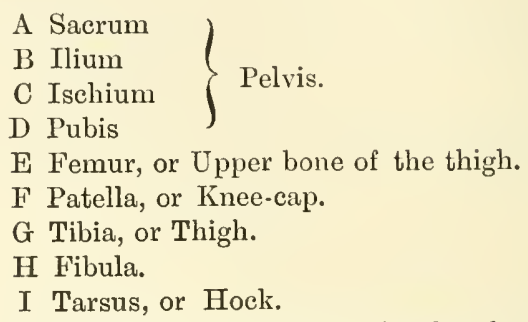

K L Metatarsus, or Shank and Splint-bones.

MI Sesamoids.

while the upper and lower pasterns, $(o)$ and $(q)$ the coffinbone $(\mathrm{P})$, and the navicular-bone $(\mathrm{R})$, resemble those of the fore-limbs.

Beginning at the upper extremity of the hind-leg, the first bone to be noticed is the femur, or true thigh, or, as it is usually termed, the upper bone of the thigh. It is entirely hidden by the various muscles of the haunch, and is therefore not easily recognised. It is short, but exceedingly strong and stout, and at the upper extremity has a distinctly rounded head on the inner side, fitting into and articulating with the acetabulum, or bony cup formed at the junction of the three pelvic bones. The lower end of the bone has two prominences which fit into corresponding depressions in the next bone, and in front of which is placed the patella, or knee-cap (F), which together form the stiflejoint. The tibia, the bone of which is known as the second thigh, extends from the stifle-joint, which it helps to form, to the hock, or tarsus; and placed behind on the outer side is the fibula, extending from its upper extremity to about one-third of its length, and attached to the larger bone by cartilage. In general character it agrees with the ulna, or small bone of the elbow, in the fore-leg.

The hock (tarsus) is an important and complicated joint, and from its nature is frequently the seat of injury, especially from shock or of strain. Like the knee, it consists 
of several small bones interposed between the long bones of the lower part of the limb, and these are six in number and of various shapes.

From an inspection of the view presented by the hock, it will be at once seen how important it is all the bones composing it should be very well developed, and a large "bony" hock be much desired. The point of the hock acts as a lever to straighten the leg, and is moved by the tendon Achilles and other tendons, arising from the muscles which

PLATE VII.

The Bones of the Hock.

G Tibia.

$\mathrm{J}$ Outer Cuneiforme.

I Cannon, or Shank.

L Splint.

N Naviculare.

P Middle Cuneiforme.

$\mathrm{R}$ Os calcis, or Point of the Hock.

$\mathrm{S}$ Astragalus.

T Cuboides.

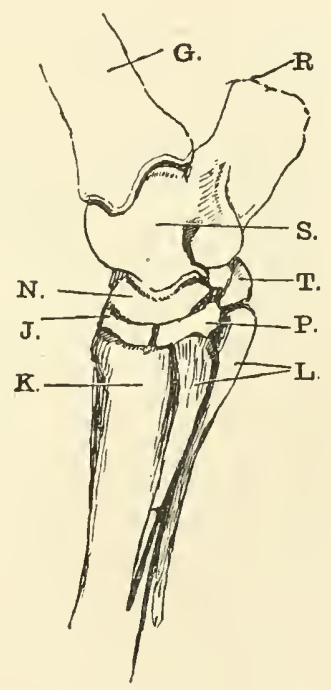

spring from the upper part of the limb. The flexor pedis $(q$, Plate IX.) one of the principal muscles for bending the foot, becomes tendinous before it reaches the hock, when it passes as a large round cord through a groove at the back of that joint, and after descending behind the shank-bone is inserted in the two pasterns. The ligaments that are attached to it are very apt to become strained, resulting in a " curb" (Plate IX.) about four inches below the point of the hock, and this is more especially the case when the head of the shankbone is weak, having, as it were, a piece cut away from the 
front of it, just below the outer cuneiforme bone. A horse with such malformation is ever likely to spring a curb.

Exostosis frequently occurs from inflammation of the hock, on the inside of the joint, and is termed a spavin. When this only occurs on the shank itself no real harm is done, for, like any form of splint, when once it has fully formed Nature gradually adapts herself to the altered conditions, and the lameness which occurred whilst the exostosis was forming gradually disappears. It is different, however, when the spavin is situated on the small bones of the hock (true spavin), for even if it does not anchylose the joint, the delicate machinery is interfered with, and stiffness in working is the inevitable result. Sometimes the small bones, the naviculare, and the cuneiforme bones, are extra developed, giving the impression to a casual observer that some exostosis has taken place; but the touch should at once dispel that idea, and also the fact that both hocks are exactly alike. Such are termed "rough" or "strong" hocks, and are really a source of strength, instead of being spavins.

\section{Flesh and Muscle.}

The bony framework having been disposed of, the next point of consideration must be its covering, that tissue of muscles we term flesh; but important as the muscles all are, it is not necessary for the ordinary horseman to take notice of more than a few, those chiefly concerned in locomotion, and these alone will now be considered. It is the due estimate of such which constitutes generally the difference between a good and a moderate judge of a horse's capabilities.

It will be patent to everyone that the head, which in itself is a great weight, as any one can test for himself by lifting one after it has been detached from the carcase in a knacker's yard, must require very powerful muscles to support it at the end of a long pole, such as the cervical vertebræ represent, and therefore the neck must be sufficiently strong. But the strength must lie in the proper muscles, or else the neck becomes too heavily clothed with flesh, some of which is not required and is a hindrance 
rather than a help to the animal. The late Charley Wise, of Eton, the eminent dealer in the "fifties" and "sixties" of the last century, than whom no better judge existed, was wont to point out that the neck was the first place where a horse began to tire; and he used to insist upon the muscles just behind the poll being very well developed (which can be particularly well observed when seated on the animal), but that when seen sideways the neck should appear light and elegant. Long subsequent experience has shown that he was very right, and it will be noticed on the Turf that no horse ever stays well in long-distance races unless he possesses such a conformation.

It may be mentioned, however, that independently of the muscles for supporting the head and neck, there is a simple arrangement by which these parts are kept in an easy and natural position when the animal is at rest. A strong and elastic ligament, the ligamentum nuchæ, arises from the back of the occipital bone (Plate IV., c) to which it is attached immediately behind the crest. In order to allow full freedom of motion to the head, it passes over the atlas (1), or first joint of the neck, in the form of a stout round cord, but is strongly adherent to the dentata (2), on which the principal strain from the weight of the head is thrown. It then proceeds backwards, terminating in the withers, the elevated spinous processes of the first dorsal vertebræ, which thus support the weight of the head and neck when in their ordinary position.

Along the upper part of the neck are two muscles, the splenius and the levator anguli scapulæ, and to the development of these two the appearance and beauty of the crest is chiefly due. The former is a large muscle, especially employed in raising the head. It arises from the entire length of the ligamentum nuchæ, and when overloaded with cellular substance or fat is apt to give an appearance of clumsiness to the massive crest and thick neck of an entire horse. The other muscle is a small narrow one, extending above the splenius, along the superior margin of the neck, and after passing behind it, descends to the shoulder, where it is not visible externally. At its origin it is inserted into 
the back of the head, and is attached to the first four bones of the neck, as well as to the great ligament already mentioned. It has a reciprocal action on the neck and shoulder, according to which is the fixed point at the time.

A muscle which also assists the two mentioned in their office is the complexus major, which forms the principal portion of the lower part of the neck. It arises from the transverse processes of the withers, and also from the five lower bones of the neck, the fibres from which unite to form one large muscle. It diminishes in size in the direction of the head, finally terminating in a tendon inserted in the occipital bone.

Immediately below the splenius, and following the course of the vein of the neck which is utilised for the operation of bleeding, and which lies immediately below, is a most important muscle, the levator humeri, or deltoides. It extends from the back of the head and upper part of the neck, and proceeds along the front of the shoulder to the top of the fore-leg, and on the development and power of this muscle many of the capabilities of the horse depend. When the head is kept up by its own proper muscles it becomes a fixed point from which the levator humeri is enabled to raise the shoulder, so that on the development of the four muscles, the splenius, the levator anguli scapulæ, the complexus major, and the levator humeri, everything else must necessarily hinge. Any weakness in any of these will absolutely prevent a horse from sustaining prolonged exertion, however much he may excel in other directions.

Adjoining the levator humeri, but below it, and following also the course of the vein which lies between the two muscles, is the principal depressor of the head, the sternomaxillaris.

It arises from the upper end of the sternum, or point of the breast, covers the lower front of the neck, and is inserted by a flat tendon into the posterior angle of the lower jaw. It is not a very large muscle, for, when those supporting the head and neck are relaxed, but little force is required to pull the head down. 
The muscles of the shoulder need hardly be described in detail, it being sufficient for the ordinary observer that that part should be muscular and generally well developed, special attention, however, being bestowed on two, the anconœus longus and the anconœus externus, which arise from the lower bone of the shoulder and are inserted into the point of the elbow, above which they form a prominent swelling. Their office is to straighten and extend the arm, and therefore need to be powerfully developed. Nor do the muscles of the back require any lengthened comment, for the latissimus dorsi covers the whole, extending from the shoulder to the haunch; it is the principal one employed in raising the fore- or hind-quarters in rearing or kicking, and also in leaping. It is strongly attached to the processes of the vertebræ and ribs, and when the latter are well arched and the muscle is correspondingly well developed, the general appearance should present "a good flat back," that well-known desideratum. A perfect back should be of this description, with the shoulders and withers sloping so far back, and the arch formed by the lumbar vertebræ coming so far forward, that there is barely room for the saddle between the two. Such a formation is very powerful, and the best for carrying weight; and it should also ensure the fore-legs being well

PLATE VIII.

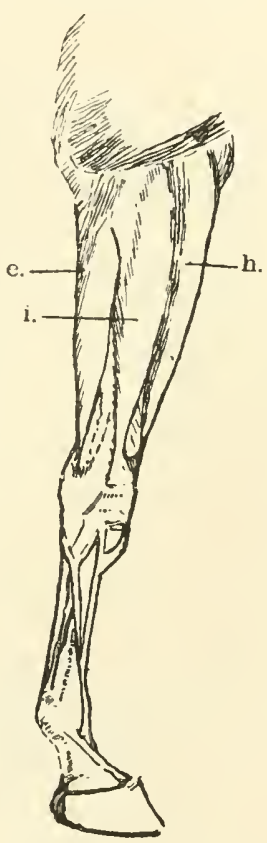
away from the hind ones, showing plenty of length underneath. If the horse has a long back it is a source of weakness unless it is of the shape known as a "roach-back." Such horses are usually good jumpers, the typical little arch being frequently alluded to as "the jumping bump." Long-backed horses are almost invariably easy in their paces, and are in request by some persons for this reason.

Seen from the outside of the "arm" are three very important muscles (Plate VIII.), which together give it its typical 
appearance, and terminate in the powerful tendons which, in conjunction with lesser ones not so easily seen, raise and bend the leg and foot. The posterior muscle $(e)$ is the external flexor, the middle (i) being the extensor digitorum

PLATE IX.

Muscles of the Hind-quarters.

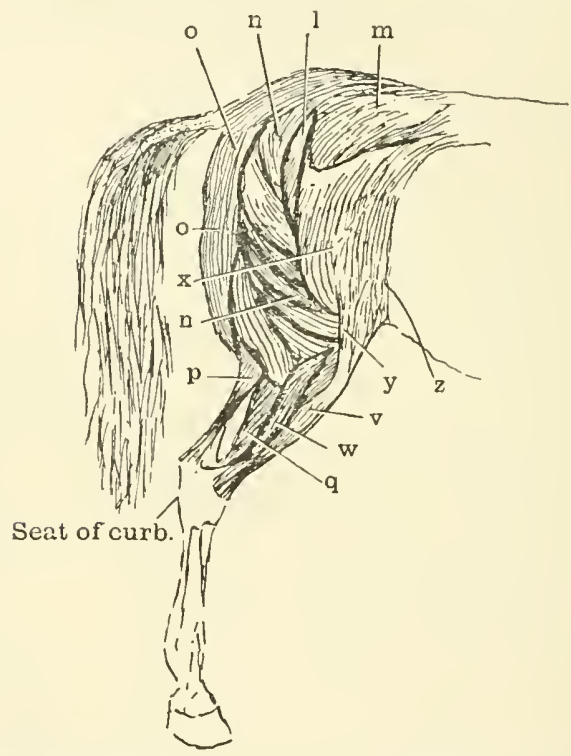

$l$ Glutœus Externus.

$m$ Glutœus Medius.

$n$ Triceps femoris.

$o$ Biceps.

$p$ Gastrocnemi.

$q$ Flexor Pedis. $v$ Extensor Pedis.

$w$ Peronæus.

$x$ Vastus Externus.

y Musculus fasciæ latio.

z Rectus.

longior, and the front one $(h)$ the extensor carpi radialis. Provided these are of good volume, the remainder will be also well developed, and as the retractile force of a muscle depends chiefly upon its length, the desirability is evident of the arm being long as well as lorge.

The prolongation of the muscles, in the form of tendons, below the knee are generally spoken of as "the back sinews," referring to those at the back of the leg, which are 
much more in evidence than the extensor tendon which passes in front. They should stand well out, appearing like hard wiry cords, which should feel clean to the touch without any suspicion of gumminess. Though to the casual observer there appear to be only two, in reality there are four separate tendons and ligaments in the upper portion, though in the lower part it may be said there are but two, since the metacarpal ligament becomes attached to the flexor perforans, and the latter is then enveloped by the flexor perforatus.

Ligaments differ from tendons in one very important point, they are inelastic.

The muscles of the hind-quarters are for the most part strongly marked, and the situation of the principal ones easily recognised. Arising from the processes of several of the vertebre of the loins and from the prominent parts of the ilium, or hip, is a very important one, the glutœus medius (Plate IX., $m$ ), often termed the "kicking muscle," which terminates at its insertion in the projection on the npper bone of the thigh (femur), and acts with considerable power in bringing the latter forward. Attached to this muscle and interposed between it and the next great muscle, is a little slender one, the glutous externus (l), which has generally a similar origin and function. The next, the one just referred to, the triceps femoris $(n)$, is the most important of all, for on it develops the duty of drawing back the stifle-joint and straightening the leg, in which function it is also assisted by the biceps (o), which lies parallel with it and immediately behind. The glutœi muscles bend the leg, preparatory to making the spring, while the triceps acts in the opposite direction, straightening the limb and propelling the body forward. It is the division between the triceps and the biceps which makes so marked a line in the quarters of high-bred horses, sometimes designated as "cuts and slashes." Another flexor" of the leg is the semi-membranosus, which forms the inner posterior border of the haunch, and unites under the tail, along the mesial line, with its fellow-muscle on the other side. When these two do not meet, and a clear space 
can be seen between them, the horse is said to be "split up behind," an indication of want of power, and a conformation to be avoided. Such horses are also sometimes termed " turkey-thighed."

Passing over lesser muscles, which, however important, are not easily recognised by the ordinary horseman, notice must be drawn to the extensor pedis $(v)$ and the peronœus $(w)$, which lift the foot forward, and are very important. The former arises behind the stifle, from the extremities of

PLATE $\mathrm{X}$.

Tendons of the Fore-leg.

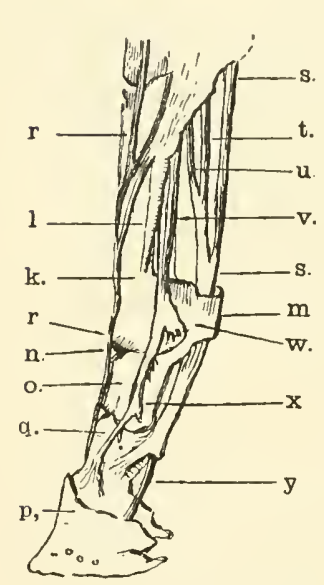

$k$ Camnon or Shank.

$l$ Splint bones.

$n$ Fetlock joint.

o Upper pastern.

$q$ Lower pastern.

$p$ Coffin bone.

$r$ Extensor tendon.

$s$ Flexor perforatus.

$t$ Flexor perforans.

$u$ Metacarpal ligament.

$v$ Superior sesamoidal ligament.

$u$ Bifurcation of sesamoidal ligament.

$x$ Continuation of branch of sesamoidal ligament.

$y$ Continuation of flexor perforans, which is afterwards inserted into the os pedis, ofter passing over the navicular bone (not shown).

the two thigh-bones, and passing in front of the hock, where a sheath confines it to its place, after it has become attentuated into a tendon, it continues its course to the foot, and is inserted into the front of the coffin-bone. The peronous arises from the fibula (Plate III., H) and taking a more lateral direction than the extensor pedis, the tendon passes on the outside of the hock, and then descends to the foot with the extensor pedis. On the other margin of the "second thigh," and just under the thigh (tibia), are the extremities of the gastrocnemi, and on their development, or the want of it, depends whether the second thigh appears 
$\mathrm{V}$-shaped, with the hock forming the apex. The thigh should appear to gradually merge into the second thigh, instead of so abruptly terminating that the second thigh seems of equal breadth throughout its length. The latter formation is a grave fault, for the united tendons of the gastrocnemi form the tendon Achilles, and are strongly inserted in the point of the hock (os calcis) ; and unless the muscles themselves are very robust, the tendon Achilles must likewise be feeble. One more great muscle in the second thigh remains to be noticed, the flexor pedis $(q)$, which is one of the principal muscles for bending the foot. It arises from the upper part of the tibia, and becoming tendinous, passes as a large round cord through a groove at the back of the hock, and then descending behind the shank-bone is inserted into the two pasterns.

\section{'THE HoOF.}

The hoof, which is a horny case covering sensitive parts, is renewed by growing downwards from the coronet, where it is secreted, and the fibres composing it should be hard and tough. These fibres run perpendicularly downwards, and at first only appear as toughened skin, but rapidly assume the appearance of horn. The crust thus formed joins the horny sole, forming a rim around it, but while this rim, in nature, is continually worn away by contact with the ground, to prevent which shoeing was invented, the sole pares itself by detaching thin flakes of horn, if left to fend for itself. With a thin-soled horse the knife of the shoeing-smith should do nothing more than remove such flakes as are about to be cast off, for if more is removed so little protection will be left to the sensitive sole that the animal will lose its action, even if it does not become positively lame.

Brittle feet are often very troublesome, as they break away so much there is difficulty in obtaining a sufficiency of hold for the nails. A mild stimulant applied to the coronary band will frequently induce a firmer secretion of horn; and as this condition of hoof often results from the 
horn being of too dry a nature, beneficial results may be looked for by standing the animal in wet swabs at night. Horses turned out in a field generally have horn of tough texture, and they are usually subjected to moisture from cvening dews, in the absence of rain, to be followed on the succeeding day by the drying action of the sun. The rings on the hoof at the end of a summer's run give a plain indication of what the weather has been, the horn having grown with increased rapidity in spells of wet weather, while there has been a corresponding diminution of growth during periods of prolonged drought.

Under the heel of the foot is situated the frog, an elastic cushion designed to obviate the shock of concussion, when the foot is placed upon the ground. It serves another purpose also - that of keeping the bars apart, and preventing thereby the foot becoming contracted. Every effort should be made to preserve a full, well-developed frog; and it should not be pared with the shoeing-smith's knife, beyond trimming away any portions which have become ragged. These, however, should be cleared away, since they would otherwise become pockets for the reception of mud and dirt, and when this gets saturated with ammonia, as it is sure to do in the stable from the horse treading upon its own evacuations, diseased horn will sooner or later make its appearance. It was with a view to prevent such occurrences that the old-fashioned practice arose of stopping the feet with a mixture of clay and cow-dung, the latter being mild in its action compared to horse manure, as all gardeners know full well. The worst effects arise, however, from the feet getting soaked by urine, from standing on thoroughly saturated straw, through deficient drainage.

Inside the hoof the arrangements are complicated, several objects having to be kept in view. The weight of the horse has to be sustained; the extensor tendon must have a firm attachment to be able to bring the foot forward; and the flexor must similarly be arranged for to withdraw the foot; whilst all must be protected from injury by concussion. To provide for the first requirement the lower pastern is supported by two bones, the chief being the bone of the 
foot, or coffin-bone, which runs into the toe; and the other, a small one, situated at the posterior part of the pastern, immediately over the tongue of the frog. The extensor tendon is fixed into the upper front portion of the coffinbone; while the flexor perforans passes underneath the navicular-bone and is attached to nearly the centre of the underneath part of the coffin-bone. Immediately below the last tendon, and the navicular-bone, is the sensible frog interposed between them and the horny frog, consisting of a fatty substance, comprising oil, elastic cellular membrane, and cartilage. The further protection of the under portion of the coffin-bone is provided by a sensible sole, thickest at the toe, attached to the bone above and the horny sole below; and its upper surface is guarded by sensible, and horny laminæ, interposed between it and the horny outside, and which bear a superficial resemblance to the gills of an ordinary mushroom. Unless a shoeing-smith is well acquainted with the anatomy of the foot, and merely looks upon it as a horny box, there is an excellent chance of his driving a nail into at least the horny laminæ, if not into still more tender parts!

\section{The Points of a Horse.}

The mechanism of the horse having now been considered in detail, which applies alike to the thoroughbred horse and the cart-horse, a summing-up of the general points will be appropriate, though these will refer more especially to the well-bred animal. The head should have length, and be lean, and unmistakably indicate the sex, for a small, pretty head for a male animal, or a masculine-looking head for a female, are never to be desired, and are apt to be only too true indications of contrary tempers. The forehead should be wide, giving promise of sense. The eye is an especial indicator of the mental attributes, a clear large full eye nearly always indicating a generous disposition, while a sullen-looking small " pig-eye," gives equal warning of a sulky character, one not to be depended on when the moment demands an extra exertion. The ears should be long, and 
show alertness by being frequently in motion, especially if first one and then the other is moved forwards and backwards; but there should be no restlessness about the movement, or the animal will probably turn out fidgety and excitable, and such do not make brilliant performers. They are too apt to dash uncontrollably forward, not looking where they are going, and then when the pinch comes they are found to have exhausted their powers prematurely. A lop-eared animal is most usually a placid-tempered one, often a good stayer, usually of a generous disposition, but sometimes a little bit inclined to be sluggish. A horse with a little small prick-ear has invariably a "temper" of some description. It may be only that it pulls tremendously hard, but it may be vice. Such horses are apt to be ungenerous in their work, to shy, refuse, or shut up in a race when collared. If the animal is pig-eyed as well it is better to look the other way when the horse is up for auction, and the auctioneer endeavours to tempt you into a bid!

The angle of the jaws must be wide, to admit of freedom for the windpipe, and to allow the horse to bend his neck properly to the bit. The upper lip should be rather long, with a correspondingly long slit for the nostril when in repose, which will dilate into a large bold orifice when the horse is excited by a gallop, and the blood-vessels glisten scarlet under the skin. The neck should be carried well up, with a becoming arch, the withers be well defined. The shoulders should have a well-marked slope, and be deep; while the points should not show through the skin when the horse is in motion, though at the same time they should be thick through, giving promise of sustaining weight. Apropos of this subject, William Osmer, who wrote an admirable treatise on the horse in 1756, remarks:-

"Add to this there is another advantage obtained to the Horse besides velocity, by the declivity of the shoulders, for his weight is removed farther back, and placed more in the centre of his body, by which an equilibrium is acquired, and every muscle bears a more equal share of weight and action: so that the nearer the articulation of the quarters 


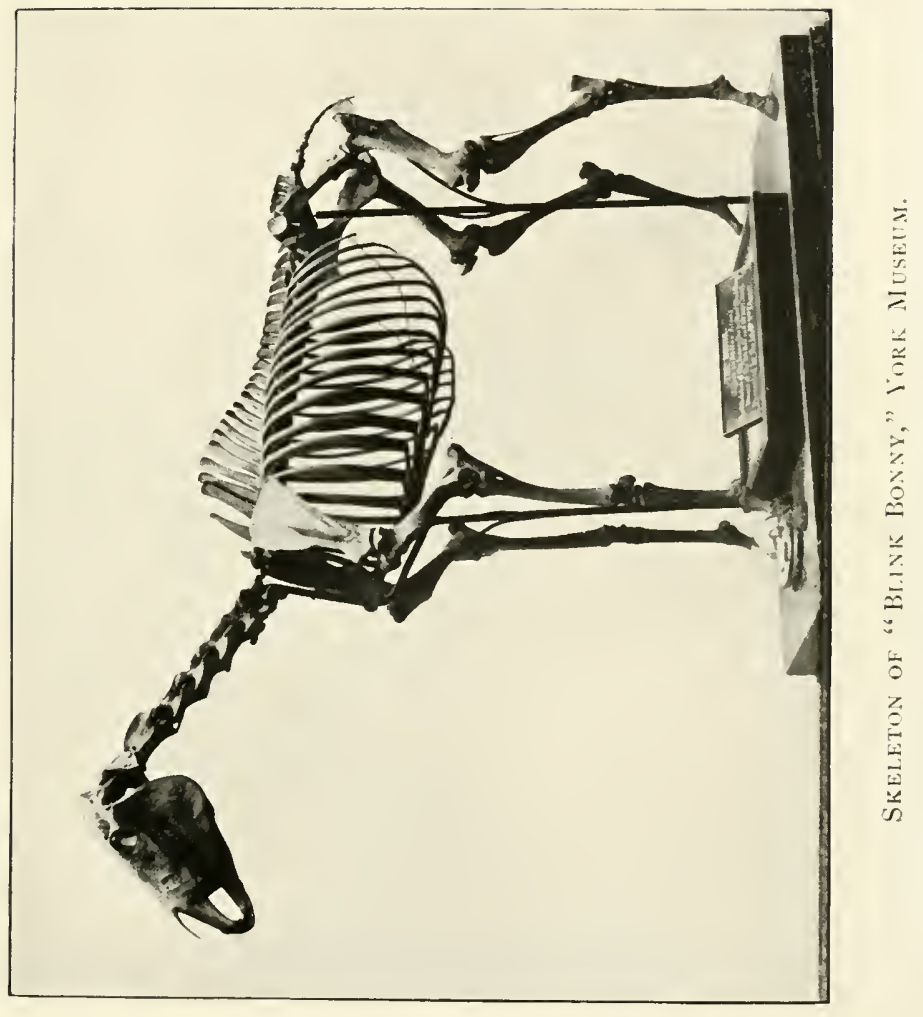



approaches to the superior part of the shoulders, so much shorter will the back be ... in any given and proportioned length from the bosom of the horse to the setting on of the dock, the nearer the superior points of the shoulders approach to the quarters, so much better will the carcase be to sustain and bring through the weight; and as much as the shoulders themselves prevail in depth, and the thighs and quarters in length, so much greater will be the velocity of the horse, because a greater purchase of ground is hereby obtained at every stride."

Certainly the most essential points of a horse were well understood a hundred and fifty years ago! They had nothing to learn in this respect.

A short, powerful back is to be looked for, but it should be combined with well-developed quarters, for there must be length somewhere and it should be found in them. A longbacked horse frequently has short quarters. The horse must also "stand over a great deal of ground," as the saying is, there being plenty between the fore and hind limbs when the horse is set properly on his legs, and not made to stand in that ridiculous fashion beloved of grooms when displaying their charges, with the fore-legs stretched out in front, and the hind-legs straggling away behind, the idea being to give a fictitious air of length. It cannot deceive anybody but the very ignorant, whilst it gives the horse the appearance of possessing one of the worst of faults, that of having his hocks away from him. A horse should stand as fair and true on his limbs as a table on its legs, and the more the perpendicular is departed from the greater must be the strain on some part or other, with every probability of it giving way when much stress is put upon it. The forearm must be long and muscular, and the elbow well clear of the body. When the fore-foot is lifted up, and the knee bent, the hoof should just clear the elbow. The knees must be large, and neither arched nor bent back, but of the two the former is to be preferred when the formation is natural, since there is less stress caused to the back tendons, though it may be a sign of weakness if the arching of the knees is very much pronounced. The back tendons should be well 
defined and wiry, and with this proviso cannot be too large. A wiry leg is always to be preferred to a larger one which is round and gummy, as it will stand twice the amount of work. The eye is apt to be deceived as to the size of a leg, according as there is harsh or silky hair, and even amongst thoroughbreds the tape often tells a different tale to what is expected. The tape is, however, a rock on which many persons get wrecked who pin their faith on so many inches below the knee, for the reasons already stated, the practical man requiring a leg likely to do its work, irrespective of how much it will measure. Moreover, the correct measurement of a leg is not so easily made as may be imagined. If taken too close to the knee a portion of the latter may be included; or if the tape is not drawn sufficiently tight an increase of half an inch, or more, may easily be added to the real amount. If the tape is placed about two inches below the knee, and drawn fairly tight, the statements of owners, and interested helpers, have a way of not tallying with the measurement by a person whose only object is to get at the truth. One often hears of a horse having so many inches of bone, but almost all bone is of sufficient bulk to sustain the weight, and it is the size of the sinews which is important, they being the ropes which move the bones. The cannon, or shank-bone, should, however, be of fair dimensions, and though round in front of the shin should be almost flat at the sides narrowing somewhat towards the back, after the fashion of a razor.

The fetlocks should be clean, and without windgalls, which betray a soft condition, although they are not often very troublesome except to an animal in training, for then they cause more or less stiffness, and prevent the holse striding out to his full capacity. The pasterns should neither be plumb upright nor too sloping, the former formation soon causing the animal to become stilty in its action, especially when the ground is hard; and in deep ground they are most unsuitable, it being found by experience that horses with upright pasterns cannot "get through dirt." Pasterns sloping too much are also unsuited to deep going, though their very elasticity is a recommenda- 
tion when the ground is hard. Such pasterns afford delightfully easy paces, when the animal is required as a hack.

The curious callosities known respectively as chestnuts and ergots must not be overlooked. The former are universal, and are placed on each limb, being of a tough, leather-like substance, the use of which is not definitely known; though it has been suggested they have formerly been glands which secreted an odour, by which animals separated from their comrades were enabled to track one another. They are very rarely absent, and the writer has only known one case. This was in a chestnut colt, bred by himself in 1898 by Queen's Counsel out of Lunette by Napsbury, who was born without chestnuts on his front limbs. Ergots are hard protuberances growing from tufts of hair behind the fetlocks, and are of identical material with the horn of the sole. There is nothing to indicate what their original function may have been. Both chestnuts and ergots are liable to grow sufficiently large to become unsightly, when they should be trimmed down with the blacksmith's knife to reasonable dimensions.

A few horses develop bony excrescences on the forehead, which are looked upon as horns, but they have no true core, and do not penetrate the skin. It is a curious circumstance that a colt who was the playmate of the colt "Crown Glass," mentioned above, and foaled in the same year, also made himself conspicuous by developing horns when he was six years old. This was Shepherd Lord, a brown, by Wellington, out of Lady Bo-Peep by Hagioscope. As both were subjected to an operation there was no chance of seeing whether they would have perpetuated their abnormal characteristics. 


\section{CHAPTER VIII}

\section{BREEDING}

CCORDING to the highest scientific authorities the
mammalian ovum is but a minute speck of animal matter, possessing no individuality. The diameter is less than $\frac{1}{100}$ th of an inch. A membrane surrounding an albuminous mass forms a simple cell containing a germinal spot, and this constitutes the ovum. That germ in the "egg" can only be seen under the highest powers of the microscope; and it only requires to be fertilised by coming in contact with the male sperm to develop into a mammala man, an elephant, a wee mouse, or any other member of the vast order which includes all mammals under its wing, each after its kind. The final development of that impregnation is as astonishing as the fact that an oak-tree is the outcome of a tiny acorn; or that luscious fruit should result from a similar fertilisation of the ovule of a flower by contact with the male pollen. Nor does it require the course of ages to produce such marvels, only a few months, or in some cases only a few weeks, being quite sufficient. When such astonishing results are duly considered it does not seem so incomprehensible that mammals have evolved from birds and fish, in the course of many millions of years.

The principles of heredity are very strange and perplexing, and though certain facts have been grasped by man, and turned to his own purpose, only the fringe of the subject has yet been touched upon. That "like produces like" is generally acknowledged, and is so far true that the union of two race-horses cannot produce a Shire horse; nor can two Shetland ponies become the parents of a Suffolk Punch. 
But at any rate the offspring will be "horses," and not dogs, or cattle, or some other branch of the mammalian order. Though what is known amongst florists as "sports" continually occur in all organic life, such departures as the above from an established "race" are quite impossible. Even the children of two white parents can never be negroes; nor those of Orientals have the features of Europeans.

Particular traits are frequently fixed in certain families, in which such are pre-eminent, and are most certainly inherited, though different members vary to a considerable extent in their possession of them. These may even lie dormant for a generation owing perhaps to disuse from want of opportunity for their exercise, or some other cause, but unless they are not called for during several generations, they are sure to crop up at the first favourable opportunity. If the same care was taken to join in matrimony human beings of like proclivities for many generations, as man takes with regard to animals under his care, such tendencies would in all probability become even more fixed than they are at present. In breeding horses of any description the same principle must be kept in mind, and individuals should be selected, as parents, from such families as have much merit in the particular direction desired. Then if welldeveloped animals are chosen, without hereditary ailments, whose immediate ancestor's, moreover, have also been trueshaped and adapted to the special work required, the foundation should be laid for a successful progeny.

The further building up of the produce must largely depend on due care and judicious feeding, both during the pregnancy of the dam, the period of suckling, and the first years of youthful development, but especially during the first winter. A young animal must always be kept growing, and should never be allowed to be checked in its growth. If the "calf-flesh" is once lost, it is both difficult and takes a long time to get the tender young one started again; and it will never be quite as good as it might have been if there had been no drawback. A very frequent cause of trouble is the time of weaning, when a foal always 
requires some extra addition to its ordinary food, to make up for the loss of its mother's milk; and also the anxiety of mind it necessarily experiences when it first loses her society. To meet the latter case it is an excellent method, I have long followed, to do the weaning gradually, extending the process over two or three days, or more if the foal takes its dam's absence much to heart. Thus the mare at first is only kept absent a couple of hours, and is then brought back and left with her foal. The next day she is not brought back till after double the period of time has elapsed, and usually the foal does not take very much notice this time of her absence, expecting she will return as she did before. If the foal seems to settle down while the mare is away, on the third day she is not brought back at all ; but this can be left to the discretion of the attendant in charge. It is most advisable that the foal should have a companion to whom it is accustomed to run along with it, though this need not be one of the same age. Almost any sort of animal will prove a comfort to it, more especially a donkey or a goat, with whom a firm comradeship is frequently cemented. The future companion should be put in the same paddock with the mare and foal before weaning takes place, if possible, and it is a further assistance if they occupy adjoining boxes at night, so that the sense of loneliness is not so pronounced when the fateful day arrives for the mare to be parted from her offspring. A little care in this respect is never time thrown away, for if the foal should fret much it will lose flesh considerably, and perhaps refuse to feed for a day or two, when the ground lost will take some time before it can be made good. It should have acquired the taste for crushed oats while still running with the dam, and to these can be added a little linseed, and some patent food, than which nothing seems to answer better than the wellknown "Valenta." If there is any tendency to constipation when the foal is deprived of its mother's milk, some linseed gruel added to a small bran mash will act as an efficient corrective. A foal can be accustomed to eat corn whilst in the paddock by following the capital plan of Mr. Robert Thornton, the experienced stud-groom at Lord Middleton's 
stud-farm at Birdsall in Yorkshire. An enclosure 10 yards square is formed, with a rail $4 \mathrm{ft}$. $6 \mathrm{in}$. from the top of the rail to the ground, and inside a feeding-trough is placed, in which crushed oats are put. The foals pass underneath the rail to feed, whilst the mares are obliged to remain outside. The foals very soon take the hint, and come galloping into the enclosure as soon as the attendant is descried approaching with the oats. A quart or two of cow's milk, if it can be spared, will be a welcome addition to the bill of fare, and skim milk will do quite well for this purpose; if it can be given till after Christmas it will help considerably in building up a bony frame, for on the way the foal gets through its first winter will very much depend its future well-being. It should be out in a paddock for several hours every day, only being kept at home in very wet weather, when rain or snow are actually falling. The paddocks should be of considerable size, at least five or six acres, and preferably more, for in very tiny ones the animals soon get tired of the small place in which they are confined, and then drift into a habit of standing about, listening at the door and waiting to be summoned home. In a sufficiently large enclosure they find enough to interest them in moving from one part to another, especially if there is any broken ground in it, or any plantation which hides the view so that some part is always hidden, thus promoting curiosity to go and see if anything is going on in that direction. It is one of the chief, and most fatal, defects in very small enclosures that the whole can be seen from any spot in them by merely raising the head, and so there is no impulse felt to go in search of something fresh. The late Mr. Leonard Morrogh first drew my attention to this about thirty years ago, having adopted the principle at the deer-paddocks, at the kennels of the Ward Union Stag-hounds. The deer were kept in some very small yards, with sheds to go into; but it was found they stood listlessly about, and when required for the chase were far from fit, and soon tired. By adopting the simple plan of putting up some detached wooden barriers to break the view in the yards, and also to hide the entrance into the sheds, and, moreover, by giving access 
from one paddock into another, the deer were always on the go, being seized with an insatiable curiosity to know " what the other fellow" was doing, whom they could not see; and so they wandered from this barrier to that, then into a house and out again, and finally made a visit of inspection into the next paddock, only to be seized with a sudden panic lest something should after all be happening in the one they had just left-true disciples of "the wandering Jew." The result was that the deer improved so much in condition that great runs took place, which were a feature during the visits of that splendid horsewoman, the late lamented Empress of Austria.

The further requirements of the foal will be plenty of good sound hay, a little rock salt, and an airy box free from draughts. If the animal is found to have little flesh on its ribs, especially if it is somewhat pot-bellied, one may at once suspect that it is troubled with internal parasites, and give a vermifuge, than which nothing is more effective than the old-fashioned one, which has stood the test of timeturpentine, linseed oil, and camphor. For a foal on the mare, or just weaned :-

$\begin{array}{lccccc}\text { Turpentine } & \ldots & \ldots & \ldots & \ldots & \frac{1}{2} \text { tablespoon } \\ \text { Camphor } \ldots & \ldots & \ldots & \ldots & \ldots & \frac{1}{4} \text { oz. } \\ \text { Linseed oil } & \ldots & \ldots & \ldots & \ldots & \frac{1}{4} \text { pint }\end{array}$

The camphor should be put in the oil in the evening, and will be dissolved in the morning.

\section{The Effects of Heredity.}

Scientists teach that the body is built up of cells, continually reproduced and added to, but it is curious to reflect how hereditary tendencies can thus be transmitted. How are these cells influenced in the making by ancestors of long ago? And why should the influence of one parent, and through it that of ancestors on its side of the house, prevail more and be more impressive than that of the other parent? We know, from observation, that the progeny often resembles a grandfather or grandmother, or some one even further 
remote, more than it does its own parents; still, other things being equal, both dam and sire are equally liable to transmit some of their own particular peculiarities to their offspring, and stamp their impress upon it.

In certain of the lowest forms of life it is found that an ancestor reproduces itself with the greatest regularity in the third or fourth generation, but as there is no such guide to assist us in breeding horses the utmost we can do is to select none but true-shaped animals of unimpeachable performances to mate together, and then if there is a tendency to throw back on the part of the progeny it must be to a good type. Other qualities, the intellectual and the nervous organisation, are also to some extent hereditary, but seem to be rather dependent upon the immediate sire and dam, especially if they are very closely related to each other, than upon more remote forbears. The doctrine of heredity, however, admits of a simple explanation. The cells which are concerned with the building up of a future creature are termed "Gametes," and when a Gametes cell from each parent meets and fuses with the other, they henceforward form a single cell, the germ of the future body. This new cell, the product of both parents, never afterwards changes in character, and contains only such qualities of each parent as may happen to be stored in the respective cells at the moment of uniting-much as the elements of each exist in the compound when whiskey and soda-water are mixed together.

The new cell is in future known as a "Zygote," and is not fresh matter, but a continuation of former material. The influence of each parent, thus bestowed, remains constant, being neither subtracted from, nor added to afterwards: and it only remains for environment and education to develop the various traits thus inherited to their fullest extent; or to allow them to lie dormant if circumstances are not favourable for their development, though they can still be further transmitted to another generation.

Gregor Mendel, that painstaking, hard-working AustroSilesian monk, who died in 1884, proved by an exhaustive 
series of experiments that plants and animals are compounds of various distinct units, inherited on definite principles, and that by rearrangement of the characters of each group new varieties could be produced. $\mathrm{He}$ proved that by mating blue Andalusian fowls together the chickens came of three colours, either blue, black, or white spotted with black, and that the proportions of each were 1, 2, 1. If, however, the black-and-white chickens were mated with each other they produced blue Andalusians only. The colours of horses no doubt follow the same law, and it has long been observed that a chestnut sire mated with a chestnut dam invariably produces a chestnut foal. Baron Von Oettingen gives some remarkable statistics from the Royal Stud at Trakehnen, which has existed over a hundred years, blacks, browns, and chestnuts being lept apart in three special studs, while in a fourth the colours are mixed; and he proves how regularly certain colours followed the respective matings; while he further remarks that a distinct atavism is often evident in the transmission of white marks and particular spots.

With reference to white markings Sir Jonathan Hutchinson, F.R.S., F.R.C.S., for a long period consulting surgeon to the London Hospital, contributed a most interesting paper on the subject to the British Medical Journal, June 18, 1910. The substance of his communication is that the upward extension of white stockings on the legs will be in ratio with the size of the star, or blaze, on the forehead. "If it occurs, as is unusual, that the forehead patch is not placed in the middle line there will probably be want of bilateral symmetry in the markings of the feet. ... I attach much importance to any conspicuous deviation from symmetry in these matters. If, for instance, the face patch is on one side only, and the two feet on one side show stockings while those on the other retain colour, it may, I believe, be suspected that the animal is not developed with perfect bilateral symmetry in other respects. He may differ from his fellows as a left-handed man differs from a right-handed. He may be a sinistral (left-handed) horse, and if so, although he may be strong and efficient for work, 


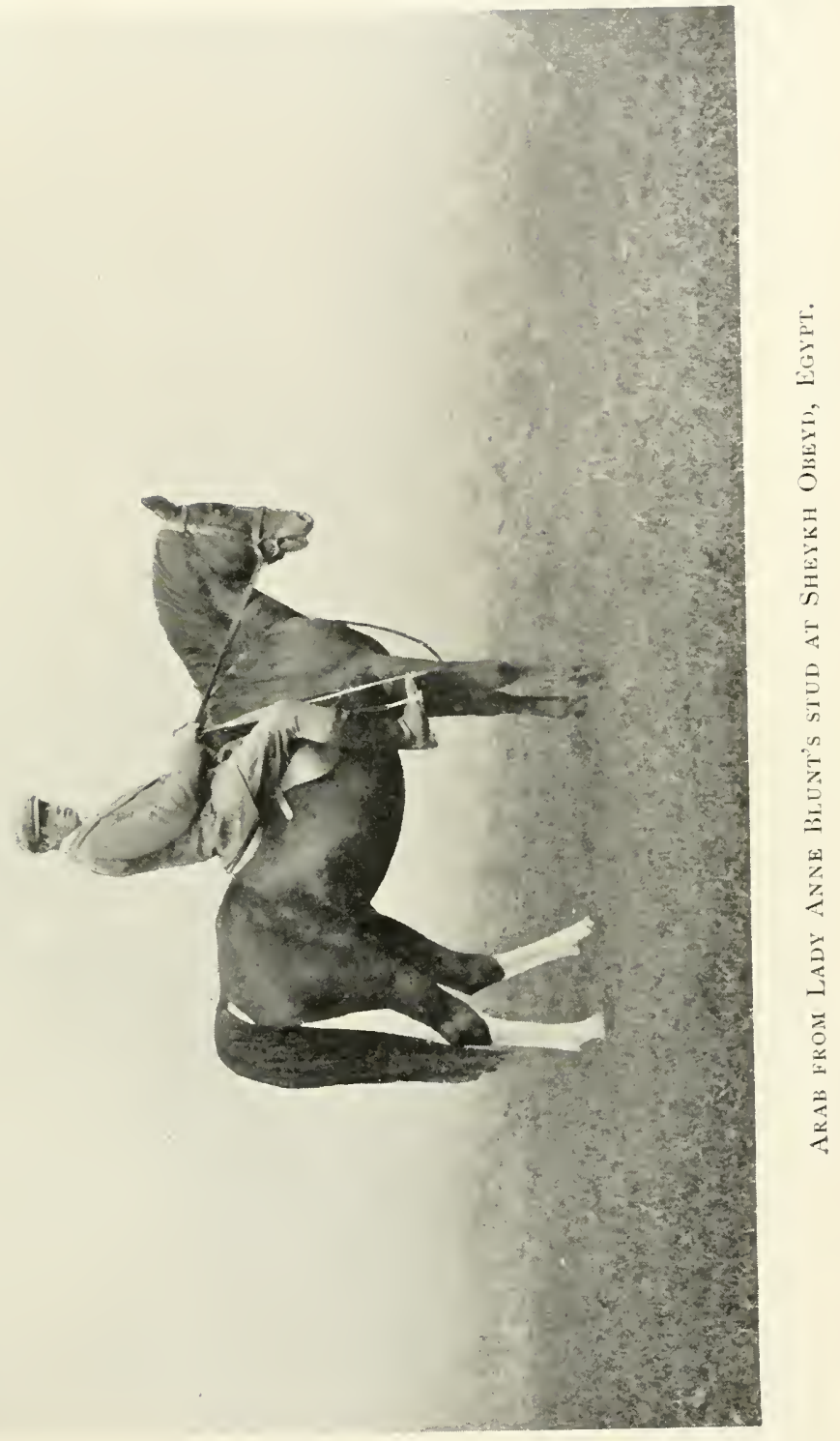



he will move more or less awkwardly, and not be pleasant to ride."

Sir Jonathan further remarks that the hind feet are almost always more involved than the fore ones, and that if one fore-foot only is white it is nearly always the left (or near) one.

Sir Jonathan has indeed put forward an interesting and totally new subject, and there is such force in his remarks that a prolonged study of the subject may result in some singular and important discoveries.

On taking at random several famous stallions of the past, I find that every one of them which had a white mark on the forehead had it placed on the middle line, and that not one of them had a white off fore-foot with the other legs coloured. Still a much more extensive search needs to be made before a universal rule can be established.

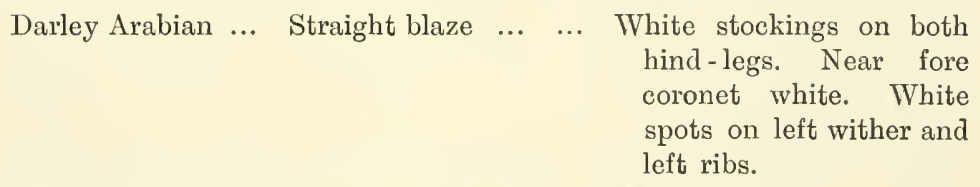

Flying Childers ... Small central star ... White reach into both nostrils. All four fetlocks white.

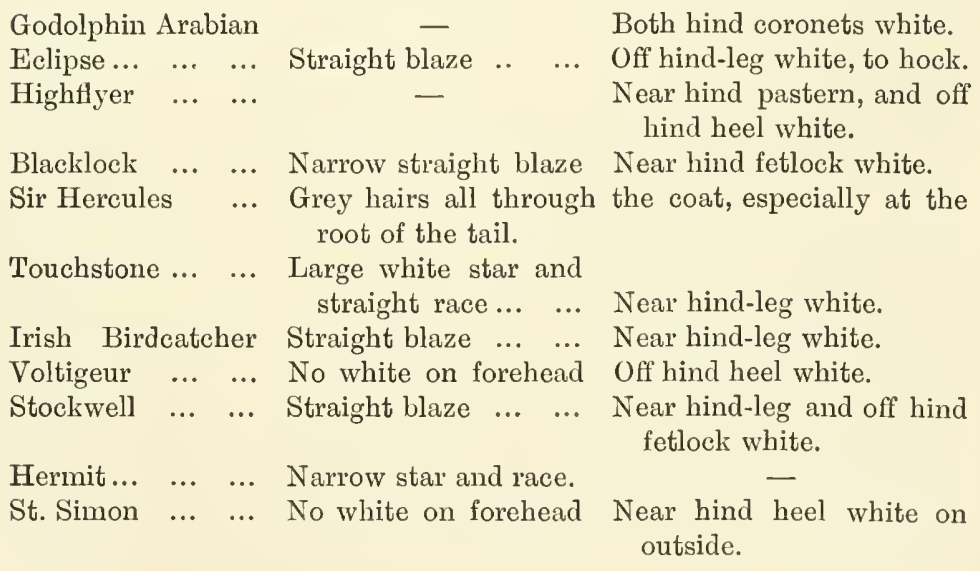

According to the ruling of Sir Jonathan none of these could be suspected of being a sinistral animal; but those who had 
much white on the legs also had a large blaze on the face, whilst the others contented themselves with having only the fetlocks, or heels, white.

\section{Brood Mares.}

The very first and most essential thing in breeding stock of any description is to see that the matrons are of such form that they can produce well-developed offspring, and so far back as the early days of Rome Virgil drew especial notice to this point. In the $3 r d$ chapter of the Georgics and the 49th verse he says:-

"Seu quis olympiaco miratus promia palmo

Pascit equos, Seu quis fortes ad aratra juvencos, Corpora præcipue matrum legat."

If this is neglected breeding must eventually result in failure.

A brood mare should be roomy in body, with plenty of length underneath to provide ample room for the growth of the foetus, for a short mare with fore and hind limbs close together, seldom produces a good foal ; and, moreover, one whose genital development is unusually small is to be avoided, unless there is a special desire to have a foal from that particular mare. In addition to being of true conformation a long low mare should be chosen in preference to one that is high on the leg, and a wiry animal rather than a big coarse one. Besides the actual make and shape, any deficiencies in which should, if possible, be counteracted by the stallion being particularly good in those points, other qualities must be duly considered, such as hardiness, good temper, and courage, and most especially that the mare is generous in her work. Hot-tempered, lazy, cowardly, and bad-tempered mares should be avoided, and also such as are bad feeders. All these qualities, good or bad, are very apt indeed to be inherited by the offspring, and are equally important in every breed and for every class of work.

Maiden mares, which have never been covered, should be invariably examined by the stud-groom, as frequently the 
development of the vagina is so contracted that the stallion is made sore in consequence, thus hindering him in his subsequent duties. The mare is also unduly irritated, and resents the attentions of the male on after-occasions through fear of being hurt. Many owners of valuable stallions will not allow them to serve maiden mares, and it is often so stated in the published advertisements. A stud-groom, when he finds the passage unduly small, should insert his hand and arm, after well oiling them, and, besides opening the vagina, should smear the part well with vaseline or some other lubricating ointment.

The actual first service is the most important one of the mare's life. Though science deprecates the notion, practical experience proves that the impressions then formed more or less dominate all subsequent offspring. At that moment the maiden knows not what is about to take place, and she closely observes everything she sees, and follows each movement of those about her. Everything is photographed in her marvellous memory, and it is of supreme importance that on this occasion she should not gaze upon any illformed horse; and if the sire has defects it is better that the mare should not see him, but be blindfolded until he has come and gone. In the thirtieth chapter of Genesis the importance of the surroundings is well emphasised, and evidently well understood at that far-off date. On subsequent occasions, though such precautions are still desirable, they are not of the same importance as at the very first time of covering.

Quietness should ever be sought, and in all well-managed establishments a special yard for such performances is an invariable rule, surrounded with such high walls that the occupants cannot see outside, and with no possibility of any disturbance from the external world. For the reasons given it is evident the use of the twitch is not to be recommended as an invariable rule, although the two interests involved may differ as to this, the owner of the stallion thinking chiefly about the safety of his horse, whilst the owner of the mare is concerned about the success of the progeny. When the mare is known to be a difficult and irritable 
animal to serve, the safety of the horse must be the first consideration; but with a docile, generous mare it is better to act without it. Some horses are so savage in their lust it is most necessary to protect the necks of the mares from injury; they receive serious bites, and may even be killed if the stallion seizes them where the gaping of the atlas exposes the spinal cord to external injury. A cover for the neck, of sacking or leather, which cannot be torn by the teeth, is therefore a wise precaution.

Apropos of this an anecdote has been related to me, my informant having been told the tale by the owner of the animals, who witnessed the scene, when a donkeystallion succeeded in killing a full-grown stallion horse. That it was a fight to a finish never crossed the mind of the spectator, who only thought it would make for peace if he allowed the two to settle the matter for themselves.

The horse commenced proceedings by assaulting the donkey, and battered his sides with kicks to the utmost of his power. These the donkey bore for some time without any flinching, but he gradually edged along the horse's flank till he could get within reach of the forearm, when he suddenly seized the horse just above the knee with a powerful grip and held on like a bulldog, despite all the struggles of the other. At length the horse could stand the pain no longer and came down upon his knees, when, being at last within his reach, the donkey instantly quitted his hold upon the forearm, and seizing the horse behind the ears, where the atlas exposes the pith, he killed the horse almost immediately.

The choice of ground for breeding stock needs to be carefully made, for some parts of the country are just as suitable as others are the reverse. Upland districts are usually the best, and limestone, new red sandstone, gravel, and chalk are generally excellent. Black soil-not peat soil, but the kind which grows excellent crops, and which is beloved by pheasants and partridges-is first rate as a change, but should be well drained, and stock in general seems to thrive apace in such localities. On clay soils horses often do well, provided they have access to light land 
close at hand, to which they can resort when they please, but otherwise clay is apt to be too cold in wet weather to suit well-bred animals with thin skins. As a general rule land which grows fine beech-trees is good also for horses, beech-trees disliking damp, while though oaks thrive in many soils they also do so in damp situations, and therefore are not such valuable indicators as fine beech-trees.

\section{Foaling.}

Some mares show unmistakably when they are in season, but others never give any sign unless tried by a stallion, and if there is not one on the premises and the mare has to be sent some distance to meet one, it is often a difficult matter to know when she is in use. A telling sign is when she is seen smelling the droppings of other mares, and in the case of a shy mare such a sign should not be neglected. If the halter of the mare is taken hold of and the other hand placed on her flank it can generally be seen if she is in use, for if not she will lay back her ears and kick. Mares remain a few days in season, but individuals vary in the length of time; a colt foal usually results from the mare conceiving at the beginning of the period, and a filly at the end of it. The mare having been covered need not be brought to the stallion for fourteen days, but every succeeding seventh day she must again be tried. After seven weeks from the date of the last service, during which time she has refused the horse, it may be safely concluded she is in foal. If, however, the mare does not conceive to the service, she will come again into season probably in three or four weeks' time.

After foaling the mare usually comes again into use seven days after, and should be covered on the ninth day, beginning the count on the day she foaled, when she is more likely to conceive than at any other time. When she is in season the foal is sure to give signs of a harmless diarrhœa, which being the natural course need cause no alarm; but it may be relieved by giving the dam a handful of dry barley twice during the first day the foal's condition 
is observed, and afterwards once a day, until the foal is dried up again.

Mares in foal should have a run out every day, except in very stormy or frosty weather, when there is a danger of slipping up and injuring themselves; but at least within a month of foaling she should be brought under cover at night, and the appearance of her udder should be observed before going out in the morning, and when she returns to her stable. Usually the udder begins to increase about a fortnight before foaling, though some are a little earlier and some later; and then wax, a yellow substance, appears on the teats and remains about a day. If this drops off, and is followed by milk dropping away, the mare will probably foal in about ten hours; but if the wax falls off and is not followed by milk, she may go for some days before she waxes again.

The box in which a mare foals should always have two doors to it, or else the door should open outwards, lest she should go down against the door, and if it opens inwardly there is no getting into the box without disturbing the mare. As soon as the foal is born a string should be tied round the navel-string, about an inch from the foal's belly. If it is tied too close, and stretches the skin of the belly in consequence, it will probably bring on inflammation; and if it is tied three or four inches away it will sway about when the colt is gambolling, and this again will bring on inflammation; from whatever cause this results, it will very probably prove fatal. The navel-string, after being tied, should be cut off close to the ligature. One of the chief reasons for tying the string is that thereby microbes are prevented from entering the wound, which is again a frequent cause of losing a foal, especially from Joint Evil. The raw place, and the whole of the remainder of the navel-string as far as the belly, should be lightly touched with a camel's-hair brush, or a clean feather, dipped in Chinosol lotion, or other antiseptic; but caution must be exercised in choosing an antiseptic for such a delicate subject as a newly born foal. Chinosol is perfectly safe, and so is carbolised collodion. 
If the mare should jump up immediately after foaling, and so break the navel-string before it has been tied, just slit the latter and twist it, which will at once stop the bleeding, and then proceed to apply a ligature in the usual manner.

After the string has been tied the foal should be drawn up to the mare's head, that she may smell and lick it; and then a little oatmeal gruel may be offered to her-as she lies, if she has not risen. In half an hour's time a warm mash should be given to her, and while she is eating it the foal should be taught to suck by holding its head to the teats, and placing one in its mouth. If it does not readily attempt to suck, it may be induced to do so by drawing off a few drops of milk from the mare, and rubbing the teat with it just as it is being put into the foal's mouth. If it still makes no attempt to suck, the middle finger, after it has been dipped into the milk, should be introduced into the foal's mouth, when it will at once suck it, and thus acquiring the taste of the milk it is almost certain to make use of the teat if placed at once again to its lips.

New cow's milk may be given at first, if the dam yields too little milk, but should soon be replaced with skim milk, which possesses a large proportion of casein, or flesh-forming food, and phosphate of lime, and so is exactly adapted to the growth of muscle and bone. Cow's milk is richer both in casein and butter fat than that of the mare, though it is deficient in sugar. If new milk is continued in use it should have one-third of water added to it, but skim milk is preferable.

The first milk of the mare contains a substance, colustrum, which is of especial service in assisting the foal to pass the focal matter, the myconium, with which it is burdened at birth. The mare should never be milked therefore, except to get the few drops necessary to induce the foal to take to the teat, until the foal has sucked. The myconium should pass away naturally in the first twelve to twenty-four hours after birth, and if this has not taken place within that period treatment should at once be 
alopted. The simplest, and usually most effective, plan is to dissolve thoroughly a small piece of soft soap (about the size of a walnut) in a teacupful of warm water, and administer it as an enema. If this does not at once produce the desired effect give two tablespoonfuls of castor oil, or linseed oil, to the foal.

Some mares foal standing up, and in the case of valuable stock it is advisable for two assistants to hold a horserug in which to receive the foal, as it otherwise may be seriously injured, especially if the mare should kick at the infant when it drops on to the straw. A close watch without attracting the mare's attention should always be kept, but if it is seen that the process is normal, the head and fore-legs appearing first, it is better to leave Nature to herself. If, however, a wrong presentation is made assistance must be given at once, or both mare and foal may be lost. If the under-jaw can be seized a leverage is obtained, whereby the position of the foal can be greatly altered.

Foals should be encouraged to eat crushed oats as soon as possible, and if they cannot reach the manger a small one should be put up close by, which need only be a temporary arrangement. They will then miss the dam much less at weaning-time in consequence; and they must be well fed during the first winter, which is the most important time of their lives. If they begin to look pot-bellied, with rough coats, suspect worms, and give linseed oil and turpentine, according to the directions already given. Dalwood's Worm Powders are also very good, and have stood the test of long experience. These should be followed up by a dose of linseed oil, and afterwards by the tonic powders containing sulphate of iron, the amount given being reduced in proportion to the age of the animal.

Stallions need plenty of exercise, and should be in hard condition to be fruitful. It is frequently noticed how successful travelling stallions are, with all the disadvantages of unskilled assistants, and excited spectators amongst the farm-hands where they visit, compared to 
stallions who remain at home to receive their consorts but do not receive sufficient exercise. The impressiveness shown by certain individuals, usually the male, is well recognised, and when a stallion is endowed with this supreme gift there is a general run upon his services. A good stallion may "make" a district for years, filling the country with good horses, and the pockets of the breeders with money, while a bad stallion may poison the neighbourhood in a similar way. And yet the breeding of the one may be equal to that of the other, while between the conformation of the two there may be nothing to choose! A very necessary point in a sire is nervous energy, and unless he possesses a full share he cannot impart it to his offspring. Without steam an engine is useless! The Spanish proverb that " a stallion, a lover, and a gamecock must have fire," contains a great deal of shrewd common sense !

Statistics show that every year a very large number of mares do not produce living offspring, and the same appears true of all countries. A stallion which can show 52 or 53 per cent. of foals must be reckoned good, and any increase is very good, although some extraordinarily vigorous and prepotent stallions may get practically all their mares in foal, if none but those giving milk are selected for their mates; but it is claimed for the practice of artificial insemination that quite 90 per cent. prove in foal-and certainly with shy breeders it is well worth a trial. It is not recommended to interfere with Nature until a mare has been twice unsuccessfully to the stallion; but when a third visit is paid it is prudent to supplement the service with an artificial insemination immediately after the stallion has performed his part of the ceremony.

Many mares are barren owing to an acid condition of the vaginal mucus, which proves fatal to the spermatozoa supplied by the stallion. It is well therefore when a mare does not hold after the first two services to give her $1 \mathrm{oz}$. of bicarbonate of potash daily in the drinking water for a week prior to the expected service; and half an hour before the 
leap to inject into the vagina a solution of $1 \mathrm{oz}$. of the same, in a quart of tepid water.

The famous summing up of the standard points of a stallion by Dame Juliana Berners, so skilled and observant in all country matters, may here be quoted. They are fifteen in number, and were laid down in 1481.

Standard Points Desirable in a Stallion.

Of a man, bolde prowde and hardy;

Of a woman, fayr-brested, fair of heere, and easy to leap upon;

Of a fox, a fayr taylle, short eeres, with a good trotte;

Of a haare, a grete eye, a dry hede, and well runnynge ;

Of an asse, a bygge chyn, a flatte legge, and a good hoof.

With regard to inbreeding, it has been noted that while a very inbred mare frequently gives birth to excellent stock, when mated with a stallion which bring in a further strain of the same family, though not inbred himself, the converse does not hold good.

An inbred sire should not consort with a mare which inherits the same strains as himself.

\section{Abortion, And Joint EviL.}

From whatever cause abortion may occur it is as necessary to prevent the mare from catching cold, as it is after foaling, and especial care must be taken that the stable is free from draught, as well as being warm. Plenty of clothing, according to the state of the temperature at the time, is also requisite. A weak solution of Chinosol, 1 to 1,000 , should also be injected twice daily into the vagina for a week to wash the uterus thoroughly before it is again closed, and thus destroy any harmful microbes which may be lurking therein. The mare should not be covered again, if the abortion takes place in the autumn or winter, until the ordinary time for foaling has passed in the following spring. If, however, the mare aborts soon after pregnancy, and having been covered early there is yet sufficient time, she may be treated the same as after foaling, and after being duly disinfected with the antiseptic solution, be covered the next time she comes into use, probably about the ninth day. 
Advisable as it is at all times to disinfect the penis of the stallion immediately after covering, it is most important to do so after serving a mare who has recently aborted, lest he carries infection with him to succeeding mares. For this purpose it is not sufficient to inject the disinfectant into the sheath with a syringe. The penis itself must be carefully drawn out by hand to its full length, and then washed with wadding soaked in $\frac{1}{1000}$ solution of Chinosol.

Though the stallion may show irritation at first, he very soon becomes accustomed to the operation, and takes no notice of it.

Joint Evil, till quite recently, has been looked upon as so serious a complaint there was but scant hope of successfully combating it, for even when the foal lived it was quite a wreck. Now, thanks to increase of knowledge regarding microbes and antiseptics, it no longer inspires the dread it formerly did. A mare, whose foal shows symptoms of Joint Evil, should have her uterus cleansed at once with the Chinosol solution, and instead of being covered when she comes into use (about the seventh day) she should have the solution injected daily throughout the period, and not go to the stallion until the next cestrum occurs.

Joint Evil is the term applied to a lameness, which usually occurs with a foal or calf between the fifth and twenty-first day after birth. Since a joint (or joints) becomes greatly swollen and inflamed, the appropriateness of the designation will be conceded. At first the attendant is apt to think the dam has trodden upon her offspring, if he has had no experience of the disease ; but the high fever which is a concomitant of Joint Evil will speedily enlighten him as to the true diagnosis of the attack. It is a dirt disease, and in the vast majority of cases the microbes effect their entrance through the lacerated end of the umbilical cord when severed after birth. It is to prevent their intrusion that the necessity arises of applying a ligature to the navel-string immediately after birth, and of dressing the raw surface with some suitable antiseptic, than which nothing is more useful than the Chinosol solution or carbolised collodion. This should be applied to the whole of the remainder of the cord up to the belly, besides the raw surface of the wound. 
If the malignant organisms effect an entrance the line of inflammation they set up travels to the liver, and thence enters into the general circulation, and so produces an effect upon a joint or joints.

The symptoms of the attack develop rapidly. At first the little patient appears dull, and then a joint begins to swell, becoming hot and painful to the touch. Points then form and discharge pus, high fever sets in, and death generally occurs between the fourth and eight day.

The treatment consists of attacking the original seat of disease with external antiseptics, and injecting others into the localised place of lodgment, the swollen joint, by means of the hypodermic syringe. To carry out the former wrap the umbilical cord in medicated cotton-wool steeped in Chinosol solution, keeping it constantly wet; or paint it repeatedly with tincture of Iodine or Vasogen, the latter being an excellent preparation, not affecting prejudicially the most delicate surface. For injection into the swelling a 4 per cent. solution of Formalin may be employed, using the syringe at a number of different points; or Acetozone may be used instead, with a dilution of 1 in 500 , which is also recommended as a draught, one tablespoonful being given every four hours, day and night. The strength must be kept up by offering milk from the mare in a baby's bottle, having a teat attached similar to those in use for calves. When able to stand again and suck the dam it will need no further treatment; but a little tonic, such as Parish's Food, will be a great assistance in regaining strength.

Extract from the Fourteenth Report of the Royal Commission on Horse Breeding, Oct. 11, 1911.

\begin{tabular}{c|c|c|c|c}
\hline & $\begin{array}{c}\text { Average per- } \\
\text { centage of Foals } \\
\text { left by the } \\
\text { 28 Stallions. }\end{array}$ & $\begin{array}{c}\text { Total Number } \\
\text { of Nares } \\
\text { Server. }\end{array}$ & $\begin{array}{c}\text { Highest per- } \\
\text { centage of Foals } \\
\text { left by any } \\
\text { Stallion. }\end{array}$ & $\begin{array}{c}\text { Lowest per } \\
\text { centage of Foals } \\
\text { left by any } \\
\text { Stallion. }\end{array}$ \\
\hline 1909 & 57 & 1,630 & 78 & 30 \\
1910 & 56 & 1,551 & 76 & 36 \\
\hline
\end{tabular}




\section{CHAPTER IX}

\section{BREAKING YOUNG HORSES}

$\mathrm{O}^{\mathrm{N}}$ the mouth of the horse largely depends his value, and the early lessons he receives are of the utmost importance, for he will recollect them all his life. Breaking a young horse should therefore be a continuous series of progressive lessons, and nothing should ever be done which he will afterwards have to unlearn. The management of the animal should from the very beginning be entrusted to an experienced, capable man, who has control over his own temper; for a person who has to learn what to do, or who is subject to fits of ill-temper, may in a moment put ideas of rebellion into the mind of a high-couraged animal which are never totally forgotten, to combat and to conquer which may canse infinite trouble.

If a foal is judiciously handled from the day of birth there will be little trouble in training it afterwards to do anything that is wanted, and it should be accustomed from the very first day to subject its own will to the wishes of its master. A supple foal's head-collar should be put on at once, so that the little animal can be held by the head whilst the hand is passed over its body, head, neck, and limbs, when it is still too weak and feeble to resist. By this simple means it learns to be groomed and touched in any part without resistance; for though it may kick for a time or two, its blows are of no account, and it quickly learns that it is not going to be harmed, and therefore passively submits to the treatment. This should be done on almost every occasion of going into the stable, and all the feet should be picked up in turn and patted with the hand, in imitation of being shod, when the smith will have no 
trouble when the first shoes have to be put on. A small surcingle may be buckled on occasionally, to accustom the young animal to the pressure of girths, and a rubber tied on, and left awhile, so that when training is commenced in real earnest there will be nothing to cause alarm or to which it has not already been accustomed. The head-collar affords a means of teaching the foal to back, and this should frequently be practised, besides leading it behind the mare when going to and from the pasture, for which purpose the help of an additional man is required for a few minutes daily. But very few lessons should be required before the foal will lead as quietly as a well-broken horse. It should also be taught to stand quietly when tied to the manger, and this is preferably carried out when it is engaged in eating a few crushed oats. The lesson need not be prolonged beyond a few minutes, for it is soon learned and recognised by the foal as being part of life in the stable. Before the first six weeks have passed all the above should have become fixed in the foal's mind as ordinary habits.

When the young animal is taken in hand for breaking, it is usual to lunge it in a circle for some little time, either in a cavesson, or with a rope fastened to a circular bit; and this latter method is the one most usually employed with thoroughbred yearlings, since it gives more control than the simple cavesson. The latter is said to be the invention of Prince Pignatelli of Naples in the sixteenth century, and, as still used in Spain, is capable of being made a most severe instrument. In that country the iron band which passes over the front of the face is used in all its nakedness, and ofttimes has the lower part shaped into teeth, like those of an ordinary rat-trap. It frequently has reins attached, to fit it for use as a bridle in riding and driving, besides its ordinary employment as a lunge with a single rope. In more humane countries the encircling steel. band is well padded and covered with wash-leather, and used solely for the lunge or for leading horses. It is of great value for the former purpose, enabling the teacher to prove to his pupil that it is really mastered, however 
refractory it may be at the beginning; but it should be used with discretion, and not abused. A horse should never be kept circling too long in one direction without being allowed to have a spell in the opposite direction; and much caution should be observed in allowing it to canter, which may easily become a gallop, when there is considerable danger of the animal slipping up and straining itself. Thoughtless grooms are too fond of urging the animal on, without thinking of possible consequences-but then they are not risking their own property! When horses are too fresh, or are given to plunging when first mounted, a few rounds in the cavesson, before being ridden, is an excellent safety-valve for exuberant spirits. When a young horse is commencing his tuition in the ring he should have a special surcingle strapped on, provided with a crupper, and also with side buckles to which reins can be fastened which are made for the purpose and which buckle also to the bit. To the surcingle all kinds of things may be fastened, varying them from day to day-stable rubbers, coloured handkerchiefs, a hunting-whip, or light poles fastened securely alongside, or anything else which may strike the fancy, and which soon accustoms the pupil to have such things flapping about. It is then little likely to be scared in after-life by anything which may happen to it. Now also is the time to let the young one get used to all kinds of noises, and sights - the beating of drums, the blowing of horns, or boys playing at football, or cricket, or other fearsome games. An ox's bladder full of peas makes an excellent rattle, and an accompaniment of a poker and shovel makes uncouth music, not to be despised as a lesson.

Part of the training of the colt should consist of leading it in the cavesson into crowded streets, where it will see all kinds of road nuisances, and taking it to any kind of gathering, or market, where strange sights can be seen, but at the same time where the animal can be kept out of the reach of doing or receiving any injury. It should be well accustomed to all such sights before training under the saddle is begun. Time spent in this manner is never 
thrown away, and as no weight has to be carried the youth of the animal does not matter, and it may be thus led about as soon as weaned.

After a few days' practice with the cavesson the headpiece and rope may be removed, and a pair of long reins substituted, by aid of which the breaker can drive the animal in front of him instead of leading it, and it thus learns to face the dangers by itself. For this purpose there should be a ring sewn on each side of the surcingle, about the height of ordinary stirrups, through which the long reins are passed. This contrivance adds greatly to the power of the breaker, enabling him to lunge the animal with as much ease as if it was guided by the ordinary cavesson rope; and amongst other advantages it prevents the horse from getting one rein over his back when kicking, and so getting both reins on one side. Some horses soon learn that trick, if there are no rings to keep the reins down. It has also another advantage. A restive horse sometimes gets the reins into confusion, but if one rein is slipped over its back, and the horse is then allowed to run backwards until it faces you, a purchase is got against the rings of the surcingle by pulling at both reins, and the horse is compelled to keep on backing, to its great bewilderment. A great leverage is obtained on the bit in this manner, and the breaker can keep the horse backing as long as he thinks fit, following after it all the time. If there are no rings, however, on the surcingle, in such a situation the horse assumes the control of the breaker, which increases the confusion! This is a useful way also of forcing a horse to back when it refuses to do so on the reins being pulled from behind. If the pupil proves very stubborn, and refuses to budge, the trainer should walk in front of it, reversing the reins from the surcingle rings, and then proceed to pull at them with considerable force. If the horse still will not move, the reins should be kept tight with one hand while a whip is flicked at the forelegs with the other, until the horse makes a step angrily backwards, probably snorting and shaking its head as it does so. The process must be repeated until the animal 
will back readily on pressure from the reins, and then it must be made to back by pulling from the rear in the ordinary way. If this is practised daily the horse will soon back cheerfully on the smallest indication.

When young horses have been allowed to run wild until they are three or four years old, and have never been handled at all, they often give considerable trouble at first, and then it is that the system introduced into England by Mr. Sydney Galvayne is of the greatest use. Until his advent Mr. Rarey's method had been the last resort of the breaker, but the disadvantage of his plan was that the breaker had to work as hard as the horse, and was also often in considerable danger. But with Mr. Galvayne's system the horse does everything after being once tied up, and the breaker has nothing to do but look on until the animal has given in. Both methods owe their success to the fact that when a horse is once thoroughly beaten he will, whilst in that state, offer but faint resistance to anything whatever. Both aim, therefore, at the complete exhaustion of the horse, and then at once insisting upon its doing the very thing it fought against at first. The animal submits because it is too fatigued at the time to fight any more, and thus acknowledging itself beaten by the breaker, thereafter looks upon him as its master and does his bidding. Mr. Galvayne's plan is to tie the horse's head to its tail, bending the neck round till the body forms a segment of a circle, and then leaving it to its own devices. As it cannot straighten itself it is obliged to travel in a circle, spinning round and round, exhausting its strength, and getting more or less giddy. As soon as it halts it should be encouraged to recommence its gyrations, and this is a grand opportunity for cracking whips in its face, firing off pistols, and making every possible noise ingenuity can suggest. Whenever it stops to rest a long pole should be rubbed against its legs, its head, and every part of it until the horse will bear being touched anywhere with equanimity; and then a saddle may be put on and girthed, and, if so desired, the rope can be untied, a rider get into the saddle, and the horse led about without any remonstrance on its part. As an addition to the ordinary 
plan it is excellent training for any animal, whilst with a vicious or an unruly horse it is invaluable.

When a long-tailed colt is the subject it is an easy thing to tie the halter rope to the long tail, and so make the animal fast; but with a short-docked horse it is not by any means an easy matter to fasten a rope securely. The simplest way is to attach a small rope to the few hairs which are left on the tail, and then to tie this rope to the halter rope. But no novice will be able to affix a rope to the hair on his own initiative, and very few professed grooms know in these days how to do it either. First of all the short hairs must be made into a plait, and to do this requires especial knowledge, for horsehair is so stiff and slippery it is difficult to get it to remain in a plait. It will only do so when mingled with something else-moistened straw will do, or string, or like material; and hence arose the custom of parading horses for sale at fairs with straw standing out from their plaited tails in ornamental patterns, since they had been brought to the fair attached to side-lines.

To plait the tail the hair must be divided into three locks, the centre one, if possible, containing the most and longest hairs. With each lock two or three straws should be mingled, and then grasping the two outsides with either hand cross first one and then the other underneath the centre one, and then plait in the usual way. When the plait is finished the straw will enable the end to be finished off in a knot, if it is long enough, or else it may be bound with string.

The next thing is to attach the rope to the plait. Place the plait over the rope at least half-way up (Plate XI., Fig. 1), and turning it towards the ground double it backwards so that it secures the rope (Fig. 2); then grasp the doubled plait with the right hand, and taking the left end of the rope, bring it underneath the plait (Fig. 3) and make at least four turns round it, working upwards and drawing tight each lap. To finish off bring the top end of the rope downwards and insert it under the first lap which was made, the end pointing towards the ground (Fig. 4). The long end, C, is then fastened to the halter-rope. 
When the rope is tightened by the animal pulling at it after it has been fastened to the halter, it will be seen that the harder the pull the more secure will be the loose end, while it can be undone in a moment in case of need directly the strain is relaxed. The knowledge how to attach a rope to a short-tailed horse may be of great use at other times, especially when a horse is needed to pull another out of a ditch, for a horse can pull an immense weight by his tail, and there is no fear of his thus being injured.

PLATE XI.

FIG. 1.

A.

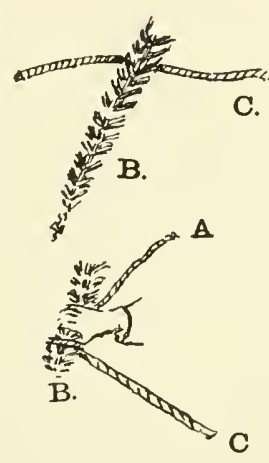

FIG. 3.
FIG. 2.

A.

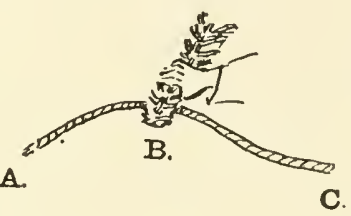

A.

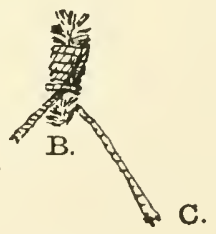

FIG. 4.

Another excellent plan introduced by Mr. Galvayne is the teaching a horse to stand quiet when tied up, without endeavouring to break the rope which holds it, by running back. Many a cunning horse learns this trick, but it remained for Mr. Galvayne to show us the remedy. It is simple enough. The head-rope must be arranged so that it communicates with another rope passing under the tail, and then when the horse endeavours to back its whole weight is thrown upon the tender skin under the tail, which it finds unbearable, and therefore at once steps forward again. After one or two tries nothing will prevail upon the horse to step back again, and in defiance of cracking whips, or squibs let off under its nose, the educated horse remains still and 
passive. A hair rope should be used for the tail, as such a one will not injure the skin as a hempen one does, the latter producing a sore, like the after-effect of a burn, when it frays the skin. After forming a loop round the tail the hair rope is twisted a few times along the top of the back to make it secure, and then one end, which has a small loop, is adjusted to reach as far as the girth-place on the near side. The long end is next passed round the chest, and brought back to and passed through the loop of the short end, when it is secured with a simple knot; it is then taken under the chest, forming a belly-band, and tied securely to the rope on the other side of the horse. If the rope is adjusted with a little care it forms a sort of harness, which cannot be moved by any exertions of the horse from its place however much it struggles. A second rope, having also a small loop, must now be secured to something solid-a strong post, or the trunk of a stout tree, being very suitable. The last process is to pass the halter rope through the loop of rope No. 2, and then to make it fast to the hair rope in front of the chest. The moment the horse runs back the strain of tugging at the stump falls both upon the halter and the hair rope under the tail, but chiefly upon the latter, and as the skin is very tender it is soon borne upon the horse that it is wise to stand still. One lesson is generally sufficient to impress upon any animal, not a confirmed halter-breaker, that when it is tied up it is powerless to resist. As soon as the horse ceases to pull at the stump the rope may be untied from the latter, and then the horse may be led about anywhere, even if it has only just been caught up for the first time, for a sharp tug at the hair rope, and consequently upon the tail, brings home at once to the animal that it is prudent to obey.

\section{To Stand Still in a Fielid.}

All young horses should be taught to stand still, when loose in a field, when approached for the purpose of being caught by a person they know, and the following simple rules will be found quite practical. For the purpose it is necessary that the horse should wear a bridle. 
1. Fasten the bridle to the stirrup.

2. Fasten a long leather rope to the bridle.

3. Allow the horse to go loose in the field to graze.

4. Walk up quietly and get alongside the rope.

5. If the horse walks away put your foot firmly on the rope so that he gives himself a sharp "chuck" in the mouth. Repeat this till he will not move when you go up to him, and when he stands still for you to approach him reward him with a carrot.

6. When he stands quite quiet with the rope fastened to the bridle remove the latter, substitute a head-collar, and fasten the rope to this, and thus gradually proceed till he will stand still with nothing on but a head-collar.

Having proceeded so far the colt should be taught to stay where he is, after being dismounted, by the mere act of throwing the reins over its head. All their horses are taught this by the Boers in South Africa. It is an accomplishment soon learned, and may be of much assistance in the case of a fall out hunting. The Boers attach a rawhide rope to the bit, doubling a portion of it to form reins, and then throw it over the horse's head and allow it to trail on the ground. The horse soon steps on it, thereby giving a chuck to his mouth; and if the rope is a long one the teacher often quietly takes hold of it, and at the instant the horse treads upon it he adds an additional emphasis with the end he holds. The horse is then left to graze by himself, and speedily learns to be very chary of moving about when reins are trailing on the ground. Sometimes a sack is added to the reins, which is still more difficult for the horse to avoid treading upon; and the horse also learns the additional lesson not to tread upon his rider after a fall.

Another plan, which can be adopted with any horse though untrained to stand still, is to pass the reins, both being on the same side, first under the throat-lash, then under the near fore-leg, and afterwards to fasten them securely to the stirrup, the length being adjusted so that the neck and body are bent into a slight curve. The animal can reach down to graze, yet cannot tread upon the reins, which are protected by the throat-lash; but it 
cannot raise its head higher than the fore-leg will permit, and is obliged to move in a circle, owing to the curve in which it is bound. It may therefore safely be left where it is for hours if need be, as the writer frequently has done in the middle of the great bustard plains of Spain.

\section{How to Knot Reins.}

It is very important to know how to make a knot in reins so that they will not become untied, and there is only one knot which can be depended upon to stand any amount of friction. When the right length has been arrived at two turns of the reins must be taken around two fingers, and then the end of the reins passed through the double loop and drawn as tight as possible the buckle end being toward the rider. Nothing can disturb this knot if well made, and this is the right way to knot the reins when riding a very hard puller in a race.

\section{SIDE-LINES.}

By the help of side-lines twelve to fifteen horses can be travelled by one man, thus saving labour and expense, and formerly, before the days of railways, it was the invariable method of taking dealers' lots from one fair to another. It might have been of much use during the Boer War-but the War Office officials knew not what side-lines were, and did not care to learn. Every cavalry soldier should be taught the method, for the amount of men required to exercise or move horses on a campaign can be reduced to a minimum.

Side-lines consist of hempen loops, made for the purpose, with long ropes attached to them. A loop is passed over the neck of a horse, resting upon its shoulders, while the rope is fastened to the plaited tail in the manner already described, the length being first adjusted so as to allow for a certain amount of play from the loop round the neck; and enough laps are then made round the tail to use up the rest of the rope. The halter of each horse is fastened near the middle of the side-line of the horse in front of it, so that its 
nose cannot reach further than about a foot in front of its leader's hip. The length of rope allowed to the halter is about a foot and a half, which gives sufficient freedom to step over inequalities in rough ground, while it does not allow the horse to drop behind the other's tail. Fastened together like this the horses give the appearance of a living chain, and can travel over the roughest moorlands just as well as over smooth roads, and are compelled to follow in turn the footsteps of the leader. The man in charge rides the horse in front, who should be the most unruly animal of the team, while the quietest animal is placed last of all. Horses hardly ever try to kick in side-lines, and are, as a rule, very quiet. 


\section{STABLE MANAGEMENT}

\section{FOOD AND WATER.}

THE first necessity, after having obtained a horse, is to 1 look after its wants in the way of food and water. Here, at the very outset, the tyro may easily go wrong, with mischievous results, if left entirely to his own devices. It will probably never occur to him that it can matter in the least whether the animal takes food or water first, and it is far from improbable that in mistaken kindness, if he thinks on the matter at all, he will suppose since hay and corn must be such dry food to eat, it will be pleasanter to have the water afterwards, to give the meal "a good wash down." It is what he would, no doubt, treat himself to if placed in a similar predicament, and yet he could not do a worse thing, or one more likely to bring on colic, or similar internal trouble. The horse having such a very small arrangement for a stomach, it is necessary that the digestion should be proceeded with after it has passed on into the intestines, and for this reason it must not be unduly hastened during its passage downwards; but if a big draught of water is suddenly poured into the masticated mass this is hurried onwards before it is sufficiently ready, and then Nature resents the undue interference with her arrangements.

It is different if water is always present, and the animal can help itself when it pleases, and this is far the preferable plan-though not always convenient to carry out, besides being opposed to the prejudices of untutored stable-helpers. When a horse can drink at any moment it likes it never 
takes more than a few swallows at a time; nor does it, as a rule, imbibe so much liquid in the twenty-four hours as when water is only supplied in a bucket twice or thrice a day. Some animals also take strange fancies when the water is always there, and one horse in the writer's possession would never begin to eat his corn until he had set it all floating in water, which he used to swill out of the water-trough into the adjoining manger with repeated sweeps of his muzzle; whilst another, a mare, was accustomed to take large mouthfuls of corn and drop it into the water-trough, and then to pick it out again and munch it at leisure, in evident enjoyment. The small amount of fluid thus taken never did any harm, nor caused any trouble, so the animals were allowed to gratify their fancies as often as they pleased.

The next question the new-fledged owner must ask himself is whether the water should be warmed or cold; and what kind should be given-stored up rain-water, or from a pond, or water from a well or tap. The answer to the first is that the water should have the chill off if given to a horse in a state of rest, as in a stable, or when very tired. It should be borne in mind that there is more risk in giving very cold water to horses in such conditions than when the circulation is still excited from exercise, the extra heat apparently raising the temperature of the water to that of the body, though the risk of a chill is still present. Even when engaged in hunting it does no harm if a horse is allowed to just wash his mouth out from any pond which may be handy, although it may be almost at the point of freezing, but the amount allowed must be very limited, and the writer for quite forty years has never permitted an animal under such circumstances to drink more than half a dozen swallows, carefully counted. As no evil results have followed in any single instance with this strictly limited regime, and the relief to the horse is very great, especially in the case of animals who suffer from excessive secretion of saliva, which after severe exertion is apt to become very saline, the practice of allowing a horse to wash his mouth out can with confidence be recommended. A valuable hint 
may also be added, which the writer learned when living in Spain in the early "seventies," and this is never to allow a horse to drink at once when crossing a ford, but, regardless of how thirsty he may be, and his strenuous efforts to drink, to force him onwards until he has nearly arrived at the other side. The reason is that many a horse will lie down and roll in the water, to the peril of the rider, if allowed to put his nose down on first entering the stream, and will make no effort to drink until he has had his roll. If, however, he is made to travel on without halting almost to the other side, he is so afraid he is not going to be allowed an opportunity of quenching his thirst that he will begin to drink the moment he at last has the chance, and will then never attempt to roll at all.

In hot weather, when the water is almost warm, a horse may be allowed a good drink if he is only going to proceed at a walking pace; and also when nearing the end of a march or approaching a camping ground it may be convenient to water the horses before reaching the haltingplace; but under such circumstances, if the water is cold, the horses should be kept moving for at least half a mile afterwards, and a short trot at a slow pace will also assist in preventing any sudden stagnation of the circulation, through the chill caused by the cold liquid admitted into the system. It is a common plan when water is drawn from a pump or tap, and is very cold, to fill the stable buckets some hours before the drinking-time, and allow them to stand in some warm place to attain the temperature of the surrounding atmosphere. Very frequently they are placed in the stable itself, and if each bucket has a light close-fitting covering thrown over it, such as a clean stable duster, there is no harm in the custom. Without this precaution many deleterious germs and microbes may be attracted by the water, for there is always dust floating in the air of a stable, which may be germ-laden, and there are often also noxious exhalations.

When water is suddenly required, and the source is known to be very cold, it is generally possible to arrange for a small supply of hot water from a kettle or hot-water tap, 
and enough may be added to take off the extreme coldness of the water. In this manner almost any cottage can supply a drink to a tired and thirsty horse after a severe run, when no gruel can be obtained for its refreshment.

As to the kind of water for permanent use, it should be soft rather than hard, and this so accords with the tastes of the horse that he will drink indifferent soft water in preference to good hard water; but if the choice is to be made between good and bad soft water, he is sufficiently a connoisseur to prefer the former. Hard water contains a number of mineral salts, some of which may be prejudicial, and when no other supply can be obtained these constituents may be somewhat precipitated by boiling. Water drawn from tanks or reservoirs, which are fed by the rainfall accumulated on roofs, should never be used unless boiled and filtered, especially if the roofs happen to be of thatch. In dry weather birds are certain to sit about on such places, and contaminate them accordingly, and when the first flush of rain occurs much deleterious matter is swept into the receptacles used for conserving the rainfall. The writer has known a very serious outbreak of fever occur in a large racing establishment from this cause, since the water from the roofs had found its way into a well which supplied the water for a particular set of stabling; and it was the animals there domiciled who alone were stricken with the illness which broke out at the end of a prolonged drought.

Since horses are susceptible to a change of water, more especially if it is to hard water after being accustomed to drinking soft, they should be closely observed whenever a change of locality takes place. When their charges are engaged in a very important race some very careful trainers bring a sufficient supply from their own stables, if they are not satisfied with what they are likely to obtain in the neighbourhood of the race-course; and if water was not such a bulky article, perhaps this would be a still commoner practice than it is now. Moreover, water requires to be very pure not to suffer ill-effects from the shaking on a long journey, especially if it has to stand for two or three 
days before being required, and the safest plan undoubtedly is to boil it after arrival, and thus destroy the power to do harm which any germs lurking in it may possess. My attention to the possible deleterious qualities of water was aroused very early in boyhood, for when my father moved his establishment to the moors for grouse-shooting, the carriage-horses which went with us were much upset. Being of an inquiring turn of mind, I wanted to know what was the matter with them, and though this occurred more than fifty years ago, I well remember the very capable groom in charge telling me it was the hard water they had to drink which was temporarily affecting the health of the horses. Since those far-off days there have been very many opportunities of noticing similar little outbreaks.

A much more serious illness used to attack horses when they first arrived on the Rock of Gibraltar, when I was quartered there with the Rifle Brigade during the "seventies," and some animals took many months before they became inured to the evil. The symptoms consisted of violent attacks of colic, with a very quick pulse and a high temperature, and an utter inability to pass any urine, though constantly straining to thus relieve themselves. At first I used local remedies, of which the most popular was the administration of a strong decoction of camomile flowers; but before long it occurred to me to test the efficacy of aconite, and this proved so successful that it soon came to be my sole remedy, and never had I cause to repent of ny reliance upon it. Frequently within twenty minutes of the first administration a horse would get relief, and the moment Nature was relieved the animal recovered so fast it could resume its ordinary routine of work almost immediately. I do not think any animal continued to suffer more than two hours after the first dose of aconite, whilst under the usual treatment it was no uncommon occurrence for the spasms to last for one or two days. Other remedies may have been found since those distant days even better than this, but as it certainly had an excellent effect, it is well worthy to have its merits recorded here. There was then no veterinary surgeon at Gibraltar, so we all had to rely upon ourselves, 
and requests for advice, by strangers as well as acquaintances, were pretty frequently made to me. One that gave some amusement afterwards, when I came to know the "ins and outs," may be related. The Surgeon-General, who stood very high in his profession, but who had only lately come to Gibraltar, and whom I had not then met, one day sent a polite little note saying that his horse was so ill he was afraid it must aie; but as it was a favourite, he would be very much obliged if I could suggest any treatment. As I had little doubt in my mind as to what the nature of the illness was likely to be, I put a small bottle of aconite into my pocket, and proceeded in quest of the sick animal. On arriving at the stables the owner was present with one or two friends, anxiously awaiting my arrival, and I at once proceeded to examine the patient, who appeared to have got over the worst, and in this opinion I was confirmed by the groom, who was indeed rather unwilling for me to intervene, as he wished to prove that his own remedies were fully sufficient. However, the pulse was still high, and my favourite remedy would at any rate expedite matters, so I turned to the Surgeon-General and requested permission to give a dose to the horse. $\mathrm{He}$ at once acquiesced, though it struck me he did so rather unwillingly, and I could see by the covert smiles on the faces of the bystanders that some mystery was behind the scenes of which I was ignorant. Now, for convenience chiefly, I generally used the homoopathic tincture, so taking the little bottle out of my waistcoat pocket I stepped up to the horse, opened his lips, and poured ten drops on to his tongue out of a tiny minim measuring-glass. After keeping my finger almost constantly on the animal's pulse for the next ten minutes I gave it a second dose, and soon noted the beats were becoming nearly normal. " He is better," I then remarked, leaving the patient, and going up to the group who were watching the proceedings, "and will soon be all right." "How do you know that?" exclaimed his owner in a tone of great surprise. In reply I stated I had noticed the symptoms were improving; that a mash should be given to the horse as soon as he would take it, which would probably 
be before very long; and that another dose, which I would leave, should be administered in case there should be any return of the complaint; and having ended the directions I began to prepare to take my leave. "But surely you are not going to leave the horse yet!" exclaimed the owner, much perturbed in his manner, and evidently thinking he was going to be left in the lurch. "On," I replied, "I will not go before I have seen the horse stale, which he will do directly, and then there will be no more trouble to be feared;" and hardly were the words out of my mouth than the horse stretched himself out, and there was no need left for me to remain. Surgeon-General — literally gasped with astonishment, and seemed quite nonplussed, so after shaking hands with him and congratulating him on the improved condition of his favourite, I was just about to depart when he suddenly ejaculated, "But you have not told us what the horse is to have to-morrow!" "Give him his ordinary food," I replied, " and let him do his work as usual, unless there is any return of sickness, which is not the least likely," and then I went away. On inquiring at the stables the next morning I found that everything had gone on satisfactorily, the horse being then out at exercise; and the Surgeon-General spread everywhere the (to him) marvellous cure which had been wrought so speedily.

A few days afterwards came an amusing enlightenment of what had taken place previous to the request being made to me to advise as to the treatment of the horse. It appeared, from the statement of a friend high up in authority, who had been the counsellor who had advised application being made to me, that the owner of the horse was most prejudiced against homøopathy in any form, declaring it utterly indefensible, and had set his face against it all his life in every possible way; and when he was told that I should almost certainly rely upon the detested practice, he at first refused to listen to his adviser. Fear of losing his favourite, however, at length prevailed, and conquering his prejudice he had eventually been persuaded to seek my advice. "You must not be surprised," our mutual friend had then mischievously 
added, "if he produces his remedy ont of his waistcoat pocket!" And so when his words proved only too prophetic the Surgeon-General had winced in the manner I had noted, and the others in the secret were highly amused.

Whilst water in general is often the vehicle for conveying unwelcome internal parasites, pond water is frequently responsible for the introduction of leeches into the mouth, especially in hot climates. They ensconce themselves mostly under the tongue, and if not removed cause great discomfort to the animal, though their presence is not always suspected by an unobservant groom. They also insinuate themselves into the nostrils, and in either locality frequently only betray themselves by the trickling down of a thin stream of blood, which issues after they have gorged themselves with a meal. Persons unaccustomed to such visitations are apt to think a blood-vessel has been broken, but on any such occurrence taking place it is well to institute a close search, when a black-looking body may be detected. Often this is minute, if the leech has not lately been indulging itself, though when gorged with blood it is easily seen. The simplest way of removing the pest is to enwrap the fingers in a handkerchief, or something similar, which enables the operator to obtain a firm grasp of the intruder, and then a sudden twitch should be effective in ejecting it from its hiding-place. Caution and skill, however, are very necessary for the due accomplishment of this apparently simple process, for if the leech should be in the least alarmed it will bury its head in the roots of the tongue and offer such resistance that its expulsion can only be effected with difficulty, while the tearing it away from its hold may result in a sore place being made in the horse's mouth. Occasionally it is even advisable to defer the operation and to endeavour to take the leech unawares on a subsequent occasion. When no hitch occurs the leech can be removed with ease, and the writer has thus extracted these pests on many occasions, sometimes in the stable, but more often in the course of a ride; and it may be mentioned that it is frequently a person riding alongside another 
who gives the first notice of the presence of a leech, as he it is who is in a position to notice the stain of blood in the mouth of the horse of his companion.

Leeches are more difficult to remove from the nostrils of a horse, as they are troublesome to reach if they are located some distance up; but fortunately it is not so common for the intruders to locate themselves there as in the mouth, and it is more usual to find them in the nostrils of cattle than of horses. Indeed, the writer has never personally met with a case of a horse having a leech in its nostril, and therefore he never had an opportunity of testing a native plan for extracting them. This is to keep the animal for a considerable time without water, and then to place a saucerful close to its nose but not allowing it actually to touch it, when it is said the leech, being in want of sufficient moisture, will partly emerge from the nostril in an endeavour to reach the water, and may then be suddenly plucked away. Whether this is the case or not, if the emergency arose, it would be a remedy at any rate worth trying.

The principal points, then, in watering horses may be summed up in the following:-

Water horses before feeding them.

Give soft water in preference to hard.

Take the chill off if the water is very cold.

Let water always be present if it can be arranged without inconvenience.

\section{Forage.}

The next item to consider is the forage, and in this is included not merely hay and corn, but also the extra adjuncts of linseed, bran, carrots, and sundries, which not only tempt the appetite but also tend largely to the promotion of health. Although straw has considerable feeding value it is comparatively little used in this country, and when it is given it is generally chopped fine and mixed with hay treated in a similar fashion; but in Southern countries it is used almost entirely, the reason probably being that hay is seldom made, for grass is too precious a commodity for grazing stock to be preserved in the form of hay. 
Wherever hay is a common article it is generally used instead of straw, a very excellent provender being thereby neglected. In Spain barley straw is commonly given, being the most easily obtained, and though when the writer first began to train English thoroughbreds in that country he went to the expense of importing bay for them from England, he soon found that they throve as well upon chopped straw when once they became accustomed to the change of diet. How fond horses are of eating straw every one is well aware who has ever had to do with a stable, and it is rather a curious fact that they generally seem to prefer dirty straw to perfectly clean litter. Whether this comes to pass from a craving for salt, which they thus appease by eating urine-stained straw, has frequently crossed the writer's mind, for it seems very probable.

Although it was really impossible to decide the question for certain, it was generally believed that horses throve better on wheat straw than on barley straw when doing fast work, and an effort was always made to obtain the former whenever practicable.

It must not be forgotten that a certain degree of bulk is necessary in all food, in order that the digestive organs may work properly, and this is one reason for giving hay or straw, in addition to the nutritive qualities they possess. During working hours food of less bulk may be given, such as corn of some description, as it interferes less with the breathing organs, but a certain amount of bulk the horse must have at some time or other, and the best time for giving this to hard-working animals is at night, when complete rest is afterwards assured.

A horse should never be fed or watered just before working it, but if a choice must perforce be made between a steed which has just been watered, or one which has just been fed, it would be likely to cause less injury to the animal to take the former than the latter. The water will soon pass out of the stomach and be absorbed into the system, whereas the food will remain undigested for a length of time and press injuriously upon the breathing apparatus, culminating probably in broken wind. 
Careful investigators have established the fact that all food does not take the same time in going through the different stages of digestion, and it is stated that hay and straw pass out of the stomach quicker than corn at the beginning of the process, though towards the end it is just the contrary ; it is, moreover, also asserted that if a mixture is given of oats and hay chaff the one which contains the most moisture will pass into the bowels first, carrying the remainder along with it, although the latter is not sufficiently ready, and this is a fruitful source of derangement of the system, even if it does not go so far as to cause actual indigestion. The soundness of the ordinary stable routine of giving the oats first, and then the hay, is thus borne out by the dictum of scientific observers, since the former requires a longer period for digestion than the latter, so that both should be ready to pass on at the same time in an equal state of preparation.

At least an hour should intervene after feeding before a horse is called upon to work, and if this is likely to be severe the food given should be of a concentrated nature, and not bulky. When an animal returns to its stable very tired it must be remembered that the organs of digestion are as fatigued as the rest of the body, and a light, easily digested meal should be at first given to him. This principle should be kept in mind, for it is not possible always to have at hand the carefully prepared gruel and bran mash which await the tired steed in all well-ordered hunting stables on its return home from its labours.

Whatever the system adopted, whether three feeds or four feeds of corn are given in the day, it is most essential that regular hours should be kept, unless, of course, actual work prevents the ordinary routine from being carried out. Whether it is advisable to divide the allowance into three, or four, feeds depends much upon the constitution, appetite, and ability to digest one feed before the next is due. Delicate horses will probably benefit by being fed at shorter intervals, with a less quantity at a time, so as not to overload the stomach, whilst hearty feeders can do with more grain at each feed, and a corresponding longer wait between 
meals. The desired point is that the manger should be quickly cleared out, and it should be an inflexible rule that during the daytime any corn left, after a reasonable time for consuming it has passed, should be removed, for nothing is more prejudicial to a delicate appetite than the presence of undesired food constantly staring it in the face. There are some horses, however, who eat but sparingly during the daytime, but make up for it in the night, if given the chance. Such animals may be so far humoured as to have an extra quantity of corn given to them at the evening feed, and if this is all eaten up by the morning it is a guide to follow in their particular case.

When three feeds of oats are the rule the daily routine in a hunting stable is as follows, with, maybe, slight variations to suit different conditions in individual stables:-

\section{Daily Routine for Horses going out early to Exercise.}

A sup of water the first thing, but only a few mouthfuls.

6 a.m. A feed of oats.

Whilst the horses are consuming this the men do various odd jobs about the stables and get their breakfast.

Exercise, but not before an hour has elapsed after the feed of corn.

Water the horses immediately on their return; and then

Dress them over. Immediately this is finished give them

Hay.

12 noon. Feed of corn.

5.30 p.m. Evening stables.

Water.

Feed of corn.

Hay.

If it is more convenient to exercise the horses late in the day they receive their full amount of water at 6 a.m., and then the feed of corn and their hay. At 11.30 a.m. the second feed of corn is given them, and at evening stabletime they get water, corn, and hay the same as the others.

On hunting mornings those going to take part in the day's proceedings should only be given the early sup of water, and, of course, no hay until their return in the evening. If they finish up quickly the early feed of corn, a small quantity more may be offered them at 8 o'clock. 
On return from hunting horses are naturally very thirsty, and should have a bucket of gruel given to them made with linseed, wheat flour, or oatmeal. Animals which are apt to be loose in their bowels need gruel made with wheat flour, which is something of a binding nature; but as a rule the reverse is the case after severe exertion, and consequently the need for linseed or oatmeal gruel is thereby indicated, preferably the former. Whenever oatmeal is used for gruel care should be taken that it is made from old oats, and particularly that it has been well scalded with boiling water, if there is not time for it to be actually boiled. Neglect of such precaution may set up violent diarrhoea, and for this reason it is always wise to have some wheat flour added to a drink of water, when obtained at a cottage on the road home after a severe run, and eschew oatmeal for the purpose. It may be pointed out that when wheat flour is employed it is necessary to mix it first with a little cold water, and then add hot water afterwards, for if the latter is poured upon the flour it makes it into paste, which will not mix properly or become gruel.

After the gruel has been given, and whilst the horse is being dressed, a lock of dry hay may be allowed, the mastication of which will promote a flow of saliva; whereas if the hay was given wet, or even damped, it would probably be swallowed after a twist or two with the tongue, and scarcely be chewed at all; but just one carrot in addition to the hay is very much appreciated, tends to quench any undue thirst, and also has a slight influence on the action of the kidneys. As soon as the body has been dressed a bran mash should be given, the hay placed in the rack, and then the horse should be shut up and left to rest in peace.

By the term "corn" it is universally understood in the British Islands that reference is made to oats, when the provender of horses is under mention. In other countries this is not necessarily the case, for in the greater part of the world oats, though undoubtedly the best grain for horses, are difficult to obtain, and maize, or barley, gram, or lentils form the corn diet of horses in those regions. Lentils are especially valuable for young growing stock as well as for 
working horses, Sir William Roberts, the great authority on food, pointing out that they contain twice as much proteid (flesh-forming) matter as wheat or oats, and nearly twice as much lime, so their use in promoting the formation of bone is of great value. They are also very rich in iron. There is a prejudice in England against giving any grain but oats, beans, and peas to animals engaged in fast work, but this is not altogether justified, and many a horse might benefit in his health if allowed a change in this respect. Horses which are not thriving may well have the experiment tried, and many seasons ago a stud of six horses belonging to a hunting and hard-riding doctor, with a large country practice, did particularly well when their owner substituted maize for their provender instead of oats. It was at first given to an unthrifty animal, which was also in a weak state and unfit for the work required of it, but in a short time there was such a marvellous change in appearance and spirits, and also in the capacity for work, that the doctor at once tried the same diet for the remainder of the stud. One and all throve upon it, though, since they had been in good working order before, there was little alteration in their appearance.

Both maize and barley are more fattening than oats, but, especially the latter, are more heating, and therefore more easily upset the digestion, so that it is not advisable to give a similar quantity of either, as of oats. Whatever the allowance may be it should be at once reduced and a bran mash given, with a little sulphur added to it, directly a disagreeable flatulence is noticed, or worse results may ensue. Animals daily doing hard work can consume with benefit a larger quantity of corn than when comparatively idle, as is well shown by the Government rations for troop horses, which are usually $10 \mathrm{lbs}$. of oats, $12 \mathrm{lbs}$. of hay, and $8 \mathrm{lbs}$. of straw per diem (the last being used for bedding only); but when the duty is severe, or when the horses are in camp, from $2 \mathrm{lbs}$. to $4 \mathrm{lbs}$. additional oats are allowed. Even this is frequently not enough under the extra work they are called upon to perform, as a captain of a troop often knows only too well. It is not an unknown practice, when field opera- 
tions are in sight, to reduce the ration of oats whilst the horses are doing very little work, the amount saved being kept as a speciai reserve to be added to the rations, when the hard work requires more than the Government serve out.

The amount a hunter will consume does not depend entirely upon the size of the animal, but rather upon its constitutior and appetite. As a general guide, it will consume about $14 \mathrm{lbs}$. of oats and $12 \mathrm{lbs}$. of hay, the real measure being what it will eat, and few will continue to consume $16 \mathrm{lbs}$. of oats. It is a good plan to chop up about $4 \mathrm{lbs}$. of the hay and mix it with the corn, as this causes the animal to masticate the grain more completely, if the oats are not crushed. When horses grind their corn thoroughly it is better to give the oats whole, as the promotion of saliva is thereby encouraged, but the droppings should be closely observed, and if undigested oats are seen in them they should be crushed accordingly. When taking their turn regularly in the hunting-field a double handful of old beans or peas, which should be split, may be given daily, either in addition to the usual allowance of corn or in substitution for about 2 libs. of oats. Carrots should be given, a daily allowance of $1 \frac{1}{2} \mathrm{lbs}$. being not at all too much, and twice a week a bran mash with linseed gruel added to it.

For carriage-horses doing light work $10 \mathrm{lbs}$. of corn and $12 \mathrm{lbs}$. of hay should suffice; in some cases $8 \mathrm{lbs}$. of corn and $14 \mathrm{lbs}$. of hay might be found sufficient, in which case it should not be exceeded. Dray-horses, which work hard every day for a number of hours and have a very large bulh to maintain, can consume $18 \mathrm{lbs}$. of oats, a pound or two of beans or peas, and 18 libs. of hay ; whilst smaller horses, such as tramway horses, should have $15 \mathrm{lbs}$. of oats, $1 \mathrm{lb}$. of beans, and 15 lbs. of hay. When maize was cheap in comparison with oats, as was the case some years ago, tramway horses were chiefly fed upon it instead of oats, but with either grain a total of $16 \mathrm{lbs}$, including $1 \mathrm{lb}$. of beans, was the usual ration. Wheat is unsuitable for horses, the germ being of an oily, viscid nature, which appears to interfere with the digestion of the animal. It contains the gluten, of such inestimable benefit to children, and mankind in general, 
when the flour is cooked before it is eaten, this process rendering it capable of being digested. Parching the grain appears to have a similar effect, and this should always be done if necessity obliges horses to be fed upon wheat. It is this viscid property which renders wheat flour so useful in making paste, and is also the reason why such flour must first be mixed with cold water, and the hot water added afterwards, when making it into gruel. Such, however, is not the case with oatmeal, which should be scalded with water as near boiling as can be procured, if there is no time actually to simmer it in a pot.

When a change is made from oats to maize or barley, and the horses have never previously been accustomed to the new grain, it is well to make the change rather gradually and to mix the maize or barley with oats for a few days. Moreover, particularly with barley, it is prudent to soak the grain at first and let it swell before giving it to the horse, gradually adding dry grain as the animal becomes accustomed to the change, for the swelling of the grain inside the animal is very upsetting to the digestion when not used to it.

In Spain the race-horses were always fed upon barley, and seemed to get as fit upon that as when fed on hay and oats. They put on flesh more rapidly than when fed in the usual fashion, and some horses certainly carried much more than we had ever been able to get them to do before when fed upon oats.

\section{HAY.}

The quality of hay is most important, especially as this forms such a large proportion of the food. Not only must it be well saved, but the locality in which it is grown has a great deal to do with the herbage of which it is composed; and so also has the kind of top dressing that is used, and hence the condition of the land. The formation of the bony skeleton, and also the production of milk, make large demands upon the land when grazed by young stock of any description, by dams who are suckling, and by milch cows, for little of the lime contained in the grasses is returned in the animal wastage, but is retained instead for their interior economy. 
It is most important, therefore, that this should be artificially replenished, either by manuring with some form of lime itself or with some substance largely containing it, of which an economical and favourite vehicle is basic slag; while ordinary farm-yard manure can also supply a small quantity, which is contained in the straw when ordinary litter has been used. Hay grown on land deficient in lime is wanting in one of the most essential elements it should possess.

The best hay is known by the fineness of the stalks and leaves composing the herbage. It should be of a green colour, and contain clover, the meadow grasses (Poas), rye grasses (Lolium perenne), sweet vernal (Anthoxanthum odoratum), crested dogstail (Cynosaurus cristatus), meadow fescue (Festuca pratensis), foxtail (Alopecurus pratensis), and some rib-grass (Digraphis arundinacea). When such grasses are recognised it is at once known that they have been grown on the uplands, and they are also certain indications of the presence of lime. 'The cocksfoot (Dactylis glomerata) is a valuable grass, in that it is always growing during the wintertime in the large tussocks it produces, thus affording a precious bite of young grass when all others are at a standstill; but it makes coarse hay, more suitable for cattle than for horses doing fast work, as there is a large bulk of woody fibre in its composition; and since it gradually diminishes, and even dies out, when pastures are well limed, the presence of a large quantity in hay points to the probability of there being a deficiency of lime. The meadow catstail (Phleum pratense), an excellent grass in itself, and often sown in conjunction with clover and Italian rye-grass as a farm crop, likewise disappears when the fields are well limed.

The presence of meadow soft grass (Holcus mollis) and of Yorkshire fog (Holcus lanatus) are most undesirable, and although occasionally occurring in upland pastures, show a want of condition in the land and a lack of drainage.

Lowland hay, from swampy ground, is known by the coarseness of the stalks and the absence of herbage characteristic of the uplands. It should not be used for horses, but given to the cattle.

Hay may be composed of the finest grasses, and gathered in 
brilliant sunshine, but may still be of little feeding value, and horses will not eat it unless forced by hunger. The reason is that it was so withered by the sun that there was not sufficient juice left in it to make it sweat properly, and it will feel quite soft to the touch instead of being crisp. To " make hay while the sum shines" is one of the wisest saws in farming, but in this, as in everything else, one may have too much of a good thing.

This is the more likely to occur when the grass is left so long before it is cut that it has ceased flowering, and the process of forming woody fibre has commenced, when the hay is practically half spoiled before it is even cut. Illadvised farmers sometimes do this, thinking thereby to increase the quantity, not realising that grass, like ordinary plants, grows no more as soon as it flowers. Others do it to save labour, for it does not take so much time and trouble as when the grasses are full of sap; but it is in this latter condition that the primest hay is made, for all the sappy portions then properly ferment, the saccharine matter is formed, and hay gains that sweet perfume so characteristic of it when first-rate.

All the different grasses flower in due succession, it making no difference whether the season is early or late. The time to catch the grasses at their best is when the early ones have ceased flowering but have not yet turned into woody fibre, while the bulk of the rest are in flower, and therefore will not grow any more, and only very few remain which have not yet bloomed. The most favourable tinie to cut the grass is when the crested dogstail is in full flower, and as a kind of "patent indicator" it is of the utmost value to the farmer. If the weather is then settled, the glass rising, and the wind from a favourable quarter, he may set about hay-making with a light heart, knowing he should secure the crop at its very best. The dogstail is one of the later grasses in flowering; the foxtail, the cocksfoot and the sweet vernal are already almost over, but their stalks are still full of sap, and have not yet commenced resolving themselves into woody fibre; the meadow grasses, the rye-grass, and the fescues are now in full flower, 
the bulk of the undergrowth is already fully developed, and the only essential required is that it should be hay-making weather! Unless that important condition is fairly assured it is very unwise to try to make hay, for badly-gotten hay is fit only for bedding. If there is a prolonged spell of fine weather before the dogstail blooms it is wise to take advantage of the opportunity, for though the quantity of hay may be less, the quality will be first-rate. Also if there is a period of wet weather when the best time for cutting has arrived, hay-making should be put off till fine weather once inore sets in, for though the quality of the hay may not be as good as it might have been, well-got hay has a high feeding value, even though there is a considerable amount of woody fibre amongst it, but ill-made it has no value at all. Hay should never be put into stack when wet, for this invariably develops mould, which, even if horses can be induced to eat it with the help of an addition of spice, is very prejudicial to their wind. In fine weather there is often too great an anxiety to get the hay into stack, and it is put up too green before it is properly saved, and therefore sweats too much, which is known by its dark appearance and peculiar smell. Horses are fond of it in this state, but they should not be allowed to gratify their taste, for it has a a powerful and bad effect upon the lidneys.

'The presence of the flowers of the grasses in their natural colour is very desirable in new hay, though this is slightly lost in sweating, as they show that the hay was cut at the right time, and if the hay itself is green, with an agreeable odour, and is crisp to handle, it may be bought with perfect confidence.

Many people prefer hay made of red clover and Italian rye-grass, and, if first-rate upland meadow hay cannot be procured, it is very good and certainly to be preferred to second-rate hay; but the advantage of the mixture of fine grasses contained in the best meadow hay can never be equalled by clover hay when both are of the best quality. Clover hay makes an excellent change, and is of especial value in tempting the appetite in the case of illness.

In some of the colonies hay is made from oats just before 
they ripen, and is fed to horses and cattle, straw and grain together as if they were ordinary hay. 'There is much feeding value in this mixture. The time to cut the crop is when there is still a suspicion of milkiness in the middle of the grain when it is squeezed, just before the stems have begun to change colour. It is made into hay in the ordinary way.

\section{Bran Mashes.}

Bran mashes are an essential item, especially after hard work and for sick horses, and in the former case may be given with advantage twice a week, cooling the blood, keeping the bowels open, and counteracting the constipating effect of highly concentrated food. Bran mashes are best prepared by well mixing the feed of oats with the bran in a bucket, stirring the mass with a thick stick, which should be kept for the purpose. Linseed gruel should then be added which has been kept simmering for at least two hours, and has become a thick gruel, and the whole must be again well stirred. As soon as the mash is thoroughly mixed, either a cloth should be thrown over the bucket or a handful or two of dry bran spread on the surface, either of which will serve the purpose of keeping the heat in, so that the oats swell and burst, and are thus more easily digested.

\section{MINerals.}

Salt is so important to the well-being of every animal * that it ranks with lime as a necessity, and should be either given in the form of rock salt, and placed in the manger for the horse to help itself as it pleases, or a small quantity should be added from time to time to the bran mash. Salt is a constituent of the serum of the blood, preventing it from decomposing; ; and from it also is derived the muriatic acid required in the digestive process.

Iron is required by the red corpuscules of the blood, and sulphate of iron is a very valuable tonic. Iron is largely contained in plants, especially in watercress, and as horses are particularly fond of this dainty it is a convenient way of

* Except dogs and pigs, to whom it is prejudieial. 
administering iron where watercress is abundant, as it frequently is. Old race-goers may remember how his trainer made quite a transformation in Kaleidoscope, converting him into a robust, thriving animal, instead of being the reverse, and so won with him the Lincolnshire Handicap, and this success he largely attributed to the free and daily use of watercress.

Other minerals which help to build up the body are phosphorus, needed for the bones, the brain, and the nervous system generally; and a small quantity of sulphur, than which there is no more valuable drug in the whole of the pharmacopœia or one more neglected. "No doubt," once remarked an eminent veterinary surgeon to me, "if sulphur was a guinea an ounce, instead of being as cheap as it is, it would be held in proper esteem and valued accordingly, and then we should use a lot of it." Sulphur purifies the blood, and is a valuable aid when the digestive process is not in thorough working order, and it also soon shows its effect upon the skin by the silkiness of the coat when it is used. A tablespoonful, once a month or so, is good for all horses, but as it has a tendency to open the pores of the skin it should only be given at the evening feed.

\section{Green Food.}

Some form of green food, which term includes carrots and other roots, should be provided for all horses habitually fed on dry, stimulating food. In Great Britain much useful greenstuff is thrown on the manure-heap, or otherwise wasted, which in hot countries is carefully garnered and made use of for the animals. Beyond vetches, and the different families of clover, or a little cut grass, we do not avail ourselves of what is at hand, and the outer leaves of cabbages and cauliflowers, and the green tops of celery, are all allowed to go to waste, though much appreciated by stallfed cattle or horses in the stable. In Spain the green tops of chicory, and of celery, used to be sold in the markets at $3 \mathrm{~d}$. for a very small parcel, and were eagerly bought; and the writer has ridden many a long journey to procure young 
dandelions, and even groundsel, for the horses in training, when other green food could not be procured. Horses are exceedingly fond of celery, and when once accustomed to it will usually select it in preference to carrots if offered the choice. In Spain barley was often sown for the sole purpose of feeding horses, being cut when quite young, as clover is here.

For some reason, which is rather obscure, it seems necessary for horses to take a certain amount of earth into their stomachs, and the craving for it on the part of horses entirely stable-fed is not very generally recognised. When such animals obtain a rare chance of a nibble at grass, it will generally be observed that instead of at once seizing the opportunity of eating the herbage they tear up mouthfuls of earth, and munch it in evident enjoyment, until a muddy trickle escapes down their chins. After their desire has been gratified for a few minutes they will then begin to graze with satisfaction, and if frequently allowed a bite of grass they do not take any notice of earth. Probably in the ordinary course of grazing some earth is unconsciously gathered up with the roots of grass, for a horse bites very close to the ground, and this is missed when a horse is fed only in the stable.

\section{Routine after Hunting.}

When attending to the legs and feet the latter should be carefully washed out, especial attention being paid that every particle of dirt is removed from the frogs, and also between the web of the shoe and the sole of the foot, but the less water that touches the former the better. Experience has proved over and over again that when the legs are washed after return from hunting, or indeed at any time when covered with mud, they are much more likely to suffer from cracked heels, or mud fever, than if the bulk of the mud is removed with a wisp of straw, the legs rubbed fairly dry, and then serge or flannel bandages wrapped loosely round the legs until the next morning, when any dry mud which remains can easily be brushed out without trouble. 
An important part of the routine should be a search for thorns, which can usually be detected by slowly passing a light touch down the legs, paying especial attention to the front of the knees, for a thorn in the knee will make its presence most painfully known the next morning if it is not discovered. When anything unusual is felt the character is more surely determined by applying the nail to it, instead of only feeling with the finger, and still further insight can often be gained by damping the hair and skin with a wet sponge. If it is certain the intruder is a thorn every effort should be made to extract it at once; but if this is impossible a linseed poultice should be applied until the next morning, when a renewed attack should be made upon the thorn if it has not been drawn out by the poultice in the meantime. When it is situated in such an awkward place that a poultice cannot be well applied it may be practicable to employ a water dressing instead, which simply consists of wet folds of linen with a waterproof covering outside, such as oiled silk, to retard the evaporation, if spongio-piline is not available. It is preferable that the linen should be steeped in water to which some antiseptic has been added; and it is obvious that if a plug of cotton-wool or something sinilar be embedded within the folds, it will act as a reservoir of moisture, and maintain the linen damp for a longer period than would otherwise be the case. Thorns frequently give serious trouble in the spring, when the sap has begun to rise, for if this gets into the wound a form of blood-poisoning, more or less severe, may ensue.

When the feet are being washed notice should be taken whether any over-reach has occurred, or other cuts are evident; and if any such are not so severe as to call for a poultice, they should at least be touched with some antiseptic. A simple and effective way of automatically doing this is to mix a little soft soap in the water before beginning to wash the feet, for soft soap is an active destroyer of minute organisms, as witness the effect of an application of it on the common green-fly, when the gardener syringes the rose-trees.

Unless the animal should break out into heavy sweating 
a tired horse does not need much dressing down, and should be comfortably clothed and left to rest as soon as possible; but often a horse will break out, some animals being much more prone to this than others, and then hand-rubbing must be resorted to, until the horse is fairly dry. Only in very obstinate cases should it be left before it has become dry, but when, as sometimes happens, it appears impossible to get the animal to cease sweating, and it has to be left wwhile, care should be taken to remove the damp rug and substitute a dry one, as soon as the sweating has at length ceased. It should be borne in mind that as weakness is often at the root of the matter, the administration of a stimulant will frequently act like magic, and the coat dry up as soon as the cordial begins to operate.

Horses with long coats are always a long time in drying, and it is most important, though strangely enough most commonly neglected, that the animal should be put into a warm stable during the process of drying. Evaporation always involves cold, and if the surroundings are also cold there is grave risk of a serious chill. In a stable warmed by the presence of others and with no draughts present, a long-coated horse can be placed in a loose box till he gets dry, without much cause for anxiety; but if placed in a cold stable, particularly if he is by himself in a place where he cannot move about, and the thermometer is low, a light rug should be thrown over him until his coat has dried. After that takes place he can go into a cold stable with impunity, or even be turned out if used to being so, and will take no harm.

Though tired hunters need not receive much dressing down on their return to their stables, it is a different inatter altogether after ordinary exercise, for then they should be dressed with vigour, but at the same time without violence or abuse, which high-couraged horses are apt to resent, and frequently become vicious in consequence. It is no uncommon thing to meet with an animal which one man can do anything with, whilst with another it is savage to a degree. After the dressing is concluded the legs claim attention, and if they have been bandaged the bandages 
must be removed, and in either case the legs require to be thoroughly brushed and hand-rubbed. After the legs are finished the feet should have any attention they require, and whatever application, such as tar ointment, applied that may be deemed necessary. Formerly they were invariably stopped with a mixture of clay and cow-dung now very seldom seen; and yet there was much to be said in favour of the practice. All hoofs require a certain amount of moisture, more especially when they are of brittle texture, and this was afforded by the wet clay, which remained moist a long time; whilst cow-dung, as the mushroom-grower can testify, is of a cooling nature, the very reverse of horse-droppings, which alone are suitable for his purpose. But the qualities which suit the gardener are prejudicial to the horn of a hoof, and therefore a main object of the stopping with the mixture mentioned was to prevent the horse filling his hoof with his own droppings when he stepped into them, as he is sure to do at times in the stable. It must, however, not be forgotten that it was the custom-even so late as my boyhood-for the smith to pare away the sole until it would "spring to the thumb," a most pernicious practice, and therefore the small amount of horn which was left was more likely to be affected by the lack of moisture, and the evils engendered by standing in the dung, than under present conditions. The practice of stopping the feet went out of fashion when the smiths treated the feet on more rational principles.

\section{Troublesome Tricks.}

Some horses contract troublesome habits, or tricks, which are annoying even when not absolutely dangerous, and ingenuity must be exercised in counteracting them. A common occurrence is that of capping an elbow, by lying in such a position that the elbow rests on the fore-foot. The swelling is composed of bloody fluid and thickened skin, and it must be noted as very dangerous ever to fire a capped elbow, or hock; the inflammation which ensues may cause suppuration, and so affect the joint as to necessitate the 
animal being destroyed. In this warning the writer is speaking from actual experience. A remedy may be sought by somewhat altering the shoeing, and it is advisable to try the Charlier, or Rational, system of shoeing, if a smith can be found who knows how to do it. One method of combating the evil, which frequently answers, is to buckle a large circular pad made of soft leather round the fetlock, which either compels the horse to alter its usual resting position, or, if it still adheres to it, prevents the hoof from coming in contact with the elbow, from the size of the roll.

A very frequent habit is to tear the clothing, which can be checked either by attaching a "sword" to the roller, or by buckling a strong leather shield to the headstall, and passing it behind the chin, which entirely prevents the horse from gripping the clothing when he turns his head for the purpose. It should be very stiff, and should be of such length that it will project a full inch below the chin when the horse turns his head round towards his side. The sword is a staff reaching from the headstall to the roller, to each of which it is fastened with a strap or a snaphook; it may be of the thickness of the bandle of a hayrake, and though the animal can lie down and get up with it on, it cannot turn its head. It is very effective, but does not allow a horse so much freedom of movement as the leather shield does. It may be further noted that a horse cannot tear a rug made of strong canvas, and therefore such a one should be placed on the outside.

A horse that is vicious in the stable, who will seize any opportunity of biting, or even worrying his attendant, should never be dressed without the lad having a switch handy, the knowledge of the presence of which will frequently prove a sufficient caution without it being necessary actually to make use of it. Some thoroughbred horses are of such a savage nature that great caution has to be exercised in attending to them, and the lad who looks after such must be of determined character, quick to observe, though at the same time quiet in his movements. Ofttimes one man can do anything with such a horse, whilst another would be attacked by the animal without a moment's hesitation. Such animals, 
besides being racked up, may be muzzled whilst being dressed, or wear a sword attached to a roller; or the old gipsy plan may be used of making a slip-knot in a length of whip-cord, and passing this over the jaw, care being taken that it goes under the tongue, which otherwise might be almost cut in two by the cord. The other end must then be brought round the neck, and either held in the hand or fastened to the loop with a slip-bow, thus making two reins. This contrivance is very severe when pulled upon, and in former days was often used by gipsies at a fair. who would not hesitate to jump on a bare-backed horse and ride it away, their only bridle being a piece of cord thus placed in the steed's mouth; but as a rule it will generally be found after a very short time that the lad will find it quite sufficient if he carries a switch in his disengaged hand, or even hangs it up within sight of the animal and within easy reach.

Sometimes an animal takes to violently knocking with his fore-foot against the manger or door, or gets his leg over the head-rope-a common trick if the ring through which it works is too near the ground-but an efficient remedy for all these cases is to buckle padded leather straps round each fetlock, connected together by a chain about a foot long, having a swivel in the centre. Though he can get up and lie down, and move about with ease under such circumstances, he can no longer indulge in his tricks, and after a while will very probably cease to attempt them altogether.

There are many plans for endeavouring to stop the habit of hicking in the stable, but it can hardly be said that there is one sovereign remedy, for what will answer with one horse may fail with another, and though a plan may be found which seems to have a due effect, after a time the horse may recommence the malpractice. A short chain is often strapped to one or both hind-legs, which inflicts a sharp blow when kicking is indulged in, and thus the animal punishes itself; and with the same idea in view a bundle of gorse is tied up behind the stall; or a sheaf of straw, occasionally soaked thoroughly wet to give it greater 
emphasis, is hung in such a manner that when it is kicked it swings back upon the offender. With a view to making it impossible for the horse to kick, a fore- and hind-leg are sometimes strapped together ; and a modified form is that of connecting both hind-legs with a strap after the manner of hobbles, but this does not prevent the horse from kicking with both heels at once if it is inclined to do so. A plan at one time much advocated, but with which the writer never had any success, was to strap a block of wood round the fetlock, which was fashioned to fit exactly into the hollow of the heel, the idea being that when the horse bent the leg to kick the block would hurt him and make him desist.

Crib-biting, and its twin-brother wind-sucking, are annoying tricks, the former habit often degenerating into the latter, which is apt to cause stomach derangement, besides flatulence and colic. Crib-biting by itself is objectionable as it wears away the front teeth, and occasionally loosens them so that one or more teeth may drop out, both conditions interfering with the animal when turned out to graze. Far the most efficient treatment of a confirmed wind-sucker, especially one that is so addicted to the habit that it can effectively suck in wind without fixing its teeth against anything, is to make it wear constantly a hollow bit open at both ends, and punctured in front with a row of holes similar to a flute, so that as fast as the air is drawn in it passes into the tube through the holes, and escapes at the ends without being taken into the stomach at all. The bit should be worn day and night, never being taken off except at feeding-time, and the attendant should be on the alert to replace the instrument the moment the feed is finished. The writer had one horse thus treated for quite a dozen years, with the best effect. Constant care is needed to keep the bit clean, and it must daily be well washed out and the holes cleared, for they continually get blocked up by the remnants of the food.

Weaving is a habit contracted by some nervous horses when in a stall, and is a constant oscillation of the head from side to side, with a corresponding change of the balance of the forepart from one fore-leg to the other. The 
remedy is to remove the animal into a loose box, or, if this is not possible, to have two bars made to fit across the end of the stall so that the horse need not be tied up, forming the stall practically into a small box. Some contrivance, some kind of wings to the side-posts, will be necessary to prevent the horse from annoying its neighbours, if they happen to stand in stalls adjoining. Other restless animals occasionally will not rest in a loose box, but keep ever on the move, tramping round and round without ceasing, and they may be successfully dealt with by transferring them into stalls. Frequently such changes as the above are a complete success.

The habit, which is occasionally met with, of sleeping standing, and never lying down, is very undesirable, and most likely arises from the horse having been cast at some period or another, and being afraid of the same thing happening again. A horse which sleeps standing is very likely to fall down in its sleep, and may injure itself when so doing; and since the weight of a horse is very considerable-a well-bred 13-stone hunter will weigh about 13 cwt., while a three-year-old Shire often weighs over a ton-it is very desirable that the legs should be freed from sustaining such burden during a portion of the twenty-four hours. No method is more efficacious in forcing a horse into lying down than attaching a weight to his tail, which sooner or later will make him think better of it, and lie down to relieve himself from the unwelcome imposition. When once relief is found by so doing there will most probably be no further trouble on that account. A 7-lb. weight may be used at first, and increased if necessary even up to $14 \mathrm{lbs}$., though if the original weight proves successful it may be altered with advantage to $3 \mathrm{lbs}$. the next day, and left off altogether as soon as it seems to be no longer required.

\section{Grooming.}

It may be asked why a horse in the stable requires grooming, whilst the same animal turned out in a field does well 
enough without it; but in this, as in everything else, " circumstances alter cases." No doubt the artificial manner in which horses are kept renders the perfect working of the pores of the skin a necessity, and the health of the horse depends largely upon the condition of his integument. Horses much exposed to the weather, though brought under a roof at night, should neither receive nor need such grooming, as they require a certain amount of grease in their coats to be able to withstand the vicissitudes to which they are exposed; whilst a horse living in a field depends entirely on the same grease, or he would speedily succumb to the cold and wet which he must necessarily meet with. By work, especially fast work, entailing more or less sweating, the secretions of the glands of the skin are enormously increased, while the pores of the skin become clogged, and the object of grooming is to remove these secretions, and get rid of dirt, dust, and scurf, which must constantly accumulate. Furthermore, the highly nutritious food upon which a hard-working horse is fed also assists to increase the secretions of the skin, and all these conditions can only be successfully met by a thorough daily dressing of the skin.

To be effectual the groom should add his weight to his muscular power, and in fact thoroughly massage the horse, thus stimulating the sebaceous glands of the skin, which by their oily secretion produce a glossy appearance on the coat, and give it a silky feel to the touch. Standing well away from the horse the groom should lean his weight on the brush, which thus used will penetrate the coat effectually to the skin, the use of the curry-comb being to clean the brush, and no other. After being well groomed the hand should not be soiled if passed over the coat against the hair. Washing horses has sometimes been advocated as more thoroughly cleansing the coat than the ordinary nethod, but the above remarks must emphasise that this practice is utterly unsuitable, and in fact does more harm than good by removing the oily secretion, and thereby increasing the liability to take a chill.

It is essential that a horse should be groomed immediately 
after exercise, as all the pores of the skin are then open, and the brush will more effectually clean the skin before the circulation is allowed to subside, for then the pores close, and the dried perspiration cakes over them. It is far better not to wash the legs. If the weather is dry, they may be brushed and then hand-rubbed; but if there is much wet mud upon them, the bulk of it should be removed with a wisp of straw, the legs afterwards being loosely bandaged with woollen or serge bandages and left until they are dry, even if they have to wait until the next morning, when the dust can be brushed out in the ordinary manner. Experience everywhere proves that this treatment is a certain prophylactic against mud fever, which is a result of the washing and not of the mud. There would be no illeffects from the washing if the legs were thoroughly dried afterwards, but this is usually not the case, and they are left in a damp condition, which causes the mischief.

The heels require especial attention, and should be rubbed thoroughly dry with rubber and hand before the bandages are put on.

On returning from exercise the first thing to attend to is washing the feet, and clearing out every particle of mud and grit from the web of the shoe, the cleft of the frog, and the bars of the hoof adjoining the frog. This latter is too often carelessly done, and a close examination will show that the mud has not been entirely removed, which, if habitually overlooked, will assuredly result in disease of the frog. The mud which is left soon becomes impregnated with ammonia from the soiled litter, and in course of time this will contaminate the frog, working into any ragged portions, and so cause suppuration to ensue.

The thorough cleaning of the mane and tail are important points, and require careful attention, and the brush must be applied with considerable force to eradicate all the dust. The eyes, nostrils, and anus must always be sponged out, and the sheath needs cleansing from time to time, soap and water being frequently required to cleanse away the accumulated secretions. 


\section{Shoeing.}

Shoeing, alas! is in this country a necessary evil, for the horn of the hoof is not sufficiently adamantine to stand the friction of the King's highway. In other countries, in wild, rather desolate regions, it is no doubt possible for horses to work unshod, but from very remote ages it has been found absolutely necessary in some way to protect the feet of the hard-working horse. Nor has any practical method ever been discovered to keep the shoes on without nailing them to the foot, during the thousands of years during which mankind has shod the horse. Therein lies the difficulty, for even when horses stand quietly to be shod from time to time they get pricked in shoeing, a nail penetrating the sensitive portion of the foot; whilst the difficulty is immensely increased when horses of violent temper have to be dealt with, or young animals unaccustomed to the process. Some smiths are more careless than others, and a inan accustomed only to shoe the heavy breeds, with large feet and abundant thickiness of hom outside the sensitive parts, is very apt to make a mistake when on occasion he is called upon to shoe the small foot of a well-bred horse. It 1s often the case that the nail is not driven very far before the horse flinches, and then the smith immediately withdraws the nail, drives it in a fresh direction, and satisfies himself that it is all right. Or perhaps the nail has not actually passed into the sensitive lamine, only into the soft, cheese-like portion of the horn immediately surrounding it; and so when the horse goes out to exercise, the pressure and concussion after a time have their due effect, and the offending nail causes more and more soreness, making the animal go "feeling" and "pottery," even if it is not actually lame. There is only one thing to do under such circunstances, and if a horse is lame or has suddenly become faulty in his action after being recently shod, take no notice of the solemn protestation of the smith that he is prepared to swear he never pricked the animal, have the shoe removed at once, and put a poultice on the foot. If the smith has not pricked the foot such a procceding will 
do no harm, and will probably do good; but if, as is almost certain to be the case, a nail has been misdirected, the poultice will soothe the pain, and prevent any inflammation which may have arisen from extending, and after a day or two's rest the shoe may be put on again, when the animal will most likely be found to be quite sound. If a horse, however, is continued to be worked when lame from a prick suppuration may follow, and possibly a considerable time may elapse before the horse recovers from what has become a serious injury from unwise treatment.

It is well to consider what function a shoe has to perform and what latitude can be allowed the smith when driving in the nails. Briefly the outer horny covering may be looked upon as an open box, the sides being termed the crust, or wall, and the bottom the sole; other items being the bars and the frog, whilst inside the box are contained the bones and sensitive portions of the foot. The sides, or wall, are composed of a number of fibres, running longitudinally downwards from the coronet, which secretes them, the outer fibres being tough and hard, of about the thickness of half an inch, whilst interiorly softer fibres of a quarter of an inch interlace with the sensitive laminx of the foot. The nails of the smith must be driven upwards, within that half-inch of toughened fibres, a slight bend being given to them to make them incline to the outside, there to be clinched and made secure. When the horse is unshod the rim of fibres forming the wall is continually rasped down by contact with the ground, and is as constantly renewed from above. For a considerable distance from the coronet, perhaps two-thirds of the way down, the newly secreted horn is chiefly composed of soft cellular material, with a hard glazed waterproof surface, and into this region the nails must not reach, but must make their exit in the lower third of the wall where the fibres have become sufficiently hard and tough.

The object of a shoe is to interpose between the rim of the wall and the ground, and thus protect it from undue wear and tear, under natural conditions the longitudinal fibres of the wall being gradually worn away, much as a 
tool is ground down on a grindstone. The thin rim composing the wall, it must be remembered, has to sustain the entire weight of the horse, and resist all concussion in galloping and jumping; so the necessity of retaining its entire substance, and not weakening it in any way whatever, will be obvious.

The sole of the foot, except at its junction with the wall, has little weight to sustain, and instead of being formed in long fibres like the wall, is secreted by the sensitive sole inside in such a manner that it does not grind away from contact with the ground like the crust, but exfoliates instead as each layer is no longer needed. Coming away in large flakes as it does, there is not only no necessity for the smith to remove any of the horn from beneath the sole, but he is actually doing harm by so doing; and yet such is the perversity of human nature that it is almost impossible, unless a master stands over the smith at the time, to prevent his removing the flakes, which would naturally slough away as soon as the layer beneath was ready to take their place. The one thing the sole needs is simply to be let alone. There is then such a thickness of hard material underneath the sensitive sole that the shallowest-footed horse can travel over newly broken stones, without being inconvenienced by treading on them in the least. The rim of the wall, however, of necessity requires different treatment, for being protected by the shoe the fibres are no longer reduced by being worn away, and therefore the knife of the smith is necessary to trim them down to proper dimensions.

When the smith cannot stay his hand from paring out the sole, which to his fancy gives it a nice open appearance, he can hardly help interfering with the bars, those important structures designed by Nature to prevent the heels contracting, and which office they efficiently perform. Especially must the angle be left alone, which is formed by their junction with the crust; for if that is removed the heels will in most cases incline inwards towards the frog, impeding its expansion and gradually squeezing it almost out of existence. Especially is this the case with those high, 
narrow hoofs, which have a natural tendency to contract, and are frequently referred to as donkey or mule's feet. These are very apt to have ill-developed frogs, while those with open and broad but possibly thin soles, have the frogs very well developed indeed.

The outer frog is an elastic wedge-shaped pad, whose chief function is to minimise concussion and jar, when the whole weight of the horse is thrown violently upon the foot, and it also acts as a drag in preventing slipping, more especially when travelling on rocky or slippery ground. It likewise is reduced naturally by exfoliation, and therefore should not be cut away with the knife; but since it is apt to become ragged and torn in the course of work, these frayed portions should be trimmed off by the smith, for they otherwise form receptacles for dirt, which is certain to absorb moisture from the soiled litter in the stable, when these pockets become originators of disease. The decaying tissue of the frog has an offensive odour peculiar to itself, and on this being perceived close investigation should immediately follow, and the affected part be at once removed.

One other caution must be given. On no account should the smith rasp away the outer portion of the crust, for by so doing he not only reduces the thickness of the sustaining wall, which is narrow enough to begin with, but he also removes the glazed waterproof surface, which has a valuable service to perform in preventing the escape of the inner moisture of the foot, and without which the horn becomes so dry as to encourage sand-crack and other evils. It is necessary, however, for the smith to use the rasp to file off the ends of the nails after they have been clinched, and to smooth down the projecting portions level with the crust, but if this is carefully done there need be no weakening of the wall itself.

How long a time shoes should last depends much upon the ground on which the work is done, for it is plain that a horse travelling entirely on the road will wear his shoes out quicker than one who is scarcely ever out of the field. The character of the ground also has much to say to it, for if it is hilly the shoes are more quickly worn at the toes than 
in a flat country, especially when the horse has to draw a load. There is a considerable difference, too, in individual horses, one animal wearing his shoes out quicker than another ; but generally speaking shoes should last a month, and if they last longer the shoes ought to be taken off, the extra growth of the horn removed, and the shoes replaced, and with many animals this remove is preferably carried out every three weeks. It is a frequent cause of animals going short in their action, or becoming afflicted with corns, when the shoes have not been removed soon enough, and they have become embedded in the hoof.

The shoe must be as long as the crust, both being of precisely the same length, for if the shoe of the fore-foot is longer than the heels the hind-foot is liable to tread on it and pull it off; whilst if it is shorter it will be likely to press on the seat of corns, and so produce that malady. But a three-quarter tip, which is often of great use in certain cases, is quite safe to employ, since it does not extend so far back as the seat of corn, and so no evil can be caused by the shortness of this shoe.

A good workman fits the shoe so that its outer edge is neither smaller than the crust nor overlaps it, just corresponding exactly with the curve of the hoof after he has lowered the crust and rounded it off, chiefly by using the rasp. A second-rate man does not take the trouble to do this, and putting on a shoe slightly smaller than the crust, proceeds to fit the foot to his shoe, rasping down the crust until the fit is at length accomplished.

The number of nails, and the situation of the nail-holes, are both matters for careful consideration. Six nails are quite sufficient for the fore shoes of hunters, though for hacks or carriage-horses five are usually sufficient; and in this case these should be round the toe, and on the outside of the foot, the reason being that the outer crust is slightly thicker than the inner, especially towards the heels. For the hind-feet six nails are necessary, for greater stress is thrown upon the hind shoes in galloping, leaping, or kicking, and therefore they are more likely to get twisted out of their position than the fore shoes. No nails should on any account 
be permitted to be driven nearer the heels than the widest part or centre of the foot, since the rim of the crust narrows after this is passed. It is of great importance that the foot surface of the shoe should present a perfectly even plane for the crust to rest upon, for if it is uneven the prominent parts will receive an undue portion of the weight of the horse when standing in the stable, which before long will make itself unpleasantly felt.

When shoes are an inch in breadth, the usual width, the nail-holes may be punched rather nearer the outside than the inside of the web of the shoe, but care must be taken that they are sufficiently far from the edge, or the iron may be caused to bulge in consequence. They must also be made exactly parallel with the sides of the shoe, and not allowed to slant across it. The punch may, however, be driven rather obliquely towards the surface, so that a slight cant is given to the direction of the nail, causing it to incline to the outside independently of the slight bend given to the point, and thus the risk of pricking the sensitive laminæ will be diminished.

Bar shoes are very useful in cases of injury or disease, when it is necessary to prevent any weight being borne by the heels or some portion of the crust. They are made by connecting the heels of the shoe with a bar of ironcompleting an oval, in point of fact. Some horses stumble very badly when ridden, who may yet be ridden in safety and comfort if shod with shoes turned up at the toes, in the same manner as the toes of the hoof would be worn away by friction with the ground if unshod. Many years ago the writer obtained a pattern of a French shoe of this description, which has proved itself at times most useful and efficient in preventing certain animals from catching their toes and stumbling, the one slight drawback being that the shoes do not last so long as ordinary ones, owing to the metal being somewhat thinned out to turn up the toe. Sufficient breadth must be allowed for the turning up, commencing at the sides, and the same width of seating must be maintained as heretofore, sufficient horn being removed from the toe to fit in with the new shape. 
Of late years a great boon to all horse-owners has been obtained by the placing of frost-studs on the market, which can be fitted into holes made in the heels of the shoes to receive them, and are an absolute protection against slipping in frosty weather. Their removal, too, is just as easily effected when the animal returns to his stable and they are no longer required, either operation being the work of but a few seconds. Riding or driving in frosty weather, when the roads are one sheet of ice, no longer inspires the terror that it used to occasion. The studs known as "Dudleys" can be particularly recommended, and are made of steel, triangular in shape, terminating in a sharp edge, while the length and breadth, apart from the neck, measure respectively $\frac{7}{12}$ of an inch. They are knocked in and removed by a few gentle taps from a hammer.

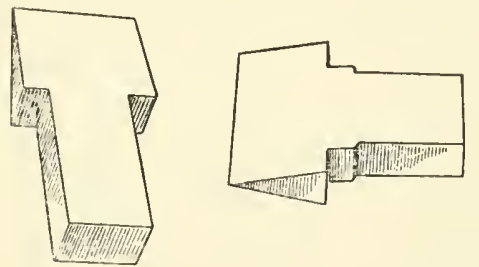

A shoe which was invented half a century ago by Monsieur Charlier, and which is known by his name, though of late years it is perhaps better known as the " Rational," deserves to be more used than it is, for it fulfils all the requirements of a shoe, is very light, and improves the feet of horses by throwing the weight on the natural cushion, the frog, thereby stimulating its development. Almost all horses are benefited by it, the few which it does not suit being those with such shallow feet that there is not sufficient horn to stand the necessary groove being cut. Smiths do not give it a whole-hearted reception, however, as the shoes require very careful fitting, and therefore take much time and skill in putting them on ; and in addition, as they are very narrow they have to be made out of special steel bars, require nails made on purpose, and the 
old shoes cannot be worked up again into new shoes. All this extra labour means also more time, so that fewer shoes can be put on in a given time than under the usual system. The action of the horse is also somewhat altered, for with such very light shoes a horse does not step so high as with heavier ones, and this does not always please dealers, nor also some grooms and owners. This mode of shoeing, however, possesses many advantages besides those already mentioned. An animal which brushes, either before or behind, seldom does so with Charlier shoes, and at any rate the evil is much lessened in degree; and it is rare for a shoe to be pulled off in deep ground. On the other hand, if the nail-holes are punched askew, or a shoe is worn too thin, the shoe may sometimes break, though if this should happen no harm, as a rule, is done. Over-reaches also seldom occur, and if they do they are very trivial, while the lightness of the shoes demands less labour from the horse.

In 1872 the writer was quartered in Ireland, and found Charlier shoes extensively used, all the Galway Hunt horses, amongst others, being shod with them, that famous pack, the Blazers, being then under the Mastership of the celebrated Mr. Burton Persse. The writer at once adopted the system, and for many years used them exclusively on hunters, chargers, and race-horses, and for these latter especially they were very suitable, since there was no occasion to plate them when they were going to run. In 1874, owing to a difficulty in finding smiths skilled in putting on the shoes, the writer started a shop of his own, which he continued for three years, and the demand for the shoes became so great there were soon three smiths in constant work. From the very commencement the three-quarter Charlier was adopted, which, in the writer's opinion, is the proper one to use.

The principle of the Charlier shoe is that it is needless for a shoe to be wider than the rim of the crust, which is all that needs protecting; and secondly, if a groove is cut in the rim sufficiently deep to embed the iron the horse will stand naturally, as Nature intended him to do, thus making full use of the frog. When this process is carefully 
and skilfully done nothing can be better; but if at all slurred a horse may readily be lamed, or at any rate he will lose his action to such an extent as to go like "a cat on hot bricks." No smith the writer has ever yet come across is content to continue treading the path which has been pointed out as the true one. When he is told that every smith invariably after a time is certain to ignore the plain directions, and will not believe it to be absolutely necessary to follow them strictly, a covert ineffable smile curls his lips, and he hints that he at least is superior to such wealiness. Young, old, and middle-aged, I have found them always the same, and they follow in the footsteps of those who have gone before them! At first the man takes great pains to do as he is told, believing all the time in his heart of hearts that the animal he is experimenting upon will never be able to walk out of the forge. To his unconcealed astonishment the horse proceeds on his way, with as free action as when he arrived, and then the smith becomes inflated with his own cleverness, and thinks nothing can happen when such skill as his is treating the case. The next stage is that he begins to imagine the simple rules laid down for his guidance are but foolish fads, entailing considerable trouble, and therefore he neglects them; nor can his carelessness be detected until the shoe is taken off. In a day or two the groom begins to notice that the horse is going very short, and tells all his cronies that " he knew all along it would never do." Very possibly he persuades his master to revert to the old style, when all concerned combine to find fault with Charlier shoes, and tell their friends not to try them, or they will assuredly lame their horses. But possibly the owner may have sufficient faith to appeal to an expert for advice, who will promptly summon the smith, have the shoes removed, and the careless errors of the man will then most certainly stand revealed. Every smith follows this same routine-it seems quite inpossible for them to avoid doing so ; but the able, clever man, having once realised that there is much more in it than he ever believed, will thenceforward scrupulously attend to the instructions, and thereby reap 
his reward; while unskilful and self-opinionated men soon give up trying to perform what is not within their province, and if they do not do so on their own account their customers will very soon afford them no opportunity of practising on the horses in their studs.

The rules which are important, and really must be attended to, are but few and simple-but unless strictly adhered to the horse is sure to go lame, sooner or later.

Rule 1. Cutting the groove. Great care must be taken to obtain a level surface.

Rule 2. At the junction of the wall and the sole a welldefined "corner" must be left.

Rule 3. The inner portion of the shoe at the toe must have its sharp edge taken off, for about three inches.

Rule 4. The shoe must fit the groove accurately.

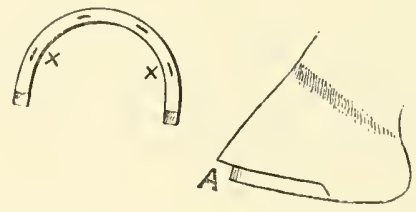

A. Groove. X. Sharp edge taken off.

It has previously been stated that the tough outer fibres of the crust are but half an inch in thickness, while the soft, cheese-like substance of the inner fibres extends inwards for another quarter of an inch. Into this latter region the shoe must not trespass, so the width of the shoe must not exceed half an inch. The groove should not be cut too deep, for there is no great amount of material between the inner edge of the shoe and the sensitive portion of the foot. Twice it has happened in the writer's experience that, in the anxiety to get the shoe level with the sole, the smith has cut the groove just a little too deep, and though no accident was apparent at the time in each case the horse quickly went lame. On removing the shoe the sole was found to have cracked all round the "corner," and in one instance the sole came completely off, leaving the sensitive portion as bare as the palm of one's hand. After 
these lessons we never sank the shoes more than half the depth of the iron, and many years of subsequent experience have proved this to be quite sufficient.

The most practical way of testing whether the surface is level (Rule 1) is, after roughly cutting the groove, to apply the shoe sufficiently hot to slightly burn the horn in every direction; all the burned part must then be removed with the rasp, and then the hot shoe applied again for a moment. Any part requiring a further use of the rasp is thus easily seen, and so long as any discolouration occurs the rasp must be used, though the hot shoe must only be momentarily applied, or the heat may have an undue effect upon the soft, yielding fibres. Very often a slight burnt crust extends for a very short space from the corner, which the smith may think of no consequence, but if this is left the shoe will press upon it and cause the animal to go short after a little time.

One of the commonest causes of a horse losing its action is non-observance of Rules 2 and 3, for if the weight of the horse presses the sharp inner edge of the shoe against the soft part of the horn a tender place is soon created in the sensitive foot. But by keeping the corner of the groove quite sharp, while the edge of the shoe is rounded off, there is sufficient room between the two to prevent them coming into actual contact. The edge of the shoe is quickly taken off by a few blows of the hammer when the iron is hot, and it can afterwards be finished smooth with the rasp.

If the shoe does not fit the groove accurately (Rule 4), sand and gravel may work in, and then there will be trouble. The groove should not be cut with the knife quite the required size, for when the hot shoe is applied it is easy to enlarge the groove to the required dimensions, with the rasp. If the maxim to leave the sole untouched is important in the case of ordinary shoes, it is doubly so with Charliers, for then the horse has to rely entirely on the thickness of the horn for protection when treading on broken road-nuetal. It is the same with the frog, which must only have the ragged parts trimmed off; but the 
development which soon takes place in this structure can only be believed when seen. One example affords the writer especial satisfaction to recall. In the summer of 1874 an especially handsome horse came up for sale at Tattersalls, which a relative was anxious to purchase, but the near fore-foot was so contracted it was almost a club foot; there was not so much space between the angles of the bars as the first joint of a man's thumb, whilst the frog was only conspicuous by its absence. Still, the horse trotted quite sound on the stones, and was only five years old, and therefore the opinion was vouchsafed that the foot would improve if shod with Charlier shoes. Nearly all would-be buyers were chary of risking such an awkwardlooking foot, and the horse was purchased for 120 guineas. He was at once shod with the proposed shoes, and when the stud was removed to Melton in November the foot had considerably improved, while he had not lost his action in any way whatever. He turned out a brilliant hunter, and when the stud was sent up for sale the following June there was not much difference between the two feet and he was bought in for 420 guineas. Three years afterwards he once more accompanied some other hunters to the sale-yard, and was again bought in for 350 guineas, there being then no difference in the width. of the two feet, while both frogs were about the same size.

Belmont was another notable instance of the Charlier system of shoeing. At the time he was purchased by the writer, one ankle was so weak from being constantly struck by the opposite foot that he could scarcely stand long enough on that leg to have the other foot shod. Charlier shoes soon put an end to the brushing, and, after winning several small races, he was only just beaten for the Grand Military Gold Cup at Sandown, and the following year won the Dunboyne Plate at Fairyhouse, and the Conyngham Cup at Punchestown, and finished up by winning the Metropolitan Plate at Baldoyle, in which races he competed against some of the best steeplechasers then in training. $\mathrm{He}$ practically owed all these races to the benefit received from wearing Charlier shoes, which enabled his weak leg 
to stand the wear and tear of training by altering the action sufficiently to avoid the constant brushing, which previously had been such a cause of trouble.

Such examples afford ample proof of how valuable the system can be, when practised by a competent and skilful smith.

In contrast to the Charlier shoes are the very weighty ones commonly employed for the heavy breeds of horses, and for training hackneys for Show purposes, one of the well-known ways for teaching them to step high being to run them with light plates, and then to change them for loaded shoes. It is rather a curious circumstance that the Americans should find the addition of toe-weights enables them to improve the speed of their famous trotters by causing them to lengthen their strides, while the Englishman employs weight to make his animals shorten theirs and step into the air!

In 1890 a scheme was inaugurated at the Mansion House in London under the auspices of the Lord Mayor, Sir Joseph Savory, for the "National Registration of Farrier's as Shoeing Smiths and Doormen." The objects of the Society are :-

1. To examine farriers by practical test in making, fitting, and putting on shoes and preparing the foot; and by an oral examination on the construction of the horse's foot.

2. To register those that pass.

3 . To encourage technical education and apprenticeship.

All candidates must pass in these subjects at the examinations which are held in various parts of the country, chiefly in conjunction with the Agricultural Societies at their annual Shows; but also through County Councils and 'Technical Colleges. 'The Farriers' Company has also followed suit, and in 1908 started an additional scheme for the higher examination and registration of shoeingr swiths.

T'hese are steps in the right direction, and can but result in increased benefit to such animals as nuay be left to us under the stress of competition with motor traction. 


\section{Chothing.}

Clothing must be regulated according to the requirements of the animal, one rug in summer and two in winter sufficing in ordinary cases. But at any time of the year if an animal's coat is seen to be staring, and it appears chilly to the hand, something additional should be thrown over the rest of the clothing, or the horse is certain to suffer from a "chill." A careful groom, who studies the wants of his charges, can thus prevent many a cold, for the proverbial "stitch in time" is extremely important when dealing with horses. Often an ordinary hood placed over the quarters and loins will afford just that additional warmth which is needed at the moment to keep the circulation up to the necessary point. The ends of all rugs should be so shaped as to come together in front, and be there secured with a broad strap and buckle, and if, as is now frequently done, the rugs do not meet underneath, and be there fastened with a buckle, they will need to be made secure with a roller round the body. Rugs must be well hollowed out over the withers, and need careful attention in this respect, it being noted whether the rug presses upon the withers when the roller is fastened in its place. If the rug should appear to be drawn tight over the withers it must at once have an additional piece added by the saddler, or a sore place will be engendered, which may eventually suppurate if the cause is not at once removed.

In very hot weather, in summer, a linen sheet should be used instead of a rug, merely to prevent flies from settling on the horse and causing annoyance.

There should be different sets of clothing for day and night, and when expense is no object, another set for exercise also. But when extra luxury cannot be afforded, the underneath night rug can be used for exercising in, as there should be time to dry it before the evening if it has rained during the time the horse was out of the stable.

At race-meetings the American rug, which is now a familiar sight, has an advantage over the ordinary hood and rug, in affording more complete protection from the 
weather, for an ordinary hood is apt to be displaced by the wind, and thus the rain can be troublesome on a tempestuous day. The American sheet is made all in one piece, completely covering the horse from the ears to the tail, and is kept in its place at the head by a browband, being also fastened underneath with a strap and buckle, and so requiring no roller; and it has another fastening in rear, at the tail. If it is quaint in appearance it certainly has the merit of shielding the animal from all vicissitudes of weather, and thus fulfils the purpose for which it is required.

\section{BANDAges.}

Without a supply of bandages a groom would indeed be at a loss, for they afford him invaluable assistance in the treatment of horses' legs. 'They should be 3 yards in length, those in ordinary use being made of serge or of flannel, and also of linen. The former are required for warmth, especially when horses become aged, or from other causes have a feeble circulation, resulting in puffy fetlock joints and filled legs, and for this purpose should be wrapped quite loosely. They are also employed for fomentations, being wrung out of hot water and immediately put on, and it is an excellent method to put another dry one outside, which serves to keep up the heat and prevent evaporation. Linen bandages are used when evaporating lotions are employed to produce cold; but for this purpose chamois leather is often substituted instead, as it has the advantage of retaining the moisture longer. When a sweating bandage is required, a linen one is the proper material to use, being applied wet, with oilskin outside, and kept continuously on until the skin becomes scurfy, this being the usual plan for reducing enlargements. Nowadays spongio-piline is perhaps more commonly employed instead of the above, being a handier way of attaining the same result.

Worn and puffy legs are frequently treated by another process, thick layers of cotton-wool being used to envelope the legs, and then either serge or linen bandages put on 
and drawn as tightly as possible, the object being to exert much pressure equally all round. An improvement upon this has been brought out by the Sandown Company, whose Fleecy bandages supply a thick material, which can be used either wet or dry, and adapts itself easily to the contour of the limbs. These bandages retain their fleeciness for a considerable time, and have the advantage of being always ready when wanted.

\section{SADDLERY.}

Saddles should be carefully fitted to every horse, or a sore back is the inevitable result. In a small stable, where economy has to be very much considered, a good-sized saddle, with plenty of width in the tree, can be made to fit all horses with normal backs, with the help of numnahs, and knitted pads; but numbers of horses have some special peculiarity which cannot be thus treated, and then a saddle should be set apart for a particular animal, and especially stuffed to suit his formation. It is false economy to have the animal perpetually laid up with a sore back, and unable to do its work in consequence. Especial attention should be paid to see that the saddle does not press on the withers when the rider is in the saddle, for a heavy man may cause a saddle to sink sufficiently to bring it down upon the withers, although there appeared plenty of room before mounting; and if a sore place should be formed it is very difficult to cure, as there is almost no flesh in that region and little power of healing. When the rider is mounted there should be sufficient room to insert at least two fingers, one over the other, under the pommel, to be on the safe side, and more space is very desirable. If the tree is too narrow it will pinch the withers, and this also will produce a painful state, which, if continued, may bring on an abscess and cause much trouble; nor is it safe to have too much width in the saddle, for then it will roll about, and mischief will ensue. In this latter case, however, a remedy is easily found, for a numnah, or one or two pads, can be placed over the withers to make the saddle fit sufficiently close. Ladies' saddles require 
even more care in this respect than men's saddles, owing to the cramped position in which a lady has to sit.

It is equally necessary to guard against the rear part of the saddle resting on the backbone, for if a lump should be raised there it is seldom ever completely reduced again, and so remains a constant nucleus of future trouble. Animals with good flat backs are seldom affected in this manner, but where the backbone forms a prominent ridge the danger is ever present. The stuffing of the saddle at this part should never be allowed to get flat; and have a well-marked division between the two cushions to provide against the evil mentioned. The stufting of saddles requires constant watching, for it always settles down when constantly used, and though it may be all right at first, in a few weeks may present a very different aspect.

Another source of trouble, often unsuspected, arises from the arms of the tree being too short, thereby not getting a sufficient grip of the sides of the horse, and allowing the saddle to shift about on its back. This again is a more essential point in side-saddles than in those of men. The stuffing must not be allowed to work into hard lumps, for these soon hurt the back, particularly if the horse has a thin skin; and when the condition is noticed the saddler should take out the stuffing, re-shred it, and then replace it, with the addition of some more. The ordinary lining also gets threadbare with use, and holes will wear in it if neglected, and these also will make a back sore. Another cause of sore back is from a rider sitting in such a cramped position that all his weight rests on one place instead of being fairly distributed-a very common occurrence when fatigue sets in after a long ride. Many kinds of lining are in use, and sometimes one sort suits a particular animal better than another, such as a lining of leather or of linen; the former needs to be kept very supple by constant greasing; and the latter must be kept very taut, or it will form wrinkles, when it will prove instead to be a cause and not a remedy of the evil.

Numnahs play an important part in the economy of the saddle-room, and are of various sorts, but the best the 
writer has ever used have been thick white ones, known as Scriven's Patent Wilson Numnah. These do not shrink as the ordinary felt ones are apt to do, and an experience of them for many years has proved their value and suitability. Leather numnahs can be also recommended, but like the similar lining for saddles they need to be kept very supple and frequently greased.

All saddles should have the lining sponged over to remove the accumulated sweat, when taken to the saddle-room after being used; they should then be dried at a distance from the fire, being afterwards gently beaten with a light stick, to get rid of any impurities which the lining has absorbed. The leather part should have any mud washed off and then have a damp sponge passed all over it, which has been previously rubbed on ordinary yellow bar soap. This is an excellent preservative of leather, and keeps it supple, while there is nothing in it to soil or stain white breeches when riding in rain, which is so often the case with ordinary saddle-pastes. Soft soap is not good for leather, for though it softens it at first it causes it afterwards to become hard, and possibly crack.

\section{GirTHs.}

Girths are of great variety, and when the ordinary kind are used broad ones are much easier for the horse than narrow ones, although they have a greater tendency to make the horse sweat underneath them. Still, the pressure being distributed over a wider area more than makes up for this slight drawback. Young horses with a low forehand are very subject to sores behind the elbow, from the saddle working forward, so that the edge of the girth comes in contact with the thin skin immediately behind the elbow, when the friction soon breaks the skin. A very simple remedy for this state of things is to tie something soft round the girths, bending the edge outwards, and well back, and then no friction can result. Nothing answers better for this purpose than an old silk boot-lace, as it lies flat and is quite soft. Perhaps the best girths of all are the 
well-known plaited leather ones, in several pieces parallel to each other, for they fulfil every requirement, except that some people rather object to their appearance. They do not heat the horse, and, taking a better grip than the ordinary ones, do not need to be drawn quite as tight.

\section{StTrRups.}

Stirrups should have good broad foot-plates, which do not tire the soles of the feet as do narrow ones; and, moreover, they keep the stirrup well forward by pressing against the heel of the boot, when there will be no risk of getting a sore lump at the junction of the shin and the foot, which so often happens when the foot is thrust too far into the stirrup. To assist in this the heel of the riding-boot should always be brought so far forward that a plummet dropped in front of the shin should just meet the fore-end of the heel. The sides of the stirrups should be flattened at their junction with the foot-plates, to obviate any soreness arising in the sides of the feet when pressing against them, which is likely to happen if this precaution is not taken. The slight increase in weight between large and small stirrups is a matter of no account when extra comfort is thereby attained, for no one can balance his weight on a horse to the same advantage if he is uncomfortable. Moreover, small stirrups are more likely to increase the risk of the feet getting fast in the case of an accident-a danger that should be minimised by any means it is possible to employ. Another advantage stirrups of a certain weight have over light ones is that they do not sway about so much after being lost from the feet when jumping a fence, and are therefore more easily recovered, which also makes for a saving of time. Saddles should be large and roomy, as well as stirrups, for if "the joint is too big for the dish" there can be no ease either for the horse or the rider; and, moreover, dangerous, and even fatal, accidents have frequently occurred through the rider coming down on the pommel or the cantle when taking a fence, owing to riding in a saddle too small for him, with 
the mistaken idea of saving two or three pounds in weight.

A horse necessarily sweats very considerably underneath a saddle, and any practical contrivance to minimise this is worthy of notice. A saddle which certainly fulfils this condition has been largely used of late years in Yorkshire hunting-fields, which admits air into the tree through several apertures, and it should therefore be an important aid in keeping the skin dry, and thereby lessen the liability to a sore back. It is on the market as Robson's Patent Ventilated Saddle.

\section{Bridles.}

Of bridles there is an endless variety : they differ as much as the hands of the rider and his capacity for making the best use of the "key to the horse's mouth." It is absolutely necessary that full control should be possessed by the rider, but so long as this is attained humanity urges that no severer bit should be used than is necessary to achieve that object; and the easier the bit the more pleasantly will the animal carry itself and its rider, when a better mutual understanding will be established between them. Bits should always be sewn on to the bridles, for buckles and straps are less neat in appearance, and if a martingale is necessary - and in many cases it is-the rings are apt to catch on the buckles, and the rider may have an awkward moment or two until they are released.

The reins should be broad, as then they are more comfortable to hold, and the leather should be thin enough to be pliable, but not so thin that the reins double up in the hand; at the same time if they are very stiff they do not afford the same delicacy of touch-although this may not make much difference to those who are heavy-handed, or, as frequently designated, mutton-fisted. Various contrivances have been tried to afford a better grasp in wet weather, when a hard-pulling horse causes the reins to be continually slipping through the fingers, and an excellent plan is to have the forepart of the rein made quite narrow, till it nears the point where the rider is accustomed to take hold when 
the horse is at speed; then for about 18 inches the breadth should be continually increased, so that it is always a little wider behind the fingers than where they are holding the reins at the moment. After a sufficient space has been so tapered, the width may at once revert to the original dimensions, by which method any appearance of clumsiness will be obviated. Another very practical plan is to have small bars of leather sewn across the reins about:3) or 4 inches apart, where the reins are usually grasped, to act as stops, which no horse can easily drag through the fingers, however wet and slippery the reins may become. These stops are more comfortable if a thin piece of leather is sewn over them as a cover, which also makes them less conspicuous, the one slight drawback to them being that they give at first rather a clumsy feel to the reins; but those whose lot it is to ride headstrong, awkward horses do not mind a trifle like this when it enables them to keep the control which they would otherwise lose.

A third method is to have the reins plaited, which affords a capital hold, though it is rather more clumsy, necessarily making a very full handful.

\section{Stabling.}

It is not proposed to give any general plan of stabling, for it must almost necessarily vary in form in every instance, and when about to be built a competent architect will no doubt be employed; but mention may be made of a few details, applicable everywhere, which, as experience has proved, answer the purpose of keeping horses in the highest health and vigour. Whether boxes or stalls are used there should be a broad ample gangway in the rear, to allow space for horses moving in and out, and also to afford extra cubical capacity. Six feet six inches is the least which should be allowed for this purpose, and 7 feet is a preferable width. The cubical space allowed for each horse should be 1,500 feet, unless the arrangements for ventilation are very good, and it should seldom be below 1,200 cubic feet. Some arrangement is advisable for 
providing ventilation independently of the windows, a small ingress near the floor in the gangway, and an egress for the warm used-up air, high up in the wall near the ceiling, both easy to open or close by a sliding shutter, being the guiding principle. In this way fresh air in graduated quantity can be admitted without any draught, which is so apt to cause colds and coughs if not carefully guarded against. Fresh air is one thing, but a draught is most pernicious, and the ancient Spanish proverb that "death comes in with the wind through a hole" has more than an element of truth in its teaching.

\section{STALLS,}

It is well to have both stalls and loose boxes, but if the stalls are also provided with doors they can be utilised as boxes, which adds so much to the comfort and health of the occupants that such an arrangement is well worth the extra cost. Many years ago the writer thus provided six stalls with doors, which he has never since regretted doing, and for horses not exceeding 16 hands they have answered extremely well. They are only $6 \mathrm{ft}$. $6 \mathrm{in}$. in width, and would have been better if they had been 7 feet, the usual width for large horses; but still the animals which have occupied them, chiefly thoroughbred horses, have thriven in them; and certainly they possess one advantage, they require far less straw for bedding-an economy not to be despised under the stress of present legislation.

It is not intended for one moment to suggest that such boxes should take the place of those of the usual dimensions, but merely to point out how much more comfortable stalls can be made if they can be turned into temporary boxes. The same attempt is often made by placing bars across the stalls, but this plan is not nearly so satisfactory as when proper doors are used. The privacy of a box is undoubtedly welcome to a tired animal which is desirous of resting, and the prevention of draughts is another very great point in favour of closing the stall behind.

For all ordinary purposes such a stall remains as if 
it did not differ from the usual ones, and the pillar reins are left in situ-so necessary for fastening up a horse after the bridle has been put on, for if it is racked up to the manger it soon rubs the bridle to pieces. Pillar reins are also most useful when breaking in a young horse, for when they are fastened to the bit the colt can play with the latter, and thus learn to stand still when held by some one on foot. Of course the pillar reins must be fixed sufficiently far away from the door to hinder the horse from reaching it and rubbing the bridle against it.

One of the great, if not the chief, advantages of a box is that the horse is able to move about, and so continually shift the weight off one foot on to the other. The poor animal tied up in a stall can only ease one limb by throwing all his weight on to the other, standing still all the time. Then he again changes the burden, but all that time there has been an immense weight compressing the structures of the foot, and the hoof being simply a horny box, it cannot allow expansion; thus the bloodvessels are constricted, and the circulation suffers. We all have experienced the unpleasant sensations engendered by standing in tight boots for any length of time, and the relief experienced when one is able to move on, and it is the same with a horse when racked up in a stall. Minor evils, resulting from deficient circulation, follow from this cause, filled fetlock joints and so forth; and all this discomfort can be obviated by allowing the horse the luxury of a box. If a horse is watched in a field or in a box it will be seen that he is always moving, at one moment nibbling something here and the next moment something there, raising and lowering his head to do so, and stretching his neck from side to side. $\mathrm{He}$ is never in the same position for long together, and all that time the weight is constantly being sustained by the different feet, those at temporary rest allowing perfect freedom to the circulation to run its course; then when there is a dry bed to lie upon, free from a cold wind or draughts, the animal lies down when he wants to rest; and that such conditions are at all times within his reach the careful horse-master will endeavour to arrange. 
All doorways should be high and wide, to prevent the danger of knocking the top of the head or the hips when passing through them; and the side-posts must never be left with a sharp edge, being carefully rounded off to minimise any possible accident; when practicable it is better to have the posts protected with a small roller, which will turn round if the horse catches against it. A groom leading a horse into a stable should never pull at the bridle, if it hangs back, for then it is certain to elevate the head, and knock it against the top of the doorway if it is low. There is no surer method of teaching a horse to be afraid of entering a stable than this, and the habit of going in and out with a rush is soon learned if a horse has once been thus hurt. If the man allows the horse a slack rein he will carry his head low, and there will then be no fear of his hitting it however low the doorway may be. The provision of light is an important one, as, though horses may rest better in the dark, their eyesight will soon suffer if they are kept habitually without sufficient light. But the windows must be placed sufficiently high up that the light does not strike directly upon the eyes, or evil consequences may be the result. This is the one objection to highly glazed bricks being employed for lining the walls of stalls, especially when white enamelled bricks are used, for they reflect many points of light, which cannot be good for the optic nerves when subjected incessantly to the strain thus imposed. Although not ornamental, nothing is better for coating all woodwork than black varnish, since it is healthy and can be renewed at any time, and horses do not gnaw it. Some animals have such a fancy for gnawing woodwork that they are with difficulty restrained from doing so, and the most effective plan is to cover all wood with zinc wherever it is needed. As a temporary measure horses can generally be stopped for a time from this annoying habit by rubbing aloes over any place which they have commenced upon; and another excellent remedy is to dab on Pilcher's Stop-rot, the taste of which is objectionable to them. 


\section{Mangers.}

Mangers should be made of iron, with a compartment for hay, and another for water, and the whole should be boarded down to the floor. One advantage iron mangers possess is that horses are not tempted to catch hold of them when being dressed, and so learn the trick of crib-biting; and they are also easily cleansed. Their disadvantage is they are necessarily small, and excitable horses which constantly lift up their heads whilst they are eating are apt to drop some oats each time they do so. When the bedding is straw they often pick up the scattered grain afterwards, scraping away the straw to do so; but if the bedding is of other materialpeat-moss or sawdust-they cannot recover much of what they have dropped.

Iron mangers should always have a "lip" round the inside, to prevent a common trick amongst horses of shoving some of the corn out with their muzzle when a manger is small; and to stop this practice when the mangers are wooden they should be of considerable length, so that an animal can spread the feed along them without pushing it out altogether.

If hay-racks are placed overhead there is always a danger of hay-seeds getting into a horse's eyes when pulling out the hay, and it is better therefore to have them placed low, the same height as the manger.

In boxes the corners can be utilised for building small brick places, one to hold an iron pot for the oats, and another to be fitted with a zinc pail for the water, both of which should be sunk deep enough for the upper part to be level with the masonry. The vessels should be movable so that they can be easily removed for cleansing purposes. The bricks should be built in the form of a cone, broad at the base and contracting to almost the width of the pot at the top, the object being to prevent a horse from standing so close to it when eating or drinking, that there will be no room for it to jerk a knee up without touching the brickwork, when irritated by flies. The outside should be coated with cement so as to leave the surface quite smooth. 


\section{Boxes.}

For horses in hard work a box 9 feet wide by 14 feet long is quite large enough, and this particular width is just the length of an ordinary railway sleeper, which may come in useful on some occasion when additional flooring is required. Sick horses, and idle ones, require more room, since it is their only chance of taking exercise, and for them boxes should be provided 12 feet by 14 feet, or even 14 feet square. Brood mares with foals lequire large boxes, and so do stallions, and for them they may be of any size up to 18 feet square.

\section{Drainage.}

Perhaps the best system of drainage is some form of surface drainage which can be easily cleansed, and does not permit liquids to sink into the flooring; and this can be carried out by having the flooring made with blue, or red, specially prepared bricks that are channelled sufficiently to carry off all liquids, while at the same time they afford good foothold to a horse. They should be laid to have a slight fall. Another method is to have the flooring of concrete largely composed of small pebbles. A third way is to have a concrete bed, with a layer of cement above in which cobblestones are embedded, a grouting of cement being finally added. When properly done this makes a capital floor and never gets slippery under any circumstances. The concrete should be formed of rough, broken bricks, or something similar, to a depth of about a foot, and then overlaid with cement for about 9 inches, the proper fall being now attended to. When the cement has become fairly stiff the cobbles should be embedded to rather more than half their depth, only a narrow breadth being done at a time, so that a man can easily reach to fit the stones properly in their places; and these should not be set too close together, to afford facility for sweeping away any accumulation that may lodge between them. When all are set a little liquid grouting can be added to obtain the necessary level between the stones. A channel leading from the stall or box should conduct all 
liquid to the ontside through a hole in the wall, and then arrangements must be made for its removal, either by drains, or some other plan, such as an iron pot which can be daily emptied.

Underground drains should only be employed when there is ample water-supply to keep them constantly flushed, and then they have many advantages. In the first place the floor can be flatter, since the necessary fall is underneath, and therefore a horse can stand more comfortably, as he is not always on an inclined plane. A horse fastened up in a stall with a sharp slope will always be seen to stand across it, if allowed to do so, to ease the strain on his legs as far as possible. The whole length of the drain in the stable should be easily accessible and capable of being cleansed every day. There should be as few angles as possible, for these arrest any solid matter which may get into the drain; and whereever one is absolutely necessary it should be as obtuse as the ground permits. There must also be some simple trap at the inflow in each separate stall. A good system of underground drainage effects a considerable saving in straw.

Accommodation must be found for housing the fodder, such as hay, straw, corn, carrots, and bran; and also a commodious saddle-room for cleaning and storing saddles, bridles, clothing, and all the minor paraphernalia connected with a stable. A glass case should not be forgotten, in which spare bits and stirrups can be stowed away and kept free from dust. There must, too, be provision for an ample supply of both hot and cold water, the former of which should be independent of the domestic arrangements, and is best provided by a boiler fitted to the saddle-room fire.

\section{Artificial Light.}

Where no gas or electric light is available, and lamps have to be employed instead, they should be hung upon strong nails fixed in convenient positions, out of possible reach of the horses; while gas and electric burners should never be placed where a horse can gain access to them if it should happen to get loose from its box. A gas bracket with a 
movable arm can often be hidden away in a recess in the wall, and the opening so secured that no animal can get at it when it is not in use.

\section{Exercise.}

Nothing is more important for the well-being of a horse than daily exercise, the amount of which must depend upon the work it is likely to be called upon to perform, and the condition in which it is in. The object sought is to get the muscles and tendons firm, and to keep them so, and also to have the lungs able to undergo long and possibly violent exertion without evil consequences ensuing, for which purpose trotting and walking for two hours should as a rule be the means employed. When horses are taken up after the summer, and have not had a weight on their backs for some months, an hour is quite long enough for the first week, increasing to two hours in the second week, and only trotting for very short periods at a time. In a month the animal should be capable of doing much longer work, and at least twice a week should be kept out from three to four hours, with an occasional short canter. But every case must be studied by itself, a gross, heavy horse requiring a longer period before commencing fast work than will a wiry, lightbodied one. Physic is a necessity on recommencing work after a long period of idleness, and at the end of a fortnight a second dose will probably be required, the symptoms calling for it being the filling of all the legs; and at any time when such is observed to be a daily occurrence, the administration of a dose of physic is usually followed by satisfactory results.

Condition can only be attained by long-continued exercise, and herein lies the supreme objection against summering horses in loose boxes. When put into work again the muscles are in such a flabby condition, and have so lost tone, that it takes weeks longer to get horses from loose boxes ready for hunting than when they have been turned out to grass. It has been reckoned that a horse at grass travels about twenty miles daily, and it will be noticed that when they have 
finished feeding for the day, just before sunset, they usually begin a game of romps and often take a sharp canter before settling down for the night. When turned out they should not be put into a meadow knee-deep in herbage, where they will rapidly fill their stonachs with succulent grass; instead they should have the run of a bare field, where they will have to work for their living, and it is often advisable to let them succeed a herd of cattle who have eaten the pasture nearly bare. The grass that springs up will then be short and sweet, full of small clover and the finer grasses. The objections urged against turning horses out are that they batter their legs from stamping on the ground when teased by flies, but this to a great extent is from the pernicious habit of docking the tails of the poor animals, depriving them of their natural means of defence. Horses with long, flowing tails do not stamp, but simply switch away the insect pests with a sweep of their tails.* If the weather happens to be very hot, and the flies are very troublesome, the horses may be brought into the stables in the early morning and turned out again in the cool of the evening; but if they have long tails such precantion is not required. They, like most other mammals, derive much benefit from having the sun on their backs, and thrive in consequence. One important thing to be on the look-out for is to see they do not become infested with internal parasites, and if an animal begins to look staring in its coat it is always wise to take it into the stable for a day or two, and give it a vermifuge. To guard against this evil, pastures where horses are

* On September 11, 1911, I watched two horses in close proximity in a grass paddock near my house. One had but a very short dock, and timing it by my watch I noted the animal averaged 28 stamps per minute, besides constantly throwing back its head to its flanks, to drive away the flies. The other animal had a long flowing tail down to its heels, and during the whole time I was observing them it never made a single stamp, nor did it lift up its head from grazing, although it had a far thinner skin than the other. But the long tail was kept constantly in motion, and it was entirely due to this that the animal was able to graze in peace and comfort.

It need, perhaps, hardly be added, the animal which had been docked had not been mutilated whilst in my possession, but had been thus barbarously treated by a former owner, before it became my property 
to be grazed should have a dressing of lime in the spring, and subsequently during the summer have a liberal sprinkling of salt, which helps to destroy the eggs of all worms. When July comes in, and during August and September, all horses at grass should be daily examined, especially towards the evening, to note whether the bot-fly has laid its eggs on their coats; these should be looked for especially on the forelegs, inside the knees, along the mane, and behind the shoulders along the ribs. Every egg should be scraped off with a knife lest the horse should lick itself, or another perform the same kind office for it; if the egg is swallowed it will turn into a large grub and live in the stomach, where it buries its head in the mucous membrane. The effect on its host is not at once apparent, but about Christmas it will be noticed that the horse is falling off in condition, and in spite of pampering with drugs and tonics the animal will get thinner and thinner, and all the blame is then laid upon the horse having been turned out to grass the summer before. It never dawns upon the groom or his master that it was to the neglect of the former, either through ignorance or apathy, that the present forlorn state of the horse is due. So matters go on, the victim getting thinner and thinner, if it is harbouring a number of the parasites, until about July, when the grubs attain maturity, let go their hold, and pass away to undergo the next stage of their cycle of existence, and, eventually becoming large flies, in their turn lay their eggs on another unfortunate animal. No medicine seems to have any effect on these parasites, and the writer has kept them alive for more than a week in spirits of turpentine, and they might indeed have gone on so living, only the experiment was regarded as fully proved, so they were thrown out and summarily despatched. Occasionally they bore holes through the mucous membrane and thus cause the death of the horse. Very large numbers are sometimes present, and the writer once noted eighty-four pass away from an animal in his possession which had been bought at auction the previous autumn. When once clear of the parasites the horse quickly picked up flesh, and became quite a different-looking animal in a short time. The bots 
themselves are about as large as blackberries. A course of sulphate of iron will expedite their departure when they are nearly ready to leave of their own accord; and a decoction of the ordinary stone-crop used to be looked upon as a remedy in some parts of Ireland.

The bot-fly is nearly as large as a honey-bee, and hovers close to the place it has selected for laying its eggs, maintaining the while a perpendicular position. It remains perfectly motionless in the air, except for extremely rapid vibration of its wings, which do not emit the slightest hum, or any other sound, and therefore the doomed victim remains quite unconscious of the vicinity of its enemy. When the critical moment arrives the fly darts forward, and suddenly elongating a wondrous ovidepositor, which it curls round in front of it, it just touches the horse and leaves an egg adhering firmly to the hair. It then resumes its former position and continues the process, if undisturbed, until that batch is laid, often depositing thirty or forty eggs at one laying. On subsequent days it will lay as many more. It appears to have a preference for dark-coated horses, if several are feeding together of different colours, and then selects bays and chestnuts, but greys the least of all.

These drawbacks, however, do not affect the principle of turning horses out to grass, which affords them the great advantage of keeping their muscles employed, and their circulation in order, by the daily exercise they take in the course of each twenty-four hours when wandering in quest of food.

Almost, if not quite, as important as the quality of the herbage is the supply of water, which should always be available, and should be pure and sweet. The germs of parasites may be imbibed with water, as well as taken up with the grass. Shelter from boisterous weather, and shade from the sun when required, are also very desirable, and these may be provided by plantations and belts of trees, which horses seem mostly to prefer to open sheds. Plantations help, too, to diversify the ground, which is another advantage, and break the view, thus preventing the bare 
and bleak appearance which an open field often presents; they give also an object to the horse to go round them out of a spirit of curiosity, to find out if anything of interest is happening on the other side.

Pastures should always be provided with a lump of rock salt, which is much appreciated, and is most conducive to the health of the animals grazing.

\section{MEMORANDA.}

Some useful memoranda are as follows, but the calculations are only approximate and intended as a rongh guide :-

One ton of hay lasts a horse six months.

One sack of oats lasts a horse 14 days at 12 lbs. per dien.

One truss of hay lasts a horse 5 days.

Two trusses of straw last a horse 5 days.

One sack of oats weighs 12 stone.

One quarter of oats $=2$ sacks $=24$ stone $=3 \mathrm{cut} .=336 \mathrm{lbs}$.

One ton $=20 \mathrm{cwt} .=160$ stone $=2,240 \mathrm{lbs}$.

One truss of old nreadow hay $=56 \mathrm{lbs}$.

One truss of straw $=28 \mathrm{lbs}$.

One quarter of oats $=24$ stone.

", $\quad$ barley $=32$ stone.

$, \quad, \quad$ maize $=34 \quad$,

$, \quad, \quad$ wheat $=36 \quad$,

One ton of oats $=6$ qrs. 2 cwt. $=13 \frac{1}{2}$ sacks.

New oats are ready for use when they have become crisp enough to be bitten in two sharply and cleanly-usually about the beginning of the New Year. It is advisable to mix them at first with old oats and thus make the change to them gradual.

\section{To Find the Quantity in a Stack of Hay.}

By multiplying the height, breadth, and length together the number of cubic yards are found contained in the stack.

From 11 to 14 cubic yards of hay = a ton, according as the hay is light or heavy. The average is abont 1.2 cubic yards. 
Hay that has been much rained upon in making, turns to dust in the stack, and weighs very light.

The breadth and the length should be measured about the height of a man from the ground, to obtain the mean.

The height should be measured from the ground to the eaves of the thatch, and then one-third of the distance from the eaves to the top should be added, to obtain the true height for purposes of calculation.

New hay weighs very much lighter than old hay. 


\section{CHAPTER XI}

\section{SIMPLE AILMENTS}

THE stitch in time is of the utmost importance in con1 ducting the affairs of a stable, when it is a question of applying a timely remedy and preventing a simple ailment from developing into a serious illness. It is not necessary to call in the assistance of the veterinary surgeon every time, although it is not well to allow a disease to run on until it becomes almost incurable before seeking professional advice; and if a change for the better does not speedily occur, when the illness is serious, the sooner the veterinary surgeon is called in the better.

The two great guides as to the progress of an inflammatory attack are the pulse, and the temperature chart, and every horse-owner should know the mode of procedure with both. The most convenient place for feeling the pulse is towards the posterior part of the jaw-bone, where the artery passes over a little groove. It should be noted whether the pulse is soft or hard, full or feeble, regular or irregular in beats and strength, and the number of beats that occur in a minute. A strong, full pulse, or a soft and full pulse, indicate health if they do not exceed forty-two beats per minute, the normal range being from thirty-four to forty-two beats, depending on the age of the animal, the state of the atmosphere, and also whether any condition is present which may cause undue excitement of the system. When the beats are irregular, when three or four follow each other with regular rhythm and afterwards an intermittent stage occurs for the space of about two beats, while still the ordinary number is not exceeded per minute, heart disease may be suspected. A weak, small pulse indicates debility. A rapid, wiry, hard pulse, the artery feeling tense 
as a wire, tells of fever; but not, as a rule, of congestion of the lungs, which is usually accompanied by a full pulse the beat of which is indistinct. Injury to the brain, or spinal cord, is shown by a particularly slow pulse.

The temperature of the horse is taken by inserting a thermometer in the rectum, and in a state of health is about $992_{2}^{\circ}$ to $101^{\circ}$ Fahrenheit. It is a surer guide than the pulse, and taken in conjunction with it affords clear indication of the condition of the patient. Anything above $102^{\circ}$ indicates sickness, $103^{\circ}$ slight fever, whilst $106^{\circ}$ means very high fever indeed.

When the patient is very feeble the pulse can sometimes be felt on the right side when it can no longer be discerned on the left. In a state of ordinary rest, standing quietly in the open air, the normal rate of breathing is about twelve times per minute.

The other indications denoting good health are a brightlooking, smooth coat, clear eyes, and the legs clean and fine with well-defined sinews; then, if the appetite is also good, the man in command need feel no apprehension about the state of his charges. One of the surest indicators of health is the condition of the dung, which should be not too dark in colour; in good large balls sufficiently soft; and, when first dropped, with a distinct glisten on their surface. If, on the contrary, the balls are small, hard, and very dark, the digestion is not as it should be, and often the temperature will be found to be above the normal, and a bran mash and linseed gruel should at once be substituted for hard corn. Another indication that the liver is out of order is shown when the dung is not formed into balls, but is a light-coloured mass with a dull surface, somewhat resembling yellowish clay. This may arise from too much heating food, but also from many other causes. Bran mashes are again indicated, and often a little sulphur and nitre, or sulphate of magnesia, with nitrate of potash, will put the animal right in a few days. Of course, it should have a holiday from work, except of very light description, and should not be taken out in rain.

More important than drugs in illness is what is known as 
"good nursing," and therein lies more than half the battle in a serious attack.

If possible a quiet, comfortable loose box should be provided, well ventilated, but free from draughts; for, especially in the earliest stages of fever, the patient is very susceptible to a draught, which may easily bring on a fit of shivering, ever a dire portent. When the fever has fully established itself the animal is not nearly so sensitive to draughts, until the weakness of the convalescent stage is reached, when again every precaution must be taken against catching cold. Unless the horse has to be tied up to prevent interference with a blister, or some wound, it is better to be loose, free to wander about at will. In all diseases of the respiratory organs, and in certain others, it is most essential that the skin should perform its proper functions, and on this account warmth is especially necessary; but whilst the patient must be kept warm and draughts must be avoided, fresh air is of the greatest importance, and this should be supplied by open windows and door's. By some means a supply of fresh air must be arranged for without any draught. If the weather is cold the temperature of the box can be artificially raised, for it is better not to overload a weak patient with too much clothing; and endeavour should instead be made to bring the fresh air within the region of a heating apparatus before entering the sick box, which may be effected by the employment of large cylinders connecting with the window, and heated in some manner, whilst the rest of the aperture is blocked with cloths.

All clothing should be loose, as thereby more comfort is obtained, and more warmth. A sick animal should have its clothing changed twice a day, two sets being in use ; but if this is not feasible, the clothing should at least be taken off for a few seconds, and well shaken and beaten before being replaced, care being taken that the animal does not get a chill while this is being done. The momentary admission of fresh air to the skin is frequently very grateful, and often seems to revivify the patient.

In cases of serious illness, especially if it is likely to be prolonged, it is well to remove the shoes at once lest they become embedded in the hoofs. 
When the circulation is poor, and the extremities are cold, flannel or serge bandages are called for, which must be put on quite loosely, for tight bandages would diminish the already weak circulation. If the legs still remain cold layers of cotton-wool placed under the bandages will be an additional help in promoting warmth. The bandages should be removed at least twice a day, when the legs should receive gentle hand-rubbing.

A sick animal does not require much grooming, if any at all; but a wisp and a rubber just passed lightly over the coat will help to remove some of the dust with which the coat is apt to become overcharged. It is, however, always advisable to sponge daily the eyes, nostrils, and dock with lukewarm water, to which a little vinegar has been added. The sheath should always be carefully cleaned at the commencement of any serious illness.

The box must be kept perfectly clean, with an ample supply of bedding, though in most illnesses a horse will not lie down unless absolutely compelled to do so by growing weakness; and it is generally a sign, especially with wellbred horses, that the patient is either much better, or much worse, when it is seen to lie down.

When the appetite fails the horse should be tempted to eat by offering it a small handful of special dainties, frequently repeated. As long as they are eaten bran mashes form the staple food, together with oats and linseed gruel. To make "boiled" or "scalded" oats a double-handful of bran should be placed at the bottom of a bucket, next a layer of two double-handfuls of oats (crushed if possible), and then alternate layers of bran and oats until the requisite quantity for the feed is in the bucket. Add linseed gruel which is actually boiling, or hot water, stir with a stick, and cover with a cloth for an hour, when it will be ready for use. Anything which is left should be thrown away, and the bucket or manger thoroughly washed out after each meal, for the smell of sour bran is very likely to increase any distaste for food. Hay on which the animal has breathed should also be thrown away, and not used as food. Green food is most invaluable for tempting the 
appetite, and as a laxative, grass, carrots, turmips, watercress, apples, the tops of celery, dandelion leaves, and lettuce leaves. Care should be taken that the grass is cut when dry, or it will soon begin to ferment. Carrots should always be sliced lengthways, for if given whole or cut across into chunks, a horse may swallow the carrot without chewing it, and get choked in consequence.

Milk is a very valuable food, and if a horse will take one or two gallons of it daily, given on four occasions, it may struggle on for a long time and wear the fever out in the end. It is when the fever has left that especial care is required, on account of the great weakness which follows, and for the first two or three days the animal should receive nourishment every three or four hours. Especially does it require attention in the early hours of the morning, and the groom who does not come to see after the invalid till seven or eight o'clock, need not be surprised if he fails to save the patient. One or two eggs beaten up and added to the milk increase its nutritive powers considerably; and if the horse does not take kindly to the milk, a little added sugar may make it more palatable.

If stimulants have to be administered during convalescence, it is usual to give beer, stout, whiskey, or brandy, all of which act as food as well as stimulants; and a convenient mode of administering them is to mix them with oatmeal gruel, and drench the horse with it from a bottle, one or two wineglasses of spirit being given, or a pint to a quart of beer or stout.

To rouse and stimulate the circulation, and for immediate effect such as in a case of shivering, or when there is great depression and prostration, diffusible stimulants are of the highest value, such as-

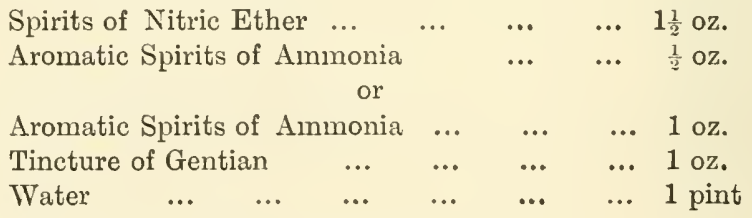

To be given as a drench, as above. 
Other medicines that should always be at hand, if there is no surgery or chemist's shop within reach, are Sedatives, Narcotics, Antispasmodics, and Tonics, besides drugs in common use.

Of sedatives the groom does not require anything more than aconite, which acts promptly in cases of severe fever; and if the allopathic tincture is used, it should be given in doses of 10 to 20 drops, which may be frequently renewed until the action of the heart is lowered, as shown by the falling pulse.

Narcotics are called for when great pain is present, and either belladonna may be given, or opium. In severe cases of colic Indian hemp (Cinnabis Indica) is a most valuable remedy, and may be completely relied upon.

$\begin{array}{llcccccc}\text { Belladonna ... } & \ldots & \ldots & \ldots & \ldots & \ldots & 1 \mathrm{dr} . \\ \text { Nitrate Potassæ } & \ldots & \ldots & \ldots & \ldots & \ldots & 1 \text {, } \\ & & & \text { or } & & & & \\ \text { Opium } & \ldots & \ldots & \ldots & \ldots & \ldots & 1 \text { to } 2 \text { drs. } \\ \text { Camphor } & \ldots & \ldots & \ldots & \ldots & \ldots & 1 \text { to } 2 \quad,\end{array}$

For Colic.

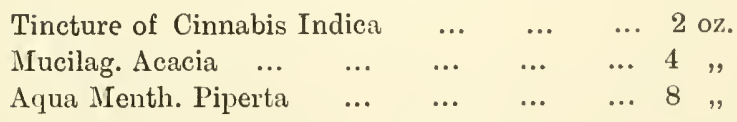

Administer the latter as a drench, and if the pain does not subside give another half-dose in half an hour.

If this remedy is not available give-

$$
\begin{array}{cccccc}
\text { Bicarbonate of Soda } & \ldots & \ldots & \ldots & \ldots & 2 \mathrm{drs} . \\
\text { Tincture of Ginger } & \ldots & \ldots & \ldots & \ldots & 1 \frac{1}{2} \mathrm{oz} . \\
\text { Mixed in a pint of water. } & &
\end{array}
$$

In cases of great pain add-

$$
\begin{array}{lllllll}
\text { Tincture of Opium } & \ldots & \ldots & \ldots & \ldots & 1 & \text { oz. }
\end{array}
$$

Another prescription for colic is-

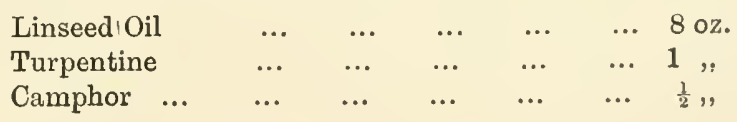


The camphor should be placed in the oil in the evening, and will be dissolved in the morning.

Since Antispasmodics act upon the brain and nerves, and through them on the muscular system, they are required in cases of spasm, and opium is one of the most powerful of them all.

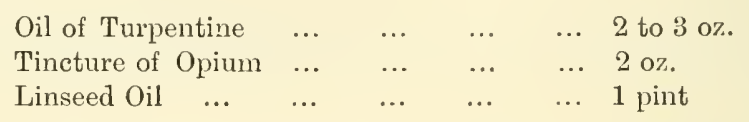

Tonics are powerful agents in restoring a convalescent to complete health, or at any time when anæmic conditions are seen to be present. Two of the most useful are the following, the arsenic being especially required after, or during, any eruption of the skin, such as so-called mudfever; while the iron is most necessary when the gums appear too pale, or when great calls are being made upon the muscular system, such as during the last fortnight before a great race:--

\section{Fowler's Solution of Arsenic (Liquor \\ $\begin{array}{llllll}\text { Arsenicalis) } & \ldots & \ldots & \ldots & \ldots & 30 \text { drops }\end{array}$}

To be dropped on a little dry bran and mixed with the feed of corn, when it is readily taken, for though it smells strongly with a peculiar odour, neither horses nor dogs ever seem to object to this. The dose may be given twice a day, if thought advisable, for the first few days; but it must be kept in mind that arsenic is an accumulative poison, being stored up in the system, and only slowly eliminated, and therefore if continued for too long a time the accustomed dose proves some day just too much, like a teacup running over which is being filled up drop by drop. It is for this reason that cart-horses get occasionally poisoned by their carters, who give them condition powders containing arsenic to improve the sleekness of their coats, and one day the usual dose proves to be a fatal one. It would be perfectly safe to give a horse a teaspoonful of Fowler's Solution daily for six weeks, and therefore a similar dose for only a fortnight is well within the bounds of caution. It will usually be found 
that a fortnight's course of the medicine is amply sufticient to start the horse well on its way to renewed vigour, and then an interregnum may be allowed, and afterwards a second course begun in about ten days' time. Another hint may be added, that aperient medicine should not be administered at the same time as arsenic, and if an occasion should arise for an opening dose, the arsenic should be stopped for a couple of days beforehand. One of the first symptoms of poisoning by arsenic is an attack of diarhoea.

There is no danger in giving an iron tonic, but it will usually be found that further benefit does not follow after a course has lasted about a fortnight. It is better then to stop it for a few days, and recommence it when thought desirable.

$\begin{array}{lccccc}\text { Finely powdered Sulphate of } & \text { Iron } & \ldots & \ldots & 2 \mathrm{drs} . \\ \text { Powdered Gentian } & \ldots & \ldots & \ldots & \ldots & 1 \mathrm{dr} \\ \text { Powdered Camomile } & \ldots & \ldots & \ldots & \ldots & 1, \\ \text { Powdered Ginger } & \ldots & \ldots & \ldots & \ldots & 1,\end{array}$

To be given daily, mixed with a feed of oats, for a week or a fortnight.

Sometimes it is necessary to apply Flectricity to a horsea valuable aid for rousing the liver and kidneys to activity, when the current is applied to the loins. It must be remembered that it is necessary to thoroughly wet the hair before applying the battery, for dry hair is a non-conductor. Electricity has a marked effect in the case of a snapped muscle, encouraging growth between the two broken ends; but it is necessary for this purpose to be familiar with the course of the muscle, so that the negative and positive currents may be adjusted in the right position to travel along the muscle. They must therefore be placed at each end of it. When the two conductors are applied to an ordinary muscle, at some distance apart, a curious effect is produced when the current is turned on, the muscle jumping about between the two points as if it was itself a living thing. 


\section{CAtARrh.}

The commonest illness which an ordinary groom has to treat is a simple catarrh, consisting of a slight inflammation of the nose, and back part of the throat. It is nearly allied to bronchitis, the difference between them being that a common cold is confined to the nose and throat, while bronchitis is seated lower, in the bronchial tubes or airpassages to the lungs. The horse coughs and sneezes, eats little or no food, whilst a watery discharge flows from one or both nostrils, and also from the eyes, which are red and swollen.

The animal should be given a linseed mash instead of its ordinary feed of corn, and if the throat is sore the hay should be slightly damped before it is offered to the patient.

The following powders should be given in the drinkingwater three times a day:-

$$
\begin{array}{llllll}
\text { Sulphate of Magnesia } & \ldots & \ldots & \ldots & \ldots & 3 \text { oz. } \\
\text { Pulveris Potassæ Nitrate } & \ldots & \ldots & \ldots & \ldots & 3 \text { drs. }
\end{array}
$$

If the attack is a severe one, give twice or three times a day in addition-

$$
\text { Tincture of Belladonna } \quad \ldots \quad \ldots \quad \ldots \quad 30 \text { drops }
$$

The glands under the jaws, and at the top of the throat, may be rubbed with mustard, which should be sponged off in about ten minutes; or the following liniment may be used instead :-

$$
\begin{aligned}
& \begin{array}{lllllll}
\text { Saponis Mollis } & \ldots & \ldots & \ldots & \ldots & \ldots & 4 \text { drs. }
\end{array}
\end{aligned}
$$

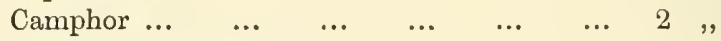

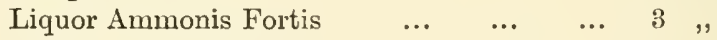

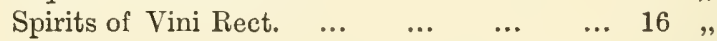

Another useful liniment, which can be obtained in almost any place, however much out of the way, is-

$\begin{array}{llllll}\text { Acetic Acid or Vinegar } & \ldots & \ldots & \ldots & \ldots & 1 \text { pint }\end{array}$

$\begin{array}{lllllll}\text { Spirits of Turpentine } & \ldots & \ldots & \ldots & \ldots & 1 & \end{array}$

Beaten up with four eggs, including the shells. 
When recovery commences a thick white or yellowish discharge sets in, flowing from both nostrils, and to assist the getting rid of it all food should be placed on the ground, so that the head must be lowered. It is usually a sign that the inflammation has abated, and the strength of the patient should be got up as soon as possible by nourishing food and tonics. For the latter Fowler's Solution of Arsenic is especially to be recommended, to be followed after four or five days by the sulphate of iron tonic, combined with gentian, camomile, and ginger, which has already been described.

\section{INFLUENZA.}

Largely resembling a common cold in its symptoms, and yet differing from it in many respects, influenza usually has more serious effects, and the patient is much longer in recovering from its ravages. With it there is a sudden attack of fever, more or less severe, great weakness comes on soon after the attack, and the illness is of a very contagious character. It usually occurs in the spring and autumn, and the symptoms vary in several respects from one year to another. Drastic purges or strong sedatives should never be given. Saline draughts should be administered, and the prescription mentioned for a catarrh, of sulphate magnesia, and nitrate of potash, is very good.

$\begin{array}{lllllll}\text { Acetate Ammonia } & \ldots & \ldots & \ldots & \ldots & \ldots & 4 \mathrm{oz} . \\ \text { Nitric Ether } & \ldots & \ldots & \ldots & \ldots & \ldots & 1,\end{array}$

should be given once or twice a day to lower the fever, and to maintain the fluidity of the blood, and if there is much fever add to the above--

$\begin{array}{lllllll}\text { Tartarised Antimony } & \ldots & \ldots & \ldots & \ldots & 1 \mathrm{dr} .\end{array}$

dissolved in water.

If much prostration sets in give extra doses every four hours of-

Nitric Ether ... $\quad \ldots \quad \ldots \quad \ldots \quad \ldots \quad 1$ to 2 oz. 
and if the prostration increases give in addition every twelve hours-

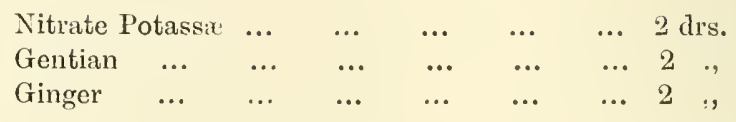

leaving out a dose of nitric ether, if the two happen to clash.

The horse must have the best food which can be got, such as malt mashes, boiled oats, linseed gruel, and green food, if it can be tempted to eat at all.

\section{Pneumonia, or Inflammation of the Lungs.}

This is far too serious an illness to be treated by the ordinary groom, if the services of a veterinary surgeon can possibly be obtained. The first symptoms are fits of shivering, the legs, ears, and skin cold, the hair rough, the nose pale and dry, the eyes have a yellowish colour, and the horse is uneasy and restless. The pulse is quick, and becomes soon afterwards frequent and full. 'I'he temperature is high, and there is a constant short cough, the animal never filling the lungs with sufficient air to emit a full, deep cough. Subsequently the horse remains standing in one place, with the fore-legs fixed and separated from each other ; the legs and ears becoms very cold, the former being fine and the hair upon them glossy; the nose gets a bluish look, the blood not being sufticiently aerated; the nose and head are held out, and the breathing becomes shorter and more difficult. Little can be done until the veterinary surgeon arrives, except bandaging the legs, keeping the skin warm by clothing, and administering a dose of-

$$
\begin{array}{lccccccc}
\text { Carbonate of Ammonia } & \ldots & \ldots & \ldots & \ldots & 1 \text { dr. } \\
\text { Water } & \ldots & \ldots & \ldots & \ldots & \ldots & \ldots & 1 \text { pint }
\end{array}
$$

while the sulphate of magnesia powders recommended for a cold should be given in the drinking-water three times a day for three days.

Inflammation, or cungestion of the lungs, occasionally 
follows too great exertion in the hunting-field, especially if the horse has been allowed to stand about after a severe run, and has thereby contracted a chill. If the animal after reaching its stable takes a little food and water, and is disposed to lie down, it may be considered all right; but if the breathing increases in frequency, and the animal grows restless, it may be concluded that the lungs are distressed, and the sooner a dose of carbonate of ammonia is administered, and the veterinary surgeon sent for, the better.

If, instead of being restless, the animal appears thoroughly exhausted, unable to eat, with rather rapid breathing, further trouble may be warded off by administering as a drench the sulphate of magnesia powders, mixed in a pint of water, with the addition of two sherry-glasses of gin or whisky.

Pleurisy, or Inflammation of the Pleura.

This is also too serious a disease for any one buc a qualified professional practitioner to take in hand.

The pleura is the membrane which lines the inside of the chest, and which covers the lungs, and hence any inflanmation in this region interferes with the due working of the lungs, and causes pain in breathing.

The horse stands in a crouching manner, and seems uneasy, but does not move on its own initative. The pulse is hard, quick, and wiry, and the temperature high. The act of drawing air into the lungs soon causes pain to be felt, when there is a short catch in the breath, and then the air is expelled as slowly as possible in a drawn-out effort. 'There is a short, hard cough, which makes the pain worse, as also does the act of taking a full breath, which the animal will only do if moved suddenly, or frightened unawares.

The internal remedies consist of giving the sulphate of magnesia powders in the water; and if the fever is severe, by administering 30 drops of aconite in a wineglassful of water twice, or three times, at an interval of two or more hours. 


\section{BROKEN WIND.}

Some cases of broken wind cannot be cured, since the aircells in the lungs have been ruptured; but what frequently passes as such is the result of a disordered stomach, with spasm of the muscular fibres which lie on the inside of the small branches of the windpipe in the lungs. This latter form is usually termed in stable language a "stomach cough." The expiration of the air is more difficult, and takes a longer time than the inspiration, the flanks are slowly drawn up and then suddenly fall down with a sort of double action, which is very characteristic. There is a short, harsh cough, with difficult breathing, especially when going uphill, and the animal becomes speedily distressed when asked to go out of a walk. In these cases of chronic cough much relief may be given, and a cure frequently effected, by paying especial attention to the feeding, and taking care the animal is not put to work for two hours after partaking of food, so as to free the lungs from unnecessary pressure. Bulky food must be avoided on days when the animal is required for work, only corn and chaff, with a handful of crushed linseed, forming the feed, while on days of idleness a little damped hay may be allowed. For treatment nothing in the writer's experience can compare with a course of Harvey's Aconite Powders, which greatly lessen the tendency to cough, and not infrequently effect a complete cure.

\section{ROARING.}

So many horses, especially the largest, fall victims to roaring, that any cure which can be relied upon will be a boon indeed. Many methods have been tried, and the most successful one so far has been the well-known practice of inserting a tube, which certainly affords great relief, and enables many a horse to continue at fast work, and even to win races, which would have been quite impossible if Nature had been left to herself. At present much is hoped for from the recently introduced operation of stripping the membrane of the ventricles of 
the larynx, but time has yet to show whether the improvement can be maintained, though the value of the immediate effect is undoubted. As the operation is performed under chloroform no pain is felt by the patient, and no one who can afford to pay the fee need hesitate, on humane grounds, to have the operation performed on a favourite animal.

The noise made by a roarer is usually due to the obstruction of the air-passage by the vocal chord, consequent on paralysis of one side of the larynx, following the failure of the left recurrent nerve. Anything which causes undue strain to the nerve makes for roaring, and so horses with long or abnormally curved necks are more prone to be thus afflicted than those with short and straight necks. There is one type of neck which so constantly results in roaring that it is known in Yorkshire as a "roarer's neck," and sooner or later the horse which is so shaped is almost certain to fall a victim to the complaint. The neck in question is a strong thick one, with the head carried high, but there is a peculiar outward curve in front, somewhat resembling that of a fallow deer, with an unusually thick thropple, the formation of which, no doubt, sustains a constant strain on the nerve, which eventually fails in consequence. A very delicate operation has occasionally been tried with success, as Mr. J. Tagg, F.R.C.V.S., has informed me that he has proved in his practice, when the ailing nerve has been excised and a healthy one grafted in its place; and in this direction there seems a promise for the future, if the stripping of the ventricle should not turn out a permanent cure on further trial.

\section{Strangles.}

Strangles attack most young horses between the first and fifth year, generally in the spring or autumn, and-like distemper in dogs-it is seldom a horse ever has them a second time. In most cases the early symptoms resemble an ordinary catarrh, with slight fever, a hot mouth, red nostrils and eyes, and a watery discharge from the eyes and nose, which 
becomes thicker as the disease advances. Cough, too, is generally present. But soon there is a disinclination to bend the neck and head, and the latter is held in a strained position. The glands under the throat begin to swell and form abscesses, and no further doubt can exist as to the character of the ailment. The general treatment consists of good nursing, tempting the horse to eat mashed carrots, boiled oats, and damped hay, and keeping it comfortably warm with clothing and bandages. In the drinking water may be dissolved-

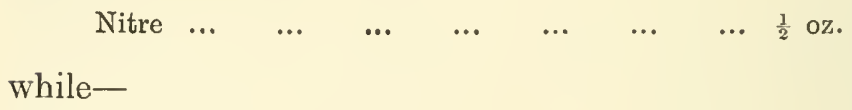

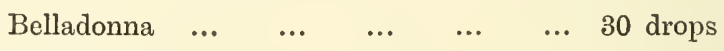

may be given daily with good results.

If constipation occurs, $4 \mathrm{oz}$. of linseed oil may be mixed with the food, or $\frac{1}{2} \mathrm{lb}$. of treacle.

Poultices should be applied to the swelling under the jaw, to bring it to a head as soon as possible, and as soon as the abscess points it should be opened with a lancet, for if left to burst the sides of the wound will be irregular, and take longer to heal. A little tow should be introduced into the opening to prevent it closing up, so that the matter can drain freely away, and should be renewed at least once a day. As the disease is very contagious among young horses, the invalid should be isolated as much as possible, and care taken to prevent the spread of the disease. Occasionally the abscesses form in other parts of the body, when the disease is termed irregular strangles, and becomes much more serious. But in ordinary cases as soon as the abscess is punctured or bursts, and the pus is discharged, the patient commences to improve and soon recovers.

\section{INDIGESTION.}

In this disease the digestion is at fault in consequence of the stomach, liver, or bowels being deranged. The skin adheres tightly to the flesh, in the condition known as hide- 
bound, the hair is rough and unthrifty-looking, the gums pale or yellowish, and the animal is thin and weak. An excellent remedy is the following:-

\begin{tabular}{lcccccc}
\multicolumn{2}{l}{ Flowers of Sulphur } & $\ldots$ & $\ldots$ & $\ldots$ & $\ldots$ & 4 oz. \\
White Resin & $\ldots$ & $\ldots$ & $\ldots$ & $\ldots$ & $\ldots$ & $4, "$ \\
Nitre $\ldots$ & $\ldots$ & $\ldots$ & $\ldots$ & $\ldots$ & $\ldots$ & $4, "$ \\
Black Antimony & $\ldots$ & $\ldots$ & $\ldots$ & $\ldots$ & $\ldots$ & $4, "$
\end{tabular}

Give every night a tablespoonful of the above in a bran mash, for twenty-one days; and every fourth morning, for three doses, a wine-bottle of-

Clear Linseed Oil.

In all cases of the blood being out of order, Flowers of Sulphur is an invaluable remedy, not nearly so much used as it deserves to be. If it did but cost a guinea an ounce it would be held in much higher estimation! A tablespoonful in a mash, with another of common salt, will often have a most beneficial effect, even though a horse is not actually ailing but only not thriving quite so well as usual.

If the gums and eyes are strongly tinged with yellow commence with-

$\begin{array}{llllll}\text { Magnesii Sulphate } \ldots & \ldots & \ldots & \ldots & & \\ \text { Pulveris Potassæ Nitrate } & \ldots & \ldots & & 4 \text { oz. } \\ & & & \ldots & \ldots & 5 \text { drs. }\end{array}$

every night and morning in the drinking-water for four days; and then follow with the prescription mentioned above.

\section{DiARRHEA.}

Too much green food, especially if grown on swampy land; new hay; worms; a chill; and over-purging from large doses of aloes, will all produce an attack of diarrhœa.

All water should be removed, and no oats, hay, or bran mashes should be allowed; but a little dry bran may be given at first, and afterwards bran, just made damp.

Gruel made from wheat flour should be given (in a drench if necessary), a teacupful of flour being well mixed in cold 
water, taking care that no nodules are left, and then filling up the bucket with boiling water, and allowing it to stand till it is lukewarm.

If the attack continues give a drench of one teacupful of starch well dissolved in a quart of warm water, with 60 drops of laudanum. If great weakness sets in give a bottle of port wine.

Or instead of the starch and laudanum-

$\begin{array}{lllllll}\text { Prepared Chalk } & \ldots & \ldots & \ldots & \ldots & \ldots & 2 \text { drs. } \\ \text { Ginger } \ldots & \ldots & \ldots & \ldots & \ldots & \ldots & 2 \text { " } \\ \text { Oil Peppermint } & \ldots & \ldots & \ldots & \ldots & \ldots & 10 \text { to } 15 \text { drops } \\ \text { Linseed Tea } & \ldots & \ldots & \ldots & \ldots & \ldots & 1 \text { pint }\end{array}$

Give three to four times per day.

If there is much pain add-

$\begin{array}{lllllll}\text { Tincture of Opium } & \ldots & \ldots & \ldots & \ldots & 1 \mathrm{oz} .\end{array}$

\section{Thrush of The Mouth.}

Occurs fairly frequently, although it is not always recognised, and it is probably thought the animal has picked up something poisonous.

Blisters occur on the tongue, inside the cheels, and on the roof of the mouth, and there is a constant and copious flow of saliva which hangs from the mouth in long strings.

When a foal is attacked smear a teaspoonful of borax and honey three or four times daily inside the mouth, and place on the tongue-

$\begin{array}{lrlllll}\text { Grey Powder } & \ldots & \ldots & \ldots & \ldots & \ldots & 10 \text { grs. } \\ \text { Bicarbonate Potash } & \ldots & \ldots & \ldots & \ldots & 1 \text { dr. }\end{array}$

and give to the dam-

$\begin{array}{lllllll}\text { Bicarbonate Soda } & \ldots & \ldots & \ldots & \ldots & \ldots & \frac{1}{2} \text { oz. }\end{array}$

For older horses place in the drinking-water night and morning-

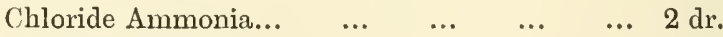

Carbonate Soda $\quad \ldots \quad$... $\quad \ldots \quad$...

Hyposulphite Soda $\quad \ldots \quad$... $\quad \ldots \quad$... 
Enteritis, or Inflammation of the Bowels.

As the general symptoms much resemble those of colic, it is well to be able to distinguish between them, for in a case of enteritis a veterinary surgeon should be sent for at once. Colic commences suddenly, and there are intervals between the attacks, when pain is not felt, while enteritis generally comes on by degrees, and the pain never ceases for a moment. Hand-rubbing the belly relieves the pain in cases of colic, but increases it in enteritis; and whilst a little gentle exercise is sometimes efficacious in colic, it has the opposite effect in enteritis. Until the advent of the veterinary surgeon, if the case is believed to be one of enteritis, the wisest course to pursue is to give every hour, until the practitioner's arrival-

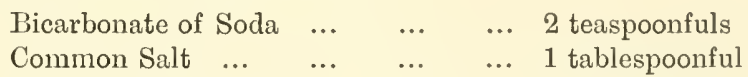

in a pint of warm water.

Since the frees will necessarily become very hard if they remain in the intestine, and difficult to pass, it will be well at the commencement to inject two or three clysters of soap and warm water, to clear the bowel as far as possible, and if this does not have the desired effect, linseed, or castor oil, may be employed as well.

The intestines are divided into small and large, and extend in length to about 90 feet. Though the lines of demarcation are imaginary, for convenience of description they are subdivided into three small and three large ones, the small ones being situated nearest to the stomach. The first receives the secretions formed by two important glands, which cause a change to take place in the food after quitting the stomach, which then passes quickly through the second into the third, whence it passes on into the first large intestine, the cocum. The entrance to this is guarded by a valve which prevents any attempt at regurgitation. When any substance, fluid or solid, once passes the valve it makes its way to the terminal portion, but in the course of time it turns backwards towards the valvular opening again, only to be there stopped, and turned 
into the second, which is the largest of the intestines. As the ingesta passes onward, a set of vessels suck up the nutritious portion, which is always a liquid, and this passes through certain glands, and thence into a receptacle, and finally into the heart. It is now that the fæces begin to harden, and assume the appearance of dung-balls; but absorption of liquid is always going on, as they pass through the remaining portion of the second and the third bowel, which explains how constipation arises, and in the case of fever this is greatly enhanced. It is to relieve this condition that the employment of enemas is so beneficial, by removing the obstructing mass and leaving a free passage in its stead.

\section{Hepatitis, or Inflammation of the Liver.}

In this affection the animal appears sleepy and unwilling to move, and eats little or nothing; the urine is scanty; the dung dark-coloured and in lumps. The membrane of the nose, and the eyes become yellow, and so also are the inside of the lips and tongue, owing to the presence of bile in the blood. The horse may frequently be observed to turn his head round to look at his right side, and when this is pressed it causes pain; while a derangement of the liver is often a cause of slight lameness in the off fore-leg. Whenever any yellowish tinge is observed about the eyes or mouth at once give sulphate of magnesia powders in the drinking-water, continuing them for four days, night and morning; these are generally all the drugs that are required. If further treatment is necessary give-

$\begin{array}{llllllll}\text { Calomel } & \ldots & \ldots & \ldots & \ldots & \ldots & \ldots & 2 \mathrm{~d} \mathbf{r s} . \\ \text { Nitre } & \ldots & \ldots & \ldots & \ldots & \ldots & \ldots & \frac{1}{2} \text { oz. }\end{array}$

for three successive mornings.

Costiveness, And when a Dose of Physic is Required.

When a horse's bowels are bound, without any other disease existing, little corn should be allowed, and no beans, 
some green food being given, and bran either dry or in a mash, with a little hay. Subsequently a wineglassful of linseed oil should be mixed, or rubbed into the oats, twice a day. A tablespoonful of sulphur may also be put into the mash; and if the rectum is full of hardened dung, an injection of warm water should be thrown up, as required.

When a dose of physic is necessary, which is generally indicated by all the legs filling when at rest, a bottle of clear linseed oil may be given, or-

$\begin{array}{lllllll}\text { Aloes } \ldots & \ldots & \ldots & \ldots & \ldots & \ldots & 3 \text { to } 5 \text { drs. } \\ \text { Gentian } & \ldots & \ldots & \ldots & \ldots & \ldots & 2 \text { drs. } \\ \text { Ginger } & \ldots & \ldots & \ldots & \ldots & \ldots & 1 \text { dr. }\end{array}$

made into a ball.

If a horse does not feed well after the physic is "set" (i.e., after the dung has begun to ball again) give-

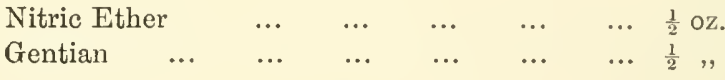

in a draught.

Physic should be given in the morning, when the horse is still fasting, and he should get bran mashes for at least two nights previously. As soon as a horse has had physic administered he must have no hay or corn, and should be muzzled, or racked up, until the appetite begins to fail from the medicine, lest he should eat his bedding. If this precaution is not taken a stoppage of the bowels may ensue, with serious inflammation. Balls are now done up in gelatine capsules, which make them far easier to administer than when done up in a paper covering, while the drugs maintain their strength for a much longer period.

An excellent purge, and one very simply given, is Edos, a gum soluble in liquids, so that it can be administered in gruel, from a soda-water bottle, if the horse refuses its food. Being quite tasteless the usual plan is to give this medicine in a bran mash, which makes it an especially valuable remedy when the groom in charge is not skilled in 
administering a ball, or if the horse is an awkward one to deal with. It should be remembered that medicine should never be mixed with a bran mash till it is stone cold, as a warm one will extract the utmost taste from a drug, and then a horse soon becomes suspicious and refuses to eat. A bran mash should be made with boiling water, and then allowed to get cold before adding anything the taste of which may be repugnant; and all powders should first be mixed in a cup with a little dry bran, or oatmeal, and then afterwards be thoroughly stirred into the cold mash.

\section{Profuse Staling.}

This frequently is caused by improper food, such as overheated hay or kiln-dried oats; and it also frequently follows from the action of the skin being checked by standing in a draughty stable, or from the administration of an overdose of turpentine; or from the turpentine being given in too raw a state, and not sufficiently incorporated with the oil which should accompany it. In any case the cause should be sought for and removed, and if the food is in fault none but the best must be given; anyway it is wise to make a change in the forage.

It is advisable also to give no water to drink for some time, but instead to keep a bucket constantly present, filled with linseed tea, for supplying the necessary liquid. When making it sufficient linseed should be put in the bucket, and then enough boiling water poured over it to cover it well; and after a short time the bucket should be filled up with cold water and then left to stand all night. In the morning the liquid portion should be poured off and given to the horse, while some more linseed, with hot and then cold water, is added to the first bucket, which must be thus filled up as required and always kept going; and as the horse empties the supply left with it, that bucket must be replenished from the other. This is an excellent method with any delicate, non-thriving horse, being continued for months if necessary, and is of especial value for horses in training who may be delicate and do not thrive. 


\section{Retention of URine.}

Many animals have a difficulty in staling after a long day's hunting, especially if they have never relieved themselves since they left the stable in the morning. A remedy which almost never fails is to place part of an onion, freshly cut and about the size of a walnut, inside the sheath of a horse, or the vagina of a mare, and leave it there, when it is seldom more than a few minutes before the desired result is obtained. Should this not prove successful, give 10 drops of tincture of aconite every 15 minutes for three or four doses.

\section{Yew Poisoning.}

This, unfortunately, frequently occurs where animals can gain unrestricted access to yew-trees, and though sometimes they appear to eat it with impunity it far too often has a fatal effect. It appears to be more dangerous in a half-dried state, such as clippings left lying about for two or three days, and also when the growing leaves are scorched by a brilliant sun after a sharp frost the night before. This, indeed, seems to be the most deadly time, whilst the late autumn and the early spring appear the most fatal seasons. At any time of the year, however, poisoning may occur from the consumption of yew leaves, even when they are quite fresh on the growing tree.

The symptoms described by medical observers are giddiness, sudden prostration, vomiting, coldness of the surface, spasms, convulsions, diarrhœa, and irregular action of the heart. Horses and cattle are almost invariably greatly distended with wind, but though instant relief can be given to the latter by puncturing the rumen with a trocar, or even a sharp penknife, when the accumulated gas rushes out, the operation is not so successful with horses with whom the large gut must be penetrated, and is seldom attempted. The spot where the puncture is made in cattle, is about half-way between the last rib and the hip-bone, the thrust being directed inwards and downwards. As great prostration is present, a stimulant should be administered 
without loss of time, any spirit being used which is promptly available; but if at hand, give-

\begin{tabular}{|c|c|c|c|c|}
\hline Aromatic Spirits of $A$ & nonia & & ... & .. $\quad \frac{1}{2} \mathrm{Oz}$. \\
\hline Nitric Ether... $\quad .$. & $\ldots$ & $\ldots$ & ... & $\ldots$ \\
\hline Tincture of Opium ... & $\begin{array}{l}\cdots \\
\text { or }\end{array}$ & $\ldots$ & ... & ... \\
\hline
\end{tabular}

in a pint of linseed gruel, or added to coffee, to be followed with an oleaginous purgative, such as-

$\begin{array}{lllll}\text { Linseed Oil or Castor Oil } \ldots & \ldots & \ldots & \ldots & 1 \text { quart }\end{array}$

\section{LAMPAS.}

Lampas is the name given to a swelling of the bars behind the front teeth of the upper jaw, which is attended with a certain amount of inflammation and soreness, making the animal flinch when eating, and so inducing it only to pick at its food. It usually goes away of its own accord in a few days, but in the meantime occasions some loss of condition, especially in the case of a horse in training. With young horses the usual cause is shedding the teeth, but with older ones it is most likely that the stomach is slightly deranged; in either case two or three sulphate of magnesia powders, or a tablespoonful of Flowers of Sulphur in a bran mash, will cool the blood and restore the tone. It is advisable, though not absolutely necessary, to lance the bars with a lancet or sharp knife and let a few drops of blood flow, which gives instant relief and often causes the swelling to disappear in the course of the next twenty-four hours. In hot countries lampas is very prevalent, especially with horses in high condition, but the above simple remedies give complete control over it, and enable many a horse to come to the starting-post without any real loss of condition.

Eczema, or Mud-Fever.

The reason for the eruption, a form of which is known as mud-fever, is very commonly a sudden chill when the animal 
is in a state of perspiration. Other causes, upsetting the stomach, will also cause local irritation of the skin, but a sudden check to the action of the skin is the most usual reason.

If the spots become irritable or sore they may be treated with-

$$
\begin{aligned}
& \begin{array}{llllll}
\text { Glycerine... } & \ldots & \ldots & \ldots & \ldots & 1 \text { part }
\end{array} \\
& \text { Water } \quad \ldots \quad \ldots \quad \ldots \quad \ldots \quad \ldots \quad 15 \text { to } 20 \text { parts }
\end{aligned}
$$

Also should be given-

$\begin{array}{lllllll}\text { Epsom Salts } & \ldots & \ldots & \ldots & \ldots & \ldots & 2 \text { oz. } \\ \text { Common Salt } & \ldots & \ldots & \ldots & \ldots & \ldots & \frac{1}{2}, "\end{array}$

in a mash for two or three nights, or-

Sulphate of Magnesia powders in the drinking-water for four days.

As soon as the powders have been finished give-

Liquor Arsenicalis $\quad \ldots \quad \ldots \quad \ldots \quad \ldots \quad 30$ drops

twice a day for ten days or a fortnight, which speedily effect a cure in almost every case if taken in hand at once.

A predisposing cause of mud-fever is the practice of washing the legs on returning to the stable, especially if warm water is used, and then leaving them only half-dried; particularly is this the case if the washing is done outside the stable door and the animal is kept there until the washing is complete. The horse ought to be taken at once into the stable, the legs rubbed down with a wisp of straw to take the bulk of the mud off, and then bandaged and left till the next morning, when the dried mud will easily brush off. If, from the circumstances of the case, it is probable that the animal may have received a chill from exposure, the horse should be warmly clothed, without any elaborate dressing, and have half a bucket of gruel with a couple of glasses of whisky or a pint of ale in it, and then be supplied 
with a mash. But if it is inclined to shiver, administer immediately-

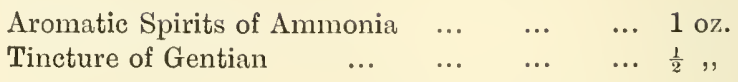

in a pint of thin gruel, or warm water, as speedily as possible, or give instead-

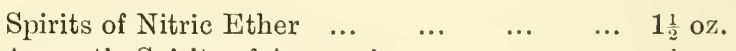

Aromatic Spirits of Ammonia $\quad \ldots \quad \ldots \quad \ldots \quad \frac{1}{2}$,

before anything else is done.

Mallenders and sallenders are also a form of eczema, chiefly affecting the heavy breeds of horses with much hair on their legs, mallenders being the name given to cracks and sores in the flexure of the knees, and sallenders when they appear in the bend of the hocks. The cause is usually too high feeding, when the inflammatory swelling of the legs which it occasions finds a vent in a discharge in the situations mentioned.

If attended to at once they are easily amenable to treatment, but if allowed to become chronic the ulcerative condition can seldom be wholly cured.

A strong aloetic purge should be given, to be followed by sulphate of magnesia powders in the water for four days, and afterwards by a course of alterative powders as recommended for indigestion.

'The sores should be cleansed with soft soap and water, and then dusted with-

\begin{tabular}{|c|c|c|c|c|c|c|}
\hline uller's Earth & .. & $\ldots$ & $\ldots$ & $\ldots$ & & 5 parts \\
\hline cic Acid & .. & & & & & 2, \\
\hline Powdered Alum & & & $\ldots$ & $\ldots$ & ... & 1 \\
\hline
\end{tabular}

for several days, occasionally using instead-

Unguent Hydrargyri Nitrate Oxyde $\quad \ldots \quad \ldots \quad 1 \mathrm{dr}$. $\begin{array}{lllllllll}\text { Cetacei } & \ldots & \ldots & \ldots & \ldots & \ldots & \ldots & 1,\end{array}$

or else apply a few drops of Friar's Balsam with a feather, and then sprinkle on it a little Flowers of Sulphur. 


\section{Cracked Heels.}

The skin of the heels in health is softened with an oily matter, and if this is diminished the condition known as cracked heels is the result. The legs swell and become hot, and sores form in the heels, causing stiffness, if not actual lameness. The causes are from the heels not being sufficiently dried after being wet, and also from being fed on more stimulating food than the stomach can bear. The heels should be poulticed, and, if it is imperative to keep the horse at work, should be well softened with zinc ointment for at least half an hour before the horse leaves the stable. The blood must be cooled by diminishing the corn and stopping all beans for a few days, and giving a bran mash for two or three nights with a tablespoonful of Sulphur in it, besides-

$\begin{array}{lllllll}\text { Epsom Salts } & \ldots & \ldots & \ldots & \ldots & \ldots & 2 \mathrm{oz} . \\ \text { Common Salt } & \ldots & \ldots & \ldots & \ldots & \ldots & \frac{1}{2} \mathrm{oz} .\end{array}$

while, if time permits, it is well to commence the proceeding with an aloetic purge of about 4 drs.

Cracked heels are very apt to occur when a horse is being forced to the highest condition, a few days before a race.

\section{Choling.}

At the back of the month are situated the openings of the œsophagus and windpipe, the upper one communicating with the stomach, and the lower one with the lungs. If the obstruction which causes choking is situated in the osophagus gentle pressure may be tried, and a little linseed oil poured down; but in giving the latter, great care must be taken not to hold the head up by force, or some of the oil may find its way into the windpipe, and so into the lungs, thus choking the horse. If any oil is forced back it will probably have to return through the nostrils. 


\section{T'etanus, or Lockjaw.}

Tetanus is a stiffening of the muscles, especially of the head and neck, accompanied by more or less spasm, and when once seen can never be forgotten. The microbe which causes it is introduced through some opening in the skin, and as its habitat is generally in the soil an injury to the foot is the usual mode of its entry into the system of a horse. It is said also to have an affinity for iron-rust, and an operation performed with a dirty knife has often been the reason of its making its dreaded appearance. It frequently follows after a prick in the foot from a nail, broken knees, castration, and docking, and usually appears seven or eight days after the injury has occurred. After ten days have passed there is not much fear of tetanus setting in.

The muscles of the jaws and neck are usually first affected, the animal having difficulty in swallowing and turning its neck ; before long these muscles become quite stiff, the mouth is nearly closed, the jaws cannot be parted, and little food can be taken into the mouth. By degrees all the muscles become affected with the same stiffness and cramp; and amongst the most characteristic signs is the pointing forwards of the ears, which are erect and fixed, and the staring of the eyes, which are drawn back into the socket, with the haw thrust forward in front; the head cannot be raised or lowered, and the legs are fixed stiffly and spread out from each other, the tail is lifted up, held straight out, and in a constant tremble, and the lips are firmly stretched across the teeth, which are partly seen. The breathing is quickened, laboured, and convulsive; the bowels are bound, and the urine is difficult to pass. When convulsions come on and keep increasing in strength there is little hope of saving the animal, but in the absence of these there is a good chance of recovery if the strength can be maintained by careful nursing. The writer has known of a case which lasted six weeks, and the patient eventually got perfectly well and was able to do its work the same as before.

As the eyes are extremely susceptible to light, the invalid 
must be placed in as dark a box as possible, covering over the windows and excluding all light, but freely admitting fresh air; and since the nervous system is in a state of continuous excitement, the utmost quietness must prevail, and all necessary duties must be performed as gently as possible. A harsh or angry word will cause the pulse to be much disturbed. One attendant only should look after the horse, and the door be kept constantly locked, no inquisitive persons being allowed to enter on any pretext whatever. The wound should be treated in the ordinary way, but it will probably already be nearly healed before the tetanus declares itself; if proud flesh should form, it can be reduced by the application of Nitrate of Silver (lunar caustic), and then Tincture of Arnica or Chinosol lotion should be dabbed on daily until a healthy scab is formed. The food should consist of a small amount of bran mash, in which is placed any green food procurable, such as grass, carrots, or celery tops, chopped up as fine as possible, so as to require no mastication; and instead of water some linseed tea should be always present, made into very thin gruel with well-boiled oatmeal porridge, so that whatever is taken will contain as much nutriment as can be managed. The groom should enter the box four times a day, remove any food which is left, replacing it with a fresh supply, and clean out the stable if needed. He should then give 10 drops of Belladonna and 10 drops of Arnica, in alternate doses, until the wound is nearly healed, after which the Arnica should be left off and 10 drops of Nux Vomica substituted instead. The man should not stay any longer than is absolutely necessary, leaving again as quickly as possible. It will be found that the horse will pick up quite sufficient food with its lips, and manage to swallow it, to keep up its strength, unless the case is very severe, and in this case convulsions will soon appear and the end will then be not far off.

If it is noticed that the jaws are becoming less fast, Liquor Arsenicalis may be substituted for the Nux Vomica, but the Belladonna should be continued.

Under the above treatment the writer has known many cases recover; but there is one treatment, too often at once 
resorted to, which he emphatically condemns-an ounce of lead in the head, from which no recovery is possible!

\section{Breaking Blood-vessels.}

Unless as the direct result of an injury, when an artery is burst, the breaking of a blood-vessel in the head is not a serious matter, the trickle of blood down the nostril soon ceasing as the circulation subsides. But it is often a sign of delicacy, especially with young animals, and this must be borne in mind in apportioning their work. After such an occurrence the horse should not be allowed to gallop for a week, or to excite the circulation in any way, being given plenty of walking exercise instead; for it must be remembered that the seat of injury requires time to heal, like a cut finger, and if pressure is put upon it too soon it is very likely to give way again. As an additional precaution the assistance of the two valuable blood purifiers should be invoked-Sulphur, and Arsenic-and a tablespoonful of the former should be given in every bran mash; whilst -

Liquor Arsenicalis $\quad \ldots \quad \ldots \quad \ldots \quad \ldots \quad 30$ drops

should be given twice a day, during the rest-week the patient is recommended to enjoy.

A horse, Bailiff, notorious for this habit, entirely outgrew it under this treatment when under the writer's care, and soon afterwards carried off two races on the same day without any evil results, nor did the misfortune happen again whilst the horse remained in his stable.

\section{Inflammation of the Eye.}

When this occurs from a hay-seed, or dirt, getting into the eye, the cause must be sought for and removed; but it also occurs from blows, or from standing in a draught and getting a chill. Whatever the cause, the eye should be shielded from daylight falling directly upon it; and it should be 
bathed with either a little warm milk-and-water or rather weak lukewarm tea, either of which remedies are generally sufficient to soothe and cure the ailment. If, however, a more potent one is required, apply with a clean sponge, or medicated cotton wool-

$\begin{array}{lllllll}\text { Rose Water ... } & \ldots & \ldots & \ldots & \ldots & \ldots & 2 \mathrm{oz} . \\ \text { Glycerine } \ldots & \ldots & \ldots & \ldots & \ldots & \ldots & 2 \text { drs. } \\ \text { Acetate of Lead } & \ldots & \ldots & \ldots & \ldots & \ldots & 2,\end{array}$

which may be relied upon if the homely remedies fail.

\section{Internal Parasites.}

The parasites which take up a lodgment in the intestines are various, but the tape-worm is not a very common one in this country, and only the three sorts usually met with, and the bot, will now be considered. Those that are usually referred to as "worms" are the large round, white, or sometimes red worm, 4 to 12 inches in length and tapering at both ends, which chiefly occupies the small intestines; the second kind are the small ones, thick at the one end and tapering away at the other, which mostly inhabit the large guts; and besides these are the thread-like worms, the oxyuris, which infest the terminal portion of the intestinal canal and cause intense itching, with consequent frequent rubbing of the tail against anything available to allay the irritation. The last pest is the "bot," the larva of the bot-fly, which buries itself in the mucous membrane of the stomach. All worms cause loss of flesh and prevent the animal from thriving, often causing cough and gripes, with a rough, dry, staring coat.

There are many remedies for the first two kinds, and if the presence of the large worm is suspected, which much resembles an earthworm in appearance, it can often be ejected by the administration of sulphate of iron. But far the most efficacious remedy for both sorts is a dose of turpentine and linseed oil ; and to give due effect to it the horse should have a bran mash, and then be fasted for at least 
twelve hours, which may be extended with advantage to twenty-four hours, previous to the dose being given.

To a foal on the mare give-

$\begin{array}{llllll}\text { Linseed Oil } & \ldots & \ldots & \ldots & \ldots & \frac{1}{4} \text { pint } \\ \text { Turpentine } & \ldots & \ldots & \ldots & \ldots & \frac{1}{2} \text { tablespoon }\end{array}$

To a yearling-

$\begin{array}{llllll}\text { Linseed Oil } & \ldots & \ldots & \ldots & \ldots & \frac{1}{2} \text { pint } \\ \text { Turpentine } & \ldots & \ldots & \ldots & \ldots & 1 \text { tablespoon }\end{array}$

To a full-grown horse-

$\begin{array}{lccccc}\text { Linseed Oil } & \ldots & \ldots & \ldots & \ldots & \frac{1}{2} \text { pint } \\ \text { Turpentine } & \ldots & \ldots & \ldots & \ldots & 1 \text { oz. }(2 \text { tablespoons }) \\ \text { Camphor ... } & \ldots & \ldots & \ldots & \ldots & \frac{1}{2},,\end{array}$

The Camphor should be put in the oil the previous evening, when it will be dissolved by the following morning.

It is of the utmost importance that the Turpentine should be thoroughly incorporated in the oil, and both should be so shaken up together that the Turpentine breaks up into small globules. This is easier effected if the Turpentine is put at first into a soda-water bottle, with the white of a raw egg, and thoroughly shaken before adding the Linseed. Oil.

Another successful remedy is to give for three mornings-

$$
\begin{array}{lllllll}
\text { Calomel } \ldots & \ldots & \ldots & \ldots & \ldots & \ldots & 60 \text { grs. } \\
\text { Black Antimony } & \ldots & \ldots & \ldots & \ldots & \ldots & 60,,
\end{array}
$$

to be followed on the fourth day by a purging ball not exceeding 4 drs. of aloes.

After either dose has been completed it is a good plan to give daily for a fortnight-

\begin{tabular}{|c|c|c|c|c|c|}
\hline Powdered Gentian & $\ldots$ & $\ldots$ & $\ldots$ & $\ldots$ & $\ldots$ \\
\hline Cammomile ... & $\ldots$ & ... & $\ldots$ & ... & \\
\hline Ginger $\quad \ldots$ & ... & .. & & $\ldots$ & - \\
\hline Sulphate of Iron & $\ldots$ & $\ldots$ & $\ldots$ & $\ldots$ & . \\
\hline
\end{tabular}

in the early morning feed. The Sulphate of Iron needs to be finely powdered, and no nodules should be left in it. 
The oxyuris can with difficulty be reached by internal medicine, as it is only situated a few inches from the fundament, and hence is more effectually dealt with by throwing up an enema of a solution of Quassia, or of common salt. To make Quassia extract a quart of boiling water is poured on to $4 \mathrm{oz}$. of Quassia chips, and then allowed to stand till nearly cold, when it may be injected from a common zinc syringe through a wooden funnel. If a solution of common salt and lukewarm water is used, it must not be made too strong, or the intestine, which is already suffering from the attack of the parasites, becomes irritated; a couple of handfuls of salt to 3 quarts of water being quite sufficient.

Bots are very troublesome in the spring months, when they have attained a large size, and greatly affect the condition of the horse. The parent-fly lays its eggs from July till the end of September, selecting the neck, mane, ribs, and the inside of the knees and fore-legs of the victim, all being parts which are easily reached by the horse when nibbling any part which is itching, or by another comrade who is performing the same kind office. In this way the pests become transferred to the stomach, where they quickly bury themselves in the mucous membrane, attaching themselves by two hooklets, and eventually growing to the size of large blackberries. By the following June or July they have completed that stage of existence, and, passing out in the ordinary way, bury themselves in the ground, shortly to reappear as flies, when their cycle of life is complete. At first they do not give much evidence of their presence inside their host, but subsequently they cause loss of condition, whilst occasionally such emaciation occurs as even to result in death. No medicine seems to have any effect upon these dreaded intruders, though a course of Sulphate of Iron may help their departure when nearing ruaturity.

An Irish friend of experience once gave me the following recipe, which he stated he had found to be efficacious in banishing the pests :-

"Give nearly a tumblerful of the common stone-crop for a week, chopped up very fine, in the feed of oats or in a bran mash; then give a ball, $1 \mathrm{dr}$. each of black antimony 
and calomel; twenty-four hours afterwards give another ball of 3 drs. of aloes."

Prevention is ever better than cure, and when horses are in the fields at the season the bot-fly is engaged in laying her eggs, the animals should be visited night and morning and every egg removed from their coats. A sharp knife quickly effects a clearance, but they are difficult to remove with only the finger and thumb, for they adhere very closely to the hair, and it is by no means easy to get them off.

\section{SANDING.}

This is a condition of affairs peculiar to very sandy, gritty soils, but in a dry summer, when the pastures are very shrunk, horses are apt to swallow some of the sand by reason of their biting so close to the ground. The result is anæmia, and finally diarrhœea, and if not attended to fatal consequences may ensue. If there is any doubt about the cause, the condition is easily detected by rubbing some of the droppings between the finger and thumb, which will feel gritty to the touch. The remedy is to remove the animal elsewhere; but first of all to treat it in the stable, giving bran mashes, and small doses of Linseed Oil, until it is well.

\section{Mange, And Ring-Worm.}

Although these two affections differ greatly, the former being the work of a parasite and the latter being of a vegetable origin, the superficial appearance in many respects is so much alike that they are mentioned here together, since the only really effectual treatment, to be absolutely relied upon, is the same for both. In the wilder parts of Ireland, nearly thirty years ago, both ailments were so rife that it was impossible not to have frequent outbreaks in the stable; for the horses had often to be put up in strange stables, whilst new purchases frequently began to show signs of being infected, soon after they arrived home. Many recipes were prescribed by different professional advisers, and tried, but when a case was obstinate the one remedy which always had to be fallen back upon was Tincture of 
Iodine. It may be remarked the stain can be removed from the hands by the application of warm water, in which a little soda has been dissolved.

In dealing with ring-worm-and the same applies to mange--the mode of procedure was to wash the affected part, to soften the skin, and then to apply compound Tincture of Iodine, rubbing it in with an old tooth-brush for a few seconds, but taking care that too large a surface of the body was not treated at the same time. In one case when an animal was so treated from head to foot it very nearly died in consequence, and was with much difficulty nursed back to health again. Unless the part affected is a very limited one it is scarcely to be expected that one application will suffice, and the moment there is any suspicion of a fresh breaking-out, another resort to the Iodine must be made. Nor does it suffice only to touch the visible signs of the evil since it creeps along under the hair, so that a considerable margin of the surrounding skin should also be included in dealing with the attack, and the touch is more to be relied upon than sight; any place, therefore, which feels at all rough when passing the hand over the coat should receive attention at once, to check the spread of the ailment before it has become actually visible.

The rug worn next the skin should also be gone over with the Iodine to prevent the complaint being started again through this agency; and every brush which is used for dressing should be kept entirely for the patient, and thrown into a bucket of soft soap and water every time after being used. The manger and walls of the box, or stall, should frequently be washed over with warm water and soft soap, to which about a gill of paraftin has been added, and for this purpose a large brush, such as is used for white-washing, will be found very useful.

There is some resemblance between eczema and mange, in that both display points of incrustation from which a discharge issues, and there is present a considerable amount of irritation, which the animal endeavours to allay by rubbing violently against anything available; it may therefore be well to point out that with eczema the itching is most felt 
while the vesicules are forming, and that when they have arrived at a head the irritation to a large extent ceases, though a tenderness to the touch, causing shrinking, may remain; but with mange there is no cessation, and the irritation increases as the disease proceeds.

Horses with much feather on the legs occasionally suffer from leg-mange, due to a parasite that lives in the region of the fetlocks, and rarely ascends high up the leg. It is chiefly active at night, remaining quiescent during the day-time, and hence its presence is not always suspected; the symptoms of stamping violently at night, and rubbing one leg against the other until sores are formed, being attributed to grease instead of the real cause. These energetic actions to allay the irritation speedily produce bare patches in the hair, which call aloud for instant treatment, which fortunately is not a difficult matter.

Since the "feather" is so voluminous it is necessary to use some agent which can deal with this, and nothing answers better than soft soap. Plaster it thickly on, no water being used, commencing at the hoofs, and work upwards against the lay of the hair until the knees and hocks are reached. In half an hour's time wash the soap thoroughly off with warm water, and then apply tincture of iodine, working it well in with a brush to the roots of the hair.

In case any parasites may escape the operation should be repeated in five to seven days' time, when the new brood will have hatched from any eggs which have been overlooked.

\section{Warts, or ANGLE-BERRIES.}

These unsightly growths are sometimes very troublesome, and often require careful treatment. When small, with a pronounced neck, and not situated in any delicate part, a piece of silk may be tied so tightly round as to stop the circulation, when in a few days the growth will drop off. Its departure can be hastened by applying-

$\begin{array}{llllll}\text { Acid Arseniosum... } & \ldots & \ldots & \ldots & \ldots & 30 \mathrm{grs} .\end{array}$

$\begin{array}{llllll}\text { Oleum Turpentine } & \ldots & \ldots & \ldots & \ldots & 2 \text { drs. }\end{array}$

$\begin{array}{lllllll}\text { Pure Lard... } & \ldots & \ldots & \ldots & \ldots & \ldots & 1 \mathrm{oz} .\end{array}$ 
Well mix. Apply a small portion to the wart for seven days, then discontinue, and apply sweet oil until the wart sloughs off. The wound usually heals without any treatment except keeping it clean, but several applications of the ointment may be required before the growth is completely removed.

Care must be taken not to apply the ointment if the surface is at all raw, or it may be absorbed, injuriously, into the system.

If the warts are situated within such delicate parts as the sheath, or the vagina, or on the penis, they should be wiped dry with cotton-wool, and then have dry, powdered Calomel applied with a camel's-hair brush. The wart will gradually slough away, coming off in flakes, and leaving each time a raw surface which must be again treated with the powder. Sometimes the animal dreads the application so much that it becomes violent, necessitating the use of a twitch; but this can often be avoided by blowing the Calomel on to the wart with a tobacco puff, such as is commonly used by gardeners for the destruction of green-fly; and when an angleberry is situated inside the ear - a not uncommon place-the puffer is most useful. It is difficult, however, to blow out Calomel by itself, since it is an excessively light powder, and should therefore be associated with one heavier than itself, but if a little Borax Powder is mixed with it there will be no difficulty found in thus using it.

\section{The Hoofs.}

Apart from accidents, such as picking up a nail, being pricked in shoeing, or being bruised by treading on some sharp substance, or an over-reach, the foot is liable to suffer from navicular, laminitis, quittor, corns, thrush, sand-crack, and seedy toe, all of which are attended by lameness more or less severe, generally, but not always curable.

\section{NAVicular.}

Navicular lameness in the earliest stages, when only inflammation of the bony structure of the navicular bone 
exists, holds out some hope of being cured; but when once actual caries of the bone has commenced there is no longer any chance of recovery. At the beginning it is necessary to relieve the frog from all pressure, situated as it is under the seat of mischief, and if the inflammation yields to the treatment adopted the horse in a few days may move again with freedom. The shoe should be sprung a little at the heel to relieve the pressure, and until the lameness is lessened the frog should be kept from touching the ground. Cold swabs should be wrapped round the foot and kept constantly wet, while the horse is allowed to rest in a loose box, with quite short litter for bedding. Blistering the coronet should be practised, and bleeding from the toe is a remedy which may well be tried. When good results follow, and the horse appears to be sound again, it is advisable to turn it out in a marshy meadow; but if that is not practicable it should for some time only be exercised on soft ground, until the cure appears to be complete.

When affected by navicular lameness the horse, when standing at rest, flexes the fetlock of the affected limb, and raises the heel, the foot resting on the point of the toe.

\section{LAMINITIS.}

Laminitis is associated with a considerable degree of fever, and almost invariably both feet are affected, which causes the horse to step with the same even action-however short it may be-although it is unwilling to move at all. The feet are intensely hot, and the horse endeavours to throw all its weight upon its heels. Unless the attack is speedily cured the inflammation is likely to cause structural changes in the feet, causing permanent unsoundness.

In chronic cases a horse is unable to do fast work, but slow work is beneficial, such as light labour on a farm.

The usual treatment is to adopt the ordinary means for reducing fever, to remove the shoes, to relieve the congestion by bleeding at the toe, to pare out the soles and apply cold poultices, and to wrap swabs round the feet, which are kept constantly wet by pouring cold water over them. 
Some years ago a Mr. Broad, a veterinary surgeon of Bath, introduced a different method of treatment, which in many cases has been most successful.

The system advocated is to construct a small bath, if no natural supply is available, in which the horse may be kept standing for hours in cold water; and at short intervals to compel the horse to take walking exercise for half an hour, by so doing forcing the congestion of the feet to be relieved. As soon as the exercise is over the horse must be placed at once again in the bath to prevent congestion recurring. In an hour's time the horse is to be sent for another half-hour's exercise, if possible on soft ground, and this rotation of walking, and resting in the cold bath, to be steadily continued until the action is once more restored. It is essential that the proceedings in the first instance must commence with a walk; and the animal must be forced to do this, even if two men have to hold it up with a sack under its belly, and a whip has to be called into requisition to make the horse move. After the subsequent rest in the cold bath the animal will be able to move freely by itself. A feature of the treatment is to shoe the animal with heavy bar shoes at the beginning, which are made thinner at the toes and heels than in the middle, forming a curve, and compelling the weight to be thrown mostly on the centre of the foot.

\section{QUITTOR.}

This is a deep, narrow abscess, opening upon the coronet, and generally is connected with an ulcer in the foot. It should be well poulticed, and a probe should be used to find out the direction of the fistula, and whether there is more than one. An antiseptic lotion, such as Chinosol, should be squirted into it three or four times a day. It often arises from a corn in the heel.

\section{CoRns.}

A corn is a bruise upon the sole of the foot at the angle between the bar and the sole. It is caused by contracted feet and tight shoes, especially if the latter become embedded 
in the hoof from not having the hoof pared out often enough. The place is painful, causing the animal to go lame, particularly after treading upon a stone, and when the corn is pared it will be seen to have a blood-red appearance, through the bursting of small blood-vessels under the horn. In some cases matter will form, and unless a vent is made it will under-run the sole, or appear at the coronet, and form a quittor.

The seat of the corn must be well pared out, and some tow saturated with tar placed over it, and then the shoe lightly tacked on, all pressure being kept off the sore heel.

If, however, matter has formed a vent must be made so that it can flow out freely; and after fomenting the foot, and syringing with Chinosol solution, a large poultice should be put on. After poulticing for a day or two, as soon as matter ceases to exude tar and tow may be placed over the vent, and the horse may be shod and resume its work.

\section{THRUSH.}

This disease consists of inflammation of the sensible frog, which in consequence secretes pus instead of healthy horn, and this issues from the cleft of the frog with an offensive odour. The ragged portions of the horn should be cut away, the frog washed with warm water, and a small piece of tow introduced into the cleft with a piece of stick, in order to wipe up the accumulated pus. A fresh piece of tow should then be smeared with a mixture of-

$\begin{array}{llllllll}\text { Tar } \ldots & \ldots & \ldots & \ldots & \ldots & \ldots & \ldots & 6 \mathrm{oz} . \\ \text { Sulphate of Copper } & \ldots & \ldots & \ldots & \ldots & \frac{1}{2} & \end{array}$

and placed in the cleft, and if necessary a bar shoe be put on to retain the dressing in its place. If properly applied it will neither fall out nor permit the entrance of dirt, and should be renewed every two or three days.

In an obstinate case a more powerful lotion may be used, but this should not be entrusted to the care of an ordinary groom. 
Make a lotion of-

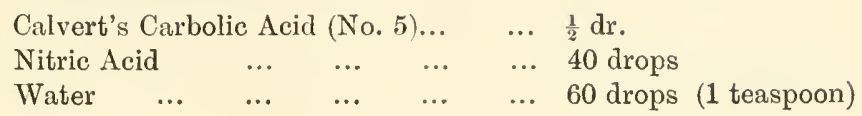

A small quantity of tow should be saturated and introduced carefully into the frog. It is very important before applying the preparation that the foot is soaked for a few minutes in warm water, and the parts thoroughly cleansed; and great care must be taken that on no account is the dressing allowed to come into contact with the skin. One or two applications are usually sufficient, and after that, tow and Stockholm tar-without any addition of Sulphate of Copper -may replace it, and will complete the cure.

In compounding the lotion, first mix together the water and nitric acid and then add the carbolic acid; and this should be done slowly, for a certain amount of effervescence will arise.

Sometimes the frog is so extensively diseased that it is better to cut away the whole, nntil the sensible frog is reached, and then the dressing of tar may be applied, and a bar shoe put on for at least one remove, or until the new frog is sufficiently grown to sustain the weight of the horse.

\section{SAND-CRACK.}

A separation of the fibres of the hoof from above downwards is thus termed, and usually commences at the coronet, though occasionally it begins at the shoe surface, and runs upward. An old thin knife should be heated redhot, and two cross-cuts be made with it at the very top of the sand-crack, and one below it, to prevent any further splitting of the fibres. In addition a round hole should be made at the apex of the crack, such as can be made with an old door-key when heated red-hot, and is very effective against any more splitting. Two holes should be drilled through on each side of the crack, and a piece of sodawater wire-which will not rust-passed through them, and 
the ends twisted together, or small nails may be driven through and then clenched; while a simple method is to bind tarred cord round the hoof, but the drawback to this is its liability to stretch. The crack itself should be filled with artificial horn made of equal parts of-

$\begin{array}{lrllllll}\text { Pitch } \quad \ldots & \ldots & \ldots & \ldots & \ldots & \ldots & 1 \text { part } \\ \text { Gutta-percha } & \ldots & \ldots & \ldots & \ldots & \ldots & 1 \text { part }\end{array}$

which should be melted in an iron spoon and run into the crack, finally smoothing it over with the bottom of the heated spoon.

Another plan is to drive in two small nails on each side of the crack, and twist wire tightly round them, in a figure of 8 .

The coronet should be slightly blistered with a mild flyblister-

$$
\begin{aligned}
& \begin{array}{lllllll}
\text { Cantharides } & \ldots & \ldots & \ldots & \ldots & \ldots & 1 \text { part }
\end{array} \\
& \begin{array}{llllllll}
\text { Lard } & \ldots & \ldots & \ldots & \ldots & \ldots & \ldots & 24 \text { parts }
\end{array}
\end{aligned}
$$

to stimulate secretion of horn; and the horse should be shod with a bar shoe, to prevent, as far as possible, any expansion of the hoof. If the animal is at grass in the company of others, and the sand-crack is situated on a hind-foot, so that a bar-shoe might be dangerous in case of kicking, a small clip may yet be used on the outside, near the toe.

\section{Seedr Toe.}

It is not the outer horn which is affected in seedy toe, but the inner portion, and a space forms between the two, which sounds hollow when rapped with the handle of a pocket-knife or stick. In 1884, Professor Axe discovered a nematode worm in the debris of seedy toe, which has been christened Polodera Axei. Every particle of detached horn should be removed, and the surface dressed with turpentine. or with the lotion directed for Thrush. If the wall of the hoof is left rery weak, after using the lotion and allowing the surface to become dry, apply surgeon's diachylon plaster 
to the surface, such as is used for binding up broken ribs, and when it adheres smear over it a little Stockholm tar.

\section{Over-REACH, OR TrEaD.}

This is caused on the heel of a fore-foot by the blow of a hind shoe; and an over-reach is generally to some extent the fault of the groom in charge, from not taking care that the inner edge of the toe of the hind shoe has been rounded off with the rasp, but has been carelessly allowed to become almost as sharp as a knife, which it will do from ordinary wear and tear.

The first step is to cleanse the wound from dirt, and this is best done by directing a stream of cold water upon the wound; or, if this is not available, by squeezing a sponge above the wound, and letting the water run down over it. A poultice may be put on for the first night, adding to it some antiseptic, such as Chinosol or Tincture of Arnica; but a prolonged use of poultices is not advisable, though one for a few hours helps much to cleanse all foreign matter from the wound. The next day a powder may be sprinkled over the raw surface composed of-

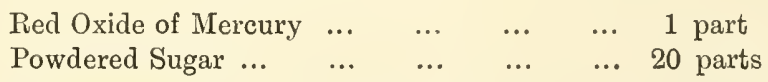

or instead Iodoform may be dusted over, either of which remedies will speedily cause a healthy scab to form.

\section{Hoof Ointment.}

A good ointment for dressing hoofs, and especially frogs, at all times is-

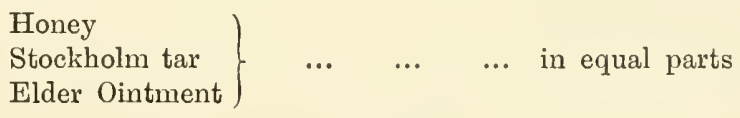

Rings in a Hoof.

When rings are seen to go right round a hoof they are usually of no consequence, but merely mark different periods 
of growth, especially when an animal has been turned out, for the horn grows faster in wet weather or in damp grass than it does when the conditions are drier. But when the rings appear only on the inner quarter attention should be paid to them, for then they often point to some disease of the foot. This is frequently well marked in cases of navicular and laminitis.

\section{Exostosis.}

In all cases of exostosis, such as side-bones, ring-bones, splints, and spavins, non-interference in the majority of cases results in a much larger deposit of bone than is the case if treatment is at once resorted to. Blistering, as a rule, limits the growth, and causes the process to become callosed more rapidly than rest alone will effect. The inflammatory action in the lateral cartilages can also be arrested by blistering, which otherwise will convert the cartilage cells into bone; and therefore there is every reason to blister at once any exostosis, wherever situated, as soon as any indication is apparent that mischief is brewing, which may become serious.

\section{Side-Bones.}

Side-bones are the ossification of the lateral cartilages of the foot, and when these are pressed upon at the heels, instead of being flexible they are found to be perfectly unyielding. Like ring-bones they are to some extent hereditary, and while formerly they were largely in evidence amongst the heavy breeds, they are now much more rarely seen in consequence of stallions being rejected as unsound when so afflicted.

\section{Ring-Bones.}

Ring-bones are a bony enlargement of the same nature as spavins and splints, but are situated above the coronet, and may encircle the whole part. Though causing lameness whilst they are forming, when once they are fully grown 
a horse may do its work perfectly well, if they do not interfere with the free motion of the pastern joint. They should be well blistered with the following:-

No. 1.

$\begin{array}{lllllll}\text { Cantharides Pulvis } & \ldots & \ldots & \ldots & \ldots & 1 \frac{1}{2} & \text { drs. } \\ \text { Adeps } \ldots & \ldots & \ldots & \ldots & \ldots & \ldots & 1 \frac{1}{2} \text { oz. } \\ \text { Oleum Terebinth } & \ldots & \ldots & \ldots & \ldots & \frac{1}{2} & \text { dr. }\end{array}$

No 2.

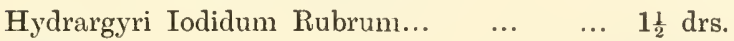

$\begin{array}{lllllllll}\text { Adeps } & \ldots & \ldots & \ldots & \ldots & \ldots & \ldots & 1 \frac{1}{2} & \text { oz. }\end{array}$

The two ointments to be made separately, the first (No. 1) being made in a water bath. The Oleum Terebinth being put in when cooling. When made the two are to be mixed together on a slab. After the traces have all peeled off apply-

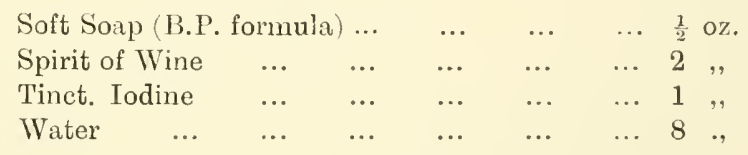

to be rubbed in on alternate days.

\section{Splints.}

These are of the same nature as the foregoing, an exostosis, or deposition of bony matter on the shank-bone, and painful, when growing, through the stretching of the periosteum, the membrane covering all bone, which is inelastic. Unless they interfere with the knee-joint, or are situated immediately beneath the tendon of the leg, sooner or later Nature will accommodate herself to their presence, and the lameness, which is sometimes severe at first, will eventually disappear. They should be treated in the same manner as ring-bone, being first blistered, and afterwards have Iodine applied for a lengthened period; it will be found that in three or four days after the application of Iodine the scarf skin will begin to rise, when the treatment should be 
stayed for a while until the scurf falls off, which will occur in about four days more.

Instead of Iodine, a sweating blister is sometimes used with good effect. A small piece of tea-lead-such as is employed for wrapping up tea-being first made smooth with the back of a knife, and then placed over the splint, with a linen bandage over it to keep it in its place.

\section{Spavins.}

An exostosis situated on the inner and lower part of the hock-joint is known as a spavin, and is of the same nature as a ring-bone and splint. Situated as it is, where there are so many small bones which constitute the hock-joint, it is a more serious ailment than those just discussed, since it interferes more or less with the free working of the hock. A spavin is held to be legal unsoundness, and a hereditary ailment, though this is scarcely borne out by experience. A stallion proved to have a spavin is at once rejected, though if he shows no other tendency to exostosis it is unlikely that his progeny will inherit a liability to spavin. The famous Derby winner, Hermit, had a spavin on his near hind hock, and yet he had a very numerous and distinguished progeny none of whom developed spavin, but were noted, on the contrary, for fine, strong hocks. The joint is so complicated, and has to sustain such stress, that it is particularly liable to concussion and sprain, and these are undoubtedly the real cause of spavin. A stallion may be constitutionally disposed to exostosis, and this he will be very likely to transmit, and also a tendency to faulty hind limbs; but beyond these predisposing causes he is not likely to pass on a liability to contract spavin, and if he has stood the test of training for two or three seasons, and been sound throughout, there need not be hesitation in employing his services, until his stock give reason to pass him by.

Baron Von Oettingen, with his immense experience of the German State Breeding Stud at Trakehnen, states his views on the subject in "Horse Breeding in Theory and Practice, and quotes Professor Eberlein, who writes:- 
"Therefore spavin is not hereditary. Scientifically it is proved, however, that a deficient formation of the hocks and a faulty position of the thighs, which predispose a horse to this disease (causa interna) are transmitted. Thus it follows that with regard to spavin, only horses with defective hocks or a faulty position of the thighs on the one hand, and badly constructed bones on the other hand, must be excluded from breeding." Baron Von Oettingen adds: "I fully subscribe to the view of Professor Eberlein" ; and then mentions several stallions afflicted with spavin, all of whom begat sound stock.

\section{Bog Spavins.}

These have nothing to do with true spavins, and are soft swellings in front of the hock, a kind of synovial dropsy, which very rarely cause lameness.

\section{Curbs.}

Curbs are a sprain of the ligaments at the back of the hock, about 4 inches below the point, where a swelling may be felt, with heat and soreness. A sudden slip in deep ground when galloping or jumping, or the catching of a toe when trotting along the road, especially by a young horse when tired, are frequent causes of curb. As horses get older they frequently grow out of the tendency to spring curbs; but those weak hocks which have a piece cut out of the shank, as it were, just below the joint in front, are always liable to contract this ailment.

To ease the pain dissolve a handful of common washing soda in a quart of warm water, and apply it to the swelling with a sponge. Afterwards soak a woollen or serge bandage in the liquid, and wrap it round with a dry one outside. The next morning mix-

$$
\begin{array}{lllllll}
\text { Sal Ammoniac } & \ldots & \ldots & \ldots & \ldots & \ldots & 2 \text { oz. } \\
\text { Vinegar ... } & \ldots & \ldots & \ldots & \ldots & \ldots & \frac{1}{2} \text { cupful }
\end{array}
$$

and add to it a quart of boiling water. When cool put it into a bottle, and sponge the curb two or three times daily 
with the mixture, after which a wet bandage must be put on.

If Sal Ammoniac is not readily available, use instead-

$\begin{array}{llllll}\text { Cornmon Salt } & \ldots & \ldots & \ldots & \ldots & 2 \text { teaspoonfuls }\end{array}$

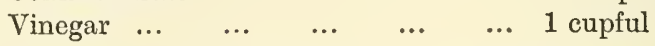

and sponge the curb with it. Afterwards continue to use the vinegar daily without the salt, sponging the curb freely, and placing a cabbage-leaf over it to prevent evaporation. When the inflammation has subsided the blister which was recommended for ring-bone should be rubbed on, and when the effects of this have passed off compound Tincture of Iodine, or a lotion made from Rhus Toxicodendron, should be applied until all signs of curb have disappeared.

\section{Thorough-pin.}

This is the name given to a bursal enlargement at the side of the hock, but beyond disfigurement it does not interfere with working the horse. No better treatment, if any is desired, can be suggested than to paint over it a lotion made from Rhus Toxicodendron for three or four days, when the scarf skin will rise, as when Iodine is used. A similar period must be allowed to elapse, and a rest given, until the scurf falls off, and then the application must be renewed until the swelling is reduced If a horse is turned out to grass for a few weeks it will generally be found that all bursal enlargements, such as thorough-pins, capped hocks, \&c., disappear when the animal comes into the stable again, and is fed on dry food.

\section{WOUNDS.}

In June, 1909, Elie Metchnikoff, the famous Russian scientist, was one of the four representatives chosen to deliver orations in the Senate House at Cambridge, at the great Celebration in honour of Darwin. Amongst other points he explained the use of inflammation; how that the circulation of the blood is checked in its course at a wounded 
place by means of the nerves, and therefore stagnated at this spot, bringing along with it thousands of phagocytes, who pass through the walls of the blood-vessels into the inflamed tissue, when they at once attack and eat up the injurious bacteria who have entered through the broken surface of the skin. The germs of disease are thus destroyed.

The phagocytes may, however, not be present in sufficient numbers to be equal to the occasion, and art can frequently assist nature. A wound should be washed clear of all dirt, as mentioned in the treatment of over-reach; and in very simple cases a little Iodoform, or powdered Alum and Fuller's Earth, may be dusted over it through a piece of fine muslin.

A wound must always heal up from the bottom, and deep ones are apt to close up too quickly, and should be probed daily to keep them open. For this purpose a tallow candle often answers, for there is nothing hard about it to cause injury, while it is sufficiently firm to force its way in. Warm water with some soft soap dissolved in it should be frequently squirted into the interior to cleanse the wound, and the Iodoform puffed in afterwards, or some other antiseptic lotion. But wounds somehow seem to form a scab quicker when a dry powder is used as a dressing than when liquids are employed. Sometimes although a wound has filled up from the bottom it still does not form a scab, and there is too much granulation or "proud flesh," which will require drying up before the place will heal. A little powdered Sulphate of Copper (blue stone) dusted over a few times will usually alter this state of things. The condition frequently arises from too much fomentation or poulticing having been employed. If the wound looks greasy and does not heal a little powdered Alum mixed with Fuller's Earth should be dusted over it.

\section{Broken KneEs.}

The above treatment should be followed for broken knees: A piece of linen, with the surface well covered with cold cream or zinc ointment to prevent any sticking to the wound, 
should also be fastened lightly above and below the knee, to keep dirt from the wound. No flies will approach when Iodoform is used; and whenever an animal can reach an injured place with its teeth the precaution should never be omitted of putting a cradle round its neck, or keeping it racked up, lest it should do itself mischief by gnawing the wound.

\section{Air getting into a Wound.}

When a serious wound occurs and the animal has a long way to travel home, the first thing to be attended to is to take means to prevent air getting into the wound, and under the skin. The next consideration is to get the horse back to its own stable if it can by any means be accomplished.

When an accident occurs which leaves a large gaping orifice, such as happens when a horse is badly staked, as soon as the journey is commenced air will get in, until the whole body is blown out to a vast size; and if the hand is passed along the skin a curious crackling sound will be both heard and felt. To prevent this occurring the wound should be plugged with anything clean and handy, a handkerchief, cotton-wool, tow, \&c., and if possible a stitch or two should be put in to draw the edges together; or a pin may be inserted through both lips of the wound and bits of string lapped round its head and point in a figure-of-eight, which will draw the wound together and keep the pin from falling out. If the body should become badly swollen a rug may be repeatedly steeped in warm water and placed over the horse as soon as it arrives at the stable, another dry rug being put on outside. This causes the skin to act freely, and by this means the air will gradually pass out through the pores, though many hours will elapse before the animal becomes entirely relieved.

\section{UNHEALTHY SORES.}

Sometimes it is necessary to apply a caustic, such as Nitrate of Silver, to sores that are unhealthy, but it is well first to apply a few drops of Friar's Balsam after fomenting the sore, and then dust some Flowers of Sulphur over it. 


\section{SPRAINS.}

A strain of the back sinews-which is more often a strain of the sheath of the tendon-should be treated similarly to a curb, fomenting well with hot water in which soda is dissolved, applying Sal Ammoniac the next morning, and subsequently relying upon plain vinegar. When all inflammation has departed the leg should be well blistered with the blister recommended in the case of ring-bone, and in bad cases the horse should be subjected to blistering three times, with an interval of about six weeks between each application. All the effects of one blister must have peeled off before the next one is begun. If any thickening should remain, a useful liniment to reduce enlargements between the skin and the tendon is-

$\begin{array}{lllllll}\text { Soft Soap } \ldots & \ldots & \ldots & \ldots & \ldots & \ldots & \frac{1}{2} \text { oz. } \\ \text { Spirit of Wine } & \ldots & \ldots & \ldots & \ldots & \ldots & 2, " \\ \text { Tincture of Iodine } & \ldots & \ldots & \ldots & \ldots & \ldots & 1, \\ \text { Water } \quad \ldots & \ldots & \ldots & \ldots & \ldots & \ldots & 8,\end{array}$

which should be applied on alternate days after the final blister has performed its office. Under this treatment and with a long rest-a year if necessary - the leg should get quite right again, without the disfiguring use of the firing-iron. The real benefit which ensues from the firing-iron is the long rest which must perforce be given to the patient, and there is no greater good to be obtained from the cautery itself than may be gained by repeated blisters. The latter also have the merit of causing no disfigurement, whilst after recovery the horse may be as good as ever; but this can never be the case with firing, for the moment the hot iron has touched the skin the form of the horse has fallen from at least a stone to two stone below what it was before. This arises from the fact that the skin never regains its former elasticity, thereby shortening the stride, and when it is considered how many strides are taken in a mile, it is evident that a loss of only 2 inches each time will result in a loss of many yards in that distance.

It is a common mistake to imagine that a horse has broken 
down when it has only struck the tendon of the fore-leg with the hind foot, when galloping or jumping. At first sight there is no difference between the two, there is the same bowed swelling and the horse is very lame, but in a few days there is a great distinction, for if it is only a blow the horse will soon be almost sound, but if it be a strain the animal will be as lame as ever. In the latter case nothing is of real benefit but a prolonged rest.

\section{Blistering.}

A few hints on blistering may be found of service. An animal should never be blistered on all four legs at once, only the alternate fore and hind limbs being blistered on one occasion-say the near fore and the off hind-legs-so that two sound legs on opposite sides are left to stand on. In two or three days these legs can then be blistered in their turn. If a fore-leg has to be blistered by itself turn the horse round and fasten it to pillar reins-without giving it room for much play-so that there is nothing in front to strike the knee against, such as there would be if the horse is fastened up to the manger. The opposite leg should be bandaged, or the horse may rub one against the other, and and so transfer some of the blister on to the wrong leg. A cradle should be put on, particularly if a hind-leg is being blistered, or the animal may screw itself round and rub its nose and eyes against the blister ; and at all times the horse must be fastened so short that the blister cannot be reached with its teeth or muzzle. If a liquid blister is used the hollow of the heel must be filled with vaseline or lard, in case some of the fluid drops upon it. Before commencing to apply a blister the part should be clipped if the hair is long, and the skin should be damped with a sponge and then dried, which ensures the blister taking a good hold.

\section{Rheumatism.}

When exposed to wet and cold a rhemmatic attack is apt to follow, which, if acute, is accompanied by increased tem- 
perature and heat, swelling, and pains in the joints or other parts. Sometimes it is present in the loins, and is similar to lumbago with mankind, when the back is raised, the belly tucked up, and the horse stands with all its legs gathered under it.

When the disease is of recent origin, with quick, full pulse and pains in the joints, give-

$$
\begin{array}{llllll}
\text { Tincture of Aconite } & \ldots & \ldots & \ldots & \ldots & 30 \text { drops }
\end{array}
$$

for two or three doses, and then give-

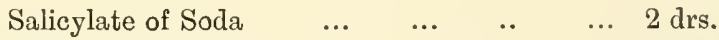

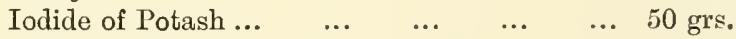

$$
\begin{aligned}
& \begin{array}{lllllll}
\text { Bicarb. Potash } & \ldots & \ldots & \ldots & \ldots & \ldots & \frac{1}{2} \text { oz. }
\end{array}
\end{aligned}
$$

in half a pint of water, twice daily, and rub gently the

\begin{tabular}{|c|c|c|c|c|c|}
\hline Menthol ．.. & $\ldots$ & $\ldots$ & $\ldots$ & $\ldots$ & ... 3 drs. \\
\hline Spirit Rectified & $\ldots$ & $\ldots$ & $\cdots$ & $\cdots$ & \\
\hline Chloroform... & $\ldots$ & $\ldots$ & $\ldots$ & $\ldots$ & $\ldots \quad \frac{1}{2}$ oz. \\
\hline Liniment Aconit & $\ldots$ & $\ldots$ & $\cdots$ & $\ldots$ & $\ldots 3$, \\
\hline Liniment Bella & & $\ldots$ & $\ldots$ & $\ldots$ & ... 6 \\
\hline
\end{tabular}
affected parts with the following liniment:-

or else make a lotion-

$$
\begin{aligned}
& \begin{array}{lllllll}
\text { Sal Ammoniac } & \ldots & \ldots & \ldots & \ldots & \ldots & 1 \text { oz. }
\end{array} \\
& \begin{array}{lllllll}
\text { Saltpetre } \ldots & \ldots & \ldots & \ldots & \ldots & \ldots & 1,
\end{array} \\
& \begin{array}{llllllll}
\text { Water } & \ldots & \ldots & \ldots & \ldots & \ldots & \ldots & 1 \text { quart }
\end{array}
\end{aligned}
$$

Dip some lint into it and place it over the part, covering it with a bandage soaked in vinegar and water.

In obstinate cases sulphur is very beneficial, and one or two tablespoonfuls should be added to every bran mash.

Condiment.-For delicate feeders, and at any time as a "pick-me-up" during, or after, severe work, Mawson's well-known Spice can be confidently recommended. It is largely given to hunters after a severe day, with beneficial results, and also to horses in training for racing. 


\section{Arteries.}

Arteries are sometimes severed out hunting, and in other accidents, and every one should have a general knowledge of their direction and how to apply "first aid," with the help of a roughly made tourniquet, or the animal may bleed to death before professional assistance can be procured. If the bleeding can be stayed until a clot of blood has formed the immediate crisis is over; but the horse should be kept quiet for at least an hour before making any attempt to proceed home, lest the bleeding should break out afresh. The writer has occasionally used dry grass plucked from the nearest hedge and twisted into lumps, or a smooth pebble, wrapping them in a handkerchief and twisting it tight by means of a pocket-knife, latch-key, or a stick, after the ends have been placed round the leg and tied together. On two occasions when a facial artery had burst, the bandage was kept in its place by adjusting the nose-band over it and then buckling it sufficiently tight.

Table of Measures.

$$
\begin{aligned}
20 \text { grains } & =1 \text { scruple }(\ni) \\
3 \text { scruples } & =1 \text { drachm }(3) \\
8 \text { drachms } & =1 \mathrm{oz} .(\xi) \\
12 \mathrm{oz} . & =1 \mathrm{lb} .
\end{aligned}
$$

Fluid Measure.

$\begin{array}{rll}1 \text { grain } & =1 \text { drop, or minim } & \\ 1 \text { drachin } & =60 \text { drops } & =1 \text { teaspoon } \\ 2 \text { drachms } & =2 \text { teaspoons } & =1 \text { dessert-spoon } \\ 4 \text { drachms } & =2 \text { dessert-spoons } & =1 \text { tablespoon } \\ 16 \text { tablespoons } & =\frac{1}{2} \text { pint } & =8 \mathrm{oz} . \\ 6 \text { tablespoons } & =1 \text { claret glass } & \end{array}$

\section{Compulsory Notice.}

The diseases of which compulsory notice must be given to the authorities are :-

Glanders, Farcy, Anthrax, and (only in the Shetland Isles) Rubies (Sarcoptic Mange). 


\title{
CHAP'TER XII
}

\section{DISINFECTANTS}

\begin{abstract}
A LAKING drain, an open cesspool, heaps carelessly A thrown together of offensive animal or vegetable matter, are likely to contaminate food or water, while milk absorbs obnoxious gases and germs even more readily. Poisons which destroy such harmful pests are usually termed disinfectants, and under this heading are grouped also antiseptics and deodorants.
\end{abstract}

Disinfectants proper are directed against the germs of infectious diseases contained in excreta or in foul drains, and also against unpleasant and sometimes dangerous odours and exhalations given off by decaying organic matter. These dread enemies may be successfully combated by Sunlight and Heat, solutions in water of Carbolic Acid, preparations such as Izal or Jeyes' Fluid, Permanganate of Potassium, Formalin, or Sulphur Dioxide-the gas which is produced by burning sulphur in the open air.

Mercuric Chloride is another most powerful agent, but is so virulent a poison that it should be used with the greatest caution; a solution of one part in one thousand parts $\left(\frac{1}{10} 00\right)$ of water will disinfect and destroy all forms of life.

Important considerations in selecting a disinfectant are cheapness and accessibility, for there is often little to choose between their respective results.

Sunlight is not so important an auxiliary in England as in many foreign countries, for its continuance and clearness often cannot be depended upon, though it is a powerful germicide. The spectroscope has disclosed that it is the blue, violet, and ultra-violet rays which alone have the power of destroying germs. 
Heat, when it is convenient to employ a temperature of $230^{\circ}$ to $250^{\circ}$ Fahrenheit, may be used for disinfecting any linen articles, but it is not suitable for woollen clothing, or anything that will char easily, such as leather. Boiling for half an hour will destroy germs in clothing, while steam can be used with perfect safety, and penetrates everywhere with ease.

Crude carbolic acid mixed with water, Izal, and Jeyes' Fluid are all cheap chemical drugs, suitable for washing stable floors and disinfecting drains, whilst they may also be used for damp, ill-ventilated cellars.

Permanganate of Potassium is suitable for the same purpose, and a mixture may be made:-

$\left.\begin{array}{lll|l}\text { P. Potassium ... } & \ldots & 10 \text { parts } \\ \text { Common Salt } & \ldots & 8 \frac{1}{2} & \text { to be dissolved in } \\ \text { Acid Sodium Sulphate } & 25 & ,\end{array}\right\} \begin{aligned} & \text { one thousand parts } \\ & \text { of water }\end{aligned}$

Formalin, or formaldehyde, has only the objection of cost. It can be used either as a spray or burnt in the solid form, para-formaldehyde, and converted into gas. It possesses the invaluable merit of not tarnishing metals, as sulphur does, or damaging clothing, and is very useful for destroying moths. As a spray, it can be used to disinfect stables, pigstyes, fowl-houses, and such-like; whilst in small places which can be closely shut up, the conversion into gas is ofttimes the preferable plan.

Sulphur Dioxide is at once one of the most effective and cheapest of disinfectants, but it is open to the objection that it tarnishes all metals, and no bits, stirrup-irons, \&c., should be exposed to its fumes. It can be easily employed in the usual way, by burning it in an open iron pot or other vessel, the place where it is used being carefully fastened up, every chink being attended to, and the place kept closed for some hours afterwards. Sulphur candles can be bought in different sizes for varying proportions of cubic capacity. Liquid Sulphur Dioxide can likewise be obtained, and used instead as a disinfectant.

Antiseptics retard the growth and activity of microorganisms, and thus promote healing. Any disinfectant in 
weak solution will act as an antiseptic; but one of the most useful in the house, as well as in the stable, and easily carried about when travelling, is quickly made by dissolving tablets of Chinosol, which should always be kept at hand. The old-fashioned Tincture of Myrrh is an excellent antiseptic, though its value as such was never suspected when it was in general use in stables; but its healing power was universally known and appreciated without understanding the reason why. Tar is another simple, easily obtained remedy, very useful in certain cases, such as thrush, or to counteract the attacks of flies on a raw wound, after it has been well diluted with honey, or some form of grease, or common vaseline. Another excellent one is Paraffin, mixed with a good body of water; while one always at hand is Soft Soap, which should be formed into a lather and applied to a wound by the aid of a plume from the wing of a hen, or some such similar feather.

Deodorants destroy or neutralise unpleasant odours, which may be charged with dangerous germs and so be prejudicial to health, and they accomplish their mission by being powerful oxidising agents.

The chief of them for stable use are :-

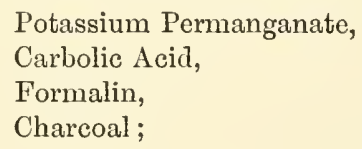

and for refuse heaps and manure, the nurseries of the common house-fly, which is a formidable agent in conveying infection.

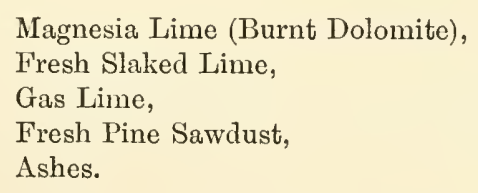

Charcoal is one of the most valuable deodorisers, as it not only oxidises, but also absorbs and condenses many foulsmelling gases. Before the days of rapid transit it was largely used when sending away presents of grouse from 
Scotland to friends in England, a piece being placed in the beak of each bird, some powdered charcoal sprinkled under each wing, and some spare pieces placed between each grouse.

When mixed with Magnesia Lime-Charcoal one part and Magnesia Lime eight parts-it increases the value of manure when spread over a heap. It acts well both with stable and vegetable heaps, and also with earth closets.

Gas Lime is a good disinfectant and deodorant, and moreover cheap, when the cost of carriage is not prohibitive. It acts well on grass-lands and in the garden, being destructive to that pest the wire-worm, as well as performing the ordinary functions of lime in correcting humic acid in the soil, thus rendering available as food for plants much which was rendered unfit before by the presence of the acid. It should not be put on fresh, however, but should either be mixed with soil, or thrown on a vegetable heap, and allowed to mellow for some months, being occasionally turned over before being applied to the ground. 


\section{CHAPTER XIII}

\section{ALCOHOL}

HROM the cerebrum of the horse being less developed 1 than that of human beings arises the fact of the sensory centres being also less highly developed than the motor centres, while the contrary is the case with man. For this reason alcohol does not act in the same way on animals as on human beings, for with the former the drug stimulates the motor functions before it acts on the intelligence, whereas with man the mind is affected before his power of movement is disturbed. In a book published by Mr. Finlay Dunn, which is a standard work of the veterinary profession, he writes thus on the subject: "Different classes of animals are somewhat differently affected by alcohol. Man, whose intellectual centres are about eight times larger than his motor centres, has his intelligence quickly acted on by doses which are insufficient to impair his motor functions. Amounts corresponding to 0.4 to the 1,000 of the total weight of the body disturb human intelligence; while 2.40 per 1,000 of weight are needed to impair motor function. Alcohol has no notable effect on dogs until 1.5 to the 1,000 of body weight is taken, and the prominent results then occurring are disturbance, not of intelligence, but of motor function. Horses and cattle receiving full doses exhibit like excitement, and perversion of motor function."

Although these remarks may be perfectly correct with regard to pure alcohol, no suggestion is made as to the vehicle in which it is conveyed into the system ; for instance, it is a well-known fact that with many human beings an amount of champagne will "go to their head" and produce a temporary hesitation of speech, which would not be the 
case if instead some spirit and water were taken, although the latter contained considerably more alcohol. In this case the thickness of speech appears to be caused through a partial paralysis of "motor function" in the tongue, while the intelligence is all the time extremely active and unimpaired. It may be a boon to such as are liable to be affected in this way and yet are compelled to attend public dinners, and make speeches, to know that by taking a very small quantity of Bicarbonate of Soda, or effervescing Citrate of Magnesia, half an hour before dining they need have no fear of any such occurrence, even after indulging in champagne! Whether any similar traits may be noticed in animals after the scientific administration of champagne is not anywhere recorded, as far as the writer is aware, though he has known it successfully given to a nervous race-horse previous to a race.

What mainly concerns the horse-owner is-when is a stimulant likely to be of service; what should be administered; and in what quantity? In respect of the first item, horses very much resemble human beings, and just as a nervous or mentally depressed person is benefited by taking a glass of wine before encountering some unusually trying ordeal, so also does a nervous animal receive encouragement in the same way. Before the stringent orders forbidding "doping" in any form whatever were issued by the Turf authorities, it was a common custom to give a little spirit, or even beer, to a horse that began shaking, and breaking into a sweat from nervousness, when taken into a paddock before a race; and the difference that "nip" often made in the horse's running was only in accordance with what common sense would expect, and of which innumerable instances could be given by any prominent jockey or trainer of those times. The bottle of port the great trainer, John Scott, used to give Taraban was the talk of the times, and a little crowd used to collect round the pair, as the time for the race drew nigh, in hopes of witnessing the interesting ceremony. In this case the stimulant was given to put heart into the horse, who was not otherwise always to be depended upon to do his best. It is difficult to understand 
why it should now be ruled as a misdemeanour to give a horse that which will enable him to produce his best powers at the very moment they are most required, while during the preparation for the event every form of medicine and tonic is allowable to bring him up to the pitch required. It seems curious reasoning to deny at the last moment what will enable a horse to win his race, though to give something which will certainly cause him to lose it instead is quite another matter! The usual argument is that doping-in which term is included the administration of a stimulant-is likely to be prejudicial to the animal in after-life, especially in the case of its progeny, which may be injuriously affected thereby. But how does this argument hold good if carried logically further? Is it absolutely necessary that geldings should be deprived of a mild stimulant, if needed, for how can their progeny suffer thereby? The knife of the surgeon should also surely be suppressed, since it renders the animal incapable of begetting progeny at all-which is going even beyond doping! Such a conclusion would have no doubt caused Euclid much merriment if the proposition had been placed before him.

The famous steeplechase trainer, the late Mr. Linde, liked an old experienced jockey to have just a "wee drappie" before getting into the saddle, for, he used to remark, it just put that heart and dash into him that brought out his best powers, which the memory of many falls, and close shaves, was apt to diminish. He was very averse though to a young jockey taking anything, for in this case, he said, he probably in his excitement forgot the little he ever knew! Is not what is good for the rider likely also to be good for the horse that carries him? Otherwise the law against administering a stimulant to the one should surely apply to the other too! It is rather necessary that there should be no long delay at the post after any such in. dulgence, as an incident at the Newbridge Races in 1879 may prove. There had been several false starts before one of the races, when at length a jockey sidled up to the starter and ejaculated in a low whisper, "Captain, darlint, can't you let us go?" Then, putting his hand to his 
mouth lest the others should hear: "Shure the dhrink is dying away within me!"

On such occasions a horse would require about a small tumblerful of spirit, added to a little water, or very thin gruel, given about a quarter of an hour before going to the post. On one occasion in the writer's experjence, a horse had left Plymouth for Landrake Races at seven o'clock in the morning, and had sixteen miles to traverse before reaching the course. The rider, however, lost his way and wandered about the country lanes in Cornwall, till at last he reached the race-course about half-past two, the race in which he was engaged being at 3 p.m. Under the circumstances it was thought better to give him something in the shape of a drink, as he must have been very thirsty, so a large bottle of beer was procured, which he greedily drank to the last drop. It freshened him up in a wonderful degree, so that he was quite perky when he cantered down the course, and he won his race from a large field by several lengths. In these days such a drench would have been illegal!

A stimulant is also most efficacious when a horse is overtired from any cause, or weakened to an extreme degree from severe or prolonged illness, and the pulse is then the indicator of what is required. That must at all costs be kept going, for if that mighty muscle, the heart, once stops nothing can set it going again-unlike a watch, which only requires winding up to be as efficacious as ever. Theory is apt to be allowed to prevail too much sometimes, both in human and equine illness. Many a man has been saved by his comrades in India and the Colonies, who have used their common sense and administered such a dose of alcohol when the collapse occurs after even typhoid fever and cholera, that the heart has been kept going when the patient would have slipped through the fingers of a medical man, who, relying too much on the teaching of books, and fearing after-effects, administers so small a stimulant that it has not sufficient result to be of use. The consequences that might possibly have ensued do not matter, if in the meantime the sufferer has died. 
A case in point occurred in the spring of 1881, when the writer was A.D.C. to the Major-General commanding the Dublin District. The stable accommodation being limited in the Royal Barracks, the late Mr. William McGrane, the famous horse-dealer who lived close by, kindly took in some of the horses. One day a well-bred mare, Lurline (which had been bred by the late Mr. Joseph Studholme, of Ballyeighan, in King's County), got a gorsespine into her leg whilst hunting, and as the sap was just beginning to run it affected the wound and blood-poisoning ensued. It was some weeks before the mare was approaching convalescence, and as she had a particularly long dock, which moreover was crooked, it was thought an excellent opportunity to shorten it sufficiently to give a handsome appearance. Mr. McGrane kindly offered to perform the operation, which he was in the habit of performing on his own purchases when needed-for this was before the present craze came in for disfiguring all hunters with short docks-so the docking-knife was hunted up, and the operation performed. It is notable, in view of the afterconsequences, that the stump was seared with a redhot iron to stop the bleeding. Some ten days afterwards, on going to visit the stable one morning, the groom in charge said he did not like the look of the mare, and the moment the door of her box was opened it was only too plain that lock-jaw had supervened. This took place before the dangers of microbes and bacteria had been made known to the world, and at that time tetanus was presumed to be produced by an injury to a nerve. Consequently this attack was erroneously supposed to have arisen from the mare having been subjected to an operation when in a weak state of health, whereas there is no doubt it originated from the knife having become somewhat rusted when lying about, and so attracted the bacillus of tetanus, for no one in those days thought it necessary to be particular about sterilising an instrument before using it.

There was a sharp frost at the time, and as I had to pass the door each day when going to and returning from skating on the ice at the Viceregal Lodge, I never failed to call in 
each time to see how Lurline was getting on, though it was not a very severe case. Often I was accompanied by a friend, who might be curious to see an instance of lock-jaw, on one occasion my companion being the late Lord Randolph Churchill, who took a keen interest in everything pertaining to horses, and was very fond of hunting. One morning when I looked in the spasm had left the mare, and her muscular system was completely relaxed, though she was very weak, for it must be remembered that this attack had followed a previous severe illness. Giving instructions to the groom to get some groats for her, to boil them with linseed, and to give the gruel to her in small quantities several times during the day, I returned about five o'clock, hoping to find the patient already better. The groom said he had been to her about every two hours, and that she seemed hungry at first, yet took very little; but on going to the box and feeling her pulse I was much alarmed, and saw there was no time whatever to lose. On the near side there was no pulse to be felt at all, while on the off side of the jaw it could be very slightly discerned, though it appeared to be getting momentarily both slower and fainter. Hurrying out of the box, I called to the head man, Whelan, the once wellknown steeplechase jockey, and asked him to fetch some whiskey, or any spirit, as quickly as possible, and after giving one glance at the patient he ran out of the stable as fast as he could. When discussing the case afterwards, Whelan said he had fully thought the mare was done for, she seemed to be at the very last gasp. Before the man returned, which he really did very quickly, the mare sank down on the straw apparently lifeless, and I thought she had gone down to die. A well-bred horse fights it out to the last on its legs, except in some diseases, and it is a bad sign when they lie down, until there is a real turn for the better. There was some gruel warming on the fire, so when Whelan arrived with a half-pint of whiskey-he said less would be of no servicewe poured most of it into a bottle, filled it up with gruel, and then, raising the mare's head, poured it down her throat as she lay, though we were doubtful if she still possessed the power of swallowing. To our relief she managed to get 
the first mouthful down, and then at slow intervals we gave her about a tablespoonful at a time, till all was finished. It was curious to note how quickly the heart responded to the stimulant. Keeping my finger continuously on the pulse, as I supported her head, I at once felt the pulse vibrate again directly the first mouthful of spirit had been taken, and by the time the bottle was finished the strength was perceptibly increased. We left her alone then and went out of the box, while Whelan prepared a warm mash, and in a little more than half an hour the mare struggled on to her legs again, ate the mash when it was given to her, and from that moment rapidly gained strength.

It must be borne in mind that there are certain times when it is not advisable to give alcohol, except under such stress as the above, when if it is not administered the heart will stop and there will be no need for any further treatment. Alcohol especially should not be administered after an accident to the head, when the brain is bruised, for it would only aggravate the mischief; nor, except under surgical advice, is it wise to administer it when the liver is affected. But it is called for in cases of great distress after hunting; in prolonged weakness after illness, such as strangles or influenza; and especially in yew-poisoning, when there is great depression of the nervous system, and the circulation becomes greatly impeded. 


\section{CHAPTER XIV}

\section{EXAMINING A HORSE FOR SOUNDNESS}

WHEN examining a horse for soundness it is well to hood of overlooking any ailment, every part being taken in due sequence. If possible the horse should be seen first in the stable, when at ease. The position in which he stands can then be studied, and whether he points a foot or favours a leg generally. After the first cursory glancewhen any glaring fault should be detected, and the general appearance, and whether the animal stands true on its legs be noted-it is usual to commence with the head, looking whether signs of injury are anywhere apparent, especially to the nostrils or mouth. The pulse should be felt, to see whether the beat is normal, and not irregular, which latter may disclose disease of the heart. The palms of the hands should be pressed against the line of the back-teeth, and if the edges are too sharp, requiring attention, the flinching of the animal will at once betray their condition. The mouth should then be opened, and the tongue glanced at, lest it has been injured at some period through a halter rope having been carelessly used as a makeshift bit; and next the teeth must be examined, and the age of the animal duly recorded. The eyes may be left until the rest of the examination is concluded. The glands under the jaws must be felt to see whether they are enlarged and hard, which may be a token of glanders; and then the width between the angle of the jaws is an important point to observe, for if narrow there may not be sufficient room for the windpipe, and the horse will also never give properly to the bit. After looking at the top of the poll for any indication of soreness (or 
poll-evil), the neck vein should be examined to see if there is any mark of the animal having been bled, and then each of the limbs must be taken in turn, commencing with the near fore-leg. It is not enough to rely upon eyesight alone, the touch also must be brought into requisition, and the hand rapidly passed down the front and the sinews of each leg down to the coronets, feeling for any indication of exostosis or thickening, when if a splint or ring-bone exists, or there is any sign of brushing, it should be quickly detected. The lateral cartileges must be felt to see whether they are elastic and free from any suspicion of side-bones. Each foot must be picked up, the state of the frog noticed, and whether the hoof is concave or flat; and if the bars are contracted; and also whether there are rings only on the inside of the hoof, which may indicate laminitis; or if there is any sign of navicular disease. It should especially be noted, if the shoes are not new ones, whether they are evenly worn, or whether there is too much wear at the toes or heels. The fore-shoes should be taken off, and the seat of corn subjected to pressure from the smith's pincers, and if the animal flinches some horn should be removed, to discover if any redness exists proving the existence of corns. The hocks must receive particular attention, signs of curb being sought, and whether the hock betrays weakness by being slightly cut away in front at the head of the shank-bone. Thorough-pins and bog (or jack) spavins must be noted; but above all the presence of exostosis must be diligently searched for, more especially at the true site of spavin, the inside of the small bones of the hock. If there is the least doubt a sure way of detecting spavin is to raise the hind-leg as high as possible, drawing it well forward at the same time, and thus flexing the hock as much as possible. After holding the limb in this position for a minute or more, let the leg down, and at once have the animal started off at a trot, when lameness will be apparent if any spavin exists.

During the examination of the hind-legs it is prudent to have the fore-leg taken up on the same side to prevent the animal from kicking at the examiner; and it is not 
generally known that if the foot is held on high simply with the fingers by the tip of the toe, the fetlock being well flexed, very little exertion is required to hold it, and no horse is able to get its leg down again; but if, as is often done, the groom holds the leg by the pastern, or takes the whole foot into his hand, and allows it to be in a line with the leg horizontal to the ground, it will tax his utmost powers to retain his grasp, if the horse should turn restive.

It is also frequently necessary to cover an eye with the hand to prevent the horse resenting being handled, and there is a right and a wrong way of doing this. The wrong way is to put the flat palm against the eye, which most likely irritates the horse, and if it should endeavour to jerk its head away it will probably succeed in doing so. The right way is to place the side of the hand behind the eye, and then turn it sufficiently to prevent the animal observing the other person examining it, when the wrist is in a position to give to the motions of the horse, and the groom can easily keep his hand in its place.

As soon as the examination of the horse is finished, it should be trotted to see if it is sound; and herein lies the advantage of trotting it after, instead of before, the examination, for it has perforce been in a state of rest whilst the latter has been made, and if there is any stiffness there is a better chance now of detecting it.

Let the horse first be walked slowly, with the head at liberty and with plenty of rein. The way in which the animal places its feet upon the ground must be carefully watched, whether the toe is dug into the ground, or whether it goes on its heels, or whether, as it should do, the feet are placed evenly and flat. The evenness of the strides must also be noted, and whether each hind-foot covers the print of the fore-foot by exactly the same distance. Unless the horse has its head quite at liberty it cannot do this, for the stride will be shorter on the side to which the head is pulled; also a horse which has carried a lady, riding in a side-saddle, throughout the winter, will almost always step shorter with the off hind-leg than with the other; but in both cases the horse will trot with level action if it is sound. 
If unsound in front, the moment the horse trots it will show lameness on the side that the hind-leg covered the fore-foot print by the greater distance-the strides of the two hind-legs being equal, while those of the fore-legs are unequal. The contrary is the case of lameness behind, for then the strides of the two fore-legs are equal, while the strides of the hind-legs are unequal. In this case the sound hind-leg covers the corresponding fore-leg to a greater extent than the lame one does, as there is a deficiency of power to bring the lame leg forward.

In cases of lameness in front the head drops as the knee of the lame leg is bent in the act of bringing it forward, and it rises again as the foot is placed on the ground. This is more plainly seen when the horse is trotted past the examiner. If the action is so slightly affected that there is some doubt as to actual lameness existing, if the horse is trotted downhill the matter should be quickly set at rest. In the case of hind-lameness, it will be better shown when the animal is trotted uphill. Care must be taken that the attendant does not hold the horse tight by the head, or give a jerk to the bridle, either of which will prevent a horse for the moment from appearing to be lame.

If a horse goes sound in soft ground, but lame on hard ground, it is generally suffering either from foot-lameness, or is developing a splint. In the case of sprains, or rheumatism, the animal goes worse, if anything, on soft ground. In foot-lameness the horse generally stands in the stable with his foot stretched out in front (except with navicular), and the heat in the foot and round the coronet is notably increased. With navicular the foot is colder than the others, and when at rest the horse draws back the affected leg, resting it upon the toe, and placing very little weight upon it.

To detect whether a horse is lame behind, place yourself behind the horse when trotting from you, up an incline if possible, and note whether the two hocks are raised to exactly the same height. If the horse is lame in the hock, or below it, the hip on that side is usually carried higher than the sound one, and the hock also is raised above the 
other. If lame above the hock the hip will generally droop somewhat in action, and the horse swerves slightly from that side, not carrying its body in a straight line, whilst the hock is not raised so high as the other one.

Acute laminitis is indicated by great heat in the foot, and almost total inability to move.

Chronic laminitis is shown by loss of the concave form of the sole, by an abnormal degree of heat, by well-marked ridges in the hoof, and by the animal treading as much as possible on his heels.

Navicular is indicated by the horse standing either with his leg flexed, as already mentioned, or else by stretching out both legs and bearing his weight upon the toes, both heels being raised off the ground. In action he goes chiefly on his toes, with short strides, but gets better with exercise, though he will be worse next day. If of long standing, the inside quarter will be straighter than the other, with small ridges on that side, and the sole will be more concave than natural. A further test may be applied by bending the foot well up, and applying pressure to the heel with the thumb, pressing upon the flexor perforans, which passes over the navicular bone prior to its attachment to the os pedis.

Lameness from rheumatism in the shoulder may be distinguished from navicular lameness on the horse being put into action; with rheumatism he only gets worse the longer he is out, but with navicular he gets better as he becomes warm, until he may appear quite sound. Also with rheumatism he walks lame; but with navicular he may walk sound, and only appear lame when he trots.

The muscles of the shoulder frequently waste in rheumatism, and remain so for a long period after it has departed, and this is best seen by standing in front of the horse, and comparing both shoulders together.

After finishing the external examination the eyes should be carefully examined, and for this purpose each must be shaded in turn with something which will not reflect light, such as a black felt hat. Close search must be made for cataract, which is sometimes so small it can scarcely be observed, and appears like a white spot in the lens itself, or 
as streaks running from the middle outwards. Cataract must not be confounded with simple specks on the cornea, the clear fore-part of the eye through which the light passes, which may be of no consequence, whether they interfere with the vision or not depending upon their situation. If there is a doubt felt about cataract being present the animal should be taken into a dark stable, and a match struck and held close to the eye, when with a sound eye three reflections should be seen, one being inverted to the other two, which are upright. When the light is waved to and fro the two reflections should follow its movement, and the other move in the contrary direction. Besides cataract and specks, it must be noted whether the pupil contracts and enlarges, according to the degree of light, for the eye may look perfectly right and yet the horse be absolutely blind, suffering from amaurosis, or gutta serena. The pupil then remains of one size, and the eye has a glassy appearance. An additional test is cautiously to advance a finger very close to the eye, when the animal will not wink or take any notice, though if this is done too rapidly, or violently, the horse will perceive that something is being done, through some subtle sense, and the supposed test be of no avail.

Even if the eyes are healthy there is yet a trap for the unwary, as sometimes the curious dark body of the eye, the corpus nigrum, is of such size as seriously to impede the sight, and hence largely to diminish the usefulness of the horse as a hack or hunter.

The eye should be large and generous-looking, and the outer portion, the cornea, not be too convex and protruding beyond the eyelids, for animals possessing such are usually short-sighted and given to shying. In stable language this formation is termed buck-eyed.

The last portion of the examination is for the wind, and no test equals either galloping the animal under the saddle, or lunging it in a circle. Although all roarers will grunt if threatened with a stick, it is not all grunters who are wrong in their wind. Coughing an animal by pinching the windpipe is also not a sure test, and it requires a carefully trained 
ear to distinguish the character of the cough. But a horse which is galloped sharply, and then rapidly twisted first one way and then the other, or which is made to gallop round fast in the lunge, will quickly betray the secret if anything is wrong. It must be borne in mind that an animal who has only just recovered from a severe cold, and whose throat is relaxed, will sometimes make a noise temporarily, yet show no signs of it when perfectly recovered. I have many a time refused to pass such a horse, but directed that it should be shown again in about six weeks' time, when the horse has frequently turned out perfectly sound.

A broken-winded horse will sometimes emit no grunt when threatened with a stick in a fair, but it cannot pass one simple test: put a man on its bare back, without a saddle, and direct him to urge it to a trot, when the ailment will be at once apparent. This is possibly because the weight is directly over the lungs.

There is one thing which should never be omitted: the horse should always be turned rapidly round, first one way and then another, on its own ground, and then made to back. If it is a shiverer this test will find it out. Shivering - so-called-is a disease of the spine, and no shiverer is able to back, although it may stand any trial in a straightforward direction.

\section{Auction Sales.}

When purchasing a horse at an auction it is advisable to study the rules in force at that particular auction, which will be found printed under the "Conditions of Sale." Although the chief auction marts are conducted on much the same lines they sometimes differ in minor particulars, and the purchaser has only himself to blame if he does not study such important items as to what constitutes a warranty at that particular mart; and what period is allowed for a trial, within which time the horse must be returned if a breach of warranty or serious misdescription is alleged.

Notice of complaint in respect of any lot not answering the description, or warranty, should invariably be delivered in writing, and a duplicate kept; and care raust 
be taken that it reaches the auctioneer's hands within the time specified in their rules.

Amongst the usual conditions held to constitute warranties are the following:-

1. That a horse described as "a Hunter" has been hunted, and is capable of being hunted.

2. "Good" or "Perfect Hunter," constitutes a warranty that the horse has been hunted, is capable of being hunted, and is sound in wind and eyesight.

3. "Good Hack" constitutes a warranty that the horse is quiet to ride, and is sound in action.

4. "Quiet to Ride and Drive,"

" Regularly Driven and Ridden,"

"Good Workers,"

"Used to Farm Work,"

"Quiet in all Gears,"

"Suitable for Town Work,"

constitute a warranty that the same are quiet and capable of being worked in saddle, harness, or gears, as the case may be ; and have not any infirmity or disease which renders them incapable of doing reasonable work, or any particular vices.

5. "Good Polo Pony" constitutes a warranty that the pony is sound in wind and eyes, quiet to ride, will go to the ball, and is capable of being played.

6. "Age," when stated, constitutes a warranty.

Descriptions which do not carry a warranty are :-

1. Height.

2. A mere statement that the horse has " been hunted up to date with," \&c., is "A fine fencer," "Has carried a lady," "Likely to win a Point-to-Point."

3. A mere statement that the horse has been ridden or driven, and went quietly.

Such may be touched in the wind, a runaway, or jibber in harness, and absolutely unsound.

The responsibility and risk is upon the purchaser from the fall of the hammer.

The responsibility for all accidents to a horse on road or rail to or from a purchaser, and whilst in his custody, must 
be borne by him, whether or not the arbitrator decides he is entitled to return it; but the responsibility for accidents, if any, to a horse while at the repository pending trial, or during the trial, must be borne by the vendor if the arbitrator decides that the purchaser is entitled to return it ; or by the purchaser if it is decided he must keep it.

Due care must be exercised by the auctioneer's servants to exclude liability for damages on the part of the firm.

\section{The Teeth.}

As a rule horses have four more teeth than mares, as it is not usual for the latter to develop the four tushes. The former have forty teeth, and the latter thirty-six. They are arranged in the following manner:-

\begin{tabular}{|c|c|c|c|c|}
\hline Front teeth, or incisors & & 6 upper and & 6 lower & $=$ \\
\hline Tushes, or canine $\quad$... & ... & 2 upper and & 2 lower & $=$ \\
\hline Molars, or back teeth & ... & $\begin{array}{l}12 \text { upper and } \\
\text { (6 on each }\end{array}$ & $\begin{array}{l}12 \text { lower } \\
\text { side) }\end{array}$ & $=$ \\
\hline
\end{tabular}

The teeth afford valuable information as to the age of a horse, owing to the changes which are constantly taking place, though it is the incisors, or front teeth, by which the examiner is guided, and more especially those in the lower jaw.

The foal is usually born with two incisors in the lower jaw (Plate XI.), or, if not, they make their appearance a day or two afterwards; and then after the others are gradually developed the whole set are replaced by the permanent incisors, which are all fully grown by the time the animal is five years old. The crowns of both sets of teeth, the milk teeth and the permanent ones, are furrowed with a groove, which they gradually lose by detrition in a regular sequence, thus enabling the age to be told. After all the marks have been worn out it is still possible to arrive at the approximate age by the different shape the teeth assume as their surface is worn away; by the shrinking of the gums, by the angle at which the teeth are placed, and by certain marks on the 
upper corner teeth. Teeth are not always normal, and those on one side often differ somewhat from those on the other side of the mouth. They are also affected by external circumstances, such as the character of the food, by the ground on which the animal has to seek its living, and by crib-biting, which "stable vice" wears the teeth away more than anything. Per contra, the state of the teeth often give the examiner a hint to look out for this evil habit.

The molars, or back teeth, are not shed like the milk teeth, but remain permanent throughout life. Sometimes the upper and lower molars do not cover each other, resulting

PLATE XI.

Foal's Teeth when born.

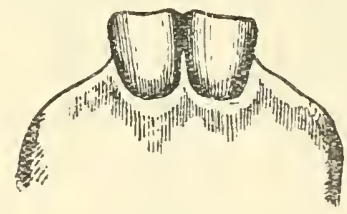

in a portion of each meeting with no opposition, and thereby failing to experience the attrition which would keep them level. Then sharp processes arise on the outer edge of the upper molars and the inner edge of the lower molars, wounding the cheek on one side and the tongue on the other, and making the animal afraid to masticate its food. It therefore either bolts its corn or "quids," dropping half-masticated food into the manger. "These sharp edges should be at once attended to, and removed by the use of the chisel and rasp.

The lower molars always wear faster than the upper ones, and the middle ones sooner than the outer ones, so that many old horses present an undulating surface. The "tables," as the surfaces are termed, are also apt to become too smooth to be of much use in grinding the food, and if this should occur there is nothing for it but to give the horse crushed oats and finely chopped hay, to assist mastication as far as possible. Molars are occasionally 
fractured, and are apt to split from the crown to the fang, and if such an accident is discovered the tooth should be at once removed. Otherwise food will get into the fissures, and when fermenting may bring on inflammation of the gums, possibly affecting the surrounding bone also. If the tooth is extracted a watch must be kept that the opposing tooth does not in consequence grow too long.

Often the crowns of the milk teeth are not duly shed though the fangs have been absorbed, and they should be at once taken out with a forceps, which is an easy matter as their attachment is but slight. If allowed to remain the space is too crowded, with the advent of the permanent teeth, and food accumulates, ferments, and gives rise to foul breath and irritation of the gums, and consequently quidding. Sometimes supernumerary teeth make their appear-

PLATE XII.

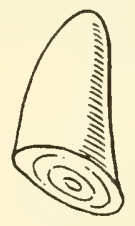

ance, which should be promptly removed, as they interfere with the movements of the tongue when rolling the food across the mouth, or prevent the lateral movement of the jaw. There is usually little difficulty in extracting them, since the fangs are generally imperfectly developed. Only this spring the writer had one removed from under the tongue of a thoroughbred mare (Plate XII.), which was so thoroughly hidden that its presence had never been suspected. The mare had been very shy of her bit during the short time she had been ridden, always carrying her head as high as she could get it, and tossing it the moment the bit was touched, but as soon as the offending tooth had been discovered, and removed, she no longer resented the bit, and carried her head in the proper position.

Sometimes two little teeth make their appearance adjoin- 
ing the molars, and are termed wolves' teeth. 'They are the remains of the very ancient days when horses had seven molars instead of six.

Occasionally incisors of the upper jaws so overhang those of the lower jaw that it is impossible for the animal to graze, and therefore it should never be turned out to grass to find a living. Such animals are said to be parrot-mouthed. As the teeth cannot oppose each other they need frequent filing when they become too long.

\section{PLATE XIII.}

Lower Jaw, showing grooves.

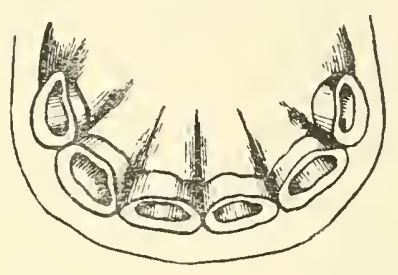

Names are given to each pair of incisors, and these are-

2 front incisors (or what would usually be called the middle ones) are termed the... Central

2 next on each side are termed the ... ... Middle

2 outside ones are termed the $\quad \ldots \quad \ldots$ Corner

In the centre of the crowns of the incisors there are grooves, or depressions, forming cups, the infundibular markings (Plate XIII.); the milk teeth lose these approximately in this order:-

$$
\begin{array}{lccccc}
\text { Central teeth lose the cups at ... } & \ldots & \ldots & 1 \text { year } \\
\text { Middle teeth } & , & \ldots & \ldots & \ldots & 18 \text { months } \\
\text { Corner teeth } \quad, & , & \ldots & \ldots & \ldots & 2 \text { years }
\end{array}
$$

when the crowns of the lower incisors become flat.

It has been mentioned that the centre incisors are present at birth or within a few days afterwards, and the others make their appearance and become level with their predecessor's 
as follows, taking about two months in the process from the time they are first seen.

Centrals appear at birth (Plate XI.).

Middle " 14 to 21 days, and are level at 2 months (Plate XIV.). Central " 6 months, " " 8 months (Plate XV.).

These foal's teeth differ from the permanent ones in being semicircular, with a shoulder, whilst the permanent teeth diminish in size from the crown downwards with a regularly graduated slope. The milk teeth have a short fang, which is gradually absorbed, so that the tooth is ready to fall off when the corresponding permanent tooth is sufficiently ready. But the permanent teeth are of considerable length, are partially curved in shape, and when first developed are

PLATE XIV.

Foal's Teeth at 2 Months.

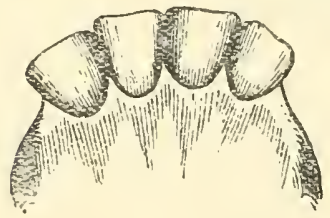

PLATE XV.

Foal's Teeth at 6 Months.

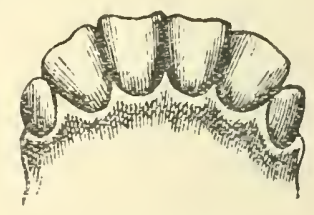

twice as wide as they are thick through (Plate XVIII.). 'In consequence of their graduated form, as the upper surface is worn away, the width and thickness by degrees alter their respective proportions, until in a very old horse they become twice as thick through as they are wide (Plate XXV.).

Similarly, from being curved, the lower teeth which were at the beginning perpendicular, become very nearly straight as age creeps on.

The two central permanent teeth, and the two middle ones in the lower jaw, have grooves down the front from their first appearance; but not so the milk teeth, which are quite smooth; and this is another aid in distinguishing between them.

The permanent teeth are thus developed, but often there 


$$
\text { PLATE XVI. }
$$

Permanent Teeth.
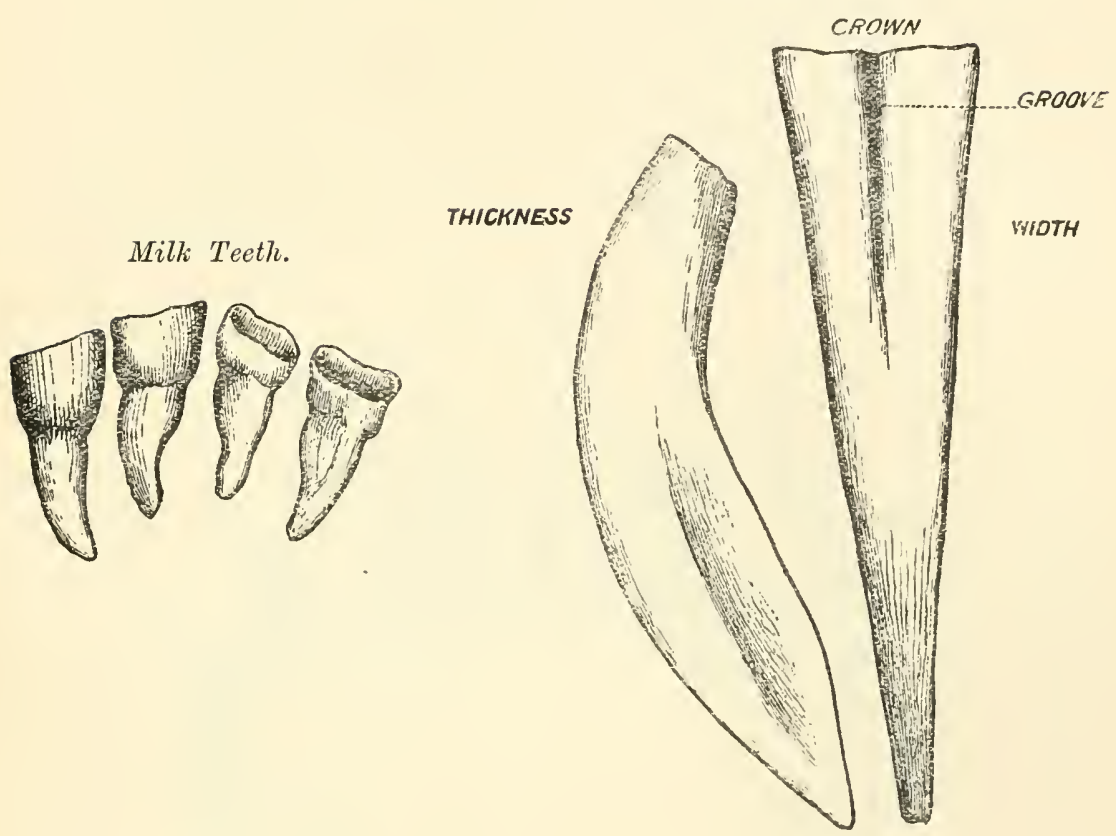

PLATE XVII.

Position of Permanent Teeth in Lower Jaw.

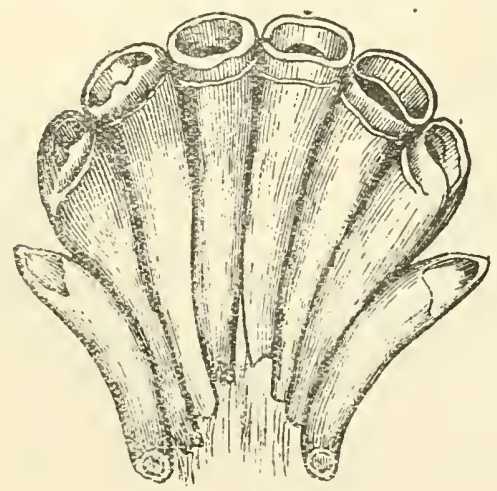


is a difference of nearly six months between animals of the same age in the growth of the teeth.

Appearance of Teeth.

Centrals commence at

,. fully grown ...

Middles commence at...

, fully grown ...

Corners commence at ...

, fully grown ...

$$
\begin{array}{llll}
\ldots & \ldots & \ldots & 2 \frac{1}{2} \text { years } \\
\ldots & \ldots & \ldots & 3 \text { years } \\
\ldots & \ldots & \ldots & 3 \frac{1}{2} \text { years } \\
\ldots & \ldots & \ldots & 4 \text { years }
\end{array}
$$

PLATE XVIII.

Outside view of Lower Jaw at 5 years old.

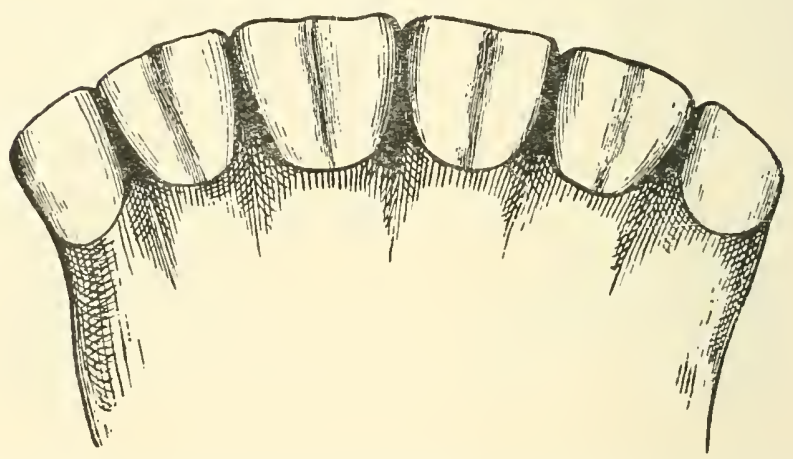

Grooves in the centrals and middles, but not in the corner teeth.

Lower Jaw at 5 years old.

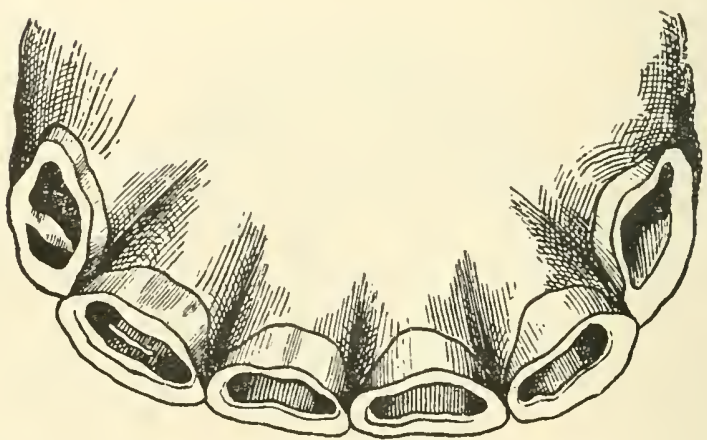

Corner Teeth.-Outside walls level, but thin. Inside walls not quite level, and thinner than the outside. 
At five years (Plate XVIII.) the incisors should be fully grown; the cups in the centre teeth still well developed, though more worn than those of the others; and the inside walls of the corner teeth should be thin compared with the outside ones, and not quite level with them.

The top corner teeth should be much wider than they are long; and a notch may be felt in the centre of the inside wall. If the milk teeth have been knocked out, from time to

\section{PLATE XIX.}

Lower Jaw of Mare's Mouth at 6 years old.

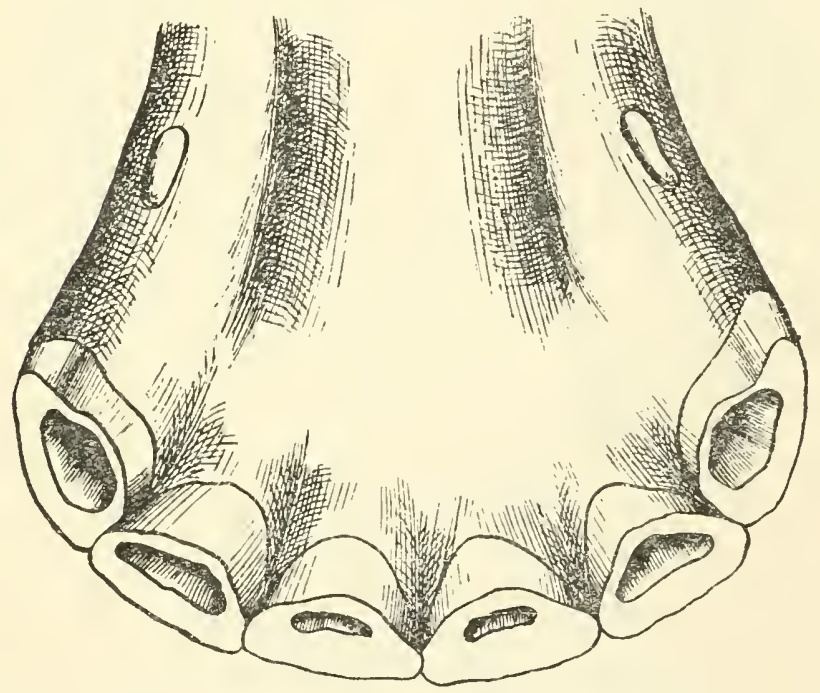

Cups leaving the centrals. Cups a little larger in the middles. Inside wall of corner teeth level. Outside wall thicker than at 5 years.

time, to force on the growth of the permanent teeth so as to make the horse appear older than he legitimately is, the guides to detection are the appearance of the cups, which will be quite gone in the centrals but fully developed in the middles, instead of the difference between the two being clearly graduated, the reason being that an unfair amount of wear has been forced upon the centrals, by the knocking out of the middle teeth before Nature intended them to be 
shed; and also the relation of the width to the length of the top corner teeth ; and whether the inside walls of the lower corner teeth are level with the outsides or not, if the horse is represented to be 6 years old.

The cups leave the crowns in this order:-

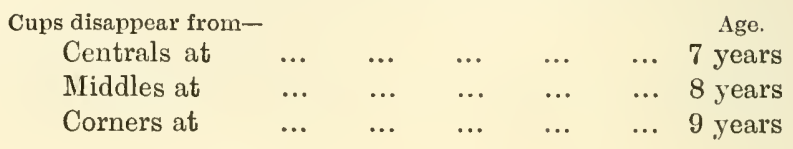

PLATE XX.

Lower Jaw at 7 years.

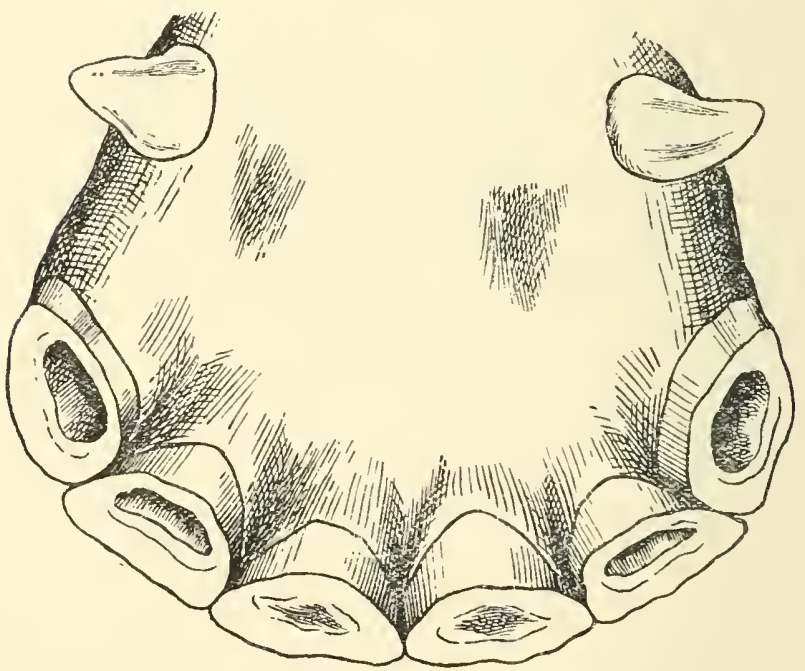

Cups entirely left the centrals. Cups small in the middles. Inside wall of corner teeth begins to show wear, and the outside wall is thicker.

At 6 years the top corner teeth are only a little wider than they are long; and the inside walls of the lower corner teeth are level with the outside walls, which are thicker than at 5 years (Plate XIX.).

At 7 years the upper corner teeth are square, or longer than wide; and the inner walls of the lower corner teeth begin to show signs of wear, and have ceased to be very thin (Plate XX.). 
At 8 years there are only small cups left in the lower corner teeth, and the walls are much thicker than formerly (Plate XXI.).

PLATE XXI.

Lower Jaw at 8 years old.

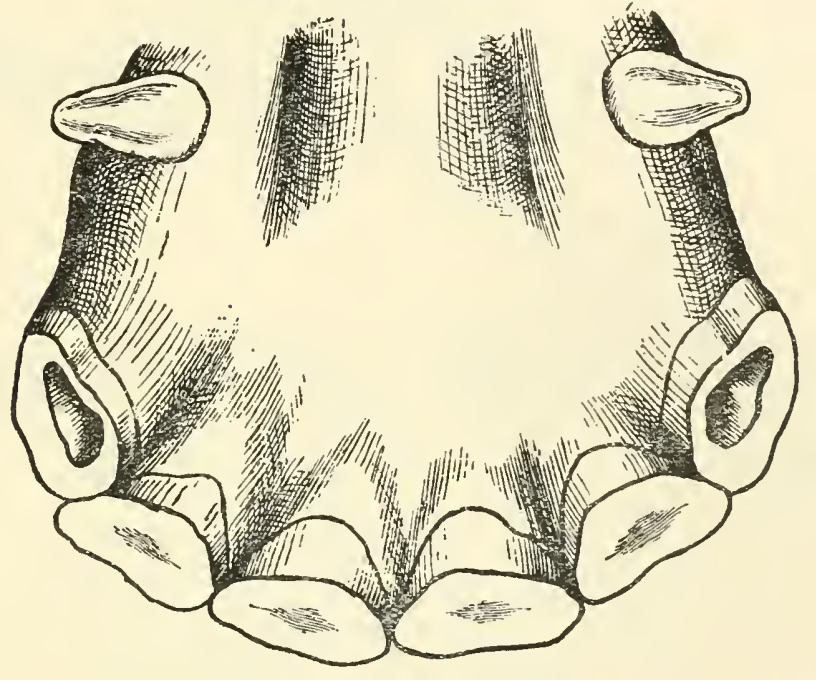

PLATE XXII.

Lower Jaw at 9 years.

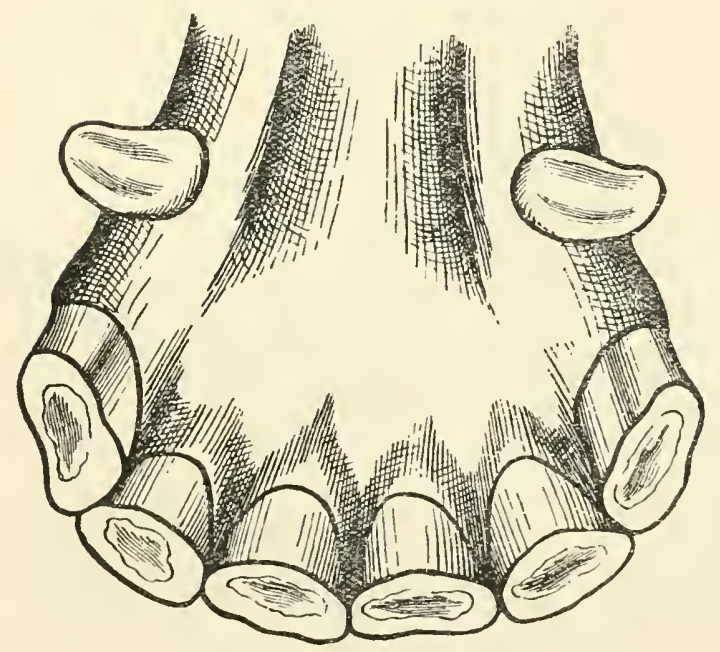

Cups left all lower teeth. 
After 9 years (Plate XXII.) the age must be told by the thickness through in comparison to the width, especially of the two centrals, which become equal in that respect at

PLATE XXIII.

Top Jaw at 10 years.

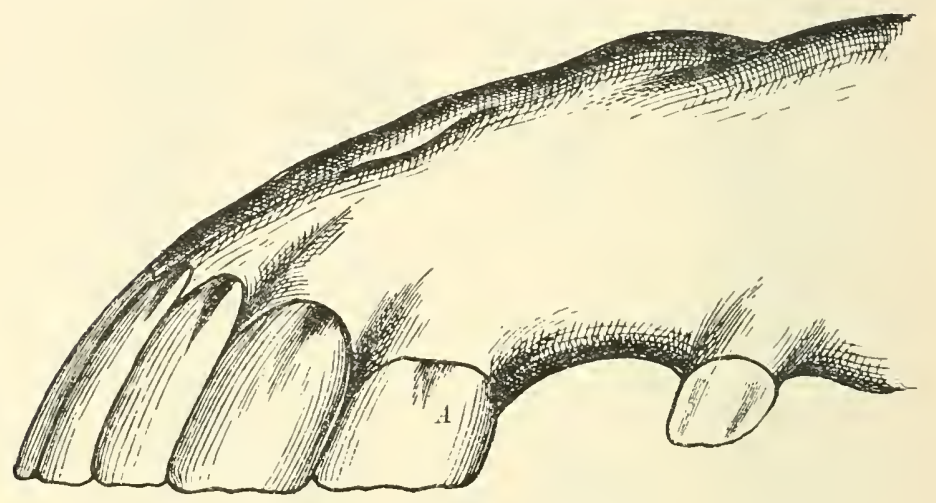

A.-Groove in corner tooth.

PLATE XXIV.

Top Jaw at 15 years.

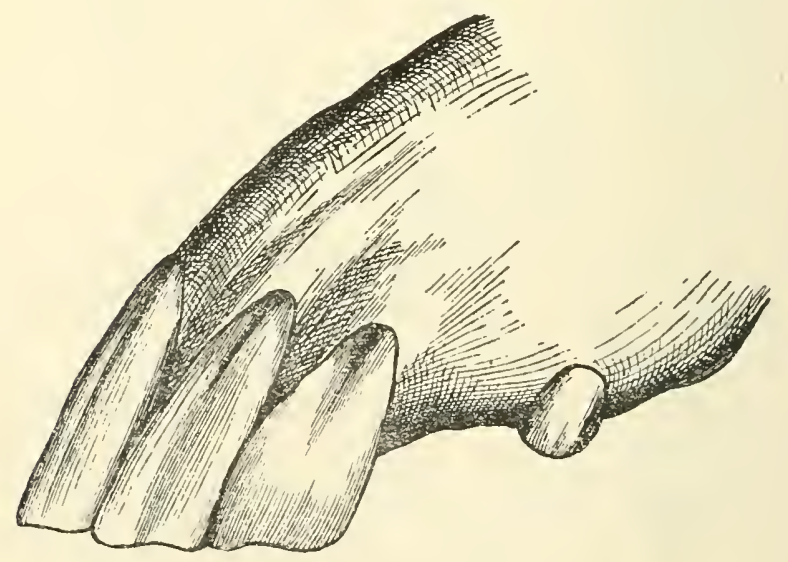

about 18 years, and afterwards exceed it; and by a groove in the face of each upper corner tooth, which begins to show at 10 years (Plate XXIII.), at 15 years will be 
PLATE XXV.

Fig. 1.-Top Jaw about 26 years.

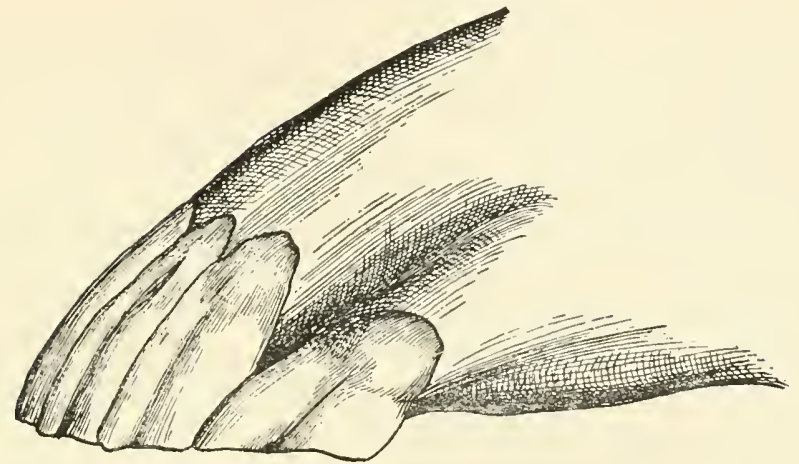

The groove extends only about $\frac{2}{3}$ from the bottom of the corner tooth.

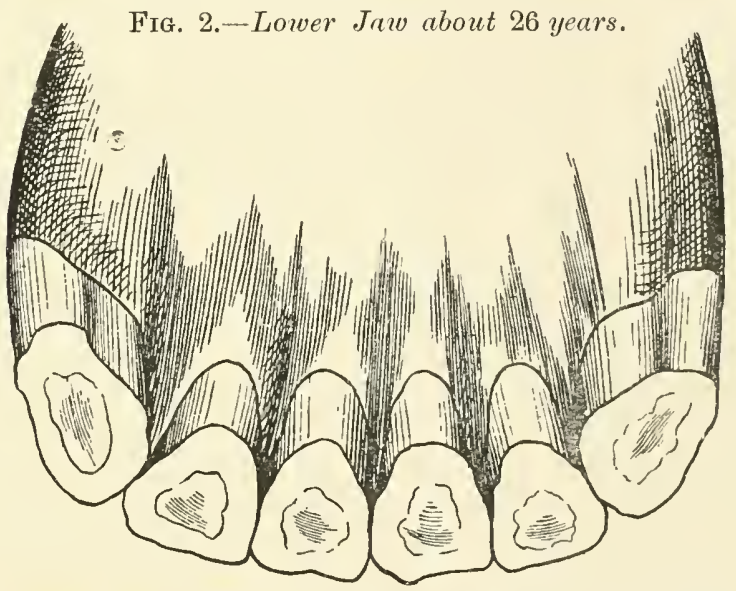

Central teeth longer across than they are in width.

Fig. 3.-Lower Jaw about 26 years.

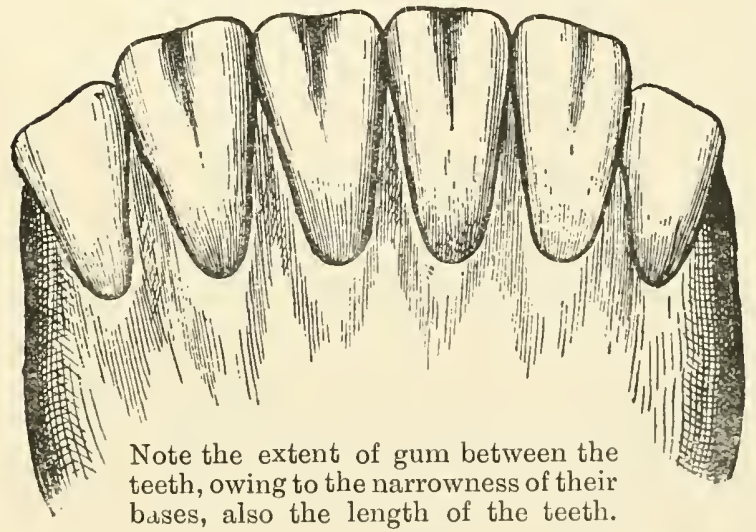


half-way down (Plate XXIV.), and in 6 more years' time will have reached the bottom, when the horse is 21 years old. By the amount of growth of this groove the age of the hor'se can be fairly calculated.

After the groove has reached the bottom it begins to leave the gums at the top, where the tooth then becomes round (Plate XXV.), and by the time the animal has reached 30 years this round, grooveless part will have descended nearly a third of the tooth. By this time also the teeth in the lower jaw will extend from the jaw in almost a straight line, having lost all curve.

Since the cups are such important guides to the age at a time of life when the animal is at its prime, dishonest attempts are made to provide fictitious cups-a process which goes by the designation of "Bishopping." The horse is thrown for the purpose, and cups are scooped out of the crowns with engraving tools, being afterwards burnt black with a red-hot iron. But round a natural cup there is always a ring which cannot be imitated, and the hot iron also stains the surrounding enamel, so that when once a bishopped mouth has been examined the deception is easily recognised when met with again.

The tushes are usually seen in geldings at 4 years, and with stallions a little earlier. They are at first pointed with sharply defined edges, but these get rounded with age, and the top gets blunter. 


\section{CHAPTER XV}

TRAINING FOR RACING, POINT-TO-POINT, Etc.

HERE is no mystery in training! When I was about
to leave Spain, during the heyday of the Spanish Turf, where for three years the stable over which I presided had carried off a large number of prizes, including the chief and most valued races, I was asked a searching question by the clever owner of the most successful stable in the Peninsula. Moreover, W. Everitt, his professional trainer and jockey, was one of the most capable men, in both lines, I have ever had the fortune to meet. I was staying with $\mathrm{Mr}$. Davies just prior to my departure for England, and whilst we were riding home together he remarked, "We have always been excellent friends, and I hope you will not mind my asking you a question. What is your secret in training? for now you are leaving us there can be no harm in telling it." "Secret"! I ejaculated. "I have no secret!" But he was quite huffed, and said in hurt tones, "You must have a secret. I have never seen horses so universally turned out well, not on any race-course in England, as yours are. You might let me know your secret now-and I think you ought to, after all I have done for you. Everitt wants to know, and told me to ask you." "I have no secret," I answered. "The only secret I know is hard work and common sense!" At first my reply did not mend matters, and seeing he was really annoyed I added, "I would tell you directly if I had anything to tell! But let us see what your system is, and I expect it will be just the same as mine." Having mollified my friend, we went into all the minutiæ of our respective methods, and, as I expected, there was no essential difference between us, any more than there 
was on the race-course. The aim I always had in view was to deliver each horse at the post in the highest possible health, full of vigour and muscle; free in his action, and thoroughly clear in his wind. This sums up the whole art of training, but if one item is wanting the animal will not win when competing against those who have similar form. For instance, a horse may have done too much work, and therefore be lacking in vigour, and disinclined to catch hold of his bit and put heart into his work; or he may be short of work and have accumulated fat inside, and consequently soon gets blown and does not catch his second wind; or he may be fairly right in his wind, in so far that he does not take long to recover it after a sharp gallop, yet has not done enough long work to fully develop the muscles, which consequently tire, and his strokes lose their power; or perhaps he gets jarred, and stiff in his joints and sinews, whereby his stride is shortened a few inches, which means a loss of many yards in the course of even a short-distance race. One thing, however, I must add: that it is far easier to train a horse in England, with a springy turf to gallop on, with better and less heating food, and a cooler and more bracing climate, than it is in a hot country, where any ailment runs its course in hours instead of days.

Supposing a horse to have done too much work, nature having been overtasked, there is a want of life about the the animal, a listlessness and slackness, which tells its tale at the end of the race, when there is no energy remaining for a struggle against an opponent. We all know what it feels like to be "above oneself," and no one can do his best work unless he feels in the humour for it. It is the same with a horse when turning out for a race; and though he may warm up in the course of the contest, and his wellhardened muscles and good wind may bring him home if he has the best of the race, he certainly will not do the big thing a well-trained horse, full of nervous energy, can accomplish. Some horses go off their feed when given too much work, and it can never be to their advantage when such is the case. If an ordinarily hearty feeder does not clean out his manger the cause must be ascertained, and 


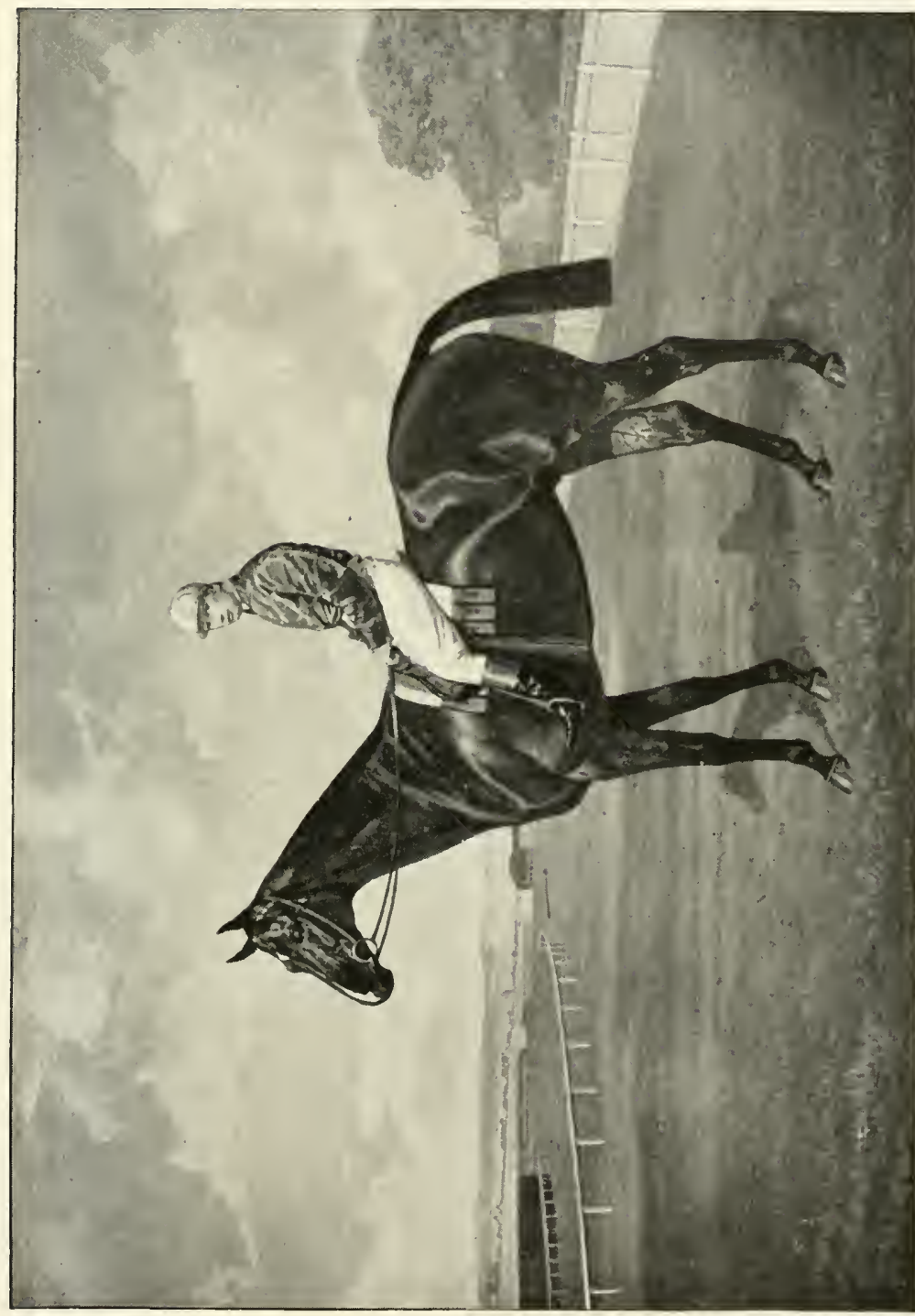

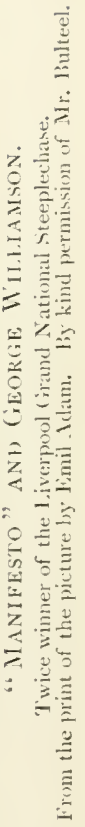



measures be adopted accordingly. A delicate feeder needs to be very closely watched, and light tasks should be given to it, though when it is asked to gallop it should generally be sent along at a very fast pace to keep the wind in order. The rest of its work should be rather that of an ordinary hack. I once had a horse, Baccarat, in training who whilst with me won the only mile and a quarter race he ever won, though a frequent winner at five and six furlongs, and he only had a fast gallop every third day, or he went off his feed at once. In my possession he showed better form than he had ever done before, and throve on his work instead of looking all skin and bone.

The best of food and water must of course be provided, for it is folly to attempt to train a horse and feed it upon inferior hay or oats, just because they happen to be on the spot. It is false economy to use anything but the very best provender, thus running the risk of upsetting the digestion. The measure of corn for each horse is what he can continue to consume with advantage to himself, and during the daytime the manger should be emptied of any corn left half an hour after the feed has been given. Any horse that has quickly finished up his allowance may then be given an additional double handful, and the capacity of each animal should soon be learned. Delicate feeders, which eat very little in the daytime, will often make up for it when all is quiet at night, and such should always be given a double feed at the last meal, which they will probably finish up to the last grain before the morning. A careful man who is a good feeder, quickly understanding the capacity and idiosyncrasy of each horse, is one of the most valuable assets a racing-stable can possess.

Some rock-salt should always be in the manger, or if there are local difficulties with regard to this, a tablespoonful of kitchen salt should be put into each bran mash. I have invariably given the horses two mashes a week with linseed gruel in them, as a rule on Wednesdays and Saturdays, and let them have easy exercise the morning after. It is more usual to give but one mash a week, but the proof of the pudding is in the eating; and as the horses are crammed 
with highly stimulating food the bran mashes are an excellent corrective, and prevent the beginning of many minor ailments. For the last fortnight or three weeks before a race a good handful of split beans or peas may be given each day, stopping them again as soon as the race is over, for if given always they lose their stimulating effect. There is nothing like a little change. When the beans are stopped a handful of lentils may be given instead, which are of assistance to young horses in providing much bonemaking material. Effort should be made to provide a little green food, whatever is in season, a handful of tares, young green corn, clover, dandelions, watercresses, chicory, and the green tops of celery all being excellent, besides carrots during the season for them. Only a small quantity should be given, the object not being to provide a meal but merely a little change, which is also cooling to the blood. The great thing is to follow the dictates of Nature, but also strictly to regulate them.

Another craving of a horse which has been long in the stable is for earth, and a little undoubtedly has an excellent effect upon the acid secretions of the stomach. If a horse has had none for a long time he will gnaw the turf at the first opportunity, and biting pieces off will champ them with the greatest satisfaction, raising his nose high in the air whilst he does so; and he prefers doing this to paying attention to the sweetest, most luscious grass, which will not be noticed till he has had his fill of earth. After a morning or two he will start grazing at once, for the small quantity of earth his system needs is then swallowed along with the herbage he picks up. When there is no opportunity of allowing the horse to graze for a minute or two, a substitute can be found by placing a lump of chalk in the manger; and I have known in Spain a native custom of putting a small quantity of chalk, obtained from the chemist, in a bran mash; or mixing it up into a mess like porridge, which the horses eat of their own accord.

Another custom of the Spanish farmers was to drive their horses down from the mountains to the vicinity of the seashore, when the warm weather began in the spring, and the 
droves of horses would rush into the sea and drink eagerly of the salt water. The natives considered this acted as a vermifuge, though no doubt it was the salt which was the attraction to the animals themselves. It is never safe to allow hor'ses to be stabled on sand from the sea-shore-as I have known done from motives of economy-since they are so apt to swallow it, for the sake of its saline properties.

Since 1872, when the late Mr. John Hubert Moore, the famous Irish trainer, first called my attention to the practice, all my horses in training have been ridden at once to a sheltered spot, as soon as ever they have finished their gallop on fine mornings, and then been allowed to graze for not more than five minutes by the watch; the boys jumping off their backs, and slipping the bits of the quiet ones under their chins during the few minutes of relaxation. The chief reason for the practice is the earth they thereby obtain.

The full development of muscle can only be obtained by plenty of work, continued over a long period of time; it is this which hardens it, and increases the volume, as witness the forearm of a blacksmith, or the muscles of the arms of an oarsman. It is impossible to develop the muscles with a short preparation, though the wind may be got right in a comparatively brief space by sharp gallops, if there is no accumulation of internal fat, which takes time to reduce. The system in vogue at the present day is very different to what it was thirty or forty years ago, but certainly the horses seen on race-courses appear to be no fitter than they were formerly, when longer work was in vogue; and personally I think they are frequently now less fit than they were then. Horses running throughout the season no doubt gradually run themselves fit, but even winners often seem to lather a good deal in these days, which shows that they are not up to concert pitch. Though a horse should sweat a little after a race-and if he does not do so it is probable he is overdone, and dried up-it should be clear sweat, with no appearance of lather. When the latter is present it may be noticed that the horse takes a longer time to cease blowing hard, and the animal is decidedly not up to the form it is capable of showing. 
In order to decide whether the muscles are properly developed, stock should be taken of their volume where they can most easily be seen, and this will be found to be in the arms and second thighs, where they are bunched together. If each muscle of the group stands well out, fully rounded in appearance, it may be concluded that enough long work has been done; and if the muscles of the quarters feel as hard as a board when lightly slapped with the palm of the hand, and the neck likewise is very firm when grasped, the muscular development is all that can be desired. But if the arms and second thighs have a rather flat appearance, with an undeveloped look, more long work is called for, though it need not be at a rapid pace. It is long work which puts on muscle, and sharp work which improves the wind. The skin should be very glossy, and feel as soft as silk, whilst it should be loose enough to be easily pinched up into a fold on either the neck, or ribs, by the finger and thumb. If it is tight and difficult to get hold of, the horse will never do himself justice in the race, and it shows that the digestion is not quite right, and that probably the animal is somewhat constipated. An extra bran mash, with a tablespoonful of sulphur in it, and a couple of the sulphate of magnesia powders in the drinking-water for the next two days, will probably improve matters, to be followed by a wineglassful of linseed oil mixed in a feed of oats for several days, until the skin becomes looser. It is a state of things which must not be allowed to continue, or all hope of bringing the animal out at the top of his form may be abandoned. In obstinate cases linseed tea to drink instead of water will almost certainly effect a cure before long. Flowers of sulphur is not nearly so much in use as it deserves, and a tablespoonful now and again in a bran-mash has an excellent effect in clearing the blood, and consequently the wind.

Frequently it may be noticed, after a horse has been a considerable time in work, that the fundament is beginning to sink inwards, and this is a sign of exhausted nature, a consequence of the whole of the fat of the intestines having been absorbed. It indicates more or less loss of form, and the only real remedy is a temporary rest. A wineglassful of 
linseed oil per diem may help matters, or linseed gruel, or linseed tea; but very gentle exercise for a month is urgently needed, or if the weather is fine, turning the animal out for a couple of hours daily into a paddock, bare of grass, for at least three weeks. What is required is, in the words of an old and most successful trainer, "To get juice into it again," and the animal will not return to its best form until this is done.

The droppings of each horse should always be left in the morning in a corner for the head lad or trainer to see, and not be removed until he has been his round, for much may be learned from them regarding the health of each horse. They should be in good-sized rather moist balls, with a glaze upon them, and the colour of gingerbread; but if so sloppy that they do not ball, or if in little, hard, very darkcoloured balls, the diet needs to be attended to at once.

A fortnight before the race the horse may probably need a tonic, and what is suitable will depend much upon the state of his skin. If there is a disposition to develop warbles, or a quantity of little pimples are seen-probably urtica (nettle-rash) - tonics for the moment are not required. Instead some sulphur in a handful of mash for a day or two, and sulphate of magnesia powders in the water should be given, and subsequently 30 drops a day of liquor arsenicalis. But if the skin is clean and silky the horse will benefit from the sulphate of iron powders, which have been mentioned earlier in this work.

The silkiness of the coat largely depends upon the thorough grooming of the horse, as explained under "Stable Management," and this should therefore be actively carried out morning and evening.

Formerly race-horses were sweated every fourth, fifth, or sixth day, wearing one or more rugs, and one or more hoods, as deemed requisite, the distance varying from three to four miles. The pace was very slow, and the day afterwards only walking exercise was done; and then on alternate days, after the usual canter, a mile, or thereabouts, was galloped at a fast pace, the same distance being done on the intervening days at a moderate rate of speed. Certainly 
the horses came to the post very fit to run, and very few bore the stigma of jadiness, which is now such a frequent attribute of the modern race-horse. Whether this is a consequence of the up-to-date methods of daily gallops over short distances it is difficult to say, but certainly the distaste for racing prevails to a considerable extent. William Day in "The Race-horse in Training" recommends that the animal should go steadily a short course for a week or two, until his condition enables him to go faster with ease; and then go the whole length of the course, whether it be a mile, two, three, or four miles, on alternate days at better speed, and the other days at half-speed, until it is as well and fit as may be. Since he was a very successful trainer, his methods must receive due respect, though few trainers nowadays would ever think of galloping a horse repeatedly four miles, however long the course might be over which it is going to run.

The new American plan is to give the horses two very slow canters daily in the morning, finishing up by doing the last quarter of a mile or so at racing pace; and once or twice a week, in the case of the more advanced, extending the quick part of the work to three-quarters of a mile, and at the most one and a quarter miles. But it is notorious that the Americans scarcely ever win a long race, though they win many short ones, and whether this is the effect of their system of training, or the fault of the material they train, it is impossible to say. The late William Day had, on the contrary, a great and well-deserved reputation for turning out the winners of long-distance races.

In my own experience I have never thought it advisable to gallop horses further than two miles when running on the flat, and three miles for steeplechasing-except perhaps once during the preparation, when the race was going to be four miles. But even when a horse is going to run over a very long distance he needs frequent sharpening up over a short distance, and certainly once or twice a week, after the preliminary canter, he should, towards the end of his preparation, gallop a mile nearly at top speed. The day after a horse has had a long gallop he needs little beyond 
walking exercise, only having a quiet canter or two at a slow pace, just to warm him up, and set the circulation going. A point, which is frequently not attended to, is that horses should always be trotted for a few minutes as soon as they come out of the stable, for this is a time when they are very likely to take cold, owing to the blood not being in full circulation. As soon as every minute vein is supplied to its full capacity, cold and blustering weather can be endured with impunity. When a horse is doing fast work he should not be required to go quite his full "distance," that is the distance which he is capable of doing at full speed. All horses, excepting those phenomenal animals to whom all distances seem alike, have a limit to their capacity, one being able to race for a mile, another for two miles, and others for not more than five or six furlongs, and it is the business of the trainer to find out what the distance is of each horse under his charge. If the distance of a horse is a mile, he should very seldom be allowed to gallop a full mile at speed in training, and never beyond it, except at a steady pace, so that the task, being well within the compass of his powers, does not become irksome to him. By continually being asked to do more than he is capable of doing easily his speed is quickly impaired, his dash destroyed, and in all probability he will turn cunning. Even for a long steeplechase of three, or indeed four miles, the animal does not need to exceed two miles very often, only occasionally going three miles, besides the smart mile work which has been already mentioned. When galloping in company care must be taken to assort horses, as nearly as may be, of similar capacity in speed and staying power, to prevent the risk of an inferior animal turning jady from always galloping in company with one which is much too good for it. The lads riding should never be allowed to push their horses in canters or gallops, and disobedience to orders should be severely punished. They should sit still and hold their horses, so that the belief may be instilled into them that the riders really wish to go a little more slowly-provided an animal is not a real slug in its work. 
If a horse exhibits signs of distress in its gallop, altering its stride, and beginning to sob in its breathing, it should be at once pulled up.

Now that all races on the flat are started by use of the "gate" it might be thought that the practice would be universal of so accustoming the animals to it they would take little notice of it; yet many trainers are averse to this, and allege that some horses take more and more dislike to it, the oftener they see it. Horses are full of whims, and what is sauce for the goose is not always sauce for the gander! But a very painstaking and successful trainer has kindly given me his views, and with most horses the plan he advocates should assuredly answer. He writes:-

"Jumping a horse off under the machine is exactly what should not be done. That makes them nervous and afraid to stand up to the machine. My plan is, and I have never found it fail, simply to walk the horses round the machine on the days they are not to do any galloping. Occasionally I pull up the machine and make them walk under it. Then when they are thoroughly familiar with the apparatus, which may take a few days, I line them up, and trot them off under it. After another few visits I canter them under, and so they gradually get to know what you want, and have no fear of it."

Another trainer, who has adopted the plan of allowing his horses to graze for a few minutes after their gallop, takes care to have them at once trotted to the machine and pulled up close to it, when the boys lead them all round, and under it, at intervals, whilst they are picking a few mouthfuls of grass; and the precaution is taken to change the position of the apparatus fairly often, that the horses may recognise it wherever placed, and connect the machine with the act of grazing. Care and trouble are never thrown away, and though success may not always be achieved, it can at any rate be deserved. A great disadvantage of our system of starting horses at a stand, drawn up in line, is that the quiet, docile horse, who will stand quietly while the others are fretting and refusing to come into their places, is at a disadvantage when the start takes place. Almost directly a horse 
stands still it begins to sink down on its fetlocks, and then a supreme effort is needed to lift the great weight of its body, and project it into motion ; and not only does it require more time to do so than do those who are "on their toes," but a considerable extra strain is thrown upon the muscles, sinews, and joints in addition. Undoubtedly the fractious horse has an advantage over the quiet one, when started from a state of rest, by being quicker into its stride, and at less exertion to itself.

At the commencement of training the work must be suited to the condition of the animal, and only short distances must be attempted at a very slow pace, both being gradually increased as the animal progresses in condition; and this is where the judgment of the trainer is required. A horse commencing training from ordinary hack work should have ten clear weeks before his race so as not to be hurried in his preparation. An animal who has been hunted during the beginning of the season, and is going to compete for a special steeplechase, or point-to-point, begins with hardened muscles and clear wind, and will require far less time to be at its best. For such six weeks should be allotted, during which there should be no hunting, except an occasional trot to a near meet, to raise the spirit of the horse by seeing the hounds again. This acts quite like a tonic to a hunter and relieves the monotony of the ordinary routine; but as soon as the hounds leave the first covert the horse should be brought back home, for the benefit desired will have been attained, and the extra fatigue is not desirable which might follow if the rider in his zeal rode after the pack. At the beginning of the six weeks' course it is well to let the horse go very easily for the first week, if he has been regularly taking his turn in the hunting-field, to recover from any staleness, and usually a mild dose of physic will clear his system and do considerable good. Following this plan I have won many races with my ordinary hunters, including the Conyngham Cup at Punchestown, and the Grand National Hunt Steeplechase, both of which were four miles.

As it may be of interest, the actual work done by the 
latter winner is appended, taken from my diary. I was then living at Scarborough, and the horses took their gallops on the sands when the frost was too severe to go elsewhere. When they practised over the steeplechase course the distance was about three miles, over a course laid out on the late Mr. James Darrell's low farm at Ayton, about four miles from Scarborough, so that merely going there and back was a journey of eight miles, in addition to the gallop. When we schooled over hurdles often only three or four were jumped, and then the horses were stopped and taken back to the commencement and the practice repeated, a group of hurdles being placed very near each other, with only about eighty yards between them. The object was to sharpen the horses up over fences after having been hunted; and in this the plan of Ben Land was followed, when he trained for Lord Paulett, the Lamb being then one of the string of steeplechasers.

Monkshood, 6 yrs.

By Uncas out of the Abbess by Confessor. (Winner of the Grand National Hunters' Race.)

\section{Diary of Work.}

Jan. 21, Friday.-Galloped $3 \frac{1}{4}$ miles on the sands.

The horse had been hunted since the beginning of the seasop, but in consequence of a hard frost had not been out with hounds for some time. He was given this gallop, and then allowed to have nothing but trotting exercise till the following week, when he was schooled over hurdles. Thinking he had not gained sufficient flesh he was given another week's trotting exercise, and then commenced training in earnest.

Jan. 25, Tuesday.-Schooled over hurdles.

Trotted daily for the following seven days.

Feb. 2, Wednesday.-Schooled over hurdles.

Feb. 3, Thursday.-Schooled over steeplechase course.

Feb. 4, Friday.-Walked and trotted for two hours.

Feb. 5, Saturday.-Galloped two miles on the race-course. Then schooled over hurdles at Ayton, and afterwards jumped two fences on the race-course.

Feb. 6, Sunday.-Galloped two miles on the race-course.

Feb. 7, Monday.-Galloped two miles on the race-course, and jumped two hurdles.

Feb. 8, Tuesday.-Cantered on the sands. 
Feb. 9, Wednesday.-Cantered two miles on the sands.

Feb. 10, Thursday.-Galloped six furlongs sharply twice on the sands.

Feb. 11, Friday.-Galloped two and a quarter miles on the sands.

Feb. 12, Saturday.-Galloped two and a quarter miles on the sands.

Feb. 13, Sunday.-Walked.

Feb. 14, Monday.-Went three times over the group of hurdles. Then galloped two and a half miles on the race-course.

Feb. 15, Tuesday.-Went twice over the hurdles. Then galloped two miles sharp on the race-course, Lady Clare joining Monkshood and Outlaw for the last quarter of a mile.

Feb. 16, Wednesday.-Trotted and walked.

(I had a bad fall the day before when hunting after the gallops had been finished, so could not get about for a few days.)

Feb. 17, Thursday.-Trotted and walked.

Feb. 18, Friday.- Schooled over the steeplechase course at Ayton.

Feb. 19, Saturday.-Galloped three miles over hurdles on the race-course.

Feb. 20, Sunday.-Walked.

Feh. 21, Monday.-Schooled over the steeplechase course at Ayton.

Feb. 22, Tuesday.-Trotted and walked.

Feb. 23, Wednesday.-Schooled over the steeplechase course at Ayton. Monkshood refused the regulation jump several times.

(Having broken a rib and dislocated the cartilage of the sternum on the left side, I was unable to ride Monkshood when schooling, as usual. He was always inclined to be shifty.)

Feb. 24, Thursday.-Trotted and walked.

Feb. 25, Friday.-Pinkney, the steeplechase rider, schooled Monkshood over the steeplechase course at Ayton. He refused the regulation jump the first time, but afterwards went well.

Feb. 26, Saturday.-Trotted and walked.

Feb. 27, Sunday.-Walking exercise.

Feb. 28, Monday.-Schooled over the steeplechase course at Ayton.

March 1, Tuesday.-Trotted and walked.

March 2, Wednesday.-Trotted and walked.

March 3, Thursday. - Trotted and walked.

Bransdale won the Hunter's Steeplechase at Malton easily, ridden by Pinkney.

Outlaw ran second to Wild Meadow, after missing a fence and having to go back.

March 4, Friday.-Bransdale ran second to Delandre, beaten a length.

Outlaw ran second to King John, beaten a length. His jockey rode a very peculiar race. IVhen leading at the bottom of the hill he stopped his horse and allowed himself to be passed some distance, saying afterwards in excuse he thought the horse was beaten. Then he set his horse goirg again, and caught the others so fast he was only beaten a length at last. I was afterwards informed he had a good win over King John.

Monkshood trotted and walked.

(I had only these three horses in training, and had nothing to lead Monkshood when the others were away.) 
March 5, Saturday.-Monkshood, led by some of the hunters, jumped two hurdles, and then galloped three and a half miles.

March 6, Sunday.-Trotted and walked.

March 7, Monday.-Tried Monkshood two and a half miles on the racecourse with Bransdale, Bob (a fast hunter who had run in Ireland) taking them along for the first half-mile.

Monkshood, 12 st. 3 lbs.

Bransdale, 11 st. 10 lbs.

Monkshood won by eight lengths.

March 8, Tuesday.-TValking exercise.

March 9, Wednesday.-Schooled over the steeplechase course at Ayton.

March 10, Thursday.-Walking exercise.

March 11, Friday.-Monkshood and Outlaw galloped four miles on the race-course.

March 12, Saturday.-Snowed all day.

March 13, Sunday.-Deep snow. Galloped on the sands.

March 14, Monday.-Monkshood left for Derby.

March 15, Tuesday.-Monkshood won the Grand National Hunters' Race, 4 miles, by ten lengths, 12 st. 10 lbs., ridden by Capt. E. R. Owen.

This was far from being what would be considered an orthodox preparation, but the details are set down to show the actual working of a stable when having to contend against weather in a very rigorous climate, besides the disadvantages of having only a very limited staff of skilled assistants and an extremely small stud of horses. I had had to break up my stable three years before for the second time, owing to prolonged malarial fever contracted on the West Coast of Africa in the Ashanti War, 1873-74, but being temporarily in better health, I was just recommencing to train again. But circumstances arose shortly afterwards which made me retire from active superintendence, and now if I occasionally have an animal in training I entrust it to the care of a professional trainer. This desultory way of doing things does not prove of much success, and most of the interest is gone when one can no longer train and ride the animals in their races.

It will be seen from the above diary that sometimes the horses were schooled several days together, and one week were galloped every day on the sands. The reason for this was that we took the opportunity of sending the horses along over jumps when there was some open weather, for the snows oft lie long and deep on the bleak north-eastern coast, 
and it was very possible, as happened the very year before, that the snow might have lain for many consecutive weeks, when there would never have been another opportunity of jumping the horses again before the big race. The sharp work on the sands was given during a hard frost to get the horses ready to take advantage of any open weather for jumping them, and therefore they were galloped several consecutive days to make up for the rather prolonged idle time they had been having, for it was found that they lathered more than was anticipated when they recommenced fast work. They were closely watched, and as they were improving in every way there was no hesitation about keeping them going, for there was plenty of time to ease them a little later on. Quite a different course would have been pursued if there had been a fair prospect of open weather before us. As it was, all the three horses came out in excellent condition, and after Monkshood's race Captain Owen stated to the writer that he thought he had never ridden a horse so thoroughly fit as Monkshood was that day, and that he could easily have galloped another round of the course had he been required to do so. Monkshood was subsequently sold to go to India to win a mile Cup race on the flat, which he did with ease.

It may be noticed from the diary that only twice was 3 miles exceeded in training, $3 \frac{1}{2}$ miles having been covered on the flat on March 5th, and 4 miles a week later, on March 11th. This was the last real gallop the horse had, four days before his race, for the gallop on March 13th was only a short, sharp one, to open his pipes. It has already been stated that 3 miles is quite sufficient to get a horse ready for any length of race, and when Frigate won the Liverpool Grand National, which is run over rather more than $4 \frac{1}{2}$ miles, her owner and trainer, Mr. M. Maher, told me she had only twice exceeded 3 miles in her preparation, having then galloped 4 miles. Moreover, she would not have been sent that distance a second time if he had not been unavoidably prevented from being present when the first 4-mile gallop was arranged, and therefore she was sent the same distance on a subsequent day in order that he might satisfy himself as to her condition. 
Unless a preparation has been so short that there is no time to be lost, a horse should always have three or four days clear between his last real gallop and the day of the race; but he needs a sharp gallop of about half a mile, one or two days before the race day, just to keep his wind right. $\mathrm{He}$ should then be full of nervous energy on the day he runs, and ready to put his heart into the race.

When horses have been very fit, and are then indulged with a complete rest, it is possible to have them ready to run in a very short time, for there has been no time to accumulate fat inside. Amongst instances that come into my mind was that of Rose Blush, by Commotion, who was bought by a very able trainer after winning the Trial Stakes at Southampton on July 16th. Being very poor in flesh, and dried up, her new trainer took her shoes off, turned her into a loose box for three weeks, and gave her plenty of grass. He then took her up again, and, after a few gallops, ran her in ten days' time from the recommencement of training at Plymouth, on August 25th, and after running third in the Tradesman's Plate of 1 mile, the same afternoon she won the Handicap Hurdle Race of $1 \frac{1}{2}$ miles. The next day she won the Plymouth Plate of 1 mile by a length; and on the same afternoon another Handicap Hurdle Race, $1 \frac{1}{2}$ miles, by a head. A fortnight afterwards she won the Borough Member's Handicap of $1 \frac{1}{4}$ miles at Tiverton, which ended her racing for the season. It was an extraordinarily daring instance of that trainer's pet theory of "getting juice into them."

I can give another instance out of my own stable. A horse of mine, Fortal, won a hurdle race at Droxford on April 25th, and then I put him out of training, riding him instead as a charger on parade. But one day I noticed that he was eligible to run for the Hurdle Race at Aldershot, then a coveted race, although there were only three weeks in which to get him ready. I therefore at once put him into work, and despite a field of eight which came to the post, seven of which were winners that season, we won the race by threequarters of a length. I could give other instances, but sufficient has been said to prove that a rest to a horse, when 
very fit, may prove of the greatest benefit to him. Not much subsequent work is needed to bring him out in excellent condition, but still the necessary hard work, and plenty of it, must have been done within a sufficiently recent period, the good effects of which have not had time to pass away.

Many a mare will again win races after having been awhile at the stud, sometimes indeed showing improved form, but in their cases a certain length of time is required in which to get them into racing trim. They must not be hurried. Perhaps the most notable instance was that of Mr. W. Elsey's Xenie, by Xenophon out of Griselle, in August, 1899. Not only was she eleven years old, but she had bred five foals, and was even then in an "interesting" condition, yet she contrived to win the Falmouth Welter Plate from six others at York Races, carrying the top weight, 9 st. $13 \mathrm{lbs}$., and giving a stone to the second; and she also carried off the Londesborough Plate a little later the same afternoon. These wins were but the precursors of others, and made a notable finish to the great deeds done on the historic course during the past century.

A beginner must have frequent schooling over fences to acquire a good style of jumping, for to a great extent steeplechases, and still more hurdle races, are won by quick jumping, by the animal that can race up to its fences and judge its distance well, and, above all, can get away quickly on the far side and be into its stride at once. Practice, constant practice, is needed until the horse has learned its lesson; and however well old practitioners may perform, they also need practice to harden and keep in order the jumping muscles. It is not necessary to jump many fences each time of schooling, nor full-sized ones, but they should be stiff enough not to allow any liberties being taken with them. Four or five fences are quite enough at a time, with as much variety as possible, but they must be properly made and properly placed. For the last half-dozen strides at least the ground should be perfectly level on the approach side of a fence, for if the horse has to begin making short strides on account of the unevenness of the ground, he is learning to be sticky instead of racing over the fences, and 
such schooling is worse than none at all. There is equal need to have the ground level on the far side of the fence for quite half a dozen strides, or the horse will seldom acquire the necessary dash. A steeplechase is a race over fences, and not a jumping match, and this is a point which seems to be often overlooked.

When hunting-men who have never had much to do with steeplechasing have the selecting of a point-to-point course, they are apt to be quite oblivious of ridge and furrow in the field to finish in, or gripes cut in it for surface drainage, or the landing side of a fence being lower than the take-off, especially towards the finish. They do not know what it is to ride a horse at full stretch, for though they may often think they are doing so in the hunting-field, a horse is never extended there beyond three-parts speed, and not often even that. At such a pace a horse can collect or extend his stride when meeting slight obstacles, but when really racing home at full stretch he has to blunder into them, and then there is a great danger of serious injury to the horse. If the landing is but 6 inches lower than the take off when racing home bad falls are often the result.

It is a mistake when schooling to keep on jumping horses over very big fences, for it is then worth their while to refuse; and also the lads riding are apt to turn nervous, and this is quickly communicated to the animal. If the fences are a fair height both horses and riders enjoy the fun, particularly if they do not get too much of it at one time. Every now and again a longer school can be taken, with one or two full-sized fences in the course of it ; but I am quite convinced that horses jump better, with more dash and nerve, if the fences are rather on the small side than if they are too big. A sure sign that a fence is too big is when the horses jump sideways at it, and this is a frequent cause of falls through the leader crossing the path of the horse which is following close behind.

When a colt is first being taught he should learn his first lessons over a low fixed bar or something similar, which he cannot knock down, and be led over it with a lunging rein, without any weight on his back. It is an excellent plan 
also to make an Irish bank with a ditch on one side, and to lead the young horses over it until they can change their feet on it in the right way, which gives them command over themselves, as a man learns when crossing stepping-stones. They should also be led over little gripes and blind places, which teaches them to look where they are going. They should be perfect in these lessons before they are asked to carry a rider over fences; and then they should at first be given plenty of time, and allowed to take the fences quite slowly before being asked to gallop over them. Animals so trained will always be able to "put in a little one" if they have misjudged their distance at a fence, and will seldom fall. A child needs to learn to walk before it can run.

Many horses at first appear to have little notion of jumping, and yet in the end make useful fencers. Occasionally a very mulish animal may be met with, which obstinately refuses to try to jump, or invariably endeavours to crash through the obstacle. Falls may even not suffice to educate the animal to do better. Before giving up the contest altogether in despair it is well to try the old dodge of the circus trainer, and keep the horse absolutely without water for two days. A fence made of railway sleepers, or strong boards, in a triangular shape, with a broad base, should then be fixed in a gateway, or similar place, where the horse cannot run round it, and a man placed with a bucket of water so that the horse can see it. The moment the horse catches sight of the water it will jump over any obstacle, to get to the bucket and slake its thirst. After the horse has had a few mouthfuls the man may take the bucket round to the other side of the fence, and the horse is compelled to jump it again, if it wishes to finish its draught. A lesson of this sort is long remembered, and frequently all further trouble is obviated thereby. It should ever be a maxim that when young horses are being taught to jump timber of any description it must be quite unbreakable, so that carelessness in jumping will be followed by a bad scramble, even if a fall is saved. But the timber should never be raised up high until the pupil has well learned its 
lesson, for a fall over high timber may be fraught with serious consequences.

When schooling horses, especially valuable ones, it is a wise plan to have them bandaged with thick bandages, which saves any blow on the fore sinews with the hind toe from being a serious injury. I often place a shield underneath the bandage, cut out of a thin felt saddle-cloth, and many a time I have been thankful this precaution had been taken. The shield should extend from just below the knee and cover the fetlock-joint. But I prefer bandages which buckle on with four or five straps, and these can be made of double serge, padded between with cotton-wool, and all sewn together in a diamond pattern. The straps need not be drawn tight, only just enough to prevent the bandage slipping down over the fetlock; but when bandages are tied on the strings have to be drawn very tight, and many a horse goes short in consequence and a swelling is raised under the ligature. Bandages which are sewn on obviate this, but then there is a temptation to keep them on in the stable on account of the time and trouble required when sewing them on. When a horse needs support they answer the purpose, especially when well padded with cotton-wool underneath. But in a small establishment where labour has to be considered the bandages with straps are far more convenient, and personally I like them better, although they do not appear nearly so neat.

When a horse first begins galloping after a long rest, in a few days' time all the legs are apt to get gummy and fill, and this is a sign that a dose of aloes is required. Indications of mischief to the tendons are when one leg alone fills and is hot, but when all the legs fill after exercise and get fine again when at work, it is merely a sign that a dose of physic is required. Except under such conditions I am averse to physic being given, and the practice of some trainers of giving strong doses of nitre or other diuretic, once or twice a week, is much to be condemned, for the kidneys cannot be frequently forced without bad results occurring in the end. If a horse has much difficulty in staling the placing of an onion inside the sheath, as already mentioned, almost 
always has an immediate result; but if the habit has become chronic an improvement can usually be effected by the free use of linseed-either as gruel, or as "tea" to drink instead of water-with plenty of green food (especially carrots or dandelion-leaves), and a tablespoonful of common salt in a handful of bran mash amidst a feed of corn. Salt and green food in combination promote a flow of urine much more beneficially than by using diuretics.

Gummy legs occur also in old horses from feeble circulation, and require more active treatment, such as being well hand-rubbed or massaged. When this is finished they should be well sponged twice a day with-

$$
\begin{array}{llllllll}
\operatorname{Alum} & \ldots & \ldots & \ldots & \ldots & \ldots & \ldots & 2 \mathrm{lbs} . \\
\operatorname{Soda} . . & \ldots & \ldots & \ldots & \ldots & \ldots & \ldots & 1 \mathrm{lb} .
\end{array}
$$

boiled in a gallon of water and applied cold. A serge bandage steeped in the mixture should then be rolled on, and a dry bandage placed over it. The same treatment should be used for windgalls in the fetlocks.

The last hint is the desirableness of allowing a horse to have a roll in the sand, which affords great enjoyment. A loose box can often be set apart for this purpose, and the sand does not need to be frequently renewed. When in Spain, now more than thirty years ago, we used to take off the saddles as soon as ever the work was over, and allow the horses to have a roll before they had a few minutes grazing, and it was amusing to watch the eagerness of the horses to be down, so that if the lads did not look out the animals were down on their knees before the former were out of the saddle. Anything which adds to the enjoyment of a horse tends to make him happy, and a contented animal thrives far better than one who is sulking or fretting. How natural it is to roll is easily seen by observing a horse when freshly turned loose, for after the first gallop round he is sure to lie down and enjoy a good roll to his heart's content. 


\section{CHAPTER XVI}

\section{DRIVING, RIDING, HUNTING, RACE-RIDING}

\section{Driving.}

FEW words may well be devoted to the harness. Brass
and plated mounts should be kept clean by rubbing with a woollen cloth or a chamois leather, and for the former lemon-juice may be used with a flannel to clean it on emergency, but for ordinary use nothing is better than Globe Polish. Whiting is required for silver-plated mounts, but not plate-powder if the harness is patent leather, lest it should burn or scratch it; and for all black leather, whether patent or ordinary, Harris's composition is quite excellent. Steel work should be thrown into a pail of water at once on being brought into the harness-room, to soften the mud and dirt, and should then be wiped dry and polished with a burnisher, any rust being removed at once with very soft and fine silver sand.

When buckling straps together, such as the end of the reins, the rule should be kept in mind that all buckles point to the right, the reason being that then the right hand pulls in the easiest direction for unbuckling the strap.

The stitching of the harness has an important bearing on its appearance, and the thread should be very regular, as will be seen in all high-class work.

The neck collar in the best work is always covered with patent leather on the outside, and the inside is stuffed with straw. A collar must fit the depressions on both shoulders, and neither be so narrow as to pinch the neck, nor so loose as to roll about. Either misfit will soon begin to gall and 
cause raw surfaces, if not at once attended to. On the outside of the collar is a roll, forming a recess to hold the hames to which the traces are attached. The hames help to preserve the shape of the collar, and also prevent it working outside the shoulder. The collar should be so fitted that the weight at the end of the trace is distributed over the whole surface of the shoulder, and to obtain this the trace must be attached to the right place on the hames, a point opposite the middle of the shoulder-blade, where this is practically immovable. If opposite a movable part, either at the shoulder-joint or the upper part of the blade, the collar is continually being pulled away from its bearing. A collar requires to be widest at its base, being there about an inch or an inch and a half wider than at any other part.

\section{The Bearing-Rein.}

The question of bearing-reins is oft discussed, and many well-intentioned but ill-informed persons believe them to be a relic of barbarism, and can see no good in them at all. If all horses had perfect mouths, perfect conformation, the most amiable dispositions, and docile tempers, bearingreins could be dispensed with, but taking horses as they come it is impossible to relegate all bearing-reins to the scrap-heap. It is the abuse of them which is to be condemned, and not the instruments themselves. They are seldom required in single harness; but to drive two or more horses together in safety, as well as comfort, bearingreins are frequently a necessity. There have been some alarming accidents this summer from horses running away, which in these days of terrifying road nuisances is scarcely to be wondered at! It would be interesting to know if in any of these cases bearing-reins had been dispensed with. Bearing-reins do not require to be so tightly fastened that the animals' heads are drawn back into an unnatural, constrained position, and so kept at a stretch for two or three hours, and such a proceeding is absolute cruelty. But they should be so adjusted that the wearer cannot get his head down low, and thus be able to throw all his weight into his 
bit, when he can run away fast enough to provide a sensational paragraph for the journals, if he has a mind to! Many a horse when standing still will hang his head as low as he can get it, and the judicious use of a bearing-rein will prevent this unseemly habit when out for show in a town, but without worrying the horse. The bearing-reins should be loose enough for the horse to make his utmost exertion when at work without unduly pressing on the bit, but they should be tight enough to take a good deal of the stress from the driver's hands if the animal begins to pull desperately hard, and shows a desire to run away.

It is against the gag bearing-rein that the crusade should be directed, for this can be made a veritable instrument of torture, and is very powerful. A gag bearing-rein is attached to the upper part of the head-stall, where it joins the brow-band, then passed through a swivel attached to a snaffle, which may be a twisted one, and after passing through another ring attached to a strap depending from the head-piece, is fixed to the pad-hook, where it can be tightened to the fancy of the coachman.

A bearing-rein should be fastened in the first instance direct to the snaffle if a double bridle is used, or to the cheek of a Pelham, and then much more freedom is allowed to the horse.

The bit should never have a bottom bar. If used without a bearing-rein a horse can hook it over a shaft in single harness, or over the pole in double harness, and an accident may be the immediate result.

Many horses have a one-sided mouth, which makes it difficult to steer them in traffic or to prevent them cutting a corner too sharp, and Mr. Walter Winans strongly advises the American Cain bit to be employed in such cases. He says :-

"I have found a remedy for horses with dead sides to their mouths, which are otherwise unpleasant, if not impossible to drive. It is the American Cain bit, a snaffle which pinches the horse's jaws and makes him drop it when he endeavours to pull on one side, much as one makes a dog let go a bone by pinching his lower jaw." 
$\mathrm{Mr}$. Winans is so expert in the management of horses that such testimony is a valuable hint.

The saddle carries the back-band, shaft-tugs, and bellyband; but neither it, nor the pad in double harness, must be permitted to press on the horse's spine.

The traces should take a slight rise from the bar to the hame-pull, and there is a loss of power if instead they incline downwards. If this is unavoidable, in the case of a small horse the evil can be diminished by lengthening the traces as far as possible.

Winkers are quite superfluous, but it is hard to resist fashion! Army horses are never driven in them, and no more are omnibus horses in the streets of London, yet neither of these classes meet with any undue share of accidents in consequence of the absence of blinkers.

\section{Double Harness.}

In adjusting the reins for double harness the hand-reins go to the outsides, the hand-rein on which the buckle is being always the near rein, and thus the buckle points to the right. 'The horses' heads should not be pulled either in or out, but be level, the horses running parallel to the pole. A young horse should always be started with the reins fastened to the cheek of the bit, and there should be plenty of length to the inside reins at first. These matters can be adjusted if necessary as soon as it is seen how the horses go.

When regulating the harness, first adjust the traces to the proper length, seeing that each horse is sufficiently far, but not too far away from the splinter-bar, when he is made to stand up into his collar as when in draught. Secondly, adjust the pole-straps. The pad must be placed just at the junction of the withers and the back, sufficient length being given to the croup-strap to enable it to do so; and the girth-strap should hang straight down when the horse is made to stand up into its collar, or if it inclines at all it should be backwards. 'The outer girthstrap should be quite loose to allow free play to the traces. 
In the arrangement of the coupling-reins lies the comfort and much of the art of driving. If one horse is free and the other sluggish, or if one is faster than the other, the one requires more holding than its comrade, to whom possibly the whip may have to be applied. It is necessary therefore that the reins should be so arranged that pressure is applied to the free and fast horse, whilst the mouth of the other is still untouched. This is accomplished by buckling the inner rein of the lively horse a hole or two nearer the driver's hand than that of the other, thus shortening the hold upon it. In this way the slow, sluggish horse may be forced to take up its fair share of the work.

When putting a pair of horses into harness, place the horses alongside the pole and then buckle the pole-pieces; they are thus fastened to the carriage, but cannot draw it if anything should suddenly startle them. Next attach the outside reins, and knotting them up, hang them over one of the pads. There is now a means of controlling the animals if needed. Then slip the traces over the roller bolts, and finally adjust the pole-straps to the right length, and buckle the coupling reins to the bits.

In taking the animals out of the carriage these processes are reversed, for the same reasoning, only the reins are unbuckled at the commencement, for the horses are likely to move away from the pole as soon as the traces are loosened, and if they are still held fast by the couplingreins they may get into a tangle.

First unbuckle the pole-straps, but do not unfasten them. Next undo the coupling-reins. Then remove the traces from the roller bolts and take the horses clear away from the carriage. If bearing-reins are used they should not be fastened to the pad-hooks until the horses are in their places alongside the carriage, and they should be unhitched before the horses are led away.

\section{The Driver's Seat.}

The height of the driver's seat should be proportioned to the length of his legs; it must be sufficiently high for him 
to be able to use all the power of his legs in holding hardpulling horses, or in stopping them suddenly, but it is a mistake to have it so high that he is almost standing bolt upright. Then if he receives a sudden jerk, such as is given when a horse falls, he is apt to be pulled off the box. On the other hand, if the seat is too low the driver feels cramped, and cannot exert his full strength. He should keep his legs straight before him, close together, with the feet turned slightly out, for nothing gives a greater impression of slovenliness than to see a coachman with legs wide apart, or with toes turned in ; whilst as for crossing one leg over the other it "gives the show away at once"! Apart from the unsightliness, it is at once evident that the driver has no idea how to apply his strength to the best advantage, and is at the mercy of his horses, and of luck! Any sudden call upon him will find him wanting in ability to cope with it.

The right hand should always be ready to catch hold of the off-rein, and when this is called for all the four fingers should be placed upon the rein, and not just one or two, which cannot provide for the full power of the arm.

\section{THE WhIP.}

The whip should be held loosely at the metal collar, which ought to be placed at the exact spot where the whip will balance in the hand without being grasped, merely being supported by the thumb and the outside edge of the palm, when the whole hand is at liberty to grasp the offrein at any moment. It should be held parallel to the dashboard, for it is bad form to hold it poking forward like a fishing-rod, detracting greatly from the smartness of the appearance. With a dogeart, or a carriage and pair, the thong may catch in the wheel if the whip is allowed to droop, and so get broken; and the proper position for it to be held is so that the stick slants across the body, just crossing the point of the left shoulder. With a four-inhand the coachman sits a long way above the wheel, and in addition the thong is curled in a "double thong," so there 
is no fear of becoming entangled in the wheel; the whip is therefore held low, almost horizontal in fact, but still parallel with the dashboard.

It should be an invariable rule to start the vehicle at a slow pace, which can be quickened immediately as much as desired. A lesson may be learned from the splendid drivers on the fast express trains, which glide off so smoothly that it is really difficult to know the actual moment of starting; whilst on some of the bye-lines one is almost jerked off one's seat, to the accompaniment of sundry groans and squeaks from the wheels, owing to the violence of the start from a state of rest.

\section{The Reins.}

There is often a considerable superfluity of rein, which gets entangled with the driver's feet or slips over the side of the carriage if allowed to remain at liberty; but if the driver just hangs the buckle end over the little finger of his left hand he will find he has conquered the difficulty, and will have no more trouble with it. In low-seated carriages, if care is not taken with the reins they are constantly getting under the tails of the steeds, especially when they have short docks; and nothing is more provocative of a bout of kicking and bolting than such an occurrence, particularly if the driver tries to unhitch the reins by dragging violently at them. The more he pulls the tighter the animal tucks down its tail, and the more it kicks and gallops; but if the driver can only keep his wits about him and at once lets down a long loop of the reins, their own weight causes them to slide down, and, feeling no resistance, the horse no longer tucks its tail in close. When long-tailed horses were in fashion for carriages - and the writer was thirty years old before he ever even saw a short-docked horse-it was very rare indeed to hear of a horse getting the reins under his tail, for the long tail down to the hocks never had sufficient sweep to rise over the reins. It is now often urged as a reason for docking horses short that it is done to prevent horses doing such a thing; but if those using this argument had only had sufficient experience, they would know that they were 
arguing on entirely wrong premises. In the Colonies, where long tails are the rule, the trick of getting reins under the tail is seldom heard of !

Horses liable to kick in harness should be driven with a kicking-strap, and in double harness may have long straps from the pad to the splinter bar connected by two crosspieces of leather, which will effectually prevent the animal from doing any harm. The colonial plan is to tie the long tail to the bar, which makes it an absolute impossibility for the animal to kick.

The colonists have another ingenions method for dealing with a jibber. The long tail is again called into requisition and tied securely to the splinter-bar, and then the vehicle is wheeled backwards until resistance is offered by the tail. On feeling the weight the animal plunges forward, and if it stops the same plan is again resorted to, and it is thus forced to drag the load some distance before the tail is released, when the culprit is usually ready to draw in the usual way.

If horses are required to canter or gallop in harness it is necessary that their strides should be of equal length, for if otherwise the carriage will sway so much there is great danger of its being overturned.

A little hint, which does not seem to occur to every one, is to draw up a carriage, when required to wait, so that the horses' heads are away from home, and then even fidgety horses may be induced to stand for a while. It is rather curious to note how often a coachman does just the reverse! He then blames the horses, which may be young or fresh, for not standing quietly when they know in which direction their stable lies, and are really displaying more sense than their driver!

\section{Riding and Hunting.}

The generation which was familiar with the top-booted squire, and the jolly old farmer riding to market, possibly with his wife behind him on a pillion, has almost passed away. The ranks of those who remember the stage-coach as the ordinary means of travel, and the gay-coated 
postilions in the chaises of the nobility and gentry, are getting very thinned. But those were the days when England was justly famous as a nation of horsemen; and now, like many a celebrity, we are living amongst the ashes of a past reputation. If a given number of persons of the younger generation were selected at random from any public gathering, say, a football match, a theatre, or a crowd assembled to gape at some public character, how many per thousand would be found who could ride even a docile horse ten miles? How many indeed would there be who had ever even been on a horse at all! We are no longer a nation of horsemen, and even the picked riders amongst us have now to take a back seat to those of foreign nations, who have lately come to Olympia to add to our national humiliation. Mechanical traction in all its various forms has taken away the necessity for riding, except in wild and mountainous districts; and has also destroyed the pleasure of an amble along our country roads and lanes. If it were not for the delights of the chase very few persons would now ride from year's end to year's end, for polo is of necessity confined to a comparatively small number of people. The various packs of hounds form assets of grave national importance, for if they were unfortunately squeezed out of existence through any modern legislation, few people indeed would ever take the trouble to learn to ride, and there would be but a scanty number of horses required to satisfy the wants of these few.

Riding, like everything else, is preferably learned in youth, and a child may with advantage begin its earliest lessons almost as soon as it can walk; for however much a horseman may know, he is ever learning something fresh about the animal, even to the end of his life. But the earliest lessons should be given by a careful instructor, who himself knows what the position and seat should be, and how the reins should be held and used, and who both can and will instruct the little pupil in all the minutiæ of the art of riding. It is at the begimning of a thing that the best teaching is required, for then faults are quickly corrected; there is nothing to unlearn afterwards, and a correct style 

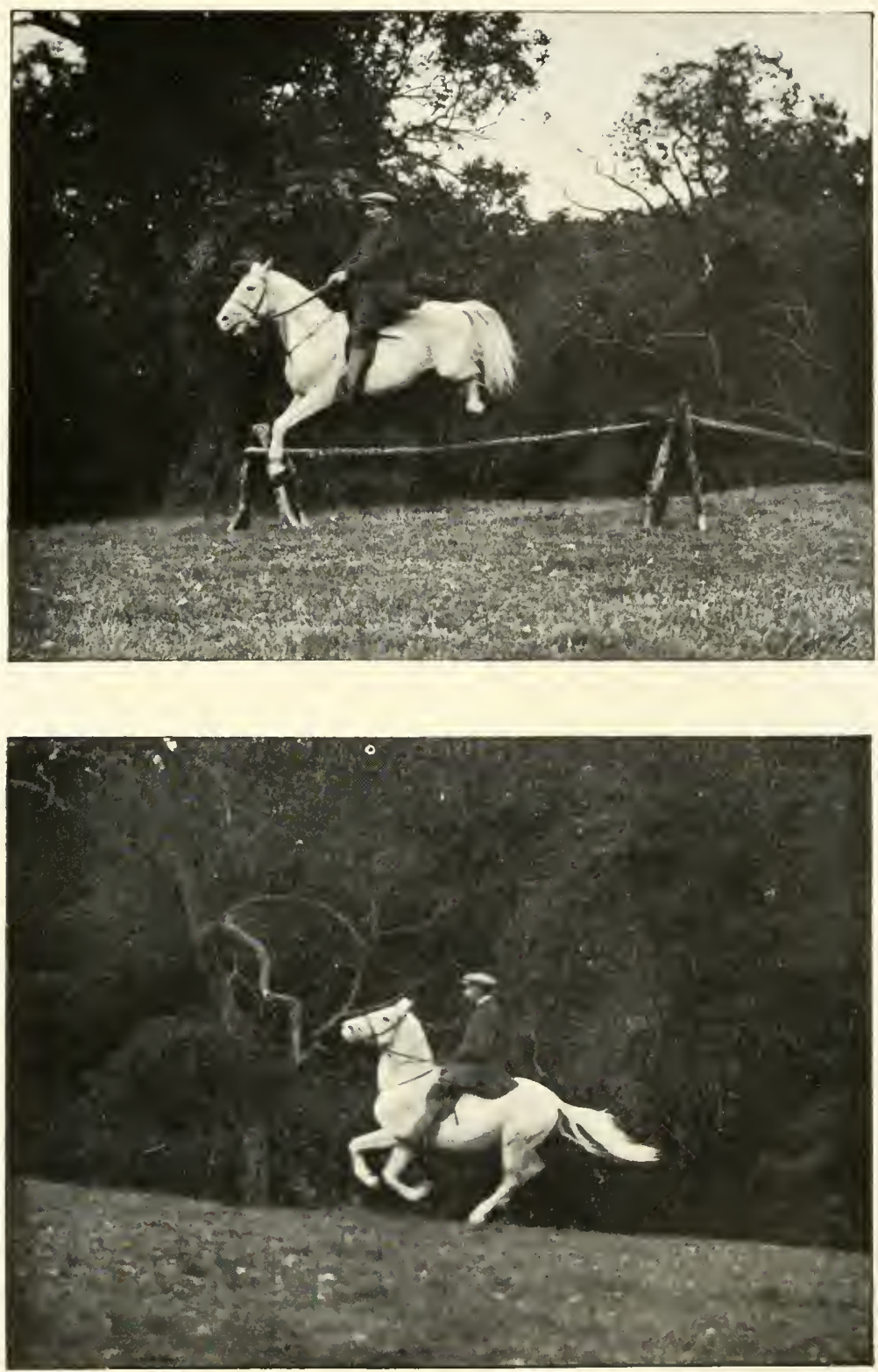

"CARnival.."

Fhoto by Hilkinson.

Owned by Admiral Sir F. Bridgeman, C.P., K.C.I.O. 

can be assured. How painfully badly most people ride is easily seen at the meet of any pack of hounds, or in Rotten Row itself. Through the innate goodness and long-suffering of their steeds many riders manage to get along somehow after hounds, but they are thrown high into the air at the leaps, as any photograph of hounds running will disclose; and most of them seem to think that the reins are intended to hold themselves on by. Those of the field who sit with grace and ease, and are really capable of teaching their animals their business, are very few indeed. Yet most of this indifferent horsemanship is the result of not having had, in their earliest years, the rudiments of riding imparted by a skilled instructor. Instead, they probably have been put upon a pony or horse, and left to find out everything for themselves. As to being taught the right length of the stirrups, the position of the feet and legs, or the length of the reins, the ordinary groom probably does not know himself-nor possibly the parents either-and therefore it is a matter of chance what kind of a beginning is made. The limbs of a child also grow quickly, and this is apt to be forgotten, and the stirrup-leathers are kept to the same length after they ought to have been dropped another hole.

A little boy must be put on a narrow pony, as a risk of grave and permanent injury is incurred if the pony's back is too broad. It is most advisable that there should be a frequent change of mounts, for after a time very slow improvement is made, when the sole experience is restricted to riding the same animal every time. But care should be taken that each pony is quiet, and without tricks, until the youthful rider has acquired complete confidence in himself; if he finds the pony is his master he is likely to lose all enjoyment in his ride, even if he does not take a positive dislike to the exercise itself. Should this occur-and in these days it seems to happen oftener with little boys than with their sisters-it is far better to fall in at once with the child's wishes, and let him defer riding until he wishes to try again on his own initiative. As he approaches adolescence he will probably have more confidence in his own powers, the spirit of rivalry will arise in him, and he will become envious of his 
acquaintances whom he sees enjoying what he is rejecting. If he has been well taught at the commencement he will be very differently situated to what he would be if he had never learned at all, for he will take up riding again where he left off; and in seat and hands he may soon even display superiority to those who have kept steadily on, but who have been allowed to pick up riding as best they could, and are sure to have acquired many little faults.

\section{STIRRUps.}

To most grooms it seems a never-ending puzzle that their master alters the length of his stirrups with almost every different horse he rides! He never dreams of doing so himself, unless he is a finished rider, which so few of the class ever seem to become. Fat horses or thin, narrow or broad, one length of the stirrup suffices for the groom, and therefore he does not attain accuracy of balance and perfect hands, although he may be able to retain his seat, regardless of plunges, and to steer an animal with the mouth of a bull.

One of the commonest faults of position is the thrusting of the feet too forward, which entails a defective balance, and a grotesque struggle to maintain it if the horse should suddenly rear-up straight on end, whip suddenly round, or, thrusting its head between its legs, indulge in a series of bucking antics. No horse-breaker, accustomed to the vagaries of bad-tempered and youthful animals, will be found to sit in such a position-and yet how often it will be seen amongst the riders in an ordinary hunting-field! The feet should be so drawn back that the ankles are under the knees, the grip being maintained by grasping the saddle with the prominent bony part of the inside of the knees, and then whatever the horse does the rider will sway with it, as if both were carved out of one block. The part between the upper calf and the knee will then take its full share of the work, and the saddle will be gripped as if in a vice. A considerable portion of the weight of the body should rest upon the thighs, and not, as is so often seen, entirely upon the buttocks. A fine rider should be able to place a sixpence 
between the stirrup-plate and the sole of his boot, and keep it there while jumping fences, or during any vagaries of his mount. Or if he is riding without stirrups let the sixpence be placed underneath the knee, and see if it is in its place after three or four fences have been jumped in succession. Many a rider who "fancies himself" will soon discover this test to be too high for his capabilities.

A rough-and-ready rule for the length of the stirrups is to place the bottom of the stirrup against the armpit, and then stretching the arm to the full extent just touch the saddlebar. If the stirrup-leathers are so adjusted before getting into the saddle no horse can throw a good rider, although, from the particular shape of the animal, the leathers may have to be altered a little afterwards, to ride in the greatest comfort and to the best advantage. When the rider has omitted this test and is already in the saddle, he should sit on his fork and allow his legs to hang to their fullest extent, and then shorten the leathers until the bottoms of the dangling stirrups barely touch his insteps. He will then find himself ready to cope with any antic the horse may indulge in. Very many riders are in the habit of riding a hole, or more, too long, when the weight is too much placed upon the fork, and a sudden shy or stumble on the part of the horse is only too apt to strain the "tailor's muscle," the painful and baleful effects of which are unfortunately only too well known. Should this happen it is possible still to manage to ride by procuring a very long soft leather strap, and after winding it two or three times round the thigh, buckle it round the waist. The relief this simple method affords can scarcely be appreciated until tried. Without some such support it may be found impossible to ride until the strain is quite recovered, perhaps only after some weeks of treatment. But almost the sole cause of the disaster is the riding with stirrups which are too long.

Whilst the legs should be rigid, when in the saddle, the body should be quite supple, swaying gracefully with every movement of the horse. The elbows must always be kept close to the sides, which adds greatly to the neatness of the appearance, and also to the power of the rider ; for the elbow 
must pass straight to the rear, the arm working backwards and forwards like a piston, when great force is required to be applied to the reins. If the elbows are stuck out at right angles there is loss of strength besides the awkward look, and ladies are frequently guilty of this. For a long time my masculine denseness did not furnish me with the reason why they affected this position, but at last one of them "let the cat out of the bag." "Look at — " she exclaimed, calling my attention, through jealousy, to a fair rival in front of us, "she is sticking out her elbows to call attention to her waist!" So the secret was out, and I have never since forgotten the reason why!

\section{Reins.}

Of course no one who aspires to be a real horseman will ride with both reins in one hand; though many make a sort of compromise, and keep possession of both reins in the left hand, whilst assisting with the right hand. But this is only doing things by halves, and as a rule the reins should be detached and held in the respective hands. The reins should be held at a good length and the hands be kept low, and as a rule the knuckles should be kept playing just over the pommel of the saddle. At this distance there is plenty of freedom for the horse to play with its bit, and yet considerable pressure can be put on in a moment if required; also a sudden snatch at the bit will not drag the rider out of his seat on to the horse's neck. It is excellent practice for forming a seat, when trotting home on a horse too tired to take liberties, to cross the stirrups over its neck, after taking the feet out of them, and to jog a mile or more riding by balance only, without holding by the reins. Another useful exercise is to let the body swing back until the shoulders touch the croup, when the horse is either standing still, or moving on slowly at a walk. The balance is improved by these little tricks, and the secret of all gymnastics is the perfection of balance, very little strength being required as a rule in addition. 


\section{Bits.}

When riding across country it is prudent to use as easy a bit as gives the necessary control over the horse. Many persons pin their faith to a plain double bridle, in which the generality of horses go pleasantly; but there is a bit which is an admirable invention, which seems to suit more horses -or possibly their riders' hands-than any other. Smooth snaffles are apt to induce horses to lean too much upon them if the man in the saddle is in the habit of steadying his balance by the reins; but this bit is more severe than an ordinary smaffle, though just as easy if a horse does not pull hard, so it lies with the animal itself whether it hurts its own mouth. Moreover, all horses jump freely into it, and there is no fear of pulling the steed into a ditch on the far side of a fence when using it. Horses are not irritated with it as they often are with a curb bridle; nor do they snatch at it, or throw their heads about when they are caught hold of to steady them at a fence. The great objection to chain and twisted snaffles is that they are always severe, but this bit combines the severity of a twisted snaffle with the ease of a plain one; and thus unites the merits of both. It consists of four smooth bars of steel, as if an ordinary snaftle had been sliced in half, with three large rollers inserted between each pair of bars, the whole constituting a "roller snaffle." When a horse is very headstrong, and determined not to stop, if the bit is drawn through his mouth from side to side all the rollers begin working, and few horses will continue to rebel under this treatment. When, however, the horse ceases pulling the bit becomes in effect a plain snaffle, and horses soon learn the easement of this.

Some horses acquire a trick of getting the tongue over the bit, when the rider is powerless to control his mount. Many inventions have been brought forward to obviate this, and one which is particularly successful when properly adjusted was the idea of the famous Allan Macdonough, as fine a horseman and steeplechase-rider as Ireland ever produced. It is detached from the reins, and is simply a plain bit with 
a high port, hanging loosely by itself. The object of it is to provide the animal with something to play with, so that by putting its tongue either through the high port, or over it, the animal feels contented, and leaves the real bit alone. For this purpose the bit should be hung very low in the mouth, only just above the tushes, with room above for the horse to get its tongue between it and the real bit, which being left alone acts as usual. Grooms are never satisfied to adhere to these directions. They always think they know better than the inventor, and so try to place the port as high as possible, even into the animal's throat. And then they say the invention is of no use, and that they knew from the first it would never do!

Occasionally a horse, when being led at exercise, acquires the trick of turning its head to the off-side, and making a rush at the same time, when no man can possibly retain control over the animal. The groom is forced to let go the leading-rein, or be dragged out of the saddle. To prevent the horse from putting this evil habit into execution, a means must be found of hindering it from turning its head; and a simple way of doing this is to fix a side-rein on the near-side, buckling it to the bit, and to the roller, the latter having a special buckle for the purpose, sewn on about half-way down. A man can hold a led-horse, so long, as its head is slightly bent towards him.

Stirrups should always be broad in the sole-plate, giving a good hold to the foot, and not tiring the rider. Then if the heels of the boots are brought well forward, ending in a line with the front of the leg, the top of the stirrup will always be kept clear of the tendon at the bend of the foot and leg, just above the upper spur-strap, which is otherwise apt to get very sore when the feet are thrust well home. The hoop of the stirrup should expand into a broad wing on each side where it joins the foot-plate, which saves the side of the foot from getting chafed. Stirrups must be wide enongh for the boot to enter easily, or there is a danger of getting the foot jammed in the stirrup in the event of a fall. On the other hand, they should not be too large for fear the foot should slip right through and so get fixed, though 
a large heel minimises this danger. The reins should not be narrow, for broad ones are easier to hold without getting the fingers cramped; and the leather should be supple, yet stiff. A horse should never be ridden without a nose-band, when only a snaffle is used, for if he chooses to open his mouth he can render the snaffle of little effect. Many grooms appear to think nose-bands are only for ornament, and buckle them far too loose to be of any service, but if the horse is only able to open his mouth a very little the nose-band will be of great use. Considerable additional power is gained by the use of a properly adjusted martingale, which is generally put on far too short, when there is a danger of pulling the horse into a fence. A short martingale may be all very well for a rearer, but it does not do for riding over a country. The right way is to hold the horse's head well up, and then so adjust the length of the martingale that the rings just reach the throat behind the angle of the jaws. This is short enough to give great power in steadying and controlling the animal, while it does not fidget or interfere with its comfort in any way.

Some horses have a habit of throwing back their heads so far that the rider receives a serious blow in the face. If the reins are merely passed through two leather-covered metal rings, fastened together and placed under the jaws, the head can be prevented from reaching the rider's face; but a preferable plan is to use a standing martingale, usually termed a "Cheshire Martingale," which terminates in two branching chains with spring-hooks, which are snapped on to the rings of the bit. This does not interfere with jumping, for a horse drops his head as the leap is made, but it effectually prevents any tossing of the head; and the first time the horse tries to do so he gets such a wrench to his mouth as much disconcerts him, and very often cures him of the habit altogether.

When galloping after hounds the rider should stand up in his stirrups, so that he can give-and-take to the swing of the horse as he passes over uneven ground. It adds greatly to the fatigue of the horse if the rider remains sitting down all the time. It is soon enough to sit down when a short 
distance from a fence; and then the body should be allowed to swing back as the horse rises, when, if exact time is kept with the movements of the horse, there is no shock on his back when he alights. A horse needs to be collected when approaching a high fence, but this does not mean pulling him altogether out of his stride! If a firm hold is taken about a hundred yards from the fence, and no change in the rider's mind is made from the place first selected, the horse will measure his distance and swing over the fence, and jump both high and wide. Fortunately, when taking our pleasure in an ordinary hunting-field, we are not expected to emulate the $7 \mathrm{ft} .3 \mathrm{in}$. that was jumped at the Olympia Show by All Fours in 1907, though this shows what it is possible for a horse to clear.

Xenophon's description of the proper carriage of the head and neck is as true now as when it was written, for it describes symmetry in a few words, and gives a good description of what a hunter should be like.

"The neck of the horse as it proceeds from the chest should not fall forward like that of the boar, but should grow upward like that of a cock, and should have an easy motion about the arch."

\section{Advice to Beginners.}

To the beginner a few words of advice may be added. Be on the alert when hounds are running in covert, and get away with them when they break; and if the scent seems good do not hesitate to jump a big fence to get to them, rather than go some distance to a gate. Give a wide berth to coverts on your way to the meet, lest you disturb a fox, and the hounds in consequence have a long draw before they find. Ride your own line if you are in front, but if you are obliged to follow any one else take care to give him plenty of room when he jumps a fence; his horse may blunder, or fall, and if you are too close you may cause a bad accident to your leader. If you view a fox hold up your hat if in sight of the field, and do not holloa when the hounds are rumning. If they should be at fault and there is no other 
means of letting the huntsman know, give but one holloa, and then wait and see if attention has been drawn to it. When you are able to tell the huntsman where the fox has gone, tell him in few words where you last saw it, in which direction it was going, and how long a time has elapsed since it passed by. Never jump an unnecessary fence, for you know not what calls you may have to make on the endulance of your steed before the end of the run ; and always keep some wind in your horse, and be careful of what you ride him at when getting blown. If hounds can jump a brook, so too can a horse ; and as a rule the fox crosses at the narrowest place. Choose a spot where the banks look sound for taking off, and if possible near a tree, for the ground is generally soundest there. Always wait for a man to mount who has jumped off to open a gate; and if you have opened a gate yourself, and some one is close behind, hold it a moment and give it a swing back that he may get through as well. Often the two or three seconds you lose in doing so are of gain to your horse if he is getting blown in a sharp gallop. Cross ridge and furrow at a slight angle, according to the stride of your horse; you will feel directly the difference in his going when he finds the dips and ridges agree with his action. It is better to select a big fence if the take-off is good, than a smaller one where it is bad. Always turn your horse's head towards hounds when the pack is passing you in the lane, and then you minimise the chance of one getting kicked. Hold your horse well by the head in deep ground, for with a slack rein he will soon be blown.

\section{RACE-RIDING.}

"Parce Puer stimulis et fortius utere loris" is advice as true to-day as when first uttered by Virgil. The words constitute the most ancient orders given to a jockey on record, and indeed are entitled to rank amongst the very best-especially in these days of "butcher-boy" jockeys, when race-riding is at a very low ebb indeed. Probably at no period of the history of the Turf have the riders been more utterly destitute of control over their steeds, and Virgil no 
doubt would have laughed them to scorn, and written some scathing lines, had he been able to observe the riding of to-day. The natural result is the constant occurrence of unintentional crossing and jostling so frequently complained of, and the many falls which have taken place during the last two decades; whilst grace of bearing, which is an invariable attribute of high skill in all athletic pursuits, is now only conspicuous by its absence.

Formerly it was quite a rare thing to hear of a horse falling on the flat-but then jockeys were able to guide their mounts, and could keep them from striking into the heels of their leaders, even in the middle of a crush of horses. But now it is quite different, and falls are frequent. The present fashionable absurd seat totally prevents the rider from utilising the powerful muscles of the back and legs (the same which are used in rowing), which the old school of jockeys employed with great success. They kept their horses to their stride in the early part of a race by putting their backs into it and bringing their weight into play, and held their horses with little exertion to themselves, or any fighting for their heads on the part of the steeds. With their weight thrown chiefly upon the lower part of the thighs, the inside of the knees, and the upper part of the calves, they could poise their balance with the utmost nicety, and give and take with the reins with great delicacy of handling. When such artists were seen in the saddle as Tom Challoner, George Fordham, Tom Cannon, Custance, Tom French, John Osborne, Jem Snowdon, and many others, a race was run smoothly all through, the horses gliding away at the start much as an express train starts from the platform under the guidance of a highly skilled driver. Although the horses were steadied they were into their stride at once, for their riders maintained their balance by grip, and not by holding on by the reins, and not an inch of ground was lost that the horse could stretch for. A photograph of one of the greatest races of a recent year reveals a very different start, and yet the riders are the best we can now produce! Only one jockey is sitting down on his horse and allowing it to strike off at once into its stride, 
and he, it may be mentioned, proved the ultimate winner. The rest of the riders are in the queerest of positions, most of them with daylight showing underneath them for the full length of their thighs, and one and all are holding so tight by the reins that the horses' jaws are wide open with the necks bent, while the laid-back ears betray the discomfort the animals are feeling. What would not any of the great jockeys of old have accomplished amongst such a crew !

It should always be kept in mind that a horse starts with only a given amount of energy in his frame, just as an accumulator is stored with electricity; and that any call made upon this energy, such as having to hold its rider in position by the mouth, is so much the less available for the struggle of the race. Also every inch lost in the fight for freedom when the rider is hanging on by the reins, which would otherwise have been gained with the same expenditure of force, is equal to carrying so much extra weight. A yard of ground is soon lost in this way, and that is the equivalent of about $1 \frac{1}{2} \mathrm{lbs}$. in weight. It is easy thus to lose many yards before the rider has got balanced, and the amount of weight so lost is often quite incalculable.

Tod Sloan introduced this present fashion, but then he was one of those talented, exceptional jockeys, who would have been certain to win races in whatever style he rode. Moreover, he had the luck to arive in England at a time when our jockeys were very moderate; though if he had only visited our shores some twenty years before he would soon have had to alter his style, or Fred Archer and George Fordham would have given him no chance whatever of holding his own with them.

Sloan formed a theory on what suited a bicycle, and sought thus to escape the pressure of the wind; and this is just the sort of catch-phrase the public delights in getting hold of, without following the matter up. Jockeys can crouch quite as low with the old seat, if they have a mind to, and there is any necessity for it, but this is only one single item in the delicate matter of riding a race. Balance, so adjusted that the weight is distributed to the greatest advantage, is equally important, and the burthen especially should not be all put 
in one place. Any one who has run a race at school with a comrade on his back, knows what a vast difference there is in carrying two persons of the same weight. One sits so lightly the motions of the limbs are scarcely impeded, and it is hardly noticed that he is on one's back; but the other allows all his weight to sag into one place, feeling as if he is so much lead, and soon tires his carrier. It must be the same with a horse, and it is common knowledge that it is more tiring to a horse to carry dead weight than a person who is as heavy, but a good rider. At the same time it is better for the horse to carry the dead weight than to have a bad rider put up. A great objection to the American seat is that the weight is all in one place, and cannot be distributed in the same way as before. Moreover, by the very forward seat, with the reins held close up to the horse's head, there is a great strain on the muscles of the neck, as the burden is imposed at the end of a long lever.

Tod Sloan overlooked the fact that a rider of a bicycle, when crouching down, still has the weight within the compass of the two wheels which support the frame; but a jockey stretched out upon the horse's neck, supporting himself to a great degree by the bit, is far beyond the limbs which support the body of the horse.

It is true that the American position takes the weight off the loins, so that the horse gallops with more freedom; but a first-class jockey in the old style, when standing up in his stirrups, and with some of his weight resting on his thighs, not only took his weight off the horse's loins but was so glued to the horse that he was carried by it as a part of itself, in a fashion no one can hope to emulate with the American seat. How many pounds this meant in favour of the former it is impossible to state, but it must certainly have been a good many.

Another difference between the effect of the forward seat on a bicycle and on a horse, is that the former being made of metal does not tire, however long the weight remains in one place. It is different, however, with a horse, whose muscles must feel the burden after a time, and the relief was great when a jockey sat down to finish his race, after 
standing up in his stirrups during the early stages of the contest, for the weight then came upon a different set of muscles. We all know what a relief it is after carrying a weight, like a pail of water, in one hand to change it into the other; the weight to be carried is just the same, but on the new muscles coming into play it seems as if it had been halved, and an extra exertion would be quite possible if suddenly called for. No doubt the horse feels this when his rider sits down on his back for the finish, but there is no such relief for him with the American seat.

When finishing in the old style much can be done by the jockey himself, if he can time himself exactly to fit the horse's stride, in propelling his own weight forward, and thus easing the horse. This can easily be tested by sitting in a wooden chair, facing the back, and then grasping it tightly with the knees endeavouring to move it on in a series of jumps. It will be found quite possible to move it a few inches, although the feet do not come in contact with the ground. The energy of Archer's finish was largely due to this, for, lapping his long legs round the horse, he got such a purchase as must have considerably lightened the horse's task. In this again the American seat can take no part.

If the American seat possesses the advantages claimed for it surely the times in which races are run should far surpass those of former days, and yet this is not the case. In spite of vastly improved racecourses, with turf like that of lawns, and straighter tracks, and all the money and care which is being bestowed in breeding the race-horse, the times in which races are lun remain very much the same. It may be indeed that the American seat is the cause of the non-improvement, since riders cannot now control their horses so well as formerly.

The supreme test of the average of races won, to races ridden, also betrays that there are no first-class jockeys now riding, though " amongst the blind a one-eyed man is king." The fatal craving for "getting the rails" which now yearly loses so many races, from the jockey getting shut in and unable to find an opening in time, is simply a consequence 
of the American seat, since the riders find they cannot hold their horses to an absolutely straight course, unless they can get alongside the rails as a guide. In former days nobody cared about the rails unless they offered the shortest way to the winning-post, which is the case on a circular course; but on a straight track Fordham, or Archer, or Tom Cannon would never have dreamt of losing one or two lengths in order to get the rails; and at Epsom Fordham never took them if he could help it, as he preferred the middle of the course, deeming it to be better going in wet weather.

Formerly no jockey was considered in the very front rank if he could not show an average of one win for every three rides, when spread over a long period; but no jockey now approaches this ideal, and thus the poverty of the land is shown. In other days several jockeys attained this average, even when they had others of their own calibre to compete against; if one such jockey should now come to the front he would have an easy task to maintain his position! During the thirteen consecutive years that Fred Archer was champion jockey, 1874-1886, he showed the remarkable average of almost $2 \frac{7}{8}$ wins for races ridden, the totals being winners 2609 , and races 7428 , and if an admirer of any of the present jockeys cares to compare the performances of his pet hero with the figures given below he will arrive at the respective merits of the two jockeys, if not of the different styles of riding :-

$\begin{array}{ccccccr}\text { Year. } & & & & & \text { Wins. } & \text { Races. } \\ 1874 & \ldots & \ldots & \ldots & \ldots & 147 & 530 \\ 1875 & \ldots & \ldots & \ldots & \ldots & 172 & 605 \\ 1876 & \ldots & \ldots & \ldots & \ldots & 207 & 662 \\ 1877 & \ldots & \ldots & \ldots & \ldots & 218 & 602 \\ 1878 & \ldots & \ldots & \ldots & \ldots & 229 & 619 \\ 1879 & \ldots & \ldots & \ldots & \ldots & 197 & 568 \\ 1850 & \ldots & \ldots & \ldots & \ldots & 120 & 362 \\ 1881 & \ldots & \ldots & \ldots & \ldots & 220 & 532 \\ 1882 & \ldots & \ldots & \ldots & \ldots & 210 & 560 \\ 1853 & \ldots & \ldots & \ldots & \ldots & 232 & 631 \\ 1884 & \ldots & \ldots & \ldots & \ldots & 241 & 577 \\ 1885 & \ldots & \ldots & \ldots & \ldots & 246 & 667 \\ 1886 & \ldots & \ldots & \ldots & \ldots & 170 & 513\end{array}$


On eight occasions Archer rode more than two hundred winners.

A point, which seems but little understood in these days, is what ought to be done when a companion is started to make running for another. The former is of course an inferior horse, and no matter what speed he goes he cannot get the other into trouble, who will always be going within himself, and therefore the horse for whom the running is made should lie close behind the leader's quarters. Unless a strong pace is required, a pace-maker would not be started on the mission; and a true pace can only be insured if the two horses go on together, for the rest of the competitors cannot allow one from whom danger is feared to go away in front, and therefore have to keep up with them. But what is very often seen is the pace-maker galloping on with a ten-lengths lead, or more, while the rest of the field follow at a more steady pace, with possibly the companion last of all. This is of no use to the latter! Except by the pacemaker, the race may be really run at a slow pace, the others simply waiting for the leader to come back to them when he has run himself out. But if the horse for whom running is made lies up with his pace-maker, and goes on in front the moment the leader begins to tire, the object of the pacemaker is fulfilled, and the race is run at a strong pace throughout.

A word may also be added with regard to riding trials. These should be run from start to finish at the best pace the horses are capable of, the object being to find out which is the best animal, and not for any particular horse to win. There is a great art in riding trials, and many jockeys fail in this, and it is very misleading to put them up. Some cannot be induced to make the most of their mounts all through the trial, for naturally every one likes to win, and by easing their mounts a little at first they can almost ensure riding the winner. Often stable-lads make good trial-riders, for their emulation is keen, and not having experience of riding races in public they do not endeavour to steady their mounts in the same degree as a professional jockey may be tempted to do. Many jockeys, however, are 
excellent trial-riders, and when this is the case their services are very valuable.

It is seldom sufficient to have only two horses in a trial, as then the pace is often not good. There should always be a pace-maker, and it is better to have two when possible. With four or five horses running in the trial a true pace should be ensured.

The introduction of the starting-gate has done much to equalise the chances of each horse at the start, though much still remains possible to be gained by the skill of the rider. Unless a horse is "on his toes" the moment the barrier is raised much extra exertion is needed to start into motion, for it is an axiom of motor mechanics that it requires double the force to move a mass from a state of rest, than to propel it when in motion. Formerly there were various little dodges to gain an advantage at the start, and my mentor, the late Sam Adams, so well known in connection with the tampering of the scales after he had won the Cambridgeshire, on Catch-'em-Alive in 1863, and who also rode Lozenge in the dead-heat with Wolsey for the same race in 1867, and was on his back again in the run-off, when he won, took infinite pains with my education in that respect, the fruits of which were afterwards reaped in many a race. Archer was wonderfully good in this respect, and having gained the start, which he almost invariably did, allowed his horse to stride out for the first two or three hundred yards, before he drew it back to a steadier pace. In his day there was none of that loitering in the earlier stages of a race which became so prominent a feature just prior to the advent of Tod Sloan. Nowadays time is lost in the efforts of the riders to maintain their balance at the start, and too often a grotesque exhibition is seen.

After getting off well, and settled into a place, the jockey must keep every faculty at its fullest stretch, to take advantage of every phase of the race, if he is not tied down with special orders. Very often there are only one or two animals he fears, and if he sees one of these in a momentary difficulty he should instantly force the pace, to take the fullest advantage of the mishap to the other. It may be a 
slight slip or a changing of its legs, or a cannon from another horse, any of which occurrences will cause it to lose from half a length to two or three lengths, if no time is given to allow it to steady itself and again get into its stride. Corners of race-courses are now so eased off that they do not have so much effect as formerly; but no horse can go at its best pace round a corner if it happens to be leading with the onter fore-leg, and if it is noted that a dangerous competitor is going round on the wrong leg a rival jockey should force the pace to its utmost, when the other must lose two or three lengths in consequence. Sometimes a jockey will commit the fatal error of trying to come up alongside another while actually on the turn, when, if there is no danger of another getting up on the inside in the meantime, the leading jockey can allow the other to creep up to his horse's neck, and then, pulling the outer rein, is able to shoulder his competitor across the course for two or three strides without actually touching the horse; quickly straightening his own horse again he will gain from the other about a couple of lengths, for it is impossible for the outer jockey to straighten his mount until the inner one allows him to do so, or so quickly as the other. It requires a nicety of judgment on the part of the inner jockey, for if he does not allow the other horse to get alongside far enough, or lets him get too far up, he cannot in either case put the manœuvre into practice. Whenever such an advantage is gained it must be made the most of, and the horse urged almost to its best pace, only a slight hold being still kept upon the reins.

When all goes well, and about three parts of the distance has been covered, and the jockey's mount is still going within his best pace, it is necessary to creep up alongside the leaders and find out whether it has the pace of them or not. If at once they increase their pace on being reached, and the horse can keep with them, it should be let out yet a little more, if possible, to see if it can get them stretched to the utmost; and if this can be done, whilst your horse has still a little in hand, keep it at the neck of the others, and conserve its powers for the final struggle. If, however, you 
find that your horse cannot keep its place without doing its very utmost, it is essential to remember whether it is a stayer or not. If it is known to be stout and honest, you can keep at it in hopes that the other horses will fail when also kept at their full stretch, and begin to tire, when you may be successful after all; but if your animal is speedy but a non-stayer, you must sit as still as possible, and steady it as much as you dare, to within a very few strides of the winning-post, and then endeavour to win by a single short rush.

There is no worse fault in a jockey than to contract a habit of lying away from his horses, when he has one under him with speed enough to live with them, and then try to make up twenty yards in the last hundred. This is practically turning the race into a very short sprint, and giving the others a start of twenty yards. The only time when a jockey can allow the others to get away in advance, if he also is riding a speedy animal, is at the beginning of a race when he perceives that the other jockeys are racing their horses at such a speed that it is impossible for them to keep it up to the very end; but this requires a jockey of the finest judgment of pace, and should only be put in force on special occasions.

Many jockeys, otherwise good, develop idiosyncrasies which become so fixed that, when noted by an observant first-class rider, a weapon is put into his hand which enables him frequently to steal a race that he would not otherwise win. In mentioning the following examples $I$ have in mind well-known jockeys of long ago, though ofttimes it would seem that their mantles have fallen upon riders of the present day! As an instance: "A " invariably makes the running if possible, and keeps the lead as long as he can; so that if it is believed that it will be a close thing between a horse which is fancied and "A's" mount, and it only can be ensured that "A's" horse is kept at the full stretch all the way, and is never allowed a pull, it will be much in favour of the other horse, who will therefore probably gain the race. This may be effected in two ways. Another horse may be started with the express purpose of racing against "A," whilst the 
Simon Pure of the stable lies a little back, watching his opportunity of tackling "A," the moment the mount of the latter shows symptoms of faltering. If this is skilfully done in all probability "A's" horse will be unable to resist the challenge of the rival, and will lose the race. Even if " $\dot{A}$ " has to be out-manœuvred single-handed the same tactics must be pursued, the rider of the other horse keeping sufficiently near to be able to go up at once and race against it, directly "A's" horse shows any signs of slackening its pace. If no opportunity is given for an "easy," even for a few strides, "A's" mount will be unable to keep up the - pressure, and will be beaten accordingly.

In another case " $\mathrm{B}$ " may have a habit of always keeping in the rear during the early part of a race, and then trying to win by a rush at the finish. $\mathrm{He}$ also can often be manœuvred out of the race. The rival jockey will go to the front at once, and, if the pace is poor, will take up the running, perhaps with a lead of two or three lengths, with the sole object of stopping the pace. If the other jockeys have waiting orders, or have not been told to see that there is a good pace, they will probably be content to keep their places behind till half the distance has been run; and if the leader is then on the alert, and immediately notes when the others-especially "B"-are increasing their speed to come up alongside him, and then instantly forces the running to the utmost, he turns the race into a sprint from that spot, with the advantage of several lengths start of "B."

Another example may be adduced of a jockey, "C," having a fancy for coming up on the rails, always trying to creep up alongside them when getting on terms with the leaders. By drawing away a little from the rails an appearance of an opening may be given, but the moment " $\mathrm{C}$ " is induced to make a rush for his favourite place the leader retakes his position on the rails, thus baulking " $\mathrm{C}$ " in his endeavour, when it is probably too late for him to draw back and come on the outside. Again the race may thus be won by an inferior horse, but an abler jockey.

"D," who has a trick of coming with a rush at the end instead of going up to the leaders in good time, 
may be trapped by steadying the leader, keeping him back to horses which are not feared, and leaving a small opening to tempt "D" to try to get through; but directly he tries his favourite game the fancied opening is closed up, and "D" appears in the report of the race as " not having been able to find an opening in time." Jockeys such as Fordham, Archer, 'T. Chaloner, Tom Cannon, and many others never failed to be in their proper places at the right time, and such mischances were scarcely ever recorded against them, however large the fields in which they rode.

In the manner of going round a turn, especially a sharp one such as is met with on country courses, ground can be easily gained, or lost. If a jockey races up to a turn at his horse's best pace the latter must perforce steady itself to get round, checking its stride to do so, and being shaken in its frame as well. It then has to get steam up again, and thus ground is necessarily lost. But if the jockey steadies his horse previous to approaching the corner the animal can swing round it with continually increasing velocity, and comes into the straight course beyond at the top of its speed. To do this, however, it is essential that the horse should be leading with the inside fore-leg, for if the outside one is leading the horse cannot retain its balance properly, and may even slip up, and fall, for it is obliged to lean considerably over when making the turn. The jockey should take note of which leg is leading before the turn is reached, and if it is the wrong one the horse may be induced to change by pulling the outside rein, thus forcing the head slightly to that side, while at the same time the jockey niggles with his spur on the same side, as far back as he can reach, which usually produces the desired result. An old horse, which knows the game, almost always changes to the proper leg, when necessary, of his own accord before the actual turn is reached.

Perhaps race-riding may be summed up with these remarks :-

Obtain a good start.

Do not race your horse off his legs at starting, but settle him into his stride as soon as possible. 
DRIVING, RIDING, HUNTING, RACE-RIDING 411

Perfect your balance.

Make your turns close.

When you have the lead, always keep something in hand for the finish.

Go up in good time to look for your race.

Utilise your horse's speed, or his staying powers, according to his abilities. 


\section{CHAPTER XVII}

\section{HORSE SHOWS AND REMOUNTS}

\section{Horse SHows.}

THe educational value that Horse Shows have afforded since their inception, well deserves recognition from the historian of the nineteenth century. They have set up a high standard, and shown breeders in out-of-the-way localities what they should aim at, and taught them what acknowledged experts consider to be the best articles of their class. They have also helped to place an increased value upon make and shape, and thus raised the general produce to a higher level. The classes for young stock should be the backbone of every Show of any pretension, for these give great encouragement to breeders to bring out the best of their produce, and also afford an opportunity to prospective purchasers to see the pick of the youngsters in the neighbourhood, at small cost and trouble. There is, too, a fresh crop each year of the respective ages amongst the youngsters, whilst this is often not the case with regard to the older horses, which are apt to make the rounds year after year with rather monotonous regularity. Such horses sometimes farm the various open prizes for quite a long period; and though it may add éclat to a Show that some famous prize-taker should grace its exhibition, local breeders are thereby discouraged from entering into competition with "the crack," and the question needs to be carefully considered and weighed, as to what course will benefit the district the most.

It is a very desirable thing to have a champion present, whom all may see and admire, but the regulations should be so compiled that the crack does not take an undue share of the 
prizes; and the object should be to cater for a multitude of owners, and send hoine as many happy and contented prizewinner's as possible, rather than that several competitions should be gained by the same animal. There is no greater stimulant than success, nor anything more dispiriting than continual defeat. It is better therefore to divide the prizemoney into many small sums, with several minor distinctions awarded to those who receive notice from the judge, and to vary the conditions in such a manner that if beaten in one class a win may be still possible in another, than to give more valuable but fewer prizes. Former winners may well be restricted to competition amongst themselves, with only one prize open to champions; and many classes should have local conditions attached to them, for the main object should be to encourage breeding in the district.

These remarks are of course intended to apply only to local Shows, which should be the feeders of the great ones, such as those at Islington and Richmond (Surrey), the Royal, the Great Yorkshire, and the world-famous Dublin Show.

None have been better or more judiciously managed than the last-mentioned, which has grown to its present height out of but small beginnings, for when located in Kildare Street there was but little scope for the competitors, and the funds were very low. The move to its present site was the making of its success. Its ample space gave an opportunity of seeing the animals to the best advantage, whilst the shrewd idea of making the jumping a chief feature by giving valuable prizes so as to attract good horses, and then to make people pay a second entrance fee to see them jump, soon provided the executive with large funds, enabling it to carry out its plans without fear of the cost. Other Stewards have grudgingly copied Dublin to a certain extent, but not having fully grasped the idea have added rather feeble jumping to their programmes; they have not gone whole-heartedly into the notion, and hence have not benefited themselves pecuniarily in consequence. They do not give sufficiently valuable prizes to attract good horses, nor do they provide such excellent fences as at Dublin, and as they feel that what they offer is but a poor 
performance they have not the temerity to make any charge for seeing it.

It is not an unusual plan to engage the services of a rough-rider to handle a horse at a Show, including the riding of it in a jumping competition, and so far no case has come into Court with regard to the liability of the owner, in case of an accident, under the Employer's Liability Act. Unless there was a special contract, binding the horsebreaker to the exclusive service of the owner for a given period, and a retainer paid accordingly, it would scarcely seem that the employer would be liable. If injury is caused to a third person, by his negligence when breaking a colt, the horse-breaker is liable for the damage and not the employer, although if the same damage was committed by a groom in the ordinary service of the employer, the latter would be responsible and not the groom. Also if a horsebreaker has improved the value of a horse under his care the law allows him a lien upon the animal, until he has been duly paid for his services. It would seem then that a horse-breaker riding in the Show-ring for a temporary period only would be held to be a professor, and free on his own account, and would not come under the category of a servant.

\section{JUDGES.}

The most important person in the Show-ring is undoubtedly the judge, for on his verdict may depend large sums of money, and the reputation of an animal to a certain extent. How difficult it is to find a competent judge only those know who have been in the ring with many who are constantly officiating. It is very seldom that one is met with who can take a horse to pieces, and having a thorough knowledge of each part of the anatomy can weigh up the good points and the defects, and balance them thoroughly in his mind. Numbers of judges take a very superficial glance at a horse, and will give a prize to an animal who looks showy at a little distance, but on closer inspection has some unpardonable fault. It is a pleasure to be in the ring with a real judge, but a penance 
to be there with an incompetent one; and the less he knows the more likely he is to be unconvinceable! Some judges have special fads, and the moment they see their favourite weakness they will look at nothing else. There are very few judges I have ever met whom I would ask to buy me a horse, from their inspection and without having seen it for myself, although I have had the pleasure of knowing one or two whose word I should take without the slightest hesitation. Certainly any mistakes made, particularly at the great Shows, are honest ones, and not from any ulterior motive; but it is to be feared that this is not always the case at small local Shows, where the judges are chosen from amongst the neighbours. An amusing and instructive instance of this occurred to me two years ago when out shooting with a friend in the West of England. A tenant of his had just won a third prize at a local Show, and as we passed his house I expressed a desire to see the animal, which the owner was delighted to bring out for our inspection. It was a very nice animal, and I complimented him on having bred such a good-looking one, and at the same time remarked that the two placed in front of it must have been very good indeed to have beaten it in their places. "Oh no," he replied, "this one is much the best;" and then added confidentially, "You see, sir, I am only a poor man, and I couldn't afford to give the judge more than five shillings, so I was bound to be beaten by they two." 'The curious part, to my mind, was that he seemed perfectly satisfied, and appeared to think that it was the ordinary way at Showsa comment indeed on the habits and customs of that part of the West!

When first I had the honour to officiate in the judgingring, more than thirty years ago, it was the usual practice to desire those who had no chance of being selected for a prize to leave the ring at once, and in the huge classes we had to adjudicate upon at Dublin it made the judge's task easier by quickly reducing the numbers, thus enabling the attention to be concentrated on the few who remained. It was soon recognised, however, to be an invidious thing to do, for it was not pleasant for those who were the earliest 
to be so conspicuously marked out for rejection. It is far better to select the best and put them in a batch for further inspection, and then send the others out in a body together. If the class is a very large one-and I have assisted to judge a class of 236 at Dublin-the most feasible plan is to divide it into large batches, and after selecting eight or ten from one batch, and a similar number from the others, to send away all the remainder, and have only twenty or so remaining from which to make a final selection. In this way nothing which is good is likely to get overlooked-which sometimes has been alleged to happen in a large class. It is a great pleasure to have as a co-judge a pleasant-mannered, good fellow, who knows the business; but with a rough, overbearing, rather ignorant person, it is very unpleasant at times.

Until I retired from judging I much preferred judging by myself, and bearing all praise or blame on my own shoulders, to running the risk of having to share the latter with another, at whose door it possibly chiefly lay. For ofttimes it is a case of judges differing, and then either a compromise must be effected, or a referee called in.

Many a horse at the minor Shows does not do itself justice in the ring for want of proper training beforehand, and will neither walk, trot, nor canter in a satisfactory manner. This is usually due to the excitement produced by the novel conditions; and care should be taken beforehand to accustom the animal to being amongst a crowd of strange horses and people, to hear bands play, and to disregard all kinds of strange noises. Agricultural horses especially should have a course of lessons at the walk, and trot, and be taught to stand squarely on their legs, for the best judges will have nothing to do with an animal who stands with its fore-legs and hind-legs stretched as far apart as possible, in the style so beloved by grooms of that class. It is then impossible to see if the hocks are properly placed under the body, or standing away from it; while the position tends to give a false impression of the body in general being too light. The groom in charge should learn the pace which his horse should not exceed at a walk, if he 
wants it to appear at its best, for whilst it should walk with plenty of vigour and fire many a Shire horse is apt to go wide behind, if forced beyond a certain speed.

In 1908 the Council of the Hackney Society passed an excellent rule respecting the shoes of exhibits, and laid down that no shoe for a horse exceeding 14 hands may be more than 2 lbs. in weight, whilst for ponies under that height the shoe must not exceed $1 \stackrel{1}{1}$ lbs. That such a rule should be necessary affords the adverse critics of the breed much food for reflection, with opportunity for drawing comparison between action for Show and for real work.

The mounting of the cavalry in any future war is likely to be a momentous affair, for the supply of suitable horses in the country is greatly depleted, on account of motor-traction having received such an overwhelming impetus since the Boer War was concluded. Moreover, the shortage of horses is likely annually to decrease, as the advent of the motor-car has practically killed the demand for a numerous class of horses suitable for 'buses, tramcars, posting, and general hamess-work, and when there is no demand the supply must fall off. In the past the omnibus horses formed a grand reserve to fall back upon, but this has now almost entirely gone. It does not pay breeders to breed especially for the Army at present prices; nor would the horses be forthcoming if the price was raised, for the numbers required annually in peace time are so very small that the demand is easily satisfied, and the surplus would be left on the breeder's hands. It is of no avail for the Govermment to register stallions and mares if the breeders find it does not pay them to produce foals.

According to the leaflet on "Types of Horses suitable for Remounts," published by the Board of Agriculture and Fisheries, the numbers of horses required by the War Office annually are approximately-

\begin{tabular}{|c|c|c|c|c|c|}
\hline Cavalry of the Line & ... & $\ldots$ & $\cdots$ & ... & 1,0 \\
\hline Royal Artillery & & & & & \\
\hline $\begin{array}{l}\text { Royal Lngineers } \\
\text { Army Service Corys }\end{array}$ & $\cdots$ & $\cdots$ & $\ldots$ & ... & 1,3 \\
\hline Wounted Infantry ... & ... & $\ldots$ & $\cdots$ & $\cdots$ & \\
\hline & T'ot.ul & $\ldots$ & $\cdots$ & $\cdots$ & \\
\hline
\end{tabular}


and in addition a small amount for the Household Cavalry. It will be seen, therefore, that the number required cannot possibly be an inducement for many breeders to take up the industry of breeding troopers. Under present conditions the only horses that will probably pay for breeding in the future in the British Isles are hunters, race-horses, poloponies, and agricultural horses, and the misfits from these will be more than sufficient to supply the wants of the Army in times of peace. Of these breeds hunters will probably very sensibly decline each year, for recent legislation is so crippling the landlords, and tenants, that those who are in a position to keep hunters are likely to become less and less so; and hunting will further droop through lack of subscriptions to the Hunt funds from the same cause. Small holdings, and barbed wire, are alike inimical to hunting. The former because of the tendency to reprisals when foxes take toll of poultry, or damage is sustained through the Hunt crossing the holding, which cannot always be duly compensatedespecially if funds are scarce; and the latter because it is cheap and handy. As the small-holder invariably cuts down all his trees as soon as he comes into possession, he has no supply of wood to mend his gaps, while he no longer has a landlord to fall back upon to supply his minor wants. Although the small-holders will probably soon disappear, hunting and shooting may in the meantime have so dwindled that it may be almost impossible to resuscitate them again. What has happened in the past will take place in the future. Under Free Trade no small-holder who has to make his living out of an ordinary agricultural holding can maintain himself during a cycle of bad seasons, and he is bound to go to the wall. In addition those who buy their holdings have to borrow the money to do so, and when the inevitable death occurs of the head of the family the crushing Death Duties will have to be paid, that are sapping the life-blood of England, and the lately purchased holding will again be thrown into the market, to meet the demands of the Chancellor of the Exchequer. All these changes must militate against the continuance of hunting, and hunter-breeding will suffer in consequence of the lack of demand for hunters. 
'The Germans have already grasped this fact, far-seeing as they are, and such a demand for Irish hunter mares and fillies for export has never been known as there has been this year, for it is fully recognised in Germany that in a short time there will be few mares to buy.

For mobilisation, including the Territorial force, 156,000 hor'ses are required, whilst the wastage would be immense, and at least three times as many horses in addition would be required within six months of war being declared. To meet this demand there are only 15,000 horses on the peace establishment, and some few thousands more registered-but these latter are only effective as transport and mounted infantry horses, and cannot be reckoned upon to take their places in the ranks of the cavalry, or the gun-teams of the artillery. Highly trained horses are necessary for both of these arms, and when Lord Haldane so light-heartedly reduced the artillery by batteries at a time, he surely never recognised how long it takes to thoroughly train a horse to be able to take any place in a gun-team which is required at the moment. Three years is the least period requisite for the horse, and seven year's for the artilleryman, to be made thoroughly effective, whilst a cavalry horse cannot be unanufactured under eight months, and even that is too limited a time in the majority of cases. I was adjutant of the Rifle Brigade for nine years, and always reckoned that it took three years to train a rifleman before he became thoroughly dependable, so that the times mentioned for the much more complicated cavalry and artillery branches of the service can easily be understood. At present we have but 7,000 trained cavalry horses, and these are not likely to be largely augmented by animals which have been used at the yeomanry trainings; for it is notorious that many of the horses are hired out for one training after another, and therefore the total of horses ridden in the ranlis each year is very different to what it may appear on paper.

The census of the horses already taken is rery misleading, as little or no distinction has been made between the animals, and brood-mares and aged pensioners have all been counted on. In my own case a mare thirty-three year's old was reckoned in the list of my horses. 
The question, then, is what should be done to provide an ample reserve in time of need, and the only possible answer is that the Government must provide it themselves.

The next question is how this should be carried out.

It would never answer for the War Office to attempt to breed troopers for themselves, for it would inevitably turn out a most costly failure if officers were appointed to superintend the breeding establishments. They have not the necessary experience; and as, moreover, especial gifts are required to be a successful breeder, the odds would be immense against any officer who possessed them being discovered and appointed to the post. Where the blind appoint the blind it is as difficult to avoid falling into the ditch as when the one is a leader of the other. The experience of the remodelling of the Remount Department after the late war is a sufficient case in point. When General Truman, the then Inspector-General of Remounts, was faced with the stupendous task of providing Remounts on a scale that had never been dreamed of by the War Office, and for which no preparations therefore had been made, and found the purchasers appointed unequal to the task, he took a wise step. He placed himself in communication with three retired officers, all of whom had judged for years at such great Shows as Islington, Dublin, Cork, Limerick, and elsewhere. One of them had been a Master of Foxhounds for many years; the second had conducted successfully a large thoroughbred stud farm (where he had bred a winner of the Oaks), and in addition had formed a famous stud of hunter stallions, and had shown a grasp of detail and business capacity which had insured success; whilst the third had been a prominent jockey in his day, besides training a considerable number of winners. If such experience was not equal to the job General Truman felt that at any rate he had done his best to secure efficiency, and knew not where else to seek it.

From the first he was constantly thwarted by higher powers, and the orders for purchasing were frequently changed as to height, ages, and other details without consulting him, which caused great confusion, and required 
considerable knowledge of men, especially of horsedealers, to get smoothed over without friction; but with the help of those he had selected, and of other officers subsequently appointed to purchase abroad and also at home, the task of keeping the Army in South Africa equipped with horses was accomplished.

The 'bus and tram horses, seasoned as they were and with muscles hardened from constant work, were invaluable for dragging big guns, and for transport in general ; and many of the ex-hunters and mountain ponies were in splendid condition for campaigning, though others proved too soft and required months of conditioning, which there was not always time to give them. With regard to the ponies rather an amusing incident occurred, which dwellers in the North will appreciate. At the beginning the orders were to purchase horses 15.3 to 16 hands, but, from having lived amongst the grouse moors from childhood, I felt sure that the animals found most suitable there would be the best for a mountainous country, and therefore urged with much force that a few galloways should be purchased as an experiment. A little correspondence took place, and then one morning a telegram was received: "What are Fell Galloways? Nobody here knows what you mean." The explanation was soon made, and happening to meet with two excellent specimens that day I wired to ask permission to purchase, and send them for inspection, and as soon as they arrived I received a telegram to purchase half a dozen more. Almost immediately afterwards another telegram arrived to buy fifty; and then yet another telegram to buy as many as possible, and in the end many hundreds were purchased and did extremely well. There is one little personal item I may perhaps be permitted to mention here, and that is the origin of the letters M.T. branded on the off fore-foot of many of the Remounts. Very early a batch of horses were sent to the Remount Depôt so unsuitable that the purchaser had to be sought and cautioned, and these were attributed to me. Feeling sure that a mistake had occurred I remonstrated, when we were ordered to come to the depôt to see the type required, and to take note of these unsuitable horses. When 
I arrived with my veterinary surgeon we were shown the rejected horses, and on looking at them we both at once declared that we had never seen them before, and, producing our books, were soon able to show that none of the markings corresponded with any we had purchased. We then passed on to the batch that were held up as the type required, when we instantly recognised the animals we had forwarded, and again producing our books triumphantly pointed out each animal, showing also from whom it had been bought, and the price paid for it. To obviate any similar mistakes being made in future-and such did occur more than once-I requested permission from the Inspector-General to have a private brand of my own, saying that I was quite willing to bear any blame on my shoulders which might be deserved, but that I did not want the faults of others to be fathered upon me. The request was readily granted, and henceforward every animal purchased by me was branded on the off fore-foot with the letters M.T., besides the War Office brand on the near fore-foot. At first the dealers were curious to inquire the reason why two brands were used, when the veterinary surgeon used delightedly to reply, "To show we are not ashamed of our purchases!" At various times I have had the pleasure of being told by men who had been out in South Africa how well some horse had carried them which was branded with the mysterious letters which they did not understand but which were always prized when seen. Another testimony to the value of the brand was supplied after the war, when some of the colonial troops were brought to England to share in the great review. My veterinary surgeon was attached to a body of them, and when he joined he found them loudly complaining of the quality of the horses which had been handed over to them. "WVe have picked out some of the best," they said, "which are down there, but the rest are brutes." A sudden thought crossed the mind of the veterinary surgeon, and he inquired, "Have the selected horses got any special mark on them, by any chance?" "Yes," was the answer, "they are nearly all branded M.T. Do you know the reason of it?" He soon enlightened them, and went at once to inspect them, 
recognising many of them; out of about 150 thus picked out some 120 bore the familiar brand, and he at once wrote to me to acquaint me with the incident.

We first commenced to purchase from the great dealers, and at the auctions and fairs; but we soon began to map the country into districts, and then advertised places where horses could be brought for inspection on a given day, by anybody who chose. I thus became acquainted with all the little dealers from Carlisle to Land's End, and also with the men, chiefly gipsies, who make a business of knowing all about every horse in their vicinity, getting, as a rule, a guinea for their information if a purchase is effected. I thus had the whole country covered with a network of workers, and when once the plan had been thoroughly started there was no difficulty in supplying any number of horses on the receipt of a telegram. For three years I was at work almost every day of the week, except Sundays, beginning at Carlisle, and working along the eastern portion of England, through Yorkshire, Lincolnshire, Norfolk, Suffolk, and Essex. I then visited some of the dealers and auctions in London, especially Tattersalls and Aldridge's; and then taking up the tale again at Taunton, proceeded down one coast of Somersetshire, Devonshire, and Cornwall, and returned by the other coast. This tour just took five weeks, and as soon as finished I returned at once to Carlisle to recommence the same route. The correspondence was necessarily immense, besides the keeping of the accounts and books, and, having no secretary, every letter had to be written by myself, and a copy kept of all the important ones. During the three years I inspected 12,614 horses, rejecting 6,189 , and purchasing 6,425 at a cost of $£ 239,617$; and I have in my books the colour, markings, and ages of almost every horse inspected, and the reason why it was rejected, if not purchased.

When going the round for the last time, and saying goodbye to those with whom friendly relations had been established, the remark was quite frequently made, "Oh, no! Not goodbye! You are sure to be round this way again!" But when I replied that there was practically no chance of this, for a new Inspector of Remounts would be 
appointed, and fresh buyers would be put in our places, the dealers were fairly lost in astonishment. "Do you nean to say," was said on more than one occasion, "that they will turn out you and Major Fife, after all the experience you have had? Why, you know the country better than any one in the trade, and they cannot possibly afford to lose you! If any firm was to conduct their business in such a way they would be ruined in no time!" But I answered that it was even so, that I was quite sure what the result would be -and I was quite right in my forecast.

Although a private firm would undoubtedly be ruined, if they were to send away their purchasing travellers after three years of making a district, to start again with entirely new employés, thus losing all the advantages of ties formed and carefully acquired local knowledge, the War Office gaily disregard any such business-like ideas! In my case, no sooner was it certain that I should be no longer required by my own Government than a far-seeing foreign one at once began negotiations, to secure my services and utilise my experience in buying Remounts for them.

Now the point I wish to make is that if the War Office pursues a policy of constantly changing their buyers, though they may have gained great experience and served them well, and replaces them with untried men without any special training for the post, what likelihood is there of suitable officers being discovered, appointed to, and retained in such a difficult post as the management and direction of breeding establishments require? Too probably it would finally result in a small proportion of foals being born, and a still smaller proportion of these becoming fit for Remounts at the age of three, or four years old. At any rate, under the system of purchase there is something to be shown for the money expended, whereas under an attempt to breed instead there may be no produce whatever for a like amount of money expended.

If Government breeding establishments are out of the question, and private breeders are not willing to speculate in producing remounts, how can the requisite numbers be supplied and an adequate reserve be formed? 
The answer to this must be that the Government will have to purchase a very much larger amount of young troopers annually, and thus create a market which will soon induce a supply, for farmers are quick enough in taking up any branch of farming which will pay. And in order to create sufficient vacancies in the ranlis to absorb the extra amount of horses annually purchased, and at the same time to create a reliable reserve in a time of need, all the horses should be passed out of the ranks after serving about three years and lent to private persons, on condition of their being forthcoming on notice being given. A small annual sum might be charged for the use of the animals, if not objected to, and the animals should be registered and inspected at stated periods by ofticers appointed by the Remount Department, who would keep an up-to-date census of those ready for service; and amongst other regulations one might profitably be inserted by which the horse would become the property of the owner after a specified number of years, thus insuring that all the Government horses were of a reasonable age for work. In this way a very large reserve of trained horses could be built up, at very small cost to the country at large. Under certain conditions a proportion of the mares might be allowed to be bred from, but these while in foal would need to be deducted from. the total of those available for immediate service. The foals themselves should be the property of the Government until three years old, and then be inspected by the district officer, and if thought suitable taken into possession at a fixed price, but if rejected shonld then belong to the breeder, to be disposed of as he thinks fit.

It would give a stimulus to breeding if remounts were purchased by the Government at three years old instead of four years, and foreign Governments already make their purchases at this age.

It would be a further inducement to breed foals if no mare might be exported under the age of five years, for then the fillies would be bred from at three years old; and after the foal was weaned, when the mare would be four years old, she would be fit for any description of work the 
following year, and have suffered no detriment whatever from having been put to the stud.

The General Conditions applicable to Army Remounts, as published in the leaflet issued by the Board of Agriculture and Fisheries, are as follows:-

Age.-The limits of age for horses entering the Army as Remounts in time of peace are between 4 and 7 years, and in time of war from 6 to 12 years.

Colour.-Whites and greys are only required for special purposes, and are always specially ordered. Very light or washy-coloured horses not accepted.

Soundness.-Entire, unmanageable, or vicious horses, crib-biters, windsuckers, parrot-mouthed or under-shot horses, or horses with capped elbows, damaged knees, injured or deficient teeth, are not admissible.

Horses with short docks are not accepted.

Soundness in eyes, wind, and limb is essential; no animals with worn, upright, or over-shot joints, and none with curby hocks, are passed.

There are no specified dates for the assembling and inspecting of horses. The Inspecting Officer of the Remount Staff is the final authority to decide on the purchase or rejection of any animal.

\section{Types of Horses Requived.}

The horses required for remount purposes may be divided into five fairly distinct types :-

Household Cavalry.-Horses for the Household Regiments must. be well bred and at the same time able to carry weight. Their work being chiefly escort duty in London, a certain amount of action is necessary, and they must be good-looking animals. The price paid for these horses is considerably higher than that paid for the ordinary trooper.

The colour required is black, and height at 4 years 15.3 hands, and at 5 years 16 hands.

Cavalry of the Line.-The class required is a deep, short-legged, shortbacked, good barrelled horse of the hunter stamp, with substance and quality, true action, and going without brushing the joints. Light, active, well-bred horses, that move truly and well in all their paces, well ribbed up, with plenty of bone and short backs, may be said to represent the cavalry type.

Height at 4 years $15.0 \frac{1}{2}$ to $15.2 \frac{1}{4}$ hands, over four years $15.1 \frac{1}{2}$ to $15.2 \frac{1}{2}$ hands.

The number of eavalry horses required annually in peace time is approximately 1,000 .

Royal Artillery.-The type required for the Artillery is the weightcarrying hunter, and as every horse, whether in the gun-team or 
not, should be capable of taking its place there on emergeney, the same type is preserved right through. For the Royal Horse Artillery an animal with a little more quality and pace is required than for the Field Artillery.

Height at 4 years 15.2 to 15.3 hands, and over 4 years $15.2 \frac{1}{2}$ to 16 hands.

Royfal Engineers and Army Service Corps.-Draught horses of the type known as the "Parcel Vanner" are required for these corps. They must be able to trot with a good load behind them, but they do not require so much pace as is needed in the Royal Artillery.

Mounted Infantry.- Mounted Infantry regiments are mounted on animals of the cob or galloway class; they require to be quick and active, and able to gallop fast for a short distance.

Height 14.2 to $15.0 \frac{1}{2}$ hands. Ages 5 years and over only.

The height taken is orer the standard for polo, so that there are plenty of animals of the stamp and quality required.

The number of horses required annually in peace for the Mounted Infantry is $\mathbf{1 4 0 .}$

THE END. 



\section{INDEX}

\section{1}

Abdallah, 137

Adams, Sam, 406

Accidents, responsibility for, 367

Alcohol, 333

when called for, 339

Aldby Park, 21, 23

Alders, Mr., 109

All Fours, 398

Allison, Mr. W., 45

Almonarch, 147

Almont, 133

Amanda, 139

Amaurosis, 345

American pacers, 148

Narragansett's, 148

l'acing Standard, 152

record-holders, 149

American Star, 139

American trotters, 112

action of, 135

breeding of, 144

bicycle sulky, 142

kite tracks, 142

length of limbs, 134

points of, 132

record-holders, 142

thoroughbred, influence on, 146

time records, 141

to breed, 128,137

trotting standard, 147

trotting wagons, 141

weight of shoes, 142

.merican Trotting Association, 147

Anchitherium, 6

Andalusia, 30

packhorses, 31

roaring unknown, 32

sires, 97

Andrew Jackson, 140

Angle-berries, 310

Antispasmodies, 282

Arabians, 10

as sires, 19

as a warhorse, 11,1 !

character of, 13

chief strains, 17

English judges, 12
Arabians, imported by Crusaders, 11 points of, 14

races at Wetherby, 10

Archer, Fred, 401, 403, 404, 406, 410

Arteries, 328

Ascetic, 87

Asil, 18

Astradam, Preface

Anchnafree, 45

Auction sales, 346

conditions, 347

Austria, Empress of, 81

b

Bandages, 257

Barbs, 26

breeds of, 28

Barcaldine, 25

Barker, Sir 'T., 101

Barley, 225, 227

green, 233

Barrow, Colonel, 19

Bavaria, King of, 108

Bayardo, 62

Beans, 226

Bear, R., 3

Bearing-leins, 383

Belkis, 18

Bellfounder, 137

Belmont, 254

Bennett, Mr., 34

Berners, Dame Juliana, 198

Bicarbonate of soda, 334

Biddell, Mr. Hermon, 127

Birds with teeth, 2,8

Birdcatcher, 87

Bits for driving, 384

riding, 395

roller-smattle, 395

tongue-bit, 396

blacklock, 42

Black Pilot, 112, 110

Black Warrior, 139

Blize, 109, 112

Blistering, 326

Blood-ressel breaking, 304

Blow on sinew, 32.5

Blunt, Lady Amme, Preface, 11, 17, 2.5 
Blunt, Mr. Wilfrid, 26

Bots, 307

Bot-Hy, 372

Boston Blue, 141

Boxes, 264, 268

Bran mash, 231, 277

Break-down, 325

Breaking, 202

long-rein tackle, 202

tying in a semicircle, 205

teaching to stand still, 208, 209

Breeding, antiseptic, 194, 198

artificial insemination, 197

building of cells, 186

colustrum, 195

cow's milk, 195

foaling, 193, 196

heredity, 182, 186

joint evil, 199

law of colour, 188

mammalian ovuu, 182

myconium, 195

navel string, 194

signs of foaling, 194

suitable soil, 192

teaching foal to suck, 195

weaning, 184

Bridgeman, Admiral Sir Francis, 29

Bridles, 262

Broad, Mr., 313

Broken wind, 2S8, 346

Brood mares, abortion, 198

barren, 197

in season, 193

maiden, 190

mating, 191

selection of, 190

twitch deprecated, 192

Bruce Lowe, Mr., 45, 61

Buckmaster, Mr., 99

Butson, Archdeacon, 79

Bush Farm, 84

Byerley, Capt., 23

Byerley 'Turk, 23

C

Camaltha, 130

Cambrian formation, 28

Canuon, T., 400, 404, 406, 410

Cano, 128

Carboniferous, 2, 8

Carbolic acid, 330

Carrots, 226

Carnival, 29

Carriage-horses, $10 \bar{\jmath}$

Cart-horses, 116 breeding, 117

bone of, 118

Cataract, 345

Catarrh, 281

Catch-'em-Alive, 406

Catfish, 2
Caverns, 6

Cave-dwellers, 4, 7, 9

Cavesson, 202

Celery, 232, 233

Challoner, T., 400, 410

Chariberta, 83, 126

Charcoal, 331

Charlier shoes, 237

Chicory, 232

Chinosol, 194, 199, 331

Chiquito, 147

Choking, 301

Churchill, Lord h., 338

Clark, Mr., 123

Clay, Henry, 140

Cleveland Bays, 105

Clothing, 256

tearing, 237

Clydesdale, 119

Coach-horse, Yorkshire, 106

Coke, Mr., 24

Common, 147

Condiment, Mawson's spice, 327

Condition, 270

Conformation -

Bones of skeleton, 153

cannow, 164

fore-leg, 154, 161

feet, $\mathbf{1 6 5}$

haunch, 161, 166

liead, 156;

hind-leg, 155, 166

hock, 167

knee, 163

ribs, 158

vertebræ, 158

Muscles of-

back, 171

fore-leg, 171

head and neck, 169

hind-quarters, 172

shoulder, 170

Tendons of -..

fore-leg, 174

hind-leg, 173

Cope, Professor, 3

Coln, 224

Corns, 313

Corona, 147

Corpora nigra, 345

Costiveness, 294

Crabbet Park, 25, 131

Cracked heels, 301

Creeping Jenny, 164

Cresceus, 142, 145

Cretaceous Age, 2, 3, 8

Crib-biting, 239

Crown Glass, 181

Dandelions, 233

Dan Patch, 149, 150 
Danegelt, 110

Darley, Miss Preface

Darley, Mr. T., letter of, 21

Darley Arabian, Preface, 21, 110

Dariel, 149, 150

Darrell, Mr. J , 372

Darrell, Mr. 'T., 83

Darwin celebration, 322

Davies, Mr., 361

Day, William, 368

Deinosaurus, 2, 8

Deodorants, 329

Devonian Age, 2, 8

Dexter, 149

Diarrhoea, 291

Diomed, 139

Diseases, compulsory notification, 328

Disinfectants, 329

Docking, evil of, 71,271

Donkey killing a borse, 192

Doping, 334

Doyle, Johnny, 42

Drainage, $26 \mathrm{~s}$

Dressing, 235

vicious hor'ses, 237

Dreadnought, 108

Driving, 386

cantering, 38?

driver's seat, 386

jibber's, 389

kicker's, 389

reins, 388

starting, 388

waiting, 389

the whip, 387

Dunn, Mr. Finlay, 333

Duroc, 139

\section{E}

Earth needed, 233, 364

Eastern sires, 97, 100

East, Messrs., 112, 113

Eberlein, Professor, 320, 3:1

Eclipse, 42, 137

Eczema, 298

Edos, 295

Elbow capped, 236

Electricity, 283

El Khamsa, 17

Ellermire, 79

Elridge, Mr., 141

Elsey, Mr. W.. 377

Emperor of Morocco, 23, 2.5

Empress of Anstria, 186

Enfield Doe, 84

Eocene period, 3, 4, 8

Eohippus, 3, 8

Ephesus, 80

Everitt, Mr., 361

Ewart, Professor Cosser, 5

Exercise, 270
Exercise, horse bolting, 396

Exostosis, 168, 318

Eyes

how to cover, 342

buck-eye, 345

examination of, 345

Eyre, Miss Alice, 82

$\mathrm{Mr}$. J., 82

F

Falmouth, Lord, 44

Farriers liegistration, 255

Feet-stopping, 236

Fever, 278

Figure system, 46

Fireaway, 111, 137

Flora Temple, 141, 149

Fly, 143

Flying Childers, 109, 111, 137

Foals, treatment of, 183

early handling, 201

vermifuge, 186, 196

Food and work, 222

during digestion, 222

after hunting, 222,224

Forage, 220

memoranda, 274

Fordham, G., 400, 401, 404, 410

Fore-foot, how to hold up, 342

Formalin, 330

Fortal, 376

Freake, Mr., 100

French, 'Tom, 400

Freney, 42

Frigate, 375

Frog, the, 242, 246

Frost studs, 249

G

Galway Blazers, 79

Galvayne, Mr. S., 205, 207

Gametes Cell, 187

Ganoid fish, 2

Ganymede, 109

Gates, Irish, 66

Genet, the, 29

George Wilkes, 149

Gilbey, Sir Walter, 101

Gilmore, Captain Parker, :?

Gimcrack, lines from, 139

Girths, 260

Give and Take Plates, 103

Glacial Age, 4

Glanders, 340

Gobi Desert, 4

Godolphin Arabian, 23

Goldsmith Maid, 128, 142, 149

Good gallops, 78

Gordon, 86, 87

Gosudar, 147 
Grand Bashaw, 140

Green food, 232

Grey Dioned, 139

Grooming, 241

Grosvenor, Lord, 131

Grosvenor, Hon. A., 82

\section{$\mathrm{H}$}

Hackneys, 97, 98 origin of, 109

Hadramaut, 18, 130, 131

Hagar, 18, 131

Halfa, 18

Hall, Mr. H., 83

Halter-breakers, 207

Hambletonian, 135, 137, 143, 146

Hamilton, Duke of, 120,127

Halness, 381

adjustingr, 385

coupling reins, 386

putting hor'ses to, 386

Hart, $\mathrm{Mr}^{\circ}, 111$

Hawley, Sir J., 101

Hay, 227

clover, 230

hay-making, 2229

haystack to estimate, 274

herbage, 228

oat-hay, 230

over-sweated, 230

time to cut, 229

Haymaker, 70

Heat as a germicicle, sื30

Health indications, 277

Heeis must be dried, 242 cracked, 301

Heinshon, Mr., 141

Helm, Mr. H. T., 125, 129, 131, 132, 135,136

Heredity, 186

Hermit, 87, 320

Hetman Platoff, 37

Highflyer imp. , 139

Highland Maid, 149

Hipparion, $4,6,8,26$

Hippopotauus, 8

Hobgoblin, 24

Hocks capped, 236

Hogging evil of, 76 origin of, 112

Holmes, Mr. G., 108

Hoots, 176,311

ointment, 317

rings in, 317

Horace, 9

Horse, four-toed, 4, 5 chestnuts of, 181

ergots of, 181

early colour, 5

horned, 181

hollow depression, j
Horse, how to measure bone, 180 points of, 177

sinistral, 188

used for food, 7

Hor'se Shows, value of, 412

employer's liability, 414

exhibits should be educated, 416

judges, 414

jumping at, 414

prizes, 412

Hospodar, 80

Hunters, 65

action, 69

character, 71

conformation, 71

essential qualities, 67

points of, 90

pony-cross, 89

speed necessary, 77

types of, 65

well-bred, 88

Hunting, advice to beginners, 398 cost of, 91

how to gallop, 397

how to jump, 398

Hutchinson, Sir J., 188

Hutton, Colonel G., 18

\section{I}

Icthyosaurus, 2, 8

Illness, 277

Inbreeding, 198

Indigestion, 290

Inflammation of the bowels, 293

of the eye, 304

of the liver, 294

of the lungs, 286

of the pleura, 287

Intestines, 293

Iodoform, 323

Iron, 231

Ivooschick, Preface

\section{J}

Jay-eye-sec, 141, 149

John o' Gaunt, 63

Johnstone, Hon. F., 83

Johnstone, Mr. J., 18

Johnston, Mr. 1R., 42

Joint Evil, 198

Jurassic Agc, 2, 8

Justin Morgan, line of, 140

K

Kama, Ii., Preface

Kaleidoscope, 232

Kars, 18

Kasan, Preface

Keller, Dr. Conrad, 112 
Kendal, Preface

Kerrison, Six E., 127

Ketcham, Mr, G. H., 143

Kettleholder, 79, 80

Keynsham stud, 101

Khirgiz, Preface

Kicking in stable, 238

King, the, 82

King of Trumps, 80

King William, 108

Kingston, 80

Kittiwake, 84

Ḱnees broken, 323

Knightly, Sir C., 44

Knocking with forefoot, 238

\section{L.}

Lackland, 131

Lady Bo Peep, 130

Lady Suffolk, 141

Lady 'Thorn, 128, 135, 141

La Flêche, 63

Lameness, how to judge, 342

Lamb, the, 372

Laminitis, 312,344

Lampas, 298

Land, Ben, 372

Land League, mischief caused by, 92

Landmark, 108

Landrake Races, 336

Lane-Fox, Mr. G., 91

Larynx, stripping of, 289

Lastic, Vicomte de, 7

Leeches, 219

Leeds, Duke of, 24

Legs not to be washed, 299

Lehndorff, Count, 35

Lemberg pedigree, 62

Lentils, 224

Libyan horses, 26

Light in stables, 266 artificial, 269

Lime, magnesian, 332 gas, 332

Lincolnshile black cart-horse, 117

Linde, Mr., 335

Liniment, 284, 325

Linseed gruel, 231

Lippasano horses, 28

Lou Dillon, 141, 142, 143, 144

Lozenge, 78, 406

Lurline, 337, 338

Luxford, Colonel G., 18

MI

MacDonough, Mr. Allan, 395

McGrane, Mr. WV., 337

Mackintosh, 112

Maclean Kaid, Sir Harry, Preface, 27

Maher, Mr. M., 375
Mail train, 130, 131

Maize, 225, 226, 227

Major Delmar, 14:, 144

Mallenders, 300

Mambrino, 129

proposed match, 131

portrait of, 138

descent of, 146

Chief, 128, 141, 146

Iammals, evolution of, 2, 3, 8

Manchuria, Preface

Mange, 308

Mangers, 267

Maple, Sir Blundell, 147

Markham Gervase, 37

Martingales, 387

Marx, Mons. A., 114

Maud, S., 142, 149

Measuring-stone, 103

Measures, table of, 328

Melbourne, 87

Melrose, Mr. J., 111

Mendel Gregor, 187

Mesozoic Age, 2, 8

Messenger, 129

breeding of, 129,133

descendants of, 143

measurements of, 135

pedigree, 138

Middleton, Lord, 89

Milk in illness, 280

Mint sauce, 45

Miocene, 4, 8

Mollusks, 8

Monkshood, 372, 374, 375

Moore, Mr. J. Hubert, 365

Morgan, 133

Morris, Capt. W. B., 84

Morris, Messrs., 120

Morrogh, Mr. L., 84, 18j

Iud-fever, 298

Mule-breeding, 28

\section{N}

Nancy Hanks, 149

Narcotics 281

National Trotting Association, 147

Navicular, 311, 344

Neander Men, 4, 8

Newminster, 87

Nosebands, 387

Numnah, 259

Nursing, 278

\section{o}

Oats, new, 274

boiled, 279

Oatmeal, 227

Oettingen, Baron Burchard Von, 36 39 , 185, 320, 321 
Ogden's Messenger, 139

Old Clothier, 108

Old Shales, 109, 112

Oligocene, 4,8

Orde, Mr., 91

Orestes, 80

Osborne, John, 41, 400

Osborn, Professor H. F., 20

Osmer, William, 38, 178

Over-reach, 234, 317

Owen, Capt. E. R., 374, 375

\section{P}

Paddocks, size of, 185

Palæolithic, 8

Palæozoic, 2

Palgrave, Mr. IV., 17

Pantaloon, 87

Parasites, 271, 30.5

Parish's Food, 200

Paterson, Mr. J, 120

Paulett, Lord, 372

Perch-climbing, 2

Peirson's Plato, 108

Permanganate of potassium, 330

Permian, 2, 8

Persimmon, 42

Persse, Mr. Burton, 79

Phagocytes, 328

Phenomenon, 109

Phosphorus, 232

Phrenacodus, 3, 8

Physic, 270, 295, 380

Piette, Mons., 7

Pignatelli Prince, 202

Pilcher's Stop-rot, 266

Pinkney, 373

Plaiting a tail, 206

Plantations, 273

Platt, Mr. James E., Preface

Plesiosaurus, 2

Pleistocene, 4, 8

Pliocene, 4

Pliohippus, 6

Pocahontas (pacer), 149

Polo ponies, Cuddington, 101

Fritz, 98

Jack, 98

Lady Polo, 100, 101

Lottery, 98

Marquis, 100, 101

measuring, 103

Play Actor, 98

Sandiway, 101

Silvertail, 100

sires for, 100

Tubby, 100

White Wings, 101

Ponies, Dartmoor, 94

Exmoor, 94

Irish, 97
Ponies, New Forest, 96

North of England, 93

Shetland, 96

Welsh, 93

Point-to-Point, 378

Portland, Duke of, 28

Post-Tertiary, 8

Pratt, Mr. A., 127

Pratt, Mr. J., 129

Pre-Cambrian Age, 2, 8

Preston, Mr., 146

Prickwillow, 111

Primary epoch, 2, 8

Prince Alert, 149, 150

Protohippus, 6

Pullen, Mr. Bevas, 108

Pulse, 276, 340

Punchestown, 84

Puncturing with a trocar, 297

Purge, 295, 300

\section{Q}

Quaternary, 4, 8

Quilter, Sir Cuthbert, 127

Quittor, 313

R

Race-riding, 399

changing position, 403

finishing, 403

getting the rails, 403

idiosyncrasies, 408

importance of balance, 401

looking for the race, 407

losing ground, 401

must be alert, 406

pace-makers, 405

riding not so good as formerly, 403

riding trials, 405

rounding turns, 410

starting, 406

starting-gate, 406

summing up, 410

Virgil's advice, 399

Rainbow, 168

Ramsdale, Mr. R., 110

Ramsden, Mr., 111

Rares, MIr., 205

Rasouli, Preface

Ration, Government, 225

for carriage-horses, 225

dray-horses, 225

hunter's, 225

tramway horses, 225

Redbourne, 78

Reins, 397

how to knot, 210

Reindeer men, $1,4,8$

Remounts, annual numbers required, 417 
Remounts, on mobilisation, 419

how to create a reserve, 425

leaflet of Government conditions, 426

purchase during Boer War, 120

special brand, 421

Reptiles, 8

Restlessuess, 240

Rheumatism, 326,344

Rhus toxicodendron, 322

Riding should be learued in youth, 390 length of reins, 394

of stirrups, 393

proper seat, 392

riders scarce, 390

liing-bones, 318

Ring-worm, 308

Roaring, 288

engrafting nerve, 289

Roberts, Sir W., 225

liobinson of Malton, 146

Romp, 140

Rope to attach to a short-docked horse, 207

hair, 208

liose-blush, 376

Rose-drop, 63

Rose-water, 101

Rosicrucian, 101

Routine, daily, 223

after hunting, 233

Roxana, 24

Royal George line, 139

Royal mares, 37

Running families, 61

R.ysdyk, Mr., 146

S

Saddlery, stufingr, 2.58

roomy, 261

Robson's ventilated, 262

Saddle-room, 269

Samara, Preface

Sampson, 129, 131, 146

Sal Ammoniac, 321

Sallenders, 300

Salt, 231

Sanderack, 315

Sanders, Millard, 142

Sanders, Mr. J. H., 147

Sanding, 208

Savory, Sir Joseph, 255

Sayers, Harry Clay, 135

Scott, John, 334

Secondary Age, 2

Securing a horse in open country, 209

Sedatives, 281

Seedy-toe, 316

Shawya Barbs, 29, 129

Shelter, 273

Shepherd lord, 181
Shire hor'se, 118

Shiverer to test, 346

Shoes, weight of, 255,417

Shoeing, 243

bar shoes, 248

Charlier, 249

necessity for,

pricking, 243

Side-bones, 318

Side-lines, 210

Sidi-Okba invasion, 27

Silurian, 2

Simbirsh, Preface

Sire families, 61

Sir Hercules, 87

Sleeping standing, 240

Slingsby, Sir C., 79

Sloan, Tod, 401, 402, 406

Smathers, Mr. E. E., 142

Smith, Mr., 127

Smuggler, 133, 135, 142, 149

Snowden, J., 400

Soft soap, 234

Solon, 25

Solutré, 7

Sores, unhealthy, 324

Soundness, examining for, 340

Spanish Armada, 97, 120

Spanish horses, 29

Spavins, 320, 341

bog-spavins, 321

Splints, 319

Speculum, 87

Spice, Mawson's, 327

Sprains, 325

Stabling, 263

Stalls, 264

Starting-gate, 370

Stallions, successful, 60

hunter sires, 85,86

treatment of, 196

Stewart, General, 20

Steeple-chasers, 377

fences for, 377

gummy legs, 381

learning to jumsp when obstinate, 379 schooling, 378

St. Lawrence, 133

Stirrups, 261, 396

Stimulants, 280, 334, 336

Stradbroke, Earl of, 127

Strangles, 289

Studholme, Mr. J., 34, 81, 82, 337

Suffolk Punch, 121

sandbag test, 121

type, 123

colour, 124

Suicide, 45

Sulphur, 232

Sulphur dioxide, 330

Sunmering hunters, 270

Sunligh t, 329 
Sunol, 142, 149

Surry, 140

Sword, 237

Swynford, 63

\section{$\mathrm{T}$}

Tadpoles, 2

Tagg, Mr. J., Preface, 289

Taraban, 324

Teeth, the, 348

age after nine years, 358

age after twenty-one years, 360

milk, 348, 352

molars, 349

permanent, 348

parrot mouth, 351

split, 350

supernumerary, 350

wolves' teeth, 351

bishopping, 360

Tertiaries the, 1,3

Tetanus, 302, 337

Thomas, Mr. R., 108

Thompson, Mr., 108

Thorndale, 133

Thoroughbred horses, 33

inbreeding, 42

deterioration of, 40

distance for, 43

fast trotters, 130

how to breed, 44

taproots, 37

Thorns, search for, 184

Thornton, Mr. R., 184

Thorough pin, 322

Thrush, 314

of the mouth, $29 \%$

Tipoo, 139

Tirhoot, Preface

Tonics, 282

Torridonean Sandstone, 2

Touchstone, stock of, 69,87

Training for racing, 361

diary of work, 372

exercise gallops, 368,371

feeding, 363

good effect of rest, 376

muscle, how developed, 365

mares winning after being at the stud, 377

state of skin, 366

sweating, 367

tonics, 367

value of earth, 364

value of rolling, 381

what to aim for, 362

Triassic, 2, 8

Trilobites, 2, 8

Troïka, Preface

Truman, General, 420

Tryon, Captain, 18
U

Urine, retention of, 297

too profuse, 296

Valenta, 184

Valentine, 38

Vasogen, 200

Velocity, 137

Venus, 143

Vetches, 23\%

Virago, 80

Virgil, 399

Volga, Preface

Voltigeur, 87

Volunteer, 133, 135

W

Wallace, Mr. J. H., 146

Warranty, 347

Warts, 310

Water, effect at Gibraltar, 216

how to select, 212

summary of hints, 220

when fording, 213

when to give, 212

Watercless, 231

Weaving, 239

Weight of horses, 240

Wheat flour, 224

Wheat unsuitable, 226

Whelan, 338

Whipeord nouse, 238

Whim, 42

Winans, Mr. W., Preface, 129, 146, $149,384,385$

Winans, Mr. L., 149

Wind, to test, 345

Windsucking, 239

Winning families, 60

Winkers, 385

IVise, Mr. C., 168

IVithers, Mr. Alfred, Preface, 113

Wolds, the, 89, 90

Wolsey, 78, 406

Wonderful, 108

Wood, Mr. Willoughby, 107

Wounds, 322

air getting into, 324

Xenie, 377

$\mathrm{X}$

Xenophon, description of horse, 398

$\mathrm{Y}$

Yew poisoning, 297

Young, Arthur, 121

Youatt, 123

Zygote, 187 



